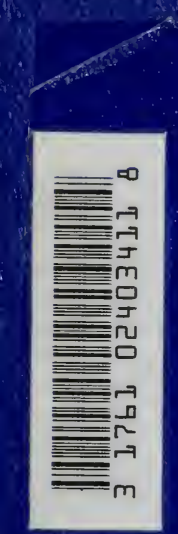




Digitized by the Internet Archive in 2007 with funding from Microsoft Corporation 
16 




T REE O F A M E R C A 



\section{TREES OF AMERICA;}

NATIVE A D F OREIGN,

\section{jictorially and Botanically 刃elineated,}

$\triangle N D$

SCIENTIFICALLY AND POPULARLY DESCRIBED;

BEING CONSIDERED

PRINCIPALLY WITH REFERENCE TO THEIR GEOGRAPHY AND HISTORY; SOIL AND SITUA. tion; propagation and CUlture; accidents and diseases; properties and USES; ECONOMY IN THE ARTS; INTRODUCTION INTO COMMERCE; AND Their application in USeful and ornamental plantations

ILUUSTRATED BY NUMEROUS ENGRAVINGS.

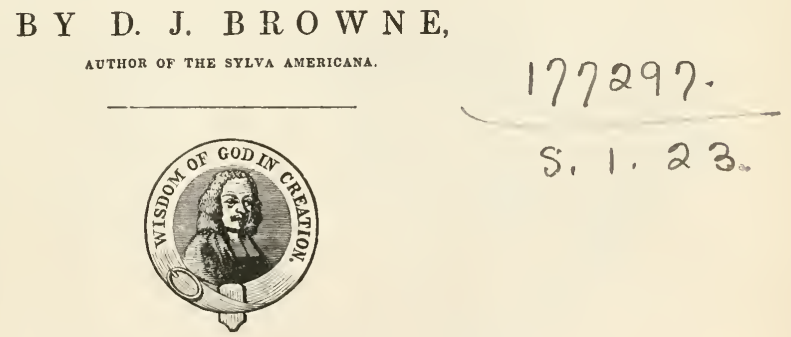

"Think of yony ancestors; think of posterity."

Galgacus.

\section{N E W Y O K :}

HARPFR \& BROTHERS, PUBLISHERS, PEARL STREET, FRANKLIN SQUARE. 
Entered, according to Act of Congress, in the year 1S46. in Harper \& Brothers,

In the Clerk's Office of the Southern District of New York.

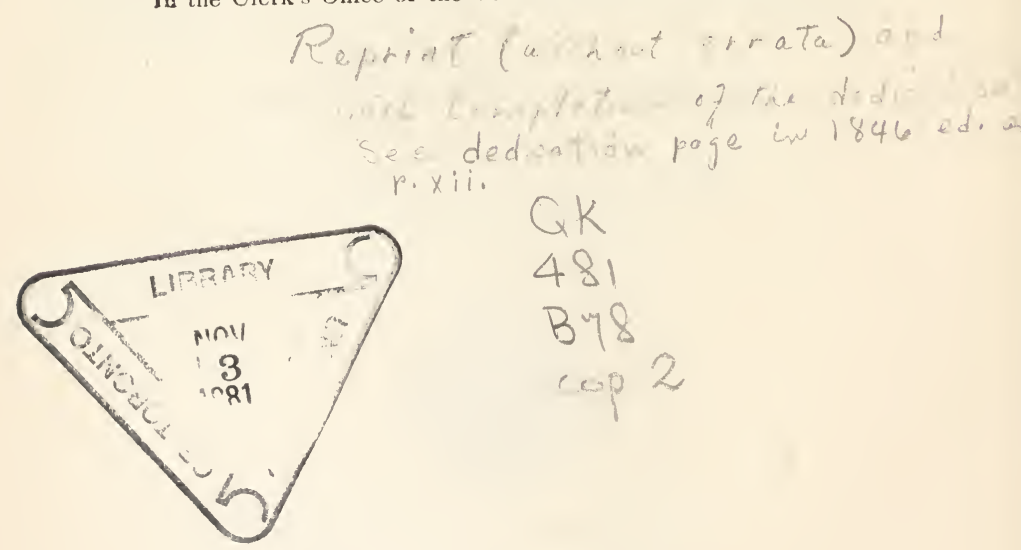


Uo the

\section{HONOURABLE JAIIES TALLMADGE, LL.D.,}

PRESIDENT OF THE AMERICAN INSTITUTE;

DISTINGUISHED FOR HIS FIRM, FAITHFUL, AND INTELLIGENT COURSE AS A REPRESENTATIVE IN CONGRESS; AS LIEUTENANT GOVERNOR OF THE STATE OF NEW YORK; AS A MEMBER OF THE TWO PRECEDING CONVENTIONS FOR REVISING THE CONSTITUTION OF THE STATE; AS A PATRON OF EDUCATION ; AND ESPECIALLY FOR IIS LONG-CONTINUED EFFORTS IN ENCOURAGING AND PROTEC'TING AMERICAN INDUSTRY, IN AGRICULTURE, MANUFACTURES, AND THE ARTS, ETC., ETC., ETC.

Chis bolnme is respertfulln Dedicated, BY 



\section{P R E F A C E.}

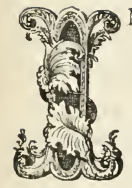

$\mathrm{N}$ presenting to the public a treatise like the present, it would naturally be expected that the author should state the grounds upon which he rests his claim to attention. With this expectation he most cordially complies. Soon after the publication of his "Sylva Americana," in 1832, at the solicitation, not only of personal friends, but with the expressed wishes of numerous individuals to whom he was comparatively a stranger, he undertook the preparation of a work on the trees of this country, more complete and extensive in its character than had hitherto been published. With this view, in connection with other pursuits, he extended his researches by travelling and residing for a time in various parts of North and South America, the West Indies, Europe, and Western Africa, where he availed himself of the advantage of not only verifying or correcting the observations which had been made by others on the trees of these countries, but examined them under various conditions in a state of nature, as well as in nurseries and collections of the curious.

In the year 1838, he announced to the public, through a "Memorial praying Congress to adopt measures for procuring and preserving a supply of timber for naval purposes," [Doc. 241, 25th Congress, $2 d$ Session, Senate, ] that he had commenced the preparation of a treatise on this subject, setting forth the course he was pursuing and the chief objects of inquiry ; but owing to the party strife and political warfare which existed at that period, he regrets to say that no action was taken in the matter beyond referring said memorial to the Committee on Naval Affairs, and ordering it to be printed.

In 1843 , at the request of his friends, definite proposals were issued by the author for publishing the work in a popular form, and a large number of wealthy and publicspirited citizens proffered him their aid, to whom he can not here omit to acknowledge his lasting obligations; but, owing to various causes which have unavoidably retarded the publication, it could not with propriety be issued before the present time.

While complying with this request, he has read or consulted the works of all the most judicious authors on the subject, both ancient and modern, with the view of giving a concise account of such trees and shrubs as are cultivated or growing in America, as would interest the general reader, and, at the same time, would prove economical and useful to the artisan, the planter, and to those interested in arboriculture, in a more ex tended sense.

The pictorial illustrations of this work have either been made directly from drawings after nature, or from accurate delineations already in existence, one figure representing the general appearance of each tree, and another of the leaf, flower, fruit, \&c., in order that the descriptions may be better and more clearly understood, and to render their identity more certain.

The classification he has preferred to adopt is the Natural System, chiefly for the sake of aiding in generalizing on the species and varieties contained in each family or tribe, which is in accordance with the plan adopted by Professor Don, in "Miller's 
Dictionary," and by Loudon, in his "Arboretum et Fruticetum Britannicum." There is one feature, as regards this arrangement, to which the author would call particular attention. It will be perceived that, in various instances, he has reduced the number of species, and even, in some cases, of varieties, which he wishes to be distinctly understood has been done, not only with the object of rendering the classification less complicated, but with an opinion that such analogies do exist; yet he is not by any means desirous to separate assemblages of species, or to alter established names, in any manner whatever. No one, he conceives, should do this who has not attained an eminent rank as a botanist, to which he has no pretensions. Hence, in most of the cases in which he has assumed a species as a variety, he has given the names as adopted by Michaux, Nuttall, Loudon, or some other botanical writer, in order that the reader may know under what heads such varieties are described in the works of these authors.

The author feels called upon to acknowledge that he is particularly indebted to Mr. J. C. Loudon for a large share of his work, taken from the "Arboretum Britannicum," and to Dr. Thaddeus W. Harris for many valuable extracts from his "Report on the Insects of Massachusetts injurious to Vegetation;" also to Mr. P. J. Selby for extracts from his beautiful work on "British Forest Trees," and to "L'Histoire des Arbres Forestiers de l'Amérique Septentrionale," par M. F. André-Michaux.

As the preparation of a treatise like the present necessarily requires time to be consummated, and is attended with considerable expense, the author has ventured to issue a volume, by which public opinion may be guided respecting its merits, and a judgment may be formed of the ability or fidelity with which it has been executed. Should the public demand an extension of the work conformably to the plan he has adopted, a supplementary volume will follow, embracing an account of most of the other trees growing in Europe and America, with statements of the sources from which the information will have been derived; copious indexes; a glossary of technical terms employed in the work; and comparative tables of the various kinds of wood, in regard to their strength, durability, value as fuel, and a variety of other useful information respecting timber and trees never before published.

In conclusion, the author requests that his readers will seasonably apprise him of whatever corrections, additions, or suggestions may occur to them, in order that the work may be rendered as complete as possible, and issued without unnecessary delay.

D. J. B. 


\section{N D E X.}

CAClA, three-thorned Virginian

1CER, generic characters of

icer campestre

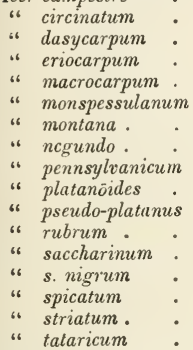

ÆSCULUS, generic characters of Eisculus flava

" hippocastanum
" h. glabra
" h. ohioensis
" h. pallida.
" hrubicunda
" macrostachya
" pavia

AILANTUS, generic characters of

Ailantus glandulosa

" procera

AMELANCHIER, generic characters of

Amelanchier botryapium

$$
\text { " canadcnsis . }
$$

AMYGDALUS, generic characters of

Amygdalus communis

$$
\begin{aligned}
& \text { persica. } \\
& \text { p. lavis. }
\end{aligned}
$$

Amyris elcmifera

Andromeda arborea .

ANNONA, generic characters of

Annona triloba

Apple, American Crab

$$
\text { " Astrachan . }
$$

A pricot-tree

Armeniaca vulgaris

Ash, American, White

"Black, Brown, Water

" Carolina

" European

" Flowering

"Manna

- Mountain, Wild Service
" Thorny, Prickly

Asimina triloba . . . . . . 31

Azedarach . . . . . . . 123

Banian-tree . . . . . . . . 469

Bass-wood, American Lime-tree : $\quad$. 47

Bay, American Rose . . . . . 359

" Loblolly. . . . . . 52

" Red, Carolina Laurel . . . . . 414

BERBERIS, generic characters of . . 33

Berberis canadensis . . . . . 37

" vulgaris . . . . . . 34

Berberry, Common * : . : $\quad$. 34

Canadian , . , 37

Bignonia catalpa . . . . . . . . 406

Birch, West India . . . . . . . . . 189

Bow-wood, Osage Orange . . . . 465

Box-wood . . . . . 350,431, 432

Bread Fruit-tree : . . . 464

Bread Nut-tree, Jamaica $\quad$. . . . 464

BROUSSONETIA, generic characters of .460

Broussonetia papyrifcra . . . . . . 461

Buckeye, Edible . . . . . . . 120 " Fœtid : . . . $\quad 110$

$$
\text { " Large, Yellow Pavia . . . } 118
$$$$
\text { “ Sniall . . . . } 118
$$

Buckthorn, Purging . . . . . 175

Buffalo Berry, Rabbit Berry . . . . . 428

BURSERA, generic characters of . . 188

Bursera gummifera. . . . . 189

BUXUS, generic charasters of . $\quad .431$

Buxus sempervirens . . . . . . 432

"bclcarica . . . . . . 431

Camphor-tree . . . . . . 420

Carob-tree . . . . . . 211

Cassena, Yaupon : $\quad . \quad 169$

CATALPA, generic characters of . . 405

Catalpa syringafolia . . . . 113, 406

CELTIS, generic characters of . . . 516

Celtis australis . .516

" rrassifolia : $\quad . \quad 5 \quad . \quad 519$

" occidentalis . . . . . . . 517

" tenuifolia . . . . . . 518

CERASUS, generic characters of . . . 251

Cerasus avium $\quad . \quad 253$

" borealis : $: \quad . \quad \div \quad \div 265$

" caproniana . . . . . 257

“ caroliniana $\quad \cdot \quad \cdot \quad \cdot \quad \cdot 272$

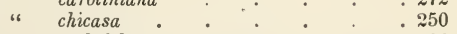

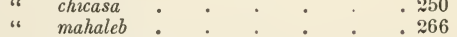

" pennsylvanica : $: \quad \cdot \quad \cdot \quad \cdot 265$

" serotina. $:{ }^{*} \cdot 268$

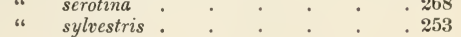

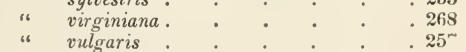

" $\quad$ semperflorens $\quad: \quad .260$ 
CERCIS, generic characters of

Cercis canadensis

" siliquastrum

Cherry, American Bird, Choke

" Carolinian, Wild Orange
" Common Garden
" Verfumed,
" Wirginian, Wild, Black
. Wean, Merry .

Chicasaw Plum

CHIONANTHUS, generic characters of

China-tree

CITRUS, generic characters of

Citrus aurantium

CLADRASTIS, generic characters of .

Cladrastis tinctoria .

Coffee-tree, Arabian

CORNUS, generic characters of :

Cornus alba

" florila
" mascula
Cow-tree

Cow-tree

CRATEGUS, generic characters of

Cratcgus cordata

" crus-galli

Cucumber-tree

CYDONIA, generic characters of .

Cydonia vulgaris

Daphne mezercum

Devil-woor, American Olive

DIOSPYROS, generic eharacters of

Diospyros virginiana

Dogwood, New-England Box-wood

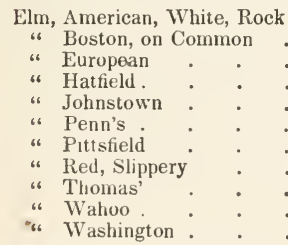

FICUS, generic characters of

Ficus earica

"syeomorus

Fig-tree, Common .

Franklinia

FRAXINUS, generic characters of

Fraxinus amerieana

Fringe-trees
Furze excelsior.

Fustic-trees

Georgia Bark, Pinckneya

GLEDITSCHIA, generic characters of .

Gleditschia, monosperma.

$$
\text { triacanthos }
$$

GORDONIA, generic characters of

Gordonia lasiunthus

$$
\text { pubens }
$$

Page 1

221 Grape-vine, American, Wild . 133

220 "

265 " . . . . . 134

272 " 6135

257 " Isabella . . . . . 134

266 Guava, Florida . . . . . 342

268 GYMNOCLADUS, generic characters of . 217

253 Gymnocladus canadensis . . . . . . 218

.250

. 370 Hack Berry, Hag Berry, Hog Berry . . 519

123 HALESIA, generic characters of . . . 365

56 Halesia tetraptera . . . . . . . . 366

57 Hawthorn, European . . . . . . 275

. 191 Hippophae argentea . . . . . . . . . 429

192 Holly, American . . . . . . . 167

. 353 " Emetic, Yaupon . . . . . 169

. 218 " European . . . . . . 160

. 347 Horse-chestnut, Common . . . 110

348 " 34 Scarlet-flowered . . . 111

. 350 Hydrangea hortense . . . . . . 349

. 348 Hypericum lasianthus . . . . . $\quad$. 52

. 464

. 353 ILEX, generic characters of . . . . 159

274 Ilex aquifolium . . . . . . 160

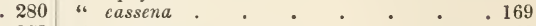

.278 "

. 277 "

14 " paraguariensis. . . . . . 171

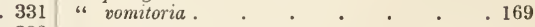

. 333

422

Judas-tree, Red-bud . . . . . . . 221

.381

. 367 KALMIA, generic characters of

282

. 368 Kalmia latifolia . . . . . . . . . 363

.350

.503

Laurel, Kalmia

.363

.507

.479

.509

. 510

.504

. 508

.501

.500

.502

.510

. 469

"Big, Magnolia

“ Carolinian, Red Bay .

" European, Sweet Bay

"Sheep, Lamb-kill · • • . 362

Laurus benzoin $. \quad . \quad . \quad 409$

" eamphora . . . . . . 420

" carolinensis

“ cassia.

" cinnamomum

" nobilis

“ sassafras

. 470 Lime-tree, American, Bass-wood.

.469

.470

“ European, Linden

Ogechee, Tupelo .

2

414

411

362

409
420

414

.409

.409

411

416

. 123

47

39

426

54 LIRIODENDRON, generic characters of . 23

383 Liriodendron tulipifera . . . . . 24

394 Locust, Black . . . . . . 195

384 " Common . . . . . . . . 195

182,371 “ Green, Yellow . . : . . 195

191 “ Honey, Sweet . . . . . 212

460 " "Red

“ Rose-flowering . . . . . 209

211

\begin{tabular}{l|l}
214 & Lotus, European \\
212 & LYONIA, generic characters of
\end{tabular}

51 52

54 MACLURA, generic characters of
209
214

198

36 :

355

. $35 f$

464 
Maclura auranbaca.

MAGNOLIA, generic characters of Magnolia acuminata a. cordata auriculata conspicua

c. alexandrina c. soulangeana frascri glauca grandiflora macrophylla

puspurea. pyramidata tripetala umbrella.

Magnolia, Conspicuous-flowered " Ear-leaved

" Large-flowered

“ Large-leaved.

“ Purple-flowered

“ Umbrella

Mahogany-tree

Maple, Ash-leaved, Negundo . " Field

“ Large-leaved

" Montpellier

"Mountain

" Norway

" Red, Swamp

- Round-leaved

" Silver-leaved

“ Striped-barked

"6 Sugar, Rock

" Sugar, Black

"Tartarian

"White, Soft, Silver

Maté, Paraguay Tea

Medlar, Dutch

MELIA, generic characters of

Melia azedarach

Mespilus arborea

MORUS, generic characters of

Morus alba

"a. multicaulis
" nigra.
" papyrifera.
"tinctoria .

Mountain Ash, Wild Service.

Mulberry, Black

$\begin{array}{ll}\text { " } & \text { Brousa . } \\ \text { " } & \text { Italianese } \\ \text { " } & \text { Paper . } \\ \text { " } & \text { Red, Virginian } \\ \text { " Tartarian } & \text { White. }\end{array}$

Myrtle, Common European

MYRTUS, generic characters of . Myrtus communis

Nectarine

NEGUNDO, generic characters of

Negundo fraxinifolium

Nettle-tree, American

NYSSA, generic characters of
Page

Nyssa aquatica

9 OLEA, generic characters of . . . 372

17 Olea americana . . . . . . 381

7 " 6 europaa $\quad . \quad . \quad . \quad .373$

2 Olive, American . . . . . . 381

. 373

"Wild
ORNUS, generic characters of $\quad . \quad$. $\quad .402$

Ornus americana . . . . . . . 404

. 402

Orange, Common : $\quad \cdot \quad \cdot \quad \cdot \quad \cdot \quad 57$

19 " .5 Navel . . 58

17 "

2 Paulononia imperialis . . . . . . 405

Pavia flava . . . . . . 118

10 " lutea . . . . . . . . 118

127 " 127 macrostachya . . . . 120

.106 " 1 rubra. . . . . . . 115

102 Papaw. . . . 31

78 Peach, Common : : : : $\quad .230$

101 Pear-tree, Common . . . . . . 287

74 "6 Wild, Tupelo : $\quad \cdot \quad \cdot \quad 423$

80 Persica vulgaris . . . . . . . 230

93 Persimon, Virginian Date Plum . . . 368

93 PINCKNEYA, generic characters of . . 353

95 Pinckneya pubens . . . . . . . . 354

76 " 7 pubescens . . . . . . 354

83 Pipperidge, Tupelo $\quad . \quad . \quad . \quad . \quad .423$

84 PISTACIA, generic characters of . . . 178

73 Pistacia officinarum . . . . 179

. 95 " vera. . . . . . 179

171 Pistachio Nut-tree . . . . . 179

. 281 PLANERA, generic characters of . . 514

. 122 Planera gmelini . . . . . . 515

123 " 12 richardii $.5 . \quad . \quad .514$

.282 " 2 ulmifolia . $. \quad . \quad .515$

438 Plane-tree, European Sycamore . . . 88

443 Plum, Common Domestic . . . . 245

445 " " . . . . . . . 250

439 "Washington .246

. 461 Poison Sumach, Poison Elder . . . 186

457 Pomegranate-tree . . . . . 338

460 Poplar, White, Yellow . . . . . 27

. 325 Pride of China, Azedarach . . . . 123

439 PRUNUS, generic characters of : $\quad . \quad .242$

445 Prunus armeniaca . . . . . . . 243

.444 " . . . . . . . . 253

.444 " .0 cerasus . . . . .257

461 " 4 chicasa . . . . . . . 250

.457 " 4 domesica .0245

.446 “ 4 mahaleb . . . . . . . . 266

.443 " . . . . . . . 268

. 343 PTELIA, generic characters of . . . 152

. 342 Ptelia trifoliata . . . . . . 153

. 343 PUNICA, generic characters of : . . 337

Punica granatum . . . . . . . 338

. 231 PYRUS, generic characters of . . . . 284

.105 Pyrus aucuparia . . . . . . . . . . . .

.106 " . . . . . . . . . 326

. 517 " . . . . . . 287

.516 " 6 c. pyraster . . . . . . . . 287

.422 " cydonia . . . . . . . 3:33 
Pyrus japonica

Page

" malus

- m. acerba

¿. m. coronaria

Quince, Common

RHAMNUS, generic characters of

Rhamnus catharticus

RHODODENDRON, generic characters of

Rhododendron maximum . ponticum

ROBINIA, generic characters of

Robinia glutinosa

$$
\begin{array}{ll}
\text { " } & \text { montana } \\
\text { " } & \text { "seudacacia } \\
\text { " viscosa }
\end{array}
$$

RHUS, generic characters of

Rhus coriacea .

" cotinus.

"6 typhina.

"venenata

"vernix

Sassafras-tree

Service-tree, Wil

SHEPHERDIA, generic characters of .

Shepherdia argentea

Snow-drop-tree

Snow-flower-tree, Virginian

Sorbus aucuparia .

Sorrel-tree, Lyonia

Sour Gum

"Tupelo :

Stillingia sebifera.

Styrax officinale

Sumach, Poisonous

$$
\text { “ Staghorn, Virginian }
$$

SWIETENIA, generic characters of

Swietenia mahogoni

Sycamore, Maple

Taltow-tree

Tamarix gallica

Thorn, Cock-spur .

$$
\text { " Dotted-fruited }
$$

“ Washington
331 TILIA, generic characters of

. 296

297

297

174

175

358

. 359

. 358

. 194

. 209

. 209

. 195

. 195

. 209

. 181

. 182

. 182

. 184

. 186

. 186

. 416

.325

. 428

. 429

366,371

. 371

. 325

. 356

. 423

. 426

431

365

. 186

.184

. 182

. 126

- 127

88

431

342,403

. 278

277

. 280

Tilia americana

" a. alba

" europaa

" glabra hcterophylla

Toothache-tree

Tree of Friendship

“ Heaven

Tulip-tree, Liriodendron

Tupelo-tree

“ Sour.

Ulmus americana.

" a. alata

" a. fulva

"6 a. opaca

"a. racemosa

" campestris.

"c. montana.

"c. m. glabra.

“ rubra.

Umbrella-tree

Uvaria triloba.

Virgilia lutea .

VITIS, generic characters of

Vitis labrusca

" l. isabella

" vinifera .

Wahoo .

White-wood

Wickoby

Witch Hazel .
ULMUS, generic characters of

XANTHOXYLUM, generic characters of . 149

Xanthoxylum fraxineum . . . . . 150

Yellow Gum, Tupelo . . . . . . . 423

Yellow-wood, Virgilia : $\quad: \quad \therefore \quad .192$

Zanthoxisum americanum . . . . . 150

" clava herculis . . . 150 


\section{TREES OF AMERICA.}

\section{Genus MAGNOLIA, Linn.} I.Iagnoliaceæ.
Syst. Nat. Polyandria Polygynia.

\begin{tabular}{|c|c|}
\hline \multicolumn{2}{|l|}{ Synonymes } \\
\hline Magnoia, & Of Authors. \\
\hline $\begin{array}{l}\text { Magnolier, } \\
\text { Magnolie, Gurkenbaum, Bieberbaum, }\end{array}$ & $\begin{array}{l}\text { France. } \\
\text { Germany. }\end{array}$ \\
\hline Magnolia, & $\left\{\begin{array}{l}\text { Spain, Italy, Britain, and } \\
\text { Anglo-America. }\end{array}\right.$ \\
\hline
\end{tabular}

Derivations. The name Magnolia was given to this genus by Linnæus in honour of M. Pierre Magnol, a distinguished botanist of Montpelier, in France. The German name, Gurkenbaum, means Cucumber-tree; and Bieberbaum signifies Beaver-tree, which is sometimes applied in America to the Magnolia glauca.

Generic Characters. Calyx of 3 deciduous sepals, that resemble petals. Corolla of from $6-9$ petals. Sta mens numerous. Pistils numerous. Carpels disposed compactly in spikes, opening by the external angle, 1-2-seeded, permanent. Seeds baccate, somewhat cordate, pendulous, hanging out beyond the carpels by a very long umbilical thread. Trees and shrubs with large, entire leaves, and solitary, terminal. large, odoriferous flowers.-Dow, Miller's Dict.

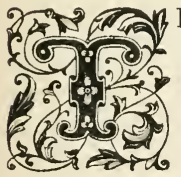

HE genus Magnolia embraces the most admirable productions of the vegetable world. All the species are highly ornamental, and may generally be cultivated in most parts of Britain, the middle and southern states of Europe and of North America, without protection during winter. But, in Russia and the northern parts of Britain, Germany, Sweden, and of the United States, the less hardy kinds are green-house plants. Few of the species ripen their seeds in England, but most of them do in France. The American species are generally produced from seeds; but those from Asia are increased by layers, or by inarching, and in some cases from seeds.

Geographical Distribution. The native country of the most hardy magnolias is North America; but there are some hardy species found in China, Japan, and probably in Hindoostan. No tree of this genus has hitherto been found indigenous to Europe, Africa, South America, nor Australia; and the geographical range of the order Magnoliaceæ in America and Asia is comparatively limited. 


\section{Magnolia grandiflora, \\ THE LARGE-FLOWERED MAGNOLIA.}

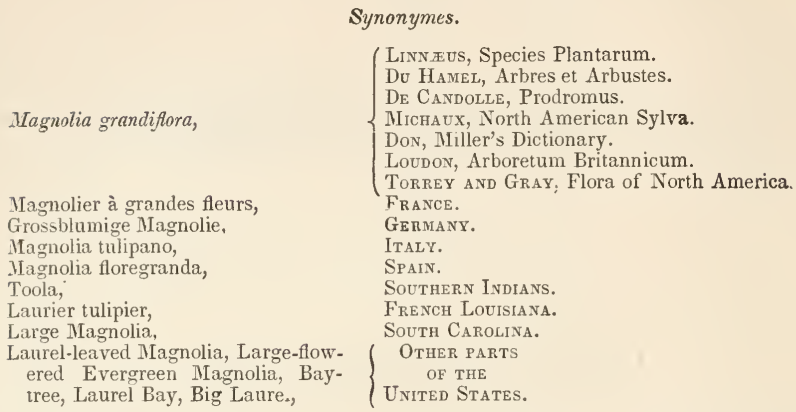

Engravings. Michaux, North American Sylva, pl. 51 ; Audubon, Birds of America, pl. v, ; Loudon, Arboretum Britannicurn vol. v., pl. 1; and the figures below.

Specific Characters. Evergreen. Leaves oval-oblong, coriaceous, upper surface shining, under surface rusty. Flowers erect, $9-12$ petals, expanding.-Don, Miller's Dict.

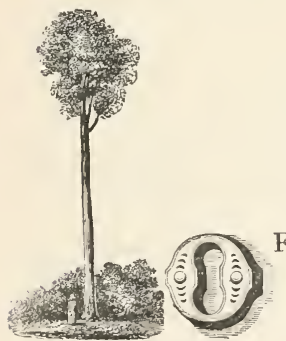
remarkable for the majesty of its form, the magnificence of its foliage, and the beauty of its flowers. It claims a place among the largest trees of the forest, varying from sixty to one hundred feet or upwards, in height, and from two to three feet in diameter. Its head often forms a perfect cone, placed on a clean, straight trunk, resembling a beautiful column; and, from its dark-green foliage, silvered over with milk-white flowers, it is seen at a great distance. The roots are branched, and yet but sparingly supplied with fibres. The bark of the trunk is smooth, grayish, and somewhat resembles that of the beech, and is disagreeably bitter when chewed to a pulp. The leaves vary from six to twelve inches in length, and from three to four inches in breadth. They are always smooth and shining on their upper sides, and perfectly entire on the edges. They vary in form according to the variety to which they belong, being sometimes oblong, oval, or acuminate, and

of "Seest thou the heavenward head

And its pure blossoms? Say, dost thou inhalo

That glory of the forest, but my heart

Traits of the ABorigines. 
at others, narrow, round, or obtuse. They are usually thick and coriaceous, of a rusty brown on their under sides, and are borne by short petioles. In Florida, Georgia, and Carolina, the flowers first appear in April or May; but in England, France, and the northern parts of the United States, they seldom put forth before June or July; and they continue in some varieties until they are destroyed by frost. The flowers are produced on the summits of the last year's shoots, and are from six to ten inches in diameter. It is remarkable that they are produced throughout the summer, whereas, those of all the other species, with the exception of the Magnolia glauca, when planted in moist situations, come forth comparatively at once, and last only a short time. Their odour is exceedingly sweet, and overpowering to some when near, though agreeable at a distance. They are succeeded by fleshy, oval cones, which are about four inches in length, and contain a great number of cells. At the age of maturity, or about the first of October, in Carolina, they open longitudinally, exhibiting two or three seeds of a vivid red, which soon after quit their cells, and for several days, remain suspended without, by white filaments attached to the bottom of their cells. The red, pulpy substance of the seeds decays, in time, and leaves naked a stone containing a white, milky kernel.

Varieties. In consequence of the great demand for this species, many variations have been produced by cultivators, and have been considered as distinct races, among which the following are deserving of notice :-

1. M. G. obovata, Loudon. Obovate-leaved Large-flowered Magnolia. This is said to be the only variety found in the wild state. When cultivated, it deserves the preference of all others for the magnificence of its foliage; but it does not flower freely. It may be known by the broad ends of its leaves, and its expanded flowers.

2. M. g. вотundifolia, Loudon. Round-leaved Large-flovered Magnolia. Not a very distinct or handsome variety, nor a free flowerer. It may be known by its roundish leaves.

3. M. g. exoniensis, Loudon. Exmouth Large-flovered Magnolia. This is the Inost distinct of all the varieties of the species; and, on account of its flowering early and freely, it is most deserving of general culture. Its form is tall and fastigiate, in consequence of which, it is less liable to be injured by a heavy fall of snow. It is also said to grow faster than any other variety. It may be distinguished by its oblong-elliptical leaves, generally rusty underneath, and by its somewhat contracted flowers.

4. M. G. Ferruginea, Loudon. Rusty-leaved Large-flouered Magnolia. This differs from the preceding in having rather broader leaves, and larger flowers. and in having a wider and more compact head.

5. M. G. Lanceolata, Loudon. Lanceolate-leaved Large-flowered Magnolia. Differs from the last-named variety in not having the leaves rusty underneath, nor of so broad and bushy a head.

6. M. G. Elliptica, Loudon. Elliptic-leaved Large-flowered Magnolia. The flowers of this variety are contracted as in the three preceding varieties, from which it differs only in the oblong-elliptical form of its leaves.

7. M. G. Angustifolia, Loudon. Namow-leaved Large-flowered Magnolia. A very distinct variety, readily known by its lanceolate, wavy leaves, pointed at both ends.

8. M. G. PRÆcox, Loudon. Early-flowering Large-flovered Magnolia. A variety which deserves a preference on account of the largeness of the flowers, and because they appear early, and continue during the summer. The leaves are oval-oblong, and the flowers fully expanded.

Geography and History. 'The Magnolia grandiflora is only found indi genous to a tract of country extending from the lower part of North Carolina 
in about latitude thirty-five and a half degrees, along the maritime districts of the more southern states and the Floridas, and as far up the Mississippi as Natchez, three hundred miles above New Orleans. It is said to grow in Texas near thc Brasos.

The introduction of the Magnolia grandiflora into France dates back as far as 1732. A fine plant was taken that year from the banks of the Mississippi by a marine officer, and planted in a poor soil in the town of Nantz. It grew there in the open air until 1758, without attracting any particular notice, when it came under the observation of M. Bonami. At the meeting of the states of Bretagne, held at Nantz, in September, 1760, he presented a branch of it in flower, to the Princess of Rohan-Chabet, which became a subject of conversation and interest to all there assembled. At that time the tree was thirty-five or forty feet in height; but, during the civil war of La Vendée, it was mutilated, and lost most of its branches. Afterwards, the burning of a house, near where it stands, having damaged its fine head, it was treated as an orange-tree injured by frost; that is, the branches were cut off close to the trunk. It shot out vigorously, at first, but the young shoots, not having had time to ripen, were destroyed by the frost. Notwithstanding this check, it again recovered, and afterwards became a fine tree, between twenty-five and thirty feet in height, with a large, well-proportioned head, and a trunk four feet in circumference, the lower branches sweeping the ground. It annually produces from three hundred and fifty to four hundred large, elegant, and sweet-scented flowers. The seeds however, never arrive at perfect maturity; although the fruit attains its ful' size, and remains upon the tree until the following spring. It may be sufficien to state, that this tree, after having sustained so many injuries, and been a living witness of all the political struggles of France for more than a century, still exists at Maillardiere, the estate of M. le Compte de la Bretesche, from whom the foregoing account was received.

The precise date of the introduction of the Magnolia grandiflora into Britain, is uncertain. In the "Hortus Kewensis," on the authority of Catesby, it was cultivated prior to 1737, by Sir John Collinton, at Fxeter; and, as far as known, the tree there was the first which was raised or planted in England. It was cut down through mistake, about the year 1794, previous to which it seems to have been rented by different gardeners, who at first sold the layers at five guineas each; but the price gradually fell to half a guinea. It is stated in the "Linnæan Transactions," vol. x., that in 1759, two fine trees about twenty feet in height stood in the American grove, at Goodwood, near the coast of Sussex, that flowered annually; also, that Mr. Collinson had a plant there, raised by himself from seed, which flowered for the first time in 1760, when twenty years old. At White Knights, near Reading, there exists at present, a magnolia wall, which is one hundred and forty-five feet in length and twenty-four feet high, entirely covered with twenty-two plants of this species, that flower every year from June till November. They were planted in the year 1800 , when the price in the nurseries, for good plants, was five guineas each.

The Magnolia grandiflora, soon after its introduction into France and England, doubtless found its way into the botanic gardens of Spain and Germany. The first planted trees in Italy were in the botanic garden at Padua. On the authority of the Abbé Belèse, who made a tour through northern Italy in 1832, these trees were planted in 1742, and at that time were sixty feet in height, with trunks four feet in diameter. We are also informed that in the botanic garden at Pisa, there are trees which flower and produce perfect seeds, from which plants have been raised by M. Marmier, on his estate at Rois, near Besançon.

It is believed that this tree has been introduced into the botanic gardens of South America and India; and, on the authority of Mr. Reeves, in Loudon's 
"Gardeners' Magazine," vol. xi., it was introduced at Macao by a Mr. Livingston, previously to 1830; and the Magnolia acuminata, glauca, and umbrella, soon afterwards.

Soil and Situation. The Magnolia grandiflora, in its natural habitat, grows in cool and shady places, where the soil, composed of brown mould, is deep. loose, and fertile. These tracts lie contiguous to the great swamps which are found on the borders of the rivers of the south, and in the midst of the pine-barrens. In Europe and the northern parts of the United States, a deep sandy loam, dry at the bottom, and enriched with vegetable mould, seems to suit all the varieties of the species.

The situation, in the colder parts of Europe and America, may be exposed to the direct influence of the mid-day sun; but in southern Europe, and its native climate, it always thrives best when in the shade of other trees, and requires a moister soil. In general, where the fig-tree will grow as a standard, and survive the winter without protection, there the Magnolia grandiflora may be planted, and treated as a standard also. Perhaps the finest situation for displaying the flowers of this tree, as a standard in a northern climate, would be a sloping bank of sandy soil facing the south-east. Here it might be mixed with a few of the deciduous magnolias, and particularly with the Magnolia conspicua soulangeana, which flowers before the leaves come out, and would be set off to great advantage by its green leaves.

Propagation and Management. The Magnolia grandiflora may be raised from the seed ; but, as plants so originated do not flower for twenty or thirty years after being planted out, it is preferable to have those which have been propagated by layers from flowering trees of choice varieties. When propagated by layers, the shoots are put down in autumn, and require two years to become sufficiently rooted for separation. They are then potted, and kept in pits, or under glass, where the climate requires it to be protected, or set in the open air, in a shady place, if the climate is too hot, till wanted for final planting. It is not recommended in any case whatever to purchase any species of magnolia for planting not grown in a pot; because plants so grown may be sent to any distance without injury to the roots, which are few and succulent, and easily damaged by exposure to air and light. In planting, the ball should be carefully broken by the hand, and the roots spread out in every direction, and covered with a mixture of leaf mould and sandy loam. The soil ought to be made firm to the fibrous roots, not by treading, but by abundant watering, and, if the plant be large, by fixing with water; that is, while the earth is being carefully put about the roots by one man, another should pour water over it from a pot held six or eight feet above it, so that the weight of the water may wash the soil into every crevice formed by the roots. Shading will be advisable for some weeks, or even months after planting. If the plant is intended to form a handsome tree as a standard, it should not only have a sufficient depth of suitable soil, but should be pruned to a single stem for at least three or four feet from the ground, to direct the growth of the head. If the plant does not grow freely after it has been three or four years planted, it ought to be bent down to the ground, and kept in that position until it throws up one strong shoot from the collar. The old stem should then be cut away, leaving only the new shoot; and this shoot, which will probably extend three or four feet the first season, will soon form a handsome tree. If the Exmouth variety (M. g. exoniensis) of this species be made choice of, layers will produce flowers in a year or two after being separated from the parent plant, if kept in pots; but, when they are planted out, and grow freely, so as to make shoots two or three feet each season, they will probably not flower for three or four years. In whatever manner this tree be treated, all the pruning it will require, after it has begun to grow freely, will be to cut out the stumps from which the flowers or 
strobiles have dropped off, or any dead or decayed wood, and branches which cross and rub on each other. For a few years after being planted as a standard, it may be advisable to protect it during winter, by forming a small cone of thatch or straw round the stem, after the manner of M. Boursault, of Paris, as described in Loudon's "Arboretum."

Casualties. In southern Florida, the Epidendrum conopseum grows parasitically upon the Magnolia grandiflora and other trees.

Properties and Uses. The medicinal virtues of this magnificent tree were familiar to the southern Indians, while they were accustomed proudly to point it out as the glory of the forest. The bark of its roots was used by them in Florida, in combination with snake-root, as a substitute for the Peruvian bark, in the treatment of intermittents.

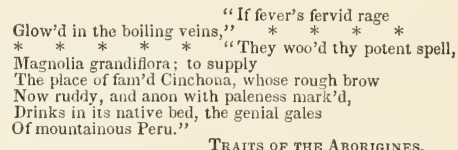

The wood of this tree is but little used in the arts or for fuel. It is soft, and remarkable for its whiteness, which it preserves even after it is seasoned, and when dry, weighs from twenty-seven to thirty pounds to a cubic foot. It is easily wrought, and is not liable to warp; but when exposed to the alternations of moisture and dryness, it soon decays. For this reason the boards are used only in joinery in the interior of buildings In trees from fifteen to eighteen inches in diameter there cannot be discerned any mark of distinction between the sap and heart-wood, except a deep-brown space about half of an inch in diameter near the centre of the trunk. In general, the utility of the Magnolia grandiflora can only be considered in the light of an ornament to plantations and shrubberies, or to the more refined beds of the conservatory.

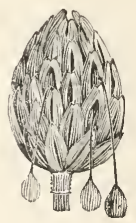




\section{THE GLAUCOUS-LEAVED MAGNOLIA.}

\section{Synonymes.}

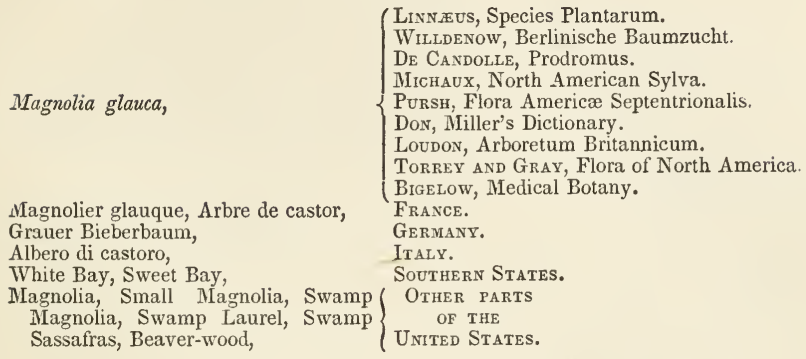

Derivations. The specific name glauca is derived from the Greek word glaucos, sea-green, alluding to the colour of the teaves. It is named Swamp Sassafras on account of its growing in boggy grounds, and resembling some of the qualities of the Laurus sassafras; and Beaver-tree, because the root is eaten as a great dainty by beavers, which are sometimes caught by means of it. Michaux tells us that it is felled by them for constructing their dams and houses, in preference to any other tree, on account of the softness of the wood.

Engravings. Michaux, North American Sylva, pl. 52; Audubon, Birds of America, pl. cxviii.; Loudon, Aboretum Britan. nicum, v., pl. 3 ; and the figures below.

Specific Characters.-Almost deciduous. Leaves elliptical, obtuse, under surface glaucous. Flowers

9-12-petaled, contracted. Petals ovate, concave.-Don, Miller's Dict.

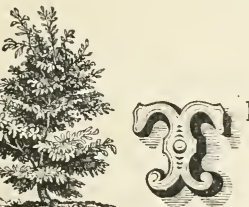

\section{Description.}

HE Magnolia glauca, though inferior in size to the preceding species, and less regularly formed, is interesting on account of its beautiful foliage and sweet-scented flowers. It sometimes attains an elevation of forty feet, with a diameter of ten or twelve inches; but it does not ordinarily exceed fifteen or twenty feet in height, either in Britain or this country, and often fructifies at the height of five or six feet. The trunk is usually crooked, and divided into a great number of divaricating branches. The young shoots are from twelve to eighteen inches in length, and the roots, like all the species of the magnolia, are branched, and sparingly supplied with fibres. The bark of the trunk is grayish, and of a bitterish taste. The leaves are five or six inches long, petiolated, alternate, oblongoval, or obtuse, and entire. They are of a shining bluish-green on their upper surface, and whitish or

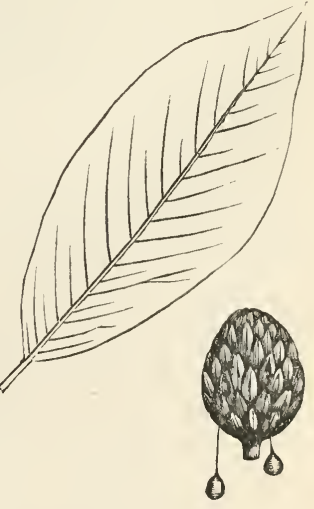
glaucous, and often silky when young, underneath. In the southern states this tree is often found with evergreen leaves, and sometimes near its northernmost limits it retains a part of its foliage during winter. The leaves usually fall, how- 
ever, in autumn, and are renewed early in the following spring. This tree begins to flower in Florida and the southern states, the last of April or early in May, and a month or six weeks later in Massachusetts. The flowers are single, two or three inches broad, and are produced at the extremity of the last year's shoots. 'Tliey have six white concave petals, and an agreeable perfume, which may be perceived at a considerable distance. If shut up in a close apartment during the night, they communicate to the air a heavy and almost insupportable odour. They are of short duration, although the tree continues flowering for several months. It is not unfrequent to find it in bloom, in the south, in autumn. The fruit is composed of numerous cellules, and varies in length from an inch to an inch and a half, and whell of full size, is an inch in diameter in the widest part. When ripe, the cones are of a reddish-brown, and the seeds, which are of a scarlet colour, burst their cells, and hang down several days by white, lax, slender threads, as in most of its congeners.

Varieties. The only aboriginal varieties of this species are the $\boldsymbol{M}$. $g$. arborea, which assumes the character of a tree; and that which retains its foliage during a greater part or all the year, and is sometimes called $M . g$. sempervirens. Two other varieties are noticed by Pursh, one of which has the under surface of the leaves somewhat silvery, and is called $M$. g. argenten, and another with longer leaves than usual, called $\boldsymbol{M}$. $g$. longifolia. There are also two varieties, supposed to be hybrids, produced between this species and the Magnolia umbrella. 'They are usually known under the names $\boldsymbol{M}$. g. thompsoniana and $\boldsymbol{M}$. g. longifolia.

Geography and History. The Magnolia glauca has the most extensive range, especially near the sea, of any of the genus. It abounds from Massachusetts to Louisiana and Missouri. Its most northern boundary may be considered a sheltered swamp in Manchester, Cape Ann, about thirty miles northerly of Boston. It here attains but a small size, and is frequently killed to the ground by severe winters. In the maritime parts of the Floridas and lower Louisiana, it is one of the most abundant among the trees which grow in morasses or wet grounds. It is not usually met with far interior, nor to the west of the Alleghanies. In the Carolinas and Georgia, it grows only within the limits of the pine-barrens.

This species was introduced into England by Rev. John Banister, who sent it to Bishop Compton, at Fulham, in 1688. It was soon afterwards generally propagated by American seeds, and became known throughout Europe many years before any of the other species. At Woburn Farm, Chertsey, there was formerly a row of these trees twenty feet high, and nearly a century old, which frequently ripened their seeds.

In France, and southern Europe generally, this species is not very abundant. from the great heat of the summers, and the general dryness of the air. At Versailles and the Petit Trianon, as well as in Belgium, it has attained the height of fifteen feet. In the north of Germany, and in Sweden and Russia, it is a greenhouse plant. At Monza, in Italy, it is found in all of its varieties.

In 1S43, a tree of this species was cut by Dr. Torrey, on Long Island, New York, nearly forty feet in height, and six or eight inches in diameter, which contained about eighty concentric rings or annual layers. On the estate of Lemuel W. Wells, in Yonkers, (formerly Philipsburgh,) New York, there is a Magnolia, glauca thirty feet in height, with a trunk six feet in circumference two feet above the ground, and is supposed to be more than a hundred and fifty years old.

Soil and Situation. In its natural habitat the Magnolia glauca grows most abundantly in deep, boggy swamps and marshes, composed of a black, miry soil ; but when cultivated in Europe or in this country, the soil should be a deep sand. or a sandy peat, kept moist, more especially in summer. The situation should be sheltered, and shaded by large trees, but it should not be overspread by them. 
Propagation and Culture. Plants of this species are generally produced from seeds; but the Magnolia glauca thompsoniana, and other varieties, are propagated by inarching, or by layers, which require two years to root properly. The seeds should be sown in pots of bog earth about the beginning of March, or later, according to the climate or season, and placed in gentle heat, if necessary, under glass. They should annually be transplanted into small pots until they are wanted for final planting. A tree in ordinary circumstances will attain the height of one foot per annum until it is fifteen or twenty feet high, after which it will remain stationary.

Insects. The Magnolia glauca is very free from the attack of insects. It is noted, however, in Smith and Abbot's "Insects of Georgia," that the Sphinx vitis feeds upon this tree as well as upon the grape-vine.

Properties and Uses. In general, this tree can only be used for ornamental purposes, and no collection should be without it. The wood, however, is sometimes employed for making joiners' tools; and the bark is also used in some parts of the country, like that of the cinchona, in the case of intermittent and remittent fevers. It is aromatic and pungent, apparently more so than the other species. When distilled, it has a peculiar flavour, and an empyreumatic smell. In a dry state it affords a little resin. The aroma is volatile, and probably contains an essential oil, or a variety of camphor. The bark, seeds, and cones, are employed in tincture, in chronic rheumatism. That from the cones is very bitter, and is sometimes used to cure coughs and pectoral diseases, and for preventing autumnal fevers. The flowers in a dried state, may be used in drawing-rooms for pot pourri, as a substitute for those of the lily of the valley. 


\section{Magnolia umbrella, \\ THE UMBRELLA MAGNOLIA.}

\begin{tabular}{|c|c|}
\hline \multicolumn{2}{|c|}{ Synonymes. } \\
\hline Magnolia tripetaı, & $\begin{array}{l}\text { Linn eus, Species Plantarum. } \\
\text { Willdenow, Berlinische Baumzucht. } \\
\text { Michaux, North American Sylva. } \\
\text { Punsh, Flora Americæ Septentrionalis. } \\
\text { Loudon, Arboretum Britannicum. } \\
\text { De CANDolle, Prodromus. }\end{array}$ \\
\hline Magnolia umbrella, & $\begin{array}{l}\text { Don, Miller's Dictionary. } \\
\text { Tonney and Gray, Flora of North America. }\end{array}$ \\
\hline $\begin{array}{l}\text { Iagnolier parasol, Arbre parasol, } \\
\text { reyblättriger Bieberbaum, Dreyblät- } \\
\text { trige Magnolie, }\end{array}$ & $\begin{array}{l}\text { France. } \\
\text { Germany. }\end{array}$ \\
\hline Imwood, & $\begin{array}{l}\text { Virginia. } \\
\text { Other parts of the United States. }\end{array}$ \\
\hline
\end{tabular}

Derivations. This species is called Umbrella-tree on account of the leaves being disposed somewhat in the form of an umbrella. It is called Elkroood in the mountains of Virginia, probably from the resemblance which the points of the shoots bear to the horns of the elk. The French names merely signify Umbrella-tree, and the German ones, the Three-petaled Beavertree or Magnolia.

Engravings. Michaux, North American Sylva, pl. 55 ; Loudon, Arboretum Britannicum, v., pl. 5; and the figures below.

Specific Characters. Deciduous. Leaves lanceolate, spreading, adult ones smooth, younger ones pubescent underneath. Petals 9-12, exterior ones pendant.-Don, Miller's Dict.

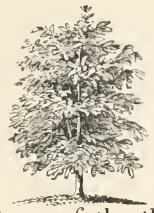

\section{Description.}

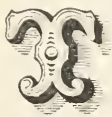

HE dimensions of the Magnolia umbrella are such as to form a connecting link between the large shrubs and trees of the third order; although it sometimes rises to the height of thirty-five or forty feet, with a diameter of five or six inches, it rarely attains this size. The stem is seldom erect, but generally inclined, and rises, from the root in twos or threes. The bark on the trunk is gray, smooth, and polished, and if cut when green, exhales a disagreeable odour. 'The leaves are eighteen or twenty inches long, and seven or eight inches broad. They are thin, oval, and acuminate at both extremities. They are often disposed in rays at the extremity of vigorous shoots; and these display a surface of two and a half feet in diameter, in the form of an umbrella. The flowers, which open in May or June, are seven or eight inches in diameter, with large, white, flaccid petals. They are placed on
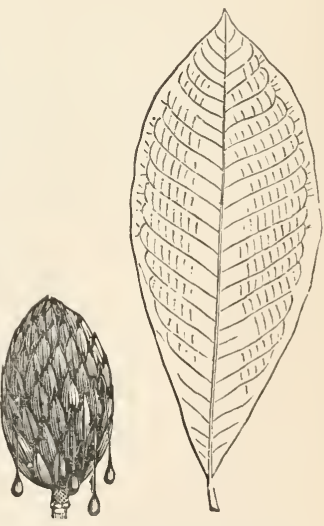
the extremities of the last year's shoots, have a languid, luxuriant appearance, and a strong odour. The fruit is five or six inches long, and about two inches in diameter. It ripens in America about the beginning of October, and about the same period in England and France. It is conical in its form, of a beautiful rose-colour, and usually contains from fifty to sixty pale-red seed.

Varieties. In 1836, at Desio, near Milan, in Italy, several young hybrid plants were raised from seeds which had been fecundated with the pollen of the Mag- 
nolia conspicua and purpurea. From the hardiness of this tree, no doubt, many other hybrids may be produced between it and the more delicate Chinese species.

Geography and History. The Magnolia umbrella, according to Michaux, is first seen in the northern part of the state of New York, and is found on wooded mountains, in Carolina, Georgia, and eastern Tennessee. In the lower parts of Georgia and South Carolina, however, it is found near the alluvial flats which lie along the banks of the rivers, in company with the Magnolia grandiflora.

This tree was introduced into England in about 1752, and soon after it passed into France, and was cultivated on the continent generally. It may now be considered as the most common of all the magnolias. In France and northern Italy it seeds freely; and even in England, at Deepdene, in Surrey, self-sown seeds have produced plants. It does not thrive in the north of Scotland without protection. In England and middle Europe it attains the height of thirty feet, which it will acquire in fifteen to twenty-five years.

In the Bartram botanic garden, at Kingsessing, three miles below Philadelphia, there is a tree of this species, thirty-five feet in height, with a trunk three feet in circumference.

Soil and Situation. In its natural habitat, this tree grows only in the shade where the soil is deep, strong, and fertile. When cultivated, the soil should be a deep, rich, sandy loam, but not very moist, like that recommended for the Magnolia glauca.

The situation should be sheltered and shady, as the exposure to the sun, or the training against a wall is injurious. A sheltered glade, in a shrubbery or wood, where it is sufficiently distant from other trees not to be injured by the roots, is the most desirable site.

Propagation and Culture. In nurseries, this species should always be propagated by seeds, although it may be multiplied by layers. In either case the plants are kept in pots until required for final transplanting. The seeds should be sown immediately after they are gathered, as otherwise they become rancid and lose their vital qualities; though, if enveloped in moist moss, or earth, they may be preserved for several months. As this tree is short-lived, and consequently flowers young, there is not the same objection to raising plants of it from seeds, as there is in the Magnolia grandiflora, which is a long-lived tree. The umbrella magnolia is hardy, and can withstand the most rigorous winters, when the sumnier has been sufficiently hot to ripen the wood. In Britain and he northern parts of the United States, it sends up various shoots from the roots, to replace the stems, which are seldom of long duration; so that a plant that has stood thirty or forty years in one spot, has had its stems several times renewed during that period.

Properties and Uses. The wood of the Magnolia umbrella is spongy, brittle, with a large pith, soft, porous, and of very little use. Hence it may be considered of little or no utility except for the purposes of ornament.

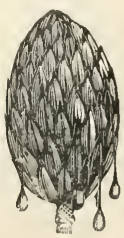


Magnolia macrophylla,

\title{
THE LARGE-LEAVED MAGNOLIA
}

\section{Synonymes.}

\author{
De Candolle, Prodromus. \\ Don, Miller's Dictionary. \\ $\{$ Michaux, North American Sylva. \\ Loudow, Arboretum Britannicum. \\ Torkey and Grax, Flora of North America. \\ Magnolier à
bananier, \\ Grossblättriger Bieberbaum, \\ Large-leaved Umbrella-tree, \\ France. \\ Germany. \\ Britain and Anglo-America.
}

Derinations. The specific name is derived from the Greek macros, great, and phullos, a leaf. It is called Umbrella-tret from its resemblance to the other species bearing that name. The French names are translations of the botanic one, except Magnolier bananier, which alludes to the resemblance the leaves of this tree bears to those of the banana-tree. The German name signifies Large-leaved Beaver-tree.

Engravings. Michaux, North American Sylva, pl. 57; Loudon, Arboretum Britannicum, v., pl. 6; and the figures below. Specific Characters. Deciduous. Leaves very large, oblong-obovate, somewhat panduriform, cordate at the base, under surface whitish, glaucous. Petals 6-9, ovate.-Don, Miller's Dict.

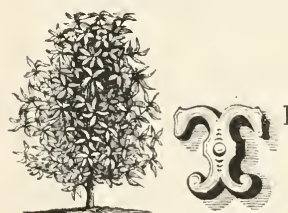

\section{Description.}

HE Magnolia macrophylla is the least multiplied of the American species, and is rarely met with in the forests. Its general appearance greatly resembles that of the Magnolia umbrella. The terminal arrangement of the leaves is the same, and it is remarkable that it is usually found growing with it. In point of size it is about the same as the above-named species, not usually exceeding thirty or thirty-five feet in height, and five or six inches in diameter, although individual trees have been found of nearly double these dimensions. The trunk is covered with a smooth and very white bark, by which, in winter, when stripped of its leaves, it is readily distinguished. At this season, also, it may be known by its buds, which are compressed, and covered with a soft and silvery down; whereas, in the Magnolia umbrella they are prominent and rounded at the end. The leaves in a wild state are about thirty-

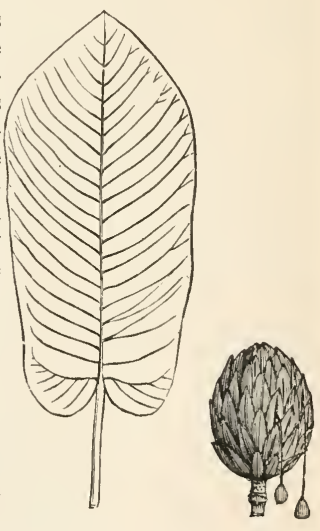
five inches long, and nine or ten inches broad; and in vigorous plants, when cultivated, they often exceed these dimensions. They are borne on petioles, short in comparison with their size, and are of an oblong-oval shape, pointed at the extremity, and sub-cordiform at the base. Their colour is light-green above, and glaucous beneath. The flowers put forth from May to July, and are larger than those of most of its congeners; for, when fully blown, they are sometimes eight or nine inches in diameter. They are composed of six white petals, longer and broader than those of the Magnolia umbrella. Within the flower, near the bottom of the petals, is a purple spot, about two thirds of an inch in diameter. The flowers emit a fragrant odour, and their beauty is heightened by the luxuriant foliage which surrounds them. The fruit is about four inches long, nearly 
cylindrical, and of a vivid rose-colour when arrived at maturity. In the arrangement of the carpels and of the seeds, the fruit resembles those of the Magnolia umbrella and acuminata. It should be remarked, however, that it is destitute of the appendages visible on that of the last-mentioned species, especially when it is dry.

Geography and History. The large-leaved magnolia is found in the mountainous regions of North Carolina, about ten miles from Lincolnton; in Tennessee, near the river Cumberland; and in Georgia on the river Chattahouchie. It is also sparingly found in Tennessee, west of the mountains, at intervals of forty or fifty miles.

This tree was discovered by the elder Michaux, in 1789, but was not introduced into England till imported by Messrs. Loddiges, in 1800. In France, it seems to have been introduced about the same time as in England; and it appears to prosper better in the climate of Paris, as there, in the nursery of M. Godefroy, it has ripened seeds, from which, in 1827, young plants were raised.

The largest tree of this species in England, is at Arley Hall, the seat of the Earl of Mount Norris. In 1837, it was twenty-eight and a half feet high, with a trunk six inches in diameter, at a foot from the ground, with a head seventeen feet in diameter.

In France, the largest Magnolia macrophylla is at Fromont, which in 1835, measured twenty-four feet in height, and the branches covered a space of fifteen feet in diameter. It had flowered every year since 1826, and ripened seeds in October, from which many young plants had been raised.

In the Bartram botanic garden, at Kingsessing, near Philadelphia, there is a tree of this species thirty feet in height and six inches in diameter.

Soil and Situation. In its natural habitat this species delights in cool situations, sheltered from the wind, where the soil is deep and fertile. The soil, in which trees have attained the largest size in England, is a deep, dry sand, with a situation perfectly sheltered on every side, and slightly shaded from the midday sun.

Propagation and Culture. Neither this species nor the Magnolia umbrella can be readily grafted or inarched on each other, or on any other tree; probably from the large proportion which the pith bears to the ligneous part of the shoots. It will root by layers with great difficulty; but plants so raised, from the want of vigour, will probably not be of long duration. The only mode of general adoption is, to raise it from seeds. In order to preserve the power of vitality in the seeds, the same attention is requisite as in the preceding species. Young plants grow very slowly till they are thoroughly established, which will require, in general, two years. The annual growth of the shoots may vary from one to two feet; so that in ten years a plant may attain a height of twelve or fifteen feet. This species may be considered as short-lived, and, like all trees of short duration, comes into flower when young.

Properties and Uses. The wood of this species is softer and more porous than the Magnolia umbrella, and has comparatively no value except for ornament.

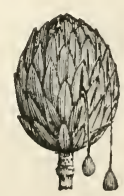




\section{Magnolia acuminata, THE POINTED-LEAVED MAGNOLIA.}

\begin{tabular}{|c|c|}
\hline \multicolumn{2}{|c|}{ Synonymes. } \\
\hline Magnolia acuminata, & $\left\{\begin{array}{l}\text { LinNieus, Species Plantarum. } \\
\text { Willdenow, Berlinische Baumzucht } \\
\text { De Candolle, Prodromus. } \\
\text { Michaux, North American Sylva. } \\
\text { Don, Miller's Dictionary. } \\
\text { Loudon, Arboretum Britannicum. } \\
\text { Torrey and Gray, Flora of North America. }\end{array}\right.$ \\
\hline $\begin{array}{l}\text { Magnolier acuminé, Magnolier à } \\
\text { feuilles pointées, }\end{array}$ & France. \\
\hline Zugespitzter Bieberbaum, & Germany. \\
\hline Cucuinber-tree, & ANGLO-AMERICA. \\
\hline
\end{tabular}

Derivations. This species is called Cucumber-tree, from its fruit resembling a small cucumber. The other names as translations of the botanic one, except Blue Magnolia, which has reference to the bluish colour of the flowers.

Engravings. Michaux, North American Sylva, pl. 53; Loudon, Arboretum Britannicum, v., pl. 7 ; and the figures below. Specific Characters. Deciduous. Leaves oval, acuminate, under surface pubescent. Flowers 6 -9. petaled.-Don, Miller's Dict.

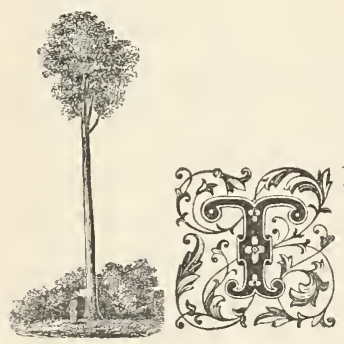

\section{Description.} and is often destitute of branches for two thirds of its length, and sometimes attains a height of sixty or eighty feet, with a diameter of three or four feet. The branches are numerous, and are disposed in a regular manner, forming an ample and beautiful fastigiate summit. 'The bark on old stocks is grayish, and deeply furrowed. The leaves upon old trees are from six to seven inches long, and from three to four inches broad, and double that size upon young, vigorous ones. In general, on adult trees, they are oval, entire, and very acu-

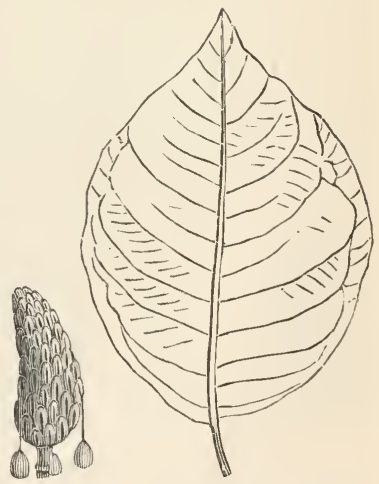
minate; but, on seedlings, they are sometimes found ovate, nearly orbiculate, and cordate-acuminate. The flowers, which open in May, are five or six inches in diameter. 'They are bluish, and sometimes white, with a tint of yellow, and emit but a feeble odour. They are large and numerous, and have a fine effect in the midst of the superb foliage. The cones are about three inches long, and nearly an inch in diameter. 'They are cylindrical, and often a little larger at the summit than at the base. 'T'hey are convex on one side, and concave on the other; and when green, they nearly resemble small cucumbers. They are rose- 
coloured, and, as in the fruit of the other species, the seeds, before they drop. remain suspended for some time by long, white threads.

Varieties. As this species is frequently raised from seeds, and as the seedlings vary much in the size and form of their leaves, and in the presence or absence of pubescence, both on the leaves and the young shoots, it would be easy to select several varieties apparently marked with distinctness. It may be deemed sufficient, however, to enumerate the following:-

1. M. a. condata, Loudon. Magnolier à feuilles en cœur, in France; Herzblättriger Bieberbaum, in Germany; and Heart-leaved Cucumber-tree, in Britain and America. This variety, in its general appearance and in the form of its fruit, very nearly resembles the type of this species. It is found growing in insulated situations on the banks of the rivers in upper Georgia, and on those of the streams which traverse the western part of South Carolina. It appears to have been discovered by the elder Michaux, and was first introduced into England by John Lyon, in 1801. The original tree is said still to exist in the nursery of Messrs. Loddiges, at Hackney, in England, and is about fifteen feet in height. In its natural habitat, it attains an elevation of forty or fifty feet, with a trunk twelve or fifteen inches in diameter. Its leaves are from four to six inches in length, and from three to five inches in width, are somewhat ovate or cordate, acute, with their under surfaces tomentose, and their upper ones smooth. Its flowers, which are odoriferous, appear in Georgia in April, and are yellow, with the interior of the petals longitudinally marked with reddish lines. 'They are from three to four inches in diameter, and are succeeded by fruit about three inches long, and nearly an inch in thickness.

2. M. a. Candolli savi, Loudon. De Candolle's Acute-leaved Magnolia. This variety can readily be distinguished by its ovate, oblong, and acute leaves, and greenish flowers. It is figured in Savi's "Bibliotheca Italica."

3. M. A. Maxima, Loudon. Large Acuminate-leaved Magnolia. The leaves of this variety are much larger than those of the original species. Hence its name.

Gengraplyy and History. The most northerly point at which this species is found is near the falls of Niagara, in latitude forty-three degrees. It grows along the whole mountainous tract of the Alleghanies to their termination in Georgia; and is common on the Cumberland Mountains, which divide the state of 'Tennessee. "At the distance of forty or fifty miles from these mountains," says Michaux, "either eastward or westward, the Cucumber-tree is met with only accidentally upon the steep banks of rivers. It is also rare in the parts of Kentucky and west Tennessee, which are most remote from the mountains, where the face of the country is less even."

The Magnolia acuminata was first discovered by John Bartram in 1736, and was sent by him to that venerable English amateur, Peter Collinson. Being readily propagated by layers, and very hardy, it was soon extensively cultivated in the gardens of Europe, and there are now numerous trees in Britain, France, and the north of Italy, from forty to sixty feet in height, which flower freely every year.

A tree of this species more than eighty feet in height, and three feet in diameter, is at present growing in the Bartram botanic garden, at Kingsessing, on the west bank of the Schnylkill, three miles below Philadelphia. It was brought by John Bartram from Lake Erie, in about 1753; and Col. Robert Carr, the present proprietor of this garden informs us, that a great part of the seeds of the Magnolia acuminata sent yearly from America to Europe, are supplied from this tree.

Soil and Situation. The situations peculiarly adapted to the growth of this tree in its native country, are the declivities of mountains, narrow valleys, and the banks of torrents, where the air is constantly moist, and the soil is deep and 
fertile. To attain a large size, when cultivated, it requires a sheltered situation, and a deep, rich soil ; but it will grow in exposed sites, and in almost any soil that is moderately free, and not surcharged with moisture.

Propagation and Culture. The Magnolia acuminata is generally propagated in the European nurseries by layers; the plants so produced flowering much sooner than seedlings; but the latter, as they make far more durable plants, should always be preferred when this species is used as a stock to graft or inarch others on. It is thus treated very generally, not only for the Magnolia auriculata and cordata, but for the Magnolia conspicua and soulangeana. The plants are sometimes grown in the free soil, but it is preferable to rear them in pots; because, in that case, they are not checked by transplanting, and at least a year is gained in their growth. Plants raised from seeds do not usually produce flowers till they are eight or ten years old, when the tree will probably be fifteen or twenty feet in height; but those propagated from layers produce flowers in two or three years.

Properties and Uses. The wood of this species is soft and light, weighing, when dry, twenty-six pounds to a cubic foot. Being comparatively rare in the United States, its timber is not in general use. Where it can be obtained, it is employed in joinery for the interior of houses, and for cabinet-making; and, from its size and lightness, large trunks are selected for scooping out into canoes. Many of the inhabitants of the Alleghanies gather the cones about mid-summer, when they are half ripe, and steep them in whiskey, which thus becomes extremely bitter, and habitually taken in the morning, is considered as a preventative against autumnal fevers. 
Magnolia auriculata,

\section{THE EAR-LEAVED MAGNOLIA.}

\section{Synonymes.}

Magnolia auriculata,

Magnolia fraseri,

Magnolier à feuilles auriculées,

Geöhr̈ter Bieberbaum,

Long-leaved Cucumber-tree, Indian

Physic, Wahoo,
Willdenow, Linnæi Species Plantarum.

De Candolle, Prodromus.

$\{$ Michaux, North American Sylva.

Dov, Miller's Dictionary.

Loudon, Arboretum Britannicum.

ToRREY AND GRAY, Flora of North America.

France.

Germany.

United States.

Derivations. The specific name, auriculata. is derived from the Latin auris, the ear, from the rounded lobes of the leaves, resembling ears. The French name is a translation of the botanic one. The German name signifies Eared Beaver-tree. It is called Long-leaved Cucumber-tree from the length of its leaves, and the form of its fruit; and Indian Physic, because it was much used hy the aborigines as medicine.

Engravings. Michaux, North American Sylva, pl. 56; Loudon, Arboretum Britannicum, v., pl. 10; and the figures below.

Specific Characters. Deciduous. Leaves smooth, under surface somewhat glaucous, spathulately obovate, cordate at the base, with blunt approximate auricles. Sepals 3, spreading. Petals 9, oblong.-Don. Miller's Dict.

\section{Description.}

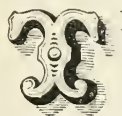

HE Magnolia auriculata is remarkable for the beauty of its foliage, the size of its flowers, and the fragrance of their odour. It attains a height of thirty or forty feet, with a straight trunk, twelve or fifteen inches in diameter, often undivided for half of its length. The branches spread widely, and ramify but sparingly, with their extremities turned upwards, which circumstances give the tree a peculiar air, so that it may readily be known at a distance, even in winter. The bark is gray, and always smooth, even on the oldest trees, except on the young shoots, which are of a purplish-red, dotted with white. When the epidermis is removed, the cellular integument, by contact with the air, instantly changes from white to yellow. The leaves are of a light-green colour, of a fine texture, eight or nine inches long, and from four to six inches broad. On young and vigorous trees, they are often one third, or even one half larger. They are smooth on both surfaces, acuminate at the summit, widest near the top, and narrowest towards the bottom. The base is divided into rounded lobes, one on each side of the insertion of the petiole. They have short footstalks, sitting near each other, and radiate in regular order, with their margins touching or slightly overlapping each other, like an umbrella. The flowers, which open in April and May, are three or four inches in diameter, of a milky white, and are situated at the extremities of the young shoots. The fruit is oval, three or four inches long, and, like the Magnola umbrella, of a beautiful rose-colour, when ripe. It differs from 
the fruit of the other species, by a little inferiority of size, and by s small appendage which terminates the carpels. Each carpel contains twe seeds, which, when ripe, spring from their cells, and are suspended, for a time, by a white, silky thread.

Varieties. A tree nearly allied to this species was discovered by John Bartrap, in the maritime parts of Georgia, particularly on the banks of the Altamaha, and was subsequently found by Mr. John Le Conte, in the western parts of Carolina and Georgia. It so closely resembles the Magnolia auriculata, except in size, which is much less, that it is regarded by most botanists as only a variety. It is usually described under the name of Magnolia pyramidata. The tree, according to Bartram, grows straight and erect, thirty feet or more in height, and of a sharp, conical form, much resembling the Magnolia acuminata in figure. It was first introduced into England in 1818, by John Lyon, and the original tree still exists in the nursery of Messrs. Loddiges. It is extremely difficult to propagate, which is done by imarching on the Magnolia auriculata.

Geography and History. The Magnolia auriculata, in its natural habitat, appears to be chiefly confined to a particular part of the Alleghanies. According to Michaux, it is nowhere found so abundant as on the steepest parts of the lofty mountains of North Carolina, known by the name of the Great Father, and Black Iron Mountains. It is sometimes found, however, on the steep banks of the rivers which rise in the Alleghanies, and on one side, roll their waters into the Atlantic. and on the other, to meet the Ohio.

This tree was discovered by John Bartram, from whom it was first received in England by Messrs. Loddiges, in 1786, and still exists in their nursery at Hackney. It was, probably, soon afterwards sent to France; because we find Madame Lemonnier, the widow of Michaux's patron and friend, describing a tree of this species, in her garden, in 1800, which was nine feet high, and had already flowered.

There is a Magnolia auriculata in the Bartram botanic garden, at Kingsessing, on the Schuylkill, fifty feet in height, with a trunk four feet in circumference. In the garden of Mr. D. Landreth, of Philadelphia, there is also another tree of this species, twenty-five years planted, thirty feet in height, with a trunk a foot in diameter.

The largest Magnolia auriculata in England is at White Knight's, which has been planted about forty years, and is more than thirty feet in height. There are several in the gardens about Paris, and some at Scéaux, which have attained a height of more than twenty feet.

Soil and Situation. 'The soil of the Alpine regions, of which this species is a native, is brown, deep, and of an excellent quality. The atmosphere in these situations, is continually charged with moisture, from the number of torrents which rush down from their summits. When cultivated, the soil should be free and deep, and the situation low, sheltered, and moist, rather than dry.

Propagation and Culture. As seeds are rather difficult to procure, the common mode of propagation is by layers, or by inarching on the Magnolia acuminata, which requires two years before the plant can be separated from the parent shoot. From the account given by Michaux, the Magnolia auriculata is found to multiply so fast from seeds, that, in its native forests, a thousand plants might be collected in a single day. Hence, the propagation of this species from seeds would be far preferable to any other mode. In England, annual shoots of young plants are from one to two feet or more, in length; and the height which the tree usually attains in ten years is from ten to fifteen feet.

Properties and Uses. The wood of the Magnolia auriculata is soft, spongy, and very light, and when dry, weighs only twenty-four pounds to a cubic foot. The bark has an agreeable, aromatic odour, and an infusion of it in some spirituous liquor, is employed as an excellent sudorific in rheumatic affections. 


\title{
Magnolia conspicua, \\ THE CONSPICUOUS-FLOWERED MAGNOLIA.
}

\author{
Synonymes.
}

\author{
Magnolia conspicua, \\ Magnolier yulans, \\ Yulans Bieberbaum, \\ Magnolia dai fiori grandi, \\ Yu lan, \\ Lily-flowered Magnolia,
}

\author{
(De Candolle, Prodromus. \\ $\{$ Don, Miller's Dictionary. \\ Loudon, Arboretum Britannicum. \\ France. \\ Germany. \\ ITALY. \\ China. \\ Britain and Anglo-America.
}

lily.

Derivations. The Chinese name, $\mathbf{Y} u$ lan, signifies the Lily-tree, from the resemblance of the flowers of this species to the

Engravings. London Botanical Magazine, pl. 1621 ; Loudon, A rboretum Britannicum, figure 34, vol. i., and pl. 12, vol. v.; and the figures below.

Specific Characters. Deciduous. Leaves obovate, abruptly acuminated, younger ones pubescent, expanding after the flowers. Flowers erect, 6-9-petaled. Styles erect.-Don, Miller's Dict.

\section{Description.}
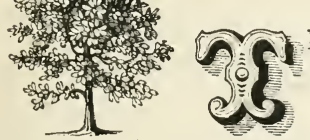

HE Magnolia conspicua, as its name indicates, is a beautiful and showy tree, and distinguishable from all others of the genus by the expanding of the flowers before any of the leaves. A full-grown tree, in its native country, is said to attain a height of forty or fifty feet, and it has arrived at nearly the same elevation in Europe and America. It assumes a regular, conical shape, with numerous branches and twigs, which generally have a vertical, rather than a horizontal direction; so that a large tree of this species, would probably be more fastigiate than any of its congeners. This tree, as well as those native of Asia generally, differs from the American species in having two opposite spathe-like bracteas enclosing the flower-buds, with ovaries somewhat distant, and in having

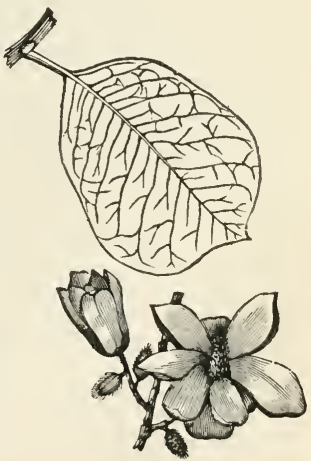
anthers bursting inwards. In young trees, the leaves are from six to eight inches in length, and from three to four inches broad. The flowers, which put forth in March, April or May, are of a milky whiteness, from six to eight inches in diameter, and emit a powerful odour. The fruit, which is of a deep-red colour, is of an irregular form, three or four inches in length, and often assumes fantastic shapes. It contains from one to four seeds, which usually mature, near New York, early in October. It is observed that at least one half of these seeds, when sown, prove abortive.

Varieties. This species has ripened seeds in various parts of Europe, and in the United States; and as it fertilizes readily with the Magnolia purpurea and gracilis, several varieties have already been produced, and many more may be expected. The two following are particularly worthy of cultivation:-

1. M. c. soulangeana, Loudon. Soulange's Conspicuous-flowered Magnolia. 
A notice of this variety will be found under the head of history. The chief ditference between this tree and the species, consists in its leaves being larger and more pointed, its flowers marked with purple within, and its fruit larger and containing more seeds.

2. M. c. ALEXandrina, Loudon. The Empress Alexandrina's Conspicuousflowered Magnolia. This variety so closely resembles the preceding, that it cannot be distinguished, except in flowering somewhat earlier.

Geography and History. The Magnolia conspicua is said to be indigenous to the southern provinces of China; and to be extensively cultivated there in the gardens of the emperor, and in those of all eminent persons, who can afford to procure it. It began to be cultivated in that country in the year 627, from which time it has always held the very first rank, as an ornamental tree, in their gardens, and is regarded by the Chinese poets as the symbol of candour and beanty. It is not only planted in the open grounds, and allowed to attain its full size; but dwarfs are kept in pots and boxes, and forced throughout the year, so as to keep up a perpetual supply of bloom in the apartments of the imperial palace. So highly is this tree valued, that a plant in flower, presented to the emperor, is thought a handsome present. In very severe winters, the trunks of the trees in the open air are sometimes wrapped round with straw ropes; but it never requires any other protection, even in the climate of Pekin.

The tree was first introduced into England by Sir Joseph Banks, in 1789; but it was many years before it attracted much attention, being considered merely as a green-house, or conservatory plant. Within the last twenty years, it has been discovered to be nearly as hardy as the American magnolias, and is now most extensively cultivated in the nurseries of Britain, continental Europe, and the United States. It flowers freely every year, as a standard in the neighbourhood of London, New York, and Philadelphia, when the wood has been properly ripened during the preceding summer; and at White Knights, in England; at Fromont, and various other places in France; and at Monza, in Italy, and Brooklyn, in New York, it has ripened seeds from which young plants have been raised.

At Fromont, near Paris, in front of the chateau of M. Soulange-Bodin, stands the largest plant of the Magnolia conspicua in Europe. It measures over forty feet in height, and twenty-four inches in circumference, two feet from the ground; and the diameter of the space covered by the branches is more than twenty-five feet. It flowers magnificently every year, at the end of March and beginning of April, and the perfume of its blossoms is perceived for some distance around. It was from the seeds of this tree that sprang the far-famed variety, Magnolia conspicua soulangeana, the leaves, wood, and general habits of which, are allied to those of the parent tree; but the flowers resemble in form those of the Magnolia purpurea, or of the Magnolia purpurea gracilis, and the petals are slightly tinged with purple. This variety was accidentally produced by fecundating the flowers of the Magnolia conspicua with the pollen of these of the Magnolia purpurea. The original plant of the Magnolia conspicua soulangeana, at Fromont, is more than twenty feet in height, and though it flowered several years before, it did not ripen seeds till 1834 . The seeds have been sown, and some new and interesting varieties produced from them.

The largest Magnolia conspicua in England is at Eastwell Park, in Kent, which is reputed to be more than forty feet in height. An original imported plant, trained against a wall at Wormleybury, in England, measured twentyseven feet in height, covered a space laterally of twenty-four feet, and had on it, in A pril, 1835, five thousand flowers!

In the garden of Mr. William Davison, in Brooklyn, New York, there is a Magnolia conspicua, ten years planted, twenty-four feet in height, with a head eighteen feet in diameter, which, in April, 1844, contained six thousand flowers ' 
In the same garden there is a Magnolia conspicua soulangeana ten years planted, twenty feet in height, with a head fourteen feet in diameter, which, in Mlay, 1844, produced eight hundred flowers. Both of these trees ripened their seeds early in October of the same year.

Soil and Situation. A rich, sandy loam seems to suit this species best ; but it will grow in any deep, free soil, properly drained, and moderately enriched.

The situation, when it is to be treated as a standard, ought to be sufficiently open to admit of ripening the wood in autumn, and yet not so warm as to urge forward the flower-buds prematurely in spring, as they are very liable to be injured by frost, from which they should be protected by some kind of covering. The tree shows itself in its greatest beauty against a wall, where it can be protected more conveniently by a projecting coping, or otherwise. In warm situations, sloping to the south or south-east, it has the finest effect planted in front of a bank of evergreens; and, indeed, wherever it is planted, evergreens should be growing near it, so as to form a back ground, on account of the flowers expanding before the unfolding of the leaves.

Propagation and Culture. The Magnolia conspicua and all its varieties are propagated by layers, or by inarching on the Magnolia purpurea, or acuminata. When grafted on the former, the tree is comparatively small, by which it is rendered very convenient for use as a shrub, or for growing in pots; but when it is intended to form a tree, it should either be grafted on the Magnolia acuminata, or raised from layers or seeds. It generally requires two years before the plant can be separated from the parent stock. The young shoots are from twelve to eighteen inches in length, and the tree, in ten years, will attain a height of ten or fifteen feet, flowering the second or third year after grafting.

Properties and Uses. Besides the value of the Magnolia conspicua as an ornamental plant or tree, the Chinese pickle the flower-buds, after having removed their calyxes, and use them for flavouring rice. Medicinally, the seeds are taken in powder, in colds, and inflammations of the chest. It is also regarded as stomachic; and water, in which it has been steeped, is used for bathing the eyes when inflamed, and for clearing them of gum.

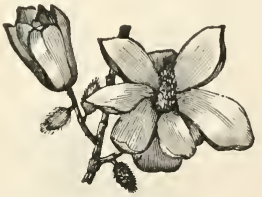




\section{Magnolia purpurea, THE PURPLE-FLOWERED MAGNOLIA.}

Synonymes.

\begin{tabular}{|c|c|}
\hline Magnvia purpurea, & $\begin{array}{l}\text { DE CANDolde, Prodromus. } \\
\text { Don, Miller's Dictionary. } \\
\text { Loudon, Arboretum Britannicum. }\end{array}$ \\
\hline Magnolier bicoloré, Magnolier & France. \\
\hline $\begin{array}{l}\text { Rother Bieberbaum, } \\
\text { Obovate-leaved Magnolia, }\end{array}$ & $\begin{array}{l}\text { Germany. } \\
\text { Britain and Anglo-America. }\end{array}$ \\
\hline
\end{tabular}

Derivations. The French names imply Two-coloured Magnolia, in allusion to the colour of the flowers. The German name signifies Red Beaver-tree.

Engravings. London Botanical Magazine, pl. 390 ; and Loudon, Arboretum Britannicum, i., figure 36.

Specific Characters. Deciduous. Leaves obovate, acute, reticulately veined; almost smooth. Flowers rect, of 3 sepals, and 6 obovate petals. Styles very short.-Don, Miller's Dist.
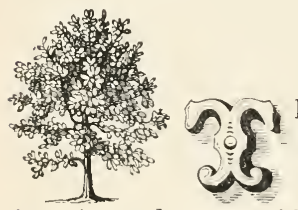

HE Magnolia purpurea is a shrub, from six to twenty feet high; native of Japan, and introduced into England in 1790 ; propagated by seeds and layers in the gardens of China, Europe, and America; grows in open situations, in sandy peat, with loam, or in sand and clay, well-drained, with manure.

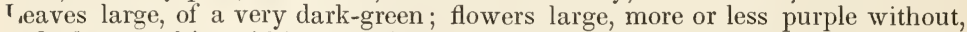
and always white within; put forth in March, April or May, but do not fully expand till a day or two before they drop off. 'The bark, when bruised, has an aromatic odour.

Varieties. Although plants of this species may exhibit slight shades of difference, there cannot be truly considered but one or two distinct varieties, the $\boldsymbol{M}$. $\boldsymbol{p}$. sracilis, and the M. p. obovata-pumila, Casoretti. 'The chief difference between the former and the species, consists in being less hardy, rather more fastigiate in its form; leaves of a paler green, and somewhat narrower in shape; flowers longer and more slender, the points of the petals slightly turned back, and exteriorly of a dark-purple.

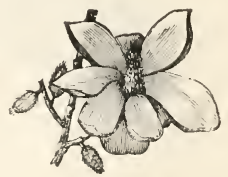




\title{
Genus LIRIODENDRON, Linn.
}

\author{
Magnoliaceæ. \\ Syst. Nat. \\ Polyandria Polygynia.
}

Derivation. The name of this genus is derived from the Greek leirion, a lily, and dendron, a tree; from the resemblance of its flowers to the lily, but more nearly to the tulip.

Generic Characters. Carpels 1-2-seeded, disposed in spikes, indehiscent, deciduous, drawn out into a wing at the apex. Calyx of 3 deciduous sepals. Corolla of 6 petals, conniving into a bell-shaped flower.-Don, Miller's Dict.

20.720 IRIODENDRON is a genus comprising but one species, a tree of the first rank, native of North America, and extensively cultivated for ornament, in Europe, and America.

Among the Magnoliaceæ, there are probably other trees, adapted to the climate of the United States, that are worthy of cultivation. (58) among which, are the Magnolia insignis, of Dr. Wallich, growing on the mountains of Nepal; also, the Michelia lannginosa, excelsa, kisopa, and doltsopa, all of which are indigenous to the elevated regions of the Himalayas. The Michelia doltsopa is one of the finest trees of Nepal, yielding a fragrant wood, much used in that country in civil architecture. The Michelia excelsa, according to Dr. Wallich, produces a valuable timber, of a fine texture, at first greenish, but soon changing to a fine yellow. 


\title{
Liriodendron tulipifera, THE TULIP-BEARING LIRIODENDRON.
}

\author{
Synonymes. \\ Liriodendron tulipifera, \\ (Linnaes, Species Plantarum. \\ De Candolle, Prodromus. \\ Michaux, North American Sylva. \\ Bigelow, Medical Botany. \\ Don, Miller's Dictionary. \\ Loudon, Arboretum Britannicum. \\ Torrey and Gray, Flora of North America. \\ Tulipier de Virginie, Arbre aux tulipes, France. \\ Virginischer Tulpenbaum, GERMANY. \\ Liriodendro tulipifero, ITALY. \\ Virginian Poplar, Tulip-bearing Lily- Britarn.
tree, Saddle-tree, \\ tree, Saddle-tree,
White Poplar, Yellow Poplar, \\ Tulip-tree, White-wood, Poplar, Old
Wife's Shirt-tree,
}

Derivations. The specific name is derived from the Latin tulipa, a tulip, and fero, to bear, on account of the resemblance the fowers of this tree bear to those of tulips. It is called Poplar, from its general appearance to trees of the genus $\boldsymbol{P}$ opulus; White-wood, and Yellow Poplar, from the colour of its timber; Canoe-wood, from the use to which it is applied by the native Indians; and Saddle-tree, from the form of its leaves. The French and German names are literal translations of Virginian Tulip.tree.

Engravings. Michaux, North American Sylva, pl. 61; Audubon, Birds of America, pl. xii.; Loudon, Arboretum Britannicum, v., pl. 13; and the figures below.

Specific Characters. Leaves smooth, truncate at the top; 4-lobed, resembling a saddle in shape. Flow ers large, solitary, terminal, variegated with green, yellow, and orange colour; furnished with two deciduous bracteas under the flowers.-Don, Miller's Dict.

\section{Description.}

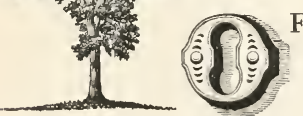

$F$ all the deciduous trees of North America, the Tulip-tree, next to the sycamore, (Platanus occidentalis,) attains the amplest dimensions; while the perfect straightness and uniform diameter of the trunk, the more regular distribution of its branches, and the greater richness of its foliage and flowers, give it a decided superiority over that tree, and entitle it to be considered one of the most magnificent productions of the temperate zones. It usually attains a height of sixty or eighty feet, with a diameter varying from eighteen inches to three feet; although, in favourable localities, it has been known to arrive at a height of one hundred and twenty to one hundred and forty feet, with a diameter of more than seven feet. The

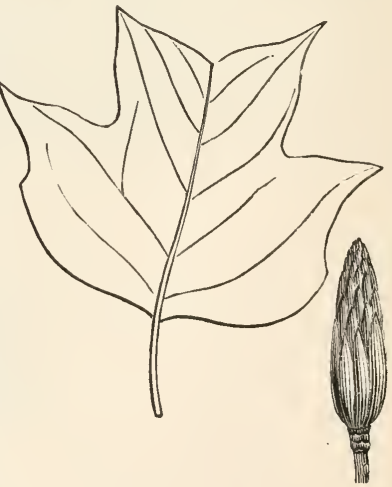
bark of the trunk, till it exceeds seven or eight inches in diameter, is smooth and even; but afterwards it begins to crack, and the depth of the furrows is in proportion to the size and age of the tree. In the development of its leaves it differs from most other trees. The leaf-buds. in general. are comnosed of scales closely 
imbricated, which in spring are distended by the growth of the minute bundle of leaves that they enclose, till they finally fall off. 'The terminal bud of each shoot swells considerably before it gives birth to the leaf. It forms an oval envelope, containing the young leaf, which is produced to the light as soon as it has acquired sufficient strength to endure the influences of the atmosphere. Within this envelope is found another, which, after the first leaf is put forth, swells, bursts, and gives birth to a second. On young and vigorous trees, five or six leaves issue, successively, in this manner, from one bud. Till the leaf has acquired its growth, it retains the two scales which composed the envelope, and which are now called stipules. In spring, when the weather is warm and humid, the growth of the leaves is very rapid. They are six or eight inches broad, borne on long petioles, alternate, somewhat fleshy, smooth, and of a pleasing green colour. They are divided into three lobes, of which the middle one is horizontally notched at its summit, and the two lower ones rounded at the base. This conformation is peculiar to this tree, and thereby renders it distinguishable from all others. In Carolina and Georgia the flowers appear in April and May, and in the northern parts of the United States, in June and July. On detached trees, they are large, brilliant, very numerous, and variegated with different colours, among which, yellow predominates. They have an agreeable odour, and, surrounded by the luxuriant foliage, they produce a fine effect The fruit is composed of numerous thin, narrow scales, attached to a common axis, and forming a conical spike, two or three inches in length. Each spike or fruit contains sixty or seventy carpels, of which, never more than a third, and in some seasons, not more than seven or eight in the whole number are productive. It is also observed, that during ten years after it begins to yield fruit, nearly all the seeds, when sown, prove abortive; and that, on large trees, the seeds from the highest branches are the best.

Varieties. The Liriodendron tulipifera comprises three varieties, which may be regarded as distinct from the species.

1. L. т. овтusiloвa, Loudon. Blunt-leaved Tulip-tree, with blunter leaves than the original, but in no other respect different from it.

2. L. т. Acutifolia, Loudon. Acute-leaved Tulip-tree, with leaves smaller and more acutely cut than either the preceding variety or the species.

3. L. T. Flava, Loudon. Yellow-flowered T'ulip-tree, very rare.

Geography and History. The southern extremity of Lake Champlain, according to Michaux, may be considered in its natural distribution, as the northern, and the river Connecticut as the eastern limit of this tree. It is only westerly of the Hudson, and southerly of the forty-third degree of latitude, that it is frequently met with, and fully developed. It is multiplied in the middle states, in the upper parts of Carolina and Georgia, and still more abundantly in the western states, particularly in Kentucky, where it displays its most powerful vegetation. Its comparative rareness in the maritime parts of the Carolinas and of Georgia, in the Floridas, and in lower Louisiana, is owing less to the heat of summer than to the nature of the soil, which, in some parts, is too dry, as.in the pine-barrens, and in others too wet, as in the swamps which border the rivers. It is commonly found mingled with other trees, such as the hickories, the blackwalnut, and butternut, the Kentucky coffee-tree, (Gymnocladus canadensis,) and the wild cherry-tree; but it sometimes constitutes, alone, considerable tracts of the forest, as was observed by the elder Michaux, on the road from Beardstone to Louisville, in Kentucky. 'The artificial geography of this tree may be said to embrace the middle region of Europe, from Berlin and Warsaw, on the north, to the shores of the Mediterranean and Naples, on the south; Ireland on the west, and Crimea on the east. It is successfully cultivated along the maritime parts of the United States, from Newburyport, in Massachusetts, to St. Mary's, in Georgia. 
The period at which the tulip-tree was iirst introduced into England is uncertain. The honour is said to lhave been conferred on the Earl of Nolfolk, as far back as 1663. It is certain that it was cultivated by Dr. Henry Compton, at Fulham, in 1688, at which time it was wholly unknown as a timber-tree. According to Miller, Mr. Darley, at Hoxton, and Mr. Fairchild, were the first who raised this tree from seeds; and from their nurseries it is probable that the numerous old trees which are spread all over Britain were procured. The oldest tree in England, estimated at over one hundred and fifty years of age, is at Fulham palace. It is about fifty feet high, and its trunk, at one foot from the ground, is three feet in diameter. The largest tree in Britain is in Somersetshire, at Hestercombe, which is one hundred feet in height, with a trunk three feet in diameter, and ripens seeds every year.

The first notice which we have of the tulip-tree on the continent, is in the "Catalogue of the Leyden Garden," published in 1731. From the number of these trees existing in France, the south of Germany, and Italy, there can be little doubt it spread as rapıdly in those countries as it did in Britain. Public avenues are planted of it in Italy, and as far north as Strasburg and Mentz. It stands the open air at Vienna, and attains a large size there; but it will not endure the climate north of Warsaw, nor Moscow, without protection. In the grounds of the palace of Läcken, near Brussels, there is a tree which has a clear stem three feet in diameter, with a compact globular head. When Lacken belonged to France, the palace was occupied by the Empress Josephine, who brought her gardener from Paris; and the poor man, while he was gathering seeds from this tree, fell from it, and broke his neck. At Schwöbber, near Hanover, there is growing, in alluvial soil, near water, a tree more than one hundred and twenty years old, and eighty feet in height, with a trunk two feet in diameter, and an ambitus of thirty feet. In Italy, the tulip-tree attains a height of seventy or eighty feet, flowers freely, and ripens seeds every year.

The elder Michaux measured a tulip-tree, three and a half miles from Louisville, Kentucky, which was twenty-two feet and a half in circumference five feet from the ground, and from one hundred and twenty to one hundred and forty feet in height. In 1842, there was felled from the estate of Mr. John Lewis, in Llangollan, Kentucky, a tulip-tree, eight feet in diameter, near the ground, and five feet in diameter seventy-five feet above. The trunk was perfectly straight and sound, and was sawed into boards of common lengths.

At Green Point, Bushwick, near New York, on the estate of Mr. N. Bliss, there is a tulip-tree which has a circumference of twenty-one feet at three feet above the groumd, and a height of seventy feet.

In $180 \%$, there existed a tulip-tree, in Hamilton, Adams county, Pennsylvania, noticed by John Pearson, in a communication to Dr. James Mease, in the "Memoirs of the Philadelphia Society for promoting Agriculture," for that year, which had a circumference of thirty-six feet, with a trunk thirty or forty feet to the forks, a large head, and, to all appearances, perfectly sound. In the same work, he mentions another tree as growing near the Virginia head of the river Roanoke, which was thirty-nine feet in circuniference four feet from the ground, apparently sound, and about forty feet to the forks.

Soil and Situation. The Liriodendron tulipifera, in its natural habitat, delights only in deep, loamy, and extremely fertile soils, such as are found in the rich bottoms, lying along the rivers, and on the borders of the great swamps which are enclosed in the forests. Like almost all other trees, however, it will grow on soils of different qualities, and have its timber and other properties affected by the circumstances in which it is placed. But, according to M. Du Hamel, it neither thrives in France on a dry, arid, gravelly soil, nor on one with a subsoil of clay, or marl. The most rapid-growing young tulip-trees in England, it is said, were 
in a deep, sandy loam, in a rather moist climate, in the West Riding in Yorkshire.

The situation most favourable to this tree, is one which, while it is sheltered from high winds, is at the same time, sufficiently exposed to the light and air to admit of the maturation of its leaves on every side, and the perfect ripening of its wood, without which it can neither resist the severe frosts of winter, nor form blossom-buds. At Kinlet, in Worcestershire, England, there is a tulip-tree, in a sandy loam, and partially sheltered situation, the lower part of which always comes into leaf before the upper part has the least appearance of doing so. 'The lower part is sheltered by high ground, while the upper part is exposed to a strong west wind. It flowers freely, and has a splendid appearance at that season, as also in autumn before it sheds its yellow leaves. If it were desired to grow the tulip-tree for the purpose of forming straight, clean timber, it should be placed in a close plantation, where one plant would draw upon another.

Propagation and Culture. The Liriodendron tulipifera is seldom, if ever, propagated otherwise than by seeds, which come up best in very fine mould, or sandy loam, in a shady situation, kept rather moist; but the varieties are, of course, multiplied by layers, budding, grafting, or inarching. When the seeds are sown in autumn, they generally come up in the following spring; but, sown in spring, or the beginning of summer, they generally remain a year in the ground. In France, and occasionally in England, the obtuse-lobed variety is raised by layers, or inarching; but, in either case, it requires two or three years before the plant can be separated from the parent stock. The tuiip-tree, like the magnolias, having roots furnished with but few fibres, does not transplant readily; and therefore, the plant ought either to be kept in pots, or, if in the free ground, transplanted into the nursery every year; or, if neither of these modes be practicable, they should be removed to their final situation, when not more than two, or at most, three years old. The progress of growth of young trees, in England, in favourable situations, has been at the rate of sixteen feet in ten years.

Insects. From the bitter qualities of its leaves, the Liriodendron tulipifera does not seem to be much attacked by insects. In Smith and Abbot's "Insects of Genrgia," it is stated, that the Phalana liriodendraria, or tulip-tree butterfly, feeds upon it. The insect went into the ground in Georgia, May 15th, came out the 5th of June; others, which went in the 11th of July, came forth on the 1st of August. The moth sits on the bodies of the trees, but is not very common.

Properties and Uses. The timber of the Liriodendron tulipifera, though classed among light woods, is yet, much heavier than that of the common poplar; its grain is equally fine, but more compact, and the wood is easily wrought, and polishes well. When dry, a cubic foot weighs twenty-five pounds. It affords excellent charcoal, the product of which, from dry wood, is twenty-two per cent. The heart-wood, when separated from the sap, and perfectly seasoned, long resists the influence of the air, and is rarely attacked by insects. Its greatest defect, when employed in wide boards, and exposed to the weather, is, that it is liable to shrink and warp, by the alternations of moisture and dryness; but this defect is, in a great measure, compensated by its other properties, and may be, in part, owing to its not being allowed sufficient time to be properly seasoned. The nature of the soil on which it grows, has so striking an influence upon the colour, and quality of this wood, that mechanies distinguish it by the names of White Poplar and Yellow loplar. The external appearances which mark these varieties are so equivocal, that they can only ascertain to which of them a tree belongs, by cutting it. It is known, in general, that the white poplar grows in dry, gravelly, and elevated places; and is recognized, too, by its branchy summit, and by the small proportion which the light yellow heart-wood bears to 
the sap-wood. The grain, also, is coarser and harder, and the wood decays more speedily; hence, it is neglected when the other variety can be obtained. The yellow poplar possesses every quality requisite to fit it fur a great variety of uses. At New York and Philadelphia, and in the adjacent country, it was formerly employed in the construction of houses, for rafters, and for joists of the upper stories, for which purposes it was esteemed, on account of its lightness and strength, but as the timber has become scarce, pine and spruce have taken its place. In the middle, southern, and western states, where this tree abounds, it is more generally used in building, and is considered as the best substitute for pine, red cedar, and cypress, and serves for the interior work of houses, and sometimes for the exterior covering. The panels of doors and of wainscots, and the mouldings of chimney pieces, are made of this wood. In some states, shingles are made of it, about fifteen inches long, which are preferred to those made of pine, because they are more durable, and are not liable to crack from the effects of intense frost and sunshine. In most of the large cities and towns in the United States, boards sawn from this tree, are generally used for the panels of carriages. When perfectly dry, they take the paint well, and admit of a brilliant polish. Large quantities of this wood are consumed in the manutacture of trunks, covered with cloth, or skins; of tables, and bedsteads, which are stained, in imitation of mahogany, and for the seats of chairs. It often enters into the composition of bureaus, and cabinet-work generally, particularly when it is inlaid with veneers. It is also used for the circular boards and wings of winnowing machines, also for the construction of sleigh and wagon bodies, where white pine is not abundant, and for the interior of canal and steamboats. As it is easily wrought in the lathe, it is often used for bowls, brush, and broom heads and handles, and numerous other articles among turners' wares. Among agriculturists, trunks of these trees are often formed into eating and drinking troughs for their animals, which, when exposed to the weather, last as long as those made of chestnut and butternut. In some parts of the country, the wood of this tree is employed for the rails of rural fences. It is found useful, also, in the construction of bridges, as it unites lightness with strength and durability. The Indians who formerly inhabited the middle states, made choice of this tree to form their canoes, for which purpose it was well adapted. The trunk being of great length and diameter, and the wood being light and strong, it was sometimes wrought by them into canoes that would carry twenty or more persons. It is still used by the Indians and others in the western country, for the same purpose. Michaux remarks that, when one of these trees is felled, the chips of the heart-wood that are left upon the ground, particularly those which are left half buried in the leaves, suffer, at the end of three or four weeks, a remarkable change; the lower part becomes of a dark-blue, and they exhale a fetid, ammoniacal odour; though the live part of the bark of the trunk, branches, and still more of the roots, has an agreeable smell, and a very bitter taste, and, even under the same circumstances as the heart-wood, it neither acquires the blue colour, nor the disagreeable smell.

The bark of this tree is considered, by some, as scarcely inferior to the cinchona, being a powerful tonic and antiseptic. The aromatic principle appears to reside in a resinous part of the substance of the bark, and, when used, stimulates the intestinal canal, and operates as a gentle cathartic. In many instances, the stomach cannot support it, unless each dose is accompanied by a few drops of laudanum. These properties were well known to the American Indians, who employed the bark of the roots of this tree for the cure of intermittents. 


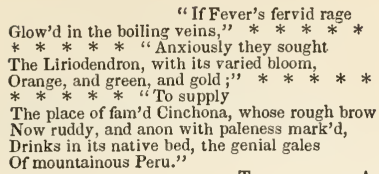

Traits of the Aborigines.

And even at the present day, in parts of the country where this tree abounds, some of the inhabitants steep the bark of the roots with an equal portion of dogwood bark, in brandy, during eight days, and take this tincture as a remedy for the intermittent fever. The bark, reduced to powder, and given in substance to horses, appears to be a pretty certain remedy for worms.

In Europe, the uses of the Liriodendron tulipifera are limited almost entirely to those of ornament; for there are numerous trees which would produce excellent timber, if cut down. We have never heard of any having been felled for this purpose. Every possessor of a tulip-tree, in Europe, values it far higher for its beauty in a living state, than for its products, or the artificial application of them. On the continent, where trees ripen seeds, they may be considered as affording some profit from that source. 


\title{
Genus ANNONA, Linn.
}

\author{
Anonacex. \\ Syst. Nat. \\ Polyandria Polygynia.
}

Synonymes.

Annona, Anona, Asimina, Orchidocarpum, Porcelia, Uvaria,

OF Authors.

\author{
Anone, Corossol, \\ Flaschenbaum, \\ Asimina, \\ Anona, \\ Custard Apple,
}

\author{
France. \\ Germany. \\ ITALY. \\ Spain. \\ Britain and Anglo-America.
}

Derications. The name Annona was given to this genus by Linnæus, who derived it from a South American fruit of a grate ful flavour, called anona, which signifies a mess, or dish of food, to be eaten with a spoon. Asimina was Latinized by M. Adanson, from a word of Canadian origin of a doubtful meaning. Orchidocarpum was probably intended to express a resem. blance between the fruit of this genus, and that of some species of Orchis. Porcelia is a name given by Ruiz, in honor of Anto. nio Porcel, a Spanish promoter of botany. Uvara was also applied to this genus hy Linneus, and is derived from the Latin uva, a grape. The German name, Flaschenbaum, signifies Flask-tree, from the shape of the fruit. The French and Italian names are merely modifications of the Spanish one. It is called Custard.Apple, on account of the pulp of the fruit often being eaten with a spoon, after the manner of eating a custard.

Generic Characters. Calyx 3-parted. Petals 6, spreading, ovate-oblong, inner ones smallest. Anthers numerous, nearly sessile. Ovaries many, but for the most part only 3 , ovate or oblong. Carpels the same number as the ovaries, baccate, sessile. Seeds many, disposed in a single or double row.-Don, Miller's Dict.

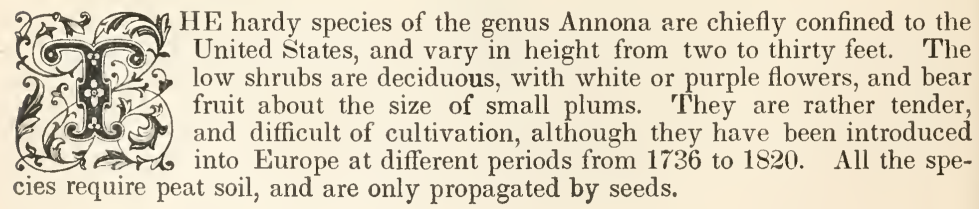




\section{Annona triloba, THE THREE-LOBED-CALYXED ANONNA.}

\section{Synonymes.}

Annona triloba,

Anona triloba,

Asimina triloba,

Uvaria triloba,

Anone à trois lobes, Asiminier de Virginie,

Dreylappiger Flaschenbaum,

Annona,

Anona,

Asiminier,

Papaw,
Linneres, Species Plantarum

( De Candolle, Prodromus.

$\{$ Michaux, North American Sylva.

Don, Miller's Dictionary.

Loudos, Arboretum Britannicum.

ToRrey and Gray, Flora of North America.

France.

Germany.

ITALY.

Spain.

French Louisiana.

Britain and Anglo-America.

Engravings. Michaux, North American Sylva, pl. 60; Loudon, Arboretum Britannicum, i., figure 39; and the figures below.

Specific Characters. Leaves oblong-obovate, acuminate; petals dark-purple; the exterior orbicular, 3 or 4 times the length of the sepals.-Torrey and Gray, Flora.

\section{Description.} height, densely clothed with long leaves, lying over one another, in such a manner as to give a peculiarly imbricated appearance to the entire plant. The trunk is covered with a silver-gray bark, which is smooth and finely polished. 'The leaves are borne on short petioles, and are alternate, five or six inches in length, and of an elongated form, widening from the base to the summit. They are of a fine texture, and the upper surface is smooth and brilliant. The flowers appear in South Carolina and Georgia in March, and a month or six weeks later farther north. They are campanulate and drooping, and put forth before the leaves; the outer petals are purple,

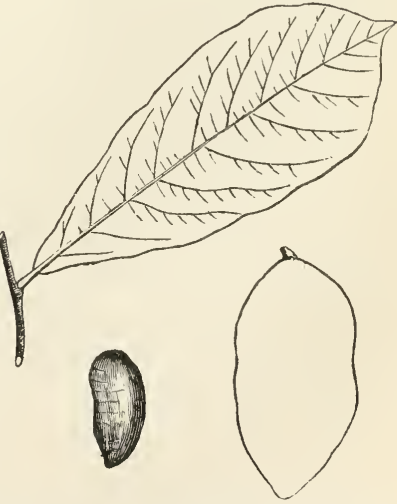
and vary in colour in different plants ; in some they are very dark, and in others light, inclining to yellow. The fruit ripens in August, and is about three inches long, and one and a half inches thick, yellow, ovate, oblong, irregular, and swelling in to inequalities. It contains a yellow pulp, of a sweet, luscious taste, in the middle of which lie, in two rows, twelve seeds, or triangular stones, divided by as many thin membranes.

Geography and History. Michaux did not observe this tree north of the river Schuylkill; and it appears to be unknown, or extremely rare, in the low and maritime parts of the southern states. It is not uncommon in the bottomlands whirh stretch along the rivers of the middle states, where, at intervals, it 
forms thickets exclusively occupying several acres. In Kentucky and the western part of Tennessee, it is sometimes seen also, in the forests, where the soil is luxuriantly fertile; of which its presence is an infallible proof. In these forests it attains the height of thirty feet, with a trunk six or eight inches in diameter, though it usually stops short of half of this height. According to Dr. William Baldwin, the papaw grows spontaneously in the island of Bermuda; and in Smith's "History of Virginia," it is stated to have been introduced on that island prior to 1623 .

This species was introduced into England by Peter Collinson in 1736; and 1t has since become known in the principal botanic gardens throughout Europe. Miller states that the largest plant he had seen was in the Duke of Argyll's garden, at Whitton, which flowered every year. Another plant is mentioned as growing at Purser's Cross, which ripened fruit.

Soil, Situation, $\& \bullet c$. This, as well as most of the other species of annona, generally grows in shady places, and in a sandy soil. All the species, when cultivated, require peat soil, and are propagated from seeds. The papaw seldom produces shoots exceeding five or six inches in length; hence a plant, in ten years, does not reach above three or four feet in height, and will not flower till of fifteen or twenty years' growth. It may be considered as a curious, slowgrowing, deciduous shrub, well deserving a place in gardens, but which ought always to be isolated, and at some distance from rapid-growing plants.

Properties and Uses. The wood of the Annona triloona is spongy, extremely soft, destitute of strength, and applicable to no use in the mechanic arts. All parts of the tree have a rank, if not a fetid, smell; and the fruit is relished by few persons, except negroes. A spirituous liquor has been made from it, bu+ it is of little worth. 


\section{Genus BERBERIS, Linn.}

Berberaceæ.

Syst. Nat.
Hexandria Monogynia.

Synonymes.

Berberns,
OF Authors.

France.

Germany.

Portugal.

ITALY.

Spain.

Britain and Anglo-America.

Derivations. The word Berberis is of very doubtful origin. Some derive it from the Arabic berberys, a word used for this olant by Averrhoes and other writers on medicine; others from the Greek word, berberi, signifying a shell, from the leaves of he common kind having a hollow surface. Bochart derives it from the Phænician word, barar, which signifies shiny like a hell. Gerard says, that it is corrupted from the word amyrberis, the name given to this plant by Avicenna. Du Hamel derives

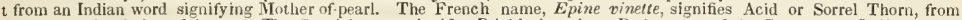
he taste of the fruit and leaves. The Spanish name signifies Prickly-hawthorn Berberry; and the German and Italian names are derived from the botanic one.

Generic Characters. Sepals 6, guarded on the outside by 3 seales. Petals 6 , with 2 glands on the inside of each. Stamens toothless. Berries 2-3-seeded. Seeds 2, rarely 3, laterally inserted at the base of the berries, erect, oblong, with a crustaceous coat and fleshy albumen. Cotyledons leafy, elliptical. Radicle long, capitellate at the tip.-Don, Niller's Dict.

LL the species of Berberis are shrubs from two to twenty feet in height: in a wild state, and sometimes attain an elevation of thirty feet, when cultivated. They all throw up numerous side-suckers, and the stronger-growing species, if these were carefully removed, might be formed into very handsome small trees. In all the species, the flowers are yelow. The fruit is generally red, always acid, and more or less astringent. The rritability of the stamens, more particularly those of the Berberis vulgaris, canlensis, and sinensis, the flowers of which expand, is a very remarkable property in vegetable economy. When the filament is touched on the inside with the point of a pin, or any other hard instrument, the stamens bend forward towards the pistil, touch the stigma with the anther, remain curved for a short time, and then partially recover their erect position. This is best seen in warm, dry weather. The cause of this curious action, like that of all other vital phenomena, is unknown. All that has been ascertained concerning it is, that the irritability of the filament is affected differently by different noxious substances. It has been found by Messrs. Macaire and Marcett, that, if a berberry is poisoned with any corrosive agent, such as arsenic, or bicloride of mercury, the filaments become rigid and brittle, and lose their irritability; while, on the other hand, if the poisoning be effected by any narcotic, such as prussic acíd, opium, or belladonna, the irritability is destroyed by the filaments becoming so relaxed and laccid, that they can be easily bent in any direction. In the original position of the stamens, the anthers are sheltered from rain by the concavity of the petals. Thus, probably, they remain till some insect comes to extract honey from the base of the flowers, and, thrusting itself between the filaments, unavoidably touches them in the most irritable part, and in this manner, the impregnation of the germs takes place.*

Geographical Distribution. Few genera of plants are more generally disseminated over the globe than the berberis. At least twenty species have been discovered, either in Europe, northern and central Asia, or in North and South America, most of which have been introduced into Britain, and treated as shrubs or small ornamental trees. 


\section{Berberis vulgaris, \\ THE COMMON BERBERRY.}

\section{Synonymes.}

Berberis vulgarns,

Epine vinette,

Gemeine Berberitze,

Berberi ordinario, Spino vinetto,

Espina de majuelas,

Berberry, Barberry, Pipperidge-Bush,

\author{
(Linnæeus, Species Plantarum. \\ De Candolle, Prodromus. \\ $\{$ Don, Miller's Dictionary. \\ Lowdon, Arboretum Britannicum. \\ Torrey AND Gray, Flora of North America. \\ FRANCE. \\ GERMANy. \\ ITALY. \\ SPAIN. \\ Britain and Anglo-America.
}

Engraxings. Willdenow, Berlinische Baumzucht, pl. 39; Loudon, Encyclopædia of Plants, figure 4922; and the figures below Specific Characters. Spines 3-parted. Leaves somewhat obovate, ciliately serrated. Racemes many-flow ered, pendulous. Petals entire.-Don, Niller's Dict.

\section{Description.}

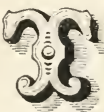

HE Common Berberry, in its wild state, is seldom found higher than six to ten feet, but when cultivated it may be grown to nearly thirty feet in height. The stems are upright, and much branched towards the top; smooth, slightly grooved, and covered with a whitish, or ash-coloured bark, which is of a bright yellow within. The main stem soon becomes so surrounded by side-suckers, as to be concealed by them; so that, even when the height of the plant is that of a tree, its character is still that of a bush. The blossoms are yellow, and, in general, are abundant, and produce a fine appearance in April, May, and June; their odour is offensive when near, but not disagreeable at a short distance. The fruit is oblong-oval, which at first is green, and, when ripe, is red, white, yellow, purple, or black, according to the variety; and it is so acid that birds seldom touch it.

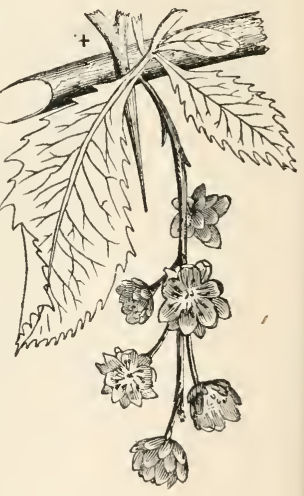

Varieties. These are numerous. Those recognized by Messrs. De Candollt and Don, are as follows:-

1. B. v. alba. Fruit white.

2. B. v. violacea. Fruit violet-coloured.

3. B. v. purpurea. Fruit purple.

4. B. v. NIGRA. Fruit black; leaves oblong; ciliately serrated; serratures few.

5. B. v. Dulcrs. Fruit red, less acid than the common variety; leaves of a bright, shining green. Native of Austria.

6. B. v. Asperma. Fruit destitute of seeds, in old plants. It is said by Du Hamel, that this variety produces the best fruit for preserving; and it is from is that the delicious confitures d'epine vinette, for which Rouen is so celebrated. are made.

Geography and History. The berberry is found wild in most parts of Eurnpe and in many part's of $\Lambda$ sia and America. In the warmer parts of the two list 
named countries, it grows on mountains, and in the colder parts of Europe and America, in plains, as in Norway, near Christiania, and in Massachusetts, north of Boston. It also grows on Mount Lebanon, and on Mount Atna; in which last situation it becomes a low shrub, in the upper zone of vegetation. In England it is found indigenous in woods and hedges, more especially on calcareous soils. It is also indigenous in Scotland and Ireland, but not very common. It was doubtless introduced into the United States from Europe, and has naturalized itself in waste places, and about cultivated grounds in the northern states, and in the British American provinces. The plant is mentioned by Pliny; and, among moderns, it appears first to have been recorded by Bauhin, in his "Pinax," and subsequently by all the writers on plants, under different names, till the time of Ray, in 1686 and 1688, who first called it berberis; which name was afterwards adopted by Linnæus, and by all botanists since his time.

Propagation and Culture. The original species of the Berberis vulgaris is propagated in the nurseries by seeds, and the varieties by suckers. For ordinary purposes, no plant requires less culture; but, to produce large fruit, it should be planted in a deep, well-manured, somewhat calcareous soil, and be constantly freed from side-suckers. The racemes of the blossoms should be thinned out, in order to reduce the number of bunches of fruit, and to increase its size. When the berberry is intended to become an ornamental tree, it should be trimmed, with a straight stem, to a height of eight or ten feet, and all suckers from the roots, and all side-buds from the stem, should be removed the moment they appear, and then suffered to branch out into a fine, orbicular, or drooping head. So treated, it forms a singularly beautiful tree, or shrub, and will sometimes endure for two or three centuries, without increasing much in size, after thirty years. It may also be employed for hedges, and as it patiently bears the shears, it may be shorn to any desirable form. The rate of growth, when the plant is young, is rapid; for the first five or six years, it will nearly attain its maximum height, unless the side-branches be removed.

Diseases, $\mathscr{S}^{\circ} c$. The Berberis vulgaris is subject to a disease called mildew, (Acidium berberidis, ) which, when magnified, is found to consist of a number of small orange-cups, with a fine film over each, as shown in the adjoining figure. When ripe, these films burst, and the tops of the cups assume a ragged, uneven appearance, in which state they look like white fungi. The cups are filled with innumerable little cases, containing seeds or sporules, and these constitute the bright-orange powder, that is seen on the leaves and flowers of the berberry, and was long supposed to

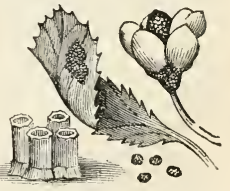
be the blight on corn both in Europe and America. This opinion, though totally unfounded, is of unknown antiquity. This error has been ably, and scientifically refuted by Messrs. Du Hamel, Broussonet, and Drs. Grenville and Lindley. The blight on corn is generally a species of uredo, and does not correspond in botanical characters with the æcidium. One of the principal reasons why corn will not thrive in the immediate vicinity of the berberry, is, on account of the meagreness of the soil in which it often grows, it being impoverished by its creeping root.

Properties and Uses. The wood of the berberry is hard and brittle, of a yellow colour, and contains a large white pith. It is of but little use in the arts except for dying. The inner bark, both of the stems and roots, affords a yellow dye. The leaves are agreeably acid, and, according to Gerard, were used, in his time, to season meat with, instead of a salad, like sorrel. The berries are not eaten raw, but are excellent, when preserved with their own weight of sugar or syrup, or candied. They are also made into jelly and rob, both of which are not only delicious to the taste, but extremely wholesome and they are pickled ir 
vinegar, when green, and substituted for capers. In some countries in the north of Europe, the berries are used instead of lemon, for flavouring punch; and, when fermented, it produces an acid wine, from which tartar is procured by evaporation. They are also in general use for garnished dishes. Medicinally, the berries, leaves, and roots, are powerfully acid and astringent; the bark is purgative and tonic; and the berries, when bruised and steeped in water, make a refreshing drink, in fevers. The astringent principle is also so abundant in the bark, that it is used in Poland in tanning leather, which it dyes a fine yellow. A decoction of the bark is said to make a good gargle to strengthen the throat and gums. When the berberry is cultivated in a garden for its fruit, it is preferable to select the variety, or rather variation, called Berberis vulgaris asperma, in which the seeds are said to be wanting, and in which the fruit is sweeter than the common kinds. This shrub makes excellent hedges; but there exists a prejudice against it among agriculturists both in Europe and in America, from its supposed influence in producing blight, or mildew, on the corn or grain growing near it.

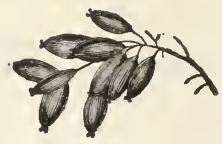




\title{
Berberis canadensis, \\ THE CANADIAN BERBERRY.
}

\author{
Synonymes. \\ (De Candolle, Prodromus. \\ Berberis canadensis, \\ Don, Miller's Dictionary. \\ Nutrall, Genera of North American Plants. \\ Loudon, Arboretum Britannicum. \\ Torrey and Gray, Flora of North America. \\ Epine vinette du Canada, \\ Canadischer Berberitzbeerenstrauch, \\ Barberry Bush, \\ France. \\ Germany. \\ Anglo-America.
}

Engravings. Audubon, Birds of America, pl. clxxxviii.; Loudon, Arboretum Britannicum, figure 48; and the figures below. Specific Characters. Spines 3-parted. Leaves obovate-oblong, remotely serrated, upper ones nearly entire. Racemes many-flowered, nodding.-Don, Miller's Dict.

\section{Description.}

HE Canadian Berberry is a low shrub, not exceeding five feet in height, with stems, roots, and flowers yellow, as in the preceding species. The leaves are much smaller and narrower, attenuate at the base, but nearly sessile. The flowers which put forth in May and June, are also smaller than those of the Berberis vulgaris, and the fruit is smaller and shorter, of a red colour, and less sour. It grows on fertile hills, and among rocks, especially in the Alleghany Mountains, and, on the authority of Pursh, it is found in Canada. Torrey and Gray remark that, "This indigenous species, very distinct from the Berberis vulgaris, with which it has been in some degree confounded, is probably a native of the southern states only; the barberry of the New England states, and, doubtless, of Canada, being the European species, and certainly not indigenous. Our species was first noticed, apparently, by Marshall, who states that he has a different species of barberry growing near New River, Virginia. Original specimens, collected and named by Pursh, exist in the herbarium of the late Professor Barton, now deposited in the rooms of the American Philosophical Society, Philadelphia." This shrub was cultivated in England in 1759. 


\section{Genus TILIA, Linn.}

Tiliaceæ.

Syst. Nat.
Polyandria Polygynia.

Generic Characters. Calyx 5-parted. Petals 5. Stamens numerous, free, or somewhat polyadelphous. Ovary globose, villous, 1-styled, 5-celled; cells 2-ovuled. Nut coriaceous, 1-celled, 1-2-seeded, from abortion.-Don, Miller's Dict.

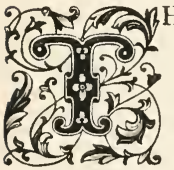

$\mathrm{HE}$ genus Tilia consists of timber trees, with mellifluous flowers, with a remarkable bractea attached to the peduncle of each of the cymes of the flowers. The number of species varies, according to the opinion of botanists, from two to ten. As there is great uncertainty respecting the number, owing to the imperfect manner in which several of them have been heretofore described, we shall adopt only two species, and include them all under Tilia europæa, and americana. The most obvious external differential characteristics of these two species appear to be, that the former have regularly cordate, and the latter, obliquely cordate leaves. 


\section{Tilia europaa, THE EUROPEAN LIME-TREE.}

Synonymes.

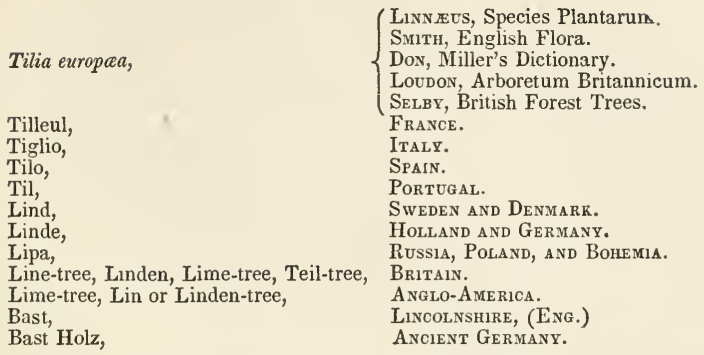

Derivations. The generic name, Tilia, is supposed, by some, to be derived from the Greek, ptilon, a feather, from the feathery appearance of the bracteas; and by others, from the Greek, tilai, light bodies floating in the air, like wool or feathers. The French, Spanish, Italian, and Portuguese names are derived from the botanical one. Nost of the other European names are derived from the Roman, linea, a line or cord, having reference to the bark, which was formerly, as at present, made into lines or ropes. The name Bast was applied to a variety of tilia, by the rustics of Lincolnshire, because ropes were made from its bark. The ancient German name, Bast Holz, signifies literally, bark-wood, and is evidently derived from the use made of the bark of this tree in making mats.

Engravings. Selby, British Forest Trees, pp. 1, 2; Loudon, Arboretum Britannicum, v., pl. 19; and the figures below.

Specific Characters. Petals without scales. Leaves cordate, acuminated, serrated, smooth, except a tuft of hair at the origin of the veins beneath, twice the length of the petioles. Cymes many-flowered Fruit coriaceous, downy.-Don, Miller's Dict.

\section{Description.}

\section{"And the Lime at dewy eve} Diffusing odours."

CoWPER.

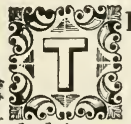
HE Linden or Limetree, in its full and luxuriant foliage, where sufficient room has been afforded it, and the soil has suited its constitution, is pronounced as one of the finest and most striking of European trees. In its native country, it often attains a height of eighty or one hundred feet, with a diameter of four to six feet, and even more. From the straightness of its stem, and the luxuriant spreading of its branches, which are likewise so tough as to withstand the fury of the winds that would disarm most other trees, it is peculiarly adapted for lining avenues, and screening the passenger from the scorching sun. This tree, however, is not so much esteemed, on account of its coming into leaf late in the spring, and beginning to decay

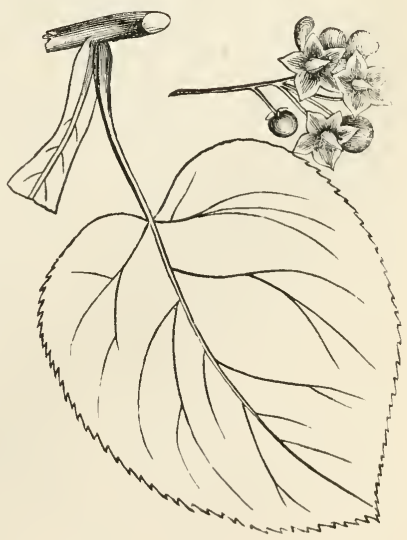
early in autumr. more especially when 
planted in a dry soil. It unfolds its leaves at Naples at the end of March; in England in the middle of April ; and at Upsula, in Sweden, and at New York, about the first of May. At the two last-named places it loses its leaves early in autumn, while at Naples it remains in full foliage during November. In Holland, where the linden abounds, the whole country, during the months of July and August, is perfumed by the fragrance of its flowers.

Varieties. "The extensive distribution," says Loudon, "and Iong cultivation of this tree in Europe, have given rise to the following races or varieties, described by De Candolle, and others, as species; from which high authority, it may be considered presumption in us to differ; but we have not done so without due consideration, and after having examined the living plants of different ages and in different situations, with the greatest care and attention."

1. 'T. e. microphylda, Loudon. Small-leaved European Lime-tree, in England; Tilleul à petites fenilles, in France; and Kleinblättrige Linde, or Winterlinde, in Germany. The petals of this variety are without scales; the leaves cordate, roundish, acuminated, sharply serrated, smooth above, glaucous, and bearded beneath on the axils of the veins, as well as in hairy blotches; the fruit is rather globose, hardly ribbed, very thin and brittle. This variety is distinguishable, at first sight, from all others, by the smallness of its leaves, which are only two inches broad, and sometimes scarcely longer than their slender footstalks. 'The flowers are also much smaller than in any of the other varieties; and they are very fragrant, having a scent like those of the honeysuckle. This appears to be the linden-tree of Gerard, the timber of which, he says, "is much harder and more knotty, and more yellow, than the timber of the other sort; and not very different from the timber of the elm-tree." In Worcestershire, England, between Horford and Ombersley, there is a tree of this variety estimated at upwards of three hundred years of age, which is seventy feet high, with a circumference of thirty feet, at three yards above the ground.

2. T. E. Platyphyla, Loudon. Broad-leaved European Lime-tree, in England; Tilleul à grandes feuilles, or Tilleul de Hollande, in France. 'The petals of this variety are without scales; the leaves cordate, roundish, acuminated, sharply serrated, downy beneath, origin of their veins woolly; branches hairy; cymes three-flowered; fruit woody, downy, turbinate, with five prominent angles. This tree can readily be distinguished by its large, rough leaves, and also by its rough bark, and hispid branches. At Syon, near London, there is a tree of this variety, supposed to have been planted about ninety years, and is nearly eighty feet high.

3. T. E. Rubra, Loudon. Red-twigged European Lime-tree. This variety is distmguished by the redness of its young branches, and it may be properly considered as a sub-variety of the two preceding. In Sweden, where linden woods extend over the low parts of the country for many miles together, the common lime-tree is met with, in some places, perhaps, for a mile together, with the twigs bright red, yellow in some, and in others quite green; from which we may infer that there is also a yellow-twigged variety, or sub-variety. Several similar coincidences occur in England among the cultivated varieties.

4. T. E. laciniata, London. Cut-leaved European Lime-tree. The leaves of this variety are smaller than those of the common species, and deeply and irregularly cut and twisted, scarcely two on the tree being alike. This variety seldom, if ever, exceeds thirty feet in height.

5. T. E. AUrea, Loudon. Golden-twigged European Lime-tree. This variety differs from the common lime-tree in the yellowness of its twigs; and, apparently, is not so vigorous in its growth as any of the other varieties, except the 'T. $\mathrm{e}$. laciniata.

6. T. E. Platyphylla aurea.

Golden-twigged Broad-leaved European Lime- 
tree. This variety differs from the common broad-leaved lime in no other respect than in the yellow colour of its twigs.

7. T. E. Dasystyla. Hairy-styled European Lime-tree. This variety is described as having petals without scales; leaves smooth, somewhat hairy at the base beneath; axils of veins bearded; style tomentose.

8. T. e. alba, Loudon. White-leaved European Lime-tree, in England; Tilleul blanc, in France; Weisse Linde, in Germany. Each of the petals of this variety has a scale at the base, inside; the leaves are cordate, somewhat acuminated, and rather unequal at the base, serrated, clothed with white down beneath, but smooth above, and four times longer than the petioles; the fruit is ovate, with five obscure ribs. This tree is at once distinguishable from all other varieties by the white appearance of its foliage, even at a considerable distance, and by the strikingly snowy hue of its leaves, when ruffled by the wind. Its wood and shoots resemble those of the common lime; but it does not attain the same height. There is a good specimen of this tree at Walton, upon the Thames, sixty feet high; and several others at High Clere, in Berkshire, some of which, in forty years, have attained a height of upwards of sixty feet.

9. T. e. alba Petiolaris, Loudon. Long-petioled-leaved European Lime-tree. This tree is described by De Candolle from dried specimens, without flower or fruit, and is probably only a sub-variety of T. e. alba.

There is another variety, with varigated leaves, but it is such a ragged, illlooking plant, that it is not deemed worthy of culture.

Geography and History. The Tilia europæa appears to be confined to the central and northern parts of Europe. It is found wild in northern Germany, Denmark, Sweden, Bohemia, and, according to Pallas, throughout the whole of Russia, and a great part of Siberia. According to Watson, it is common all over Britain, and in the south-western, north-eastern, and north-western counties of Ireland. The T. e. platyphylla is said to inhabit Sweden, and most parts of Europe, as far south as the Alpine regions of Switzerland, and Spain. The T. e. microphylla appears to be indigenous chiefly in the uorth of Germany, in Sweden, and Russia; also in the south-eastern and north-eastern counties of Eng land, and north-western counties of Scotland. At Shawley, eight miles northwest from Worcester, England, there is a wood of about five hundred acres in extent, the greater part of the undergrowth of which, is of this variety. So extensive a tract in Britain, covered with the linden, strongly tends to prove that this tree is truly indigenous. It is said, however, that the lime seldom, if ever, ripens its seeds in England, which would operate unfavourably to its reproduction. The T. e. alba is found in the woods in Hungary, where it is rare, and also near Constantinople, whence it was introduced into England in 1767, and planted at Mile End.

The European lime-tree has long been cultivated for ornament and shade, both in the United States and in the British American provinces.

The lime-tree appears to have been known to the Greeks and Romans. Theophrastus, Homer, Horace, Virgil, Columella, and Pliny mention it, and celebrate its bark and wood. According to Theophrastus, it is of both sexes, which are totally different as to form; probably referring to the small-leaved and largeleaved varieties. The leaves, he says, are sweet, and are used as food for most kinds of cattle. This tree was highly esteemed by the Romans for its shade; and, according to Pliny, for the numerous uses to which its wood might be applied. In modern times, the lime-tree was one of the first to attract the attention of dendrological writers previously to the time of Linnæus, who describes only two species, Tilia europæa and americana. M. Ventenat, in 1798, described three European species, and three American ones; and De Candolle has described ten. Evelyn, speaking of the lime-tree, says, "It is a shameful negligence that we are 
no better provided with nurseries for a tree so choice, and so universally acceptable. We send, commonly, for this tree, into Flanders and Holland, while our woods do, in some places, spontaneously produce them." 'The linden has long been a favorite tree for avenues and public walks, in some of the principal towns of France, Holland, and Germany, one of the most celebrated of which is in Berlin, called Die Linden Strasse. It also forms avenues to country-seats, on the continent of Europe, in Britain, and in America. "The French," says Du Hamel, "growing tired of the horse-chesnut for avenues, adopted the lime for that purpose, in the time of Louis XIV.; and, accordingly, the approaches to the residences of the French, as well as the English gentry of that date, are bordered with lime trees;" and Fenelon, "in conformity to this taste, decorates with 'flowering lime-trees,' his enchanted isle of Calypso."

The introduction of the European linden into America, no doubt, took place soon after its settlement. In general, as it is but a short-lived tree, in this country, in consequence of the ravages of insects, but few specimens are to be found of advanced age and size, which renders it difficult to determine the precise period at which it was brought from Europe. There exists, at present, however, a noble and venerable tree of this species, in Cambridge, Massachusetts, which is reputed to be above two hundred years old, with a trunk measuring more than eight feet in circumference at three feet from the ground. Its trunk is pierced and grooved with numerous holes by the Saperda vestita; several of its large branches, and a portion of its top have fallen, apparently in consequence of the depredations of these insects, and in a few years more, it will probably moulder to earth.

The largest and the most remarkable linden in Europe, and probably in the world, is at Neustadt, in Würtemberg, so famous for its size, that even the city itself takes its name from it, being called by the Germans, Neustadt an der Linde; that is, Newtown by the Great Linden-tree. This monstrosity of unknown antiquity, is nearly one hundred feet in height, and eighteen feet in diameter near the ground. Its trunk rises fifteen feet before it begins to ramify. 'The branches extend to nearly one hundred feet on each side of the trunk, and are supported by one hundred and eight pillars of wood and stone. There is a place of entertainment formed in the head of the tree, which may be ascended by a flight of steps. In the hollows of the branches, earth has been placed, and gooseberry bushes planted, the fruit of which is sold to visiters.

At Fribourg, in the public square, there is a large lime-tree, the branches of which are supported by pieces of timber. This tree was planted on the day that the victory was proclaimed of the Swiss over the Duke of Burgundy, Charles the Bold, in 1476; and it is a monument admirably accordant with the then feebleness of the Swiss republics, and the extreme simplicity of their manners, it being the custom in the middle ages, during the struggles of the Swiss and Flemish people to recover their liberty, to plant a lime-tree on the field of every battle that they gained over their oppressors. In 1833, the trunk of this tree measured about fourteen feet in circumference. In the village of Villars-enMorig, near Fribourg, there is a large lime-tree, which existed there long before the battle of Morat, (which the tree of Fribourg commemorates,) and which now is of extraordinary dimensions. According to De Candolle, in 1831, it was seventy feet high, and thirty-six feet in circumference at four feet from the ground, where it divided into large and perfectly sound branches. It is estimated as being nearly one thousand years of age.

At Knowle, south of London, there is an immense lime-tree, which spreads over nearly a quarter of an acre of ground. What is very remarkable, the branches of this tree, many years ago, rested their extremities on the soil, rooted into it, and sent up a circle of young shoots, which surrounded the parent tree. 
These young shoots, in process of time, partook the character of trees themelves, and, in turn, stretched out their branches, rested them on the ground, and hrew up a second circle of trees, which, in 1820, were twenty or thirty feet in teight. This tree is said to stand in a lawn in an ancient geometrical garden, nd must be, at least, two hundred years old.

In the cemetery of the hospital at Annaberg, in Saxony, a man planted a lindenree, and was afterwards buried under its shade, who left a sum of money to tave a sermon preached every 'Trinity Sunday, under it. This tree is said to have rown to an enormous size, and was planted in a reversed position, with its head lownwards.

Mythological and Legendary Allusions. In Prussia, near Königsberg, two arge lindens were grown on a grassy bank, beneath which, it is said, were buried, $\mathrm{n}$ one grave, a bride, who died on her wedding-day, and her husband, who did tot long survive her loss. The tree was ever afterwards a favourite retreat for orrowful lovers.

In the churchyard, at Seidlitz, in Bohemia, it is said there are some old limerees, the leaves of which are hooded; and the peasants affirm that they have ver been so since some monks from a neighbouring convent were hanged on their oughs.

Ovid tells us in his "Metamorphoses," that Baucis, when Jupiter and Merury, after they had partaken of her hospitality, offered to grant any request she night make, only asked to die on the sanie day as her husband; that the gods, ranting her prayer, when she and Philemon had both attained a good old age, he was changed into a lime-tree, and her husband into an oak. While the ransformation was taking place, they continued speaking affectionately to each ther, till the bark had closed quite round them; and that, even when they had ecome trees, they entwined their branches closely together.

Soil and Situation. A deep, and rather light soil is recommended by $\mathrm{Du}$ Hamel, for the lime-tree, or an argillaceous soil, inclining somewhat to sand, and ather moist; but the largest trees are generally found in a good, loamy soil, or $\mathrm{n}$ the alluvial deposites of low-lying meadows, along the margins of lakes, rivrs, \&c. In Lithuania, where this tree abounds, the soil is rather a clayey than isandy loam.

In dry situations, it never attains a large size, and it loses its leaves, perhaps, arlier than any other tree. Being an inhabitant of the plains, rather than of he mountains, it does not appear suitable for exposed surfaces; but it requires a pure air, rather than otherwise; for, it is found in abundance in many of the ities of continental Europe, but sparingly so in the British cities, where more nineral coal is consumed, which appears to be more injurious to the lime than to he elm, the plane, or some other trees.

Propagation and Culture. This tree is seldom propagated otherwise than by ayers, which are made, in the nurseries, in autumn, or winter, and which become rooted, so as to be separated from the parent stock, in a year. Du Hamel fays that the lime-tree may be raised from seeds, which ought to be sown immeliately after being gathered; because, if they are preserved dry till the following pring, they will not often come up till the second year. If, however, the seeds are mixed with sand, or with soil, not too dry, and kept in that state during the winter, they will generally spring up the first year. Owing to the slowness of he growth of plants raised from seeds, the French and Belgian gardeners cut off he stock of an old tree, close to the surface of the ground, which soon sends up great number of young shoots; among these they throw a quantity of soil, which they allow to remain one, two, or three years, after which, they find the hoots well rooted, and of a sufficient height and strength to be planted at once where they are finally to remain. The lime-tree bears transplanting when of a considerable size: but, when it is grown in the nurseries for this purpose, it ought 
always to be taken up and replanted every two or three years. A tree which has stood some years without being removed, should have the roots cut round, at three or four feet from the stem, a year before removal, for the purpose of stunting the growth, both of the head and roots, and of forming smaller roots and fibres.

Insects. The foliage of the Tilia europæa affords a pabulum to the larvæ of many lepidopterous insects, some of which feed exclusively upon it, while others prey upon that of various trees. Among those which prove the most injurious to it in the United States, are several species of the Geometridæ, such as spanworms, loopers, measurers, etc., some of which also feed indiscriminately upon the elm, maple, horse-chesnut, sycamore, (Platanus,) poplar, apple, cherry, and plum. Within the last five or six years, soon after the unfolding of the leaves of these trees, they have been attacked by the larvæ of these insects, and in some instances have been entirely divested of their foliage. They usually emerge from the egg, at New York and vicinity, about the middle of May, and during the month of June suspend themselves by their silken lines from the trees along the streets and avenues, greatly to the annoyance of the citizens. After gorging themselves with the tender foliage for three or four weeks, they quit the tree, enter the ground, or some other place of concealment, and undergo their transformations. The perfect insects of most of the species appear about the 20th of July, and others at various periods in autumn, and in the following spring. They commonly consist of small, whitish, or variegated millers, and, in some species, the females have no wings. Soon after their appearance, the females make provision for their future progeny, by laying their eggs upon the leaves, branches, or trunks of trees, and then die. Various expedients have been resorted to for the destruction of these insects, and but a few of these have proved effectual, except those of crushing them to death, when on the trees, or by destroying the chrysalides, or the eggs.

Another insect, in this country, which is more pernicious and fatal to the European linden-tree than the preceding, is a long-horned beetle, (Saperda vestita, Say,) described and figured by Dr. T. W. Harris, in Hovey's "Magazine of Horticulture," vol. x., p. 330. It was discovered about twenty years ago by Mr. Thomas Say, near the southern extremity of Lake Michigan, and has been known for several years in Pennsylvania, Massachusetts, and New York. The insect, in the winged state, is a little more than half of an inch in length, and is covered with a greenish down, having two dark spots on each wing cover, as indicated in the adjoining figure. It makes its appearance in the month of May, and commences eating the young bark and tender twigs, and often the petioles of the leaves. The female deposits her eggs on the branches and trunks of the trees, where they remain during the autumn and winter. According to Dr. Harris, a strip of the bark of the large linden in Cambridge, mentioned in a preceding page, $t$ wo feet wide at the bottom, and extending to the top of the trunk, has been destroyed, and the exposed surface of the

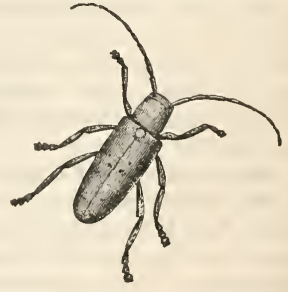
wood is pierced and grooved with countless numbers of holes, wherein the larvæ of these insects have been bred, and whence swarms of beetles have issued in times past. The lindens in Washington square, in Philadelphia, were also attacked by these borers a few years since, and in 1842 , it became necessary to remove them entirely. The superintendent of the square informed us, that soon after the European species was cut down, they attacked the American lindens, which probably would have bern destroyed, had not the insects been arrested 
him. The two beautiful rows of European lindens, in front of the state use, in Philadelphia, have likewise been perforated by them, and in a year or ro more, they will probably fall from their prey. The same insect also is said attack the mountain ash. Various experiments have been tried to arrest eir course, but most of them have proved fruitless, except by crushing the incts to death, or by destroying their eggs.

Properties and Uses. The wood of the lime-tree, as compared with that of e oak, the ash, and other timber trees, holds but an inferior rank, and is only ed in such works as are not to be exposed to the alternations of moisture and yness. It is of a pale yellow, or white, close-grained, soft, light, and smooth; id, when seasoned, it is not liable to be attacked by insects. It is used by anoforte-makers, for sounding-boards, and by cabinet-makers for a variety of arposes, as it does not warp under atmospheric changes. It is turned into mestic utensils of various kinds, carved into toys, and turned into small boxes $\mathrm{r}$ apothecaries. The most elegant use to which it is applied, is for carving, for hich it is superior to every other wood. Many of the fine carvings in Windsor astle, Trinity College Library, at Cambridge, and in the Duke of Devonshire's ansion, at Chatsworth, are of this wood. It is said to make excellent charcoal r gunpowder, even better than alder, and nearly as good as hazel, or willow. askets and cradles were formerly made from the twigs; and shoe-makers and overs are said to prefer planks of lime-tree for cutting the finer kinds of leather on. The leaves of this tree are collected in Sweden, Norway, Carniola, and witzerland, for feeding cattle; though in Sweden, Linnæus says, they commucate a bad flavour to the milk of cows. One of the most important uses of the ne-tree, in the north of Europe, is that of supplying material for making ropes id mats; the latter of which enter extensively into European commerce. The ussian peasants weave the bark of the young shoots for the upper parts of their oes, the bark of the trunks or large branches serving for the soles; and they so make of it, tied together with strips of the inner bark, baskets and boxes for mestic purposes. The outer bark of old trees also supplies them, like that the birch, with tiles for covering their cottages. Ropes are still made of the ark of this tree in Cornwall, and in some parts of Devonshire. The manufacre of mats from the inner bark, however, is now chiefly confined to Russia, ad to some parts of Sweden. Trees from six to twelve inches in diameter are lected at the beginning of summer, when, from the expansion produced by the cending sap, the bark parts freely from the wood. The bark is then stripped om them in lengths of six to eight feet, and is afterwards steeped in water till it parates freely in layers. It is then taken out, and divided into ribands or rands, and hung up in the shade, generally in the forest were it grows, and, in e course of the summer, is manufactured into mats, so much in use by garden$\mathrm{s}$ and upholsterers, and for covering packages generally. The fishermen of weden make nets for catching fish, of the fibres of the inner bark, separated by aceration, so as to form a kind of flax or hemp; and the shepherds of Carniola eave a coarse cloth of it, which serves for their ordinary clothing. The sap of e lime-tree, drawn off in spring, and evaporated, affords a considerable quanty of sugar. The honey produced from the flowers is considered superior to 1 other kinds for its delicacy, selling for three or four times the price of common oney; and it is used in the preparation of medicine, and for making particular queurs, more especially rosoglia. This lime-tree honey is only procured at e little town of Kowno, on the river Niemen, in Lithuania, which is surrounded y an extensive forest of lime-trees, and where the management of the honey-bee ccupies the principal attention of the inhabitants. The Jews of Poland produce close imitation of this honey, by bleaching the common kind in the open air, uring frosty weather. ' The fruit of the lime-tree had long been thought of little 
use, till M. Missa, of Paris, by triturating it, mixed with somc of its flowers, succeeded in procuring a butter, perfectly resembling chocolate, both in taste and consistency; but, unfortunately, it was found that the lime-tree chocolate would not keep. It has been suggested whether some of the American varieties of tilia would not prove successful in this particular. In England, there are many ancient lime-trees, planted in towns, because, in olden times, their odour was considered as purifying to the air, and to be good against epilepsy.

In landscape gardening the principal use of the linden is as a detached tree on a lawn, or in scenery which is decidedly gardenesque; because, from the symmetrical and regular form of its head, it is unfitted for grouping with other trees in a picturesque manner. It is recommended as preferable to the elm, for sheltering gardens, or orchards, because the roots, do not, like those of the elm, spread and impoverish all around them. Evelyn commends the lime for its "unparalleled beauty" for walks; "because," says he, "it will grow in almost all grounds, lasts long, soon heals its wounds, when pruned, affects uprightness, stoutly resists a storm, and seldom becomes hollow." Scattered trees of it harmonize well with immense masses of Grecian or Roman architecture; but it is less suitable for the narrow, perpendicular forms of the Gothic. For architectural gardening it is well adapted, from the patience with which it bears the knife, or the shears. In some of the public gardens in the vicinity of Paris, and Amsterdam, there are numerous colonnades, arcades, walls, pyramids, and other architectural masses formed of this tree, which produce an imposing effect. 
Tilia americana,

\title{
THE AMERICAN LIME-TREE.
}

\section{Synonymes.}

\author{
(Linxæus, Species Plantarum. \\ Tilia americana, \\ Tilia glabra, \\ Tilleul de l'Amerique, Tilleul du Canada, France. \\ Amerikanischer Lindenbaum, Germany. \\ Tiglio americano, ITALY. \\ Tilo americano, Spain. \\ Lenikby, \\ White-wood, Bass-wood, \\ Lin, Linden, \\ Lenni Lenape Indians. \\ Canada. \\ Lime-tree, Black Lime-tree, Smooth-leav-
ed Lime-tree, Bass-wood,
}

Derivations. The name Bass-wood, is probably a corruption from bast, which is applied to the European lime-tree by the rustics of Lincolnshire, because ropes were made from its bark. The Indian name is derived from lenni, original, and wikby,
the last word by itself, meaning the tree, the bark of which peels freely all the year round. It is called Black Lime from the dark colour of the bark.

Engravings. Mlichaux, North American Sylva, pl. 131; Selby, British Forest Trees, p. 11; Loudon, Arboretum Britannicum, v., pl. 22 ; and the figures below.

Specific Characters. Leaves obliquely cordate, or truncate at the base, somewhat coriaceous, glabrous, abruptly acuminate; petals obtuse or truncate, crenate at the apex.-Torrey and Gray, Flora.

\section{Description.}

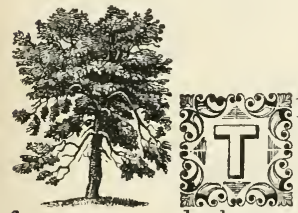

forest trees, and when cultivated, proves highly ornamental. In our native woods, it often rises more than eighty feet in height, and frequently upwards of four feet in diameter; and there is little doubt but, if cultivated, and judiciously treated, it would reach a size little inferior, if not equal, to the European species. Its body is straight, uniform, and surmounted with an ample and tufted summit. In winter, it is readily recognized by the robust appearance of the trunk and branches, and by the dark-brown colour of the bark on the shoots.

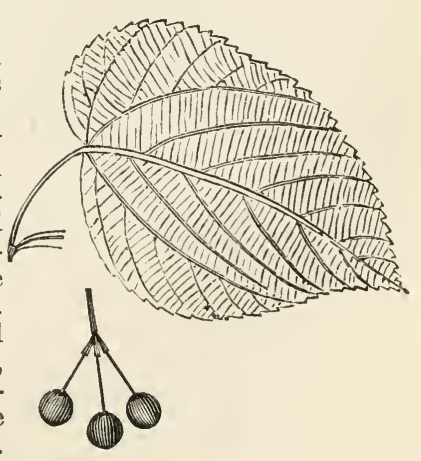
The leaves are from three to four inches wide, obliquely heart-shaped at the base, abruptly and acutely pointed at the summit, finely and sharply toothed, glabrous above, of a deep-green, and paler beneath, with foot-stalks about two inches long. The flowers, which appear in June, are about half of an inch in diameter, borne by peduncles from four to six inches long, and are garnished with a long, narrow floral leaf. The cymes are compounded, having from twelve to eighteen flowers, pendulous, and sıbdivided 
at the extremities. The sepals are triangular-lanceolate, pubescent outside, and woolly within. The petals are longer than the sepals, and are of a yellowishwhite. 'The staminodia are obovate-lanceolate, exactly like the petals, but smaller. The style is sometimes longer, and at others shortcr than the petals, and hairy towards the base. The fruit, which ripens in September and October, is about the size of a pea, ncarly round, and covered with a short, gray pubescence, usually perfecting but one seed.

Varieties. The other American limes we regard as nothing more than varieties of this species, and they may be described as follows :-

1. T. a. Laxiflora, Loudon. Loose-cymed-flovered American Lime-tree. The petals of this variety have each a scale at the base, inside; the leaves are cordate, gradually acuminated, serrated, membranaceous, and smooth; the cymes are loose; the petals emarginate, and shorter than the styles; and the fruit is nearly round. 'The tree is usually forty or fifty feet in height, and produces yellowish-white, sweet-scented flowers, from May to July. 'This variety greatly resembles the Tilia americana, and is essentially the same, except in size.

2. 'T. A. pubescens, Loudon. Pubescent-leaved American Lime-tree. This variety is of much less vigorous growth than the preceding, and seldom exceeds forty feet in height. The colour of the bark is dark, and the branches are slender. The leaves are smaller, and differ widely in size, according to the exposure in which they grow. In dry and open places, they are only two inches in diameter; but in cool and shady situations, they are twice the size. They are truncate at the base, somewhat cordate, and oblique, denticulately serrated, and pubescent beneath; they are most pubescent soon after their first expansion, but as they increase in size, a part of the down falls off, and the hairs which remain form little starry tufts. The flowers, which resemble those of the Tilia americana, appear. in May and June, and vary in size with the leaves; they are more numerous, and form larger branches; the petals have each a scale at the base, insidc, as in the other varietics; they are emarginate, and shorter than the style. The fruit is globose and downy.

3. 'T'. a. pubescens leptophylda, Loudon. Thin-leaved Pubescent American Lime-tree, in the United States; Tilleul de la Lonisiane, in France. This varicty is represented as having very thin leaves, with but few serratures. It is said to closely resemble the T. a. pubescens, and is doubtless a sub-variety of that race, as it is only found associated with it.

4. T. A. Alba (T. alba, Mich.) White-leaved Lime-tree, White Lime, Warhew, in the United States; Tilleul blanc de l'Amerique, Tilleul de Virginie, in France. This tree usually grows to a height of forty or fifty feet, with a diameter of twelve to eighteen inches. On the banks of the Ohio, however, it often rises to an clevation of sixty or eighty fect, although, in France, aceording to the "Nouveau Thu Hamel," it attained the height of twenty feet in seventy years. The young branches are covered with a smooth, silver-gray bark, with a rough surface, and may readily be distinguished in winter by their thickness and the large size of their buds. The leaves are larger than those of any other variety, either European or American, bcing often six or seven inches long, and from three to five inches broad. 'They are obliquely heart-shaped, and pointed like those of all 
th: other American varieties, are of a dark-green on the upper surface, and $w^{\prime}$ iitish beneath, with small reddish tufts of hairs at the intersections of the princıpal nerves. 'The flowers, which are also larger than those of any other lime-tree in America, appear in June, having petals of a white colour, and of an agreeable odour. The seeds are globose, downy, with five ribs. The wood is white and tender, but is not nuuch used in the arts.

5. 'T. a. alba glabra ( $T$. heterophylla, Nuttall.) Smooth-frnited White-leared American Lime-tree, Large-leaved Lime-tree. 'The chief difference betwecn this tree and the preceding variety, is, that its branches, when young, are of a purplish colour, and somewhat glaucous; its flowers are more ycllow, and its fruit is always without ribs.

Geography and History. The Tilia americana is found in Canada and the northern parts of the United States. It becomes less abundant towards the south, except on the Alleghanies, where it is found quite at their tcrmination in Georgia. It is profusely multiplied on the borders of Lake Erie, Ontario, and in Maine, New Hampshire, and Vermont. It was cultivated in England by Miller, in 1752 , but has not been very extensively distributed. The 'I'ilia americana laxiflora is said to abound from Maryland to Georgia, near the sea coast. It was introduced into Britain in 1820, and is but sparingly cultivated in that country. The Tilia americana pubescens belongs to the southern parts of the United States, Florida, Kentucky, and Texas. It is said to be the only variety found in the maritime parts of Carolina, Georgia, and Florida. Seeds of this tree were carried from this country to England by Mark Catesby, in 1726; but it does not appear to have been much cultivated. The Tilia americana alba is not met with east of the river Delaware, but it is found in Pennsylvania, Maryland, Delaware, Virginia, Ohio, Kentucky, and Georgia. It is said, also, to grow on the river Santee, in South Carolina, and on the Mississippi. It is remarkable, that, although this variety was known in France in 1755 , it should not have been introduced into England till 1811.

Soil and Situation. Like the European species, the American lime-tree affects a rich, loose, and deep soil ; and seems to prefer, in general, the borders of lakes and rivers, and moist bottom-lands, which are but little subject to inundation. They are all highly ornamental, and well deserve a place in collections, where the climate is adapted to other trees, which naturally grow with them. For instance, the 'Tilia americana will grow where the sugar maple, white ash, and hemlock spruce will best thrive; the Tilia americana pubescens with the Magnolia grandiflora; and the Tilia americana alba with the tulip-tree, and the sycamore (platanus.)

Propagation and Culture. All the varieties of this species may be propagated from seeds, by cuttings, and by grafting; but, from the facility with which they can bc multiplied by layers, the former mode should rarely be adoptcd.

Insects. 'The insects which prey upon the Tilia americana are but few. Those which prove the most injurious are the Hybernia tiliaria, or lime-tree moth, of Harris, and the Saperda vestita, of Say. The Chrysomela scalaris of Le Conte, also inhabits this species, as well as the Papilio turnus, or swallowtailed butterfly, well known, from Newfoundland to Mexico. 'There is often an appearance in the foliage of this species, the cause of which is unknown, unless it is the work of some minute insccts. The leaves become corroded or destroyed in many trees of the same forest, so that it is difficult to find a perfect leaf, except such as have just been unfolded. IVhatever the cause may be, the effect is very detrimental to the beauty of the tree.

The Tilia americana alba is devoured by the larvæ of the Papilio comma aureum, or American comma buttcrfly. In Smith and Abbot's "Inscets of Georgia," it is stated that thc larva suspended itself by the tail, May $29 \mathrm{th}$, 
changed on the 30th, and appeared on the wing June 7th. The butterfly lives through the winter in places of shelter, and comes forth very early in the spring. This insect is found as far north as Virginia.

Properties and Uses. The wood of the American lime-tree, when dry, weighs thirty-five pounds to a cubic foot. It is very white, when green, but becomes of a light-brown hue, when seasoned. It is soft, easily worked, and is often sawed into boards, which do not warp, like those formed of resinous trees. In the northern parts of the United States, and in the British provinces, where the tulip-tree does not abound, it is used for the panels of carriage bodies, and the seats of chairs. In Kentucky and the western states, the wood of the white lime is often substituted for that of the white pine. In various parts of the country, it is turned into domestic utensils of various kinds; and is also carved into images for the heads of vessels, and other ornamental work. The young trees are sometimes cut, and employed as rails for rural fences; but they are not durable when thus exposed. The wood is almost useless as fuel, when green, being too full of sap, and of but little value when dry. The cellular integument of the bark is separated from the epidermis; and, after being macerated in water, is formed into ropes, after the manner of making them in Europe, of the other species. The bark was also employed by the Lenni Lenape Indians for making lines and ropes, as well as for covering their habitations. The outer bark of the Tilia americana is rough and stringy, and the inner portion viscid and sweet. The twigs and buds are very glutinous when chewed, and afford considerable nutriment. In severe winters, when fodder is scarce, it is common for the farmers of the British American provinces, as well as those of Maine, New Hampshire, and Vermont, to drive their cattle into the woods in the morning, and fell a bass-wood, or other tree on which they eagerly browse during the day. 


\section{Genus GORDONIA, Ellis.}

Ternströmiaceæ.

Syst. Nat.
Monadelphia Polyandria.
Syst. Lin.

Synonymes.

Gordonia, Hypericum,

Gordonia,

Gordonie,
Of Authors.

France and Italy.

Gerirany.

Derivations. This genus was named in honour of Alexander Gordon, a celebrated nurseryman, at Mile End, near Lonchn, who lived in the time of Phillip Miller. The name Hypericum is supposed to be derived from the Greek huper for, and ereike, heath, and was applied by Linnæus, from a supposed resemblance that plants of this genus bear to the heath.

Generic Characters. Calyx of 5 rounded coriaceous sepals. Petals 5, somewhat adnate to the urceolus of the stamens. Style crowned by a peltate 5-lobed stigma. Capsules 5-celled, 5-valved; cells 2-4seeded. Seeds ending in a leafy wing, fixed to the central column, filiform.-Don, Miller's Dict.

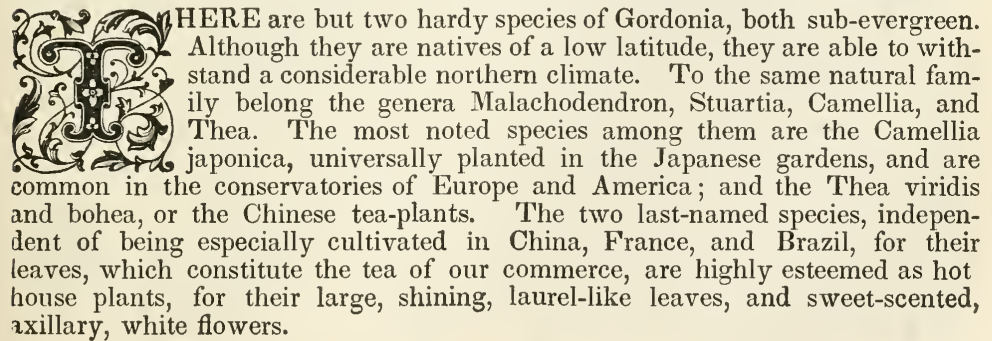




\title{
Gordonia lasianthus, \\ THE WOOLLY-FLOWERED GORDONIA.
}

\section{Synonymes.}

\author{
Hypericum lasianthus, \\ Linnaud, Species Plantarum. \\ (Linnæeus, Mantissa Plantarum. \\ De Candolle, Prodromus. \\ Gordonıa lasianthus, \\ $\{$ Michaux, North American Sylva. \\ Loudon, Arboretum Britannicum. \\ Torkey and Gray, Flora of North America. \\ Gordonia à feuilles glabres, Alcée de la \\ Floride, \\ Langstielige Gordonie, \\ Loblolly Bay, \\ France. \\ Germany. \\ United States.
}

Derivations. The specific name, lasianthus, is derived from the Greek lasios, woolly, and anthos, a flower. The French name Alcee de la Floride, signifies Florida Althea, or hollyhock, and the other name has reference to the smoothness of the leaves. The German name signifies Long-peduncled Gordonia.

Engravings. Michaux, North American Sylva, pl. 58; Audubon, Birds of America, pl. clxvii. ; Catesby, Natural History of Carolina, i., pl. 44.; Loudon, Arboretum Britannicum, figure 93; and the figures below.

Specific Characters. Pedicels axillary, usually shorter than the leaves. Leaves oblong, coriaceous, smooth, serrated. Calyx silky. Capsules conoid, acuminated.-Don, Miller's Dict.

\section{Description.}

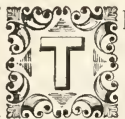

HE Gordonia lasianthus, in its native country, is a beautiful sub-evergreen tree, growing to a height of fifty or sixty feet, with a diameter of eighteen or twenty inches. The trunk is often straight, for the first half of its height, and the small divergency of its branches gives it a regularly fastigiate form; but, as they ascend, they spread more loosely, like those of other trees of the forest. The bark is very smooth while the tree is less than six inches in diameter; but, on old trunks, it becomes thick, and deeply furrowed. The leaves are from three to six inches in length, alternate, oval-acuminate, slightly toothed, and smooth and shining on the upper surface. The flowers are more than an inch broad, white, and sweet-scented; they begin to appear about the middle of July, and continue to

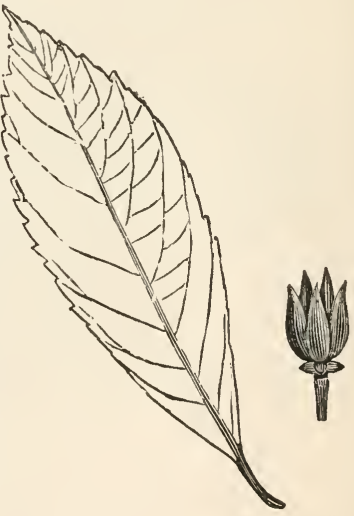
put forth, in succession, during two or three months. This tree possesses the agreeable singularity of bearing flowers when it is only three or four feet high. The fruit is an oval capsule, divided into five compartments, each of which contains small, black, winged seeds.

Geography and History. This tree appears to be confined to the maritime parts of the United States, from Virginia to lower Louisiana. According to Michaux, tracts of fifty or one hundred acres are met with in the pine-barrens, which, being lower than the adjacent ground, are kept constantly moist by the waters collected in them after great rains. These spots are entirely covered with this species and are called bay swamps. 
This tree seems first to have been recorded by Catesby, and was soon after described by Ellis, in the "Philosophical Transactions," and figured there, as well as in Catesby's "Carolina." It was introduced into England, in about 1768, by Benjamin Bewick; but it has never been very successfully cultivated, apparently from neglecting to imitate its natural habitat. The largest plants in England are at Purser's Cross, at White Knight's, in some of the London nurseries, and a few others. No plants, as yet, have exceeded twenty feet in height. In the vicinity of New York, Philadelphia, and other places, this tree is planted in gardens, and succeeds well, with some slight protection during winter.

Soil and Situation. In the natural habitat of this species, the vegetable mould is often not more than three or four inches deep, and reposes upon a bed of barren sand; yet its growth is surprisingly luxuriant. A swampy soil, and a low, sheltered situation appear to be the most congenial to its growth. In preparing an artificial soil, either for this species or the Gordonia pubescens, it should be composed of peat, or leaf-mould, and sand; and it should be so circumstanced, as always to be kept moist, without having the surface alternately moistened by the watering-pot, and dried by the sun. In order to do this, a considerable mass of soil ought to be brought together, and placed in an excavation, on a retentive substratum, in a low situation. During summer, water ought to be supplied from below, rather than from the surface, in order that the degree of moisture may be maintained as uniformly as possible. This may be effected by laying the bottom of the foundation or substratum of broken stone or coarse gravel, to which water can be supplied through a shaft, or tube, communicating with the surface. Such a preparation is well worthy of the expense, in order to insure the growth of these species, as well as the Magnolia glauca, and other plants, requiring a similar situation.

Propagation and Culture. In the British nurseries, this species is generally propagated by layers; but sometimes seeds are imported for the purpose. These require to be sown on peat soil, kept moist and shaded; and, for this purpose, a covering of moss (sphagnum) is thought desirable, as the seeds which drop from the plants in their native habitats, only germinate successfully in this substance.

Properties and Uses. The wood of the Gordonia lasianthus is extremely light, a cubic foot of which, when dry, does not weigh more than twenty pounds. In trunks of these trees, which exceed fifteen inches in diameter, four-fifths of the wood is heart. It is of a rosy, or mahogany hue, and of a fine, silky texture, which render it very proper for the inside of furniture, though the cypress is generally preferred. When seasoned, it is exceedingly brittle, and rapidly decays when exposed to the alternations of moisture and dryness. The bark may be taken off this tree during three months of the year, which shows that the sap is in vigorous motion a much longer period than it is in most other trees. The value of the bark, in tanning, compensates, in some measure, for the uselessness of the wood, for which purpose it has been employed in times past, throughout the' maritime parts of the southern states and Florida. Although this branch of industry was never so extensively practised in the southern as in the northern parts of the United States, the regions where this tree abounds do not afford a sufficient quantity of bark, proper for tanning, to supply the wants of the inhabitants. Hence, nearly all the leather, and articles manufactured therefrom, consumed in the southern states, are carried from the north. A bark, suitable for the purpose of tanning, is more valuable in the United States, than at first sight might be supposed. Although there are a great variety of oaks, and many of the species profusely multiplied, yet there are but a very few of them that are sufficiently rich in tannin to be worth using. 


\title{
Gordonia pubescens, \\ THE PUBESCENT-LEAVED GORDONIA.
}

\section{Synonymes.}

\author{
Gordonia Pubescens, \\ Behaarte Gordonie, \\ Franklinia,
}

Derivations. The word pubescens is derived from the Latin pubesco, to become downy; and the German name has the same signification. The name Franklinia is so called in honour of Dr. Franklin.

Engravings. Michaux, North American Sylva, pl. 59; Audubon, Birds of America, pl. clxxxv.; Loudon, Arboretum Britannicum, figure 94 ; and the figures below.

Specific Characters. Flowers almost sessile. Leaves obovate-lanceolate, pubescent beneath, somewhat serrated, membranaceous. Petals and sepals rather silky on the outside.-Don, Niller's Dict.

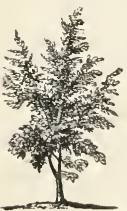

\section{Description.}

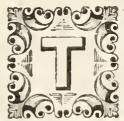

HE Franklinia is a deciduous tree, much smaller than the preceding species, and rarely exceeds thirty feet in height, and six or eight inches in diameter. The bark of the trunk is smooth, and presents a ridged surface, somewhat like that of the Carpinus americana. The leaves are alternate, oblong, narrowed at the base, finely and sharply toothed, shining above, canescent beneath, and rather thin. The flowers are white, with yellow anthers, and are nearly three inches in diameter. They are of an agreeable odour, and appear in Carolina about the beginning of July, and a month later near Philadelphia. They open in succession during two or three months, and mature

hen the tree is only three or four feet high. In the neighbourhood of London, it seldom comes into flower vefore September; and so continues until the flower-

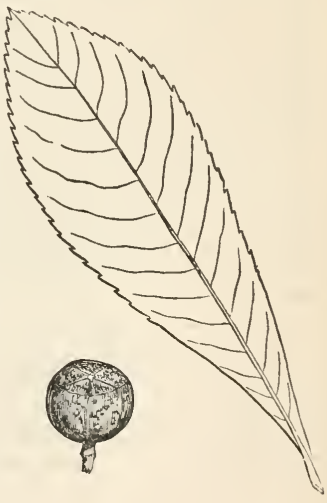
buds are destroyed by frost. The fruit consists of round, ligneous capsules, which, when ripe, open at the summit in four seams, to release the small seeds.

Geography and History. The Gordonia pubescens is found only on the banks of the river Altamaha, in Georgia, where it was discovered, in 1770, by John Bartram, who gave it the name of Franklinia. It was introduced into England, in 1774 , by Mr. William Malcolm. There are plants ten feet high in the Mile End nursery, London, and of a larger size at Purser's Cross, and at Syon. It is also cultivated in the Jardin Impérial des Plantes, in France; and a few years ago there was a tree of a considerable size in the garden at 'Trianon. The largest tree of this species which we have on record, is in the Bartram botanic garden, at Kingsessing, near Philadelphia. It is fifty-two feet in height, with a trunk three feet and nine inches in circumference. 'There is also another vigorous tree fifteen feet high, in the garden of Mr. D. Landrein, of Philadelphia. 
Soil, Situation, $\&^{\circ} c$. The native soil of this species is sandy wastes, where there is peat and an abundance of moisture a great part of the year. It is considered somewhat hardier than the Gordonia lasianthus, and has been more generally cultivated. The soil, situation, and culture, may be considered, in all respects, the same as those described in the preceding species.

Uses, $S^{\circ} \cdot$. No particular application has been made of this tree, except for ormament. 


\title{
Genus CITRUS, Linn.
}

\author{
Aurantiaceæ. \\ Polydelphia Icosandria. \\ Syst. Nat. \\ Syst. Lin.
}

Derivation. The meaning of the word Citrus has escaped the ingenuity of philologers and etymologists; it was probabis corrupted from the Latin word cedrus, a name applied by the Romans to various kinds of trees, which they ignorantly con founded. It is supposed by some to be derived from kitron, the Greek name of the lemon-tree.

Distinctive Characters. The common character of the citrus family, is that of low, evergreen trees, with ovate or oval-lanceolate, entire, or serrated leaves. On trees in a wild state, or on ungrafted cultivated ones, there are often axillary spines. The flowers occur in peduncles, axillary or terminating, and single or many-flowered. The fruits are large berries, round, spheröidal, or oblong, and generally of a yellow colour. The species appear to be the most easily distinguished by the petiole, which, in the orange and shaddock, is winged; while in the citron, lemon, and lime, it is naked. The form of the fruit, although not constant, may serve, in a measure, for a distinction. In the orange and shaddock it is spherical, or rather flattened at the ends, with a reddish yellow, or golden-coloured rind; in the lime, the form is spherical, or oblong, with a pale, yellowish rind; in the lemon, oblong, rough, with a pointed protuberance at the end; and in the citron, the form is oblong, with a very thick greenish, or yellow rind. The flowers of the citron and lemon have ten stamens, but those of the orange more. After all, it is very difficult to determine what is a species, and what a variety in this family.

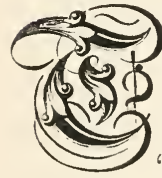

$\mathrm{HE}$ beautiful and tree-like forms of this genus, clothed as they are in shining and perennial verdure, odoriferous flowers, and adorned with brilliant, fragrant, and delicious fruits, must have attracted the attention of aboriginal man, long before other fruits of less brilliancy, though more nutritious, and grateful to his senses. The "golden apples" of the heathens, and the "forbidden fruit" of the Jews, are supposed to have reference to this family, though we have no authentic records of any species of citrus having been cultivated either by the ancient Greeks or Romans. The citron was introduced into Europe from Media, under the name of Medica, and was cultivated in Italy by Palladio, in the IInd century; but the introduction of the other species has been, comparatively, of recent date. They are all natives of the torrid zone, chiefly of India, and have been disseminated throughout the warmer and more temperate regions of the habitable globe. The limes are classified by modern botanists under the name of Limonia, a new genus, derived from the Arabic, lymoun, a citron. It is not very well known, however, but it is said to include nearly twenty species, one of which is a native of East Florida, the Limonia ambigua, of Nuttall. There are also several half-hardy kinds, natives of the Himalayas and Nepal, which are said to grow at considerable elevations, and are adapted to the climate of the temperate parts of Europe, and of the United States, without protection in winter.

The most splendid work on this genus which has ever appeared, is the "Histoire Naturelle des Orangers," by Risso, of Nice, and Poiteau, of Versailles, pubished in folio, at Paris, in 1818. There are described in this treatise one hundred and sixty-nine sorts, one hundred and five of them figured, and their French and Italian culture given at great length. They are classified as sweet oranges, of which they describe forty-three varieties or races; bitter and sour oranges, thirty-two; bergamots, five; limes, eight; pampelucos or shaddocks, six; sweet limes, twelve; lemons, forty-six; and citrons, seventeen varieties.

Dr. Sickler, who lived several years in Italy, and paid particular attention to the culture of the orallge, published, in 1815, a work entitled "Der Volkommen Orangerie Gartner," in which he describes above seventy kinds of citrus. And Galesio, in his "Traité du Genre Citrus," etc., Savonna, 1818, has given a synopsis of forty principal kinds cultivated in Italy. 


\section{THE GOLDEN-FRUITED ORANGE-TREE \\ Synonymes.}

Citrus aurantium,

Oranger, Orangenbaum,

Oranjeboom,

Melarancio.

Naranjo,

Laranjêira,

Pomeranez,

Cay Cam,

Orange-tree,
OF Authors.

France.

Germany.

Holland.

ITALY.

Spain and Spanish America.

Portugal and Portuguese America.

Russia.

Cochin-China.

Britain and Anglo-America.

Derivations. The specific name, aurantium, is derived from the Latin aurum, gold, from the colour of the fruit of this tree ; and, for the same reason, the English name, orange, is derived from the French word, or, gold. The Spanish, Italian, and Poriuguese appellations are derived from the Arabic, narunj, or more remotely from the Sanscrit, nagrungan, the name of this tree.

Engravings. Risso et Poiteau, Histoire Naturelle des Orangers; Poiteau et Turpin, Traitè des Arbres fruitiers de Du Hamel; Audubon, Birds of America; Catesby, Natural History of Carolina; and the figures below.

Specific Characters. Calyx, quinquefid. Petals white, oblong, and 5 in number. Antheræ, 20-androus, with their filaments grown together, so as to form various pencils. Fruit, a 9 to 12-celled berry, globose, or flattened at the ends, with a thin or rough golden-yellow, or tawny rind, and a sweet, or bittersour pulp. Petioles, winged, sometimes nearly naked. Leaves, oval-oblong, elliptical, acute, or acutecrenulate.

\section{Description.}

"Kennst du das Land? wo die Citronen blühn,
Im dunkeln laub die Gold-Orangen glühn,
Ein sanfter Wind vom blauen Himmel weht,
Die Myrte still und hoch der Lorber steht."

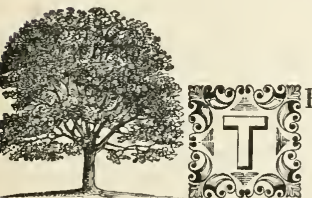

HE Citrus aurantium, under favourable circumstances, usually attains a height of twenty-five or thirty feet, and is graceful in.all its parts. The trunk is upright, and branches into a regular or symmetrical head. The bark of the twigs is of a soft and almost translucent green, while that of the trunk and older branches is of a delicate ash-gray. The leaves are moderately large, beautifully shaped, of a fine healthy green, and shining on the upper sides, while the under sides have a slight appearance of down. The flowers occur in little clusters on the sides of the branches, are pleasing in their form, of a delicate white in the sweet oranges, and in the more acid varieties slightly tinged with pink. In some plants, they have a more powerful sdour, and are, for the moment, more rich; but, in the orange-grove,
GOETHE.

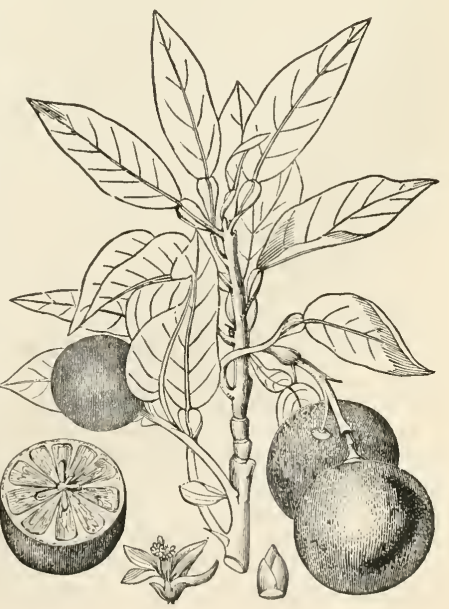


there is a fragrance in the aroma which never satiates nor offends; and, as the tree is at one and the same time in all stages of its bearing-in flower, in fruit just set, and in golden fruit, inviting the "hand to pull and the palate to taste," -it is hardly possible to conceive or imagine any object more delightful. There is something, too, peculiar in the organization of the fruit of this tree. Its rind, or external covering, is of a spongy texture, containing but little juice or sap of any kind in its substance; but the external surface is covered, or tuberculated with iittle glands, which secrete an acrid, volatile oil, very inflammable, and of a strong, pungent taste. The interior of the fruit is usually divided into from nine to twelve carpels or cells, which contain the pulp, seeds, and juice, and are united by a whitish pellicle or leathery skin, radiating from the centre to the rind, and may easily be separated without wasting the juice. The seeds are solitary or several, and are attached to the inner angle of the carpel, and in some varieties, are entirely wanting.

Varieties. The varieties or races of the orange have been greatly multiplied; but whether from the proneness to change from some original differences in the species, or from difference of soil and climate, it is difficult to determine. It was the opinion of Galesio, who described forty principal kinds, as cultivated in Italy, that they were all derived from the common orange, although some are more acid, and others more bitter in their flavour. The most important varieties may be described as follows :-

1. C. a. umbilicata. Navel Golden-fruited Orange-tree; Oranger nombriz. of the French; Nubel Orangenbaum, of the Germans; Melarancio umbilico, of the Italians; Naranjo ombliggo, of the Spaniards ; Laranjêira embiga, of the Portuguese and Brazilians. This variety is a curious lusus naturæ, differing from the common orange by having, near the crown, and in some instances, quite outside of the pulp, at the end opposite the stcm, an excrescence resembling a small orange when the rind is removed, into which is drawn all the superfluous or objectionable portion of the fruit, leaving the legitimate production free from impurities, and rendering it the most delicious and agreeable of its kind. The fruit is usually round, or slightly oblong, rather larger than that of the common orange, with a rind of about the same colour, surface, and thickness. The pulp is of a yellowish colour, of a delicious flavour, and better filled with juice than oranges generally in the torrid zone. It is chiefly cultivated in the neighbourhood of Bahia, in Brazil, where it is thought to be one of the greatest prodigies of the vegetable kingdom. The author of the present work claims the honour of first introducing this variety into the United States. He brought several trees from Brazil, in 1S35, and causcd them to be planted on the estate of the late Z. Kingsley, on Drayton Island, Lake George, East Florida, where they are believed still to exist.

2. C. A. sinensis. Chinese Golden-fruited Orange-tree, with ovate-oblong leaves; round, smooth, and rather flattened fruit, which is much esteemed, and is called by the Portuguese, Laranja da Xina; by the French, Orange douce; and Porto-gallo or Poma de Sino, by the Italians.

3. C. A. Pyriformis. Pear-shaped Golden-fruited Orange-tree. This variety may be known by its elliptical, acute leaves, and large, top-shaped fruit. It is one of the most hardy kinds, and is well worthy of cultivation.

4. C. A. sanguinea. Blood-red-pulped Golden-fruited Orange-tree, distinguished by its ovate-oblong pellucid leaves, and medium-sized, round, rough, and reddish-yellow fruit, with a pulp irregularly mottled with crimson. The Arancio di sugo rosso of the Sicilians, is a sub-variety of it, who call the true blood-red variety, Arancio di Malta sanguigno. There is another sub-variety with small fruit, growing about Nice, called by the Italians, Arancio a foglio stretta.

5. C. A. contidulcicula. Nweet-slinned Golden-fruited Orange; Pomme 
d'Adam, or forbidden fruit of the shops of Paris. This variety may be known by its broad, taper-pointed leaves, roundish, rather ovate, heavy fruit, and a deepyellow, smooth, thick, sweet, soft rind. Its pulp is sub-acid, and pleasant, of a deep-yellow colour, and is soft and melting in the mouth, like the flesh of a clingstone peach.

6. C. A. NoBiLis. Far-famed Golden-fruited, or Mandarin Orange-tree, with flattened, rough, deep-orange-coloured fruit, and a thin rind, which separates spontaneously from the pulp. It "is cultivated in China, where the fruit is chiefly consumed in presents to the officers of state, whence its name. Its singularity consists in the rind so completely separating from the pulp, when quite ripe, that the latter may be shaken about within. In quality it is inferior to no other kind.

7. C. a. asperma. Seedless Golden-fruited, or Saint Michael's Orange-tree, known by its small, round, seedless fruit, with a thin rind, and extremely sweet pulp. When in a state of perfection, it is, perhaps, the most delicious of all the varieties, and by far the most productive.

8. C. A. bigaradia. Bigarade or Bitter Golden-fruited Orange-tree. The branches of this variety are spiny; leaves elliptical, acute, with a winged stalk; flowers very white; fruit medium-sized, uneven, more or less globose, with an acid and bitter pulp. This tree is somewhat smaller than those of the preceding varieties, having broader leaves, and larger and sweeter scented flowers. It is called bigaradier by the French, and melangolo by the Italians. 'There are several sub-varieties of it cultivated, principally on account of their flowers, among which, the following are deserving of notice:-1st. Melangolo a frutto cornuto of the Italians, or Horned-fruited Bigarade, with a large, pale-yellow, ribbed fruit, the sides of which project into horns. It is much esteemed on account of the powerful and delicious perfume of its flowers. 2nd. The Female Bigarade, with a deepyellow, large, coarse fruit, containing orange within orange, which latter circumstance is not at all uncommon in the genus citrus, but exists, in the present instance, in perhaps the most striking manner. An orange, in its natural state, consists of one whorl of carpels, which are consolidated into a round fruit, each lobe being a carpel. It sometimes happens, however, that two whorls of carpels combine to form the same fruit, in which case, the inner whorl is consolidated into a central orange, and the outer whorl grows over it. Or, it may happen, that three whorls of carpels constitute the fruit, in which case, the innermosi whorl will combine into an orange in the centre; the second whorl will form a coating over it, and the most exterior one will enclose the whole. Finally, the carpels may separate wholly, or in part, and then the fruit consists of a number of lobes more or less distinct. 3rd. Curled-leaved Bigarade, called by the French gardeners, Le Bouquetier, and Bigaradier riche dépouillé ; and by the Italians, Melangolo riccio. The leaves of this sort are very compact, blunt, small, and curled, and its flowers grow in thick clusters at the ends of the branches. The fruit is coarse, very light, and uneven, having a large, conspicuous scar at the point. The tree itself is rather small, and is one of the most hardy of its race, being a common object of cultivation throughout the south of Europe. 4th. Double-flowered Bigarade, with rather thick leaves, double flowers, round, granulated fruit, and a thick rind. It is much esteemed on account of the profusion of fragrant double flowers it produces, which do not fall in pieces so quickly as the single ones. If the soil in which it grows is not kept in a very rich condition, it loses the property of producing double flowers. 5th. The Seville Bigarade, or Bitter Orange-tree; Naranjo amargo, Naranjo agrio, or Naranjo de Sevilla of the Spaniards, distinguished by its winged petioles, acute, crenulate, elliptical leaves, round, dark fruit, with an uneven, rugged, and extremely bitter rind, filled with a bitter, or bitter-sour pulp. It grows sponta- 
neously in East Florida, and on the Island of Cuba. 6th. Myrtle-leaved Bigarade, with small, very compact, ovate, sharp-pointed leaves, and small, round fruit. If well cultivated, it is generally both in flower and fruit at the same time. On this account, and its dwarfy habit, it is a very common object in houses and gardens. It is said to be employed by the Chinese gardeners as an edging of flower-beds, in the same manner as the dwarf box in Europe and America.*

Geography and History. The orange is believed to have been originally a native of the warmer parts of Asia, and has long since been acclimated to the shores of the Red and Mediterranean Seas, to the temperate and tropical isles of the oceans and seas, and to the warmer portions of Africa and America. It is especially cultivated with a view to profit, and abounds in Portugal, Spain, France, Italy, Greece, Turkey, Egypt, northern Africa, and many of the islands adjacent to those countries; also in the Azores, Brazil, the island of Cuba, and East Florida.

At the time of the crusades for the recovery of Syria from the dominion of the Saracens, oranges were found abundant in that country. Though they were, in reality, cultivated trees, the beauty and excellence of their fruit, by the aid of romance and credulity, naturally led the infatuated adventurers to believe and state that they jwere indigenous, and formed a part of the glories of the "Holy Land." The fables of the profane writers, and the ambiguity of the descriptions of vegetables in Holy Writ, helped further to confirm this opinion. As the oranges were in the form of apples, and the colour of gold, it was easy to make them the "golden apples of the garden of the Hesperides;" and the only point that remained to be settled, was to fix the locality of that enchanting and imaginary abode. The authority of Moses was brought into requisition to confirm the existence of the Syrian fruit, even at the time when the children of Israel were wandering in the wilderness; and the boughs of the "goodly trees" horne in the procession commanded in the twenty-third chapter of Leviticus, were considered no less than those of the orange. The mala medica of the Romans, which is mentioned by Virgil, and afterwards by Palladio and others; the kitron of the Greeks; and the citrus of Josephus, were all understood to mean the same fruit. Although there was much written upon the subject, there was no attempt to examine the authorities with that minuteness which the search of truth demanded. This opinion prevailed until the XIXth century, when the history of this fruit was carefully investigated by Galesio. He maintains that the orange, instead of being found in the north of Africa, in Syria, or even in Media, whence the Romans must have obtained their "mala medica," was not in that part of India, watered by the Indus, at the time of Alexander the Great's expedition, as it is not mentioned by Nearchus, the commander of the fleet, among the fruits and productions of that country. It is not noticed either by Arrian, Diodorus, or by Pliny; and even so late as the year 1300, Pietro di Cuescenga, a senator of Bologna, who wrote on agriculture and vegetable productions, does not make the least mention of the orange.

The first distinct notice of this fruit on record, is by Avicenna, an Arabian physician, who flourished in the $\mathrm{X}$ th century. He not only describes oleum de citrangula, (oil of oranges,) and oleum de citrangulorum seminibus, (oil of orangeseeds,) but speaks of citric acid (acid of citrons.) According to Galesio, the Arabs, when they entered India, found the orange tribes there, further inland than Alexander had penetrated; and they brought them to Europe by two routes, - the sweet ones through Persia to Syria, and thence to the shores of Italy and the south of France, and the bitter ones, by Arabia, Egypt, and the north of Africa, to Spain and Portugal.

* Penny Cyclopædia, vol. vii., p. 214. 
It does not appear that the orange was of Chinese origin, as it is not mentioned by Marco Polo, who is so minute in describing all the other wonders of the "Celestial Empire." It is said to have been found by the Portuguese upon the east coast of Africa; but it is not known whether it had been indigenous there, or disseminated by the Arabs. When the Portuguese reaclied India, in the early part of the XVIth century, they found the orange there, and also in China, which was then visited by them for the first time by sea.

At the Azores, nothing can exceed the rich luxuriance of the orange groves, from November to March, when the emerald tints of the unripe, and the golden hue of the mature fruit, mingle their beauties with the thick, dark foliage of the trees. Although the oranges of the Azores are among the best that are to be met with, they are not indigenous productions of those islands ; but were introdnced there by the Portuguese, as the same fruit was originally sent, by the Spaniards, to the West Indies, and the continent of America. In the midst of a forest, on the banks of the Cedeno, Baron Humboldt, in 1800, found wild orangetrees, laden with large and sweet fruit. These were probably not indigenous, however, but the remains of some old Indian plantations.

The orange plantations of the Azores are usually of large extent, always encircled by walls fifteen or twenty feet in height, and within thick belts of other trees, to protect them from the breezes of the sea. The trees are commonly propagated by cuttings or layers, arriving, in seven years after planting, to good bearing, and in time, spread out with the majestic luxuriance of chesnut trees. Each tree, a few years after, upon an average, annually produces from twelve thousand to sixteen thousand oranges, and one instance is recorded of a single tree producing twenty-six thousand fruits in a year!

The amount of oranges and lemons usually exported from the Azores in a year, is upwards of one hundred and twenty thousand boxes, and seventy or eighty vessels are sometimes seen lying in the roads, waiting to take their cargoes. Besides these, a large quantity of the sweet lemon is cultivated, for home consumption, which are produced by grafting the sour lemon on the orange. This fruit is tasteless and vapid, though esteemed salutary and refreshing.

In Algarve in Portugal, and in Andalusia in Spain, there are trees of great size; and extensive orchards of oranges have formed the principal revenue of the monks for several centuries. In Cordova, the seat of Moorish grandeur and luxury, there are orange-trees still remaining, which are supposed to have been planted as early as the XIth century; and in the craggy mountains of that province, which are covered with gardens and vineyards, and forests abounding in fruit, the air is perfumed with the flowers of the orange, and carries back the imagination to the days of the Moorish poets and historians, when the land they conquered was adorned with all the refinements of their taste and intelligence, and the luxuries of the east were fully realized.

The orange is said to have been introduced into Portugal by Camoens. In apostrophizing on a little grove that waved upon an open casement, that poet was heard to say, "Yes, I have made a bower for the honey-bee, hung with golden lamps."

In France, the orange country is chiefly Provence, or that part which lies to the eastward of the Rhone; and plantations or groves of oranges are the most abundant, and the nost beautiful, on the banks of the Var, and especially in the environs of Nice, where the varieties are very numerous, and come to great perfection. According to Risso, there was a tree in that neighbourhood, in 1789, which generally bore upwards of five thousand oranges, and was more than fifty feet in height, with a trunk so large that it required two men to embrace it. Here, 
the Provence rose, the tuberose, and countless other flowers, blend their sweets with that of the orange; and amidst all the richness of these perfumes, the pestilent airs of the tropics, and even the sirocco of southern Italy and Sicily, are altogether unknown.

In Italy, the orange groves accompany the chain of the Apennines round the whole gulf of Genoa, and until, upon the confines of the plain of Tuscany, they subside in elevation, and bend more toward the Adriatic; although, further to the south, the climate and vegetation of Tuscany cannot be compared to those of the little valleys of Provence and Liguria, especially the latter. About Florence, there are still orange-trees in the gardens; but there are none of those aromatic groves and plantations which are found further to the west. Mr. Spence, who passed some winters in Florence, states that the cold is so great there, that skating is sometimes practised occasionally four months of the year, and the thermonieter repeatedly stands at $24^{\circ}$ to $26^{\circ} \mathrm{F}$, at 8 A. M. Eastward of Tuscany, though further south, the country is even less adapted to the production of the orange; the sea-coast is barren, the interior is dreary, and over the whole, the "pestilent malaria" creeps, forbidding man to approach, even for the cultivation of the fields. In the gardens at Rome, however, notwithstanding the thermometer ranges from $2^{\circ}$ to $4^{\circ} \mathrm{F}$., lower, during the winter, than at Nice, the orange-tree flourishes, and attains its usual size. At the convent of Santa Sabina, in Rome, there is a tree of this species thirtyone feet high, which is reputed to be upwards of six hundred years of age. After the gulf of Gaeta is passed, and the shelter of the more elevated mountains in the kingdom of Naples is obtained, the orange groves again make their appearance, and particularly abound along the western shore of Calabria, and in the vicinity of Messina and Palermo, in the island of Sicily.

The precise period at which the orange was introduced into Britain, is not with certainty known; but it is supposed that it was brought from Portugal, by Sir Walter Raleigh, towards the end of the XVIth century. The trees were planted near a wall in the open air, at Beddington, in Surry, with a movable cover, to protect them from the inclemency of winter. They flowered, and bore fruit, and, at the beginning of the XVIIIth century, they had attained the height of eighteen feet, with a diameter of nine inches, and the spread of the branches of the largest one, was twelve feet in one direction, and nine feet in the other. In 1738, they were surrounded by a permanent enclosure, like a greenhouse, and were destroyed by a great frost in the winter following.

Parkinson, in his "Practise of Plants," published in 1629, gives some curious directions for the preservation of orange-trees, from which, one would be led to infer that the trees at Beddington, with their ainple protection of a movable covering in winter, had not been in existence at that time. "The orange-tree," says he, "hath abiden, with some extraordinary branching and budding of it, when as neither citron nor lemon-trees would, by any means, be preserved for any long time. Some keepe them in square boxes, and lift them to and fro by iron hooks on the sides, or cause them to be rolled on trundles or small wheels under them, to place them in an house, or close galerie, for the winter time; others plant them against a bricke wall in the ground, and defend them by a shed of boardes, covered with seare-cloth, in the winter; and by the warmth of a stove, or such other thing, give them some comfort in the colder times; but no tent or mean provision will preserve them."

Towards the end of the XVIIth and in the early part of the XVIIIth centuries, the orange-tree was a very fashionable article of growth, in conservatories, in France, as well as in Britain. The plants were mostly procured from Genoa, with stems generally from four to six feet in height; they were planted in large boxes, and were set out during summer, to decorate the walks near the 
houses, in the manner still practised at Versailles, the Tuileries, and some other collections in Europe, and in America.

The largest trees in Britain are said to be those at Smorgony, in Glamorganshire; they are planted in the floor of an immense conservatory, and produce fruit in abundance. It is said that these plants were procured from a wreck on the coast in that quarter, in the time of Henry VII.

In the south of Devonshire, and particularly at Saltcombe, one of the warmest spots in England, it is said there are gardens containing orange-trees, which have withstood upwards of one hundred winters in the open air. The fruit is represented as being as large and fine as any from Portugal.

In East Florida, the orange grows spontaneously in the neighbourhood of New Smyrna. In noticing that town, in 1791, Bartram observes, "I was there about ten years ago, when the surveyor run the lines of the colony, where there was neither habitation nor cleared field. It was then a famous orange grove, the upper or south promontory of a ridge nearly half a mile wide, and stretching north about forty miles. * * * * All this was one entire orange grove, with live oaks, magnolias, palms, red bays, and others." He also makes frequent mention of extensive groves of wild oranges, in Florida, as far north as latitude twenty-eight degrees. Dr. Baldwin, in 1817, in speaking of Fish's Island, says, "Here are the remains of perhaps the most celebrated Orange Grove in the world. Some trees still remain that are thirty feet in height, and still retain a portion of their golden fruit." In the same year, in describing the beauties of the St. John's he says, "You may eat oranges from morning till night, at every plantation along the shores, while the wild trees, bending with their golden fruit over the water, present an enchanting appearance." "These trees are not regarded as originally natives of the new world, but were introduced by the Spaniards, at the time they settled Florida, or by a colony of Greeks and Minorcans, who founded New Smyrna, in 1769, while that country was in the possession of the English. Audubon, as late as 1832, observes, "Whatever its original country may be supposed to be, the wild orange is, to all appearances, indigenous in many parts of Florida, not only in the neighbourhood of plantations, but in the wildest portions of that wild country, where there exist groves fully a mile in extent." 'This wild fruit is known in Florida by the name of the bitter-sweet orange, which does not differ materially from the Seville orange, and probably originated from that variety. The occurrence of these trees, wherever they grow, is a sure indication of good land.

For many years past, no small degree of attention has been paid to the culture of the common edible orange, at St. Augustine, and on the river St. John's. 'The number of trees owned by different individuals, prior to 1835 , varied from ten to fifteen hundred. Perhaps no person in Florida had more than the latter number in full bearing condition, at the time of the great frost, which occurred on the 9th of February, of that year. There were many trees then to be found in St. Augustine, which exceeded forty feet in height, with trunks from twenty to twenty-seven inches in diameter, and which, probably, were more than a century old. But there are many persons in that vicinity, at the present time, who are extensively engaged in the business. The late Mr. Kingsley left upwards of six thousand bearing trees, in 1843, all of which are on the St. John's. In addition to these, there are also on the same river, more than one hundred orange groves, which, it is estimated, contain twenty thousand trees. At St. Augustine, it is said, there are, at least, thirty thousand standard trees, four thousand of which are owned by Mr. J. Douglass, about the same number by Mr. V. Sanchez; and by Mr. J. Drisdale, and the lady of the late Dr. Anderson, fifteen hundred each. Notwithstanding the injuries which the trees have suffered by the depredations of insects, for a few years, as well as by the discouragement 
caused by frost, it may be observed, that there are more standard trees planted in Florida, at the present time, than there ever were at any former period. Previous to 1535 , St. Augustine produced annually from two million to two million five hundred thousand oranges, which were equal in bulk to about fifteen thousand barrels. They were shipped to Charleston, Baltimore, New York, Boston, \&c., and usually brought from one dollar to three dollars per hundred, or about three dollars per barrel, producing in the aggregate, a little short of fifty thousand dollars per annum. During the orange season, the port of St. Augustine formerly presented quite a commercial aspect, there being frequently from fifteen to twenty vessels in it at a time, loading with fruit. A person who was the owner of one hundred standard trees, could safely rely on a yearly income arising therefrom of two thousand dollars, sometimes three thousand, and even four thousand dollars! In 1829, Mr. A. Alvarez gathered from a single tree; six thousand five hundred oranges; and it is said that there was a tree on the St. John's, which bore ten thousand fruits in one year! But ordinarily each tree produces about two thousand fruits.

The orange has also been an object of culture for a long time in Carolina and Georgia: and in 1762, it will be seen by the London "Annual Register" for that year, that there were four barrels of this fruit shipped from Charleston to England.

Soil and Situation. The orange is found to flourish best in a warm, fertile soil, composed of sand and loam, or sand and clay, not too dry, and sheltered from chilly and parching winds. But it is cultivated in varied soils, and will thrive in any country, with a mean annual temperature of $62^{\circ}$ to $84^{\circ} \mathrm{F}$. Hence the locality favourable to the growth of this species depends fully as much upon soil and situation as upon latitude; and we are induced to infer, that, if the temperature be sufficiently high for maturing the flavour, the fruit is delicious in proportion to the uniform salubrity of the air; and that those high temperatures which often force a very large expansion of fruit are against the fineness of its quality. For instance, we will contrast the fruit of St. Michael's, in the Azores, of Bahia, in Brazil, or of some of the West India Islands, with that of Malta. The former is always exposed to the equalizing breezes wafted across the Atlantic, while that of the latter, lying near the arid and sultry coast of Africa, is subject to more changes of season, and a greater and higher range of temperature. There is also some difference in the soil of these places. The artificial earth, which forms the soil of Malta, was originally brought from Sicily; and by the decomposition of the rock, or of the saline particles brought by the same "pestilent sirocco" that blasts the fruit of the south of Italy and Sicily, a crust is formed, which, if not removed by trenching, at the end of a certain number of years, ceases to be productive, or the oranges become so bitter, that they are neither palatable nor healthful. But St. Michael's, Bahia, and the other places referred to, have no such disadvantage; the soils in those places are native, and deposite nothing calculated to injure their fertility or impair the qualities of their fruit. The same fact may be corroborated in comparing the climate of the slopes and valleys of the Estrella, near the lower Tagus, and that of the maritime Alps, and the Apennines, in Provence and Liguria, with that of Andalusia. At St. Angustine, in Florida, the fruit is generally of a superior quality, owing to some peculiar influence of the soil and climate. The mean annual temperature of that place in 1842 , was $73^{\circ} \mathbf{F}$. and in $1843,72^{\circ}$. The extreme heats from June to September are usually as high as $92^{\circ}$; but they liave been known to reach $97^{\circ}$. The extremes of cold generally range from 38 to $40^{\circ}$; but sometimes the mercury has fallen as low as $30^{\circ}$. On the 9th of February, 1835, the time that nearly all the orangetrees of Florida were cut off by frost, it is said that the thermometer indicated a 
temperature of 10 to $15^{\circ}$. In February, 1823, as well as in the same month in 1839, the trees also suffered in their extreme branches, from the effect of frost. On the morning of the 9 th of January, 1765 , the thermometer stood at $26^{\circ}$, at St. Augustine, and the ground was frozen to the depth of an inch, on the banks of the St. John's. This extreme cold proved fatal to the orange, and many other trees. Propagation and Management. T'Te orange may be propagated by seeds, suttings, layers, and grafting, or inoculation. The object of raising plants from seeds, is either to obtain new varieties, or stocks for grafting. They do not readily bear fruit, and often arrive at an age of twenty or twenty-five years without flowering. Mr. Henderson, of Woodhall, in England, well skilled in the culture of the citrus tribe, considers cuttings as the quickest mode of obtaining plants in that country, and gives the following directions:- "Take the strongest young shoots, and also a quantity of the two-year old shoots; these may be cut into lengths of from nine to eighteen inches. Take the leaves off the lower part of each cutting to the extent of about five inches, allowing the leaves above, that remain, untouched; then cut right across, under an eye, and make a small incision in an angular direction on the bottom of the cutting. When the cuttings are thus prepared, take a pot, and fill it with sand; size the cuttings, so that the short ones may be all together, and those that are taller in a different pot. Then, with a small dibble, plant them about five inches deep in the sand, and give them a good watering over head, to settle the sand about them. Let them stand a day or two in a shady place, and if a frame be ready with bottom-heat, plunge the pots to the brim. Shade them well with a double mat, which may remain till they have struck root; when rooted, take the sand and cuttings out of the pot, and plant them into single pots, in the proper compost. Plunge the pots with the young plants again into a frame, and shade them for four or five weeks, or till they are taken with the pots; when they may be gradually exposed to the light. From various experiments, I found that pieces of two-year old wood struck quite well; and in place, therefore, of putting in cuttings six or eight inches long, I have taken off cuttings from ten inches to two feet long, and struck them with equal success. Although I at first began to put in cuttings only in the month of August, I now put them in at any time of the year, except when the plants are making young wood. By giving them a gentle bottom-heat, and covering them with a hand-glass, they will generally strike-root in seven weeks or two months." When the wood of the orangetree is fully ripened, and the sap is at rest, grafts and cuttings may be kept in the dark for two or three months together, provided the air be kept dry.

Within the tropics, where the circulation of the sap is nearly uniform throughout the year, the orange may readily be propagated by the following method:Select a vigorous branch of any tree of the variety wished to be propagated, with flowers and fruit upon it, if desirable, and bind round it, at its junction with the trunk, or limb from which it grows, a funnel-shaped mass of fine, rich mould, firmly kept in its place by pieces of tin, bark, cloth, or other substance. This mass should constantly be kept moist, and new mould or earth added, if necessary, until shoots protrude from the branch and take root. As soon as these roots are sufficiently developed, the branch surrounded by mould may be sawed off close to the trunk or limb from which it proceeds, and transplanted, without disturbing the mould, into a box of light, rich, natural soil, or to some other place congenial to its growth. We have obtained vigorous trees in this manner in Cuba and Brazil, in six or eight weeks' time, that would bear transportation.

If grafting or budding be adopted in the propagation of the orange, the proper period for performing these operations is, when the sap is in brisk motion, which 
usually occurs in the northern hemisphere in the month of March. For small grafts, less than half of an inch in diameter, the whip, or splice method should be adopted, and for larger ones, the saddle mode is preferable, as practised in the apple and pear. But the most sure and expeditious method is that of spring budding, by which the bark of the stock, as early in the season as it will separate from the wood, is cut like the letter T inverted, (thus, L) as shown by (a) in the adjoining figure; whereas, in summer budding, it forms a $\mathrm{T}$ in its erect position. The horizontal edges of this cut in the stock, and of the shield bark, containing the bud, should be brought into the most perfect contact, as denoted by $(b ;)$ because the union of the bark in spring takes place by means of the ascent of the sap, whereas, in summer budding, it is supposed to be caused by its descent. The parts should then be immediately bound with water-proof bass $(c)$ without applying either grafting-clay or grafting-wax. The buds may be inserted either in a healthful branch,
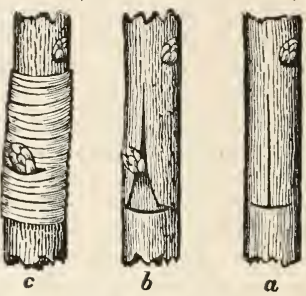
or in a stock near the ground. In general, two buds are sufficient for one stock; and these should be of the same variety; as two sorts seldom grow with equal vigour. The bass ligature, which confines the bud, may be removed, if the season be moist, in a month after budding; but if it be hot and dry, not for six weeks, at least. As soon as the inserted buds show signs of vegetation, the stock or branch, containing them, should be pruned down, so as to leave one or two buds or shoots above. If the stock is allowed to have a leading shoot above the inserted buds, and this shoot is not shortened, the buds inserted probably will not show many signs of vegetation for several weeks.

Though orange-trees will grow exceedingly well in large pots and boxes, yet to have them produce the finest crop of fruit, they should be planted in the ground like peach-trees, and trained like them, or as standard cherries in a conservatory. The latter mode has by far the best effect, especially when the stems of the trees are seven or eight feet high, and the head forms a handsome cone; but the largest fruit is produced when the trees are planted against the backwall trellis of a narrow house, and treated like peach-trees.

At Genoa and Florence, orange-trees are grown in a strong yellow clay, which is highly manured; and this soil is considered by the first Italian gardeners as best suited to their natures. In France, in preparing a compost for them, they endeavour to compensate for quantity by quality; because the pots or boxes, in which the plants are placed, ought always to be as small as possible, relatively to the size of the tree. The following is the composition recommended :- "To a fresh loam, which contains a third of clay, a third of sand, and a third of vegetable matter, and which has lain a long time in a heap, add an equal bulk of half-rotten barnyard manure. The following year turn it over twice. The succeeding year mix it with nearly one half its bulk of decomposed horse manure. Turn it over twice or three times, and the winter before using, add one twelfth part of sheep manure, a twentieth of pigeon dung, and a twentieth of dried ordure." Mr. Henderson, already mentioned, takes one part of lightbrown mould from a piece of ground that has not been cropped, nor manured for many years; one part of peat earth, such as is used for growing heaths; two parts of river, or pit sand, if it be free from saline substances; and one part of rotted hot-bed dung, with one part of rotted leaves of trees, and mixes them all well together, so as to form a compost soil of uniform quality.

The usual mode of propagating the orange in Florida, is to plant the seeds and wait patiently for about twenty years, till the trees become of a sufficient 
height to bear fruit, which is ordinarily about fifteen. or twenty feet. It is well known there, that the period of bearing might be hastened by grafting or budding; but this has never been resorted to generally. It is true, several individuals have practised these operations very successfully on wild stocks, but these are mere exceptions. The propagation of the orange by cuttings, or by layers, does not succeed well in Florida, probably owing to the aridity of the soil and climate.

Near the equator, the fructification of the orange is constant, and is at one and the same time, in all stages of its bearing; but in higher latitudes, it continues flowering during nearly all the summer, and the fruit takes two years to come to maturity; so that perpetually, at the equator, and for a considerable portion of the year in higher latitudes, a healthy tree exhibits every stage of the production, from the flower-bud to the ripe fruit in perfection, at the same time. The gathering of oranges, intended for the European and American markets, usually takes place from October to January, while they are green; but they do not fully mature before spring has commenced. And it is a remarkable fact, that the trees from which the fruit is gathered green, bear plentifully every year, while those upon which the fruit is suffered to ripen, afford abundant crops only on alternate years.

Insects. The principal insects that infest the orange-tree, are several species of coccidæ, or bark-lice, the habits of which are nearly uniform, and may be described as follows:-On examining the trees early in the spring, the female insects may be found, in a lifeless state, fastened close to the bark, having been fixed in this position ever since the year before. A little later in the season, their bodies become more distended, and on carefully removing them, numerous eggs will be found beneath them. At this period, the internal parts of their bodies appear to be dried up and dead, their outer skins only remaining, which serve as shields for protecting their future progeny. On the approach of the heats of summer, the larvæ are hatched, and escape at the lower extremities of the shields, which are slightly elevated or notched at these parts. In this stage of their existence, they usually have the appearance of small, oval, roundish, or oblong scales, of a brownish colour, and much in the shape of their parent shields, but thinner, more flattened, and of a paler colour. At first, they are full of activity, disperse themselves over the young shoots and leaves, puncture the tender parts, exhaust the sap by suction, and increase in size, till they prepare for change. In the early period of their growth, their heads are completely concealed beneath the shells of their bodies; their beaks or suckers appear to proceed from their breasts; and their legs, which are six in number, are so short that they are not visible from above. When they have completed the larva state, they prepare for transformation by emitting from the under sides of their bodies, numerous little downy threads, by which they securely confine themselves to the bark. After becoming thus fixed, they remain, for a time, in a torpid state, and under these inanimate scales, the transformations of both sexes take place. The outer coverings of the males serve as cocoons, from which they appear to shrink and become detached. In the course of time, they push themselves out of their shells, at the little fissures at their extremities, and appear in their perfect form, having two wings, which lie flatly upon their bodies, but no beaks, as they had previous to their transformation. In a few days after the females fasten themselves to the bark, they contrive to burst, and throw off in flakes, their outer coats, and betake similar forms as those which they before assumed, and enter into the pupa or chrysalis state. When mature, they retain their beaks or suckers, and are wingless, but are destined never to change their places after they have once become fixed. In this condition, their bodies are greatly enlarged, and in some species, approach more or less to a spherica 
form. It is in this condition that they receive the embraces of the males, after which, they continue to increase in size for a time, eject their eggs, and gradually shrink away, leaving nothing but their dry, outer skins, and perish on the spot. After the eggs mature, they imperceptibly pass under the body of their mother, where they remain, until they undergo the changes before described.

The species that commonly attacks the orange in southern Europe, the Azores, and the West India Islands, is the Coccus hesperidum, which also infests the myrtle. It may be known by the oblong-oval form, and brownish colour of its shield, which is covered, as it were, with a coat of varnish. Another species, the pest of Florida, for the last five years, is the Coccus ****? It is about one-eighth of an inch in length, and one tenth as wide as it is long, of a brownish colour, pointed at the extremities, and straight, or curved, according to the nature of the surface to which it adheres. The larvæ make their first appearance at St. Augustine as soon as a few warm days occur, in January or February; but their general hatching period is not considered to begin before March, and is never suspended from that time until the commencement of the cool weather in November or December. Myriads of these young insects, scarcely discernible to the unaided eye, may be observed crawling over the trees, puncturing the tender shoots and leaves, and sucking their sap, by which they gradually increase in size, and in about eight days, permanently fix themselves to the trunk, branches, and leaves, to undergo their transformations. Soon after the commencement of hot weather in May, vast numbers of the perfect male insects may be seen, and, as the season advances, they become still more numerous, until they are checked by cool weather, in September or October. In shaking violently a tree infested with these insects, myriads and myriads of them may be seen flying between the observer and the rising sun. And during the summer, the young leaves, branches, and other uninfested parts of the trees become rapidly and successively covered with the scales of these insects, which are at first scarcely perceptible to the naked eye, but soon increase to their full size. This circumstance tends to prove that there are many broods or generations in the same season.

This insect first made its appearance in Florida, in Robinson's grove, at Mandarin, on the St. John's, in 1838, on some trees of the Mandarin variety, which had been procured in New York. In the course of three or four years they spread to the neighbouring plantations, to the distance of ten miles, and were the most rapid in their migrations in the direction of the prevailing winds, which evidently aided them in their movements. In 1840, Mr. P. S. Smith, of St. Augustine, obtained some orange-trees from Mandarin, and had them planted in his front yard. From these trees the insects went to others of the same enclosure, and rapidly extended themselves to the trees and plantations to the northerly and westerly parts of that city and vicinity, obviously aided in their migration by the south-east trade-winds, which blow there almost daily during summer; and what is remarkable, these. insects were occupied nearly three years in reaching trees in the south-east part of the city, only about half of a mile from their original point of attack. They have since, however, extended themselves to all the trees in and about the city; but have not yet travelled in any direction beyond ten miles. Being aided in their dispersion by birds and other natural causẻs, impossible to guard against, they must eventually attack most, if not all the trees in Florida; for the wild orange groves suffer equally with those which have been cultivated, and no difference can be perceived in their ravages, between old and young trees, nor between vigorous and decayed ones. Various remedies have been tried to arrest their progress, such as fumigating the trees with tobacco smoke, covering them with soap, lime, potash, sulphur, shellac, glue, and viscid or tenacious substances, mixed with clay, 
quicklime, salt, etc., but all have failed partially or entirely, and it appears not to be in the power of man to prevent the ravages of these insignificant and insidlous destroyers. Most of the cultivated orange-trees in Florida have already been injured by them, their tops and branches having been mostly destroyed. Their roots and stems, it is true, remain alive, and annually send forth a crop of young shoots, only to share the fate of their predecessors. The visitation of these insects in Florida, probably is not destined to continue much longer, at least with its present violence; for, among the means which nature has provided to check their increase, are various species of birds, that devour inconceivable numbers of them, and the coccidæ are invariably accompanied by considerable numbers of yellow lady-birds, (coccinella, ) which, it has been conjectured, have been appointed to keep them down.

Properties and Uses. The wood of the orange-tree, when dry, weighs fortyfour pounds to a cubic foot, is hard, compact, flexible, slightly odoriferous, and is susceptible of being polished. When recently cut, it is of a yellowish hue, but in the course of time it fades. From its scarcity and small size, it is but little employed in the arts, the only particular uses to which it is applied being to make boxes, dressing-cases, and other articles of fancy; and in Florida, considerable quantities of straight, young shoots, are cut, and shipped in bundles, to be made into walking-canes.

The fruit of the orange may be obtained fresh, in any region of the globe, and at almost every season of the year. The aromatic oil and the rind preserve it from the effects both of heat and of cold; and the acridity of the former renders it proof against the attacks of insects. It is true that oranges decay, like other fruit; but that does not happen for a long time, if the rind remains uninjured, and they are kept from humidity, and so ventilated as not to ferment. With regard to the quality of this fruit in various places, there appears to be a diversity of opinion. Some consider those of Malta the best; others, those of St. Michael's; while others prefer those of Bahia, Havana, or of St. Augustine.

The Maltese oranges are usually large, the rind thick and spongy, and the glands which secrete the volatile oil, are prominent. The pulp is red, and delicious, although, sometimes, there is a trace of bitterness in their taste. They are shipped in boxes, of an irregular size, and are generally packed in shavings or saw-dust.

The St. Michael's oranges are of a small size, the rind is thin and smooth, the glands small, which secrete but little volatile oil, the pulp light-coloured, and of a delicious, sugary taste. They are put up in boxes of three hundred and fifty to four hundred, with each fruit enveloped in paper, or in the husks of maize.

The celebrated Navel oranges of Bahia, are of difficult transport to Europe and the United States, in consequence of the length of the voyage, and of the humidity and warmth of the climate through which they have to pass. If they are gathered green, however, and suspended in the air above deck, or at the stern of the vessel, in netting, they will endure through the voyage.

The Havana oranges are usually of a good size, with a moderately rough rind, and a pulp well filled with delicious juice. From the shortness of the voyage to any of the American markets, they may be safely transported during the winter months. The fruit is ripe in Cuba at the end of October, and is usually shipped in barrels of two hundred and fifty to four hundred fruits in each, put up loosely, without any envelopes.

The St. Augustine oranges are superior, both in size and quality, to those of Cuba, or the Mediterranean. They resemble those of Havana in flavour, but are much larger, and bring from twenty to thirty per cent more, in the New York and Boston markets. Of the smaller sizes, it requires about three hundred fruits to fill a barrel, but of the largest ones, only one hundred are necessary. 
In Europe, the Valencia oranges are eagerly sought after, on account of their early appearance, large size, and beautiful colour. They are put up in boxes of two hundred and twenty to two hundred and forty fruits in each, enveloped in brown paper.

The Sicilian oranges, and those of the south of Italy, may be regarded as nearly of the same quality. They are of a medium size, with a fine colour, and are rather acid in their flavour. Those shipped from Messina are put up in boxes of two hundred to two hundred and ten fruits in each, and those of Palermo, which mature later, are shipped in boxes of three hundred or more fruits in each. The oranges of Reggio ripen very early, so much so, that it is not unusual to send them away by the 20th of October. They are packed in boxes of two hundred and forty fruits in each, and like most of the oranges of the Mediterranean, are enveloped in paper.

The Provence oranges come to great perfection, and may be classed with those of Genoa. Along the river Var, they have two harvests of the orange, the first commencing from the 10th to the 15th of November, when the fruit begins to turn, and continues till the 4th of December; the second begins about the 10th of January, and is prolonged nearly to the end of February. They are put up in boxes of one hundred and twenty to three hundred and sixty fruits in each, according to their size and qualities.

With the Seville oranges may be classed those of Faro, St. Ubes, Oporto, Andalusia, Malaga, and the bitter oranges of Cuba and Florida. This fruit is usually of a good size, of a beautiful colour, but unfit to eat, on account of its bitter flavour. Those shipped from Seville are put up in large boxes, of one thousand fruits in each; while those of Faro and St. Ubes are badly packed, in cases of three hundred to three hundred and fifty in each. Those of Spain and Portugal are principally carried to England and the Baltic, and are employed in cookery, and in the manufacture of cordials and other aromatic liquors. The essential product of the fruit is in the rind or peel; it is cut into quarters, separated from the pulp, and caused to be quickly dried. It is much used in Holland in aromatizing a certain liquor, called curaçoa. In East Florida, the immediate vicinity of a wild orange grove, is of some importance to the planters. They collect the fruit, extract the juice by horse-mills, and send it off to different markets, where it is used as an ingredient in cooling drinks. The fruit is sometimes given by them to their horses, which seem to eat it with relish. In Cuba it is much used by the inhabitants in the cure of fluxes, intermittent, and other fevers. In France, in the department of the Var, and particularly at Grasse, the flowers of the Seville orange are brought into use. A volatile oil is listilled from them, called neroli, the colour of which varies from a reddish-yellow to a deep red. It is very fluid, of an agreeable odour, and is chiefly employed in pharmacy and in perfumery. For the latter purpose, this variety is superior to the ordinary orange.

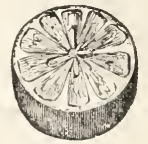




\section{Genus ACER, Linn.}

Aceracex.

Syst. Nat.
Polygamia Monœcia.

\section{Synonymes.}

Acer,
Erable,
Ahorn,
Acero,
Acer, Arce,
Maple,

Acer,

Erable,

Acern,

Maple,
OF Authors.

France.

Germany.

Itali and Portugal.

Spain.

Britain and Anglo-America.

Derivation. The word Acer signifies in Latin, hard or sharp, and is derived from the Celtic, ac, a point. The name is sup. posed to be applied to this genus because the wood of some species is extremely hard, and was much sought after by the ancients for the purpose of making pikes and lances.

Generic Characters. Sexes hermaphrodite, or monœciously polygamous. Flowers with a calyx and corolla. Calyx divided into 5 parts, or some number between 4 and 9 . Petals the same in number. Stamens 8 , or some number between 5 and 12. Anthers 2-lobed. Carpels 2, very rarely 3 , each a samara ; that is, a fruit, which is called, in England, vernacularly, a key. Leaves lobed and toothed, or, rarely, neither lobed nor toothed. Flowers generally yellow, with more or less green blended with the yellow; red in Acer rubrum.-Loudon, Arboretum.

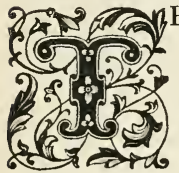

$\mathrm{HE}$ species of this genus are chiefly low and middle-sized deciduous trees, highly ornamental, and valuable in some kinds, for their timber, and in others, for the sugar they produce. The flowers are not individually conspicuous, but interesting in those species which put forth at leafing-time, from their number and rarity, and from the enlivening effect of the numerous bees, and other insects, that generally attend them at that season. The tips of the wings of the samaræ of several of the European kinds are of a light-red, at the end of summer, and in autumn. It is in this genus too, that we early observe the sylvan beau, weary of his summer suit, first shifting his dress to ochrey shades, then trying a deeper tint, and, lastly assuming an orange or scarlet vest. The larger-growing species are often many years before they come into flower, and even then, they do not mature their seeds for several seasons, probably from being only of one sex. In general, it may be observed, that there is great uncertainty, in the different species of acer, with regard to sex.

Geography and History. The genus acer is confined to Europe, North America, northern India, and to southern Russia, in Asia.

The ancients held the maple in great esteem; and tables inlaid with curious portions of it, or formed entirely of its finely variegated wood, in some instances brought their weight in gold. To such a height did the fondness of the Romans for curious woods, carry them at one period of their history, that their tables were even more expensive than the jewels of their ladies. Maple dishes are frequently mentioned by the Latin poets, and Virgil celebrates the maple, as the throne of the "good Evander," and its branches as the canopy under which he received and seated Aneas :-

\footnotetext{
"On sods of turf he sat the soldiers round:

A maple throne, raised higher from the ground,

Received the Trojan chief; and, o'er the bed

A lion's shaggy hide, for ormament they spread."
}

Cowper, and many modern poets, also mention bowls of maple as being used by shepherds and hermits. Pliny gives an elaborate account of the properties and uses of the maple. He enumerates ten different kinds that were known to 
the Romans, in his time, and that the wood of some species was considered next in value to the citron-wood. He treated at length upon the brusca and molusca, or knobs and excrescences of the maple, of which, furniture and cabinet-work of the most costly kind were made.

General Remarks on Propagation, Culture, $\&^{\circ} c$. The maple tribe, in general, prefer a free, deep, loamy soil, rich rather than sterile, and neither wet nor very dry. The situation that suits them best, is one that is sheltered and shady, rather than exposed. They are seldom found on the north sides of lofty mountains, or on mountains at all, except among other trees; but in the plains they are found by themselves. They are chiefly propagated by seeds; but some kinds are increased by layers, cuttings of the shoots, and roots, and by budding, or grafting. The seeds of most of the species ripen in September or October, and may be gathered by hand, or by shaking the tree, when the keys begin to turn brown. The maturity of the seeds may be proved by opening the keys, and observing whether the cotyledons are green, succulent, and fresh; if the green colour is wanting, they are good for nothing. The seeds of all the species may be sown in autumn, or in the spring; and the latter time is preferable where moles or other vermin abound, which are liable to devour them. If sown in spring, they come up in five or six weeks, with the exception of those of the Acer campestre, which are said never to vegetate till the second or third year. The seeds should not be covered with more than one fourth or one half of an inch of soil, and the ground where they are sown may be advantageously shaded with leaves, heath, or straw. 


\section{Acer tataricum, \\ THE TARTARIAN MAPLE.}

\section{Synonymes.}

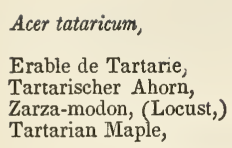
(Linn жus, Species Plantarum.
$\{$ De Candolle, Prodromus.
Lovdon, Arboretum Britannicum.
France.
Germany.
Russia.
Britain and Anglo-America.

Engravings. Loudon, Arboretum Britannicum, i., figure 114, o. 434, et v. pl. 25; and the figures below.

Specific Characters. Leaves cordate, undivided, serraied, with obsolete lobes. Racemes compound, crowded, erect; wings of fruit parallel, young ones puberulous.-Don, Miller's Dict.

\section{Description.}

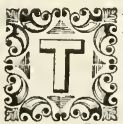

HE Tartarian Maple, in favourable situations, attains a height of forty or fifty feet; but near the river Wolga, and its tributaries, it forms a hemispherical tree, about twenty feet in height, with a summit as broad and as high as the tree itself. The branches are numerous, and disposed into a compact head, densely covered with leaves, which are distinguished by a peculiarly veiny appearance, and lively green. The flowers, which appear in May and June, are of a pale, greenish yellow, sometimes slightly tinged with red, as are the fruit or keys, before their maturity.

Geography and History. The Acer tataricum is found in Tartary, and is common throughout all the south of European Russia; but it does

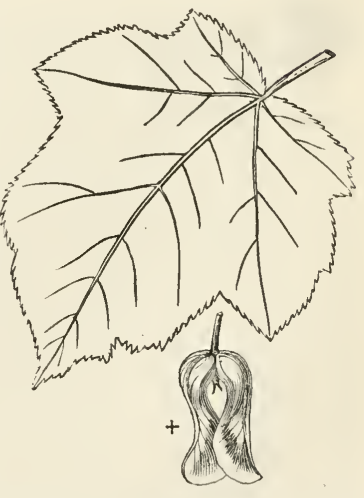
not occur on the Ural Mountains, nor on the Caucasus. It was introduced into Britain in 1759, and is cultivated in the chief gardens in Europe solely as an ornamental tree.

The largest tree in Britain is at Endsleigh Cottage, in Devonshire, which, at eighteen years planted, was forty feet high.

Properties, Uses, \&.c. The wood of this species is hard; and being of a whitish colour, veined with brown, it may be used for cabinet-work. In ornamental plantations, the tree is valuable on account of the early expansion of its leaves, which appear before those of almost every other kind of maple; and it is said to thrive in a moister soil. When raised from seeds, the plant will come into flower in five or six years; and in good soil, it will attain the height of fifteen feet in ten years. Pallas informs us, that the Calmucks, after depriving the keys of their wings, boil them in water, and afterwards use them for food, mixed up with milk and butter. 


\section{Acer spicatum, THE SPIKE-FLOWERED MAPLE.}

\section{Synonymes.}

Acer spicatum.

Acer montanum,

Erable de montagne,

Berg Ahorn,

Acero di montagna,

Mountain Maple, Low Maple,
( Linn 压, Species Plantarum.

De Candolle, Prodromus.

Don, Miller's Dictionary.

Loudon, Arboretum Britannicum.

Torrey and Gray, Flora of North America.

Michaux, North American Sylva.

France.

Germany.

ITALT.

Britain and Anglo-America.

Engravings. Michaux, North American Sylva, pl. 47; Audubon, Birds of America, pl. cxxxiv.; Loudon, Arboretum Britannicum, 1, figure 115 , pl. 435 , et v. p. 26; and the figures below.

Specific Characters. Leaves cordate, 3- or slightly 5-lobed, acuminated, pubescent beneath, unequally and coarsely serrated. Racemes compound, erect. Petals linear. Fruit smooth, with the wings rather diverging.-Don, Miller's Dict.

\section{Description.}

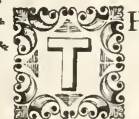

HE Mountain Maple is a low, deciduous tree or shrub, seldom exceeding a height of ten or twelve feet in its native habitat, and it often flowers at an elevation of less than six feet. It most frequently grows in the form of a shrub, with a single stem, and a straight stock. The leaves are large, opposite, and divided into three acute and indented lobes. They are slightly hairy at their unfolding, and when fully grown, they

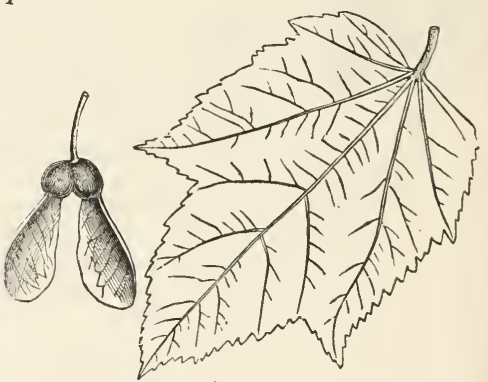
are uneven and of a dark green on the upper surface. The flowers, which appear in May and June, are small, of a greenish colour, and consist of semierect spikes from two to four inches in length. The seeds, which are smaller than any of the other American maples, are fixed upon slender, pendulous footstalks. They are reddish at maturity, have each a small cavity on one side, and are surmounted by a membraneous wing. They are usually ripe in the early part of October.

Geography and History. The Acer spicatum is most abundant in Canada, and along the range of the Alleghany Mountains, as far south as the forty-first degree of latitude. It was introduced into England in 1750, by Archibald, Duke of Argyle, and has since been cultivated in many of the gardens on the continent.

According to Loudon, the largest tree of this species in England, is at Croome, in Worcestershire, which, in 1835, had been planted thirty years, and was forty feet high, fifteen inches in diameter near the ground, with an ambitus, or extent of branches, of twenty feet. He mentions another at Edinburgh, in the Caledonian Horticultural Society's garden, which, nine years after planting, was thirty feet high. Also, another at Florence Court, the residence of the Earl of Enniskillen, in Ireland, which at thirty-eight yea`s' growth was fifty feet high. 
Soil, Situation, S.c. This tree, in its natural habitat, prefers the declivities of mountains exposed to the north, and in cool, moist, and shady places; or on the abrupt and rocky banks of torrents and rivers. When cultivated, the soil should be free, deep, loamy, and rather rich than otherwise, and neither wet nor very dry. It may be propagated either by seeds or by the modes recommended in the general remarks at the commencement of this genus. Michaux states that this species, grafted upon the European sycamore, (Acer pseudo-platanus) is, like the Acer striatum, augmented to twice its natural dimensions.

The mountain maple is ordinarily too small to be profitably applied to any useful purpose in the arts, and consequently can be of but little value except for rnament. 


\section{Acer striatum, \\ THE STRIPED-BARKED MAPLE.}

Synonymes.

\section{Acer striatum,}

Acer pennsylvanicum,

Erable jaspé,

Gestreifter Ahorn,

Acero screziato,

Striped Maple,

Dogwood, False Dogwood,

Moose-wood, Snake-barked Maple,
Michadx, North American Sylva

De Candolle, Prodromus.

Loudon, Arboretum Britannicum.

CLinnжus, Species Plantarum.

Du HaMeL, Traité des Arbres et Arbustes.

Torrey and Gray, Flora of North America.

France.

Germany.

ITALY.

New Jersey and Pennsyluania.

NEW YORK.

New England and British Amrrican Provinces.

Derivation. The specific name striatum, is derived from the Latin strio, striped, in allusion to the colour of the bark.

Engravings. Michaux, North American Sylva, pl. 45; Loudon, Arboretum Britannicum, i., figure 116 ; pp. 336, 337, et v. pl. 27; and the figures below.

Specific Characters. Leaves cordate, 3-lobed, acuminated, finely and acutely serrated. Racemes pendulous, simple. Petals oval. Fruit smooth, with the wings rather diverging.-Don, Miller's Dict.
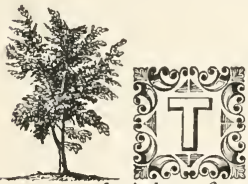

$\mathrm{HE}$ Acer striatum is a beautiful, deciduous tree, or shrub, growing, in its natural habitat, to a height of ten or twenty feet, and to nearly thirty feet in height, in a state of cultivation. The trunk and branches are covered with a smooth, green bark, longitudinally marked with light and dark stripes, by which the tree is readily distinguished at all seasons of the year. In the regions where it naturally grows, it is one of the first productions that announces the approach of spring. Its buds and leaves, when beginning to unfold, are of a roseate hue, and soon change to a yellowish-green. The leaves are of a thick texture, four or five inches wide, rounded at the base, and finely serrated. The flowers, which appear in May or June, are of a yel-

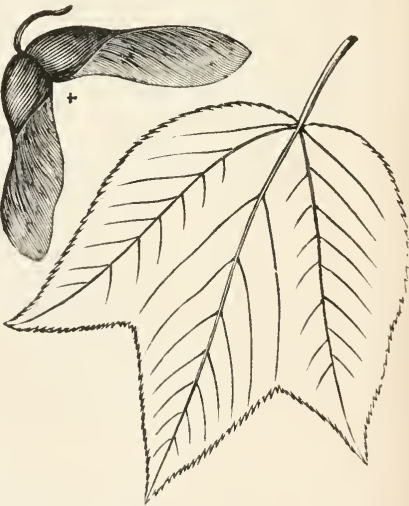
lowish-green, and are grouped on long peduncles. The fruit, which, like that of all its congeners, consists of samaræ or keys, is remarkable for a cavity on one side of the capsules. It is produced in great abundance, and ripens in September or October.

Geography and History. The Acer striatum is a native of North America, and makes its first appearance in about fifty-one degrees of latitude. It is particularly abundant in Nova Scotia, Canada, Maine, New Hampshire, and Vermont. In approaching the river Hudson, it becomes more rare; and beyond this boundary, it is confined to the mountainous tracts of the Alleghanies, in which it is 
ound in cold, shaded exposures, along the whole range, to their termination in feorgia. In many of the forests of Maine and New Hampshire, this species onstitutes a great part of the undergrowth, seldom exceeding ten feet in height; ut where it is not shaded by other trees, it attains a height of twenty feet and pwards.

This tree was introduced into England in about 1760, and was cultivated, not ar from that time, by Miller. It was probably soon after introduced on the coninent, where it is still growing in many of the gardens.

The largest tree of this species in Europe, and probably on the globe, is at chönbrunn, in Germany. In 1835 it was between thirty and forty feet high, rith a trunk eighteen inches in diameter.

The largest specimen in England, in 1835, mentioned by Loudon, was at Vhite Knight's, near Reading. At twenty-five years after planting, it was wenty-one feet high. Another tree is noticed by him at Oriel Temple, in Ireand, which, at thirty-five years planted, was twenty-seven feet high.

Properties, Uses, $\mathcal{S}^{*}$. The wood of the Acer striatum is white, and finerained and is sometimes used by cabinet-makers as a substitute for holly, or ther woods, for forming the lines with which they inlay mahogany. According Michaux, in Nova Scotia cattle are fed with the leaves of this tree, both in the reen and dried state; and in spring, when the buds begin to swell, horses and attle are turned into the woods to browse on the young shoots, which they devour ith avidity. The same thing is practised, at present, in regions where this tree bounds, both in Canada, and in the United States.

From the great beauty of the bark and foliage of this tree, it deserves a place 1 every collection. It is propagated by seeds, or by grafting on the Acer pseudolatanus

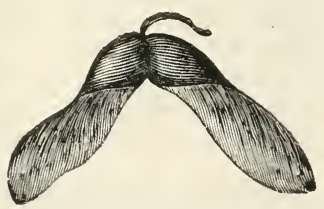




\section{Acer macrophyllum, \\ THE LARGE-LEAVED MAPLE.}

\section{Synonymes.}

Acer macrophyllum,

Erable à grandes feuilles, Grossblättriger Ahorn, Large-leaved Maple,

\author{
(De Candolle, Prodromus. \\ НоокеR, Flora Boreali Americana. \\ Don, Miller's Dictionary. \\ Loudon, Arboretum Britannicum. \\ Nuttall, North American Sylva. \\ France. \\ Germany. \\ Britain and Anglo-America.
}

Derivations. The specific name is derived from the Greek macros, great, and phulos, a leaf. The other names are translations of the botanic one.

Engravings. Hooker, Flora Boreali Americana, i., pl. 33; Nuttall, North American Sylva, pl. - ; Loudon, Arboretum Britannicum, i., figures 117 et 118, pp. 438 to 441 , et v. pl. $2 \$$; and the figures below.

Specific Characters. Leaves digitately 5-lobed, with rounded recesses. Lobes somewhat 3-lobed, repandly toothed, pubescent beneath, racemes compound, erect. Stamens 9, with hairy filaments. Ovaries very hairy.-Don, Miller's Dict.

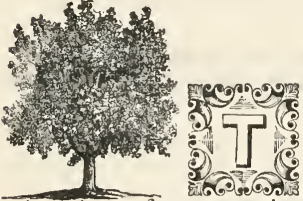

\section{Description.}

rying from forty to ninety feet in height, and from two to five feet or more in diameter. The trunk is covered with a rough, brown bark, and the branches are wide and spreading. 'The leaves vary much in size, and also in the manner in which they are lobed. Some are cut nearly to the base, so as almost to merit the appellation of palmate, while others are not more deeply cut than those of the Acer platanöides. The largestsized leaves are nearly a foot broad. The flowers are of a greenish-yellow, and very fragrant, appearing in April and May. The fruit is hispid, with elongated, slightly diverging, glabrous

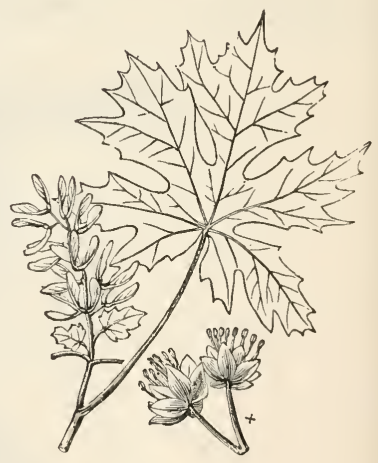
wings.

Geography and History. The Acer macrophyllum is a native of the northwest coast of North America. It is found exclusively in woody, mountainous regions along the sea-coast, between forty and fifty degrees of latitude, and on the great rapids of the river Columbia.

"This noble tree," observes Dr. Hooker, "was unquestionably discovered by Mr. Menzies, the first naturalist who visited the coast where it grows." Mr. David Douglass, who subsequently found it, prophetically adds, "It will, at some future time, constitute one of our most ornamental forest trees in England." It was introduced into Britain in 1812, where, however, it had not flowered in 1835. The largest specimen of this tree is in the garden of the London Horticultural Society, where it attained a height of twenty-five feet in twenty-three years. 
Properties and Uses. The wood of the Acer macrophyllum is whitish, beautifully veined, and resembles the curled maple. It is said to exhibit a grain scarcely inferior in beauty to the finest satin-wood. Hence, from its great size, it cannot fail to be admirably adapted for cabinet-making, as well as for numerous other purposes. The tree contains, perhaps, as much sap as any of its congeners, except the Acer saccharinum; but it is not used by the natives for making sugar.

This magnificent species cannot be too warmly recommended to the attention of amateurs and planters, as it is perfectly hardy and well suited for general cultivation, both in Europe and in America. It is propagated by layers in the nurseries of Messrs. Loddiges, where the annual shoots often acquire a length of six to ten feet. 


\section{Acer platanöides, \\ THE PLATANUS-LIKE MAPLE.}

\section{Synonymes.}

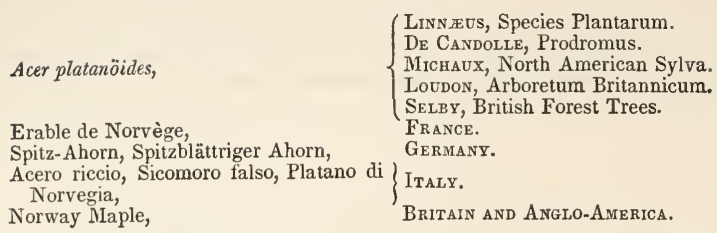

Derivations. The specific name is derived from the Latin platanus, a plane-tree, and the Greek eidos, form, from the resemblance which the leaves of this tree bear to those of the Platanus orientalis.

Engravings. Michaux, North American Sylva, pl. 44; Selby, British Forest Trees, pp. 23 et 26; Loudon, Arboretum Britannicum, i., figures 119, pp. 442 et 443 ; et v. pl. 29; and the figures below.

Syecific Characters. Leaves cordate, smooth, 5-lobed. Lobes acuminated, with a few coarse, acute teeth. Corymbs stalked, erectish, and, as well as the fruit, smooth; fruit with divaricated wings.-Don, Miller's Dict.
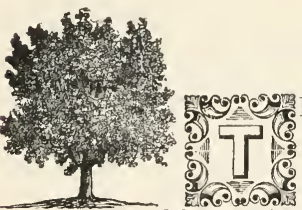

\section{Description.} a distance, is like the Acer pseudo-platanus, but on a nearer approach, the leaves are found of a smoother and finer texture. The trunk is somewhat shorter than that of the sycamore, and the tree seldom exceeds sixty or seventy feet in height. The roots extend considerably, both laterally and downwards. The bark is green on the young shoots, but it afterwards becomes of a reddish-brown, dotted with white spots; that of the trunk is brown, and somewhat cracked. The buds are large and red in autumn, becoming of a still darker hue in the course of the winter; those on the points of the shoots are always the largest. The leaves are thin, green on both sides, and shining. In an early or half-expanded

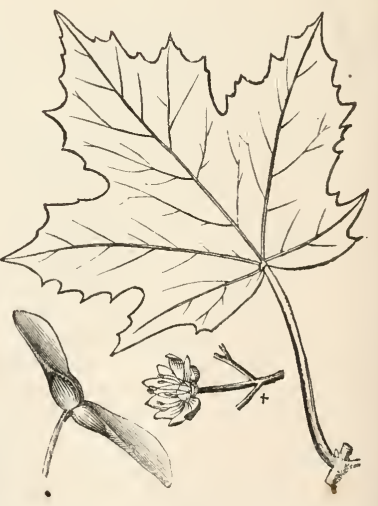
state, they are of a delicate yellowish-green, and in autumn, before they fall, become of a clear red, or of a rich, warm yellow. They fall, in England, about the end of October. When the petiole is broken, an acrid, milky sap issues from it, which coagulates on being exposed to the air. The leaves are about five inches long, and nearly of the same width. The petioles are longer than the leaves. The flowers appear just before the leaves, near the end of April, and form a short raceme, somewhat corymbose. They are yellowish-green, sweetscented, and eagerly sought after by bees, to which they afford an early, and at the same time, a valuable pasture. The fruit or keys have their wings yellow. 
They ripen in England in September and October, and generally prove abortive until the tree arrives at an age of nearly forty years.

Varieties. At least four varieties of the Norway maple are known, and may be distinguished as follows :-

1. A. P. Lobelir, Loudon. Lobel's Platanus-like Maple. The leaves of this variety are very slightly heart-shaped. irregularly toothed, five-lobed, with the lobes more or less abruptly pointed. The bark of the young wood is striped, somewhat in the manner of that of the Acer striatum; by which circumstance the plant, in the young state, may readily be known. It is a large tree, native of the kingdom of Naples, and found on mountains.

2. A. P. Pubescens, Loudon. Downy-leaved Platanus-like Maple. This variety may be distirguished by the pubescence of the leaves on their under sides.

3. A. P. albo variegatum, Loudon. Silvery Variegated-leaved Platanus-like Maple. This variety has been represented as having its foliage beautifully and handsomely marked; but it is thought to be inferior in beauty to the variegated sycamore.

4. A. P. Laciniatum, De Candolle. Cut-leaved Platamus-like Maple. This is a very distinct variety, with the leaves deeply and variously cut. There is a sub-variety of this race, sometimes called by nurserymen, the eagle's claw, or hawk's-foot maple.

Geography and History. The Acer platanöides is a native of Europe, from the west coast of Norway to Switzerland, and from France to the eastern boundary of European Russia. Pallas says that it does not occur beyond the Ural Mountains, nor in Siberia, but that it is common through all the woods of Russia. In the north, it forms a stunted bush, but in the Ukraine it is a lofty tree.

This species is recorded as having been first cultivated in Britain in the Edinburgh botanic garden, by Mr. James Southerland. It is also stated by the late Dr. Walker, of Edinburgh, that it was first introduced at Mount Stewart in 1738. Since that time it has very generally been propagated in Britain, and on the continent.

The largest tree on record, is at Schwöbber, near Hanover, in Germany. It had attained the height of eighty feet in 1835 .

At Charleville Forest, in King's county, Ireland, there was, in 1835, a tree of this species, sixty years planted, which had attained the height of sevènty-eight feet, with a trunk three and two-thirds feet in diameter, one foot from the ground.

At Taymouth, in Perthshire, Scotland, there was, in 1835, a Norway maple, fifty years planted, which was fifty feet high, with an ambitus, or spread of branches, of fifty-one feet.

This species was introduced into the United States by the late Mr. Prince, of Flushing, New York, prior to 1820, and is usually found in American nurseries and collections.

Soil and Situation. To attain a considerable size, this tree should be planted in a free, deep, rich soil, not surcharged with moisture; and the situation ought to be low rather than high. It thrives remarkably well along the sea-shore on the Baltic, and on the west coast of Norway.

Accidents, $\oint^{*} c$. The leaves of the Acer platanöides, in common with those of the Acer pseudo-platanus, and perhaps those of several other species of the same genus, are subject to what is commonly called the honey-dew, which, from its clamminess in the neighbourhood of the smoke of mineral coal, is apt to attract and retain the particles of soot that are continually floating in the air. In consequence of insects resorting to the leaves in quest of the honey-dew, they are frequently blackened with their excrement. This honey-dew, or manna, as it is called in some parts of France, is thought by some, to be produced by the extra 
vasated sap of the leaves, and by others as the exudation of plant -lice (aphides.) Bees are so fond of it, that it has been recommended by some, to plant this species in the vicinity of places where they are kept, to afford them forage; but according to others, the bitterness of this substance on the leaves, prevents them from being attacked by insects.

Properties and Uses. The wood of the Norway maple, in its young state, is white; but at a more advanced age, it becomes gray. It promises to be of more value in England, and adapted for a greater variety of purposes, than that of the Acer pseudo-platanus. It is close-grained, firm, heavy, and frequently exhibits those beautiful appearances in the direction and disposition of the fibres, for which the American "bird's-eye maple" is so highly prized. When dry, it weighs forty-three and a quarter pounds to a cubic foot; and in seasoning, it loses about one twenty-fourth part of its weight. It is easily worked, takes a fine polish, and absorbs and retains various kinds of dyes and colouring substances. From the sap, sugar has been made in Norway, Sweden, and Lithuania. This tree, however, does not produce so great a quantity of sap as the Acer saccharinum, or the European sycamore; but it contains more saccharine matter than the latter, and less than the former.

Independently of the above-named uses, this tree has much to recommend its general culture, both in Europe and in America. In a suitable soil, it grows with rapidity and luxuriance, and even thrives upon soils of an inferior quality, provided they are not charged with too much moisture. Another recommendation it possesses, is its aptitude to withstand the effects of the sea-breeze, which it has proved to do upon the western coast of Scotland, as well as upon the shores of the Baltic, and eastern coast of Norway.* It may be propagated by seeds, by layering, or grafting. The seeds, when gathered, should either be sown immediately, or mixed with sand or earth, and kept moderately dry till spring. In either case, they will come up the first year.

* Selby, British Forest Trees, p. 24.

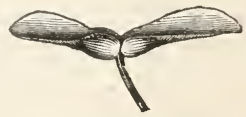




\section{Acer saccharinum, THE SUGAR MAPLE.}

Synonymes.

Acer saccharinum,

(Linnzus, Species Plantarum.

De Candolle, Prodromus.

Michaux, North American Sylva.

$\{$ Don, Miller's Dictionary.

Hooker, Flora Boreali Americana.

Lorjon, A rboretum Britannicum.

Torrey and Gray, Flora of North America

Erable à sucre,

France.

Zucker Ahorn,

Germany.

Acero zuccheroso, Acero del Canada,

ITALY.

Ininawtig,

OJibway Indians.

Rock Maple, Hard Maple, Bird's-eye Ma-

ple, Sugar Maple, Sugar-tree, Black Britain and Anglo-America.

Sugar-tree, Sap-tree,

Derivations. The specific name is derived from the Latin saccharum, sugar, having reference to the sugar contained in the ap.

Engravings. Michaux, North American Sylva, pl. 42; Loudon, Arboretum Britannicum, i., figure 122, pp. 446 et 447, et v., pl. 31 ; and the figures below.

Specific Characters. Leaves cordate, smooth, glaucous beneath, palmately 5-lobed; lobes acuminated, serrately toothed. Corymbs drooping, on short peduncles. Pedicels pilose. Fruit smooth, with the wings diverging.-Don, Miller's Dict.

\section{Description.}

ge 020 Acer saccharinum 2) 8 is one of the most noble Q) 18 and majestic of Ameri(16) ble situations it sometimes grows to a height of seventy or eighty feet, and from two to four feet in diameter; but usually it does not exceed an elevation of fifty or sixty feet, and a diameter of twelve or eighteen inches. The trunk is generally straight, though often studded with projections and excrescences. In all healthful and vigorous trees, the outward bark is light-coloured, by which they may readily be distinguished. When growing in open situations, with room to spread on every side, where all its branches are exposed to the free action of light, this tree is an object of great beauty. It somewhat resembles the English oak, in its outline, in the form of its trunk, and

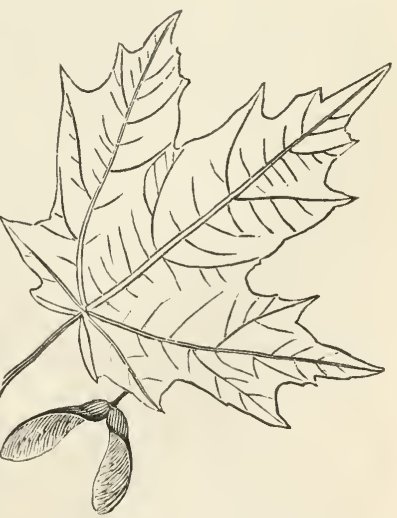
disposition of its branches, and in the dense and massy character of its foliage. The leaves are from three to five inches broad; but they vary in length, according to the age and vigour of the tree. They are opposite, attached by long petioles, palmated or unequally divided into five lobes, entire at the edges, of a bright-green above, whitish, and very pubescent at first, but later, minutely so. or nearly glabrous beneath; and except in the colour of the under surface, they 
greatly resemble the Norway maple. In autumn, after the appearance of the first frost, their colour changes from green to all shades of red, from the deepest crimson to light orange. The flowers, which appear in April and May, are small, of a pale greenish-yellow, and are suspended by slender, drooping peduncles. The seed is contained in two capsules, united at the base, and terminating in membraneous wings about an inch in length. It usually ripens in Pennsylvania and New York by the first of October, though the fruit attains its full size a month or six weeks earlier. Externally, the keys appear equally perfect; but one of them, Michaux informs us, is always empty. The fruit matures only once in two or three years.

Variety. The Acer saccharinum has been confounded by some botanists with another tree so nearly allied to it, that it can only be regarded as a variety. From the dark hue of its leaves, it was very appropriately designated by Mr. Loudon, under the name of $A . s . n i-$ grum, (Acer nigrum, Michaux,) or Black Sugar Maple. According to Michaux, the leaves of this variety are pale-green beneath, the veins of the lower surface and petioles minutely villous-pubescent, and the wings of the fruit a little more diverging than those of the species, as indicated in the adjoining figure. "The leaves," he says, "are five or six inches long, and exhibit, in every respect, nearly the same conformation as those of the true sugar maple." "They differ from it," continues he, "chiefly in being of a darker green, and of a thicker texture; and in being somewhat more bluntly

lobed. The tree is indiscriminately mixed with the common sugar maple, through extensive regions of country in New Hampshire, Vermont, and Connecticut ; but is readily distinguished from it, by the smaller size it attains, and the darker colour of the leaves." When the tree stands alone, it naturally assumes a regular and agreeable form. In Canada and New England, it rarely exceeds fifty feet in height, with a diameter of fifteen or twenty inches; but in western New York, and in the immense valleys through which flow the great rivers of the west, it is common, and attains the full magnitude of the species.

Geography and History. According to the elder Michaux, this tree is first seen a little north of Lake St. John, in Canada, near the forty-eighth degree of north latitude, which, in the rigour of its winter, corresponds with the parallel of about the sixty-eighth degree in Europe. It is nowhere more abundant than between the parallels of forty-three and forty-six degrees, comprising all, or a great part of Canada, New Brunswick, Nova Scotia, the states of Maine, New Hampshire, Vermont, and New York, the true region assigned by nature for the growth of this tree. It is also found, but more sparingly, in almost every state in the union, particularly on the flanks of the entire range of the Alleghanies to their termination in Georgia.

This species was introduced into England, in 1734, by Collinson, and since that time, it has been cultivated in the principal gardens throughout Europe. Count Wingersky is said to have planted a great number of trees on his estate in Moravia, and to have drawn off the sap from them at the age of twenty-five years, in order to make sugar. He succeeded in procuring a very good article; but in consequence of depriving the trees of their sap every year, they became sickly, and soon afterwards died. 
The largest recorded tree of this species, in Europe, is at Wörlitz, in Saxony. At the expiration of sixty years after being planted, it was fifty feet high.

The largest sugar maple in the neighbourhood of London, is at Purser's Cross, which, in 1835, had attained the height of forty-five feet.

Several large trees of this species are found on Goat Island, at the falls of Niagara; but they are far inferior in size to myriads of others, in Canada, New England, and other parts of America.

Soil, Situation, \&*c. The natural habitat of the Acer saccharinum is the steep and shady banks of rivers, which rise in mountainous regions, and in all elevated situations, where the soil is cold and humid, free, deep, and fertile, and not surcharged with moisture. When cultivated, the same soil is recommended as in the Acer platanöides; but as it is less hardy, the situation should be more sheltered. In Europe, it is always propagated by seeds, where its rate of growth varies from one to four feet per annum. In the United States it is either propagated from seeds, in nurseries, or is transplanted from the woods or fields, to the site where it is intended to remain. The age of this tree in America does not usually exceed two hundred years.

Insects. Few insects or their larvæ seem to feed upon the leaves of the sugar maple, with the exception of the Apatela americana, described by Dr. Harris, in his "Report on the Insects of Massachusetts injurious to Vegetation," and also figured and described in Smith and Abbot's "Insects of Georgia," under the name of Phalana aceris. The caterpillar of this insect eats the leaves of the various kinds of maple, as well as those of the elm and chesnut. 'They commence spinning in October or November, and come out from their webs or cocoons from April to July. The moths fly only in the night. But this fine tree suffers much from the attacks of the borers or larvæ of the Clytus speciosus, denoted by the accompanying figure. This insect is accurately described and figured in Say's "American Entomology;" and an account of its habits is given by Rev. L. W. Leonard, of Dublin, New Hampshire, in Harris' "Report." He discovered the insect in the beetle state, under the loosened bark of one of the trees, and traced the recent track of the larva, three inches into the solid wood. Dr. Harris says, "It is the largest known species of Clytus, being from nine to eleventenths of an inch in length, and three to four-tenths in breadth. It lays its eggs on the trunk of the maple in July and August. The grubs burrow into the bark as soon as they are hatched, and are thus protected during the winter. In spring, they penetrate deeper, and form, in the course of the summer, long and winding galleries in the wood, up and down the trunk. In order to check their devastations, they should be sought for in the spring, when they will readily be detected by the saw-dust that they cast out of their burrows; and, by a judicious use of a knife and stiff wire, they may be cut out, or destroyed before they have gone deeply into the wood."

Properties and Uses. The wood of the Acer saccharinum, when newly cut is white, but after being wrought and exposed for some time to the light, it takes a rosy tinge. Its grain is fine and close, and when polished, its lustre is silky. It is very strong and heavy, but wants the property of durability, for which the - Euglish and American white oaks are so highly esteemed. The northern wood, when dry, weighs forty-six pounds to a cubic foot, but that grown south, weighs much less. When cut, and properly dried, it makes excellent fuel, which is equally esteemed by some, for that purpose, with the oak and hickory. When exposed to the alternations of moisture and dryness, it soon decays, and for this 
reason, it is not much used in eivil and naval architecture. In Maine, New Hampshire, Vermont, and farther north, where the oak is not plentiful, the timber of this tree is substituted for it, in preference to that of the beech, the birch, or the elm. When perfectly seasoned, which requires two or three years, it is used for axletrees, spokes, runners of common sleds, mill-cogs, and for ehairs, and eabinet-work. It is also sometimes used for the frames of houses, keels, and the lower frames of vessels, piles, and foundation pieces for mills, canal locks, and for many other purposes where strength is required, and the work is not exposed to the alternations of moisture and dryness. The wood of this tree exhibits several aceidental forms in the arrangement of its fibre, of which eabinet-makers take advantage in manufacturing beautiful articles of furniture, sueh as bedsteads, writing-desks, and other fancy works, and for inlaying mahogany and black walnut, in bureaus, piano-fortes, etc. These forms or varieties may be classified and described as follows:-

1. Curled Maple. Erable gris ondulé, French. The undulations or medullary rays of this variety, like those of the red-flowered maple, are lustrous, and in one light appear darker, and in another lighter than the rest of the wood. Sometimes the zig-zag lines are erossed by beautifully coloured veins; but, unfortunately, the lustre of these shades disappear by long exposure to light and air.

2. Bird's-eye Maple. Erable moucheté, French. 'This variety exhibits small whitish spots or eyes, not exceeding a tenth of an inch in diameter, sometimes occurring a little way apart, and at others contiguously disposed. The more numerous these spots, the more beautiful and valuable the wood. They are seen only in old trees, which are still sound, and appear to arise from an inflection of the fibres from the centres of their trunks towards the surface across the grain. To obtain the finest effect, the wood should be sawed as nearly as possible in a direetion parallel with the concentric circles.

In addition to the above-named varieties, two other kinds occur in the wens, or exereseenees which grow on the trunk or roots of this tree, and like them, are covered with bark. The most valuable variety is known by the name of Variegated Maple-knob, or Loupe d'érable de couleurs variées, of the French. It presents an assemblage of shades, agreeably disposed, sometimes resembling Arabic characters, whieh renders the wood. very appropriate for fancy works, and from its searcity, it usually commands high prices. 'The other variety, known by the name of Silver-white Maple-knob, or Loupe d'érable blanc argenté, of the French, exhibits a silvery lustre by the arrangement of its fibres, and is highly prized for the same purposes as the preceding, although more eommon.

The wood of this species is easily distinguished from that of the red-flowered maple, which it resembles in appearance, by its weight and hardness. There is besides, a very simple and certain test. A few drops of water saturated with copperas, (sulphate of iron,) being poured upon samples of different woods, that of the sugar maple turns greenish, and the white maple and the red-flowered maple change to a deep blue. The ashes of the sugar mapie are rieh in the alkaline prineiple, and it has been asserted, that they furnish four-fifths of the potash exported from the United States to Europe. In the forges of Maine, New Hampshire, Vermont, and places farther north where this tree grows, its charcoal is preferred to that of any other wood; and it is said to be one fifth heavier than that made from the same species in the middle and southern states.

'The extraction of sugar from this tree is a valuable resource in a new eoun-? try where it abounds; but it is obvious that this mode of obtaining sugar is only destined for a eertain stage in the progress of society, and eventually gives way to the sugar of commerce, produeed by eane. For this reason, we shall not detail the process of its manufacture, as it cannot be regarded as a matter of 
practical utility. In a country like the United States, intersected by canals, railroads, and other channels of intercommunication, where labour is expensive, and fuel is becoming more and more valuable, the manufacture of this article camnot fail to be an unprofitable occupation. Besides, the annual drawing of the sap renders the trees sickly, and causes a premature decay.

Ordinarily, the sap begins to flow about the last of February or early in March, and continues for five or six weeks; after which, it becomes less abundant, less rich in saccharine matter, and, at length, is incapable of crystallization. It is sometimes the case, however, in the northernmost regions where this tree abounds, that there is an ascent of sap in autumn, as well as in spring. 'This only occurs late in the season, when there are slight frosts at night, succeeded by warm, pleasant days. 'The sugar produced from this sap, when properly made, is equal to that manufactured from the cane, or the beet-root, the properties of the three being essentially the same. That of the maple, as it is usually made, has a peculiar taste, which is much relished by those who are unaccustomed to its use. The amount of sugar produced from each ree, in a year, varies from different causes. A cold and dry winter renders the trees more productive than a changeable and humid season. It is observed, that, when a frosty night is followed by a dry and sunny day, the sap flows abundantly; and two or three gallons are sometimes yielded by a single tree, in twenty-four hours; but, in cold, frosty weather, or rainy weather, or when the nights are mild, the sap almost ceases to flow. The yearly product of sugar from each tree varies from two to four pounds. Trees which grow in low and moist places afford a greater quantity of sap than those which occupy rising grounds; but it is less rich in the saccharine principle. That of isolated trees, left standing in the middle of fields, or by the sides of fences, is best. It is also remarked, that, in districts which have been cleared of other trees, and of the less vigorous sugar maples, the product of the remainder is proportionably greater. In the United States and the British provinces of North America, there is annually made, from seven million to twelve million pounds of sugar from this tree. Holes are made through the bark into the wood of the trunk, in March, April, and May, into which tubes are introduced to lead the juice into vessels placed below. It is observed that the higher the holes are from the ground, the more saccharine the juice, and the more injury the tree receives from its abstraction. Towards the end of the season, when the sap becomes uncrystallizable, it is either made into molasses or syrup, or is exposed for two or three days to the sun, when it is converted into vinegar, by the acetous fermentation It is also sometimes made into a kind of beer.

Wild, and domestic animals are inordinately fond of maple juice, and break through their enclosures to sate themselves; and when taken by them in large quantities, it has an exhilarating effect upon their spirits.

From the great height, extended branches, regular and often pyramidal form, and the rich verdure and cleanliness of the foliage in spring and summer, the sugar maple is accounted as one of our finest shade-trees, and is higlly recommended to be planted along streets and avenues, in pastures, and ornamental grounds. And it is no less beautiful in our forest or woodland scenery, in autumn, when it puts on its bright-orange, and deep-crimson robes. At first, the extremities of the bouglis alone change their colour, leaving the internal and more sheltered parts still in their verdure, which "gives to the tree the effect of great depth of shade, and displays advantageously the light, lively colouring of the sprays." Later in the season, on the contrary, when the tints become more and more gorgeous, and the full beams of the sun-shine fall upon the large masses of foliage, the warm and glowing colours of the whole summit possess a great deal of grandeur, and add much to the beauty and effect in the landscape. 


\section{Acer pseudo-platanus,}

\section{THE EUROPEAN SYCAMORE-TREE.}

\section{Synonymes.}

\begin{tabular}{|c|c|}
\hline Acer pseudo-platanus, & $\left\{\begin{array}{l}\text { Linneus, Species Plantarum. } \\
\text { Michaux, North American Sylva. } \\
\text { Don, Miller's Dictionary. } \\
\text { Loudon, Arboretum Britannicum. } \\
\text { SELBY, British Forest Trees. }\end{array}\right.$ \\
\hline $\begin{array}{l}\text { Erable blanc de montagne, Fausse pla- } \\
\text { tane, Grand erable, Erable sycomore, }\end{array}$ & 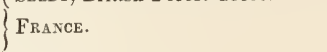 \\
\hline $\begin{array}{l}\text { Ehrenbatim, Weisser Ahorn, Gemeiner } \\
\text { Ahorn, }\end{array}$ & Germany. \\
\hline $\begin{array}{l}\text { Acero fico, Acero sicomoro, Platano falso, } \\
\text { Platano salvatico, }\end{array}$ & ITALX. \\
\hline $\begin{array}{l}\text { Great Maple, Mock Plane-tree, } \\
\text { Plane-tree, } \\
\text { European Sycamore, }\end{array}$ & $\begin{array}{l}\text { England. } \\
\text { Scotland. } \\
\text { Uniten States. }\end{array}$ \\
\hline
\end{tabular}

Lerivations. The botanic name, pseudo-platanus, is derived from the Latin, and signifies false plane-tree. The other nam are generally significant in themselves.

Engravings. Michaux, North American Sylva, pl. 44; Loudon, Arboretum Britannicum, v., pl. 32 ; Selby, British Forest Trees, pp. 14, 15 et 21 ; and the figures below.

Specific Characters. Leaves cordate, smooth, with 5 acuminated, unequally toothed lobes. Racemes pen dulous, rather compound, with the rachis, as well as the filaments of stamens, hairy. Fruit smouth, with the wings rather diverging.-Don, Miller's Dict.

\section{Description.}

"Nor unnoticed pass

The sycamore, capricious in attire;

Now green, now tawny; and ere autumn yet

Has changed the woods, in scarlet honours bright."

COWPER.

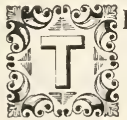

HE Great Maple or Sycamore, vying in point of magnitude, with tlie oak, the ash, and other trees of the first rank, presents a grand, unbroken mass of foliage. It forms a beautiful contrast in appropriate situations, and when judiciously grouped witl trees of a lighter and more airy character, it affords an "impenetrable shade." In favourable situations, it attains a height of seventy to one hundred feet, and from three to six feet in diameter; but ordinarily, it grows only to one half of these dimensions. It is a tree of quick growth, with a sinooth, ash-gray bark, and round, spreading branches. The bark of old trees, in peeling off, frequently leaves patches on their trunks of various hues, in a similar manner as that of the

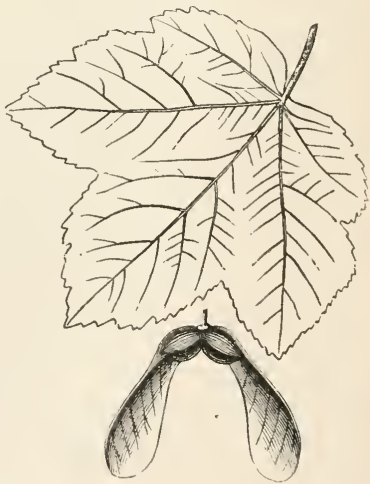
platanus. The leaves on long foot-stalks are four or five inches broad, palmate, with five acute, variously serrated lobes; the middle one largest, pale, or glaucous beneath. The flowers, which appear in IIay and June, are green, about the size of a currant-blossom, and disposed into axillary, pendulous, com- 
pound clusters. The fruit, or capsules are smooth, with two, and sometimes three, large diverging wings.

Varieties. The principal cultivated varieties of this species may be described as follows :-

1. A. P. Flava variegata, Loudon. Yellow Variegated-leaved Sycamore, or Costorphine Plane-tree. The leaves of this variety are variegated with yellow. The original tree stands in the grounds of Sir T. Dick Lauder, in the parish of Costorphine, near Edinburgh.

2. A. P. albo variegata, Loudon. White Variegated-leaved Sycamore-tree. The leaves of this variety are blotched with white. It is more common in Europe than the preceding. It has much to recommend it in spring or beginning of summer, from the beauty of its foliage; but later in the season, they soon become ragged, and in autumn, in dying off, they acquire a dirty colour, and a diseased appearance.

3. A. P. Purpurea, Loudon. Purple-leaved Sycamore-tree. The leaves are of a fine purple beneath, when matured, and have a beautiful appearance when slightly ruffled by the wind.

4. A. P. subobtusa, Loudon. Half-obtuse-leaved Sycamore-tree. The lobes of the leaves of this variety are blunt; and the fruit and wings are large.

5. A. P. Laciniata, Loudon. Cut-leaved Sycamore-tree. 'The lobes of the leaves in this variety are jagged.

Geography and History. The Acer pseudo-platanus is found in various parts of Europe, particularly in Switzerland, Germany, Austria, and Italy, in wooded mountainous situations. In England, it is found in hedges and about houses, but not truly wild. The first record of this tree as being cultivated in Britain. is in 'Turner's "Herbal," in 1551; it is mentioned by most other British authors since, as of doubtful indigenousness. . Gerard, in 1597, says " it is a stranger in England, only found growing in the walks and places of pleasure of noblemen, where it is planted for the sake of its shadow." Ray speaks of it as being very common in courtyards, churchyards, avenues, \&c. Martyn observes, in his edition of "Miller's Dictionary," that, "if it were truly indigenous, the country would have been full of it; since the tree comes up with such wonderful facility from the seed." Sir T. Dick Lauder says, "It is a favourite Scotch tree, having been much planted about old, aristocratic residences in Scotland; and, it the doubt of its being a native of Britain be true, which, however, we cannot believe, then it is probable that the long intimacy which subsisted between France and Scotland, may be the cause of its being so prevalent in the latter country." Evelyn accuses it of "contaminating the walks, where it may lic planted, with its leaves, which, like those of the ash, fall early, and putrefy, with the first moisture of the season." He further remarks, that it "should be banished from all curious gardens and avenues," though he acknowledges that "for more distant plantations it is desirable, particularly where better timber will not prosper so well, as in places near the sea; it being in no way injured by the spray, which is so prejudicial to most trees." In Switzerland, this species is found from two thousand to three thousand feet above the level of the sea, reaching up the mountains to the point where the Vaccinium vitis-idæa commences; provided. however, that the soil be dry and of a good quality. In such situations it suffers much less from frost and snow than any other tree.

The Acer pseudo-platanus, in the language of flowers, signifies curiosity, because it was supposed to be the tree on which Zaccheus climbed to see our Saviour ride in triumph to Jerusalem, when the people strewed leaves and branches of palm and other trees in his way, exclaiming,

"Hosanna to the Son of David." 
The tree called sycamore, to which allusion is frequently made i. Holy Wuit, was not the Acer pseudo-platanus, but the Ficus sycomorus of botanists; Sycomore of the French; and Indischer Feigenbaum of the Germans. The supposition that this species was the sycamore of the scriptures, induced many religious persons in Britain, in the XIVth and XVth centuries, to plant it in churchyards, courtyards, avenues, and near houses.

'The oldest recorded sycamore, and perhaps the largest tree of the kind in Britain, is that at Kippenross, in Perthshire. In 1823, it measured twenty-eight feet nine inches in circumference, at a foot from the ground. It appears that it went by the name of "the big tree in Kippenross," in the time of Charles II. Another tree of this species is mentioned by Loudon, as growing at Taymouth, which had been planted more than two hundred years, and attained the height of one hundred feet, with a trunk six feet in diameter, and an ambitus of forty feet. At Bishopton, on the Clyde, there is another tree, figured by Strutt, in his "Sylva Britannica," which is described as being sixty feet high, with a trunk six and a half feet in diameter.

Perhaps the most remarkable sycamores in Scotland, are those called "dooltrees," which were used by the powerful barons in the western part of that country, for hanging their enemies and refractory vassals upon, and for this reason, were called dool, or grief-trees. One of these trees is said still to be standing on the banks of the river Doon, near the fine old castle of Cassilis, a seat of the Marquis of Ailsa, who descended from the powerful family of the Kennedys. It is raised on a pyramid, consisting of six steps, covered with turf, and has a large, spreading head, nearly two hundred feet in circumference. The last time this tree was used as a gibbet, was for the execution of Johnny Faa, the gipsy, and seven of his men, who were hanged for eloping with the Countess of Cassilis.

Two other dool-trees are said to exist on the estate of Blairquhan, recently in possession of Sir David Hunter Blair. The largest is seventy-two feet high, with a trunk seventeen feet in circumference, at ten feet from the ground. The other tree is somewhat less in size. They are probably nearly three centuries old. The date on the old coat of arms of the Kennedys, in the adjoining court of the castle, is 1573 .

In France, in the botanic garden at Toulon, there is a sycamore, about sixty years planted, which is one hundred feet in height.

In Switzerland, there are many remarkable trees of different species, which are more or less linked with the history of the country. They speak to the imaginations of the people, and are connected, not only with the amusements of the successive generations, but with the victories, that, in ancient times, secured the independence of that republic. Among these are the great lime-trees at Fribourg, already mentioned; and as a monument of a similar nature, we will now introduce that venerable old sycamore of Trons, in the Grisons, in the same canton. It was under the shade of this tree, that the deputies of the country swore to free themselves from the yoke of their lords. In 1835, it measured twenty-six and a lialf feet in circumference, at eighteen inches from the ground, and was estimated to be nearly five hundred ycars old. It is celebrated in all the local poems as being a lime-tree, but the fact is, it is the Acer pseudo-platanus. In the "Bibliotique Universelle de Genève," for August, 1831, there is a letter from M. Bontemps, in which it is stated, that the probable reason why this tree is ealled a lime in the local poems is, that the German word Ahorn, which signifies a syeamore or maple, is very unpoetical, while that for a lime-tree, Linde, is soft and liquid; and this eaused the former to be rejeeted by the writers of the old ballads.

The European sycamore appears to have been introduced into the United 
States by Governor Christopher Gore, prior to 1810. The trees are said to be growing on the estate which he formerly occupied in Waltham, Massachusetts. and have attained a considerable size.

In the Bartram botanic garden, at Kingsessing, near Philadelphia, there is a tree one foot in diameter and thirty feet in height. On the estate of Mr. Henry Codman, in Roxbury, Massachusetts, there is also another tree of this species nearly of the same dimensions.

Soil and Situation. The European sycamore will grow in any soil not saturated with moisture; but it seems to prefer one that is dry and free, rather than stiff or moist. It will grow in exposed situations, and especially on the seacoast, and maintain its erect position against the sea-breeze better than most other trees. It is in use for this purpose in Scotland, and also for planting round farm-houses and cottages on bleak hills. In such situations, it is said, an instance can hardly be found of the head of the tree leaning more to one side than to the other. Even when the wind blows strongly in one direction for nine months in the year, this tree maintains its perpendicular position and symmetrical form.

Propagation and Culture. This species is generally propagated by seeds ; and the variegated-leaved and other varieties by layers, or by budding and grafting. It will also propagate freely by cuttings of the roots. The seeds may either be sown immediately after they are gathered, or they may be kept in sand until the following spring. If they are kept dry and unmixed with earth or sand till spring, they seldom come up the same year, and sometimes lose their germinating properties altogether. This tree reaches its usual height in sixty years; the wood, however, continues to improve till it is eighty or one hundred years old, and it frequently remains undecayed for another century.

Accidents and Diseases. The leaves of this species are often covered with a sweet, clammy matter, or honey-dew, eagerly sought after, and imbibed by various insects. By some, this substance is supposed to be exuded by the leaves themselves, and it is thought by others, that it is generally produced by insects, or voided by the aphides which infest the tree. It is also subject, when planted in too humid a soil, to dropsy, or an oozing out of the sap from the trunk, in consequence of a redundancy or an irregular assimilation of the juices. In such cases, the roots soon grow spongy and rotten, and the tree becomes a prey to parasites, and finally dies. The leaves, also, towards the end of summer, become spotted and unsightly, by the growth and spreading of two kinds of fungus, Xyloma acerinum, and Erineum acerinum. Few lepidopterous larvæ feed upon the leaves, but among those which occasionally do so, are those of the Pygæra bucephala, or buff-tip moth. The flowers are sweetly, but not powerfully scented, and are the resort of various hymenopterous insects, particularly the Bombus hortorum, and terrestris. The young shoots of this tree are eaten by hares, horses, cattle, goats, and other ruminating animals.

Properties and Uses. When young, the wood of the Acer pseudo-platanus Is white; but when advanced in age, it becomes a little yellow, and often brown, especially towards the heart. It is compact and firm, without being very hard; of a fine grain, sometimes veined, susceptible of a high polish, and easily worked, either on the bench, or in the turning-lathe. It does not warp, and is not subject to the attack of worms. When dry, it weighs forty-eight pounds to a cubic foot, and in seasoning, loses about one twelfth part of its bulk, and one fourth part of its weight. According to M. Hartig, an eminent German dendrologist, the wood of this tree is the most valuable of all woods for fuel, both for the quantity of heat which it imparts, and the time that it continues burning. It surpasses the European beech, in these respects, in the proportion of 1757 to 1540 . Converted into charcoal, it is superior to the beech in the proportion of 1647 to 1600 . He 
felled trees two hundred years old, and upwards of one hundred feet in height, the timber of which was perfectly sound.

In France and Germany, the wood of the sycamore is much sought after by wheel wrights, cabinet-makers, turners, sculptors in wood, manufacturers of musical instruments, and especially of violins, and makers of toys, and other small wares. The roots, which are often beautifully veined, and the stools or stumps where the plant has long been treated as a bush, and cut periodically as coppice-wood, is eagerly sought after for curious cabinet-work, and for inlaying. The wood is used for pestles, for tables, rollers, spoons, plates, and other household articles; it is also used for gun-stocks, and in every kind of structure, whether under water or in the air. 'The leaves, gathered green, and dried, form an excellent forage for sheep, during the winter. The sap has been drawn from the trees in Germany, and various experiments made upon it. At first, it is as clear as water, and sweet; but, after it has flowed from the tree for some time, and begins to run slowly, it takes a whitish colour, and becomes sweeter, and of a thicker consistence; though it contains less sugar than that of the first flowing. The proportion of sugar produced by the sap varies. Sometimes an ounce of sugar from a quart of liquor has been obtained; but, generally not so much. The variations depend upon the age of the tree, the vigour of its growth, the nature of the soil, the temperature of the season, and a number of other circumstances, of which little is known.

In Britain, the uses to which the sycamore is applied are much less varied than in France and Germany. It is used by joiners, turners, cabinet-makers, musical instrument makers; for cheese and cider presses, and sometimes for gunstocks. It is also extensively used, when of sufficient size, for machinery, in printing and bleaching works, for beetling-beams, and in foundries for making patterns, \&c. In the western Highlands of Scotland, it is said that the sap of this tree is made into wine.

As an underwood, the sycamore shoots freely from the stool to an age of eighty or one hundred years. As a timber-tree, it is most advantageously felled at the age of eighty years, or from that age to one hundred.

As an ornamental tree, it produces the best effect, either singly, in groups of two or three, placed sufficiently near to form a whole, but not so as to touch each other; or planted in rows in avenues. Its picturesque beauties are thus described by Sir T. D. Lauder. "The spring tints of the sycamore are rich, tender, glowing, and harmonious; in summer its deep-green hue accords well with its grand and massive form, and the brown, and dingy reds of its autumnal tints harmonize well with the mixed grove, to which they give a fine depth of tone."

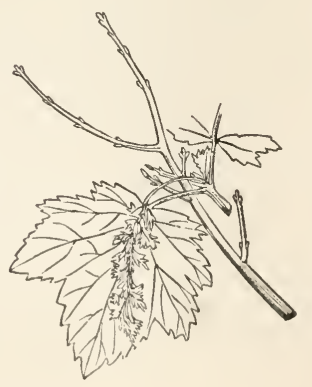


Acer circinatum,

\section{THE CIRCINAL-LEAVED MAPLE.}

Synonymes.

Acer carcinatum,

(De Candorite, Prodromus.

Нооке R, Flora Boreali Americana.

Loudon, Arboretum Britannicum.

Torrey and Gray, Flora of North America.

Nuttall, North American Sylva.

Erable circinal,

Kreiselnder Ahorn,

Acero acchiocciolato,

Round-leaved Maple,

GeRMANY

ITALY.

Britain.

Derivations. The specific name, circinatum, is derived from the Latin circino, to roll, having reference to the marner of he rolling of the leaves. The European names are translations of the botanical one.

Engravings. Nuttall, North American Sylva, pl. - ; Hooker, Flora Boreali Americana, pl. 39 ; Loudon, Arboretum Britanaicum, i., figures 112 , et 127 , in p. 454 ; and the figures below.

Specific Characters. Leaves orbicular, rather cordate at the base, 7-lobed, smooth on ooth surfaces, lobes acutely toothed; nerves and veins hairy at their origins.-Don, MIiller's Dict

\section{Description.}

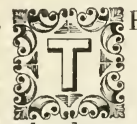

HE Acer circinatum, in its native country, attains a height of twenty to forty feet. The branches are slender, pendulous, and crooked; often taking root in the manner of those of many species of ficus, and sometimes of the linden-tree. The bark is smooth, green when young, and whitish when fully grown. The leaves, which are about the size of those of the Acer rubrum, are membraneous, heart-shaped, with seven to nine lobes, and the same number of nerves. They are smooth above, except hairs in the axils of the nerves, when young, but glabrous when older, and downy beneath, with the axils of the nerves woolly. The lobes are ovate, acute, and sharply serrated; the sinuses are acute, the foot-stalks rather short, from

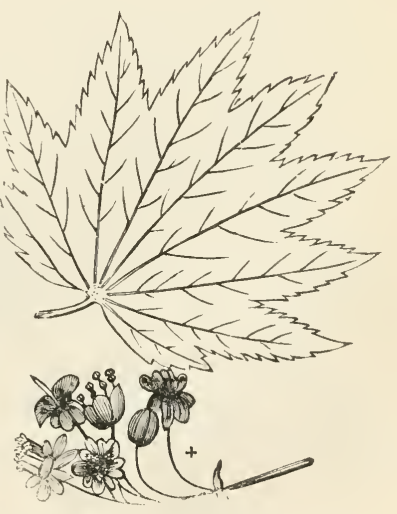
which radiate the nerves to the tip of each lobe. The flowers, which appear in April and May, are of a middling size, and occur on nodding corymbs, with long peduncles. The fruit has thin, straight wings, which are so divaricate as to form right angles with the peduncle. This species is very marked, and may readily be distinguished by the regular form of its leaves, and their pale, reddish-green colour.

Geography and History. This tree is common along the west coast of North América, between the forty-third and forty-ninth degrees of latitude, and is particularly abundant on the great rapids of the river Columbia. Like the Acer macrophyllum, it is exclusively confined to the woody, mountainous country that skirts the shores, and there forms, among the pine forests, almost impenetrable thickets. 


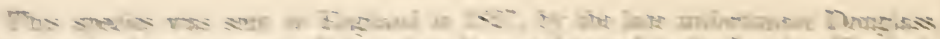

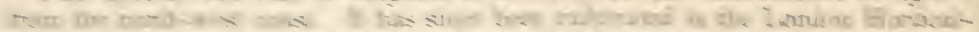

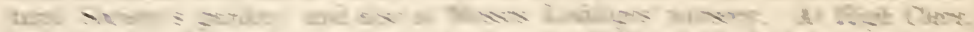

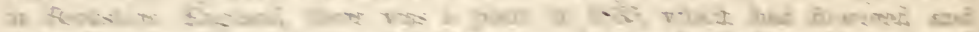

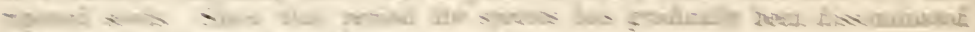

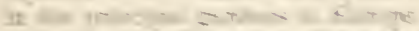

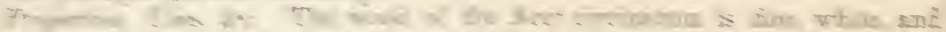

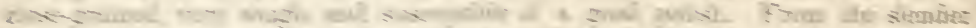

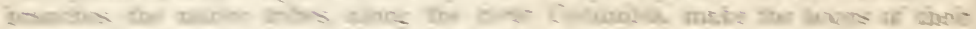

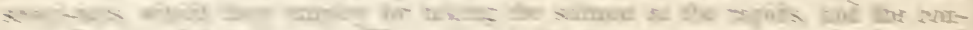

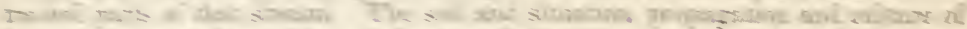

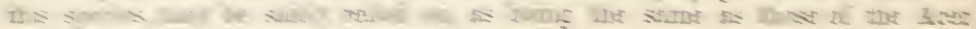

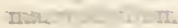

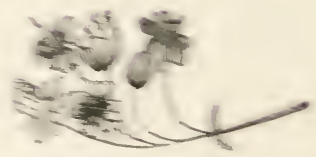


scattered, and leaves an open passage for the sumbeams. According to Dr. Hooker, the young leaves, and germs, are very downy; but the old leaves, and perfect fruit, are glabrous.

Geography and History. The banks of the river Sorel, in Lower Canada, in latitude forty-five degrees, may be considered as the northern, and those of the tributaries of the Penobscot, in the state of Maine, as the eastern limit of the Acer eriocarpum. But, like many other trees, it is stunted by the rigorous winters of these latitudes, and never reaches the size which it attains a few degrees farther south. It is found on the banks of all the rivers which flow from the Alleghanies to the ocean; though it is less common along those which water the southern parts of the Carolinas and Georgia. In no part of the United States is it more multiplied than in the country west of the mountains, and nowhere is its vegetation more luxuriant than on the banks of the Ohio, and on those of the streams which flow into it. There, sometimes alone, and at others mingled with the willow, which is also found along all these waters, it contributes singularly, by its magnificent foliage, to the embellishment of the scene. "The brilliant white of the leaves beneath, forms a striking contrast with the bright-green above, and the alternate reflection of the two surfaces in the water, heightens the beauty of this wonderful moving mirror, and aids in forming an enchanting picture; which," says Michaux, "during my long excursions in a canoe in these regions of solitude and silence, I contemplated with unwearied admiration." "Beginning at Pittsburg," continues he, "and even some miles above the junction of the Alleghany and Monongahela Rivers, white maples, with short trunks, twelve or fifteen feet in circumference, are continually to be met with at short distances."

The Acer eriocarpum was introduced into England by Sir Charles Wagner, in 1725, and has since been in general cultivation throughout Europe, for ornament.

The largest tree of this species in the neighbourhood of London, is at Kew, where, in twenty-five years after planting, it had attained the height of fifty feet. At Trentham, in Staffordshire, there is another tree mentioned by Loudon, of the same height.

At Pfauen Insel, in Prussia, there is an Acer eriocarpum, which, at the age of forty years, had attained the height of fifty feet. And another is recorded, as growing in the garden of Christianholme, near Lolland, in Sweden, of the height of forty feet. And another of still more rapid growth, at Niedzwiedz, in Poland, which had attained the height of thirty-six feet in twenty years.

Insects. The Acer eriocarpum is chiefly preyed upon by the larva of the Apatela americana, of Harris, and by those of several species of the Geometridæ, all of which feed with more or less avidity on the leaves of various other maples, the elm, chesnut, and probably many other trees.

Soil, Situation, $f \cdot c$. In its natural habitat, the Acer eriocarpum is found in a sandy loam, on the banks of such rivers only as have limpid waters, with a gravelly bed; and it is seldom, if ever, found in swamps and other wet grounds enclosed in forests, where the soil is black and miry. When cultivated, this tree requires a deep, free soil, and more moisture than most of the other species. 'Though it will not grow in swamps, yet it attains its greatest dimensions on the alluvial banks of rivers which are occasionally inundated. It ripens its seeds, both in Europe and in the United States, by midsummer, or earlier; and if these are immediately sown, they come up, and produce plants, which are eight or ten inches high, by the succeeding autumn.

Properties and Uses. 'The wood of the Acer eriocarpum is very white when newly cut, and of a fine texture; but it is softer and lighter than that of any other maple in the United States; and from the want of strength and durability it is little used. When dry, it weighs thirty-eight pounds to a cubic foot, and 
n seasoning, loses nearly half of its weight. It is sometimes used in cabinetmaking, instead of the holly or other light-coloured wood, for inlaying furniture of mahogany, cherry-tree, and black walnut; though it is less suitable for this purpose, as it soon changes colour by exposure to light. Wooden bowls are also made of it, when that of ash, or tulip-tree cannot be obtained. The charcoal of this wood is preferred by hatters and dyers to every other, as it affords a heat more uniform, and of longer duration. The sap is in motion earlier in this species than in the sugar maple, beginning to ascend, in the middle states, about the 15th of January ; so that, when it is employed for making sugar, the operaions are sooner completed. Like the sap of the red-flowered maple, it yields not more than one half the product of sugar, from a given measure, as that of the Acer saccharinum. Its inner bark produces a black precipitate with copperas, (sulphate of iron,) and is sometimes employed in domestic dyeing.

The Acer eriocarpum is highly prized as an ornamental tree, both in Europe and America, on account of the rapidity of its growth, the graceful, divergent tirection of its branches, the beauty of its leaves, and the profusion of its early lowers. It is admirably adapted for overspreading artificial ponds, or other waters, with a mirror-like surface, where the lover of nature can calmly admire the brilliant white of the leaves beneath, which he may pleasingly contrast with the bright-green above.

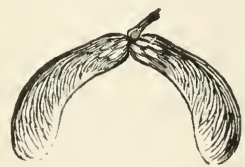




\section{Arer rubrum, \\ THE RED-FLOWERED MAPLE}

\section{Synonymes.}

Acer rubrum,

Erable rouge.

Rother Ahorn.

Szarlet-flowered Iaple,

Iaple.

Red Iaple, Soft Japle, Swamp Iaple,

\author{
(Lisxars, Species Plantarum. \\ De Caxdolte, Prodromus. \\ MIrchacx, North American Srlva. \\ Lorpor, Arboretum Britannicum. \\ TORREY AND GRAT, Flora of North America. \\ Fratee. \\ GERMANY \\ Britain. \\ Westeri States. \\ Other pakts of the Uited States.
}

Durimions. The sparific name. rubrum, is derived from the Latin ruber. red, having reference to the colour of the Eow ers. fruit and young shoo's of this tree. The other names hare chiefiy the same signiticarion as the botanical one.

Eszratings. Michaux. Norh American Srlva. pl \pm 1 : Audubon, Birls of America, pl, liv. et Ixrii.; Loudon, Arboretum Sritarinieum, i., tgure $130 ; \mathrm{p} .45 \%$ et $\mathrm{r} ., \mathrm{pl} 39 ;$ and the figures below.

Specitic Characiors. Leares cordate at the base. glancous beneath. deeply and unequaliy toothed, palmately 5-lobed, with acute recesses. Flowers conglomerate, 5-petaled, pentandrous. Oraries smooth.-Don, Miller's Dict.

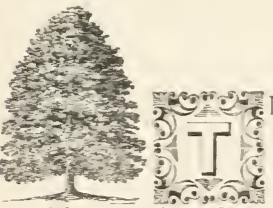

\section{Description.} 1t neither attains the size nor the height of the sugar maple. it much resembles that tree in its general appearance: but it may be easily distinguished from it by its trunk. which. when young. is more profusely marked with broad. pale-yellow lichens. In open situations, it often ramifies at the ground, and assumes the form of sereral small trees, growing in a clump. The bark; in such situations, is usually of a darker colour, and smoother, when young. than it is on trees growing in shady woods. When the tree is old. however. the epidermis of the trunk. like that of the liquidambar. and white oak, becomes brown, chapped. and deeply furrowed. The ordinary height of this species does not exceed fifty or

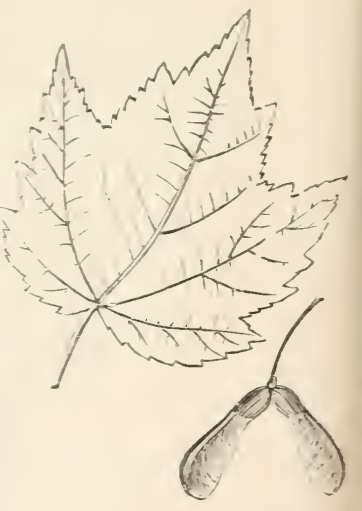
sixty feet: but in farourable situations, as in the maple siramps in New Jersey and Pennsylrania, it often attains a height of seventy or eighty feet. with a trunk three or four feet in diameter. The blossoms of this tree are the first that announce the return of spring. It flowers near st. Mary's. in Georgia, from the 20th to the last of February, and five or six weeks later near Philadelphia and New York. The flowers, which are of a beautiful purple or deep-red, unfold more than a fortnight before the leares. They are small. aggregate, and are situated at the extremity of the branches. The fruit is suspended by long. flexible peduncles, and is of the same hue of the flowers: though it varies in size and in the intensity of its colouring, according to the exposure and dampness of 
tne soil. The keys and seeds are at least one half smaller than those of the Acer eriocarpum, and ripen two or three weeks earlier. The leares are alsc smaller than those of that species, and in some respects resemble them. They are glaucous and whitish underneath; palmated or divided into three moderately acuminate lobes, irregularly toothed; but they are longer than they are broad, usually rounded at the base, with two small lobes, or large teeth below the lateral lobes. The extremities of this tree, which are formed by numerous twigs united at the base, and when garnished with flowers and fruit of a deep-red. before vestation has generally begun to revive, presents a very singular and grand appearance.

Varieties. The Acer rubrum has long been confounded by British authors with the Acer eriocarpum; but whether they are only varieties or races of the same species, or not, there is a marked difference between them, both in the habit of their growth and the colour of their fiowers. The principal distinction, nowerer, consists in the fruit of the Acer eriocarpum being woolly, and that of the Acer rubrum being smooth.

There are two varieties, however, among cultivators, known by the name of A. $r$. coccineum, and A. $r$. intermedium, which differ so slightly from the Acer cubrum, as hardly to be worthy of notice. The leaves of the former variety are somewhat redder in spring, when they expand, than those of the species.

Geography and History. The natural habitat of the red-flowered maple. towards the north, according to Michaux, begins about Malebaye, in Canada, in forty-eight degrees of latitude, where it is sparingly found; but in proceeding southward, it soon becomes more common, and abounds in Florida and Lower Louisiana. It also grows beyond the Rocky Mountains, on the authority of Nr. Douglass, at the sources of the Oregon.

This tree was first cultivated in England by Mr. John Tradescant, jun., in 1646, at South Lambeth, near Vauxhall; and since that time, it has been propagated in the principal European nurseries, but less extensively than the Acer eriocarpum.

There are several recorded trees of this species, both in Britain and in Ireland, which, in 1835, had arrived at nearly their maximum height. In Surrey, on an eminence, in the arboretum at Milford, a tree is mentioned, as being forty feet high, which, in autumn. when its leares assume a dark-red colour, looks like a column of scarlet, and is seen from a great distance all round the country. At Woodstock, in Kilkenny, Ireland, there is a tree, which, at sixty years planted, was fifty feet in height.

In France, in the botanic garden at Toulon, there is a tree of this species. which, in forty-fire years after planting, attained the height of twenty-nine feet. In Saxony, at Wörlitz, an Acer rubrum attained the height of fifty-five feet n sixty-five years after planting.

In Bavaria, at Munich, a tree of this species is mentioned which attained the leight of forty feet in twenty-four years.

Soil, Situation, Propagation, \&॰c. "Of all the trees which flourish in grounds which are occasionally overflowed," says Michaux, "this species is most multiblied in the middle and southern states. It occupies, in great part, the borders of reeks, and abounds in all the swamps, which are often inundated, and always niry." In these situations it is accompanied by the Nyssa biflora villosa. (black zum,) Liquidambar styraciflua, Carya squamosa, (shell-bark hickory,) Quercus prinus discolor, (swamp white oak,) Fraxinus a. sambucifolia, (black ash.) and he Fraxinus a. quadrangulata (blue ash.) To these are added, in Carolina and Feorgia, the Magnolia glauca, Quercus aquatica, (water oak,) Gordonia lasianhus, (loblolly bay,) Nyssa biflora. (sour gum,) and the Laurus carolinensis red bay.) "It is a remarkable fact," continues Michaux, "that, west of the 
mountains, between Brownville and Pittsburg, the red-flowering maple is seen growing on elevated ground, with the oaks and the walnuts; but in such situations, it does not attain such ample dimensions, as in Pennsylvania and New Jersey. In these states exist extensive marshes, called maple swamps, exclusively covered with it." Elliot observes that, in "descending the mouths of our large rivers, the red maple is the last tree found in the swamps, diminishing in size as the soil becomes impregnated with salt, until it dwindles down to a shrub, and mingling with the Myrica cerifera, (candlebery myrtle,) and the Baccharis halimifolia, it finally disappears."

This species, when cultivated, contrary to the general character of the maples, is said to thrive best in moist soil, which must, however, at the same time, be rich; and for the tree to attain a large size, the situation should be sheltered. In Britain it is chiefly propagated by layers; but on the continent, almost always by seeds, which ripen before midsummer, even sooner than those of the Acer eriocarpum, and, if sown immediately, they will come up the same season. The seeds, however, do not keep well, even when mixed with earth; and in general, but a small proportion of those vegetate which are sent from the United States to Europe.

Insects. The insects which attack this species are the same as those which prey upon the Acer eriocarpum.

Properties and Uses. The wood of the Acer rubrum, when dry, weighs fortyfour pounds to a cubic foot, and when green, it is soft, full of aqueous matter: and loses in drying nearly one half of its weight. In this tree, as in others which grow in wet places, the sap-wood bears a large proportion to the heart-wood, the latter of which consists of an irregular column, star-like in its transverse section, and occupies the central part of large trunks, with its points projecting into the sapwood. This wood has but little strength, is liable to injury from insects, and ferments, and speedily decays, when exposed to the alternations of moisture and dryness. Yet it is solid, and for many purposes, is preferred by workmen, to other kinds of wood. It is harder than that of the white maple, and of a finer and closer grain; lience it is easily wrought in the lathe, and acquires, by polishing, a glossy and silky surface. It is principally employed in the manufacture of chairs, saddle-trees, -shoe-lasts, ox-yokes, broom-handles, and various other articles of domestic use. It sometimes happens that, in very old trees, the grain of the wood, instead of following a perpendicular direction, is undulated; and this variety bears the name of curled-maple. This singular arrangement is never found in young trees, nor even in the branches of such as exhibit it in the trunk; it is also less conspicuous in the centre of the tree than near the bark. Trees offering this disposition, however, are rare. The serpentine direction of the fibres, which renders this wood difficult to split and to work, produces, in the hands of a skilful mechanic, the most beautiful effects of light and shade. These effects are rendered more striking, if, after smoothing the surface of the wood with a double-ironed plane, it is rubbed with a little sulphuric acid, and afterwards with linseed oil. On examining it attentively, the varying shades are found to be owing entirely to the inflection of the rays of light; which is more sensibly perceived in viewing it in different directions by candle-light. Before mahogany became generally fashionable in the United States, the best furniture in use was made of the redflowered maple, and bedsteads are still made of it, which in richness of lustre, exceed those of the finest imported woods. But one of the most constant uses to which the curled-maple is applied, is for the stocks of rifles and fowling-pieces, which, to elegance and lightness, unite toughness and strength, the result of the tortuous direction of the fibres. The cellular matter of the inner bark is of a dusky-red. By boiling, it yields a purplish coloured liquor, which, with the addition of sulphate of iron, (copperas,) acquires an intense dark-blue, or black 
ad is sometimes employed as ink, by American youth in village schools. For is purpose, however, it is very inappropriate, as it never dries properly, and damp weather, the writing becomes glutinous and blots. A fluid prepared in similar manner, by adding sulphate of alumina, (common alum,) instead of ppperas, is also used for dyeing black. The French Canadians make sugar om the sap of this maple, which they call plaine; but, as in the preceding ecies, the product of a given measure, is not more than one half as great as at of the sugar maple.

In Britain, and throughout Europe, the sole use of the Acer rubrum is as an namental tree; and, whether it is viewed in the beauty of its flowers and pening leaves in early spring, or admired for its red fruit in the beginning of immer, and its crimsoned foliage in autumn, it deserves to be ranked as one of e most ornamental of hardy trees.

Acer monspessulanum,

\section{THE MONTPELLIER MAPLE.}

Synonymes.

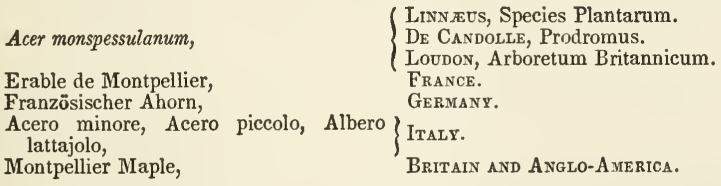

Engravings. Loudon, Arboretum Britannicum, i., figure 131, p. 458; et $\nabla .$, pl. 41 ; and the figure below.

ecific Characters. Leaves cordate, 3-lobed; lobes almost entire, and equal. Corymbs few-flowered, pendulous. Fruit smooth, with the wings hardly diverging.-Loudon, Arboretum.

\section{Description.}

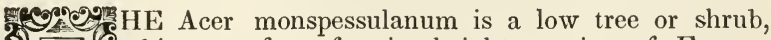
thirty or forty feet in height; native of France, Spain, and Italy; grows chiefly on rocky, exposed situations; and introduced into Britain in 1739. The trunk is covered with a reddish-brown bark. The leaves are chiefly threebed, with an entire margin, of a dark-green colour, and bear a general resemlance to those of the Acer campestre, which are about the same size, but of a aler green, and five-lobed; in mild seasons, they remain on the trees a great art of the winter, more especially in France. The flowers are produced just efore the leaves, in May; they are pendulous, and grow in corymbs, one from Imost every bud, and consist of from six to ten flowers; they are of a pale-yelow colour, and form a great source of attraction to bees. The wood is hard nd heavy, and is used in France by turners and cabinet-makers. It is auch planted in that country for hedges, on account of the persistency of the eaves. In England, this tree may be considered as purely one of ornament. $t$ is propagated either by seeds or layers, and well deserves a place in every ollection, both in Europe and in America, wherever it will grow. In France, in he Jardin des Plantes, at Paris, there is a tree of this species, which had attained he height of fifty-five feet in one hundred and thirty years after planting. 
Acer campestre,

\title{
THE FIELD MAPLE.
}

\section{Synonymes.}

\author{
(Linnaus, Species Plantarum. \\ Acer campestre, \\ De Candolle, Prodromus. \\ Dos, Miller's Dictionary. \\ Loudon, Arboretum Britannicum. \\ SELBy, British Forest Trees. \\ France. \\ Erable champêtre, \\ Kleiner Ahorn, Feld Ahorn, \\ Germany. \\ Galluzzi, (when small,) Loppo, Pioppo, ) \\ Chioppo, Stucchio, Festucchio, Fistuc- Italy.
chio, Albero da vite, \\ Field Maple, \\ Britain and Anglo-America.
}

\begin{abstract}
Derirations. The specific name, campestre, is derived from the Latin campus, a field, having reference to this tree as growing about hedges and open fields. 'The French, German, and English names have the same signification.

Engravings. Selby, British Forest Trees, p. 27; Loudon, Arboretum Britannicum, i., figure 132, p. 458, et. v. pl. 43; and the figures below.

Specific Characters. Leaves cordate, with 5-toothed lobes. Racemes erect. Wings of fruit much divaricated.-Don, Miller's Dict.
\end{abstract}

\section{Description.}

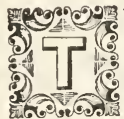

HE Field Maple, when cultivated under favourable circumstances. forms a tree of the second or third order, with a handsome outline, and picturesque appearance. In its natural habitat, it seldom exceeds the height of twenty feet, although in a state of cultivation, it often attains more than double that elevation.

Varieties. In the Acer campestre,

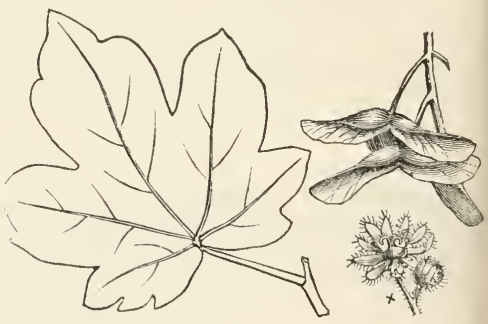
we recognize six forms or varieties, which may be described as follows:-

1. A. c. Hebecanpum, Loudon. Downy-fruited Field Maple. This variety is the form usually regarded by British authors as the type of this specics, and is characterized as rather a small tree, with spreading branches; the bark corky, and full of fissures; that of the branches smooth. The leaves about one and a half inches broad, downy while young, as are their footstalks, obtusely fivelobed, irregularly notched, and sometimes quite entire. The flowers grow in clusters, which terminate the young shoots : they are hairy, erect, short, somewhat corymbose, and of a green colour. The anthers are hairy between the lobes. The capsules downy, spreading horizontally, with smooth, oblong, reddish wings.

2. A. c. Folis variegatis, Loudon. Variegated-leaved Field Maple. This variety is considered as the handsomest of all the variegated-leaved maples. 
The leaves are blotched and striped with white, or whitish-yellow, and preserve their vegetation with a healthy appearance.

3. A. c. collinum, Loudon. Hill-inhabiting Field Maple. This variety is a native of France. The fruit is smooth; the lobes of the leaves obtuse, and the flowers small.

4. A. c. austriacum, Loudon. Austrian Field Maple. This variety, as its name imports, is a native of Austria ; also of Podolia and Tauria. It is larger in all its parts than the Acer campestre hebecarpum, and is of much freer growth. The trunk rises erect and straight, and sends out its branches regularly on every side, so as to form a cone, almost like a fir-tree. The lobes of the leaves are somewhat acuminated, and the fruit is smooth.

5. A. c. Levigatum, Loudon. Smooth-leaved Field Maple.

6. A. c. nanum, Loudon. Dwarf Field Maple.

Geography and History. The Acer campestre is found throughout the middle states of Europe, and in the north of Asia. According to Pallas, it abounds in New Russia, and about Caucasus. It is common in hedges and thickets in the middle counties and south of England; but in the northern counties, and in Scotland, it is rare. It is not indigenous to Ireland, and perhaps not to Scotland.

The largest tree of this species in Britain, and possibly on the globe, is at Blairlogie, in Stirlingshire, which, in 1835 , was three humdred and two years old, fifty-five feet high, with a trunk four feet in diameter, and an ambitus or spread of branches of forty-five feet. Another tree at Braystock, in Essex, had arrived at the height of fifty feet in eighty years.

In France, in the botanic garden at Toulon, there is a tree of this species, which attained the height of forty-five feet at forty-eight years after planting.

In Saxony, at Wörlitz, there is an Acer campestre, which attained the height of forty feet, in sixty-five years after planting.

This species was introduced into the United States in 1822, by the late Mr. Prince, of Flushing, New York, and may be found in the American nurseries and collections.

Soil, Situation, $\& \cdot c$. A dry soil suits the Acer campestre best, and an open situation; but, to attain a timber-like size, it requires a deep, free soil, and a situation sheltered by other trees. In nurseries, plants of this species are raised from seeds, most of which often remain eighteen months in the ground before they come up, though a few vegetate the first spring. The varieties are propagated by layers.

Insects, $\oint^{\circ} c$. There are but a few insects or their larvæ which appear to feed upon the leaves of this species, with the exception of a small, dark-green aphis; and the tree is not much liable to accidents and diseases. Loudon observes that the misletoe is sometimes found growing upon it.

Properties and Uses. The wood of the Acer campestre, when allowed to become a tree, and of a proper age, is very compact, possesses a fine grain, sometimes beautifully veined, and is susceptible of a high polish. When dry, it weighs fifty-two pounds to a cubic foot. It makes excellent fuel, and produces charcoal of the best quality, which is sometimes employed in the manufacture of gunpowder. It was celebrated among the ancient Romans for tables; and Pliny, who has treated at length upon the brusca and mollusca, the names under which she knobs and excrescences of this tree were known, informs us that cabinetwork of the most costly description was fabricated from them. In France, and other European countries, it is still extensively used by turners, carvers, and cabinet-makers, and the wood of the roots, which is often knotted and curiously marbled, is wrought into snuff-boxes, pipes, and various other articles of fancv. 
The British poets generally place a maple dish in every hermitage they speal of. Wordsworth, in his "Ecclesiastical Sketches," says :

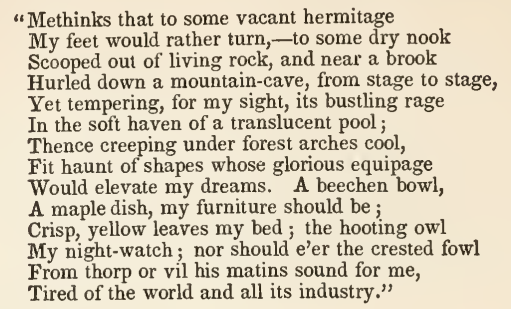

Wilson and Cowper both furnish the hermit's cell with the article so requisite for such a habitation:

"Many a visitant

Had sat within his hospitable cave;

From his maple bowl, the unpolluted spring

Drunk fearless, and with him partook the bread

That his pale lips most reverently had blessed,

With words becoming such a holy man,

His dwelling a recess in some rude rock,

Books, beads, and maple dish his meagre stock.

***** It seemed a hermit's cell,

Yet void of hour-glass, skull, and maple dish."

The young shoots of this tree, being tough and flexible, are employed by coachmen, in some parts of France, instead of whips. In that country it is also much used for forming hedges, and for filling up gaps in old fences. It is advantageously employed in topiary works, and in geometrical gardens, being found to bear the shears better than most other trees. The leaves and young shoots are gathered green, and dried, for winter provender for cattle. The sap yields more sugar, in proportion to the quantity taken, than that of the sycamore.

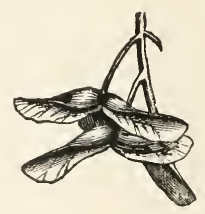




\title{
Genus NEGUNDO, Møench.
}

\author{
Aceraceæ. \\ Syst. Nat. \\ $\underset{\text { Diœcia Pentandria. }}{\text { Syst. Lin. }}$
}

Synonymes.

Negundo, Acer,

Erable,

Ahorn, Eschenahorn,

Negundo,
OF Authors.

France.

Germany.

Britain, Italy, and Anglo-America.

eneric Characters. Sexes diœcious. Flowers without a corolla. Calyx with $4-5$ unequal teeth. Male flowers upon thread-shaped pedicels, and disposed in fascicles; anthers 4-5 linear, sessile. Female flowers disposed in racemes. Leaves impari-pinnately divided.-De Candolle, Prodromus

HIS genus was constituted by Mœnch from the Acer negundo of Linnæus, and comprises three species, one native of CochinChina, one of California, and the other of Canada and the United States. The Dobinea vulgaris, a hardy shrub, native of Nepal, with elliptical, oblong, acutely-serrated leaves, belongs to the same natural family. No other genus, has hitherto been discovred, or recorded as belonging to the order Aceracæ, either of a hardy or tender ature. 


\section{Negundo fraxinifolium,}

\section{THE ASH-LEAVED NEGUNDO.}

\section{Synonymes.}

Acer negundo,

\section{Negundo fraxinifolium,}

Negundo aceröides,

Erable à feuilles de frène,

Eschenblättriger Ahorn,

Acero a foglie di frassino, Nigundo,

Erable à giguières,
Michaux, North American Sylva.

( Nuttall, Genera of North American Plants.

De Candolle, Prodromus.

Lovdon, Arboretum Britannicum.

Torrey and Gray, Flora of North America.

France.

Germany.

ITALY.

French ILlinols.

Other parts of Anglo-America.

Derivations. The meaning of the word Negundo, is unknown. It is supposed by some to have originated among the Frenca of rivais, and had some connection with the tremulous and playful motions of the long pinnated leaves of this tree. The Illiof Thinois, and had some connection with , literally, Romping or Frisky Maple. The specific name, acercides, is derived from nois name, Erable a giguieres, signifies, literally, Romplang or was originally applied by Monch, from the analogy this spethe Latin acer, a maple, and the Greek eidos, raxinifolium, is derived from the Latin fraxinus, the ash, and folium, a leaf.

Engravings. Michaux, Nortly American Sylva, pl. 46; Loudon, Arboretum Britannicum, v., pl. 46; and the figures below.

Specific Characters. Leaves of from 3 to 5 leaflets, the opposite ones coarsely and sparingly toothed, the odd one oftener 3-lobed than simple.-De Candolle, Prodromus.

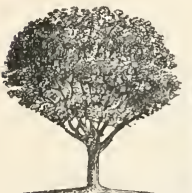

\section{Description.}

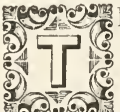

HE Negundo fraxinifolium, in favourable situations, attains a height of forty or fifty feet, with a diameter of fifteen to twenty inches. The bark of the trunk is brown, the inner portion of which has a disagreeable odour; and that of the young branches is of a smooth, rush-like appearance, interrupted only by a few buds, and is of a beautiful pea-green, like the shoots of the Jasminum officinale, but on a larger scale. The trunk ramifies at a small distance above the ground, and forms a loose, and wide-spreading head. The leaves are opposite, and from six to fifteen inches long, according to the vigour of the tree, and the moisture of the soil in which it grows. Each leaf is composed of two pair of leaflets, with an odd one. The leaflets are petiolate, oval-acuminate, and sharply

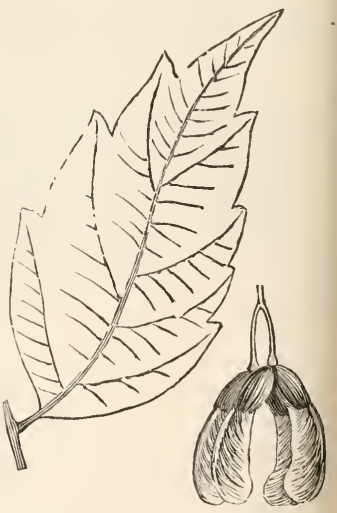
toothed. 'Towards autumn, the common petiole becomes of a deep red. The flowers are produced profusely, in April or May, and appear with the leaves. They occur in slender pendulous racemes, are small, and of a green colour, which renders them difficult to be seen, unless they be closely watched in the flowering season. The racemes of fruit, that succeed the flowers, increase gradually to the length of six or seven inches, and as the season advances, they appear conspicuous among the foliage.

Variety. According to Loudon, there is a variety of this species growing in the arboretum of the London Horticultural Society, called Negundo $f$. crispum, 
or Curled-leaved Ash-leaved Negundo. It is of the male sex; the inflorescence consists of pendulous panicles of flowers, that are green, with some redness from the colour of the anthers; and each is placed upon a slender peduncle of about an inch in length.

Geography and History. The Negundo fraxinifolium is a native of the United States, and of Canada. According to Dr. Hooker, it is abundant about Red River, in latitude fifty-four degrees, in the latter country, which may be considered as its most northern limit. It is seldom found growing wild in the northern parts of the union, nor in the maritime districts of the southern states. It commences on the banks of the Delaware, in the neighbourhood of Philadelphia, and becomes more abundant towards the Alleghany Mountains, at the west of which, it is still more multiplied.

This species was first introduced into England in 1688, by Bishop Compton, at Fulham; and since that time it has been cultivated throughout Europe. The original tree, planted at Fulham, is believed still to be in existence. In 1793, it measured six feet and four inches in circumference three feet from the ground, and was computed to be forty-five feet in height. In 1809, it measured seven feet one and a half inclies in girt; and in 1835, the dimensions had scarcely varied. The largest tree of this species recorded in England, is at Kenwood, which had attained the height of forty-five feet in thirty-five years after planting.

The negundo was introduced into France by Admiral Gallisonière, in the time of Du Hamel. According to Baudrillart, the administration of forests at Paris, received a quantity of seeds from the neighbourhood of Lyons, from which a number of young plants were raised, and distributed through the national forests. Hence it appears that they had both the male and female trees in France, at that period.

Michaux informs us that a row of these trees was planted in the Jardin des Plantes, in the Rue de Buffon, which gave an excellent idea of their appearance in their native forests. The largest of these trees which remained in 1835, estimated at upwards of sixty years of age, was fifty-one feet in height, with a head fifty-four feet in diameter.

At Brück, on the Leytha, in Austria, there is a tree of this species, which attained the height of eighty feet in forty-eight years after planting, with an ambitus, or spread of branches of forty-eight feet.

In the Bartram botanic garden, on the west bank of the Schuylkill, there is a tree of this species, fifty feet in height, with a trunk four feet in circumference. And there is another fine specimen growing in Washington square, in Philadelphia, which has been planted about thirty years.

Soil, Situation, $\& \cdot c$. In the bottoms which skirt the rivers in its native country, where the soil is deep, fertile, constantly moist, and often inundated, the Negundo fraxinifolium is most abundant, and attains its largest size. Even here, however, it seldom exceeds fifty feet in height, with a trunk twenty inches in diameter; and "trees of these dimensions," Michaux observes, "are found nnly in Tennessee, and in the back parts of Georgia, which lie far to the south." At the west of the Alleghanies, instead of being confined to the river sides, as in Virginia and the Carolinas, it grows in the woods, with the locust, (robinia,) wild cherry, (Cerasus virginiana,) and the coffee-tree (gymnocladus.) But in such situations, it does not attain so ample dimensions as in Tennessee and Georgia. When cultivated, the soil and situation of this tree may be the same as those of the Acer eriocarpum. When raised from seeds, they should always be sown, if possible, as soon as practicable after gathering, on account of the difficulty of keeping them until spring. The plants grow with amazing rapidity when the soil is deep, and somewhat moist; but as it is not a long-lived tree, it should not be placed in situations where the permanent effect of wood is of 
importance. It arrives at maturity in fifteen or twenty years, and has been known to attain a height of forty or fifty feet, when cultivated under favourable circumstances.

Properties and Uses. The wood of the Negundo fraxinifolium has a fine, even grain, and is saffron-coloured, slightly mixed with violet, but is rather tender. The proportion of the alburnum to the heart-wood is large, except in very old trees, in which the heart-wood is variegated with bluish and rose-coloured veins. In America, it is seldom employed for any other purpose than that of fuel; but in Europe, it is used in cabinet-making, particularly for inlaying. It works well, is elastic and sonorous. It has been stated that sugar has been extracted from the sap of this tree, but this is denied by Michaux. He suggests that, from its rapid growth, after being cut down to the ground, it might form a valuable underwood, to be cut every three or four years, for fuel, charcoal, and other purposes. But this has been tried in France; and, unless the soil be kept constantly humid, the stool is found to decay in a few years. In England, it is solely to be considered as an ornamental tree; and there, as well as in the United States, it merits the attention of cultivators and amateurs, in situations where immediate effect is the object; for it is rapid in its growth, showy in its appearance, by the fine green of its shoots, its large, pinnate leaves which move by the slightest breeze, and its wide-spreading summit. It also merits attention from its faculty of grcwing in almost any kind of soil.

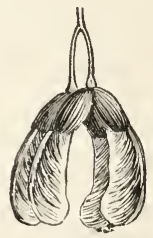




\section{Genus ASCULUS, Linn.}

Isculaceæ.

Syst. Nat.
Heptandria Monogynia.

\section{Synonymes.}

Esculus, Hippocastanum, Pavia,

Marronier d'Indie,

Rosskastanie.

ippocastano,

Horse-chesnut, Buckeye,
OF Authors.

France.

Germanx.

ITALY.

Britain and Anglo-America.

Derivations. The word Esculus, derived from the Latin esca, nourishment, was applied by Pliny to a species of oak which tad an edible acorn. The name Hippocastanum, derived from the Greek hippos, a horse, and castanon, a chesnut, is suposed to have been given to this tree, because, in Turkey, the nuts were used for curing horses of pulmonary diseases. The tame, Pavia, is so called, in honour of Peter Paw, a Dutch botanist.

Distinctive Characters. Calyx campanulate, 5-lobed. Ovary roundish, trigonal. Seeds large and globose : albumen wanting. Embryo curved, inverted, with fleshy, thick, gibbous cotyledons, not produced above ground in germination. Plumule large, 2-leaved.-Loudon, Arboretum.

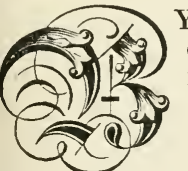

$\mathrm{Y}$ most modern botanists, the order Aisculaceæ, is supposed to embrace two separate genera, Fisculus and Pavia, distinguished from each other chiefly by the former having echinated capsules, and the latter by having them smooth; and also of the comparative roughness of their leaves. To us it appears doubtful, whether these circumstances are a sufficient generic distinction, since they vary much in different individuals, and since, in some of the kinds, which have apparently been produced between æsculus and pavia, the fruit is as smooth, or nearly as much so as in the paviæ proper. We shall, therefore, mbrace them all under four species, and regard the others as varieties.

All the species, except one, which is a shrub, are deciduous trees, with deeply cut leaves, and showy flowers. They are mostly natives of North America, and some of the varieties are recognized, in Brazil, northern India, and Japan. Their fruit is usually large and bitter, sternutatory, abounding in potash and starch, and containing a febrifuge called asculine. Their bark is tonic and astringent. 


\section{Asculus hippocastamum, \\ THE COMMON HORSE-CHESNUT.}

Synonymes.

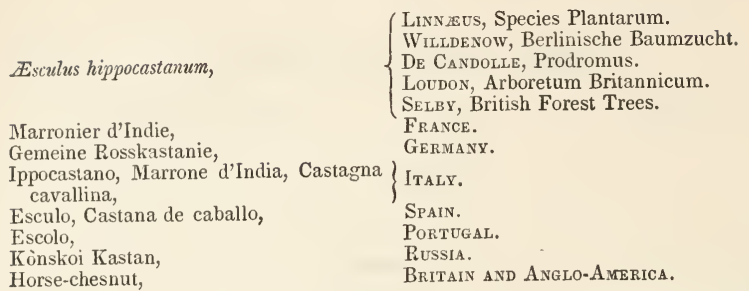

Engravings. Selby, British Forest Trees, pp. 31, 35, et 36 ; Loudon, Arboretum Britannicum, v., pl. 48; and the nguree Delow.

Specific Characters. Leaflets 7, obovately cuneated, acute, and toothed.-Loudon, Arborctum.
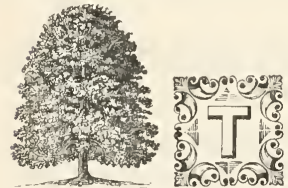

$\mathrm{TH}$

Horse-chesnut is a tree of the largest size, with an erect trunk, and a pyramidal head, sometimes attaining a height of ninety or one hundred feet. The leaves are large, of a deep-green, and singularly interesting and beautiful, when first developed. When enclosed in the bud, they are covered with a pubescence, that falls off, as they become expanded, which occurs sooner or later, according to the dryness or moistness of the season. The buds are covered with a gummy substance, which protects their downy interior from the wet. The growth, both of the tree and of the leaves, is very rapid, sometimes the young shoots and leaves being perfected in three weeks from the time of their first unfolding. The flowers appear a short

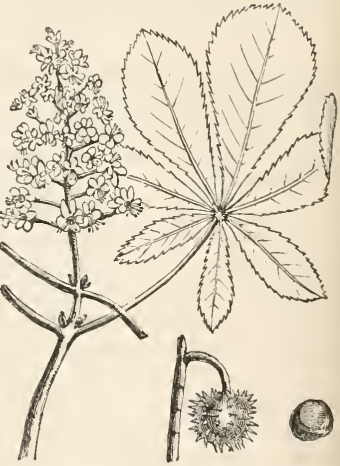
time after the leaves, and are white, variegated with red and yellow; and in Britain and the northern parts of the United States, they expand in May, and the fruit ripens about the end of September or early in October.

Varieties. 'The following varieties are recognized under this species, and may be described as follows :-

1. A. H. Flore pleno, Loudon. Double-flowered Horse-chesnut. This variety is recorded in nurserymen's catalogues, but it is not common.

2. A. H. variegata, loudon. Variegated-leaved Horse-chesnut. The leaves of this variety are blotched with yellow, or yellowish-white; but they have a ragged and unhealthy appearance, and are by no means ornamental.

3. A. н. онгеnsis, Loudon. Ohio Horse-chesmut or Fretid Buckeye. This variety is found on the banks of rivers in Pennsylvania, Virginia, Ohio, and 
Eentucky. It is a low tree, with a rough, blackish bark, the cellular integu1ent of which, emits a disagreeable, fœtid odour. The ordinary stature is ten r twelve feet, but it sometimes attains a height of thirty or thirty-five feet, ith a diameter of twelve or fifteen inches. The leaflets are glabrous, uneual in size, oval-acuminate, irregularly toothed, and of a fine green colour. 'he flowers are white, about half the size of the Aisculus hippocastanum, and ppear in May or June. The fruit is also about half the size, of the same colour, nd is contained in fleshy, prickly capsules, and matures early in autumn.

4. F. H. RUBicunda, Loudon. Scarlet-flowered Horse-chesmit; Marronier rubiund of the French; and Scharlachrother Rosskastanienbaum of the Germans. 'he colour of the flowers of this variety is scarlet. The leaves are of a deeper reen than those of any other kind. It is distinguished from the Esculus hippoastanum by the leaves being fuller and more uneven on the surface, and of a eeper green; and from the Asculus rubra, by its larger and rougher leaves. is doubtful whether this tree is a native of America, or originated in British urseries. It was first cultivated in England in 1820; and a tree at Endsleigh ottage, in Devonshire, attained the height of thirty feet in eighteen years after lanting.

5. A. H. GLabra, Loudon. Smooth-leaved Horse-chesnut. This variety is a w tree, native of North America, and introduced into Britain in 1822. Its eaflets are of a pale-green, very smooth, and fall in autumu sooner than those f most other varieties. The flowers are of a greenish-yellow, and appear in une. The whole plant is comparatively glabrous, and even the fruit partakes f that quality.

6. F. н. PALlida, Loudon. Pale-flowered Horse-chesnut ; Gelblicher Rosskasinienban of the Germans. This variety is a native of the forests of Kentucky, nd was introduced into Britain in 1812. It closely resembles the preceding varity, but is somewhat more robust in its growth. Its flowers are paler, being of a hitish, or greenish-yellow, and its leaves are not quite so smooth.

7. A. н. asplennfolia. Fernlike-leaved Horse-chesunt. This is a French ariety, having leaves resembling those of ferns.

8. E. H. Folis ARgenteis, Loudon. Silver-leaved Horse-chesnut, the leaves of hich are blotched, or striped with white, instead of yellow.

Geography and History. The native country of the common horse-chesnut, Ir. Royle observes, "is yet unknown, though stated, in some works, to be the orth of India." He says that he never met with it, though often visiting the 1ountains of that country, where, if anywhere, it was likely to be found, and here the Indian horse-chesnut was found in abundance.

According to M. Bon de Saint-Hilaire, the horse-chesnut passed from the 1ountains of Thibet to England in 1550, and thence to Vienna, by Clusius, and fterwards to Paris by Bachelier. It is also stated by Clusius, in his "Rariorum lantarum Historia," that there was a plant of this species at Vienna, in 1588, hich had been brought there twelve years before, but which had not then owered. It has also been said that this tree was first raised in France, from eeds procured from the Levant, in the year 1615, by one Bachelier. Parkinson, 1 1629, says, "Our Christian world had first a knowledge of it from Constantiople." The same author placed it in his orchard, as a fruit-tree, between the ralnut and the mulberries. We afterwards find it mentioned in Johnson's edion of Gerard's "Herbal," in 1633, as then growing in Mr. Tradescant's garden, $t$ South Lambeth. From this period till the time of Miller, it appears to have ttracted great attention, and acquired a high reputation as an ornamental tree, s he represents it in 1731, as being very common in England, and extensively mployed in the formation of avenues and public walks.

The largest horse-chesnut, supposed to exist in Britain, is at Nocton, in 
Lincolnshire It is represented as being a most magnificent tree, fifty-nine feet high, with immense branches, spreading over a space of three hundred and five feet in circumference. The branches are supported by props, so that at a little distance, the tree appears like an immense Indian banian. At Coombe Abbey, in Warwickshire, there is another tree of this species, which attained the height of seventy feet in one hundred years after planting, and had a trunk seven feet three inches in diameter, with an ambitus, or spread of branches, of one hundred and three feet. Sir T. Dick Lauder, speaking of horse-chesnuts in Scotland, says, "The horse-chesnuts on the lawn, which was formerly the garden of Dawick, the seat of Sir John Murray Nasmyth, Bart., a few miles from Peebles, in Tweeddale, are certainly the oldest and finest in Scotland; or, perhaps, we should say there are none equal to them in Britain. They stand twelve feet from each other; but they support a mass of foliage that appears to be but one head, which takes a beautiful form, and covers an area of ground, the diameter of which, is ninety-six feet. 'The larger of the two is in girt, immediately above the root, sixteen and a half feet. The smaller tree is twelve and a half feet in circumference at the base, and ten feet at three feet high." The age of these trees was estimated by him to be from one hundred and eighty to one hundred and ninety years. Mr. Loudon has recorded another tree of this species, as growing at Enfield, near London, which, in 1835, had attained the height of one hundred feet.

The largest horse-chesnut in France, and which was considered as the parent stock from which all others have been propagated in that country, formerly existed in the garden of the Temple. The second tree of this species introduced into that kingdom, was planted in the Jardin des Plantes, in 1650, and died in 1767. A section of its trunk is still preserved in the Museum of Natural History. There is a tree of this kind existing in the garden of the Tuileries, which is distinguished, even in summer, from all others in the same garden, by the profusion of flowers with which it is covered, and also by the earliness of their putting forth. It is said to unfold its leaves always a fortnight earlier than any others, which is exemplified by the following historical incident. On Napoleon's entry into Paris, on the 20th of March, 1815, after his return from the island of Elba, this tree furnished to him and his friends, foliage for their personal decoration, zeing the only tree in the leaf in the garden of the Tuileries.

In Germany, the horse-chesnut, after having been planted at Vienna, soon iound its way to Baden, where it was planted about the end of the XVIth century, and where some of the trees are said to be still in existence.

The introduction of the common horse-chesnut into the United States probably dates back to about the middle of the XVIIth century. The tree, supposed to be the first brought to this country, is still standing on the estate of Mr. Lemuel W. Wells, of Yonkers, (formerly Phillipsburgh,) New York, and is ten feet in circumference at a yard above the ground, sixty-five feet in height, with an ambitus, or spread of branches of fifty feet. It is in a flourishing condition, and bears a profusion of fruit, from which the New York nurseries and seed-stores are annually supplied. It is said to have been planted by Frederick Philipse, the founder of Phillipsburgh, who formerly lived on the place of its present proprietor. In the vicinity of this tree there are numerous others of nearly the same magnitude, which were raised from its nuts, and from the accounts of the oldest residents of Yonkers, they have not increased materially in size within their recollection.

Poetical and Legendary Allusions. The horse-chesnut, when allowed to attain Its proper shape on a lawn, has been compared by some authors to an immense"lustre or chandelier," its long racemes of flowers tapering up from its drooping foliage like light; a "giant's nosegay ;" a "gigantic hyacinth ;" a "Brobdignagian 
lupine;" and, from the manner in which it scatters its flowers on the grass, and the comparative uselessness of its fruit and timber, it is regarded by poets as a symbol of ostentation.

In Paris, the magnificent trees in the garden at the Luxembourg have been celebrated by Castel.

"La de marroniers les hautes avenues

S'arrondissent en voûte, et nous cachent les nues."

Soil, Situation, \&॰c. The horse-chesnut requires a deep, free, loamy soil, and will neither attain an ample size, nor flower freely, except in a situation rather sheltered than exposed. It is always propagated by the nut, sown in autumn or spring, and covered with from two to three inches of soil. The cotyledons do not rise to the surface, as in the oak, the beech, and some other trees. "Some nurserymen," says Loudon, "cause the nuts to germinate before sowing them, in order to have an opportunity of pinching off the extremity of the radicle; by which means the plants are prevented from forming a taproot; or, at least, if a taproot is formed, it is of a much weaker description than it would otherwise be. and the number of lateral fibres is increased; all of which is favourable for transplanting. When the tree is intended to attain the largest size, in the shortest time, the nut ought to be sown where the tree is finally to remain; because the use of the taproot is mainly to descend deep into the soil, to secure a supply of water, which, in dry soils and seasons, can never be obtained in sufficient quantities by the lateral roots, which extend theniselves near the surface in search of nourishment and .air." This is admitted, by Selby, to be the case for a certain number of years, but he doubts whether a transplanted tree will not ultimately attain as large a size as one reared in the manner recommended above. He cites an instance of a tree at Twizell, eighteen years planted, which measured, at two feet from the ground, four feet, two inches in circumference, with a height of thirty-eight feet.

Insects. The foliage of the Esculus hippocastanum is rarely eaten by the larvæ of insects, except by those of several species of the Geometriæ, some of which indiscriminately attack every tree within their reach, and persist in their devastations, unless the qualities of the leaves are disagreeable to them in the extreme. Among the trees, in which the leaves are unpleasant to them, are the Ailantus glandulosa, Catalpa syringæfolia, and Broussonetia papyrifera (paper mulberry.)

Properties and Uses. The wood of the horse-chesnut is white and very soft, and according to Loudon, when dry, weighs from thirty-five to thirty-seven pounds to a cubic foot. It is unfit for use where much strength and durability in the open air are required; nevertheless, there are many purposes for which it is applicable, when sawn into boards; such as for flooring, lining to carts, packing-cases, \&c. In France, sabots, or wooden shoes are made from it; and it is said to be used by carvers, turners, \&c. Boutcher says, that it is suitable for water-pipes that are to be kept constantly under ground ; and it is also recommended for this purpose by Du Hamel. The charcoal made of this species may be used in the manufacture of gunpowder; and the ashes of every part of the plant, more especially of the fruit, afford potash in considerable quantity. The bark, which is very bitter, is employed for tanning, and also for dyeing yellow; and it has been used medicinally as a substitute for Jesuit's bark. In 'Turkey, the nuts are ground, and mixed with horse-food, especially when the animals are broken winded; and in their crude state, they are eaten by goats, sheep, deer, and hogs. They are used in Ireland to whiten linen, and for this purpose are rasped into water, in which they are allowed to macerate for some time. The saponaceous juice, which they contain, is very useful, not only in bleaching, but in 
washing linens and other stuffs. The nuts must be peeled and ground, and the flour of twenty of them is sufficient for ten quarts of water; and either linens or woollens may be washed with the infusion, without any soap, as it effectually eradicates spots of all kinds. The clothes, however, should afterwards be rinsed in clean water. The nuts, when ground into flour, and mixed in the proportion of one third with the flour of wheat, are said to add to the strength of bookbinder's paste; and when steeped in hot water, and mixed with an equal proportion of bran, it makes a nutritious food for pigs and poultry. M. Vergaud has proposed to change the starch contained in the flour, into sugar, and afterwards employ it in distillation.

In Europe and America, the horse-chesnut can only be considered as an ornamental tree. It produces a splendid effect when in flower, either singly, in avenues, or on the margins of plantations. Gilpin objects to this tree, as being "lumpish in its form;" but in saying this, he evidently judged of the tree merely with reference to picturesque beauty, to which it has but few pretensions till it becomes very old; whereas in point of floral beauty, it is unequalled by few other trees. "To the painter the magnificence of its stature" and the richness of its drapery, especially when clothed in the beauty of its broad palmated leaves, and embroidered with its profusion of silver flowers, "scarcely atone for the exceeding regularity of its form, terminating, as it invariably does, when left to the hand of nature, in an exact parabola." And in addition to these beauties, its massive and luxuriant summit contrasts well with those of trees of a more airy character, and thus produces that breadth of light and shade so essential to landscape scenery. 


\section{Aisculus pavia, \\ THE SMALL BUCKEYE.}

\section{Synonymes.}

\section{Esculus pavia,}

\section{Pavia rubra,}

Marronier pavie, Pavie à fleurs rouges,

Rothe Rosskastanie,

Pavia, Marrone di Paw,

Red-flowered Pavia, Small Buckeye,
(Linneus, Species Plantarum.

$\{$ Elliott, Flora of South Carolina.

Torrey and Gray, Flora of North America.

De Candolle, Prodromus.

Don, Miller's Dictionary.

Loudon, Arboretum Britannicum.

France.

Germany.

ITALY.

Britain and Anglo-America.

Engravings. Audubon, Birds of America, pl. Ixxxviii. ; Loudon, Arboretum Britannicum, v., pl. 51; and the figures below.

Specific Characters. Fruit smooth. Corolla 4 petals, that are longer than the stamens. Leaflets 5, elliptic-oblong, tapered at both ends, and smooth, as is the petiole; axils of the nerves hairy on the under surface of the leaf.-De Candolle, Prodromus.

\section{Description.}

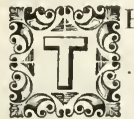

HE Small Buckeye is a slender-growing tree or shrub, varying in height from two to twenty feet, in its natural habitat, and sometimes thirty feet when in a state of cultivation. The leaves are oblong-lanceolate, cuneate-oblong, or oval, slightly acuminate, unequally serrulate, minutely pubescent, or nearly glabrous, except along the veins beneath. The racemes are lax, and generally with ternate flowers; the corollas are tetrapetalous, with their connivent claws of the length of the calyx; the stamens are seven, and shorter than the corolla. The flowers appear in Georgia and Carolina in March, and a month or six weeks later near Philadelphia and New York; and according to Mr. Audubon, they are scentless, but much sought after by humming-birds.

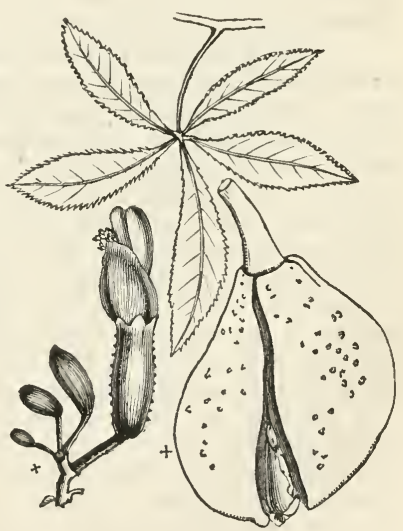
The fruit resembles that of the common horse-chesnut, but is much smaller.

Varieties. The variations which are recognized under this form may be described as follows:

1. A. P. arguta (P. r. arguta, of Loudon.) Sharp-toothed Small Buckeye. This variety was introduced into the garden of the London Horticultural Society from the nursery of M. Castros, of Bordeaux, under the name of Asculus pavia parviflora. It is said to be a handsome small tree, with dark, brownish-red flowers, differing but little from the Asculus pavia. The tree in the Society's garden attained the height of fifteen feet in ten years.

2. A. P. sublaciniata (P. r. sublaciniata, of Loudon.) Slightly-cutleaved Small Buckeye. The leaflets of this variety are acutely serrated; in other respects it differs but little from the species. 
3. A. P. humils (P. r. humilis, of Loudon.) Dwarf Small Buckeye. This is a diminutive, weak, straggling recumbent bush, only from two to three feet in height.

4. A. P. DISColor (Pavia discolor, of Loudon.) Two-coloured-flowered Small Buckeye. The whole plant of this variety, when young, is covered with pubescence. The leaflets are often somewhat doubly-serrate, sometimes smooth, and a little shining above. The inflorescence resembles that of the $\mathbb{E}$ sculus flava, but the flowers are decidedly those of the Esculus pavia. They are large, showy, being yellow, white, pale, dull-red, or purple-variegated, continuing a long time expanding, and numerous, though they are but sparingly succceded by fruit. This plant varies in height from three to ten feet, and when raised from seed, it is re. markable for its thick, fleshy, carrot-like roots, which, in free soil, penetrate perpendicularly to the depth of eight or ten feet, as was the case in the Hammersmith nursery, in England.

5. Æ. P. HYbRida (Pavia hybrida, of Loudon.) The leaves of this variety are clothed beneath with velvety pubescence, the petioles are smooth, and the flowers yellow. The leaves and flowers of this form bear some resemblance to those of the Esculus pavia discolor, but its flowers are more sparingly produced.

6. Æ. P. NEgLecta (Pavia neglecta, of Loudon). The leaves of this variety have rufous down on the veins on their upper sides, are smooth beneath, and rather plicate. The flowers are pale-yellow, and veined with red. This is a tree resembling the preceding variety, and, like it, is apparently a hybrid between the Esculus pavia and $\mathbb{E}$. pavia discolor.

7. E. P. Macrocarpa (Pavia macrocarpa, of Loudon.) This variety appears to be intermediate between some variety of $\mathbb{E}$ sculus hippocastanum and $\mathbb{E}$ sculus pavia. The leaves are large, smooth on the upper surface, and shining. The flowers are nearly as large as those of the common horse-chesnut, but with the petals less spreading, and of a pale-red colour, mixed with yellow. The branches are spreading and loose; and the whole tree has an open, graceful appearance, and quite different from that compactness of form and rigidity of branches which characterize most of the larger trees of this genus.

Geography and History. The small buckeye is found in fertile valleys and on mountains, from Virginia to Georgia, Louisiana, and Arkansas ; and is said also to be a native of Brazil and of Japan. It was introduced into Britain by Thomas Fairchild, in 1711, and since that time it has been generally cultivated as an ornamental shrub throughout Europe.

In England, at Ham House, in Essex, in 1835, it had attained the height of twenty-one feet, with an ambitus or spread of branches of thirty-two feet. At Wardour Castle, in Wiltshire, in twenty years after planting, it had arrived at a height of thirty feet. A plant of the dwarf variety was engrafted on the common horse-chesnut by Messrs. Loddiges, at Hackney, and produced a beautiful, pendulous, low tree.

In France, at Paris, in the Jardin des Plantes, a tree of this species attained the height of thirty feet in twenty-three years after planting.

In Hanover, at Schwöbber, there is a small buckeye over forty feet in height.

At Philadelphia, in the garden of Mr. D. Landreth, there is a tree of this species, thirty ycars planted, which is twenty-five feet high, with a trunk three and a half feet in circumference.

Properties, Uses, $\mathcal{S}^{\circ} c$. The wood of the Esculus pavia resembles that of the common horsc-chesnut, but is of no particular use, thus far, in the arts. On the authority of Elliott, the bruised branches, or powdered seeds of this tree are sometimes employed to stupify fish. When the water of small ponds is impregnated with them, the fish rise to the surface almost lifeless. and may readilv be 
taken with the hand. The root, he says, is used as a substitute for soap in washing woollen clothes.

It has been recommended to engraft this species into the points of the shoots of the common horse-chesnut, of twenty or thirty years' growth, care being taken afterwards, once or twice every year, to rub off all the buds from the stock as soon as they appear, so that the entire force of the plant may be directed to the nourishment of the scions.

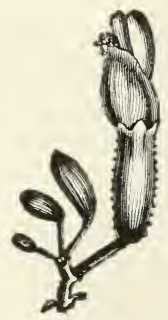




\section{Asculus Aava, \\ THE LARGE BUCKEYE.}

Synonymes.

\section{Asculus flava, \\ Pavia lutea, \\ Pavia flava,}

Pavie à fleurs jaunes,

Gelbe Rosskastanie,

Pavia gialla, Marrone d'India gialla,

Yellow Pavia,

Large Buckeye, Big Buckeye, Sweet
Arton, Hortus Kewensis.

$\{$ Torrey and Gray, Flora of North America.

Michaux, North American Sylva.

(De Candolle, Prodromus.

DoN, Miller's Dictionary.

Loudon, Arboretum Britannicum.

France.

Germany.

ITALY.

Britain.

United States.

Engravings. Michaux, North American Sylva, pl. 91; Loudon, Arboretum Britannicum, v., pl. 55; and the figures below

Specific Characters. Petioles pubescent, flattish towards the tip. Leaflets 5-7, pubescent beneath, and above upon the nerves.-De Candolle, Prodromus.

\section{Description.}

10 25 vourable situations, sometimes attains an elevation of seventy or eighty feet, with a trunk three or four feet in diameter; but in the southern states it often dwindles down to a small shrub, not more than four or five feet in height. The leaves are much paler than those of the Eisculus pavia, are lanceolate, pointed at the summit, serrate, slightly furrowed, and pubescent. The flowers, which appear in April and May, are of a light, agreeable yellow, and are disposed in upright bunches at the ends of the shoots of the same season. The fruit is contained in a fleshy, oval capsule, about two inches in diameter, which is often gibbous, and the surface of which, unlike that of the common horse-chesnut, is smooth. Each capsule contains two

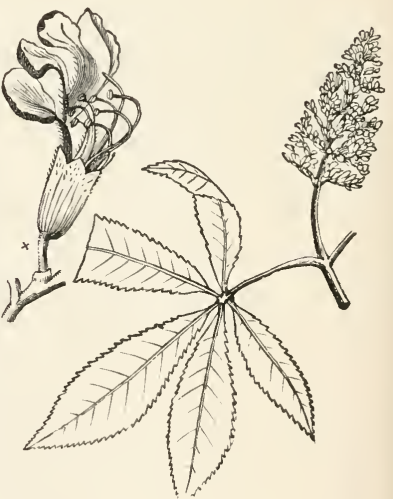
seeds or nuts, of an equal size, flat upon one side and convex on the other. They are larger, and lighter coloured than those of the common horse-chesnut, and, like them, unfit to eat.

Variety. F. F. AURantia. Orange-coloured-flowered Large Buckeye. This variety differs from the species in the deep-orange and yellow hue of its flowers, in its smooth, irregularly-toothed leaves, and more acute divisions of the calyx. It grows in the vicinity of Cincinnati, Ohio.

Geography and History. The natural habitat of the Æsculus flava is near the large rivers in the western states, and along the Alleghanies, from the thirtyninth degree of latitude, in Virginia, to their termination in Georgia. It may be considered as a stranger, east of these mountains, with the exception of a tract thirty or forty miles wide, situated, as it were, beneath their shadow 
This species was introduced into Britain in 1764, and has since been cultivated in many gardens on the continent. The largest tree in England is at Syon, which, in 1835, was forty feet in height.

At Paris, in the Jardin des Plantes, there is a tree, which attained the height of forty-four feet in fifty-five years after planting.

In Hanover, at Schwöbber, there is also a tree forty feet in height.

In the Bartram botanic garden, at Kingsessing, near Philadelphia, there is a large buckeye, ninety feet in height, with a trunk six feet and a half in circumference.

Soil, Situation, \&॰c. In its native country, the Assculus flava prefers the declivities of mountains, where the soil is loose, deep, and fertile. It is commonly propagated by budding, because the colour of the flowers is found to vary much in plants raised from seeds. It may also be grafted, like the Esculus pavia, on the common horse-chesnut. This species is not quite so free a flowerer as the last-named species, and it is one of the first trees of the genus to drop its leaves. The wood of this tree, from its softness, and want of strength and durability, can subserve to but few useful purposes.

Although the Esculus flava is much inferior to the common horse-chesnut both in point of grandeur and floral beauty, and besides, has the disadvantage of losing its leaves late in summer or very early in autumn, it well deserves place in every collection.

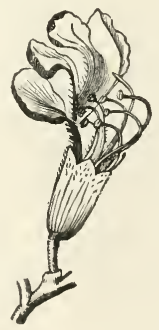




\section{Asculus macrostachya, THE EDIBLE BUCKEYE.}

\section{Esculus macrostachya, \\ Pavia macrostachya, \\ Pavia edulis,}

Pavier à longs epis, Pavier nain, Langährige Rosskastanie, Pavia bianca,

Edible Buckeye, Long-racemed Pavia,
Synonymes.

(Michaux, Flora Boreali-Americana.

Torrey and Gray, Flora of North America.

De Candolle, Prodromus.

Don, Miller's Dictionary.

Loudon, Arboretum Britannicum.

$\{$ Poitead et Turpin, Traité des Arbres fruitiers de Du Hamel.

France.

Germany.

ITALY.

Britain and Anglo-America.

Derivations. The specific name, macrostachya, is derived from the Greek macros, large, and stachus, a spike or raceme, in alısion to the long racemes of flowers. The French name, Pavier nain, signifies Dwarf Pavia, from the small size of the plant. The other French name signifies Long-spiked Pavia, and the German name has the same signification.

Engravings. Poiteau et Turpin, Traité des Arbres fruitiers de Du Hamel, pl. 88; Loudon, Arboretum Britannicum, i., figure 137 ; and the figures below.

Specific Characters. Stamens much longer than the corolla; racemes very long. Root stoloniferous. Flowers white.-De Candolle, Prodromus.

\section{Description.}

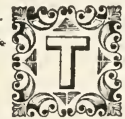

HE Edible Buckeye, in its natural habitat, is a low evergreen shrub, seldom exceeding a height of three or four feet; but in a state of cultivation, with proper management, it partakes the character of a large shrub or small tree. The shoots are slender, spreading, and rooting at the joints where they happen to rest on the soil, with ascendant extremities. The leaflets are from five to seven, ovalobovate, acuminate, serrate, and velvety-canescent
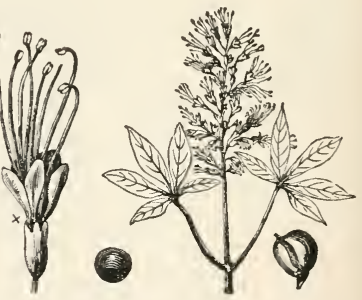

beneath. They are supported on long slender petioles, which, from their graceful disposition, combined with the feathery lightness of the racemes of flowers, give the whole plant an air of elegance, unlike that of any of the dwarf races of this genus. The flowers, which put forth in its native country in April and May, appear in England, and in the middle and northern parts of the United States, a month or six weeks later than those of the common horse-chesnut. In large plants, however, situated in a moist soil, it continues in bloom for three months or longer, forming one of the greatest floral ornaments of the shrubbery, at a season too, when very few trees or shrubs are in flower.

Geography and History. The Fisculus macrostachya is a native of the western parts of South Carolina and Georgia, usually growing on the banks of rivulets or streams. It was introduced into Britain in 1786, by Mr. John Fraser, and has since been cultivated in most of the gardens on the continent.

The largest recorded plant of this species in England, and perhaps on the globe, is in Berkshire, at White Knight's, near Reading, which had attained a height of fifteen feet in twenty-five years after planting. Several other plants, 
n England, are mentioned by Mr. Loudon, varying from six to twelve feet in leight.

Propagation, \&*c. This species may be propagated either by layers or from eeds. When plants are to be raised from the nuts, they should be sown immeliately after gathering; for, if kept exposed to the air, they shrink, and soon ose their power of vitality. The fruit is small, and seldom ripens in Britain, out in its native country, it may be eaten, boiled or roasted, in the same manner is the chesnuts in the south of France and Spain.

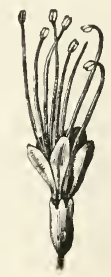




\title{
Genus MELIA, Linn.
}

\author{
Melıaceæ. \\ Syst. Nat. \\ Decandria Monogynia. \\ Syst. Lin.
}

Derivation. The word Melia is derived from the Greek meli, honey, and is the name in that language for the manna ash, which one species of this genus is thought to resemble.

Generic Characters. Calyx small; sepals 5, united below. Petals oblong, spreading. Stamen-tube 10 . cleft at the apex, with 10 anthers in the throat; the segments 2-3-parted. Ovary seated on a short disk, 5-celled, with 2 ovules in each cell, one above the other. Style columnar, breaking off from the top of the ovary. Stigma 5-lobed. Drupe ovate, with a 5-celled bony nut; cells 1-seeded. Embryo enclosed within a thin, fleshy albumen. Cotyledons foliaceous. Trees, with bipinnate leaves. Leaflets toothed. Flowers in axillary panicles.-Torrey and Gray, Flora.

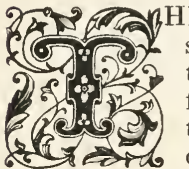

HE species of the genus Melia are few, and mostly natives of Persia, India, and Japan. The half-hardy kinds are all deciduous trees, without visible buds, and appear to be peculiarly eligible for growing in the southern states of Europe and America, or for training against conservatory walls in the more northern parts of these countries. The species most worthy of culture, besides the Azedarach, are the Melia australis, a native of New Holland, and is said to grow to the height of twenty feet; the Melia japonica, indigenous to Japan, and growing to the height of thirty feet; and the Melia buckayun, of Nepal. A tree described by some, under the name of Melia sempervirens, or Ever-green Melia, and known in the West Indies by the name of Indian Lilac, is said to grow sometimes to a height of twenty or thirty feet; but others consider it as only a variety of the Melia azedarach. 
by the red-breasts, which, in their annual migrations to Florida and the southern states, often glut themselves to such an inordinate degree, that they are sometimes found stupified by its narcotic power.

Geography and History. The Melia azedarach is supposed to have been originally a native of Persia, where it was known as long ago as the year 980, by Avicenna, an Arabian physician, who noticed the venomous principle which resides in its fruit; but some botanists are of the opinion that it is also indigenous to Florida and the United States, or at least has become so from habit; for it is found there, growing wild in the forests, and attains its fullest magnitude. It is propagated for ornament or use, in all the warm countries of the civilized world. It is also cultivated in conservatories in the temperate and colder parts of Europe and America, and even there it often flowers, and ripens its fruit.

The largest recorded tree of this species in Europe, is in the garden of Count Mellerio, at Brianza, near Milan, in Italy. It attained the height of forty feet in twenty-six years after planting, and flowers and seeds freely every year. The species is planted as an ornamental tree in Spain, Portugal, the south of France, and Italy; but there are few places in those countries where it attains so large a size as at Brianza. There are trees of it in the public walks at Montpellier, at Toulon, and the various cities of Italy.

In Greece, and along the shores of the Archipelago and the Mediterranean, the azedarach is always planted in the area of monasteries, for the sake of the nuts contained in the fruit, which are made into rosaries by the monks.

This species has been found growing in British green-houses since the year 1656, where it was introduced under the name of Indian lilac. It has been tried in that country in the open air, both as a standard and against a wall, and has stood through several winters, in the open air, at Biel, in East Lothian. At Bungay, in Suffolk, a plant, which had been nine years planted against a wall, was, in 1834, nine and a half feet high, with a trunk nine inches in diameter, and an ambitus of thirty-six feet.

In the southern cities of the United States, as well as on plantations, this tree is planted near houses, and is highly esteemed for the beauty of its flowers, the elegance of its foliage, and for the medical uses to which it is applied.

In the public square in Savannah, there are numerous trees of this species, which have nearly attained their fullest magnitude, after being planted about fifty years.

Propagation and Culture. The azedarach is propagated from seeds, which should be sown in a similar manner as those of most other kinds of stone fruit. It prospers either in a warm loamy, or a dry sandy soil, and hence is peculiarly adapted for planting worn-out and exhausted fields, which have been abandoned in Florida and the southern states. It grows with such rapidity there, that from the seed, it attains a height of twelve or fifteen feet in four or five years. This surprising vegetation is chiefly observed in plants less than ten years of age, in which the concentric circles are more distant than in any other tree. It possesses the valuable property of converting its sap-wood into perfect wood, in the earliest stages of its growth. In a stock six inches in diameter, there is often to be found not more than one inch in thickness of sap.

Insects, Casualties, $\mathcal{f}^{\circ} c$. The only insect recorded as feeding upon this tree in this country, is the yellow-underwing cooper moth or Phalana amasia, of Abbot, which, in Georgia, spun among the leaves May 2d, and came out the 2Sth. The common food, however, of the same insect, is the leaves of various kinds of oak.

At St. Mary's, Georgia, January 7th, 1813, Dr. William Baldwin took from 
e Melia azedarach, a specimen of Epidendrum magnoliæ, where it had been anted the spring before. What was remarkable, it had continued to flower all e winter on the azedarach, while in the woods no flowers were to be found !

Properties and Uses. The wood of the azedarach is of a reddish colour, and organized in the distribution of its fibres similar to those of the ash. It is suffiently strong and durable to be employed in civil architecture, and is adapted various uses in the mechanic arts. It has already been employed for pulleys, hich in Europe are usually made of elm, and in America of ash. It is said make good fuel. The fleshy part of the fruit, like that of the olive, yields a red oil, which is bitter, and is considered as anthelmintic, and a narcotic stimant. The leaves are universally used in India for poultices, and both the wers and seeds are stimulant. The berries, though said by the Arabian phyian, Avicenna, to be poisonous, and the pulp of which was mixed with grease, r the purpose of killing rats and dogs, are often eaten by children in the south, thout injurious effects. According to Mr. Royle, however, the fruit is consided as poisonous when used in large doses. The bark of the root, when green, s a bitter, nauseous taste, yielding its virtues to boiling water, and may be iployed as a cathartic or emetic, and is considered as an efficient vermifuge, d also may be used with advantage in intermittents. In Persia, an ointment made, for the cure of some cutaneous eruptions, by mulling the leaves with rd. It is also said that a kind of toddy is obtained by fermenting the sap of ung and vigorous trees. The nuts are often bored, as before stated, by monks, d strung into beads. Hence the names of Bead-tree, and Paternostri di San omenico.

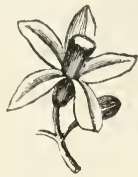




\section{Genus SWIETENIA, Linn.}

Cedrelaceæ.

Syst. Nat.
Decendria Monogynia. Syst. Lin.

Derivation. This genus was named in honour of the illustrious Gerard L. B. Van Swieten, a celebrated naturalist and physician of the last century.

Generic Characters. Calyx short, obtusely 5-cleft. Petals 5, reflexed. Filannents 10, united into a subcampanulate, 10-toothed tube; anthers included in the tube, alternate with the teeth, attached by the middle, apiculate. Style short; stigma discoid, 5-radiate. Ovary ovoid, surrounded at the base by an annular disk, 5-celled, with about 12 ovules in each cell. Capsule ovoid, 5-celled, dehiscing from the base upward, with 5 septifragal valves; the very thick and woody sarcocarp at length separable from the endocarp; the axis large, persistent, 5-angled above, 5-winged below, with the dissepiments. Seeds suspended from the summit of the axis, about 12 in each cell, imbricated in two rows, rather flat; the thickened and spongy integument expanded above into an oblong wing, which is traversed by the filiform funiculus. Embryo transverse; radicle very short, looking towards the side of the cell. Cotyledons conferruminate and confounded with the fleshy albumen. Leaves abruptly pinnate; leaflets small, somewhat inequilateral. Panicles axillary, or somewhat terminal, loosely flowered.-Torrey and Gray, from Ad. Jussieu.

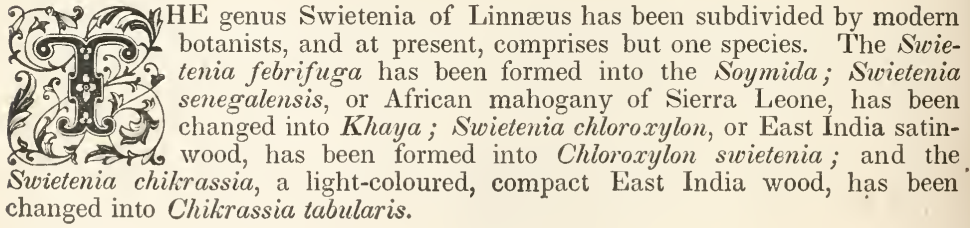




\section{Swietenia mahogoni, \\ THE MAHOGANY-TREE.}

\section{Swietenia mahogoni,}

Acajou, Mahagon,

Mahagonyholz, Mahagonybaum,

Albero di acajou,

Caoba,

Pao magno,

Mahogany-tree,

Synonymes.

Derivation. The specific name, mahogoni, is derived from the Arrowauk Indian name of this tree, which is variously written, as mahogony, mahagon, mahagony, and mahony.

Engravings. Catesby, Natural History of Carolina, pl. 81; Woodville and Hooker, Medical Botany, pl. 220; and the figures below.

Specific Characters. Leaves pinnate in 4 pairs. Leaflets ovate lanceolate, equal at the base. Panicles axillary.
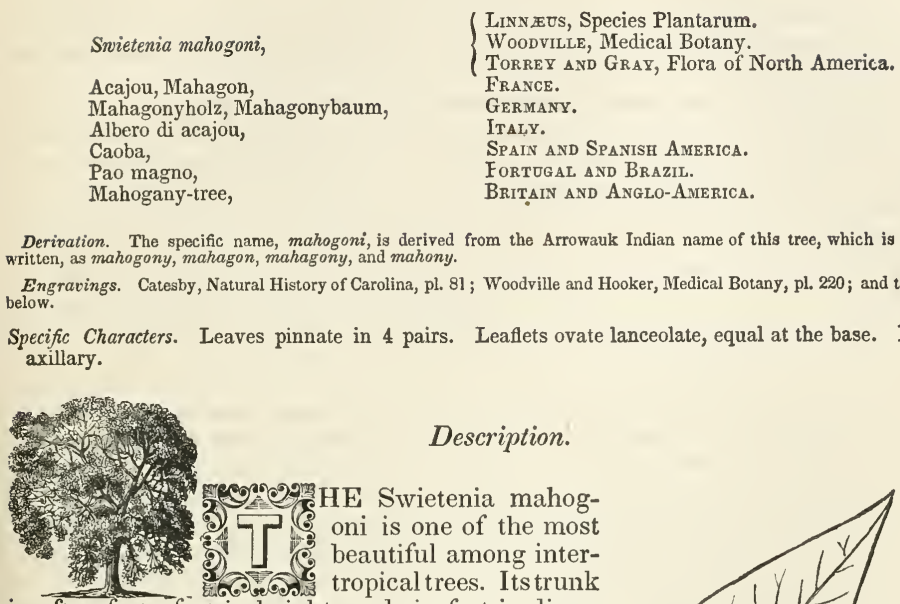

is often forty feet in height, and six feet in diam eter; and it divides into so many massy arms, and throws the shade of its glossy foliage over so great an extent of surface, that few more magnificent objects are to be met with in the vegetable world. Its summit is wide and spreading, subevergreen, and adorned with abruptly-pinnate, shining leaves. The flowers, which are produced in handsome spikes not unlike those of the lilac, are whitish, sometimes reddish or saffron colour, and are succeeded by fruit or capsules of an oval form, about the size of a turkey's egg. 'The fruit ripens in early summer, bursts into five parts,

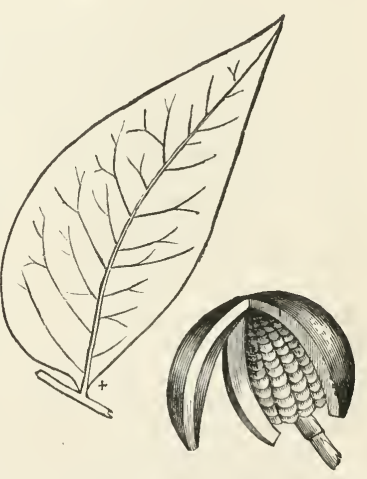
and discloses its winged seeds, which are soon after dispersed by the winds; some, falling into the crevices of rocks, strike root, then creeping out on the surface, seek other chinks or crevices, re-enter, and swell to such a size and strength, that at length, the rocks are forced asunder, to admit the deeper penetration of the roots, and in this manner, in process of time, increase to large trees.

Geography and History. The mahogany is a native of the warmest parts of America, and grows plentifully in Cuba, Jamaica, and Hayti or St. Domingo. There are also many trees found on other West India Islands, on the Bahamas, and in South Florida. It was formerly very abundant in Jamaica, but the best trees are mostly cut down in all accessible situations; and the same thing holds good in the other islands. The principal importations into Europe and the United States are made from Brazil, Campeachy, and Honduras. That which is brought from the islands is usually called Spanish mahogany, but it is not 
so large as that from Honduras and Brazil. The trees are seldom found in clusters or groups, but single, and often much dispersed.

The mahogany flourishes as well in India as in its native country. Dr. Roxburgh, in the "Transactions of the Society of Arts," at London, for 1806, states that two plants were sent from Jamaica, in 1795 , to the court of directors of the botanic garden at Calcutta, and that in 1804, about five hundred trees had been grown from them. And according to Mr. Royle, in his "Essay on the Productive Resources of India," published in 1840, this tree thrives so luxuriantly in Bengal, that many thousands of them are growing there, and even small pieces of furniture have already been made of the wood.

The excellency of the wood of mahogany, for all domestic purposes, has long been known. It was used by the Spaniards in the XVIth century, in the construction of ships, for which purpose it is better adapted than most other kinds of timber, being very durable, resisting gun shots, and admitting the balls without splintering; nor is it so liable to be attacked by marine insects as that of the oak, and hence is preferable for the construction of ships intended to sail in intertropical seas. It was used in repairing some of Sir Walter Raleigh's ships, at Trinidad, in 1597, but was not brought into use in Britain till 1724. According to Mr. Burrowes, the first use to which it was applied in England, was to make a box for holding candles. "Dr. Gibbons, an eminent physician in the beginning of the last century, had a brother, a West India captain, who brought over some planks of this wood as ballast. As the doctor was then building a house in King street, Covent Garden, his brother thought they might be useful to him; but the carpenters finding the wood too hard for their tools, they were laid aside as useless. Soon after, Mrs. Gibbons wanting a candle-box, the doctor called on Wollaston, his cabinet-maker, in Long Acre, and requested him to make one of some wood that lay in his garden. Wollaston also complained that it was too hard; the doctor said that he must get stronger tools; the candle-box at last was made, and so highly approved of, that the doctor insisted on having a bureau made of the same wood, which was accordingly done; and the fine colour, polish, etc., were so pleasing, that he invited all his friends to come and see it. Among them was the Duchess of Buckingham, who begged some of the wood of Dr. Gibbons, and employed Wollaston to make a similar bureau." From this introduction it came into general use throughout the civilized world.

The largest log of mahogany on record was cut in Honduras, and shipped to England. Its length was seventeen feet; breadth, fifty-seven inches; depth, sixty-four inches; cubic contents, four liundred and thirty feet; and weight, eight tons. The next largest log we have on record, was a few years since sold by anction, at the docks, in Liverpool. It was purchased for $\mathbf{\$} 378$, and afterwards sold for $£ 525$. It is believed to have realized, to its final owners, $£ 1000$. It is likewise stated that the cost of labour, in the process of sawing into veneers,

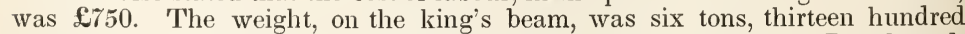
weight. According to Mr. M'Culloch, a few years ago, Messrs. Broadwood, the distinguished piano-forte manufacturers, in London, gave the enormous sum of $£ 3000$ for three logs of mahogany, all the product of a single tree! They were each about fifteen feet long, thirty-eight inches square, and contained, all together, about four hundred and fifty cubic feet. They were cut into veneers of an eighth of an inch in thickness. The wood was peculiarly beautiful, capable of receiving the highest polish, which, when done, reflected the light in the most varied manner, like the surface of a crystal; and from the wavy form of the fibres, offered a different figure in whatever direction it was viewed.

Season for Felling, \&॰c. The cutting of mahogany at Honduras takes place at two different seasons of the year, one soon after Christmas, or at the end of the "wet season," and the other early in August. At the last-named period the 
colour of the foliage of the mahogany is of a reddish-yellow, and is an unerring guide to the woodman in distinguishing it from that of other trees. At these periods the labourers are actively employed in felling the trees, conveying them on wheels to the rivers, or precipitating them into the streams which are to forward them to their places of shipment. The trees are usually cut about twelve feet above the ground, and a stage is erected for the axeman to stand upon to perform this work. 'The trunk of the tree, from its size, is deemed the most valuable; but for ornamental purposes, the branches or limbs are generally preferred, being of a much closer grain, and the veins are more rich and variegated. Hence, to avoid injury by the fall of the whole tree at once, they are removed separately. The wood felled between February and September is very liable to crack in seasoning; but to avoid this it should be immersed as soon as possible into deep water, and remain until it is ready to be shipped:

The billes or logs of mahogany which are shipped from Campeachy and Honduras are usually from ten to fifteen feet in length, and three, four, or five feet deep; those from St. Domingo are from seven to ten feet long, and fifteen to twenty-five inches deep; and those from Cuba are from twelve to eighteen feet long, and the same number of inches deep.

To test the soundness of mahogany, closely examine the ends of the logs by cutting into them with an axe, or some other instrument, and if there be any signs of decay, it will at once be detected. The following mode has also been resorted to with success. Let one individual place his ear close to the end of the log to be examined, and another person slightly touch the opposite end with the point of a pin or needle. If the wood be sound, the touch of the needle will be distinctly heard by the person with his ear at the log, while the individual at the opposite end, who performs with the needle, may not hear it. If the wood be in a state of decay, the touch of the needle will not be heard.

Properties, Uses, $\&^{\circ} c$. The wood of the mahogany-tree varies in its weight, texture, and grain, according to the nature of the soil and situation in which it grows. On rocky and mountainous places it is of a smaller size, heavy, of a close grain, and beautifully shaded; while the product of low and rich lands is observed to be more light and porous, of a paler colour and open grain ; and that of mixed soils holds a medium between the two. The mahogany which is accessible in Honduras grows upon moist land, and is, generally speaking, decidedly inferior to that of Cuba and St. Domingo, being soft, coarse, spongy, and weighing, when dry, only thirty-five to forty pounds to a cubic foot, while the other is hard, close-grained, of a darker colour, sometimes strongly figured, and weighs, when dry, from fifty-four to sixty-six pounds to a cubic foot. Honduras mahogany has, however, the advantage of holding glue admirably well, and for this reason is frequently used as a ground on which to lay veneers of finer woods. The trees which are grown on the Bahama Islands are not so large as those of the warmer parts of America, but are more curiously veined, or mottled, and are known in England by the name of Madeira-wood.

The colour of mahogany is a reddish-brown, of different shades, and various degrees of brightness; sometimes yellowish-brown, often much veined and mottled with darker shades of the same colour. The texture is not uniform, and the concentric layers are not always distinct. It has not much taste nor smell, shrinks but a very little, and warps and twists less, perhaps, than any other kind of timber. It is durable, when kept dry, but does not last long when exposed to the alternations of moisture and dryness. There are several varieties of mahogany, much admired, and sought after, for the beauty of their figures, and the gradations of their colours, which may be described as follows :-

1. Plain Mahogany. Acajou uni of the French, the wood of which is of one colour, and equal throughout. 
2. Veiny Mahogany. Acajou veiné, French. The wood of this variety is veined longitudinally with the grain, displaying alternately dark and light streaks, continuous, interrupted, or re-appearing.

3. Watered Mahogany. Acajou moiré, French. This variety is known by the transverse waves which exhibit to the eye an effect similar to those of a watered riband.

4. Velvet-cord or Caterpillar Mahogany. Acajou chenillé, French. This variety is distinguished by its whitish lines, accompanied by a figured shade of fragments of roseate sprigs, here and there disposed diagonally, longitudinally, interrupted, or crossing one another.

5. Bird's-eye Mahogany. Acajou moucheté, French. This variety is besprinkled with little oval knots, which, when duly proportioned, render the wood half light and half dark.

6. Festooned Mahogany. Acajou ronceux, French. This variety offers in its colour a mixture of light and shade usually resembling sheaves of wheat, feathers, wreathes, festoons, or figures of shrubs.

As the wood of mahogany is generally hard and takes a fine polish, it is found to serve better than that of any other tree for cabinet-making, for which purpose it is universally admired. It is very strong, and answers well for beams, joists, planks, boards, and shingles, for which it was formerly much used in Jamaica. Its adaptation to ship-building we have already mentioned in the history of this tree.

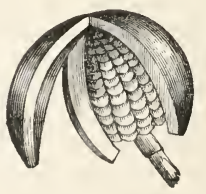




\section{Genus VITIS, Linn.}

Vitaceæ.

Syst. Nat.
Pentandria Monogynia. Syst. Lin.

Synonymes.

Vitis, Cissus, Ampelopsis,

Vigne,

Weinstock, Rebe,

Vite,

Vid,

Fidêira,

Ninograd,

Enæb,

Grape-vine,
OF Authors.

France.

Germanx.

ITALY.

Spain.

Portugal.

Russia.

Arabia.

Britain and ANglo-America.

Derivatıns. The Latin word Vitis, from which are derived nearly all the European names, comes from the Celtic guya, a tree or shrub; the letter $g$ being suppressed in the pronunciation, according to the usage of tine Celtic nations. Cissus, the Greek name of the ivy, was applied to this genus by Linnæus, from the supposed resemblance of some of the species to that plant. Ampelopsis is derived from the Greek ampelos, a vine, and opsis, appearance, and was applied by Michaux to several species of American grape-vines, from the resemblance of their habits, leaves, and flowers to those of the Virginiar creeper (Ampelopsis quinquefolia.)

Generic Characters. Flowers hermaphrodite, diœcious or triœcious. Calyx commonly 5-toothed. Petals 5 , cohering at the top, separating at the base, and deciduous. Stamens 5 . Climbing shrubs, deciduous, with leaves simple, lobed, or serrated, sometimes compound, and small greenish-yellow flowers in thyrsoid racemes. - De Candolle, Prodromus.

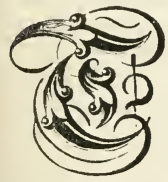

$\mathrm{HE}$ genus Vitis is found indigenous in the equinoctial regions of both continents, and extends into the temperate zones as far southward as the Cape of Good Hope and New Holland; and northward, to Japan and North America, as well as from the plains of India to the defiles of Caucasus. The Vitis vinifera or wine-bearing vine of Europe, has long been celebrated in the old world, and may be traced back to remote antiquity. Its cultivation was probably among the earliest efforts of human industry; for we read that one of the first acts of Noah, after being saved from the deluge, was to plant a vineyard.

\footnotetext{
"And Noah began to be an husbandman, and he planted a vineyard;" GENEsis, ix. 20.
}

thus plainly indicating that the planting of a vineyard, even at that early day, was deemed one of the primary and most important acts of him who tilled the earth. The grape, among fruits, is what wheat is among the cereal grains, or the potato among farinaceous roots; and like them, in every country where it will grow, is cultivated with pre-eminent care.

The Vitis vinifera is generally considered to have originated in Persia; and Dr. Sickler, in his "Geschichte der Obst-Cultur," has given an interesting account of its migration to Egypt, Greece, and Sicily. From the latter country, which is regarded as one of the oldest seats of civilization in Europe, it is said to have found its way into Italy, Spain, and France. It is supposed to have been introduced into Britain by the Romans, but Juring what reign is uncertain. There were vineyards, however, in England, according to the venerable Bede, towards the close of the IIId century. This species has existed for ages, in a wild state, in the woods and hedges of Provence, Lal guedoc, and Guienne, in France, where it differs from the cultivated vine, in häving smaller and more cottony leaves, and very small fruit, rather austere than sweet. These wild vines, which were called by the ancients labrusca, are still known in the south 
of France by the names of lambrusca and lambresquiero. The wine-bearing grape is successfully cultivated in France as far north as latitude forty-nine degrees; but in Britain it seldom arrives at maturity unless protected, when grown in the open air. The most northern limit in Prussia where it can ripen, is at Königsberg, in latitude fifty-four degrees and forty-two minutes; and even at Berlin, more than two degrees farther south, the fruit is very poor. It is also successfully cultivated in Hindoostan, along the borders of the Euphrates, in Syria, Lower Egypt, Abyssinia, Barbary, the Azores, Madeiras, Canaries, and Sandwich Islands. In South America, it is cultivated at Buenos Ayres, and various parts of Brazil, Guayaquil, Pisco, northern Chili, Valparaiso, and Valdivia, in latitude forty degrees south. In North America, it perfects its fruit, in the open air, in Jamaica, Cuba, Mexico, the United States, as far north as New York, in latitude forty degrees and forty-two minutes, and at San Francisco, on the north-west coast, in latitude thirty-eight degrees north. In comparing the climates of the above-named places, it will be seen that the successful culture of the grape does not so much depend upon mean annual temperature, as upon the parallels of latitude under which they lie. For instance, the fruit will not arrive at maturity in the latitude of Edinburgh or Copenhagen, where the mean annual temperature is somewhat higher than at New York, although the latter place is situated more than fifteen degrees farther south. This is owing almost entirely to the increased length of summer, in low latitudes, which arises from the fact that, although the heats of June and July may be as great in higher latitudes, they are several degrees lower in August and September, than in places situated nearer the equator. Nor does elevation above the level of the ocean retard the maturation of the grape like an increased degree of latitude, for the summers are equally long at high altitudes, as in low places situated under the same parallels. In central Germany, the vine is cultivated at an elevation of one thousand to fifteen hundred feet above the sea; on the south side of the Alps, at two thousand feet; on the Apennines and Sicily, five thousand feet; and on the Himalayas, at an elevation of ten thousand feet.

The history of the vine, as a fruit-bearing shrub, and all that relates to its varieties, have been described at length, by Du Hamel, of France, Dr. Sickler, of Germany, and Don Roxas de Clemente y Rubio, librarian to the royal botanic garden at Madrid, in Spain.

Of the North American species and varieties, more than one hundred have already been described, and from the proneness of this genus to change from original differences, through the effects of soil, climate, and hibridization, many more will doubtless be found to exist. As varieties without end may be propagated from seeds, it has been recommended to sow those of some of our native grapes of several successive generations, in order to produce fruit of a better and a milder quality. A seedling vine of the wine-bearing species of Europe, carefully treated, will show blossoms in its fourth or fifth year; and if it would produce perfect fruit the next year after flowering, a new generation might be obtained every sixth year. 
Vitis labrusca,

\title{
THE AMERICAN WILD VINE.
}

\author{
Synonymes. \\ Vitis labrusca, \\ (Linn五us, Species Plantarum. \\ Miснаux, Flora Boreali-Americana. \\ $\{$ De Candolle, Prodromus. \\ Loudon, Arboretum Britannicum. \\ Torrey and Gray, Flora of North America. \\ Vigne cotonneuse, Vigne sauvage de \\ l'Amerique, \\ Filziger Weinstock, Baumartige Rebe, \\ Vite lambrusca, Uva labrusca, \\ Wild Vine, Grape-vine, Fox Grape, \\ Shominawtig, \\ France. \\ Germany. \\ ITALY. \\ Britain and Anglo-America. \\ Ojibway Indians.
}

Derivations. The specific name labrusca, according to Loudon, is derived from the Hebrew busca, a grape, and was applicd to this species by Linnæus, from a supposed resemblance which it bore to the wild vine of Europe; hence the Italian names. The French and German appellations have reference to the down on the under side of the leaves. It is called Fox Grape, (or rather Northern Fox Grape, in contradistinction to the Fox Grape of the southem states, or the Vitis vulpina of Linnæus,) because the whole plant has sometimes a disagreeable, foxy smell. The Indian name is derived from shomin, a grape, and atotig, a tree.

Engravings. Plumier, Description des Plantes de l'Amerique, t. 259, figure 1; Hoffy, Orchardist's Companion, ii., pl. Loudon, Arboretum Britannicum, i., figure 141 ; and the figure below.

Specific Characters. Sexes diœcious or polygamous. Leaves heart-shaped, rather 3-lobed, acutely toothed, downy beneath, with the peduncles tomentose and rather rusty.-De Candolle, Prodromus.

\section{Description.}

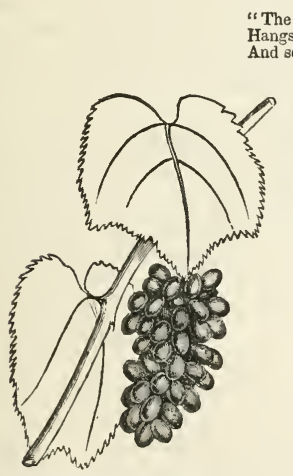

"The vine too, her curling tendrils shoots,

Hangs out her clusters glowing to the south,

And scarcely wishes for a warmer sky." pound racemes, with short, umbelliferous branches. The berries, which usually arrive at maturity in October, are half an inch or more in diameter, globose or oblong, and are generally of a dark purple, when ripe, and of a pleasant flavour, particularly when cultivated; but in some varieties, they are of an amber-colour, or greenish-white, of a strong, musky taste in a wild state, and are filled with a tough pulp. A peculiarity exists with regard to several varieties of this species, of producing a second crop of fruit on the shoots of the same year; but it seldom arrives at maturity except in a warm season, with late autumnal frosts.

Varieties. Several attempts have been made to classify the varieties of this species, but not with much success. In most cases, the form and colour of the 
fruit alone have been considered, and in others, the shape and clothing of the leaves; but as it will be impossible for us to enter into all of these considerations, we shall only treat of a few of those that have successfully been brought under cultivation, which are as follows:-

1. V. L. ISAbella, Prince. Isabella Grape-vine. This variety is distinguished by its large, dark-purple fruit, of an oval form, and of a juicy, musky flavour. It possesses great vigour of growth, is a healthy and abundant bearer of fruit, and what renders it exceedingly valuable in our climate is, that it requires but little protection during winter. Concerning its origin and history, we are indebted to General Joseph Swift, of Geneva, in New York, for the following account, which we trust will be no less acceptable in coming from so respectable a source, than in the interest elicited in so valuable a production. It appears that General Smith, of Smithville, North Carolina, in 1808, procured from Dorchester, South Carolina, several roots and cuttings of a hybrid vine, which, it is said, had been originated there by some families of Huguenots, between the Burgundy grape of Europe, and the native fox grape of that vicinity. In the year 1817 , a vine produced from these cuttings, was transplanted from Smithville, by Mrs. Isabella Gibbs, in honour of whom this variety was named, to the garden then owned by her husband, Colonel George Gibbs, which was situated along the southerly side of Cranberry, between Willow and Columbia streets, in Brooklyn, New York. In 1819, the garden was purchased by General Swift, who very generously distributed roots and cuttings of this vine among his neighbours and others, more especially to the late William Prince, of Flushing, Long Island, through whose efforts it became widely disseminated throughout the union, and was sent to several countries in Europe, Madeira, \&c. The garden has since been divided into lots, and occupied by buildings, and the original Isabella vine, after attaining a circumference of more than a foot, was severed to the ground in 1838. Fortunately, however, several vigorous vines have since sprung up from the roots, which continue to bear fruit in abundance. From other statements, it would seem that this variety is not a hybrid, but was known in this country prior to 1800 .

2. V. L. Bacols albis, Loudon. Bland's Pale-red Grape, Bland's Fox Grope, Bland's Virginia Grape, Red Skuppernong Grape, Carolina Grape, Mazzei Grape. This variety may be known by its pale-green leaves, lengthened clusters, with large berries, of a roundish or oblate form, pale-red colour, and sweet, juicy pulp, of a pleasant flavour; in some cases, however, at full maturity, the fruit is said to acquire a dark-purple or red-wine colour. It is more esteemed by some, as a table fruit, than that of the Isabella, having a thinner skin, and containing a pulp of less consistency. It was deemed for some time, as unsuitable for our northern climate; but it has been found to succeed in maturing its fruit in most seasons, in the neighborhood of New York, and may successfully be cultivated as a wall fruit in a much higher latitude, both in Europe and America. It has been contended that this variety was brought from Italy by Mazzei; but it is well known that it was cultivated by Colonel Bland, of Virginia, long before that gentleman visited this country. The original vine is said to have been found on the eastern shore of Maryland, by Mr. Bland, who presented cuttings of it to the late William Bartram and Samuel Powel, of Philadelphia, and some of the persons who received slips of it from the latter gentleman, gave it the cognomen of Powel Grape.

3. V. L. catanbiensis. Catawba Grape-vine. The fruit of this variety occurs in loose bunches, of an inconsiderable size, and of a beautiful appearance. The berries are large, and much varied in their flavour and colour, according to their exposure to the rays of the sun. Those which receive the full effect of the sim, are of a bluish-purple, and a slight musky flavour, but when partially exposed, 
they are of a lilac hue; and those which grow entirely in the shade, are of a translucent white, sweet, and devoid of musk in their taste. The fruit is earlier in ripening than that of the preceding variety, and when allowed to remain on the vine until perfectly mature, the pulp nearly disappears. It is esteemed as a table grape, and has also been manufactured into an excellent wine. The original vine is said to have been procured from the banks of the Catawba, and planted in the garden of the late Mr. Schell, at Clarksburg, in Maryland, and has been known to bear nearly eight bushels of fruit in a single season

4. V. L. elsinburgensis, Prince. Elsanborough Grape-vine. This variety is noted for its sweet, juicy fruit, which is free from pulp, and musky taste. The clusters are of a medium size, with loose berries of a blue colour, which are said to make an agreeable wine. Its foliage is of a pale-green, and resembles that of the wine-bearing grape of Europe, more, perhaps, than that of any other American variety. It somewhat resembles the Isabella, in its bark and wood, but its fruit is thought to assimilate more nearly to that of the Meunier, of France. The original vine was found and brought under cultivation by Dr. Hulings, in Elsanborough, in New Jersey, where, undoubtedly, it was indigenous.

Geography and History. The Vitis labrusca is found in sheltered situations in woods and thickets, and sometimes near the margins of waters, from Canada to Florida, Louisiana, and 'Texas. It was introduced into Britain in 1656, by John Tradescant, jun.; but it can only be considered, in that country, as an ornamental shrub. A plant, however, of the red-fruited variety, placed against a wall with a western aspect, in the garden of the London Horticultural Society, is said to ripen fruit every year, of an agreeable flavour. There are several varieties of this species cultivated in North America, the most celebrated and extensive of which, is the Vitis labrusca isabella. As this variety is preferred, in the middle and northern parts of the United States to all others, principally on account of the quality and abundance of its fruit, its hardihood, and the facility with which it is propagated, we shall chiefly confine our remarks to its culture, rather than to those of a less hardy nature. We would not by any means discourage the propagation and amelioration of the other varieties, whereever the soil and climate are favourable to their growth and maturity; but on the contrary, we would recommend a successive reproduction from seeds, by grafting, or inoculation, and if possible, by hibridization; and doubtless many valuable varieties would be the result.

The manufacture of wine from the American wild grape has long been a subject of contemplation, and many unsuccessful attempts were made by the early settlers of the colonies; but the want of success was not so much owing to the qualities of the fruit, as in the requisite skill and care in making the wine. It appears, however, by Holmes' "Annals," that, in the year 1769, the French planters on the Illinois River, made upwards of one hundred hogsheads of strong wine from the wild grapes of that country. Frequent mention is also made in Dodsley's "London Annual Register," of wine being manufactured, in small quantities, from the American grape, and in some instances, of a rich and agreeable flavour. More recently, the Swiss and German settlers of the west. especially in the valley of the Ohio, have turned their attention to this branch of industry, and their labours have been crowned with considerable success. Mr. Nicolas Longworth, of Cincinnati, Ohio, in a communication, published in the "American Agriculturist," in December, 1842, says, "I have thirteen vineyards, and more under way. The greatest yield is at the vineyard managed by Mr. Mottier, who is well known as an intelligent, enterprising vinedresser. He made within a fraction of fifteen hundred gallons. A part of the vineyard that did not suffer by rot, yielded six hundred gallons to the acre. The next vineyard in its yield, is under the charge of Mr. Myers, an intelligent 
German, of much experience in the enlsivation of the vine. There were some vincyats in the conntry that produced a more abundant erop, on the same

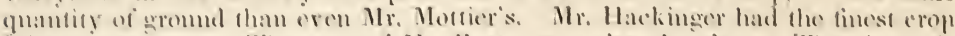

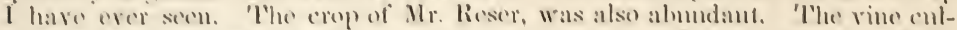

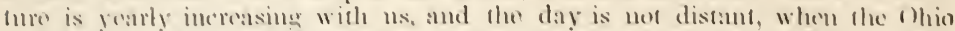

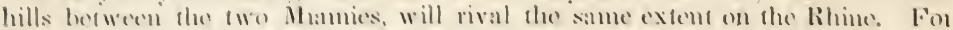
this, we shall be chiegly indebed fo om Geman imigrants: and they are grati-

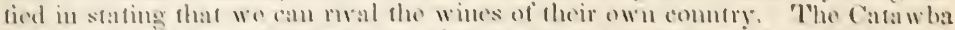

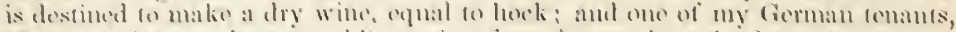

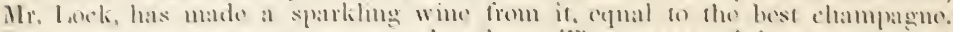

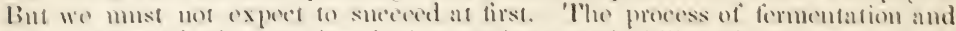

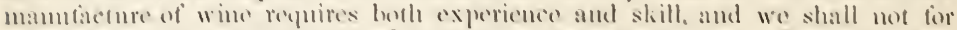

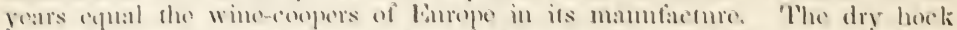

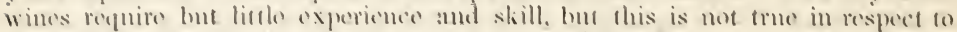
many of the thest wmes." The cultivation of the vine has also become an

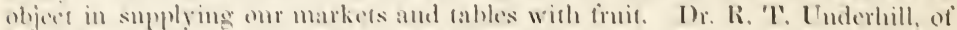
New Lork, informs ns that he has mearly fwenty ateres of vines, at croton Point, on the Hndsom, ehiefly of the lsathella and catawba variefies, from which

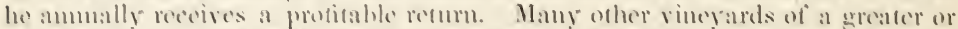

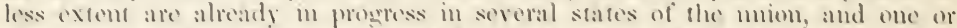
more vines are thonghi w be an almost indispensable appendage to erery garden sund homso-lot in the combery.

Noil and Nifmotion. 'The lsaluella grape-vine dlomrishes best in a soil that is

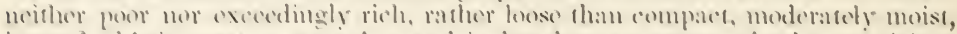

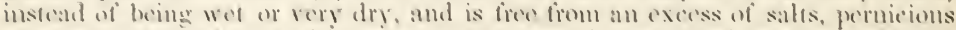

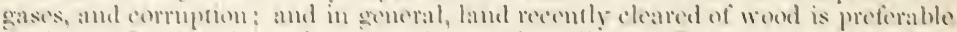
6) that which has bern ber some rime moder tillige. 'The simatron should be chosen on moderately rising gromed rather than on that which is plan or

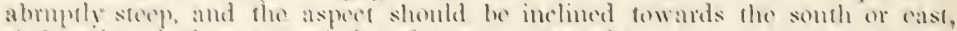

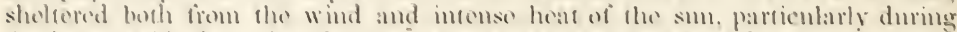
the latere half of the day. bue mot so much so as to impede a tiec cirentation of sir. The chimate shonlit be rather dry tham mess, and warm instead of heing

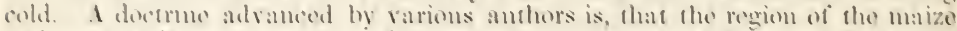

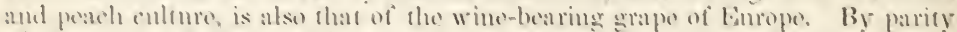
of wetson, the lsabellat, and sereral wher vatrefies, which are equally or more

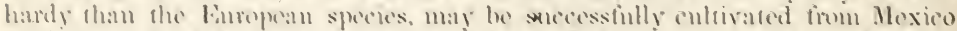

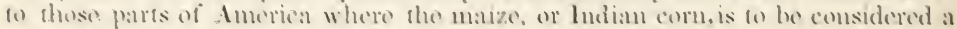

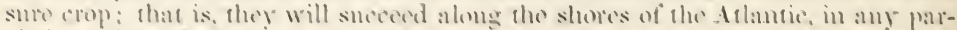

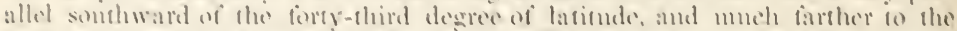
morthward, west of the lioky Momentims. The lsabella will atso ofeon prosper moder cormmstames considerably al variance with any of those above stafed,

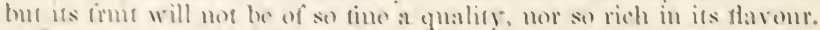

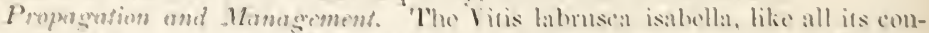

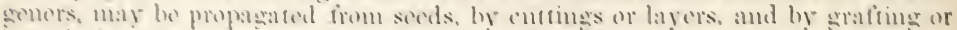

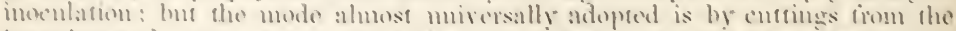

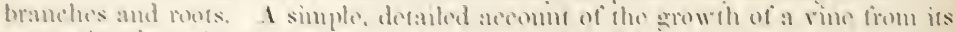

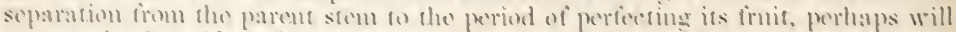

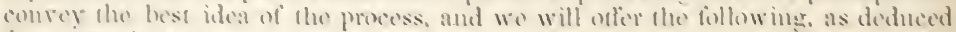
from ixpreiches:-

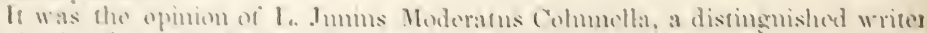

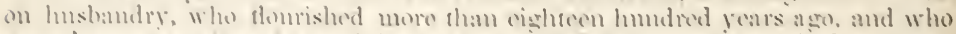

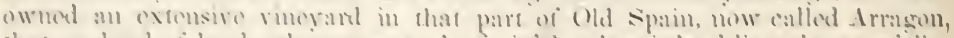

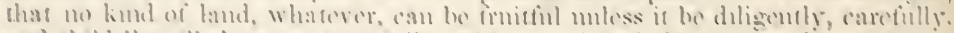

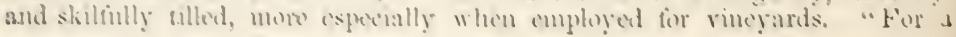


vine," said he, "is a delicate, tender, and weak thing, and can by no means bear with hard usage; and, for the most part, it is consumed by too much labour, and bearing too great a quantity of fruit; and, if you do not restrain it within due bounds, it perishes by its own fruitfulness. But when it has, in some measure, strengthened and hardened itself, and attained, as it were, to the vigour of youth, it may prosper under neglect. But a young vineyard, while it is growing up, unless it receives due care and attention, will be reduced to the poorest and most starving condition, and will pine and waste away, in stch a manner, that it can never afterwards, by any experience whatsoever, be recovered and restored. 'Therefore, the foundations, as it were, must be laid with the greatest care, and from the first day of planting, it must be managed like infants, with unceasing attention, which, unless we do, all our expenses will be laid out to no purpose; nor can the proper season of anything be recalled, when once we let it pass." First, then, let us select a proper site of ground, and proceed at once, and trench it to the full depth required. If it be situated on a plain, or in a valley, it shonld be dug two feet in depth, and on rising ground three; but on a hill-side, somewhat steeper, it should be turned up at least four feet, in order that the roots may penetrate beyond the reach of drought. If the cuttings are intended to be planted in drills or rows, let there be formed trenches three feet in length, two feet in depth, and the width of a spade, leaving intervals or baulks, a yard in length, between the trenches, till the row is finished. Then, with good virgin soil, if it be at hand, if not, let it be procured from the woods, let us fill the trenclies therewith, mixing it at the same time with a due proportion of leaf-mould or well-rotted manure, or what is still better, the leaves and husks of vines, or grape-seeds, $*$ in order to quicken and strengthen the growth of the plants. If a vineyard be the object which we have in view, let the rows or drills be trenched from five to ten feet asunder, according to the surface of the ground and the latitude of the place. If the situation be on a plain, in a high degree of latitude, the rows should be eight or ten feet apart; but if it be on the side of a very steep hill, or in a low degree of latitude, five feet will be sufficient; and on moderately inclined surfaces, or in higher latitudes, six or eight feet apart will be all that is required. With regard to the direction of the

* This method of manuring vines was known and practised by the Carthaginians long before they were conquered by the Romans. One Mago, reputed among the classical ancients for the princely employment of delivering precepts concerning the tilling of the earth, who flourished more than two hundred years B. C., and wrote twenty-eight books on husbandry, proved that the husks of grapes and grapeseeds, mixed with dung, and put into the trenches with the vine-plants, quickened their growth, strengthened the stems, and drew forth new roots. This idea accords precisely with the most enlightened principles of modern chemistry and vegetable economy. It shows that a vineyard may be made to maintain perfect fruitfulness without the application of any manure, except the leaves and branches that are pruned from the vines. Indeed, an instance is recorded, where a man, in Germany, had a vineyard which he manured by no other means, and kept it in a thriving condition for thirty years. His mode of applying the vine-leaves and branches, was to hoe them into the soil after having cut them into small pieces. During this long period, no carbon was conveyed to the soil nor to the vines themselves, except that contained in their pruned branches, the rains, dews, and in the atmosphere, so that the vines were placed in exactly the same condition as trees in a forest, which receive no manure except from their decayed branches and leaves. Under ordinary circumstances, a manure containing potash must be used, otherwise the fertility of the soil will decrease. From this it follows, that in nature every vegetable produces its own pabulum or support, and that the earth only serves to bear the plant, and not to aid or nourish it in vegetation. The food of plants is thus supposed to be derived from air and water, heat and light, or electricity in different proportions, adapted to the various productions of the vegetable world. This doctrine may further be corroborated by an instance which occurred in France in 1840. Messrs. Poillard and Bernard, who date their letter at Brest, assert that they succeeded in raising perfect wheat upon a pane of glass covered with straw. They state that there was not the smallest particle of earth upon the glass, and that the plants were left entirely to themselves, without being watered or attended to in any way whatever, from the time of sowing to the time of reaping. And we can aver that we have seen fields of sugar-cane, in the island of Cuba, which have produced abundant crops from the same roots, for nearly a quarter of a century, without any manure, except the tops and leaves of the cane that have been left on the ground, and worked into the soil by the hoe. 
rows, and the height to which the vines should be trained, they may run in a manner that will allow them to face any point of the horizon between south and east; and they may be supported on props, or trellises, from six to ten feet in height, and even more, according to the vigour of the vines. But in cities, and about houses in the country, single vines may be trained on the sides and ends of buildings, along the sides of fences, or on the trunks and branches of trees.

The most favourable season for planting the Isabella grape-vine in the United States, is when the red-flowered maple is in bloom, which usually occurs in Georgia from the 20th to the last of February, and five or six weeks later near Philadelphia and New York. In selecting the cuttings for a vineyard, they should be of one variety, and taken from the most fruitful part of the vine. Let us not content ourselves with single clusters, but those which are the most prolific. The greatest proportion of fruit grows from the buds on the last year's shoots next to the old wood, with the exception of the nearest eye, the top buds being unfruitful and seldom bearing at all. Some prefer to plant cuttings containing a considerable portion of the old wood; but, as it is not always prudent nor economical to mutilate a favourite vine too much, it is best to select fruitful cuttings of the last year's growth, with the wood well ripened. They should be of a moderate size, short-jointed, and containing from six to eight eyes or buds in each. They should be cut off, transversely from the vine, with a sharp knife, close to the old wood, and not less than two inches of blank wood should be left for the protection of the terminal buds. The ends of the cuttings that are to remain above the ground should be cut in an oblique direction, and the sloping side should be opposite the side containing the uppermost bud. If possible, they should be planted in calm weather, immediately after separation from the parent vine, and be obtained from a soil, situation, and climate, similar to those in which they are intended to grow; but if any difference in these respects should unavoidably occur, it will be better to transplant from a poorer to a richer, and from a dryer to moister soil, as also from a colder to a warmer climate. But should it be necessary to convey the cuttings from a distance, their lower ends should be immersed in a composition of fine earth, well mixed with linseed or other oil, of about the consistence of tar, as soon as they are cut off from the parent stock, at the same time, taking the precaution not to cut off the top ends till the moment they are to be used.

\section{MANAGEMENT DURING THE FIRST YEAR.}

The ground having been prepared in the manner above described, the cuttings are next to be planted in the centres of the trenches, so that each terminal bud will be even with the surface, and directed towards the south. Then the earth must be firmly pressed round each plant, and should it subsequently settle and leave more than one bud above the ground, more earth or mould must be added to bury them up.

As soon as the season becomes hot and dry, it will be necessary to protect the cuttings from the mid-day sun, by means of matting or other materials, which should be removed towards evening, and allow them to remain uncovered until the next morning, at about the time of the disappearance of the dew. Strict attention must now be observed in keeping the soil around the cuttings continually moist, and should not this be effected by natural means, it must be done by sprinkling rain or river water over them, or what is still better, soap-suds, or other stimulating fluids, specially prepared for the purpose, but not too strong. Soon after the cuttings begin to take root, which may be known by the swelling of the buds, above the surface, young shoots will gradually protrude, and the plants will require but little attention during the remainder of the 
season, except an occasional hoeing, to destroy the weeds, and to loosen the soil in order to admit the air and moisture about the roots. Should the season prove dry, however, and the earth around the plants become parched, it will be necessary to irrigate them frequently with rain or river water, or with prepared liquids as suggested above. Early in autumn, rub off all the buds from each plant, except two, which are to be reserved for training the ensuing year.

The method of managing the vine from the first to the sixth year, as practised by Mr. B. E. Valentine, of Philadelphia, and published in Hoffy's "Orchardist's Companion," for 1841, is the same as that recommended by Clement Hoare, a highly esteemed writer on the cultivation of the vine, and whose mode, with a slight variation for climate or seasons, is believed to be best adapted for this species of culture of any practised in the United States. "On the first of December, or as long as the weather remains open," says he, "the soil round the roots should not be covered over; but, as soon as frost comes, a good covering of litter, or well-rotted manure must be laid over the ground, as far as the roots extend; and if the weather be very severe, it will be better also to cover over the stem to the depth of five or six inches above the top of it. 'The young plant being thus well protected from the severity of the winter, may remain in this state till the first of March.

SECOND YEAR.

March 1st. Remove the covering, and fork up the surface of the ground, to the depth of two or three inches, that the sun and air may freely penetrate it. A pril 1st. Keep the soil round the roots free from weeds, and the surface of it loose, either by raking or forking it up as often as necessary. May 1st. Now remember that only a single shoot is permanently to be trained throughout the summer; the object of leaving two buds the previous autumn, being to provide against the loss of a shoot in case of any accident. As soon, therefore, as the strongest has grown sufficiently to be out of danger of being accidentally rubbed off, the other is to be cut out, as hereafter directed. If any other shoots have pushed besides the two principal ones, rub them all off. As soon as the shoots have grown about a foot in length, nail them to the wall or fence, as the case may be. Do this very carefully, for they are as yet extremely tender. When they have grown about six inches from the last nailing, they must again be nailed, and continually kept so, never suffering the tops of the shoots to be blown about by the wind. As the tendrils and lateral shoots successively appear throughout the summer, pinch off the former when they have grown about three inches in length, and the latter to an inch beyond the first eye. June 1st. Throughout this month, and the two following ones, whenever the ground appears parched through by the heat of the weather, give the roots, once a day, about half a gallon of soap-suds, or dung-water. Keep the ground free from weeds, and the surface loose and open, by raking or forking it up once a week throughout the summer. July 1st. The young shoots being firmly united to the preceding year's wood, and therefore past all danger of being broken off by any accident, unnail the weakest shoot of the two, and cut it out close to the stem, making the surface of the wound quite smooth and even. The remaining shoot must be kept nailed to the wall as before directed. November 1st. Cut the vine to the two lowermost buds, and in the winter, if the weather be frosty, cover the ground nver in the same manner as in the preceding winter.

THIRD YEAR.

March 1st. The winter covering mav now be removed, (provided there should 
be no hard frost,) and the surface of the ground must be made quite mellow by using lightly a garden fork or trowel, observing great care to avoid disturbing the roots, as they will now be found very near the surface. Let the subsequent treatment throughout the season be precisely the same as in the preceding sum. mer. If any fruit be shown, pinch it off as soon as it appears. November 1st. It is presumed the stem of the vine will now be more than two inches in girth, and therefore two leading shoots are to be permanently retained the next year. For this purpose, cut the vine down now to the three lowermost buds, thus reserving one to spare, in case of accident. The vine will then resemble the adjoining figure. The roots being now sufficiently strong to withstand the severity of the weather, will not in future require covering.

\section{FOURTH YEAR.}

March 1st. Clean the surface of the ground, and fork it up lightly, and let the subsequent management throughout the season be the same as before. May 1st. As soon as the shoots have grown a sufficient length, nail or tie them carefully to the wall or trellis, and rub off all the others, if any should have pushed. If fruit be shown, pinch it off as in the preceding year. July 1st. Unnail and cut out the weakest of the three shoots, and train the two remaining ones carefully during the remainder of the season. September 1st. Pinch off the tops of the shoots. November 1st. As the girth of the stem will not be less now than three inches, the vine may be permitted to mature fruit the next year, not exceeding five pounds weight; for this purpose, cut down the two shoots to the seven lowermost buds each. Prune away the remaining portion of the tendrils and dead wood close to the shoots; and cut out carefully all the lateral shoots close to the base of the buds, whence they have sprung. If the outer bark of the stem be decayed, rub it off clean; and then nail or tie the shoots to the wall or trellis in a temporary manner.

\section{FIFTH YEAR.}

February 1st. As soon after this time as the weather is open, cut out of each shoot the first, second, fourth, fifth, and sixth buds; then bend the two shoots carefully down, and secure them in a horizontal position, similar to that represented by the shoots in the adjoining figure. March 1st. Clean the surface of the ground, and fork it up as in the preceding year. May 1st. Train the shoots that push from the buds 3 and 7 , in the manner represented by the dotted lines $1,2,3,4$, and if more fruit shows than is equivalent to the weight before mentioned the excess must be cut off when the berries are set. July 15 th. Continue the same course of management as in the preceding year, and when the roots require watering, they are now sufficiently strong to have applied to them for that purpose any description of liquid manure that can be most conveniently obtained. September 1st. Pinch off the tops of the shoots, and the sap will then accumulate in the buds." Here we will leave our author, and pursue a somewhat different treatment. Early in October, or soon after the fruit is gathered, let the shoots numbered 1 and 4 , he. 
ut back to as many buds as may be deemed necessary to produce the quantity f fruit which the vine can mature the next year, and let those marked 2 and 3 , e cut back to the three lowermost buds. The lateral shoots, as also the stumps f the tendrils, should be cut out as directed in the preceding year. Let the oose and decayed bark be rubbed or scraped off, and the shoots fastened to the vall or trellis, to protect them during the winter.

\section{SIXTH YEAR.}

Vommence early in March, and treat the ground in every respect, during the eason, as in the preceding year, taking care to. incorporate all the leaves or clipings of the vines with the earth about the roots. Early in May, or as soon as he shoots numbered 2 and 3 , have grown a sufficient length, fasten them careully to the wall or trellis, and let them grow until the first of July. Then cut ut the weakest of the three young shoots, and treat the two remaining ones (as ndicated in the adjoining igure) precisely as those lumbered 1 and 4 were the rear preceding, due care eing observed to deprive ll the shoots of any superinous fruit or leaves which nay put forth. In October, oon after the fruit is gathred from the shoots numered 1 and 4 , cut them lown to the three lowernost buds, thus reserving ne to spare in case of acident, in order to produce louble shoots the following jear. No further treatnent will be required than ubbing or scraping off all oose and decayed bark rom the vines, until the lext spring.

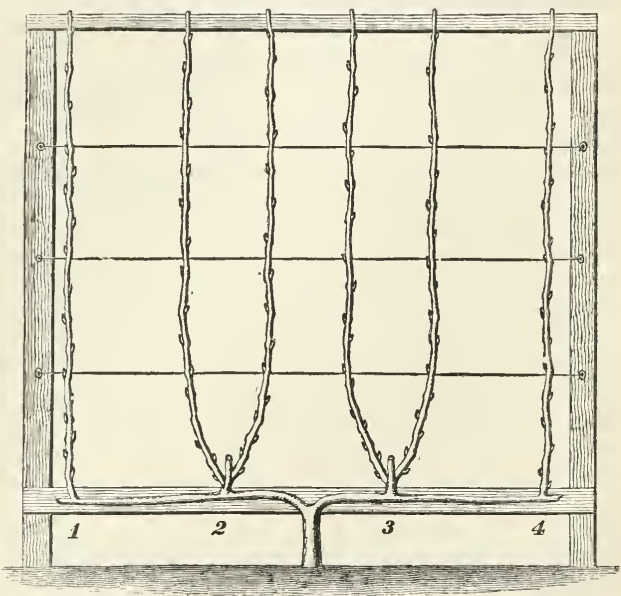

SEVENTH YEAR AND SUBSEQUENT TREATMENT.

Zommence early in the month of March, and treat the ground throughout the ieason as directed for the preceding year. Early in May, or as soon as the hoots numbered 1 and 4 have attained a sufficient length, carefully fasten them o the wall or trellis, and let them grow until the first of July. Then cut out he weakest of the three young shoots, and treat the two remaining ones (indieated by 1 and 4 in the annexed figure) in every respect as those numbered 2 and 3 were the year before. By the end of the seventh year, if the plant belongs in a vineyard, in which the vines are grown at the distance of six feet apart, it will have acquired a sufficient number of leading shoots to bear fruit in abunlance; but if it be an isolated vine, the horizontal branches may be allowed to extend themselves, and a pair of new shoots added each year, as long as the ertility of the soil and the nature of the situation may require it. During very subsequent year, the treatment of the ground during spring and summer hould be the same as in the two seasons preceding. Early in September, the 
tops of the young shoots should be pinched off, in order that the sap may be assimilated into buds; and in October, or soon after harvesting the grapes, cut back the shoots of the same year and leave but four eyes to each; as, by leaving too many, the vine becomes exhausted, and yields but little fruit, and is soon destroyed by premature decay. The shoots should be cut off in an oblique direction, opposite to, and about an inch and a half above, the fourth eye from the old wood, in such a manner as will shed the rain and allow the buds to suffer no injury from the wet. In the course of the month of May, the vines should be examined, and

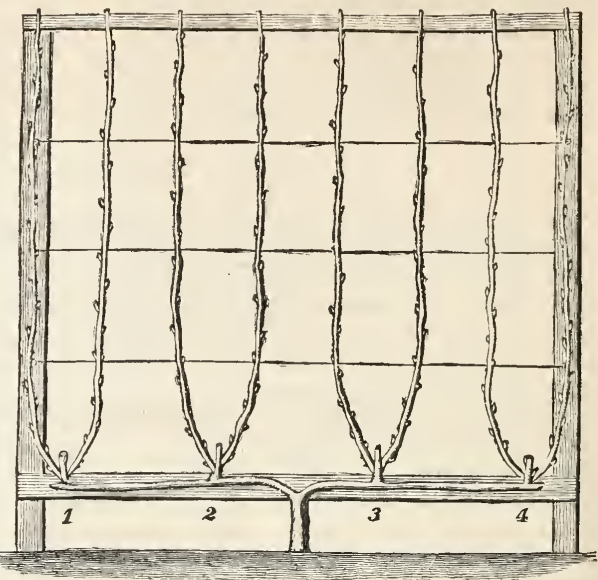
all the shoots from the old wood rubbed off; and if an eye of the last year's growth should be found to produce twin shoots, the weakest of the two must be removed, in order that the remaining one may the better thrive. In the course of the season, the superfluous leaves and twigs must often be thinned out; and about the first of September, as in the preceding years, pinch off the tops of the shoots, in order that the sap may assimilate in the buds that are to be reserved for the next year. If the vines appear to be too exuberant, they may be pruned at the roots, without injury, at any season of the year. The most convenient period, however, for performing this operation, where the climate is mild, is in November, when the roots should be exposed to the light and air, by drawing away the earth, and letting them remain till spring; but where the winters are severe, and subject to continued ice and frost, early in December they should be re-covered with earth, mixed with well-rotted manure, leaf-mould, husks and seeds of grapes, or the clippings and leaves of vines. If they remain exposed during winter, early in March the earth shonld be restored, and mixed with the manure or other substances, as named above. This mode was called "ablaqueatio," by the Romans, and is still practised with advantage in some parts of Italy and Spain.

Although spring and summer pruning of the vine may advantageously be adopted in all countries of the globe, yet in places exposed to the sun, with mild winters, pruning in autumn is thought to be the best, the most natural, at which time, trees and shrubs, by a divine and eternal law, drop both their fruit and leaves. "Snag pruning" is thought to be preferable by some, because, in "close pruning," the wounds spread, and prevent the protrusion of buds near the affected parts; but if these parts be covered at the time of pruning, with a preparation of fine earth or white-lead, mixed with linseed oil, they will immediately heal.

Mr. Loudon, in treating of the vine, mentions three modes of pruning it in hot-houses, viz. :- the fruit-tree method, in which the plant is spread out in the manner of a fan, and trained like a common fruit-tree; the long or young-wood method, in which all the wood above a year old is cut out down to the stool or stock; and the spurring-in method, in which the fruit is produced from young 
wood grown annually from the seeds of the main shoot, or shoots of old wood. The two last methods he regards as the best.

It is customary with many to cultivate flowers, or vegetables of various kinds between or near their vines, without reflecting that they are doing them great injury by abstracting their proper nourishment from the soil; a practice not only strictly guarded against by the most intelligent vine-dressers of the present day, but condemned by all ancient writers on the subject; and Moses, in exhorting the people of Israel, very forcibly elucidated his discourse by commanding them not to defile their vineyards with the fruit of divers seeds:

\footnotetext{
"Thou shalt not sow thy vineyard with divers seeds; lest the fruit of thy seed which thou hast sown, and the fruit of thy vineyard, be defiled."
}

Deuteronomx, xxii. 9.

thus plainly showing that the wisdom and prudence of this important law was well understood even at that early day.

Insects, Casualties, \&ैc. The Vitis labrusca, like most of its congeners, is subject to the attack of various tribes of insects or their larvæ, and requires the vigilant attention of the cultivator during all the warmer months of the year. Among the Coleoptera we recognize the Pelidnota punctata, Anomala varians, Melolontha subspinosa, and the Haltica chalybea. 'T'he former is a large beetle, sometimes found in great abundance in the months of July and August, and is described by Dr. Harris, as being of an oval shape, about an inch long, having dull, brownish-yellow wing-covers, with three distinct black dots on each; the thorax darker, and slightly bronzed, with a black dot on each side; and the legs and body beneath of a deep bronze-green. These beetles fly by day, and devour the leaves of the vine, which constitute their only food. They may be destroyed in considerable numbers, by snatching them from the vines and crushing them under the foot. Their larvæ live in decayed wood, and like those of beetles in general, consist of grubs. The Anomala varians, which is said to resemble, in its habits, the vine-chafer of Europe, is found in June and July, feeding upon the leaves of the vine, as well as upon those of several species of rhus. Both the males and the females are of a broad oval shape, and of varied colours, measuring from four to five lines in length, the former being the least in size. The head and thorax of the male are greenish-black, margined with dull-ochre or tile-red, and thickly punctured; the wing-covers are clay-yellow, irregularly furrowed, and punctured in the furrows; the legs are pale-red, brown, or black; and sometimes the whole insect is entirely black. The thorax of the female is clay-yellow or tile-red, sometimes with two oblique blackish spots on the top, and at others nearly black; the wing-covers resemble those of the male; the legs are clay-yellow or light-red. The Melolontha subspinosa, or common rose-bug, is also a diurnal insect, and appeared for some time to be confined to its favourite food, the blossoms of the rose; but within thirty years, according to Dr. Harris, this species has prodigiously increased in number, has attacked at random various kinds of plants, in swarms, and has become notorious for its extensive and deplorable ravages. The grape-vine in particular, has annually suffered by its depredations, as well as most of our fruit-trees, garden and field vegetables, and even the trees of the forest. "The unexpected arrival of these insects in swarms," says Harris, "at their first coming, and their sudden disappearance, at the close of their career, are remarkable facts in their history. They come forth from the ground during the second week in June, or about the time of the blossoming of the damask rose, and remain from thirty to forty days. At the end of this period, the males become exhausted, fall to the ground, and perish, while the females enter the earth, lay their eggs, return to the surface, and, after lingering a few days, die also. The eggs laid by each female are about 
thirty in number, and are deposited from one to four inches beneath the surface of the soil; they are nearly globular, whitish, and about one thirtieth of an inch in diameter, and are hatched twenty days after they are laid. The young larvæ begin to feed on such tender roots as are within their reach." ****** "They attain their full size in the autumn, being then nearly three-quarters of an inch long, and about an eighth of an inch in diameter." * * * * * "In October, they descend below the reach of the frost, and pass the winter in a torpid state. In the spring they approach towards the surface, and each one forms for itself a little cell of an oval shape, by turning round a great many times, so as to compress the earth, and render the inside of the cavity hard and smooth. Within this cell the grub is transformed into a pupa, during the month of May, by casting off its skin, which is pushed downwards in folds from the head to the tail. The pupa has somewhat the form of the perfect beetle; but it is of a yellowishwhite colour, and its short, stump-like wings, its antennæ, and its legs are folded upon the breast, and its whole body is inclosed in a thin film, that wraps each part separately. During the month of June, this filmy skin is rent, the included beetle withdraws from it its body and its limbs, bursts open its earthen cell, and digs its way to the surface of the ground. Thus the various changes, from the egg to the full development of the perfect beetle, are completed within the space of one year. Such being the metamorphoses and habits of these insects, it is evident that we cannot attack them in the egg, the grub, or the pupa state : the enemy, in these stages, is beyond our reach, and is subject to the control only of the natural but unknown nieans appointed by the Author of Nature, to keep the insect tribes in check. When they have issued from their subterranean retreats: and have congregated upon our vines, trees, and other vegetable productions, in the complete enjoyment of their propensities, we must unite our efforts to seize and crush the invaders. They must indeed be crushed, scalded, or burned, to deprive them of life, for they are not affected by any of the applications usually found destructive to other insects. Experience has proved the utility of gathering them by hand, or of shaking them or brushing them from the plants into tin vessels containing a little water. They should be collected daily during the period of their visitation, and should be committed to the flames, or killed by scalding water." The Haltica chalybea or steel-blue flee-beetle, as it is sometimes called, also inhabits the vine and preys upon its buds and leaves, in almost every part of the union. An interesting account of its habits and ravages is given in the xxvith volume of Silliman's "American Journal of Science and Arts," by Mr. David Thomas, of Cayuga county, in New York. The brilliant insects of this species, were observed by him, in the spring of 1831 , creeping on the vines, and destroying the buds, by eating out the central succulent parts. Some had burrowed even half their length into the buds. When disturbed, they jump, rather than fly, and remain where they fall for a time, without motion. In 1830 and 1831, he also found the vine-leaves infested by small, chesnut-coloured, smooth worms, which he fed in a tumbler, containing some moist earth, until they were fully grown, when they concealed themselves below the surface. In about two weeks after, some beetles were found in the tumbler, which led him to suppose that their larvæ undergo their transformation in the ground. These beetles, according to Dr. Harris, are exceedingly variable in their colour, being sometimes of a darkpurple, violet, Prussian blue, greenish-blue, and deep-green colour. The most common tint of the upper sides is a glossy, deep greenish-blue; the under sides of a dark-green; and the antennæ and feet are of a dull black. The body is oblong-oval, and the hinder part of the thorax is marked with a transverse furrow. It measures rather more than three-twentieths of an inch in length. In Massachusetts, these beetles begin to come out of their winter quarters towards 
the end of April, and continue to appear till the latter part of May. A second brood also make their appearance towards the end of July.**

Among the Hemiptera, which prey upon the vine, is the Tettigonia vitis, or vine-hopper, of Harris, which was for a long time supposed to be the vine-fretter of Europe. In a perfect state, this insect measures one tenth of an inch in length, is of a pale-yellow, with two small red lines on its head; the hinder part of the thorax, the scutel, the base of the wing-covers, and a band across their middle, are scarlet; the tips of the wing-covers are blackish, between which and the above-named band there are several small, red lines. The head is crescent-shaped above, and the eyelets are situated just below the ridge of the front. $\dagger$ These insects, according to Dr. Harris, inhabit both the foreign and native grapevines, under the surface of the leaves, among which they may be found during the greater part of the summer, where, also, they pass through all their transformations. They make their first appearance in June, when they are wingless, and of course in their larva state. They remain perfectly quiet for most of the time, with their beaks thrust into the succulent parts of the leaves, from which they derive their nourishment. If disturbed, however, they leap with great agility from one leaf to another, from which circumstance they are called vine-hoppers. As they increase in size, they frequently cast their skins, which may often be found, during summer, adhering to the leaves, and upon the ground beneath the vines. They generally reach their perfect state in the month of August, when they become still more active by the aid of their legs and wings, and are enabled to leap and fly from tree to tree. They do great injury to the vines by depriving their leaves of sap, which not only causes them to turn yellow and fall, even at mid-summer, but by this exhaustion, their most important functions are interrupted, the fruit becomes stunted and diseased, and if the evil be suffered to continue, the plant itself, in a few years, is rendered barren, and consequently of no value. In autumn, these insects quit the vines, shelter themselves beneath the fallen leaves or decayed tufts of grass, where they remain till the following spring, when they emerge from their winter retreats, and in due time deposite their eggs upon the leaves of the vine, and then die. The Vitis labrusca is also attacked by a species of bark-louse, of a globular form, nearly half the size of a pea, and of about the colour of the bark itself. It sometimes occurs in great numbers, which imbed themselves in the furrows of the bark, abstract large quantities of its sap, and thereby impoverish the vine. The most efficacious. means employed for the destruction of the vine-hopper or bark-lice, are fumigations of red-pepper seeds, tobacco, or other hot, acrid plants, which require frequent repetition, and much precaution to kill the insects and to prevent injury to the vines.

Among the Lepidoptera, which feed upon the vine, there are several species of Sphinx, the Procris americana, and the Eudryas grata. As it would occupy too much space to enter at length into the characters and habits of all these: insects, we must refer the reader to Dr. Harris' "Report," from which much valuable and practical information may be gained on this subject, that cannot be found in any other work. From the sphinges he has selected a group to which he has applied the name of Philampelus, signifying literally, "I love the vine," from the circumstance that their larvæ live upon the grape-vine. When young, they have a long and slender tail, recurved over the back like that of a dog, which, after one or two changes of the skin, disappears. Some of these caterpillars are of a pale-green, and others are brown, having the sides of their bodies ornamented by six cream-coloured spots, of a broad, oval shape. They have the power of withdrawing the head and the first three segments of the body

* See Harris' Report, p. 104. † Encyclopædia Americana, viii., p. 43. 
within the fourth segment, which gives them a short and blunt appearance wnen at rest. As they attain a length of three inches or more, and are of a proportionable thickness, they devour great quantities of leaves, which is often evinced by the long, leafless branches of the grape-vine, as well as those of the Virginian creeper (Ampelopsis quinquefolia.) They arrive at full growth in the month of August, enter the earth, where they undergo their transformations, and appear in the perfect or moth state, in June and July, of the following year. The vine suffers still more severely from another species of sphinx caterpillar, smaller in size than the preceding, and, like them, solitary in their habits. According to Dr. Harris, they are not content with eating the leaves alone, in their progress from leaf to leaf down the stem, but stop at every cluster of fruit, and, either from stupidity or disappointment, nip off the stalks of the half-grown grapes, and allow them to fall, untasted, to the ground. These caterpillars are fleshy and naked, generally of a pale-green, but sometimes brown, with a row of orange-coloured spots on the top of the back, and six or seven oblique lines, of a brown or dark-green, on each side. The head and fore part of the body are somewhat retractile, but less so than those of the preceding species; and on the hinder extremity of the body there is a short horn or spine. When fully grown, they conceal themselves, early in autumn, under the fallen leaves, which they draw together by a few threads, form themselves a cocoon, or cover themselves with grains of earth and rubbish, by a similar process, where they transform, and finally appear in a winged state in the month of July of the succeeding year. The larvæ of the Procris americana are gregarious in their habits, and congregate side by side on the same leaf, and only disperse when they are about to form their cocoons. They are represented as being slightly hairy, of a greenish colour, with black bands; their cocoons of an oblong-oval, very tough, and fastened by one side to the leaves or stems of the plants on which they feed. The winged insects make their appearance, in Massachusetts, towards the end of July. They are of a bluish-black, with a saffron-coloured collar, and a notched tuft on the extreme end of their bodies. Their wings are very narrow, and expand about an inch. The larvæ of the Eudridas grata, when fully grown, are an inch and a half or more in length, of a blue colour, transversely banded with deep-orange across the middle of each ring, with the bands dotted with black. The head and feet are also of an orange, the top of the eleventh ring somewhat bulging, and the fore part of the body hunched up when the insect is at rest. They occur in the greatest abundance in the months of July and August, and none will be found on the vines after September. They devour all parts of the leaves of the grape-vines, as well as those of the Virginian creeper, even to the mid-rib and staiks. When at rest, they generally cling to the under sides of the leaves; although many may be found on the same plant, they do not associate with each other. When they quit the vines, they bury themselves in the ground, to a depth of three or four inches, and change to dark-brown chrysalides without cocoons. The moths, which sometimes appear towards the last of June, are small in size, expanding from an inch and a half to an inch and three-fourths, and outvie all its congeners in delicacy of colouring and beauty of design.*

Among the Hymenoptera, we recognize but one species which attacks the grape-vine, the Selandria vitis, or saw-fly, of Harris. The perfect insect is described by him as being of a jet-black colour, except the upper side of the thorax, which is red, and the fore legs and the under side of the other legs, which are whitish or pale-yellow. The wings are semi-transparent, of a smoky colour, with dark-brown veins. The body of the female measures one fourth of an inch in length, and that of the male somewhat less. These flies rise from 
the ground in the spring, not all at one time, but at irregular intervals, and lay their eggs on the lower side of the terminal leaves of the vine. In the month of July the false caterpillars, hatched from these eggs, may be seen on the leaves, in little swarms, of various ages, some very small, and others fully grown. They feed in company, side by side, beneath the leaves, each swarm or fraternity consisting of a dozen or more individuals, and they preserve their ranks with a surprising degree of regularity. Beginning at the edge, they eat the whole of the leaf to the stalk, and then go to another, which, in like manner, they devour, and thus proceed from leaf to leaf, down the branch, till they have grown to their full size. At this period, they are about five-eighths of an inch in length, somewhat slender and tapering, and thickest before the middle, having twentytwo legs. The head and the tip of the tail are black; the body, above, is lightgreen, paler before and behind, with two transverse rows of minute black points across each ring; and the lower side of the body is yellowish. After their last monlting they becorne almost entirely yellow, and then leave the vine, burrow into the ground, and form themselves small oval cells of earth, which they line with a slight silken film. In about two weeks after entering the ground, having in the mean time passed through the chrysalis state, they come out of their earthen cells, take wing, pair, and lay their eggs for another brood. The young of the second brood are not transformed to flies before the following spring, but remain at rest, in the mean time, in their cocoons.* A solution of one pound of whale-oil soap in six or seven gallons of soft water has been recommended to be thrown upon the vines in order to destroy these flies; but should this prove ineffectual, fumigation with tobacco, red-pepper seeds, or other hot, acrid substances may be tried.

The Vitis labrusca is sometimes attacked by several species of the Geometridæ, such as span-worms, loopers, measurers, etc.; but not often to very great injury. When the wounds, made by pruning the branches, the roots, or the ends of the cuttings, are not protected by a coat of fine earth, white-lead mixed with oil, or some other substance, the soft pith and decayed wood are also liable to be attacked by ants, centipeds, and other wood-eating insects, (Xylophagidæ,) which sometimes perforate an inconsiderable portion of the stem, thus secretly destroying its vigour, and eventually its life, without any visible external cause. This species of vine is not subject to any other accidents of importance, except in some of its varieties, which are sometimes killed or greatly injured by the rigours of winter, or by vernal northerly winds. To guard against these evils, it is only necessary to bend down the vines from the trellis even with the ground, late in autumn, and cover them over with earth to the depth of eight or ten inches, and let them remain until early in the following spring, when the covering must be removed, and the shoots readjusted to the trellis as in the year before; and to protect them in situations exposed to the northern blast, they may be sheltered by walls, buildings, or by hedges of other trees.

Properties and Uses. The wood of the Vitis labrusca, from its diminutive size, open texture, and comparative scarcity, is very limited in its use in the arts. When reduced to charcoal, it may be employed by painters for drawing outlines, or may be used as a tooth-powder. It has been suggested that the prunings of this species may be cut into small pieces, bruised, put into a vat, and boiling water poured upon them, which, on being fermented like malt, would make a fine beverage, either strong or weak; and on being distilled, would produce a spirit analogous to brandy. The green twigs, or fresh cuttings, have been recommended, as a substitute for rape, in flavouring vinegar. The fruit, when ripe and fresh, is considered as wholesome, nutritious, refrigerant, 
and if taken freely, is diuretic and laxative. The husks and seeds are indigestible, and should be rejected, although the latter may be substituted for coffee, and treated in the same manner for a beverage. If taken without the husks, this grape is regarded as one of the most safe and nutritious of our summer fruits. Although it is apt to disagree with dispeptics and children, medicinally considered, it proves invaluable in febrile and inflammatory diseases, in which it allays the thirst, and diminishes the heat. It is said, also, to have been found serviceable in dysentery, phthisical complaints, as well as in affections of the lungs.

Our fruiterers have a considerable trade in importing preserved grapes, princ1pally from Europe, packed in saw-dust, in large earthen jars, closely sealed. Although the American grapes are preserved in a similar manner to a considerable extent, which add much to the luxury of our winter desserts, and afford great relief to the infirm and sick, there is not enough of this rare and excellent fruit to supply a ten-millionth part of what our population would demand, if it were sold at a reasonable price.

This art of preserving grapes was well known to the Romans, and was among the first objects of their care. Columella recommends them to be put into small jars, that will contain only one bunch in each; and that the fruit should be made quite dry by the sun, and after being cooled in the shade, to be suspended in the jars, and the spaces around them to be filled with clean oat chaff. The jars, he says, must be well baked or burnt, and not such as will imbibe moisture; and the openings at the tops must be closed, and pitched, to exclude the air. The American grapes may be preserved for several months, by packing them in tin cases, of any convenient size, in clean chaff, bran, saw-dust, powdered charcoal, or in clean sand, all of which nust be well baked and perfectly dry, when to be used. As soon as the cases are filled, they must be sealed or soldered up, air-tight, and kept in a place of uniform temperature, from $40^{\circ}$ to $60^{\circ} \mathrm{F}$., until they are required for use. This may be done by burying them in dry earth to a depth of four or five feet; or a room or cellar may be specially prepared for their reception, by being surrounded with a layer of charcoal-dust, or any other materials known to be bad conductors of heat. The preservation of grapes may also be prolonged by allowing them to remain upon the vines; but in being thus exposed, they soon lose their flavour, are liable to drop, or to be devoured by vermin or birds.

The cultivation of this species, independent of the profits arising from its fruit and wine, is highly ornamental as a climbing shrub. No person who possesses two square yards of unoccupied ground, sheltered from the cold northerly winds, and half of the day from the intense heat of the sun, can apply it to a more valuable purpose than planting it with a vine. But let it be remembered that, if ornament and shade are the objects in view, the vine must be left to pursue its natural vigour, and is not to be pruned more than is required to give it a graceful form.

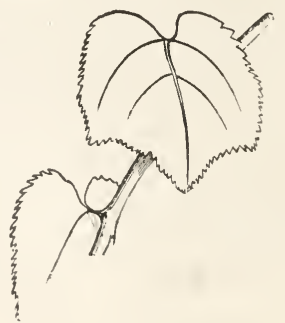




\section{Genus XANTHOXYLUM, Linn.}

Xanthoxylaceæ.
Syst. Nat.

Xanthoxylum, Zanthoxylum,

Clavalier,

Zahnwehholz,

Santossilo,

Toothache-tree,
Diœcia Tri-Pentandria. Syst. Lin.

\section{Synonymes.}

OF Adthors.

France.

Germany.

ITALY.

Britain and Anglo-America.

Derivations. The word Xanthoxylum is derived from the Greek xanthos, yellow, and xulon, wood, from the yellowness f the wood, more especially of the roots. The French name means Club-tree, and the German one, Toothache-tree.

Generic Characters. Sepals 5 or more, petaloid, with a minute glandular beard at the apex. Petals none. Ovaries as many as sepals, and opposite to them. Styles terminating in clavate stigmas, which are at first connate.-Colden, Planta.

ofe Pf: a the Ptelea and Ailantus. There are at least two species indigenous to North America, the Xanthoxylum fraxineum and tricarpum, and several varieties, some of which are much valued for their medicinal qualities. The Xanthoxylum clava herculis, of

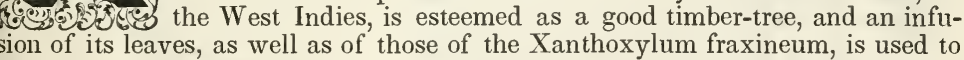
cure the toothache. Mr. Royle, in his excellent work entitled "Illustrations of the Botany and other Branches of Natural History of the Himalayan Mountains, and of the Flora of Cashmere," mentions two species, the Xanthoxylum hostile and alatum. Several other trees of this genus are enumerated in Loudon's "Hortus Britannicus," as natives of China and Japan, but they are not considered as very ornamental. All the species may be propagated by ripened cuttings of the branches or of the roots. 


\title{
Xanthoxylum fraxineum, \\ THE ASH-LEAVED XANTHOXYLUM.
}

\section{Zanthoxylum clava herculis, Zanthoxylum fraxineum, Zanthoxylum americanum,}

Xanthoxylum fraxineum,

Clavalier à feuilles de frêne,

Eschenblättriger Zahnwehholz, Frassino spinoso,

Prickly Ash, Thorny Ash,

\section{Synonymes.}

Toothache-tree, Great Prickly Yellow-wood, Other Parts of ANglo-America.

Derinations. The specific name, fraxineum is derived from the Latin fraxinus, the ash, from the resemblance of the leaves of this tree to those of the ash. The French name signifies Ash-leaved Club-tree; and the German one, Ash-leaved Toothache-tree.

Engrarings. Bigelow, Medical Botany, pl. 59; Catesby, Natural History of Carolina, vol. i., pl. 26. ; Loudon, Arboretum Britannicum, vol. i., figure 158; and the figures below.

Specific Characters. Leaves pinnate, of 4 to 5 pairs of leaflets, and an odd one; the leaflets ovate, obscurely sawed, equal at the base; the petiole round and devoid of prickles; prickles in the situation of stipules. Flowers in axillary umbels without petals. The sexes dicecious.-De Candolle, Prodromus.

\section{Description.}

\author{
"That unpitying pain \\ Which plucks the nerves, close-sealing with a frown \\ Ev'n beauty's lips, which the bold Ayrshire bard \\ Wish'd in his patriot vengeance to entail \\ On Caledonia's foes, yielded its rage \\ To the rough genius of that lofty tree, \\ Whose yellow armour bears in countless studs \\ The horrid thorn." \\ Traits of the Aborigines.
}

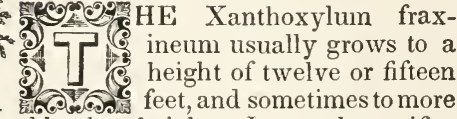
than double that height. Its trunk ramifies some distance above the ground, and then branches out into a regular head. The whole tree, when young, is armed with powerful prickles, which are thick at the base, and angular and sharp at the point, but become less so when old. The leaves are pinnate, a foot in length, often nearly glabrous when mature, and sometimes tomentose beneath; and in the place of stipules, there are straight thorns a third of an inch in length. The flowers, which appear in April, May, or June, are of a greenish or yellowish colour, with red anthers, and are succeeded by capsules

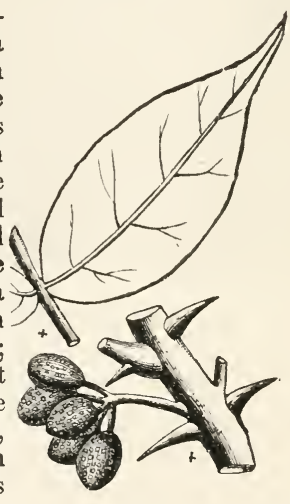
containing large black seeds.

Variety. A tree is recognized by botanists as belonging to this genus, growing in North America, which does not differ from the present species, except in being thornless, and may bear the name of Xanthoxylum fraxineum mite. 
Geography and History. The Xanthoxylum fraxineum is usually found on the borders of rivers and other waters, from Canada to Virginia, and as far west as the Mississippi. It was introduced into Britain in 1740, and is common in European collections, but is never seen there of any great size.

Properties, Uses, $\oint^{\circ} c$. The bark and capsules of this species are of a hot, acrid taste, and when taken internally, act as a powerful stimulant. They are sometimes used for relieving the pains of toothache, and for the curing of intermittents and rheumatism.

The medicinal virtues of this tree were also well known to the American aborigines. Lawson remarks, that "they extracted from its berries the salivating power of mercury, and made use of decoctions of the plant, as strong perspiratives."

No other particular use is made of this tree except for ornament. It is generally propagated by seeds or by cuttings of the roots, and usually attains a height of six feet in ten years after planting.

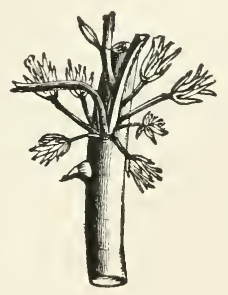




\section{Genus PTELEA, Linn.}
Xanthoxylaceæ. Syst. Nat.
Ptelea, Bellucia,
Orme de Samarie,
Lederblume,
Ptelea,
Trefoil,

Monœcia Tetra-Pentandria.
Syst. Lin.

\section{Synonymes.}

Of Authors.

France.

GermanY.

ITALY.

Britain and Anglo-America.

Derivations. Ptelea is the Greek name of the elm. It is derived from ptao, to fiy, in allusion to the winged seed.ressels of this tree.

Generic Characters. Polygamous. Sepals 3-6, commonly 4, small. Petals much longer than the sepals, spreading. Stamens alternate with and longer than the petals; filaments thickened below and hairy on the inside; in the fertile flowers very short and with sterile anthers. Ovary of 2 united carpels, placed on a convex torus; ovules 2 in each carpel, situated one above the other; styles short, united, or none; stigmas 2. Fruit a 2-celled samara, turgid in the centre, the margin expanded into a broad, orbicular membranaceous and reticulated wing. Seeds oblong, solitary in each cell. Leaves pinnately 3- (rarely 5-) foliate, with pellucid dots, the lateral leaflets inequilateral. Flowers whitish, cymose; cymes corymbed or panicled.-Torrey and Gray, Flora.

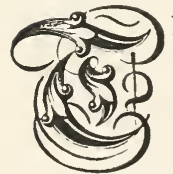

HE genus Ptelea embraces at least five species, four of which are indigenous to North America, and one to Cochin-China. The Ptelea monophylla, having simple, ovate, lanceolate leaves, is a native of Carolina, and grows to the height of four feet. The Ptelea pentandra and podocarpa are indigenous to Mexico, and grow to a height of six to ten feet. The Ptelea ovata is a simpleleaved species, native of Cochin-China. The other species, and the only one that has been cultivated with success, or has attained much size, is the Ptelea trifoliata, which, as appears by its history, well deserves a place in collections, both on account of the singularity of its leaves and fruit, and the general beautv of the tree. 


\section{Ptelea trifoliata, \\ THE THREE-LEAFLETED-LEAVED PTELEA.}

\section{Synonymes.}

\section{Ptelea trifoliata,}

Orme de Samarie à trois feuilles, Dreyblättrige Lederblume, Ptelea,

Shrubby Trefoil, Tree Trefoil,

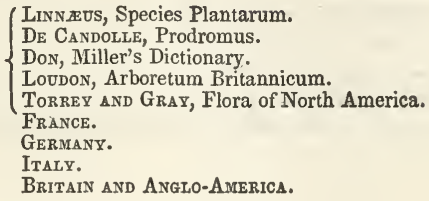

Engravings. Loudon, Arboretum Britannicum, v., pl. 59; and the figures below.

Specific Characters. Leaf of three leaflets that are ovate acute, the middle one much tapered towards the base. Flowers in corymbs, usually tetrandrous.-De Candolle, Prodromus.

\section{Description.}

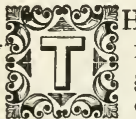
HE Ptelea trifoliata, in its
natural habitat, usually
grows to a height of six or
eight feet; but, when cultivated under favourable circumstances, it sometimes attains an elevation of forty feet and upwards. When the plant is pruned up with a single stem, it forms a handsome low tree, with a hemispherical head; but it is more frequently cultivated as a large shrub, with numerous stems proceeding from the same basal point. The leaflets are sessile, ovate, mostly acuminate, obscurely crenulate, the terminal one cuneiform, and attenuate at the base. 'The flowers, which appear in June and July, are of a green-

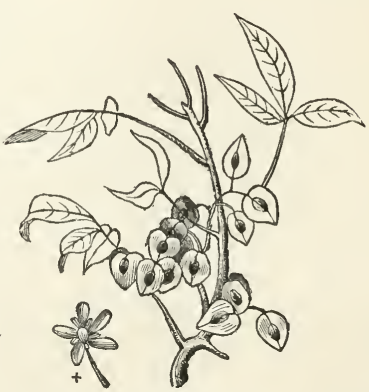
ish-white, grow in corymbose clusters, and have a disagreeable odour. They are succeeded by flattened winged capsules, somewhat resembling those of the elm; whence the French name orme.

Varieties. The varieties which have come under the notice of botanists are as follows :-

1. P. т. Pentaphylla, Munch. Five-leaflet-leaved Shrubby Trefoil. This variety can generally be distinguished in having five leaflets.

2. P. т. Pubescens, Pursh. Pubescent-leaflet-leaved Shrubby Trefoil. This variety is described as having its branchlets, petioles, and lower surface of its leaves clothed with a soft tomentose pubescence, even when old.

Geography, History, \&॰c. This species is found in moist, shady hedges, and on the borders of woods among rocks, from Lake Ontario to Florida, and as far west as Kentucky and Texas. It was originally sent to England by Banister, and plants of it were raised by Bishop Compton, at Fulham; but they were lost, and the species was re-introduced from Carolina by Catesby, in 1724. Being hardy, and of easy culture, in any ordinary soil, this tree is not uncommon in the collections of Europe, and it well deserves a place there, as well as in those of the United States, both on account of the beauty of its leaves and fruit. and its general appearance. 
The largest tree of this species, existing in Britain, and probably on the globe, is at Gordon Castle, in Bamffshire, Scotland. In 1835, it had attained the height of forty-five feet, with a trunk fifteen inches in diameter, and an ambitus or extent of branches of twenty-seven feet. It was grown in a loamy soil and in a sheltered situation.

In France, at Paris, in the Jardin des Plantes, there is another tree of this species, which attained the height of thirty-seven feet in sixty years after planting, with a head forty feet in diameter.

In Saxony, at Wörlitz, there is also a tree of this species, which attained the height of twenty-five feet in forty-five years after planting; and another tree of the variety Ptelea trifoliata pentaphylla, that reached the height of fifteen feet at thirty-four ye'xrs planted. 


\section{Genus AILANTUS, Desf.} Xanthoxylaceæ
Syst. Nat. Monœcia Polygamia.

Synonymes.

Ailantus, Ailanthus, Rhus,

OF Authors.

Aylante, Aylanthe, Verne du Japon, An-
gik, Angika, Langit,

Götterbaum,

Germany.

Ailanto,

Tong-yen-tsao, Tchean-theum,

Ailanto, Ailantus,

Italy and Molucca IsLands

China.

Britaln and Anglo-America.

- Derivations. The word Ailantus (sometimes improperly written Ailanthus) was given to this genus by Desfontaines, woo ormed it from the Molucca name, ailanto. For a long time this tree was considered as a species of rhus, whence the French name, Verne. Angik or Angika, it is said, signifies the Tree of Heaven; hence the German name, Götterbaum, Tree of the Gods.

Generic Characters. Male Flower. Calyx, 1-leafed, 5-parted, very small. Corolla, 5-petals, acute, convolute at the base. Stamina, filaments 10, compressed, the length of the corolla.-FEmale FiowER. Calyx, as in the male. Pistils, germs $3-5$. Styles lateral. Capsules compressed. Seeds solitary, and lens-shaped. Bisexual flowers as in the above.

ONG before this genus was rightly named and its characters well understood, one of its species was cultivated in the gardens of Europe and America, and was thought to be a kind of sumach; but as the tree, in general, bore only male flowers, much doubt and many conjectures were entertained, until it was accurately described by Desfontaines, in 1786. There are several species in this genus, all natives of China, India, or the adjacent islands, but none are very hardy except the Ailantus glandulosa, indigenous to the northern provinces of China, and cultivated as an ornamental tree in nearly every countrv of the civilized globe. 


\section{Ailantus glandulosa, \\ THE GLANDULOUS-LEAVED AILANTUS.}

\section{Synonymes.}

\section{Avlantus gianauıosa,}

Ailantus procera,

Aylante glanduleux, Tilou,

Drüsiger Götterbaum,

Ailanto, Albero di Paradiso,

Ailantus, Tree of Heaven,

\author{
(Desfontaines, Actes, etc., Paris, 1786. \\ De Candolle, Prodromus. \\ Loudon, Arboretum Britannicum. \\ Salisbury, Prodromus. \\ France. \\ Germany. \\ ITALY. \\ Britain and Anglo-America.
}

Engravings. L'Héritier, Stirpes, pl. 84 ; Du Hamel, Traité des Arbres et Arbustes, i., pl. 35 ; Loudon, Arboretum Britannicum, l., figure 159, et v., pl. 60 ; and the figures below.

Specific Characters. Leaves impari-pinnate; the leaflets coarsely toothed at the base; the teeth glandulous on the under side.-De Candolle, Prodromus.

\section{Description.}

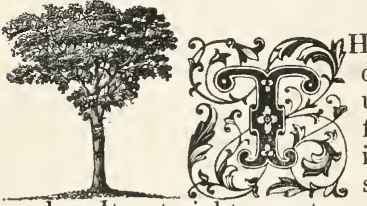

E Ailantus glandulosa is a deciduous tree of the first rank, growing to a height of sixty feet and upwards. Its straight, erect, column-like trunk, from two to three feet in diameter, its gigantic boughs and shoots, clothed with large, pendulous leaves, give it a noble appearance, and seem to justify the oriental appellation, "Tree of Heaven." The leaves are from one and a half to six feet in length, pinnated, with an odd one, and having leaflets with coarse, glandular teeth near the base. On the first approach of frost, the leaflets begin to fall, without having previ-

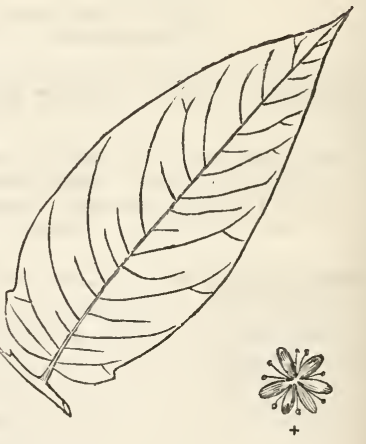
ously shown much change of colour, displaying, in this respect, a striking difference from the leaves of most species of rhus, to which those of this tree bear a general resemblance. The flowers, which appear in June and July, occur in rather large, compact panicles, of a whitish-green colour, and exhale a disagreeable odour. The keys, or fruit, resemble those of the ash, but are much smaller and more numerous. In some years, the tree is said to bear only male flowers; and L'Héritier states that only twice in ten years it bore both male and female blossoms at the same time, in France. In his time, it had produced fruit in the Jardin des Plantes, at Paris, and in the botanic garden at Leyden; but in both cases it was immature. It has since, however, produced perfect fruit, from which plants have been raised. It has also ripened seeds at White Knight's, near Reading, in England. At Philadelphia and New York, the seeds of this tree ripen freely in October, and plants are raised from them in abundance.

Geography and History. The Ailantus glandulosa is a native of the northern provinces of China, more particularly in the neighbourhood of Pekin. Mr. Loudon states that seeds were first sent to England, to the Royal Society of London, 
y the Jesuit missionary, D'Incarville, in 1751 ; and that they were sown by Miler, in the Chelsea botanic garden, and by Philip Carteret Webb, at Bushbridge, in surry, the same year. As the tree produced suckers freely, it was soon geneally propagated, and there are many fine specimens of it growing in different arts of that country.

The largest tree of this species in Britain, is at Syon, near London. In 1835, had attained the height of seventy feet, with a trunk three feet, ten inches in liameter, and an ambitus, or spread of branches, of forty feet. Its trunk formed in erect column about thirty feet high, before it ramified, and its head was hemspherical. This tree is said to flower, and occasionally to produce fruit.

The Ailantus glandulosa was introduced into France in 1780, by M. Blaikie, nd the oldest specimens are at St. Leu, and at Paris. At St. Leu, there is a tree, lanted by M. Blaikie, in 1794, which attained the height of eighty feet in forty rears, with a trunk from three to three and a half feet in diameter. In the ardin des Plantes, at Paris, there is another tree, which, in 1835, had attained he height of sixty-eight feet, with a head forty-four feet in diameter, flowering nost years, and occasionally ripening seeds.

At Geneva, in Switzerland, at the entrance of the botanic garden, there is a ree of this species, fifty or sixty feet in height, which, when in flower, emits so owerful an odour that it may be perceived at a distance of nearly a quarter of mile (cinq minutes de distance.) The suckers from this tree shoot from the round in every direction, for forty or fifty feet.

Many other interesting specimens are to be met with in the chief gardens and ollections in Britain, Ireland, and continental Europe, and the tree is generally ultivated for ornament in all the temperate countries of the civilized world. It $\mathrm{s}$ not destined to thrive, however, in a very rigorous climate, for it dwindles lown to a mere shrub, no farther north than Montreal, in Lower Canada.

The Ailantus glandulosa found its way into the United States from two disinct sources. It was first introduced from Europe, in 1784, by Mr. William Hamilton, at the Woodlands, near Philadelphia, and a sucker, planted from the riginal tree, in 1809 , is at present standing in the Bartram botanic garden, which is sixty feet in height, with a trunk nearly two feet in diameter.

On the authority of Governor Charles Collins, of Newport, this species was rought from South America, in about the year 1804, and was presented to General Andrew McCorrie, of Portsmouth, in Rhode Island, by a master of a vesel. From this tree there were numerous others produced by cuttings, and six r eight of them were planted in 1807, by Governor Collins, at Bristol, several f which were felled and sawn into boards about twenty years after. In about he year 1810, Rev. Henry Wight, of the last-named place, procured a young hoot, and planted near his house, which has grown to a magnificent tree, fiftyive feet in height, with a trunk seven feet in circumference, at a yard above the rround, and an ambitus or spread of branches of fifty feet. In Portsmouth, Bristol, and Providence, there are numerous other trees of this species with runks nearly two feet in diameter.

In about the year 1820, Mr. William Prince, of Flushing, Long Island, imported he ailantus from Europe, and from this source, most of the plants of this species $n$ New York and vicinity, have been supplied. It may here be remarked, that ooth male and female trees grow in abundance in the last-named places, and hat the male may generally be distinguished by its more graceful leaves and landsome form.

Propagation, Culture, $\& \bullet c$. The Ailantus glandulosa may readily be propagated rom seeds, or by cuttings of the roots; but the former mode is far more preferable, as the tree is not so liable to throw up suckers as when produced by cutings. The seeds should be sown, if possible, as soon as they are gathered; and 
If they are to be transported any great distance, they may be sown in boxes of light earth, or sand and peat, protected under glass. It will grow in any soil, though one that is light and somewhat humid, and in a sheltered situation, is considered the best. In France, it is said to thrive on chalky soils, and attain a large size, where scarcely any other tree will prosper. It grows with great rapidity for the first ten or twelve years, producing annual shoots from three to six feet in length, and under favourable circumstances, it often attains a height of fifteen or twenty feet in five or six years. Afterwards, its growth is much slower, which renders it very valuable as a shade-tree, in situations of limited space; although there is the disadvantage of the unpleasant odour of its flowers. The leaves are not liable to be attacked by insects, which is a very great desideratum, and as we before remarked, they continue on the tree, and retain their verdure till the coming of the autumnal frosts, when the leaflets drop suddenly off and often leave the petioles on the tree some weeks longer.

Properties and Uses. 'The wood of this species is very hard, compact, of a deep-red colour, when old, resembling newly-wrought mahogany, and is often beautifully veined with deep-gold colour and red. It is susceptible of the finest polish, and has a fine, satin-like lustre, which renders it well suited for the purposes of cabinet-making. From its capability of being raised on meagre and worn-out soils, and the rapidity of its growth, it is thought that this tree might be profitably cultivated for cabinet-wood, or to be treated as a coppice, to be cut every third year for fuel. In France and Italy, it is much valued for shading public walks, and is planted for that purpose along with the American tulip-tree, (Liriodendron, ) the horse-chesnut, the oriental plane, and other large-leaved exotic trees. It also graces lawns and avenues in various parts of the United States, and succeeds equally well as in its native country.

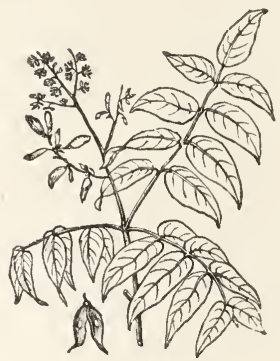




\section{Genus ILEX, Linn.}

Aquifoliaceæ. Syst. Nat.
Tetrandria Tetragynia. Syst. Lin.

Derivation. The name Ilex was given to this genus by Bauhin and Loureiro, on account of the resemblance of its leaves to iose of the Quercus ilex, or the true Ilex of Virgil.

'encric Characters. Sexes hermaphrodite, very rarely, by defect, diœcious or polygamous. Calyx 4-5toothed. Corolla 4-5-cleft. Stamens 4-5, inserted into the tube of the corolla. Fruit including 4 or 5 nuts. Evergreen shrubs, with, mostly, coriaceous leaves. Flowers many on a peduncle.-De Candolle, Prodromus.

23 LEX is a genus very abundantly diffused in the warm and colder climates of both continents, and in many islands in the ocean. Besides the Ilex aquifolium, which constitutes so beautiful a feature in the winter scenery of many parts of England, there are also worthy of note, the Ilex opaca of the United States, and the Ilex dipyrena of the Himalayas, which is nearly allied to it; the lex balearica, or broad-leaved holly of Minorca; the Ilex canariensis, with lack berries; the Ilex vomitoria or yaupon of the southern Indians; the Ilex araguariensis, or Paraguay tea ; the Ilex dahoon of Florida, which may be conidered as one of the most ornamental of the whole family; and the Ilex cassine r broad-leaved dahoon holly of Carolina and the Floridas. 


\section{Ilex aquifolium, THE EUROPEAN HOLLY.}

Synonymes.

llex aquifolium, $\quad\left\{\begin{array}{l}\text { LinNeUs, Species Plantarum. } \\ \text { DE CANDOLLE, Prodromus. } \\ \text { Don, Miller's Dictionary. } \\ \text { Loudon, Arboretum Britannicum. } \\ \text { SELBY, British Forest Trees. }\end{array}\right.$

Houx, grand Housson, Agron grand pardon, Fraxce.

Stechpalme, Stechpalmenbaum, Stechbaum, Stecheiche, Stechlaub, Stechapfel, Stechwinde, Hülse, Hülsenbaum, Hülsenstrauch, Hüllgenholz, Myrtendom, Christdorn, Mausedorn, Zwieseldorn, Kleezbusch, Walddistel,

Agrifoglio, Allora spinoso, Leccio spinoso, Itazx.

Acebo, Acervino, Agrifolio, Sparn.

Azevinho, Agrifolio,

Schubbig Hardkelk,

Waefoscheld, Ostrokof, Padub,

Holly, Hulver, Hulfere, Holm,

Gernany.

Portugal.

Holland.

Russia.

Britain and Anglo-Averica.

Derivations. The specific name, aquifolium, is derived from the Latin acutum, sharp, and folium, a leaf, in alluston w the sharp points of the leaves. The Greek authors called this species agria, that is, wild, or of the fields; whence some of the French, Spanish, Italian, and Portuguese names. The English name, holly, is probably a corruption of the word, holy, from its being used to commemorate the holy time of Christmas, not only in houses, but in churches. The German name, Christ. dorn, the Danish name, Christorn, and the Swedish name, Christtorn, would seem to justify the same conjecture.

Engravings. Selby, British Forest Trees, pp. 37 et 47; Loudon, Arboretum Britannicum, v., pl. 64; and the figures below.

Specific Characters. Leaves shining, wavy, ovate, spiny-toothed, and sometimes entire. Peduncles axilary. Flowers nearly umbellate. Fruit a 4-celled berry, globose, and containing four solitary, horny, oblong seeds, rounded on one side, and cornered on the other.

\section{Description. \\ ***** "et illum nemo impune lacessit." \\ "Touch me, I 'll prick."}
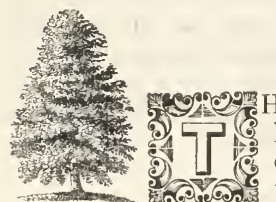

HE European Holly is a handsome conical, evergreen tree, growing to a height of twenty or thirty feet, in a wild state, with a trunk from eighteen inches to two feet in diameter, and to double these dimensions in a state of cultivation. In viewing it as a hedge-plant, or as an ornamental tree or shrub, it is not surpassed by any other evergreen whatever, whether we look upon it in its native woods, with its shining, deep-green leaves and coral-red berries, which persist for half the year, or in its numerous variegations of silver or golden leaves, and its white or yellow fruit.

Varieties. In general, the deviation from the common form and colour observable in wild plants, or in those in a state of cultivation, more especially in trees and

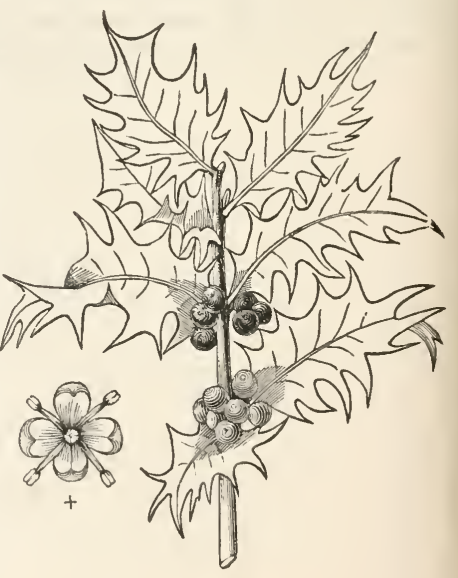


hrubs, is accompanied by a ragged, or otherwise unhealthy appearance in the eaves: but the holly is one of the very few exceptions to this rule. Its variegaions are chiefly confined to the modifications of white and yellow in the leaves; ut there are some kinds in which the deviation results from the size, form, and rickly state of the leaves; and others consist of differences in the colour of he fruit, which is red, yellow, black, or white. The following varieties are ll that are regarded as truly distinct; but the shades of difference under each ame are almost innumerable:-

1. I. A. HETEROPhyllum, Loudon. Various-leaved Holly.

2. I. A. Angustifolium, Loudon. Narrow-leaved Holly.

3. I. A. Latifolium, Loudon. Broad-leaved Holly.

4. I. a. altaclerense, Loudon. High Clere Holly. Leaves broad, thin, flat. 5. I. a. marginatum, Loudon. Thick-margined-leaved Holly. Leaves broad, ntire.

6. I. A. LaURifolium, Loudon. Laurel-leaved Holly. Leaves small, entire.

7. I. A. ciliatum, Loudon. Ciliated-leaved Holly. Leaves small, with prickles long the margin like hairs.

8. I. a. ciliatum Minus, Loudon. Smaller-ciliated-leaved Holly. Leaves smaller han the preceding.

9. I. A. RECURvUM, Loudon. Recurved-leaved Holly.

10. I. a. Serratifolium, Loudon. Serrated-leaved Holly.

11. I. A. CRispum, Loudon. Curled-leaved Holly.

12. I. A. FErox, Loudon. Fierce-spine-leaved, or Hedgehog Holly. Leaves olled and covered with spines.

13. I. a. Crassifolium, Loudon. Thick-leaved Holly.

14. I. A. Senescens, Loudon. Aged or Spineless Holly.

15. I. a. albo marginatum, Loudon. White edged-leaved Holly. Margins of eaves white, or pale-yellow.

16. I. A. aUreo marginatum, Loudon. Golden-edged-leaved Holly. Margins f leaves light and dark yellow.

17. I. A. ALbo PICtum, Loudon. White-spotted-leaved Holly, Milk-maid Holly. Iargins of leaves green, middle white.

18. I. A. AUReo Pictum, Loudon. Gold-spotted-leaved Holly.

19. I. a. Ferox argenteum, Loudon. Silver-blotched Hedgehog Holly.

20. I. A. Ferox aureun, Loudon. Gold-blotched Hedgehog Holly.

21. I. A. Fructu Luteo, Loudon. Yellow-fruited Holly.

22. I. A. FRUCTU ALBo, Loudon. White-fruited Holly.

23. I. A. FruCtu Nigro, Host. Black-fruited Holly.

Geography and History. The Ilex aquifolium is indigenous to most parts of he middle and south of Europe, and it is said to be found in China and Japan. $t$ does not appear to be a native either of America or of India, unless the Ilex opaca f the United States, and the Ilex dipyrena in the Himalayas, should prove, by ultivation, to be varieties of it. According to Pallas, it scarcely occurs within he ancient limits of the Russian empire, though frequent on the southern side f Caucasus, where it forms a low, branching shrub, about ten feet high. In rance, it is abundant, more particularly in Brittany. In Germany, it abounds n many forests, especially in the southern and middle states; where, when heltered by lofty trees, it attains the height of twenty feet; but in exposed situtions, it does not exceed a height of six or eight feet. This tree appears to ttain a larger size in England than in any other part of the globe: It abounds $n$ that country, more or less, in the remains of all aboriginal forests, and perlaps, at present, it prevails nowhere to a greater extent than in Needwood Forst, in Staffordshire. In Scotland it is found in most natural woods, as an 
undergrowth to the oak, the ash, and the pine. In Ireland, the holly is not very common; but about the lakes of Killarney it attains a large size.

The holly has been much admired from the earliest periods. Its use for ornamenting churches and dwellings, at Christmas, is well known, though the origin of the practice is uncertain. The custom of putting evergreens in places of religious worship prevailed long before the birth of Christ; and several passages in Holy Writ have reference to it:-

\footnotetext{
"And they found written in the law which the Lord had commanded by Moses, that the children of Israel should dwell in booths in the feast of the seventh month:

"And that they should publish and proclaim in all their cities, and in Jerusalem, saying, Go forth unto the mount, and fetch olive branches, and pine branches, and myrtle branches, and palm branches, and branches of thick trees, to make booths, as it is written."

Nehemiah, viii. 14, 15.
}

The holly appears to have been first employed for this purpose by the early Christians, at Rome; and was probably adopted for decorating the churches at Christmas, because it was used in the great festival of the Saturnalia, which occurred about that period. It was the policy of the Christians to assimilate the festivals of the Pagans as nearly as possible in their outward forms, to avoid exciting unnecessarily their prejudices; and it was customary among the Romans to send boughs of holly, during the Saturnalia, as emblems of "peace and good-will," with the gifts they presented to their friends at that season. It was for this reason, independently of any desire to conciliate the Pagans, well adapted to be an emblem of the principal festival of a religion which professes, more than any other, "to preach peace and good-will to man." Whatever may have been the origin of the practice, it appears to have been a very ancient usage; for Bourne, in his "Antiquities of the Common People," cites an edict of the Council of Bracara, forbidding Christians to begin to decorate their houses at Christmas, with green boughs, at the same time that the Pagans decorated theirs at the Saturnalia, which commenced about a week earlier. Dr. Chandler, in his "Travels in Greece," supposes that this custom was derived from the Druids, who, he says, decorated their dwellings with evergreens during winter, "that the sylvan spirits might repair to them, and remain unnipped with frost and cold winds, until a milder season had renewed the foliage of their darling abodes." The earliest record of this custom in Eingland, perhaps, is in a carol in praise of the holly, written in the time of Henry VI., and preserved in the Harleian MSS., in illustration of which, it must be observed, that the ivy, being dedicated to Bacchus, was used as a vintner's sign in winter, and hung outside of the door.

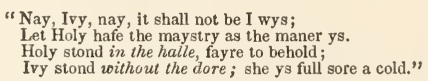

Stow, in his "Survey of London," in 1598, says that, in his time, "every man's house, the parish churches, the corners of the streets, conduits, market-crosses, \&c., were decorated with holme, ivy, and the bayes, at Christmas." Formerly, in England, when it was customary to enclose and subdivide gardens by hedges, the holly was employed by all who could afford to procure the plants, and wait for them to grow. Evelyn had a magnificent hedge of this kind, at his gardens at Say's Court, which he thus rapturously describes:-"Is there under heaven a more glorious and refreshing object of the kind than an impregnable hedge, of about four hundred feet in length, nine feet high, and five in diameter, which $I$ can show in my now ruined gardens, at Say's Court, at any time of the year, glittering with its armed and varnished leaves, the taller standards, at orderly distances, blushing with their natural coral ?" Other holly hedges, famous in 
neir day, were those of Lord Dacre, at his park in Sussex, and of Sir Matthew Decker, at Richmond. "I have seen hedges," observes Evelyn, "or, if you fill, stout walls of holly, twenty feet in height, kept upright; and the gilded ort budded low, and in two or three places one above another, shorn and fashoned into columns and pilasters, architecturally shaped, and at due distance; han which nothing can possibly be more pleasant, the berry adorning the intercoimniations with scarlet festoons, and encarpa." In Scotland, the most celebrated olly hedges were those of the Earl of Haddington, at Tyningham, and those at iollington House, and at Moredun, near Edinburgh. Those at Tyningham vere chiefly planted in 1712, and are two thousand nine hundred and fifty-two ards in length, from ten to twenty-five feet in height, and from nine to thirteen eet wide at the base. Most of the hedges are regularly clipped in April, and re carefully protected, by ditches on each side, from the bite of cattle, and ore particularly of sheep, which are very fond of the bark, shoots, and young eaves of this tree.

Pliny tells us that there was a holly-tree, in his time, growing near the Vatian, in Rome, on which was fixed a plate of brass, with an inscription engraven I Tuscan letters; and that this was older than Rome itself, which must have een more than eight hundred years. The same author notices a holly-tree, in usculum, the trunk of which measured thirty-five feet in circumference, and hich sent out ten branches, of such magnitude, that each might pass for a tree self. He says, that this single tree alone, resembled a small wood.

Cole informs us, in his "Paradise of Plants," that he knew a tree of this kind thich grew in an orchard, and "the owner," he says, "cut it down, and caused to be sawn into boards, and made himself thereof a coffin ; and, if I mistake ot, left enough to make his wife one also. Both the parties were corpulent; nd, therefore, you may imagine the tree could not be small." Evelyn menons some large holly-trees near his own place, at Wooton, in Surry, in the eighbourhood of which was once a fort called "Holmsdale Castle," from, as he upposes, the number of holms or hollies, which once grew there. The names f "Holmsdale," "Holmwood," and "Holme Castle," occur in various parts of cotland, and are generally supposed to have been applied in consequence of the bundance of hollies at these places at the times the names were given. Hayes zentions a variegated silver holly at Ballygannon, in Ireland, twenty-five feet igh, with a trunk five feet in circumference; and another, on Innisfallen Island, a the lake of Killarney, with a trunk fifteen feet in circumference, and of about he same height before it began to branch out.

The largest holly in England, is at Claremont, in Surry. It grows in a sandy oam or gravel, and in 1835, measured eighty feet in height, with a trunk two eet, two inches in diameter, and an ambitus, or spread of branches, of twentyve feet.

At Paris, in the Jardin des Plantes, there is a tree of this species, which ttained the height of thirty feet in fifty years after planting. And Baudrillart peaks of holly hedges, in France, that are upwards of two hundred years old. In Prussia, the holly grows wild in a forest twenty miles from Berlin, neverheless, in the botanic garden of that city, it requires protection during winter. In Italy, at Monza, there is a tree of this species, which attained the height of wenty feet in thirty years after planting.

The European holly was probably among the first trees introduced into North Imerica by the early settlers, but owing to the severity of our climate in winter, appears not to have thrived north of the Potomac. There are several fine pecimens of this tree in Virginia, which have long been standing there, and robably were planted soon after the settlement of Jamestown, in 1607.

Poetical and Legendary Allusions. In the language of poets, thiș tree is 
regarded as a symbol of foresight, and was considered by the ancient Romans as an emblem of "peace and good-will." The disciples of Zoroaster believed that the sun never shadows the holly-tree; and the followers of that philosopher, who still remain in Persia and India, are said to throw water impregnated with the bark of this tree in the face of a newly-born child. A number of curious carols, and other verses, ancient and modern, in reference to the holly, will be found in Forster's "Calendar," and an elegant poem by Southey, alluding to the circumstance of the lower leaves of large plants being spinous, while the upper ones are entire, is printed in Johnston's " Flora of Berwick upon Tweed," from which we make the following extract:-

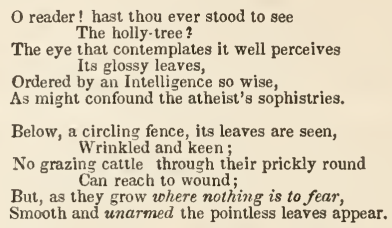

In ancient times, Pliny tells us that "Tiburtus built the city of Tibur near three holly-trees; over which he had observed the flight of birds that pointed out the spot whereon the gods had fixed for its erection;" and that these trees were standing in his own time, and must, therefore, have been upwards of twelve hundred years old.

Soil and Situation. The holly, according to Loudon, attains its largest size in a rich, sandy loam; but it will grow, and even thrive, in almost any soil, provided it is not overcharged with moisture. Cook says, it does best on soils somewhat gravelly; Miller, that it prospers on gravel over chalk; and Boutcher, that it refuses not almost any sort of barren ground, hot or cold; in short, it is found on all soils, except in bogs or marshes. The largest hollies at Surry and Kent, are in loam or chalk; those at Tyningham are on a deep, alluvial sand; and those in Aberdeenshire, on granitic clay. The most favourable situation for the holly, in England, is said to be a thinly scattered wood of oaks, in the intervals of which, it grows up at once sheltered and partially shaded. Yet it will thrive completely beneath the shade and drip of other trees; for which reason it is surpassed, as undergrowth, by no other evergreen shrub or tree, except the box.

Propagation and Culture. The holly may be propagated by seeds, by cuttings, or by budding and grafting. As the seeds, like those of the hawthorn, do not come up the first year, the berries, in England, are commonly buried in the soil, or kept mixed up in a heap of earth for one year. Mr. Loudon recommends mixing the berries as soon as gathered, in a heap of earth, which should be turned over several times in the course of the season, to facilitate the decomposition of the pulp and husks. This will generally be effected by the autumn succeeding that in which they are gathered from the tree; and they may then be taken, and separated from the earth, with which they are mixed, by sifting, and sown in beds of finely prepared soil, and covered to a depth of about a quarter of an inch. Thus prepared, when sown in autumn, they will come up the June following. A covering of half-rotten leaves, or of straw, placed over the seed-beds, will protect the soil from extreme heat and drought, and will greatly facilitate the progress of the germination. As the holly is liable to suffer from transplanting, it should never be kept in the nursery longer than two years in one place. When the seeds are to be sown immediately after gathering, Boutcher directs that the berries should remain on the trees till December; or, if they could be kept out of the reach of birds, till February or March. As soon 
s they are gathered, he says, "throw them into a tub with water, and rub them etween your hands till the seeds are divested of their thick, glutinous covering; our off the water, with the light seeds that swim, the mucilage, \&c., and spread ne sound seeds on a cloth, in a dry, airy place, rubbing them often, and giving nem a fresh cloth daily till they are quite dry. If this be done in autumn or inter, mix them with sand, and keep them dry till spring; but, if they have een gathered in spring, let them be sown immediately." "When cuttings are ade choice of for the propagation of the holly, they are selected in autımn, of e ripened summer shoots. They are planted in a sandy soil, in a shady bor$\mathrm{er}$, and covered with hand-glasses; and they generally strike root the following pring. It has been found by experience, that cuttings of trees and shrubs genellly, which are grown nearest the ground, or on the north side of the tree, and planted as to be kept moist and shaded, always take root more readily than 1ose which have been taken from the summit, and more exposed to the influnce of light and air, the moisture and shade being the predisposing causes of le production of the roots. The operations of budding and grafting may be erformed at the usual times and in the usual manner; but it has been observed y Tschoudi, that cleft-grafting does not succeed nearly so well with the holly whip-grafting. In England, the stocks budded or grafted, are generally of ur or five years' growth; and the grafting is performed in March, and the buding in July. No plant requires less care than the holly, when it is once estabshed. This species rarely needs pruning; and the varieties which have been rafted or budded require little more than the removal of shoots from the stock. 'o prepare them for removal, however, whether of a large or small size, they ight to be taken up and replanted every other year. The seasons most usually dopted for the transplanting of evergreens, are the spring, and in mild weather ininter, although summer and autumn are generally stated to be the proper mes for performing that work. The principle which justifies the practice of emoving them in winter or spring is, that most plants are more safely removed then they are in a comparatively dormant state, and when the weather is temerate, the air moist and still, rather than dry and in motion. It is well known lat the greatest degree of torpidity in plants or trees exists a short time before ney begin to germinate or push out shoots; consequently, as evergreens begin grow only a week or two later than deciduous trees of the same climate, the roper time for transplanting them must be nearly the same. The chief difrence to be observed is, the circumstance of evergreen trees being at no time hatever in so completely a dormant state as deciduous ones; and hence, such reather in winter, autumn, or spring, must be chosen for removing them, as ill least affect their fibrous roots and leaves by evaporation. When the holly to be planted as a hedge, if it is desirable that the growth shall be rapid, the oil ought to be trenched to the depth of three or four feet. If the subsoil be oor, it is recommended to dig a trench, in the direction of the intended hedge, aree or four feet wide, and as many deep, and to fill up the space with good urface soil taken from the neighbouring ground or elsewhere. The soil in the ench should be raised at least a foot above the adjoining surface, to allow for ettling; and along the middle of this ridge, the plants should be set from one oot to eighteen inches apart. According to Miller, holly hedges should never e clipped, because, when the leaves are cut through the middle, they are renered unsightly; and the shoots should therefore be cut with a knife close to a eaf. This mode, undoubtedly, is more appropriate for hedges in gardens and leasure-grounds, where it is desirable to preserve an effect more pleasing to the ye; but, as this method leaves a rougher exterior surface, and involves a much reater expense than clipping, it is unsuitable where the object is to prevent irds from building in the hedges, and to maintain effective fences at the least 
expense. The proper time for clipping appears to be just after the leaves have arrived at maturity; because at that season, in the holly, as in the box, the wound is repaired, in a measure, by the healing over, prodnced by the remaining sap, still in circulation. When it is desired to cultivate the holly for timber, it should be grown in the same manner as in close plantations, either with or without nurse-trees, according to the situation; and the stems should be deprived of their side branches, when they are less than half an inch in diameter, to at certain height, say one fourth of the entire height of the tree, in order to have a clean trunk.

Properties and Uses. The wood of the holly is almost of an ivory whiteness, except near the centre of very old trunks, where it is of a brownish hue. It is very hard and compact, with a fine grain, and susceptible of a high degree of polish, which renders it well adapted for many purposes in the arts. When dry, it weighs forty-seven and a half pounds to a cubic foot, and is very retentive of its sap, in consequence of which, it is liable to warp, unless it is well dried and seasoned before being used. It readily takes a durable colour of almost any shade, and hence it is much used by cabinet-makers in forming what are technically called "strings and borders," in ornamental works. When properly stained black, its colour and lustre are little inferior to those of ebony. It may be applied to a great number of purposes by joiners, cabinet-makers, turners, engineers, mathematical instrument-makers, and, next to the box and pear-tree, it is the best wood for engraving upon, as it is compact, and stands the tool well. Among its principal uses in England, at present, is, when dyed black, to be substituted for ebony, in the handles of metallic teapots, \&c. In France, the young shoots and the branches are given to sheep and deer, during winter; and the stronger straight shoots, deprived of their bark, are made into whip-handles and walking-canes. The bark of the holly contains an abundance of viscid matter; and, when macerated in water, fermented, and then separated from the fibres, it forms bird-lime. Medicinally, the bark of this tree is mucilaginous, emollient, and solvent, and is said to possess strong febrifugal powers. The berries are purgative, and six or eight of them, when swallowed, will cause violent vomiting; though they are considered as poisonous to men, they form the food of some birds, more especially of the thrushes.

As a hedge plant, in temperate climates, the holly forms, perhaps, the most impenetrable and the most durable of all live fences; and it has this superior advantage over deciduous-leaved trees, that it is seldom attacked by insects, and will well endure the shears. Its chief objection is the very indifferent progress which it makes for the first few years after planting; but, after it becomes established in a suitable soil, or about its third or fourth year, there are but few hedgeplants that will surpass it in their growth. It may be carried to a great height, and, consequently, is well adapted for situations where strength and shelter are required, especially during winter, when most other hedges are deprived of their leaves.

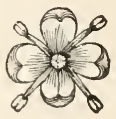




\section{Ilex opaca, \\ THE AMERICAN HOLLY.}

\begin{tabular}{|c|c|}
\hline \multicolumn{2}{|c|}{ Synonymes. } \\
\hline Ilex opaca, & $\left\{\begin{array}{l}\text { Aiton, Hortus Kewensis. } \\
\text { DE CANDolLE, Prodromus. } \\
\text { MichaUx, North American Sylva. } \\
\text { Loudon, Arboretum Britannicum. } \\
\text { ToRREy and Gray, Flora of North America }\end{array}\right.$ \\
\hline $\begin{array}{l}\text { Houx de l'Amerique, } \\
\text { Amerikanischer Stechpalmenbaum, } \\
\text { Agrifoglio a foglio di quercia, } \\
\text { Agrifolio americano, } \\
\text { American Holly, }\end{array}$ & $\begin{array}{l}\text { France. } \\
\text { Germany. } \\
\text { Italy. } \\
\text { Spain and Portugal. } \\
\text { Britain and Anglo-America. }\end{array}$ \\
\hline
\end{tabular}

Derivation. The specific name, opaca, is derived from the Latin opacus, thick, bushy, as if giving shade.

Engrcvings. Michaux, North American Sylva, pl. 84; Loudon, Arboretum Britannicum, v., pl. 66; and the figures berow. pecific Characters. Leaves ovate, flat, coriaceous, acute, toothed in a scolloped manner, spiny, and gla brous, but not glossy. Flowers scattered at the base of only those branches that are a year old. Teeth of the calyx acute. Sexes diœcious. - De Candolle, Prodromus.

\section{Description.}

14. 200

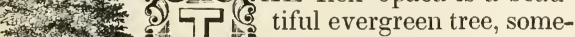
13 o times growing to the - 12 trunk four feet in diameter; but its ordinary eight, in favourable situations, is not more than nirty or forty feet, with a diameter of twelve or fteen inches; and near its northernmost limits is seldom found to exceed ten feet in height. he bark of the trunks of old trees is smooth, and f a whitish-gray; but on the young shoots and ranches it is green and shining. The leaves are vate, acute, spinous, glabrous, and flat; and are $f$ a light-green colour. The flowers, which apear in the months of May and June, are whitish, ut not conspicuous, and are succeeded by handome, round, scarlet berries, that remain long ttached to the branches, often during the winter.

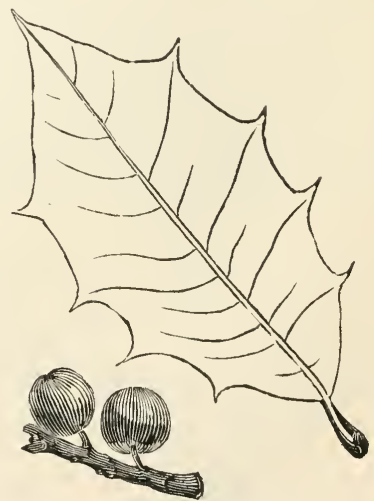

Varieties. The only distinct variety of this species is the Ilex opaca laxicolia, which is found in Carolina, with loose, whitish flowers, and yellowish-red erries. The following variations, however, are mentioned by Loudon, on the uthority of Rafinesque, but it may be questioned whether they were not mostly educed from leaves of trees of different ages, or in the early period of their rowth :-

1. I. o. MACrodon. Long-toothed-leaved variety.

2. I. o. LATIFOLIA. Broad-leaved variety.

3. I. o. ACUMinata. Sharp-pointed-leaved variety.

4. I. o. GLoвosa. Round-leaved variety.

Geography and History. The northernmost limits of this species may be con. idered as Quincy and Cohasset, in Massachusetts; and it is found more or less 
abundantly along the maritime parts of the United States, to the Floridas, and also in lower Louisiana, and western Tennessee; but it is observed to become rare in approaching the mountains. It was introduced into Britain in 1744, and is cultivated in many of the European gardens and collections. The largest trees of this kind recorded in England are in the gardens at the Walton House, at Syon, and at White Knights, near Reading. 'The height of those at Syon exceed twenty-five feet.

There are several fine specimens of the Ilex opaca on the farm of Colonel Minott Thayer, in Braintree, Massachusetts, which are about a foot in diameter, a yard above the ground, and twenty-five feet in height. They have maintained their present dimensions for more than fifty years, and probably are several centuries old.

Soil, Situation, \&.c. In New Jersey, and on the eastern shore of Maryland, and in certain parts of Virginia, where it is particularly abundant, this species grows almost exclusively on open grounds, and in dry, gravelly soils; while in South Carolina, Georgia, and lower Louisiana, it is seen only in shady places, on the edges of swamps, where the soil is cool and fertile. In Massachusetts, Rhode Island, and Connecticut, it usually grows in a warm, sandy loam, and in sheltered situations. It may be propagated in the same manner as the European holly, and formed into hedges, or cultivated as an ornamental tree in gardens.

Properties and Uses. The wood of the American holly resembles that of the European species, except that it is rather browner at the heart. It is compact, heavy, of a fine grain, and is susceptible of a brilliant polish. Its principal use is for inlaying mahogany furniture, and for turning into small boxes for druggists, and for small screws. When perfectly seasoned, it is very hard and unyielding, which renders it well adapted for pulleys used in ships. It may be dyed of various colours, so as to resemble many foreign woods. The bark may be employed for making bird-lime, in a similar manner as that of the preceding species. Medicinally, it is emetic and cathartic. The berries, taken to the number of fifteen or twenty, will excite vomiting, and will also act as a purgative.

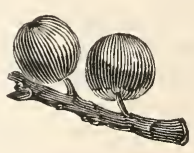


head. It was an annual custom for a chief to give notice to the inhabitants of a town, in spring, to assemble at the public house, which was previously purified by fire. After they had convened, the chief was first served with a bowl or conch-shell, never before used, of their emetic broth; and next to him were served each individual of the company, according to his rank, till at last they came to the women and children. They had a belief that this beverage restored lost appetite, strengthened the stomach, and gave them agility and courage in war. Lawson, in recording a tradition of this tree, says: "The savages of Carolina have it in veneration above all the plants they are acquainted withal, and tell you the discovery thereof was by an infirm Indian, who laboured under the burden of many rugged distempers, and could not be cured by all the doctors; so, one day he fell asleep, and dreamt that if he took a decoction of the tree that grew at his head, he would certainly be cured; upon which he awoke, and saw the Yaupon or Cassine-tree, which was not there when he fell asleep. $\mathrm{He}$ followed the direction of his dream, and became perfectly well in a short time." Among some of the tribes, it was held in such high esteem, that the decoction of its toasted leaves, called "black drink," was forbidden to be used by their women.

Properties, Uses, $\& \cdot c$. The leaves and young shoots of the cassena are inodorous, the taste sub-aromatic and fervid, being useful in stomach fevers, diabetes, small-pox, \&c., as a mild emetic; but the "black drink" of the Indians is a strong decoction, and a violent, though harmless vomitive. At a certain season of the year they often travel a distance of some hundred miles, from parts where this tree does not grow, to procure a supply of the leaves. They make a fire on the ground, and putting a kettle of water on it, filled with leaves, place themselves around it, and with a wooden vessel holding about a pint, commence by taking large draughts, which, in a short time, cause them to vomit freely. Thus they continue drinking and vomiting for two or three days, until they are sufficiently purified, when they return, with large quantities of the leaves and boughs, to their homes. The leaves and young shoots of the Ilex cassena and dahoon, and of many other shrubs, appear to be substituted indiscriminately by the Indians for making their "black drink." In North Carolina, it is said, the inhabitants of the sea-side swamps, having no good water to drink, disguise its taste by boiling in it a little cassena, or other plants of a similar nature, and use it constantly warm, as the Chinese do their daily tea. This circumstance gave rise to the opinion that this species was the Ilex paraguariensis, and was erroneously called "Paraguay Tea."

This tree may be cultivated by seeds or by layers, in a similar manner, and in the same kind of snil as the Ilex opaca; but its situation should be more sheltered.

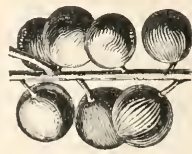


Ilex paraguariensis,

\section{THE PARAGUAY TEA.}

Synonymes.

Ilex paraguayensis,

Ilex paraguariensis,

Maté,

The Peragua, Maté,

Yerba maté, Yerba de palos,

Gongonha,

Caa,

Paraguay Tea, Maté,
Lambert, Monograph of the Genus Pinus.

S St. Hilaire, Histoire des Plantes du Brés1 ${ }_{4}$.

De Candolle, Prodromus.

France.

ITALY.

Spain and Spanish America.

BraziL.

GUarani Indians.

Britain and Anglo-America.

Derivations. The word Mate, is applied by the South American Spaniards, to the cup or vessel from which the hot liquid is imbibed; whence the name of the herb. The Spanish name, Yerba de palos, signifies Tree-herb.

Engravings. Lambert, Monograph of the Genus Pinus, pl. ii.; Hooker, London Journal of Botany, vol. i., pl. 1; Loudon, Arboretum Britannicum, vol. ii., figure 189; and the figures below.

Specific Characters. Evergreen. Leaves glabrous, lanceolately-cuneated, oblong-oval, obtuse, remotely serrated. Drupes with persistent calyxes crowned with 4-lobed stigmas.

\section{Description.}

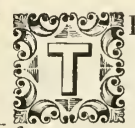

HE Ilex paragua-
riensis, when un-
obstructed in its
growth, usually attains a height of twenty or thirty feet, with a trunk sometimes a foot or more in diameter. In places, however, where the leaf is regularly gathered, it becomes stunted, from the branches being cut every two or three years, but not oftener, owing to an opinion that this time is requisite to season the leaves, which remain, during winter, upon the trees. The bark of the trunk is smooth, shining, and whitish; and the boughs, which spring upwards like those of the laurel, are leafy and tufted. The leaves are elliptic, cuneiform, from four to five inches long; thick, glossy, crenated, of a dark-green above, and paler below. The petioles are of a dark-red, and about half an inch in length. The flowers,

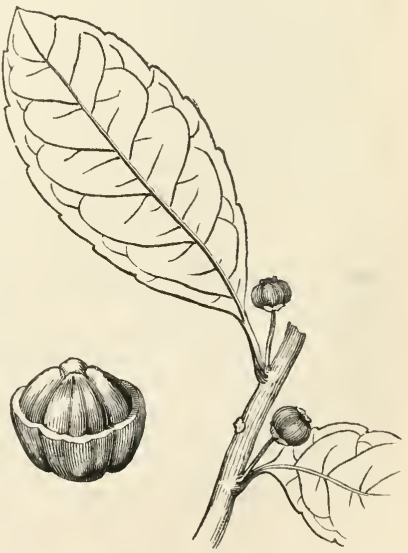
which appear in October and November, in its native country, are produced in umbels of thirty or forty florets each, with four whitish petals, and with the same number of stamens. The berries are red, very smooth, about the size of small peas, and containing four nuts or seeds.

Varieties. The two following races usually considered as species, and described under the name of Ilex gongonha, may be regarded only as varieties of the same plant:-

1. I. p. Parvifolium. Small-leaved Paraguay Tea.

2. I. P. angustifolium. Narrow-leaved Paraguay Tea. Both of these varieties are cultivated in the botanic garden at Rio Janeiro, and are somewhat exten- 
sively used there for tea. Their leaves are nuuch longer and narrower than those of the trees of Paraguay and the Organ Mountains, and their under surfaces are invariably dotted with minute black glands.

Geography and History. The Ilex paraguariensis is found growing spontaneously, intermingled with other trees, in the forests which cover the banks of the rivers and streams that fall into the Parana and Uruguay, as well as the sources of the Ipane and Jejui. Its principal harvest is made in the eastern part of Paraguay, and about the mountains of Maracaja, as well as in the marshy valleys which intervene between the hills. It also grows abundantly in Brazil, near Curutiba, and about the Organ Mountains, in the country adjacent to Rio Janeiro.

In the beginning of the XVIIth century, an infusion of this plant was a general beverage of the inhabitants throughout the provinces of Paraguay, and there can be no doubt but the aborigines of that country taught its use to their Spanish conquerors; for, among the creoles and mestizoes of the present day, there are many who charge the Paraguayanos with having exterminated their Indian slaves by hard labour, in gathering the leaves of this tree. In no country in the world is the Chinese tea more extensively drank, in proportion to the population, than is the yerba maté, throughout a great portion of South America. Large plantations of it are owned by the Jesuits of Paraguay, who derive a large revenue from its harvest, the annual product being estimated at five million six hundred thousand pounds, more than thirty thousand of which are carried to Chili, Ecuador, whence Lima and Quito are supplied, and the remainder is consumed in the Argentine and Cisplatine republics.

This species was introdnced into Britain in 1828, and plants are growing in the botanic garden at Glasgow, and in the garden of the Horticultural Society of London.

Properties and Uses. The people of South America attribute innumerable virtues to this tree; but most of the qualities ascribed to it are doubtful. It is certainly aperient and diuretic, and like opium, produces some singular and contrary effects. It is said to give sleep to the restless, and spirit to the torpid; and like that drug, when a habit is once contracted of using it, it is difficult to leave it off; its effect on the constitution being similar to that produced by an immoderate use of spirituous liquors. There are three kinds of the herb in the prepared state, though produced by one plant, and are called by the Indians, caa-cuys, $c a a-m i n i$, and caa-guazu; the prefix caa, signifying the tree or leaf itself. The former consists of the half-expanded buds, which will not keep long, and is entirely consumed in Paraguay. The caa-mini, is the leaf as prepared by the Jesuits, carefully picked and stripped from the nerves before roasting; while the third is made by roasting without any preparation, and is denominated by the Spaniards, yerba de palos. The amount daily gathered by a labourer is usually from one hundred to three hundred pounds. In preparing the leaves for market, a bundle of long poles is constructed, in the form of a cylindrical vault, under which a large fire is made, and upon which the branches are placed, and remain there till the leaves are sufficiently dry. After this, the fire is removed; and on the hard and hot platform, after being swept clean, they throw the branches, which they give a thorough beating. In this manner the leaves are separated from the boughs, which, after being sufficiently manipulated, are next densely packed into large bags made of hides; and in this state, without further preparation, they are fit for use; but they are not considered as seasoned till they are a few months old, as the aromatic bitterness which they possess, when newly prepared, is partially dissipated by age. The leaves are used by infusions, in Paraguay, Uruguay, the Argentine republic, Chili, Peru, and Ecuador, by all classes of persons, and at all hours of the day. The creoles drink the infusion 
In a pot, called maté, from the spout of which the tea is drunk, witlı or without a little burnt sugar, cinnamon, or lemon juice. They drink it at every meal, and seldom eat before they have taken some of it. The more wealthy and refined portion of the population partake of the infusion from a maté or teapot, formed of silver or other materials, by means of a tin or silver pipe, called bombilla, perforated with holes at one end, to prevent swallowing the pulverized herb which floats on the surface. The quantity of leaves used by a person who is fond of it, is an ounce. It is customary, in good society, to supply each of the party with a maté and pipe, with the infusion as near as possible to a boiling temperature, which, those who are habituated to its use, can swallow without inconvenience; but often the whole household and their visitors are supplied by handing the maté from one to another, filling it up with hot water as fast as it becomes exhausted. If the water is suffered to remain long on the leaves, the decoction becomes of an inky blackness. The taste of the leaves, when green, somewhat -resembles that of the mallows, or the inferior kinds of green tea from China. Mr. Stenhouse, of Glasgow, has recently detected an alkali in them, not dissimilar to theine, a bitter tonic substance, which is found in the leaves of the tea of China, and the Paulliania sorbilis of the banks of the Amazon, and which is also identical with caffeine, obtained from the seeds of coffee, and theobromine, the principle yielded by chocolate. On this subject Liebig remarks, "We shall never, certainly, be able to discover how mankind were led to the use of the hot infusion of the leaves of a certain shrub, (tea,) and of a decoction of certain roasted seeds (coffee.) Some cause there must be which would explain how the practice has become a necessary of life to whole nations. But it is still more remarkable that the beneficial effects of both plants, on the health, must be ascribed to one and the same substance, the presence of which, in two vegetables, belonging to different natural families, and the products of different quarters of the globe, could hardly have presented itself to the boldest imagination." **

The Ilex paraguariensis is highly ornamental, and doubtless would flourish in any soil and situation where the Magnolia grandiflora would thrive. Hence, its introduction into the middle and southern sections of the union is well worthy of the attention of all who have proper conveniences for cultivating it.

* While on this subject it may be interesting to notice incidentally, the plants employed as tea in various countries of the globe. In China, Thea bohea and viridis mixed with the leaves of Camelia sasanqna and oleifera, and sometimes with those of Olea fragrans; also Rhamnus theezans; New Holland and Kurile Isles, Correa alba; Kamtschatka, Pedicularis lanata; Argentine Republic, Paraguay, \&c., Ilex paraguariensis; Brazil, Thea bohea, Ilex paraguariensis, and Paulliania sorbilis, from which the people on the banks of the Amazon make a beverage called guarana; New Granada, Alstonia theaformis, which is said to be equal to the tea of China; Chili and Mexico, Psoralia glandulosa or "culen;" Carolina, Georgia, and Florida, Mex vomitoria, or cassena ; Virginia, Pennsylvania, \&c., Gaultheria procumbens, or mountain tea, which, when properly cured, is much esteemed; also, Ceanothus americanus, or New Jersey tea, (having actually been used in the revolutionary war as a substitute for tea,) and Solidago odora or golden-rod, the flowers of which, gathered when fully expanded, and carefully dried, afford a most agreeable substitute for tea, and in former times were exported to China, where they brought a high price; and in Canada, Labrador, \&c., Ledum latifolium, Indian or Labrador tea. 


\section{Genus RHAMNUS, Lam.}

Rhamnaceæ.
Syst. Nat.
Pentandria Monogynia.

Syst. Lin.

Derivation. The name Rhamnus was derived from the Celtic word, ram, signifying a tuft of branches; which the Greeks changed to rhamnos, the Romans to ramus, and the French to rame, or in old French, rerm.

Feneric Characters. Calyx urceolate, 4-5-cleft. Petals 4-5, emarginate or 2-lobed, usually more or less convolute. Torus thin, lining the tube of the calyx. Ovary free from the calyx, not immersed in the torus, 2-4-celled; styles 2-4, distinct or more or less connected. Fruit drupaceous, containing $2-4$ cartilaginous nuts. ***** Leaves alternate or rarely opposite, on short petioles. Flowers minute, usually in short, axillary clusters.-Torrey and Gray, Flora.

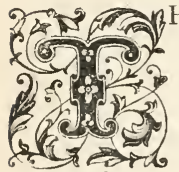

HIS genus is composed of deciduous and evergreen shrubs, one or more of them with the habit of low trees, and some of them subprocumbent, or procumbent; and all of theni, except the latter, are distinguished by an upright, stiff mode of growth, with numerous strong thorns in their wild state. Many of those described by botanical writers as species, are doubtless, only varieties; but till l.. whole are brought together and cultivated in one garden, this cannot be determined. The flowers in all are inconspicuous; but the Rhamnus alaternus and its varieties are most valuable evergreen shrubs, and several of the other species are ornamental, both from their foliage and their fruit, the latter of which is also useful in dyeing. The article of commerce, known under the names of French or yellow berries, graine de jaune, graine d'Avignon, graine de Perse, graine d'Espagne, graine du Levant, \&c., are produced by the Rhamnus infectorius, oleöides, amygdalinus, and saxatilis. The Rhamnus frangula, known in France by the name of bourdaine, is preferred to all other kinds of wood for making charcoal employed in the manufacture of gunpowder. The leaves of the Rhamnus theezans are substituted in China for those of tea. The fruit of the Rhamnus ziziphus is employed throughout the southern or temperate parts of Europe, in the manufacture of jujubes. The species procurable in nurseries, and well deserving of cultivation, are the Rhamnus alaternus, hybridus, alpinus, frangula, saxatilis, latifolius, and catharticus, the latter of which, from its medicinal qualities, and utility for live fences, is worthy of particular consideration. 


\section{Rhammus catharticus, \\ THE PURGING BUCKTHORN.}

Synonymes.

\section{Rhamnus catharticus,}

Nerprun cathartique, Abführender Kreuzdorn, Ramno catartico, Ramno purgativo, White Thorn, Buckthorn,

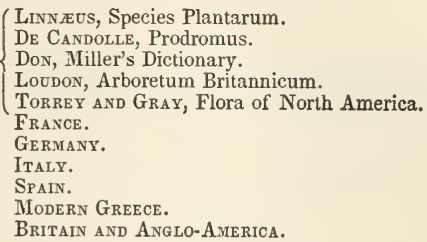

Derivation. The specific name, catharticus, is derived from the Greek kathairo, to purge, from the medicinal nature of the berries of this tree.

Engravings. Woodville, Medical Botany, pl. 114; Loudon, Arboretum Britannicum, ii., figure 198, et v., pl. 70, and the figures below.

Specific Characters. Erect. Leaves ovate, toothed. Flowers in fascicles, polygamo-diœcious. Berries 4-seeded, rather globose.-Don, Miller's Dict.

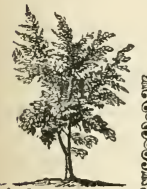
in a state of cultivation. It naturally partakes the character of a bush, unless it is carefully trained to a single stem. Its branches are numerous and irregular, the young shoots of which have a smooth, grayish-brown bark; but the older branches are rough and armed with short thorns. The leaves on old trees are ribbed, smooth, about an inch in length, and from half an inch to three-fourths of an inch in width, and of a bright-green colour; but on young plants, or in hedges, they are often found from two inches to two inches and a half in length, and nearly as broad as they are long. The flowers, which appear in May and June, are of a yellowish-green colour. They are, for the most part, hermaphrodite, clustered when grown wild, but fewer and nearly solitary in a state of cultivation. The berries are of a bluishblack, globular in their form, with four cells, and as many seeds, and are ripe in Britain and the northern parts of the United States in October. It often remains on the tree after the leaves have fallen.

Geography and History. The Rhamnus catharticus is indigenous to Europe and the north of Asia. In Britain it is found native in the woods, and according to Pallas, it is common in the southern parts of Siberia. It has also become indigenous in the vicinity of Boston, in Massachusetts, and near West Point, 
New York, and is cultivated for use and ornament in the various countries of Europe and of North America.

The first cultivated tree of this species in the United States, of which we have any record, stood in the garden of the venerable Dr. Holyoke, in Salem, Massachusetts. It bore an abundance of fruit, which was long used by him, in his practice, as a cathartic. On the estate of Mr. E. Hersey Derby, in that town, there are several buckthorn-trees, from thirty to forty years planted, which have attained a height of twelve or fifteen feet, and bear an abundance of berries every year.

Propagation, Culture, Uses, \&ैc. The Rhamnus catharticus, in common with most plants of its genus, may be easily propagated by seeds, or by cuttings and layers. It prefers a rich, moist soil, in rather a shady situation; but it will thrive in any place where the current or gooseberry will succeed. It is cultivated in Europe as an ornamental shrub, and is becoming of great utility in America as a hedge-plant, as will be seen by the following extract from Mr. Derby's paper in the "Transactions of the Essex Agricultural Society." "In the year 1808, I happened to have some young plants which had come up from the chance-scattered seeds of the American buckthorn,* and finding they had made a good growth in the nursery to which they had been removed, I determined to try to form a hedge of them, and I have been well pleased with the result. They were set out in 1809, and very soon became a fine hedge, of about twenty rods in length, which has remained so until the present time, [Sept. 1842] not a single plant having failed from it, nor have I ever known it to be attacked by any insect. This hedge being my first experiment with the buckthorn, I did not keep it down so closely as I have since found it expedient to do, and consequently it is not quite so impervious at the bottom as some of my younger hedges, which have been more severely pruned. Being fully satisfied that I had at last found the plant I wanted, I have, since that time, set out various hedges of it, at different periods, until I can now measure one hundred and sixty rods of them, all, in my opinion, good hedges; and I do not hesitate to pronounce the buckthorn the most suitable plant for the purpose that I have ever met with. It vegetates early in the spring, and retains its verdure late in autumn. I have often seen it green after the snow had fallen. Being a native plant, it is never injured by our most intense cold, and its vitality is so great that the young plants may be kept out of the ground for a long time, or transported any distance without injury. It never sends up any suckers, nor is disfigured by any dead wood; it can be clipped into any shape which the caprice or ingenuity of the gardener may devise; and being pliable, it may be trained into an arch, or over a passage-way, as easily as a vine; it needs no plashing or interlacing, the natural growth of the plants being sufficiently interwoven. It is never cankered by unskilful clipping, but will bear the knife to any degree. During the last winter, I found one of my hedges had grown too high, casting too much shadow over a portion of my garden, and wishing to try how much it would endure, I directed my gardener to cut it down within four feet of the ground. This was done in mid-winter, and not without some misgivings on my own part, and much discouraging advice from others; but it leaved out as early in the spring as other hedges, and is now a mass of verdure. I have been applied to for young plants by persons who have seen and admired my hedges, and have sent them to various states in the union, and I have never, in any instance, heard of their failure.

"My method of forming a hedge is to set the young plants in a single row, about nine inches apart, either in the spring or autumn; if the latter, I should clip it in the following spring, within six inches of the ground; this will cause

* The writer believing it to be a native plant. 
the hedge to be thick at the bottom, which I regard as a great point of excellence; after this, all that remains to be done is to keep it from weeds, and clip it once a year. I consider June as the best time to trim it, as it soonest recovers its beauty at that season. The clipping may be done either with the gardenshears, a hedge-knife, or even with a common scythe."

The adjoining figure will show a pleasing mode of growing a hedge of this species in front of a dwelling, or in enclosing ornamental grounds. As the plants will attain a considerable height, they may be trained over an arch or trellis, and form a beautiful, densely-shaded arbour or walk.

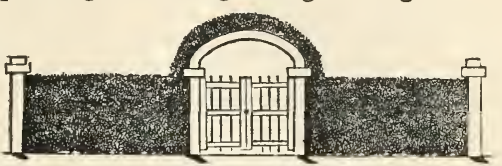

It appears from the above that this species is very eligible for forming hedges, in consequence of its robust and rigid habit of growth. Although it does not make much show, when in flower, yet in autumn and early winter, when profusely covered with black berries, it becomes highly ornamental.

The wood of the Rhamnus catharticus is hard, compact, and of a reddish hue. The juice of the unripe berries has the colour of saffron, and is used for staining paper and maps. They are known in commerce under the name of French berries. The juice of the ripe berries, evaporated to dryness with lime or alum, is the sap-green of painters; but if the berries are gathered late in autumn, their juice is purple. They are strongly purgative, if eaten to the number of twentyfive or thirty, while an ounce of the expressed juice is required to produce the same effect. They were formerly much employed as a cathartic, but the violent operation, and the sickness, griping and thirst occasioned by them, have led to their disuse. The syrup of buckthorn, (syrupus rhamni,) is the only preparation at present employed in Pharmacy. The inner bark of this tree affords a beautiful yellow die, and like that of the common elder, is a strong cathartic, when taken, and excites vomiting. 


\section{Genus PISTACIA, Linn.}

Anacardiaceæ.

Syst. Nat.
Diœeia Pentandria. Syst. Lin.

Synonymes.

Pistacia, Terebinthus,

OF Authors.

Dertvations. The word Pistacia, is derived from the Greek pistakia, or, according to some, from the Arabic foustaq, the name of the true pistachio. Terebinthus is derived from the Greek terebinthos, the name of the Turpentine-tree.

Generic Characters. The sexes are diœeious, and the flowers without petals. In the male plants, the flowers are disposed in racemes that resemble catkins; every flower is bracteated by a scale; the calex is 5-cleft; and the stamens are 5, inserted into a calycine disk, or into a calyx, and have 4-cornered, almost sessile :nthers. In female plants, the flowers are disposed in a raceme, less closely than in the male; the caly $\mathrm{x}$ is 3-4-cleft; the ovary is $1-3$-celled; the stigmas are three, and thickish; and the fruit is a dry; ovate drupe, the nut of which is rather bony, and usually 1-celled, though sometimes it shows two abortive cells at the side; the cell contains a single seed, which is affixed to the bottom. The cotyledons of the seeds are thick, fleshy, and oily, and bent back upon the radicls. The species are trees with pinnate leaves. - De Candolle, Prodromus.

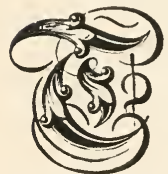

HE genus Pistacia is chiefly confined to western Asia, southem Europe, and northern Africa. The four principal species are the Pistacia vera or true pistacia; the Pistacia terebinthus or Venetian turpentine-tree, which produces the Venetian and Chian turpentine, used for manufacturing sealing-wax; the Pistacia lentiscus, or mastic tree, which produces the mastic of commerce; and the Pistacia atlantica, or Mount Atlas turpentine-tree. Mastic and turpentine are regarded as astringent and diuretic; although they retain a place in Materia Medica, they are not much used by modern practitioners. Mastic is employed by the Turkish and Armenian women as a masticatory for cleaning their teeth, and for imparting an agreeable odour to their breath. It is also used to fill the cavities of carious teeth. 


\section{Pistacia vera, \\ THE TRUE PISTACHIO NUT-TREE.}

Synonymes.

Pistacia vera,

Pistacia officinarum,

Pistachier,

Pistazienbaum,

Pistacchio, Pistacchio verde,

Alfocigo, Alhocigo,

Alfostigo,

Pistacia, Pistachio Nut-tree,

\author{
Linnexus, Species Plantarum. \\ De Candolle, Prodromus. \\ $\{$ Michadx, North American Sylva. \\ Don, Miller's Dictionary. \\ Loudos, Arboretum Britannicum. \\ Arton, Hortus Kewensis. \\ France. \\ Germany. \\ ITALX. \\ Spain. \\ Portugal. \\ Britain and Anglo-America.
}

Engravings. Michaux, North American Sylva, pl. 103; Loudon, Arboretum Britannicum, ii., figure 221 ; and the figures below.

Specific Characters. Leaves deciduous, impari-pinnate, of $3 \rightarrow 5$ leaflets, rarely of 1 ; the leaflets ovate, a little tapered at the base, indistinctly mucronate at the tip.-De Candolle, Prodromus.

\section{Description.}

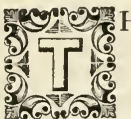

HE True Pistachio, in favourable situations, attains a height of fifteen or twenty feet, and often, when a mere shrub, produces fruit in five or six years after planting. The trunk is clothed with a grayish bark. The branches are spreading, but not very numerous, and are garnished with winged, alternate leaves, on long petioles. The inflorescence takes place in April and May. The male flowers, which appear first, shoot out from the side of the branches in loose panicles, and are of an herbaceous colour. The female flowers put forth in clusters, in the same manner. The fruit is oval, and about the size of an olive. It is furrowed, of a reddish colour, and contains an oily kernel, mild and agreeable to the taste.

Varieties. According to some authors, the

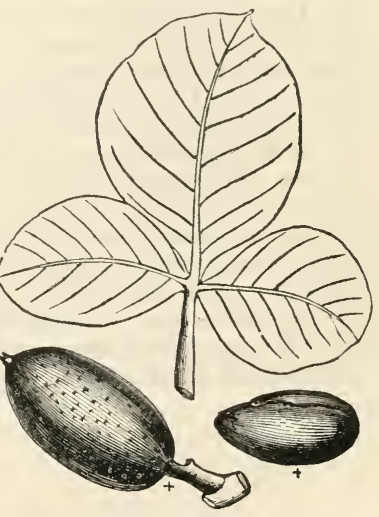
following races are regarded as species; but Du Hamel says that they are by no means entitled to be so considered. They differ only in the size, shape, and consistency of their leaflets.

1. P. v. trifolia, Loudon. Three-leafleted-leaved Pistachio-tree.

2. P. v. narbonensis, Loudon. Narbonne Pistachio-tree. This variety has . pinnate leaves, with leaflets having prominent veins.

Gengraphy and History. The Pistacia vera is a native of Syria, Barbary, Persia, and Arabia. It was brought from Syria to Italy by the Emperor Vitellius, in the IId century, and afterwards found its way into the south of France, where it is so far naturalized, as to appear in some places as indigenous. It was 
introduced into Britain in 1770 , where, in sheltered situations, it will bear the cold of ordinary winters without covering; but, in severe frosts, they are often destroyed. Miller observes that this tree flowers and produces fruit freely in England; but the summers are not warm enough to ripen the nuts. He mentions a tree in Dr. Compton's garden, at Fulham, upwards of forty years old, planted against a wall; and another which had been planted as a standard, in the Duke of Richmond's grounds, at Goodwood, in Sussex, where it had stood many years without the slightest protection.

Soil, Culture, $\& \circ c$. This species will grow in any common garden soil, and may be propagated either from nuts, specially put up abroad, or even from those of commerce, and by cuttings. It is cultivated in the south of France and in Italy for its fruit. As the male flowers appear before those of the female, the Sicilian gardeners, when the trees stand far asunder, pluck bunches of the former, ready to blow, plant them in pots of moist mould, and cause them to remain suspended on the female trees till they have done flowering. This operation is called tuchiarare, and never fails to produce fructification. Sometimes the male buds are ingrafted upon the female trees, in order to produce the same effect. This tree resists a greater degree of cold than either the olive or the almond, and hence is adapted to the climate of many parts of the United States, and doubtless could be cultivated with profit.

Properties and Uses. In commerce, the fruit of this tree is known under the following names and qualities:-

1. Aleppo Pistachio-nuts, which may be distinguished by their large size, yellow interior, and usually are shipped with the external shell or husk on. When obtained fresh, these are unquestionably of the best quality known.

2. Tunis Pistachio-nuts. These are small, with a delicate, rose-coloured pulp, and of a clear green interior. They are much sought after by the French confectioners, who manufacture them into sugar-plums, by covering them with sugar or with chocolate, and sell them under the name of diablotins. Creams and ices are also composed of them, coloured green with the juice of spinach.

3. Sicily Pistachio-nuts. These vary much in their size, and may be known by their violet-coloured pulps, and rich, green kernels. They are much used in France in the preparation of sausages and other seasoned meats.

In general, the fruit of this species, is thought to be a fortifier of the stomach, and is taken to ameliorate coughs and rheums. It is frequently used as a dessert, sometimes eaten raw, but oftener in a dried state, like almonds.

As an ornamental shrub or low tree, this species is highly deserving of cultivation in the middle and southern sections of the union; and from its singular and beautiful foliage, no conservatory wall should be without it. 


\title{
Genus RHUS, Linn.
}

\author{
Anacardiacæ. \\ Syst. Nat. \\ Pentandria Trigynia. \\ Syst. Lin. \\ Synonymes. \\ Rhus, Rhamnus, Cctinus, Zizyphus, Myrica, Toxicodendron, OF Autнors. \\ Derivations. The name, Rhus, is derived from the Greek rhous, or more remotely, from the Celtic word, rhudd, a syno- \\ nyme of rud, red; in allusion to the colour of the fruit and leaves of some of the species in autumn. Cotinus is the name of \\ a tree with red wood, described by Pliny, as growing on the Apennines. The other names belong to genera which were sup. \\ posed by some botanists to include species more properly coming under the head of rhus. \\ Generic Characters. Sexes hermaphrodite, diœcious, or polygamous. Calyx small, 5-parted, persistent. \\ Petals ovate, and inserted into a calycine disk; all of them in the flowers of the male and hermaphro- \\ dite sexes bearing anthers. Ovary single, perhaps from defect, sub-globular, of 1 cell. Styles 3 , short, \\ or not any. Stigmas 3. Fruit an almost dry drupe of 1 cell, with a bony nut, which includes a single \\ seed; and, in some instances, $2-3$ seeds ; when one, perhaps, by defect. Each seed is pendulous by a \\ thread, (the raphe,) that rises from the bottom of the cell. Cotyledons leafy, their edges, on one side,
} and the radicle, in contact.-De Candolle, Prodromus.

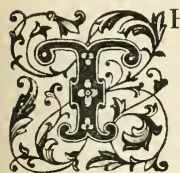

HE genus Rhus chiefly consists of deciduous shrubs, generally with alternate compound leaves, and are natives of Europe, Asia, and North and South America. The foliage widely varies, both in form and size; and, in autumn, before it falls, it changes to a yellow, dark-red, or scarlet, on which account, at that season, it is highly ornamental. Don, in "Miller's Gardeners' Dictionary," describes ninety-seven species of this genus; but Mr. Loudon was of the opinion that, if it were possible to bring them all together, and cultivate them in the same garden, he questioned much whether there would be found more than a fourth part of them entitled to be considered specifically or permanently distinct. Most of them are poisonous, some of which are highly so, and probably they all may be used in tanning, and dyeing yellow and black. The species most worthy of note, and which have been cultivated for ornament, or have been applied to useful purposes in the arts, are the Rhus typhina, venenata, aroinatica, and copallina, for ornament; and the Rhus radicans, for medicine, in North America; the Rhus cotinus and coriaria, for tanning and dyeing, of the shores of the Mediterranean; and the Rhus vernicifera, or varnish-producing sumac; of Japan and Nepal. 


\section{Rhus cotinus, \\ THE VENETIAN SUMACH.}

Synonymes.

\section{Rhus cotinus,}

Cotinus coriacea.

Sumac fustet, Arbre aux pérruques,

Perücken Sumach,

Cotino, Scotino, Roso, Ruoso,

Zumaque cabelloso,

Venice Sumach, Venus Sumach, Wild

Olive-tree, Fringe-tree,

\author{
Linsæus, Species Plantarum. \\ $\{$ De Candolle, Prodromus. \\ (Lovdon, Arboretum Britannicum. \\ Ito Hamez, Traité des Arbres et Arbustes. \\ France. \\ Germany. \\ ITALY. \\ Spain. \\ Britain and Anglo-America.
}

Dervations. The French name, Arbre aux perruques, signifies Wig-tree; on account of the large shaggy hairs which grow on the elongated pedicels. The Italian name, Scotino, is derived from the Greek skotios, obscure, or happening in the dark ; probably in allusion to the pedicels being clothed or concealed by hairs.

Engravings. Du Hamel, Traité des Arbres et Arbustes, pl. 178; Loudon, Arboretum Britannicum, ii., figure 223; and the figures below.

Specific Characters. Leaves obovate, sessile, entire, very narrow at the base, and smooth on both sides ; a great part of the flowers abortive, the pedicels at length elongated, and clothed with shaggy hairs. Corymbs axillary.

\section{Description.}

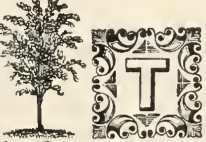

HE Venetian Sumach, in a wild state, is seldom found higher than five or six feet; but when cultivated, it often attains more than double that height, and forms a highly ornamental shrub, more especially when garnished with its large, loose panicles of elongated pedicels. It is easily distinguished from all other species of rhus by its simple, obovate, smooth, stiff, lucid, green leaves, rounded at their points, and supported by long footstalks, which do not fall till they are killed by frost, so that the plant is almost sub-evergreen. The flowers, which appear in June and July, are produced at the ends of the branches, and are of a pale purple, or flesh colour. They are composed of five small oval petals each, which spread open; and the sexes are hermaphrodite.

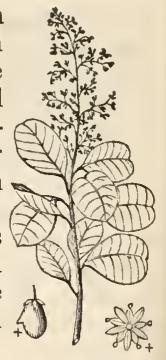
The drupes are half-heart-shaped, smooth, and veiny, containing a triangular nut.

Geography and History. The Rhus cotinus is native of sunny places in western Asia, and in southern Europe, from Spain to Caucasus; and, according to Mr. Nuttall, it is truly indigenous on the high rocky banks of Grand River, in Arkansas, North America.

This plant appears to have been known to Pliny, who mentions it as an Apennine shrub, under the name of coggygria. It was introduced into Britain in 1656, and was cultivated by Tradescant, and is described by Gerard as an excellent and most beantiful plant, "with leaves of the capparis, and the savour of the pistachia." Mr. Loudon observes that there are old plants of it at Syon ; and a very fine one at Deepden, the diameter of the head of which is nearly twenty feet; but the largest specimen in England is at Enville, in Staffordshire, where it has attained more than double that size.

This shrub was introduced into the United States by the late William Prince, of Flushing, New York, in about 1790, and may be found in most of the nurseries and collections in various parts of the country. 
Soil and Culture. This shrub prospers best in a dry loam, though it will grow in any common garden soil. It may be propagated by seeds, or by pegging down the branches flat to the ground, in the spring, and strewing earth over them. Young shoots will rise and take root at the base, which may be severed from the parent stock in autumn, and planted in pots or in the site where they are intended to remain. As an ornamental shrub, this species deserves a place in every garden and collection where there is room for it to extend itself. And there is but little doubt but it might be profitably cultivated in many parts of the United States, for the purposes of tanning and dyeing.

Uses, $\& \bullet c$. In Greece, and in the south of Russia, the whole plant is used for tanning, and for dyeing leather, wool, and silk, yellow. In Italy, particularly about Venice, it is used for dyeing black. In Syria, Palestine, France, Spain, and Portugal, this species, as well as the Rhus coriaria, are cultivated with care, if they do not grow naturally, and the shoots are cut down every year quite to the ground, which, on being dried, are reduced to powder by mills, and thus prepared for use. In the commerce of the south of France, there is another plant employed as sumach, called redoul, and known by botanists under the name of Coriaria myrtifolia. When reduced to a powder, it somewhat resembles the Sicilian sumach in colour, but may be readily distinguished from it by an unpleasant herbaceous odour, while that of the latter is fragrant, penetrating, and agreeable. 


\section{Rhus typhina, \\ THE ANTIFEBRILE RHUS.}

Synonymes.

Rhus typhina,

Sumac de Virginie,

Virginischer Sumach, Färberbaum,

Sommacco peloso, Sorbo salvatico,

Zumaque de Virginia,

Stag-horn Sumach, Virginian Sumach,

\author{
(Linnæus, Species Plantarum. \\ De Candolle, Prodromus. \\ $\{$ Don, Miller's Dictionary. \\ Loudon, Arboretum Britannicum. \\ Torrey and Gray, Flora of North America. \\ France. \\ Germany. \\ ITAI,Y. \\ SPAIN. \\ Britain and Anglo-Averica.
}

Derivations. The specific name, typhina, is derived from the Greek tuphos, stupor or senselessness, on account of the roots of this shrub being used in medicine as a febrifuge. The German name, Färberbaum, signifies Dyer's-tree.

Engravings. Du Hamel, Traité des Arbres et Arbustes, ii., pl. 47; Loudon, Arboretum Britannicum, ii., figure 224; and the figures below.

Specific Characters. Leaf of 8-10 pairs of leaflets, and the odd one, that are lanceolate, acuminate, serrated, hairy beneath. Petiole and branches hairy.-De Candolle, Prodromus.

\section{Description.}

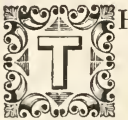

HE Rhus typhina, in its arborescent form, attains a height of ten to twenty-five feet, although under some circumstances it dwindles down to a mere shrub, from ten to two feet in height. Its stem is woody, with a summit composed of numerous irregular branches, generally crooked and deformed. The young shoots are covered with a soft, velvet-like down, resembling that of the new horns of the stag, both in colour and texture. The leaves are large, slightly downy beneath, and are distinguished in autumn, before they fall, by changing to a purplish or yellowish-red. The flowers appear in June, and are of a greenish-yellow. They are produced in close spikes at the ends of the branches, and are succeeded by drupes or berries, densely clothed with crimson hairs, which soon become conspicuous, and remain upon the tree during winter.

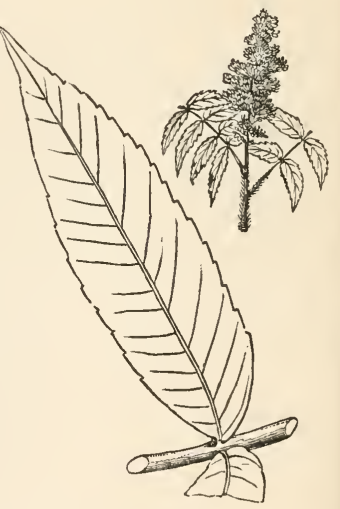

Varieties. There are many varieties of this species in North America, and from the confusion existing in botanical works, it is often difficult to decide which are species or which are varieties in this genus. The following races, however, appear to be sufficiently distinct, to be classed under the present head.

1. R. T. VIRIDIFLora. Green-flowered Sumach, with green flowers in upright racemes.

2. R. T. GLABRa. Glabrous Rhus, or Scarlet Sumach, with glabrous leaves, and fruit covered with red, silky hairs.

3. R. T. HERMAPHRODITA, with hermaphrodite sexes, glabrous leaves, and greenish flowers.

4. R. т. Diorca, with diœcious sexes, glabrous leaves, and greenish flowers. 
5. R. T. coccinea. Scarlet-flowered Sumach, with diœcious sexes, leaves glaucous beneath, flowers red, and fruit of a rich, velvety crimson.

Geography and History. The Rhus typhina is found in a wild state in almost every part of North America, from Canada to Texas, and even west of the Rocky Mountains. It was cultivated in England, by Parkinson, in 1629, and is now common in most of the European gardens and collections.

Soil, Culture, \& $\bullet$. This species, or its varieties under notice, grows abundantly, both in cultivated and in uncultivated tracts. In woodlands, it is found near the margins of open glades; and, in arable fields, suitable for growing corn, it is more common than in low meadows. In some parts of the country it flourishes like a weed, and a field left uncultivated for a few years, becomes overrun with it from berries which have been disseminated by birds, or other natural causes; and, when the ground is again brought into tillage, the roots prove a great impediment to the plough. This shrub, like all others of the genus, is easily propagated by seeds or by cuttings of the roots. As it is of an open, irregular growth, and of not many years' durability, it should never be placed where it is intended to serve as a screen. The most striking situation in which it can be placed, is when standing alone on a lawn. If trained to a single stem, it forms an interesting little tree, and well deserves to be cherished, from its large and beautiful foliage, its varied colours in autumn, and its spikes of dark-red fruit, which diversify the scenery of a northern winter.

Properties and Uses. On cutting the stem of this shrub, a yellowish, resinous juice flows out from between the bark and wood. One or two of the outer circles of the wood are white, but those innermost, are of a yellowish-green, or orange-colour, having a strong aromatic odour. It contains a soft pith, of a brownish colour, and is frequently more than half of an inch in diameter. The wood and leaves are used in tanning the finer kinds of leather, and the roots are prescribed as a febrifugal medicine. The branches, boiled with the berries, afford a black, ink-like tincture; and the berries may be employed alone for dyeing red. They are eaten by children with impunity, though they are very sour. Professor Rogers, in "Silliman's Journal," observes that they contain a large portion of malic acid, and are used as a substitute for lemons in various preparations of domestic economy, and in medicine.

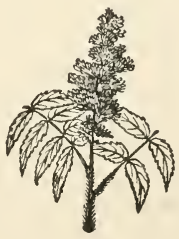




\section{Rhus venenata, \\ THE POISONOUS RHUS.}

Synonymes.

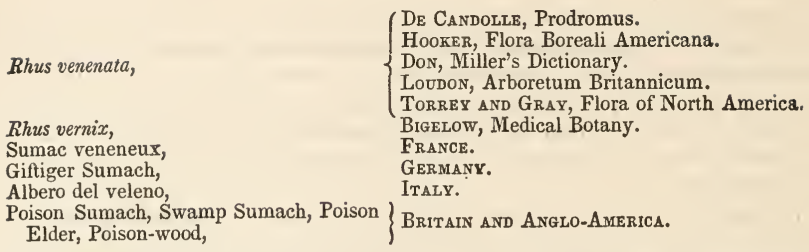

Derivation. The specific name, venenata, is derived from the Latin venenum, poison, on account of the poisonous nature of this shrub to most persons.

Engravings. Bigelow, Medical Botany, i., pl. 19; Loudon, Arboretum Britannicum, ii, figure 226; and the figures below.

Specific Characters. Leaf rather glabrous than pubescent, of 5-6 pairs of leaflets, and the odd one, which are ovate-lanceolate, acuminate, entire, and beneath reticulately veined.-De Candolle, Prodromus.

\section{Description.}

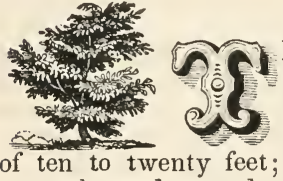

HE Rhus venenata, in its natural habitat, is a deciduous shrub, or low tree, growing to a height but when cultivated on more elevated grounds, it does not attain so great an elevation. The leaves are divided like those of the Rhus typhina, but differ in being smooth and shining; the leaflets are very entire, narrow, and pointed, with purplish-red veins; and in autumn they change to an intense red, or purple. The flowers, which appear in May, June, and July, are mostly diœcious, small, and of a greenish colour. The drupes are whitish, and about the size of peas; and the nuts are rather broader than long, compressed and furrowed.

Geography and History. The Rhus venenata is indigenous to North America, and may be found in swamps, and moist, shady situations,

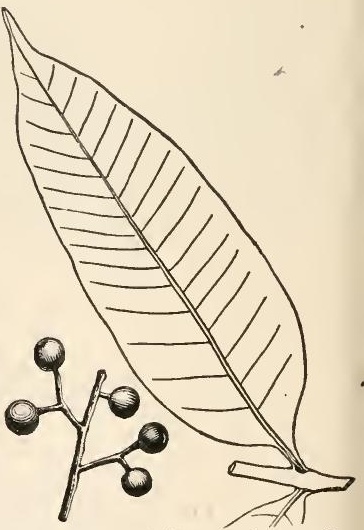
from Canada to Louisiana. It was introduced into Britain in 1713, and is cult1vated in several of the European collections.

Properties, Uses, \& c. Every part of this shrub, even when reduced to charcoal, is in a high degree poisonous to most persons, either by touching or smelling any part of it. It operates somewhat differently upon different constitutions; and some, it is said, are incapable of being poisoned by it at all. This may be true under some circumstances, but is liable to fail under others. A few years since, in a hot day in the month of August, while prosecuting a public survey, we directed a number of men to cut a pathway through a swamp, densely filled with this poisonous plant. As most of us had never suffered any inconvenience from 
it before, and had frequently handled it with impunity, we fearlessly went to work, and after a few hours' excessive toil, made our way through. In about two days afterwards we were all more or less affected by it, and several were so badly swollen in their faces and limbs that they were unable to work. After repeatedly moistening the parts inflamed with a solution of borax (sub-borate of soda) and water, in five or six days, the eruptions mostly disappeared. Kalm, in his travels, states that this plant had no effect upon him, except once, on a hot day, when, being in some perspiration, he cut a branch, and carried it in his hand for half an hour, occasionally smelling it. During a week, his eyes were very red, and the eyelids very stiff, but the disorder went off by washing the parts in cold water. The persons most susceptible to the effects of this poison, are usually of irritable and unstable habits. In about forty-eight hours after being exposed to it, inflammation appears on the skin, in large blotches, principally on the face and extremities, and on the glandulous parts of the body; soon after, small pustules appear in the inflamed parts, and become filled with watery matter, attended with an almost insupportable itching and burning. In two or three days, the eruptions suppurate; after which, the inflammation subsides, and in a short time the ulcers heal.

It appears, from a notice in "Nicholson's Journal," vol. xxiii., that this poison is sometimes fatal to bees. A large swarm having settled on a branch, in the county of West Chester, New York, was taken into a hive at three o'clock in the afternoon, and removed to the place where it was to remain, at nine. About five the next morning, the bees were found dead, swollen to double their natural size, and turned black, except a few, which appeared torpid and feeble, and soon died, on exposure to the air.

Between the wood and bark of this shrub, there exists a milky juice, having a nauseous smell, which stains linen of a dark-brown. Were it not for its poisonous qualities, this juice might be advantageously employed as a varnish, like that of the Rhus vernicifera, the plant from which the real Japan varnish is extracted.

Loudon remarks that this species is not very common in British gardens; but it well deserves culture, on account of the beauty of its smooth, shining foliage, at all seasons, and of its almost unparalleled splendour in the autumn, from the time that the leaves begin to change colour, till they ultimately drop off with the first frost. He recommends that the plant should always have a label attached to it, indicating the poisonous quality of the leaves, even when touched or smelled.

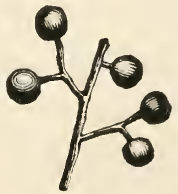




\section{Genus BURSERA, Jacq.}

Burseraceæ.

Syst. Nat.
Diœcia Polygamia.

Derivation. This genus was named in honour of Joachim Burser, professor of botany at Sara, in Naples.

Generic Characters. Hermaphrodite. Calyx 5-toothed. Petals 5. Stamens 10. Style 0. Capsules . valved, 1-seeded.-MaLe. Calyx 5-toothed. Petals 5. Stamens 10.-Loudon, Encyc. Plants.

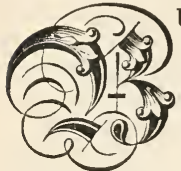

URSERA is a genus embracing but one species, a native of the warmer parts of America. It abounds in a copious, watery, balsamic fluid, resembling in its qualities, the gum-elemi of the shops, the history of which is involved in great obscurity. Linnæus, and the London and Dublin colleges after him, describe this substance as the resin of Amyris elemifera; but that distinguished botanist confounded, under one name, two distinct plants, namely, the Icica icicariba, a tree of Brazil, and the Amyris plumieri, of the Antilles, both of which yield similar gum. From some accounts, it would appear that it came from Ethiopia, by way of the Levant. Possibly it may be the product of the Canarium zephyrinum sive sylvestre primum Conari Barat, of Rumphius, (Herb. Amb., lib. iii., c. ii., p. 153,) which he says yields a resin so much like elemi, that it may be taken for it, and he puts a query, wliether this tree may not be the source of it. The Canarium balsamiferum of Ceylon, is said to produce a resin which strongly resembles it, both in odour and in general appearance. There are at least three kinds of elemi met with in commerce, viz.:-1st. Elemi in flag-leaves; Résine élémi en pains, Guibourt; Resina Elemi orientalis, Martius. This occurs in the commerce of Holland, in triangular masses, weighing from one to two pounds each, enveloped in a palm-leaf, and probably is brought from some of the Dutch colonies in the East or West Indies, or in South America. Martius ascribed it to the Amyris zeylandica, (Balsamodendron zeylandicum, Kunth,) of Ceylon. 2d. Brazilian Elemi, Résine élémi du Brésil, Guibourt. This variety is believed to be obtained from the Icica icicariba, by making incisions in the stem, and gathering the gum twenty-four hours afterwards. It is imported in cases containing two or three hundred pounds in each, is soft and unctuous, but becomes hard and brittle by cold and age. It is translucent, of a yellowish-white, mixed with greenish specs; its odour is strong, agreeable, analogous to that of fennel. 3d. Elemi in the lump. This differs from the preceding variety in being of a much paler yellow.*

* See Pereira's Materia Medica, ii., p. 609. 


\section{Bursera gummifera, THE GUM-BEARING BURSERA.}

Synonymes.

Bursera gummifera,

Gommart gommifere, Gommier blanc, Gummitragender Bursere,

Almacigo,

West-India Birch,

Gumbo-limbo,
(VoN J ACQUIN, Stirpium Americanarum.

Lunan, Hortus Jamaicensis.

Nuttald, North American Sylva.

France.

Germany.

Spain and Spanish America.

British West Indies.

Southern Florida and Bahama Islands.

Engravings. Nuttall, North American Sylva, pl. -; Loudon, Encyclonædia of Plants, figure 14389; and the figures below Specific Characters. Leaves pinnate. Leaflets ovate-acute, entire, opposite, and slightly circinate. Raceines axillary.

\section{Description.}

megog $\mathrm{HE}$ Bursera gummifera is an evergreen tree, attaining a height of fifty or sixty feet, with a trunk from three to five feet in diameter. In open situations its trunk is often short, and divides itself into a number of large limbs, so divergent that they form a spacious head. The bark of the trunk and branches is of a reddishbrown, and has a loose epidermis, resembling that of the yellow birch (Betula excelsa.) The leaves are pinnate, from six to twelve inches in length, and somewhat drooping. The leaflets are from three to four inches long, ovate-acute, opposite, and are borne on short footstalks. They are of a dark-green, and shining on their uyper sides, and light beneath, with numerous veins, connected in a singular manner. The flowers, which appear in November or Decem-

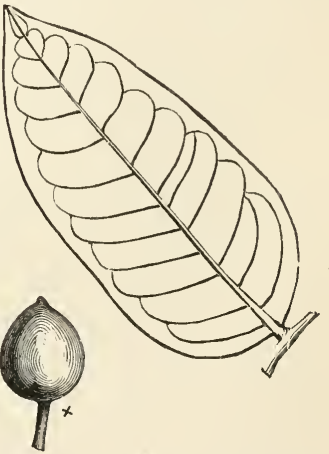
ber, are of a yellowish colour, occur in clusters, and are situated on separate stalks. The fruit, which ripens in January or February, is roundish, or slightly oblong, with a sharp protuberance at the end, and is about one fourth of an inch in diameter. It is of a purplish colour, hangs in clusters, and is joined to the axil by a footstalk about one fourth of an inch long. Each berry contains a hard, white seed, of a triangular form, which is surrounded by a clear, balsamic fluid, much sought after by various species of birds.

Geography and History. This species is particularly abundant on the islands of Cuba and Jamaica, and is also found in considerable quantities on the Bahamas and in southern Florida, and along the coast to the Spanish Maine. It was introduced into Britain in 1690 , and can only be reared there as a hot-house plant.

Several large trees are growing in the suburbs of Havana, in the island of Cuba, and in the town of Key West, in Florida.

Soil, Culture, $\oint^{\bullet} c$. In its natural habitat, the Bursera gummifera prefers a 
dry, rocky soil, covered with a rich, vegetable mould or peat; but it will grow in any situation where the sugar-cane will succeed. It may be readily propagated from seeds, or by cuttings, but the latter mode is far preferable where a large growth is soon required. When employed for live fences, it is only necessary to cut truncheons of any size, at the commencement of the rainy season, and plant them in a continuous row, ten or twelve inches apart, with the butends downward, buried from a foot to a foot and a half deep. For ordinary fence they may not be cut more than six or eight feet in length, and three or four inches in diameter. When thus planted, they immediately take root, and in a short time become a durable barrier. This tree is of a rapid growth, and consequently will not live to a great age.

Properties and Uses. The wood of the Bursera gummifera is white, soft, full of juices, and rapidly decays. It is appropriated to no particular use, except in forming live fences in the countries where it abounds, for which it answers an admirable purpose. The fruit, when cut, discharges a clear balsamic fluid, esteemed in Jamaica as a good vulnerary, particularly for horses. On wounding the bark, a thick, milky liquor, of a peculiar odour, is obtained, which concretes into a resin, not materially different from gum-elemi. The bark of the root is very bitter, and is said to possess the same properties as quassia. The inner bark of the trunk and branches is yellow, and has been employed on the island of Cuba in the manufacture of muscovado sugar. When boiled in the svrup of cane it imparts to the sugar a yellowish tinge.

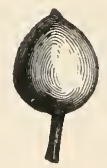




\section{Genus CLADRASTIS, Raf.}

Leguminaceæ. Swst. Nat.
Decandria Monogyna. Syst. Lin.

\section{Synonymes.}

Cladrastis, Virgilia, Sophora,

OF Authors.

Derivations. The name Cladrastis, is derived from the Greek clados, a branch, aud rasso, to break in pieces, having reference to the brittleness of the branches of this genus. It was called Virgilia by Lamarck, in honor of the poet Virgil, whose "Georgics" entitle him to botanic commemoration. The name Sophora, was derived from the Arabic sophero, a papilionaceous flowering tree.

Generic Characters. Calyx protuberant, campanulate, unequally 5-lobed. Petals 5, unequal, unguiculate, superior, larger obovate notched, 4-oblong, obtuse, subcordate at the base. Stamens 10, free, unequal, filiform. Pistils stipitate, oblong. Style curved, compressed. Stigma acute. Legume stipitate, linear, flat, membranaceous, 4-6-seeded. Leaves oddly pinnate. Flowers racemose without bracts.

2An genus Cladrastis embraces but one species, a native of the United States. It was classed by Michaux among the African 1 Virgilias, from which it differs in having the calyx bilabiate, 2) 5 two of the petals cariniform, the stigma obtuse, and the seeds lenticular. To the same natural family belong the Spanish broom, is manufactured, in the south of Europe; the Laburnum, (Cytisus laburnum, )
is so much admired in ornamental plantations; and the Furze, (Ulex europæa,) celebrated among the classical ancients, and cultivated in modern times for nedges, fodder for cattle, underwood, and the protection of game. As a shelter to young trees, furze is sometimes sown where acorns, beech, masts, or chesnuts are to be sown, or where young trees are to be planted, in order to protect them for a few years, till they are grown up, and have sufficient strength to shelter ne another, when they will overtop the furze, and destroy it. 


\title{
Cladrastis tinctoria, \\ THE VIRGILIA, OR YELLOW-WOOD.
}

Synonymes.

Virgilia lutea,

Cladrastis tinctoria,

Virgilia,

Yellow Locust,

Virgilia, Yellow-wood,

\author{
Michadx, North American Sylva. \\ De Candolle, Prodromus. \\ Loudon, Arboretum Britannicum. \\ Torkey AND Gray, Flora of North America. \\ Britain, France, Germany, and Italy. \\ Kentucky, Tennessee, and Alabama. \\ Other Parts of the United States.
}

Derivations. The specific names tinctoria and lutea, have reference to the yellow colour which the wood of this tree 'mparts to water.

Engravings. Michaux, North American Sylva, pl. 78; Loudon, Arboretum Britannicum, v., pl. 78; and the figures below.

Specific Characters. Leaves pinnate. Leaflets 9-11, petiolate, alternate, ovate-acuminate, entire, glaucous beneath, the odd one larger, ovate-rhomboidal, base acute. Flowers in simple, lax, nodding racemes, white, odorous. Pods smooth.
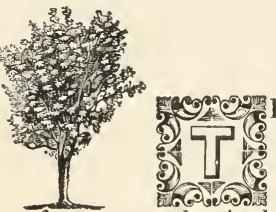
favourable situations, at-
tains a height of thirty
to fifty feet, and a diameter of ten to twelve inches. The trunk is covered with a greenish bark, which is smooth, instead of being furrowed, like that of most other trees. The branches are brittle, and like the petioles and nerves of the leaves, are of a yellowish hue. The leaves on young and thrifty stocks are from a foot to a foot and a half in length, and on old trees they are not more than half of that size. They are composed of two rows of leaflets, which are petiolulate, broadly oval, entire, smooth, the terminal one rhomboid-ovate, acuminate, an inch and a half to two inches broad, and from three to four inches long. As in the Platanus occidentalis, (sycamore,) the lower part of the common footstalk

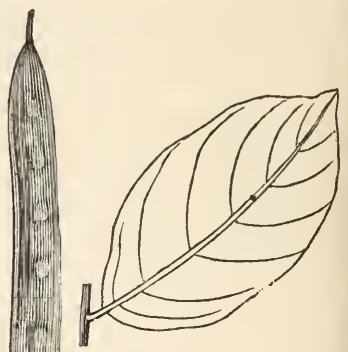
contains an embryo bud, which becomes visible in removing the leaf. The flowers, which appear in April and May, form elegant white, pendulous racemes, from six to ten inches long, resembling those of the Robinia pseudacacia, (locust,) but less odoriferous. The seeds are contained in flat, even pods, from three to four inches long, and about one fourth of an inch wide, the margins of which are often somewhat undulate by the abortion of a portion of the seeds. In the United States the seeds mature in the month of August; but in Britain, the tree is seldom seen in flower, which is probably owing more to the age of the trees than to the effects of the climate.

Geography and History. The Cladrastis tinctoria is a native of Kentucky, western Tennessee, and northern Alabama, where it is sparingly produced. It is successfully cultivated as an ornamental tree in many parts of the United States, and is perfectly hardy as far north as Massachusetts. 
This tree was discovered by Michaux, the younger, and was sent by him to France, previous to the year 1809. It was first introduced into England by Mr. John Lyon, in 1812, and seeds having since been frequently sent to Europe, it is low to be met with in all the chief collections.

The largest recorded tree of this species in England, is at White Knights, near Reading, which attained the height of twenty-three feet in twenty-five years after planting, with a trunk five inches in diameter, and an ambitus, or spread of branches, of twenty feet.

In Ireland, near Dublin, in the Cullenswood nursery, there is another tree, which attained the height of twenty-five feet in seventeen years after planting.

At Cambridge, in Massachusetts, in the botanic garden, there is a Virgilia about thirty feet in height, with a trunk ten or twelve inches in diameter. In the Bartram botanic garden, at Kingsessing, near Philadelphia, there is also a tree of this species of about the same dimensions, and another in the garden of Mr. D. Landreth, of Philadelphia, twenty-five feet high, with a trunk six feet in circumference, and about thirty-five years planted.

Soil, Situation, $\oint^{\bullet} c$. In its natural habitat, the Virgilia grows on gentle declivities, in a loose, deep, and fertile soil, and is usually associated with the Morus rubra, Gymnocladus canadensis, Gleditschia, Juglans, and other trees which delight in a good soil. When cultivated, an open, airy situation is desirable, in order that it may ripen its wood; and, to promote the same purpose in a cold climate, the soil should be dry, rather than rich. It is readily propagated by seeds, in the same manner as the common locust.

Properties and Uses. The wood of the Cladrastis tinctoria is soft, fine-grained, and is remarkable for the deep-yellow colour of its heart, which speedily imparts this hue to cold water. But the colour is fugitive, even when the wood is boiled with alum. There is but very little use made of this tree either in Europe or America, except for the purposes of ornament and botanical interest. It is rather late in coming into leaf, and its leaves fall very early, previously becoming of a fine yellow. Independent of its beautiful vegetation, the brilliant colour of its heart would appear to be a sufficient inducement for cultivating the species for the purpose of dyeing.

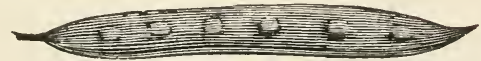




\title{
Genus ROBINIA, Linn.
}

\begin{abstract}
Leguminaceæ. Syst. Nat.
\end{abstract}

Diadelphia Decandria.
Syst. Lin.
Synonymes.

Robinia, Eschynomene, Pseudacacia,
Of Authors.

\begin{abstract}
Derivotions. The genus Robiniz was named in honour of Jean Robin, a French botanist, once herbalist to Henıy IV., of France. Eschynomene is a name given by Pliny to a plant, resembling the locust in its character, which contracted its leaves from the touch of the hand. It was derived from the Greek aischunomui, which signifies to be modest. Pseudacacia is 'erived from the Greek pseudos, false, and acacia, from the resemblance of trees of this genus to the Acacia vera, or true Egyptid.l acacia.

Generic Characters. Calyx short, and somewhat campanulate, 5-toothed or 5-cleft; the two upper segments shorter, approximated or cohering. Vexillum broad and large; keel obtuse. Stamens diadelphous, deciduous. Style bearded along the inside (next the free stamen.) Legume many-seeded, compressed, nearly sessile, the seminiferous suture margined; valves flat and thin. Seeds flat. Leaves unequally pinnate; leaflets petiolulate, stipellate. Flowers showy, white, or rose-colour, in simple, usually pendant axillary racemes.-Torrey and Gray, Flora.
\end{abstract}

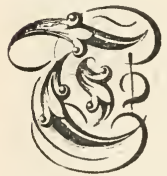

HE trees of the genus Robinia are chiefly natives of North America, and are highly prized for their use and beauty. They are all readily propagated from seeds, by cuttings of the branches and roots, or by grafting; and they will grow in any kind of soil that is not too wet. They are generally rapid in their growth, and of a corresponding longevity. In common with most trees and plants of rapid growth, they have the property of extending the principal roots close under the surface where the soil is usually the richest. But the same cause that produces this luxuriance at first, ultimately occasions the tree to grow more slowly, unless the roots are allowed ample space on every side; since, as they seldom penetrate deep, they soon exhaust all of their proper pabulum from the soil within their reach. For this reason, also, such trees are objectionable in hedge-rows, or scattered in groups in arable lands, where their roots prove a serious impediment to the plough, and shoot up in suckers, which injure the crops. On the other hand, roots which penetrate the earth perpendicularly, as well as horizontally, helong to trees more slow and uniform in their growth, and attain a larger size in proportion to the extent of ground they occupy. It does not appear, however, that a rich soil is particularly injured by the Robinix; for, it is remarked that in Kentucky and western Tennessee, where the Robinia psendacacia attains its largest size, and produces excellent timber, the land, when cleared, will yield from thirty to sixty bushels of maize to an acre, for several years in succession, withont manure. And it has been asserted that moderately poor and worn-out lands in America may be restored to fertility by planting them with the locust, from the deposition of its leaves, bark, seeds, \&c..: which undergo rapid decomposition, and are thereby converted into vegetable mould. 


\section{Robinia pseudacacia, \\ THE COMMON LOCUST-TREE.}

\section{Synonymes.}

\section{Robinia pseudacacia,}

Robinia pseudo-acacia,

Robinier faux-acacia, Acacia blanc, Acacia commun, Acacia des jardiniers, Carouge des americains,

Gemeine Acacie, Schotendorn,

Acacia falsa, Acacia, Pseudacacia, Robinia, Italy.

Acacia falsa, Algarrobo americano, Sparn.

Acacia bastarda,

Virginian Acacia, False Acacia, Bastard ?

Acacia, Locust-tree,

Yellow Locust,

Black Locust,

Red Locust, Green Locust, White Locust, Other PARTs of the United States.

Portugal.

Britain.

State of Maine.

WESTERN STATES.
Linneus, Species Plantarum.

De Candolie, Prodromus.

LaMarck, Illustration des Genres.

Du Hamei, Traité des Arbres et Arbustes.

Loudon, Arboretum Britannicum.

Selby, British Forest Trees.

Torrey and Gray, Flora of North America.

Michadx, North American Sylva.

Derizations. This species, when first introduced into Europe, was supposed to be the Egyptian acacia, (Acacia vera, out was afterwards contradistinctively named False Acacia. It was named Locust-tree by the missionaries, who were among the early collectors of trees, and who fancied that it was the tree that supported St. John in the wilderness. The word Carouge, is the French name for carob bean, the locust-tree of Spain; which, being also indigenous to Syria, is probably the true locust, mentioned in the New Testament. The German name, Schotendorn, is compounded of schote, a pod or legume, and dorn, a thorn, having reference to the pods and spines which this species bears.

Engravings. Michaux, North American Sylva, pl. 76; Audubon, Birds of America, pl. cix.; Loudon, Arboretum Britan. nicum, v., pl. 83 ; and the figures below.

Specific Characters. Prickles stipular. Branches twiggy. Racemes of flowers loose and pendulous ; and smooth, as are the legumes. Leaflets ovate. The flowers are white, and sweet-scented; the roots rreeping, and their fibres sometimes bearing tubercules.-De Candolle, Prodromus.
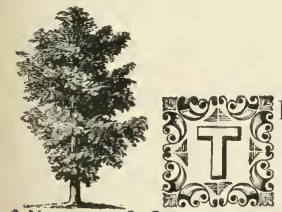

Description. of the American forest. In favourale sites of the American forests. In favourable situations, it attains a height of eighty or ninety feet, and sometimes exceeds four feet in diameter; but ordinarily, it does not surpass half of these dimensions. On the trunks and large limbs of old trees, the bark is very thick, and deeply furrowed, but on young trees, not more than two or three inches in diameter, it is armed with strong, hooked prickles, which disappear altogether as they grow old; and in some varieties they are wanting even when young. These prickles are only attached to the bark, like those of the common rose, or the

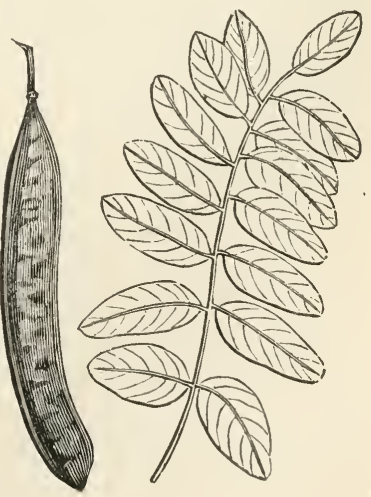


bramble; but do not proceed from the wood, like the spines of the hawthorn, cockspur, and other thorns. The branches have a general tendency upwards when the tree is young, but as it grows old, they partake more of a horizontal direction; and like the trunk, become somewhat contorted. The foliage is light and agreeable to the eye, each leaf being composed of opposite leaflets, eight, ten, or twelve, and sometimes more in number, surmounted by an odd one. The leaflets are nearly sessile, oval. thin, with a texture so fine and a surface so smooth, that the dust which falls on them will scarcely adhere; which last circumstance renders this tree particularly eligible for planting along roadsides, in the neighbourhood of cities and towns, or in great thoroughfares. The flowers, which open in March, at St. Mary's, in Georgia, and two months later in Pennsylvania, sometimes appear at the former place late in autumn. 'They are disposed in pendulous bunches, from three to five inches long, perfectly white, and sometimes yellowish, and diffuse an agreeable odour. They are succeeded by narrow, flat pods, from two to three inches long, and about half of an inch wide; each of which contains five or six small, brown, or black seeds, that ripen in the niddle and northern states in the month of October.

Varieties. We are inclined to believe that there are but two forms of the Robinia indigenous to North America, that may be regarded as distinct, and that the several varieties or races commonly treated as species, are the result of soil, climate, or cross fecundation. For, the common locust varies much in its different native localities, and also has long been cultivated from seeds in Europe, which has bronght forth numerous varieties, the foliage of which is tolerably distinct when the plants are young. By carefully comparing the descriptions of various authors, we recognize the following varieties or races, which may be classed under this species:-

1. R. p. intermedia, Soulange-Bodin. This kind is thought to be a hybrid between the Robinia pseudacacia and viscosa. The branches, petioles, \&c., are furnished with but few glands, and are rarely clammy. The flowers are sweetscented, and of a pale rose-colour. The pods are sometimes thickly set with slıort prickles.

2. R. P. HISPIDA, Lin. The Hispid Rose Acacia. The leaves of this race are obovate, and are nearly twice the size of the Robinia pseudacacia. The branches and legumes are hispid. The flowers are large, of a dark rose-colour, and inodorous.

3. R. P. Rosea, Pursh. Rose Acacia. This variety differs from the R. p. hispida in not having the branches and petioles hispid, and in growing to an inconsiderable shrub.

4. R. P. grandiflora, Loudon. The Large-flowered Rose Acacia. The leaves of this variety are large, and ovate-roundish. The branches and peduncles are glabrous, and without prickles. The flowers are large, of a rose-colour, and inodorous.

5. R. P. Flore luteo, Dumont de Courset. Yellow-flowered Robinia.

6. R. P. Inernis, De Candolle. The Unarmed Robinia. Leaves flat. Prickles wanting, or nearly obsolete.

7. R. P. CRISPA, De Candolle. The Crisp-leafleted Robinia. The prickles of this variety are wanting. The leaflets, for the most part, are undulately curled. 8. R. P. Tortuosa, De Candolle. The Twisted-trunked Robinia. The branches of this variety are much crowded and twisted. Flowers small, and not abundant.

9. R. p. umbraculifera, De Candolle. The Parasol Acacia. The branches of this variety are much crowded, and smooth; its head orbicular; and, according to Dumont de Courset, its flowers are yellow. 
10. R. P. Pendula, De Candolle. The Pendulous Robinia. The shoots of this variety are somewhat drooping, but not decidedly so.

11. R. P. sophoR those of the Sophora japonica.

12. R. P. AMORPHefolia, Link. This variety has leaves resembling those of the Amorpha fruticosa.

Geography and History. The common locust naturally abounds in the country west of the Alleglianies, as far as Arkansas. It is also plentiful in the Canadas, but is not found indigenous in the United States east of the river Delaware, nor does it grow spontaneously in the maritime parts of the middle and sonthern states, within the distance of fifty to one hundred miles from the sea. It is planted, however, for purposes of utility and ornament, from Maine to Georgia. It was observed by Michaux, that "the locust forms a much smaller portion of the American forests than the oaks and walnuts, and that it is nowhere found occupying tracts, even of a few acres exclusively." Hence the tree, where it is met with, is often spared by settlers, as being ornamental, and comparatively rare, and old specimens, which formerly belonged to the aboriginal forests, are frequently seen growing in the midst of cultivated fields.

Of all American trees that have been cultivated in Europe, there is no one, of which so much has been said and done, as the locust. It was among the first plants that were carried to that country, and it has been more extensively propagated than any other, both in Britain and in France, where it has been alternately extolled and neglected; and even at the present day, though the beauty of its foliage and flowers is universally admired, and the valuable properties of its wood have enthusiastically been praised and acknowledged, it is not considered as holding a high rank as a timber-tree, or as being generally planted with a view to profit.

The seeds of this tree, it is stated by some, were first sent to Europe to Jean Robin, gardener to Henry IV., of France, in 1601; but according to others, they were sent to Vespasian Robin, (son to the preceding,) who was arborist to Louis XIII., and was planted by him in the Jardin des Plantes, in 1635. In England, it appears to have been first cultivated by Tradescant, the elder; but whether he obtained it from France, or direct from Virginia, is uncertain. Parkinson, in his "Theatre of Plants," published in 1640, first mentions this tree, as having been grown in England by 'Tradescant, "to an exceeding height," which renders it possible that he received it from America before either of the Robins. Evelyn, in the first edition of his "Sylva," published in 1664, says, "The French have lately brought in the Virginia acacia, which exceedingly adorns their walks. The tree is hardy against all the invasions of our sharpest seasons; but our high winds, which, by reason of its brittle nature, it does not so well resist; and the roots, (which insinuate and run like liquorice under ground,) are apt to emaciate the soil, and, therefore, haply not so commendable in our gardens as they would be agreeable for variety of walks and shade." Miller, in his "Dictionary," published in 1731, speaks of the Robinia as being very common in gardens near London, where there were, in his time, several large, old trees. He says that they were very hardy, but would not endure exposure to high winds, which break their branches, and render them unsightly. "Many people," he adds, "have neglected to cultivate them on that account; but they will do well if planted in wilderness among other trees, where they will be sheltered, and make a beautiful variety." In another edition of the same work, published in 1752, he remarks that, "These trees were formerly in great request in England, and were frequently planted in avenues, and for shady walks; but their branches being generally broken or split down by the wind, in summer, when they are 
clothed with leaves, the trees are rendered improper for this purpose; and their leaves coming out late in the spring, and falling off early in the autumn, occasioned their being neglected for many years; but of late they have been much in request again, so that the nurseries have been cleared of these trees; though in a few years they will be as little enquired after as heretofore, when those which have been lately planted begin to have their ragged appearance."

In Dr. Hunter's edition of Evelyn's "Sylva," published in 1786, we have a history of the employment of the locust in ship-building, communicated by Mr. Joseph Harrison. This gentleman, who had resided some time in Virginia, states that in "about the year 1733, the first experiment was made respecting the application of the locust-tree to any purpose in ship-building, by an ingenious shipwright, sent over to America by some Liverpool merchants, to build two ships there. The shipwright thought that the oaks, elms, ashes, and many other timber-trees common to both countries, were much inferior to the same sorts in England; but frequently spoke of the locust-tree as being of extraordinary qualities, both in strength and duration. He had observed some very old timber in houses in New England, that had been built of the wood of this tree, when the country was first settled, perfectly firm and sound; and, after having completed his engagement for his employers, he began to build a small vessel for himself; when, being at a loss for a sufficient quantity of iron, and having observed the extraordinary strength and firmness of the locust-tree, he took it into his head that trenails, or tree-nails, that is, wooden pins, of that timber, might be substituted for iron bolts in many places where they would be least liable to wrench or twist, (as in fastening the floor timbers to the keel, and the knees to the ends of the beams, which two articles take up a large proportion of the iron used in a ship,) purposing, when he arrived in England, to bore out the locust trenails, and drive in iron bolts in their stead. The ship, being finished and loaded, sailed for Liverpool, and returned back to Virginia the next year; the builder himself being the captain of her, paid particular attention to see the effect of the locust trenails. After the strictest examination, he found that they effectually answered the purpose intended. It was, however, thought prudent to take several of them out, and to put in iron bolts in their room; and this operation afforded another proof of their extraordinary strength and firmness, as they required to be driven out with what is technically called, a set bolt, (an iron punch,) just as if they had been made of iron; whereas oak trenails are usually bored out with an auger." The use of the locust for trenails was neglected for some years, till it was revived at the instance of Mr. Harrison, by a ship-builder of eminence, at New York, where, as in other parts of the United States, as well as in Great Britain, it has been in general use ever since.

About the latter end of the last century, public attention was powerfully directed to the locust, both in Europe and in America, and various papers in the "Transactions" of societies, and pamphlets began to be published on the subject. In 1786, a "Memoir on the Common Acacia" was published at Paris, in which it was recommended to plant this tree on the banks of rivers, in order to strengthen them by its running roots. The writer also recommends it for peasticks, hop-poles, vine-props, wedges, cogs to wheels, \&c., and even as a substitute for saint-foin, as a forage crop, to be mown thrice a year, and either used green, or dried, as hay, and stacked, mixed with straw, for winter use.

In the "Gentleman's Magazine" for 1791, there is a long account of a plan for growing locust-trees, and American oaks, for the use of the royal navy. The distance at which the writer proposes to plant these trees is sixteen and a half feet, so that he calculates an acre will produce one hundred and sixty trees, of about one and a half tons each. The locust, he says, will be fit for shipbuilding in twenty-five or thirty years, the live oak in forty years, and the white 
oak in sixty years, from the time of planting. He states that posts made of the locust wood have stood exposed to the weather, to his certain linovledge, for eighty or a hundred years before they began to decay. He recommends the locust-tree to be planted in a poor soil.

In February, 1793, the national convention of France decreed that an impression of "LiAnnuaire du Cultivateur" should be struck off, and distributed in the various departments of that country, the committee of public instruction thinking it worthy of a place among the elementary books intended for the use of the national schools. In this work, each day in the year is marked by one or more natural productions, or their attendant phenomena; and the 6th of May, (14 $4^{\text {me }}$ Prairial,) was consecrated to the Robinia pseudacacia, and a notice given of its appearance, propagation, culture, and uses.

Dr. Pownal, in "Young's Annals of Agriculture," remarks that "the locust wood which is used in America for ship-building, trenails, and posts, has commonly been grown in barren, sandy, or light soils; and that in England, where it is generally planted in rich soils, and in sheltered situations, the tree may, probably, outgrow its strength; and thus the branches may become so brittle as to be easily broken by the winds; while the wood will be less hard and tenacious, and in all probability, much less durable than in America." He therefore recommends planting the locust, in England, only on poor soils, when it is intended to employ the timber for useful purposes.

In the year 1803, a work was published in Paris, entitled "Lettre sur le Robinier," by M. François de Neufchâteau, containing, in substance, all that had been previously published on the subject in France, a translation of which occupies the first one hundred and fifty-six pages of Wither's "Treatise on the Acacia."

In the year 1823, an extraordinary excitement was produced in England concerning this tree, by William Cobbett, who resided in America from 1817 to 1819, and chiefly occupied himself in farming and gardening, on Long Island, near New York; and during that period, as he tells us in his "Woodlands," published in 1825 to 1828 , that he was convinced that nothing in the timber way could be of so great a benefit as the general cultivation of this tree." "Thus thinking," continues he, "I brought home a parcel of the seeds with me in 1819, but I had no means of sowing it till 1823. I then began sowing it, but upon a very small scale. I sold the plants; and since that time I have sold altogether more than a million of them !" Elsewhere, in the same work, he more especially directed attention to this subject, urging, in his clear and forcible manner, the immense importance of this tree in ship-building; and he was the means of thousands of it being planted in various parts of Britain. The name of locust, as applied to this tree, before Cobbett's time, was but little known in England, and many persons, in consequence, thought it was a new tree. Cobbett had a large kitchen-garden behind his house at Kensington, which he converted into a nursery; and he also grew trees extensively on his farm at Barnes, in Surry. Although hundreds of the Robinia pseudacacia stood unasked for in the British nurseries, the "locust plants," which every one believed could only be had genuine from Mr. Cobbett, could not be grown by him in sufficient quantities to supply the demand. He imported the seeds in tons; but when he fell short of the real American ones, he procured others, as well as young plants, from the LonIon nurseries, and passed them off as his own raising or importation. Had the people of England known that locust seeds and locust plants were so easily to be obtained, it is probable that the locnst mania would never have attained the height it did. To show the folly or the knavery of this extraordinary individual, we quote the following from Loudon's "Arboretum Britannicum," which should be preserved more as a literary curiosity rather than a historical record. "It is 
wortlyy of notice," says Loudon, "that Cobbett, apparently without ever having seen a hop-pole made of locust, boldly affirms that the tree is admirably adapted for that purpose; that trees from his nursery, after being four years planted on Lord Radnor's estate, at Coleshill, were 'fit for hop-poles, that will last in that capacity for twenty or thirty years at least ;' that 'such poles are worth a shilling each ' (that is, nearly double what was at that time the price of good ash hop-poles;) that 'five acres would thus, in five years, produce $£ 529$;' and that 'each stump, left after the pole was cut down, would send up two or three poles for the next crop, which, being cut down in their turn, at the end of another five years, would, of course, produce two or three times the above sum!' that locust wood is 'absolutely indestructible by the powers of earth, air, and water ;' and that 'no man in America will pretend to say that he ever saw a bit of it in a decayed state.' After this, it will not be wondered at, that Cobbett should call the locust 'the tree of trees,' and that he should eulogize it in the following passage, which is so characteristic of the man, and so well exemplifies the kind of quackery in which he dealt, that we quote it entire:- 'The time will come', he observes, ' and it will not be very distant, when the locust-tree will be more common in England than the oak; when a man would be thought mad if he used anything but locust in the making of sills, posts, gates, joists, feet for rick-stands, stocks and axletrees for wheels, hop-poles, pales, or for anything where there is liability to rot. This time will not be distant, seeing that the locust grows so fast. The next race of children but one, that is to say, those who will be born sixty years hence, will think that the locust-trees have always been the most numerous trees in England; and some curious writer of a century or two hence, will tell his readers that, wonderful as it may seem, "the locust was introduced to a knowledge of it by William Cobbett." "What he will say of me besides, I do not know ; but I know that he will say this of me. I enter upon this account, therefore, knowing that I am writing for centuries and centuries to come.'-( Woodlands.) The absurdity of the above passage renders it almost unworthy of comment; but we may remark that, even supposing all that Cobbett says in it of the application of the locust were true, the uses which he has enumerated do not amount to a hundredth part of those to which timber is applied in this country. Hence, were his predictions to be verified, and were the locust to become more prevalent than the oak, we should find its wood a miserable substitute, in the construction of ships and houses, for that of our ordinary timber trees. Every experienced planter or timber owner, both in Europe and America, has felt this; and this is the true reason why the tree never has been, and never will be, extensively planted."

M. Miller, editor of the "Journal des Forêts," for 1830, gives a very interesting memoir on the history of this tree in France, from its introduction up to that time. The result of all that had been said in favour of the Robinia in France, is, that it is generally employed in that country to decorate pleasure-grounds; but no mention is made of forest plantations of locust for the express purpose of raising timber for carpenter's work, or for ship-timber.

In Britain, the rage for planting the locust has long since subsided; but the importance of this tree in ship-building, and for other valuable purposes, was laid before the public in 1836, by Mr. W. Withers, of Holt, in Norfolk, England, in his "Treatise on the Growth, Qualities, and Uses of the Acacia-tree, \&c." He commences with a translation of the "Lettre sur le Robinier," of M. François, and some abstracts from the "Pièces relatives à la Culture et aux Usages de cet Arbre," which the last-named gentleman had appended to his work. He then gives extracts from the writings of MM. F. C. Medicus and A. Michaux, as well as from the various British authors who had written on the subject; and concluded, by giving various original communications from gentle- 
men in different parts of Britain, who had cultivated the locust, or who had applied it to practical purposes. The facts collected in this work confirm the rapid growth of this tree, in favourable soils and situations, and of the "suitableness and durability of its timber for trenails, posts, and fencing, and also for axletrees of timber carriages ;" but none of them afford any evidence either of the tree attaining a large size, or of its timber being applied to the general purposes of construction.

Selby, in his "History of British Forest-trees," published in 1842, says : "From our own observations on this tree, we are decidedly of opinion that it cannot be grown to profit, or at least to equal profit, with many other trees, even for those minor uses for which it is stated to be so well adapted, such as posts, railings, hop-poles, \&c., much less as a timber-tree applicable to general purposes. The durability of the wood of the locust we do not deny or dispute; indeed, our own experience has proved that when mature, it possesses the quality of resisting decay in the most trying situations, to an eminent degree; what we contend for is, that this solitary advantage of durability, (an advantage we believe possessed in nearly an equal degree by the larch, and perhaps the wild cherry,) is not sufficient to counterbalance the disadvantages under which it labours." Among the various objections to which the cultivation of the locust upon an extensive scale, in England, and with a view to profit, is liable, the following are mentioned by Mr. Selby, as holding a prominent place: "1st, it requires a rich, free soil, and a sheltered situation, to attain a size fit for any useful purpose, and even with these advantages, it seldom attains dimensions to make it generally useful; $2 \mathrm{~d}$, from the succulent and exhausting nature of its roots, it requires a much greater space to reach maturity than many other trees producing timber of a larger scantling and of greater value; $3 \mathrm{~d}$, it is not a tree to plant in mixed plantations; the surrounding species, notwithstanding the rapidity of its early growth, generally overtopping and destroying it before it acquires size sufficient to repay the planter for its occupancy; 4 th, trees equally, or, in some respects, better qualified for the uses for which the locust has been recommended, can be grown upon inferior soil, in less time, and in much greater bulk, both individually and per acre; such we hold to be the case with the larch, where posts, railings, hurdles, and other enduring articles are required; and such is the case with the ash, the Spanish chesnut, and the gean, where hop-poles are the object in view. Indeed, with respect to the fitness of the locust for the latter purpose, the evidence adduced by Mr. Loudon is pretty conclusive against it; as he shows, that at a hop-pole size, it does not last longer than other woods, that the stools do not throw up shoots so freely as those of many other trees, and that the essential requisites of a hop-pole, viz., length and straightness, cannot be produced from the locust even in the most favourable situations, or when drawn up in nursery rows. The growth of the tree precludes the possibibility of a perfectly straight pole; for as it never ripens the whole length of its young and rampant shoots, the following year's growth being from a side-bud, is necessarily at an angle with that of the preceding year."

The largest tree of this species recorded in England, is at Syon, near London, which in 1836, had attained the height of eighty-one feet, with a trunk three feet, four inches in diameter, at one foot above the ground, and an ambitus, or spread of branches, of fifty-seven feet.

In Scotland, at Airthrey Castle, in Stirlingshire, there is a locust-tree, which attained the height of sixty-two feet in forty-three years after planting, with a trunk two feet in diameter, and an ambitus of thirty feet. It grows in light loam or gravel, and in a sheltered situation.

In Ireland, at Shelton Abbey, in Wicklow, there is a locust which attained 
the height of sixty-five feet, in fifty years after planting, with a trunk twentyfive inches in diameter.

In France, and in the south of Germany, M. Baudrillart informs us in the "Dictionnaire des Eaux et des Forêts," published in 1825, that the locust was first received with enthusiasm as an ornamental tree; but was afterwards rejected, on account of the late appearance of its leaves, its fragile branches, disagreeable spines, and above all, because it would not bear the shears. Until the introduction of the modern style of gardening, it had almost become forgotten, when a reaction took place in its favour, and from the rapidity of its growth, and useful qualities, it was preferred to all other trees. Many authors, who have written on this tree, in France, have generally exaggerated its merits. Thus, M. François was in favour of planting it in particular soils and situations, but others recommended it to be planted everywhere; and, in consequence of its not succeeding in unsuitable soils, a third class of writers were for discontinuing its cultivation altogether. As examples of want of success in cultivating this tree, there were several instances where large tracts of land were ploughed, and sown broad-cast with locust seeds, which came up, but the plants never attained any magnitude, owing to the lightness and sterility of the soil. M. Baudrillart refers to a case on the heaths of Gondreville, where the tree was extensively planted in a white sand, and proved a complete failure, except on the banks of ditches; although the Pinus maritima and sylvestris, and the birch had been cultivated there with tolerable success. He makes mention of another instance in the Bois de Boulogne, where locusts, that were planted at the same time with, and among masses of the birch, the yew, the chesnut, the perfumed cherry, and the common sallow, grew rapidly for five or six years, rising far above them at first, but gradually disappeared after a certain time, the other trees having become nore vigorous, and finally choked them out. He further states that, "M. Mallet had no better success in the Forest of Mareuil, in the department of Vienne, where the soil is moist and aquatic; nor in the Forest of Chatellerault, where it is dry and sandy." M. Baudrillart concludes, by repeating, after Michaux, that "it is only in a favourable climate, and in a good soil, that the tree attains a great size, even in its native country."

In France, at Paris, in the Jardin des Plantes, the remains of the parent tree, planted in 1635, by M. Vespasian Robin, is said still to exist, and is nearly eighty feet in height. At Villers, there is another tree of this species, which attained the height of sixty feet in twenty years after planting.

In Germany, at Schwöbber, in Hanover, the remains of an old Robinia still exist, which has been planted nearly one hundred and thirty years. At Wörlitz, in Saxony, there is another which attained the height of sixty feet in sixtyfour years after planting.

In Denmark, at Dronengaard, near Copenhagen, there is a locust which attained the height of sixty feet in forty years after planting.

In Russia, upon the foundations of the Palace of Yalomensk, in the neighbourhood of Moscow, there is a liedge of acacia, according to Leitch Ritchie, planted in such a manner as to indicate the plan of the building. This palace was built by Peter the Great, and at a short distance from it is another tree, surrounded by a table and benches, under which young Peter received his lessons. At Moscow, the locust does not attain any considerable size; but, according to Descemet, it thrives in the Crimea in all its varieties.

In Switzerland, there are several locust-trees, which have attained a height of fifty to seventy feet.

In Italy, in the palace gardens at Monza, there is a noble tree of this species, which attained the heiglit of seventy-five feet in twenty-nine years after planting, with a trunk two feet in diameter, and an ambitus of forty feet. 
In America, the locust has been planted for ornament, in great abundance about farm-houses, and along fences and avenues, for more than fifty years; and since the forests were in a measure destroyed by the axe or fire, by the European settlers, along the sea-board and navigable waters inland, many persons in the middle and eastern states have cultivated this tree with a view to profit, and have not only supplied timber and trenails to the shipwrights of the cities or commercial towns, but have exported large quantities to England and elsewhere. These plantations seldom exceed an area of thirty acres, notwithstanding the agricultural societies of several states have offered premiums for their encouragement. 'Though the Robinia had never been known to be injured by any insect, towards the end of the last century, in Massachusetts, it was generally attacked by the larvæ of the Cossus robiniæ, which gradually extended their ravages to the sonthernmost points where this tree has been propagated. In consequence of this discouragement, the locust has been but little cultivated for the last twenty years in any part of the United States, or in Canada, except for the purposes of ornament or shade. In a communication received by us, from Mr. Stephen H. Smith, of Smithfield, in Rhode Island, dated on the $22 \mathrm{~d}$ of November, 1844 , he states that, in the winter of 1817 , he cut from a lot a heavy growth of timber, principally chesnut. The soil on which it grew, is a rich loam, or a slightly tenacious subsoil. In the following spring, he set out, in the same ground, at equal distance, about one hundred good-sized, yellow locust-trees to the acre. They kept pace with the natural growth of the forest that sprang up about them. In 1S37, twenty years after, all the wood was again cut off the same lot, producing twenty cords to the acre, the locusts measuring at the stump from nine to twelve inches in diameter, each tree niaking three posts, seven feet long. The sprouts and offsets now occupy one half the ground, to the exclusion of a portion of the native timber. 'The borers have not assailed these trees at any time. It may be reasonable to conclude that, the thick underwood has protected them from this enemy; as those standing near, in open, cultivated ground; of like quality, have not escaped.

Poetical and Legendary Allusions. No tree, perhaps, possesses more themes for the poet, yet less noticed, than the locust. The poetical ideas connected with it, are said, by Philips, in his "Sylva Florifera," to arise from its being, when planted in shrubberies, the favourite resort of the nightingale, which probably selects it for building its nest from an instinctive feeling of the protection afforded by its thorns. He also mentions an instance of a child, who had observed the peculiarity of the leaflets of this tree folding themselves up at night, saying that "it was not bed-time, for the acacia had not begun its prayers." We are told that the American Indians make a declaration of love by presenting a branch of this tree in blossom to the object of their attachment.

Soil and Situation. The soil in which the locust appears to grow best, is a light, and somewhat sandy loam, rich rather than poor; and to attain any considerable size, it requires much room, and an airy, but at the same time, a sheltered situation, free from the fury of the winds. It has the quality of thriving for a iime on poor, shallow soils, which, no doubt, is owing to its power of rapidly abstracting whatever nourishment such soils may contain, by its large, succulent roots, that run near the surface; but after a few years it becomes stunted and unhealthy, decays at the heart, and never attains a size sufficient for any useful purpose, except for fuel. The only trees that will prosper on such soils, and ultimately become timber, are the resiniferous, needle-leaved kinds, as the pine, the fir, the cedar, and the larch. When cultivated for ornament, this tree generally looks best planted separately on a lawn, or in small groups in a shrubbery, or along the confines of avenues and plantations, where it is allowed to extend "its branches 
freely on every side, and to assume its own peculiar shape, feathering," as G11pin says, "to the ground."

Propagation and Culture. The locust may readily be propagated in the moist climate of Britain, by cuttings of the roots, and also by large truncheons, as well as by the suckers, which shoot up in great numbers in that country, and to a considerable distance around the trees; but, in general, both in Europe and in America, the simplest and the best mode is by seeds. According to M. Roland, the elder, a distinguished French agriculturist, the most favourable time for sowing, is late in the year, when, he says, the seeds germinate best; but they may either be sown as soon as they are ripe, in October, or in the March or April following. Whether they be sown in autumn or spring, they will come up the ensuing summer, and the plants, by the end of the season, will be fit either for transplanting into nursery lines, or to the places where they are finally to remain. 'The seeds, if exposed to the air two years after being gathered, lose their power of vitality; but if they be kept in their pods, and buried a considerable depth in dry soil, they will remain good for five or six years, or perhaps longer. As seedbearing trees seldom produce two abundant crops in succession, a reserve should be kept from one year to another. The great difficulty experienced in causing locust seeds to vegetate, operates as a discouragement with many, as they require to be prepared before sowing, in order to soften their hard and shelly pericarps, or hornlike envelopes, in which nature has deposited their germs. A writer in the "Maine Cultivator," recommends pouring water over the seeds, previously heated to the boiling point, and suffering it gradually to cool. After twenty-four hours, to decant the water from the seeds, and select such as have opened, for immediate sowing. He also recommends another mode, and perhaps a somewhat more economical one, so far as time is concerned, which is, to subject the seeds to the action of nitric acid, mixed in the proportion of half an ounce to two quarts of water. The seeds are to be steeped in this mixture for twenty-four hours before sowing, and the water kept tepid, or slightly warm, by means of a stove or oven. By this process the perfect seeds will at once evince signs of vitality and germination, while those which remain unaffected at the end of twenty-four hours, will probably be unsound, and may be thrown away. An experiment is related in Wither's "Treatise," by the results of which, it appears that, "immersion in hot water accelerates germination, but tends to destroy or injure the seeds." Mr. Loudon, in his "Arboretum Britannicum," remarks that, steeping Australia and Cape acacia seeds for twenty-four hours, in water which had been poured on them in a boiling state, or nearly so, accelerated their germination nearly two years. Great caution should be observed, however, in experiments of this kind, as even a short continuation of seeds in water at the temperature of $212^{\circ} \mathrm{F}$., must of course destroy the vital principle. The seeds should be sown in a good, free, warm soil, rather rich than otherwise, an inch or two apart every way, and covered with finely pulverized earth, from a quarter to three-quarters of an inch deep. In fine seasons, the plants will grow from two to four feet in height; the largest of which may be removed in the following autumn, to the places where they are finally to remain, and the others may be transplanted into nursery lines. In regard to the removal of the locust, Loudon observes, that "it will transplant at almost every age, and with fewer roots than almost any other tree." The trees should never be suffered to stand nearer than fifteen feet apart, in any soil, and should they be consigned to a soil thin and light, they should be planted at least twenty feet asunder. As they advance in age and growth, care should be taken to clear out all broken branches or dead wood from their tops, and to keep down their suckers, which will sometimes issue from their roots, where the soil is moist and rich. Under favourable circumstances, tr 
olants will sometimes produce annual shoots from six to eight feet long for seveal years after planting; whereas, in wet or poor soils, they will not exceed one-ourth of this length. After the first ten or twelve years, upon good land, the ocust will probably have attained a height of fifteen or twenty feet, with a diamter of three or four inches; and then its growth, in general, becomes very slow ; and few trees, at the expiration of fifty or sixty years, will be found over fifty eet in height, and one foot in diameter.

Insects, Accidents, $\mathcal{f}^{*} c$. The Robinia pseudacacia, in Europe, is very free from he attack of insects; but in those parts of the United States where this tree is culivated, it is preyed upon by three distinct species of borers, or wood-eaters, the unchecked operations of which threaten an almost entire destruction of this valuable tree. Dr. T. IV. Harris, in his "Report on the Insects of Massachusetts njurious to Vegetation," observes that, "One of these borers is a little reddish caterpillar, whose operations are confined to the small branches and to very young rees, in the pith of which it lives; and by its irritation it causes the twig to swell, around the part attacked. These swellings, being spongy, and also percorated by the caterpillar, are weaker than the rest of the stem, which therefore easily breaks off at these places. My attempts to complete the history of this nsect have not been successful hitherto ; and I can only conjecture that it belongs to the Egerians, or possibly to the tribe of Bombyces." In the same work, he lescribes a second lind of borer, called Clytus pictus, or the painted clytus. "In the month of September," he says, "these beetles gather on the locust-trees, where they may be seen glittering in the sun-beams, with their gorgeous livery of black velvet and gold, coursing up and down the trunks in pursuit of their mates, or to drive away their rivals, and stopping every now and then to salute those they meet, with a rapid bowing of the shoulders, accompanied by a creaking sound, indicative of recognition or defiance. Having paired, the female, attended by her partner, creeps over the bark, searching the crevices with her antennæ, and dropping therein her snow-white eggs, in clusters of seven or eight together, and at intervals of five or six minutes, till her whole stock is safely stored. The eggs are soon hatched, and the grubs immediately burrow into the bark, devouring the soft, inner substance, that suffices for their nourishment till the approach of winter, during which, they remain at rest, in a torpid state. In the spring, they bore through the sap-wood, more or less deeply into the trúnk. the general course of their winding and irregular passages, being in an upward direction from the place of their entrance. For a time, they cast their chips out of their holes as fast as they are made, but after awhile, the passage becomes ulogged, and the burrow more or less filled with the coarse and fibrous fragments of wood, to get rid of which, the grubs are often obliged to open new holes through the bark. The seat of their operations is known by the oozing of the sap and dropping of the saw-dust from the holes. The bark around the part attacked begins to swell, and in a few years the trunk and limbs will become disfigured and weakened by large, porous tumours, caused by the efforts of the trees to repair the injuries they have suffered." According to the observations of a writer in the "Massachusetts Agricultural Repository and Journal," vol. vi., the larvæ of this insect attain their full size by the 20th of July, soon after which, they pass into the pupa state, and are transformed into beetles early in September. The third class of borers which attack this tree, is the Xyleutes robiniæ, or locust-tree carpenter moth, of Harris; or the Cossus robiniæ, described and figured by Professor Peck, in the Vth volume of the "Massachusetts Agricultural Repository and Journal." According to Michaux, the ravages of these insects were first observed about sixty years ago; but their habits were 1ot generally known before the year 1803, when they first attracted the attenion of Professor Peck, of Harvard University. He observed several locust-trees 
that had been blown down by a storm, which were much bored by the larvæ of these insects, with their heart-wood dead. In splitting some billets of these trees he found that they contained several of the caterpillars or borers, of different magnitudes, which enabled him to watch them through the various stages of their growth. "The furrows in the bark of the locust," says he, "are large and deep, extending, in some places, even to the liber or inner bark. It must be in the deepest of these furrows, that the egg to produce the caterpillar is deposited. The inner bark is thick and succulent, affording to the young larvæ a tender and proper food. The sap-wood is harder; this, too, is perforated to the perfect, or heart-wood, on which it is afterwards to feed. This it bores in various directions, obliquely, upward, and downward, making them larger as it increases in bulk. Some of these perforations are large enough to admit the little finger. The grubs

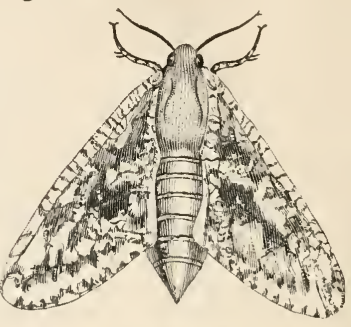
of the wood-eating beetles always provide a path for the escape of the perfect insect out of the wood, before they go into the nympha or chrysalis state. In the same manner docs the caterpillar of the locust form an opening quite through the bark, before it forms its cocoon. An inspection of the scene of its labours, clearly discovers how everything is done." Professor Peck supposed that the larva lives in the wood three years or more, before it attains its full growth. 'The moths, which come forth about the middle of July, have thick and robust bodies, broad, and thickly veined wings, two distinct feelers, and antennæ, that are furnished on the under side, in both sexes, with a double set of short teeth, rather longer in the male than in the female. The larva of this insect is said also to prey upon the wood of the black oak (Quercus tinctoria.) The other insects that attack the common locust-tree, is a species of apion, which inhabits the pods and devours the seeds; and the Eudamus tityrus, which feeds upon its foliage, as well as upon that of the Robinia viscosa.

Properties and Uses. The wood of the locust, which is commonly of a greenish-yellow colour, marked with brown veins, is very hard, compact, and susceptible of a brilliant polish. It possesses great strength, with but little elasticity; and its most valuable property is that of resisting decay longer than almost any other species of wood. When newly cut, it weighs sixty-three pounds, three ounces to a cubic foot; half dry, fifty six and a quarter pounds, and when quite dry, only forty-eight and a quarter pounds, or according to others, only fortysix pounds. According to M. Hartig, the German dendrologist, its value for fuel, when compared with that of the beech, (Fagus sylvatica), is as twelve to fifteen. For duration, he places it next below the oak, (Quercus robur,) and next above the larch, (Larix europæa,) and the Scotch pine (Pinus sylvestris.) Barlow, in Wither's "Treatise," gives the strength of locust timber, as compared with nther woods, as follows :-

Teak, ('Tectona grandis,) . . . . . . . . . . . 2462

Ash, (Fraximus excelsior,) : : . : . : . : . . : . 2026

Locust, (Robinia pseudacacia,)

Oak, (Quercus robur, ) . . . . . . . 1672

Beech, (Fagus sylvatica, ) . . . . . . . . . 1556

Norway spar, (Abies excelsa, ) . . . . . . . . 1474

Riga fir, (Pinus sylvestris rigensis, ${ }_{\text {) }}$. . . . . . . 1108

Elm, (Ulmus campestris, ) . . . . . . . . . . . 1013 
From some experiments made at Brest, in 1823, the weight of the locust wood was found to be one sixth heavier than that of the English oak; its strength as one thousand four hundred and twenty-seven to eight hundred and twenty; and its elasticity as twenty-one to nine. By experiments made in the yard of the royal naval college, at Woolwich, it appears that the lateral strength of locust timber, in resisting fracture, is greater than that of the British oak, in the proportion of one hundred to seventy-five. From all these experiments, however widely they may differ in their results, we may safely conclude, that sound, well-seasoned locust timber "is heavier, harder, stronger, more rigid, more elastic, and tougher, than that of the best English oak;" and consequently is more suitable for trenails. Michaux remarks that, "if the trunks of the locust-trees grown in the north of Pennsylvania, exceed fifteen inches in diameter, when they are cut down and split open, they are frequently found to be decayed at the heart; but that this is not the case with trees that have grown farther south;" which would tend to show that a poor soil and a cold climate are not sufficient to produce good timber.

There are at least three popular varieties of the common locust, distinguishable by the colour of the heart-wood, which may be described as follows:-

1. Red Locust, with the heart red, and is esteemed as far the most beautiful and durable timber. Posts of this variety, perfectly seasoned before they are set in the ground, are estimated to last forty years, or twice as long as those of the white locust.

2. Green or Yellow Locust. This is the most common variety, being known by its greenish-yellow heart, and is held next best in quality to the red locust.

3. White Locust, with a white heart, and is considered as the least valuable of them all.

All of the above-mentioned variations are supposed to be owing entirely to the soil and situations in which they grow, being caused in a similar manner as the various colours of the flowers of the hydrangea, which depend on the nature of the earth in which they are planted, and even on the colour of the water with which they are irrigated.

In naval architecture, the timber of the locust is much esteemed by Americau shipwrights, and enters, with the live oak, the white oak, and the red cedar, into the upper and the lower parts of the frames of vessels, though in very small proportions. It is considered as durable as the live oak, and the red cedar, with the advantage of being lighter than the former and stronger than the latter. It is used for trenails in the dock-yards of Europe and the United States, in preference to any other kind of wood; and instead of decaying, it acquires, in time, an extraordinary degree of hardness. In civil architecture, in this country, it enters but little into the composition of houses, on account of its scarcity, and its value in ship-building, and for posts of rural fences, sc. When employed in the construction of houses, it is more particularly applied for the support of the sills, which usually consist of more destructible timber, and which, if they were placed immediately on the ground, would sooner decay. From the hardness of the wood when seasoned, the firmmess of the grain, and its lustre when polished, it lıas been extensively used in cabinet-making, and has been substituted by turners for the box-wood, in many species of liglit work, such as small domestic wares, toys, \&c. It has also been employed by mill-wrights for cogs, but it is less valuable for this purpose than that of the rock maple.

The most important use to which the locust is applied in Britain, is that of forming trenails for ship fastenings: and large quantities are annually imported into that country from America. As long as we can supply them for the prices which they at present bear, it never would repay the grower to cultivate them in England for this special purpose.

In France, the locust has been extensively cultivated in the Gironde, in copses, 
which are cut at the age of four years, for vine-props; and these props are said to last more than twenty years. In the same district, old trees are pollarded, and their branches lopped every third year, for the same purpose. In Paris, many small articles are made of the wood; such as salt-cellars, sugar-dishes, spoons, forks, sand-boxes, paper-knives, $\mathbf{i c}$.

In Lombardy, the wood of the locust is used for many rural purposes. Young plants of it were formerly much employed for live fences; but this practice has long since been abandoned, because the tree was found to impoverish the soil; and, with age, lost its prickles; besides, from being continually pruned, to keep it low, or from being cropped by animals, the hedges became thin and open at the bottom, and eventually became mere stumps. Italy, as well as the southern departments of France, Michaux considers the countries in which the greatest advantages may be derived from the rapid growth of this tree. In good soils, in such climates, at the end of twenty or twenty-five years, he says, that a mass of wood may be obtained from the locust, twice as great as from any other species of tree.

In countries where clovers and root crops are not cultivated, the leaves of the locust may serve as a substitute for these articles as provender for animals. When this species is cultivated for this purpose, it should be mown every year; or the trees may be allowed to grow to the height of eight or ten feet, and treated as pollards, the branches being cut off every other year, which should be done at mid-summer, when they are succulent, and can be dried for winter's use. In performing this operation, one or two shoots should be left on each tree, to keep up vegetation, which may be pruned off the following winter or spring. When the shoots are to be eaten green, none should be taken but those of the same season; because in them the prickles are herbaceous, and, consequently, do not injure the mouths of the animals.

The roots of the locust are very sweet, and afford an extract which might be substituted for licorice. The flowers have been employed medicinally, as antispasmodics, and have been distilled into an agreeable, refreshing syrup, which is drunk with water to quench thirst. The flowers retain their fragrance when dried; and those of a single tree are sufficient to perfume a whole garden.

As an ornamental tree, the locust, with its light and elegant foliage, its sweetly perfumed flowers, its beautiful pendent form, often "feathering to the ground," will always be entitled to a place in our parks, lawns, and pleasure-grounds; but, as Gilpin says, "its beauty is frail, and it is of all trees the least able to endure the blast. In some sheltered spot it may ornament a garden; but it is by no means qualified to adorn a country. Its wood is of so brittle a texture, especially when it is encumbered with a weight of foliage, that you can never depend upon its aid in filling up the part you wish. The branch you admire to-day may be demolished to-morrow. The misfortune is, the acacia is not one of those grand objects, like the oak, whose dignity is often increased by ruin. It depends on its beauty, rather than on its grandeur, which is a quality more liable to injury. I may add, however, in its favour, that, if it be easily injured, it repairs the injury more quickly than any other tree." It has also "the further disadvantage of coming late into leaf, and being among the very first to cast its foliage in autumn, and this without undergoing any change of colour, or exhibiting those beautiful and mellow tints which enrich the landscape at this season of the year."

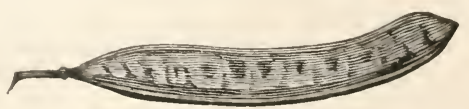




\section{Robinia viscosa, \\ THE VISCOUS-BARKED ROBINIA.}

Synonymes.

Robinia viscosa,

Robinia glutinosa,

Robinia montana,

Acacia visqueuse,

Klebrige Acacie,

Robinia rosa, Robinia di fior rosso,

Rose-flowering Locust,

\author{
(Mrchadx, North American Sylva. \\ De Candolle, Prodromus. \\ $\{$ Du Hamed, Traité des Arbres et Arbustes. \\ Loudon, Arboretum Britannicum. \\ Torrey and Gray, Flora of North America. \\ Curtis, London Botanical Magazine. \\ Bartram, Travels. \\ France. \\ Germany. \\ ITALY. \\ Britain and Anglo-America.
}

Derivation. The specific name, viscosa, is derived from the Latin viscus, properly a species of shrub, which yields a giut1 nous substance, called bird-lime, and has reference to the viscid or clammy nature of the bark of this tree.

Engraving8. Michaux, North American Sylva, pl. 77; Loudon, Arboretum Britannicum, ii., figure 306, et $\nabla .$, pl. 87 , and the figures below.

Specific Characters. Branches and legumes glandular and clammy. Racemes crowded, erect. Bracteas concave, deciduous, each ending in a long bristle. The three lower teeth of the calyx acuminated Roots creeping.-De Candolle, Prodromus.

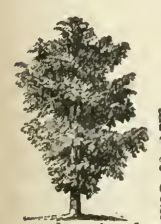

\section{Description.}

twelve inches ' shoots, is of a dull red, and is covered with a viscid substance, which, when touched, adheres to the fingers. In every other respect, this tree strongly resembles the preceding species. The branches are armed with spines, which, however, are smaller and less numerous. The foliage is thicker, and of a dusky green. The leaves are five or six inches long, and are composed of opposite leaflets, with a terminal odd one. The leaflets are about an inch in length, oval, nearly sessile, smooth, and of a fine texture. The flowers usually appear in June and July, but in some seasons, they put forth a second time, both in England and in the United

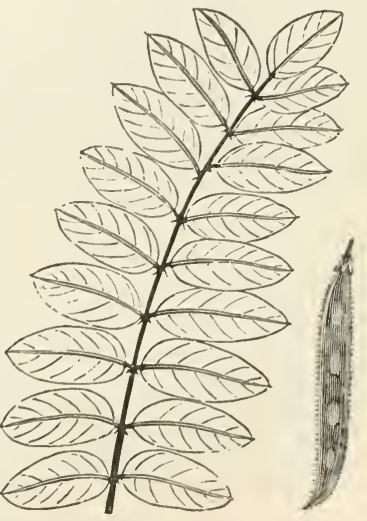

States. 'They occur in numerous, open bunches, four or five inches long, and are of a beautiful rose-colour, mixed with white, but are destitute of fragrance. The seeds, which are small, are contained in hairy pods, two or three inches long, and about half of an inch broad.

Geography and History. In its natural habitat, this species appears to be chiefly confined to the Alleghanies, in the western parts of Georgia and the Carolinas, although it is found on the banks of the rivers in these states, particularly on the Savannah. It was introduced into Britain in 1797 , and is much cultivated for ornament in various parts of Europe. 
The largest recorded tree of this species in England, is at Croome, in Worcestershire, which, in thirty years after planting, attained the height of forty-five feet. In Berkshire, at White Knights, there is another tree, which, in thirty-four years after planting, attained the height of thirty-three feet, with a trunk nine inches in diameter, and a spread of branches of twenty-four feet.

Soil, Situation, Culture, $\mathcal{4} c$. The natural habitat of this tree is near rivers; but it will thrive in any soil where the common locust will prosper, and may be propagated and treated in the same manner, its rate of growth, in different situations and circumstances, being nearly the same for the first five or six years.

Insects. The leaves of the Robinia viscosa are particularly relished by the larvæ of the great silver-spotted skipper butterfly, Papilio tityrus, of Smith and Abbot, or the Eudamus tityrus, of Harris. This caterpillar was taken by Mr. A bbot, feeding on a wild locust-tree, the latter end of August. It spun the leaves together, to secure itself from birds, \&c., like the rest of the tribe, on the 5th of September, and became a chrysalis in two days after. The butterfly was produced in Georgia the 10th of April following. According to Dr. Harris, they make their appearance from the middle of June till after the beginning of July. The females lay their eggs, singly, on the leaves of the common locust, as well as on this species. The caterpillars are hatched in July, and mostly feed in the night, and keep themselves closely concealed during the day. This tree is sometimes nearly deprived of its leaves by these insects, or presents only here and there the brown and withered remains of foliage, which has served them for a temporary shelter.

Properties and Uses. The wood of the Robinia viscosa resembles that of the common locust, both in its appearance and in other properties; but owing to its inferior size, and being of less durability, it is but little employed in construction and in the arts. As this tree soon arrives at perfection, and is rendered conspicnous by its large roseate flowers, it well deserves a place in every ornamental plantation. At the same time, let it be borne in mind, that its creeping roots are a great nuisance in all cultivated grounds. The clammy matter which exudes from the bark of the young shoots is said to have been examined by Vauquelin, and found to contain a new vegetable substance. 


\section{Genus GLEDITSCHIA, Linn.}

Leguminaceæ.

Syst. Nat.
Polygamia Diœcia.

Syst. Lin.

Synonymes

Acacia, Gleditschia,

Os Authors.

Derivaticns. The word Acacia, is derived from the Celtic $a c$, a point, and has reference to the spines of the true acacia, an Egy ptian tree which this genus somewhat resembles. The generic name, Gleditschia, was so named in honour of Gottlieb Gleditsch, of Leipsic, once a professor at Berlin, and defender of Linnæus against Siegesbeck.

Generic Characters. Branchlets supra-axillary, and often converted into branched spines. Leaves abruptly pinnate; in the same species pinnate, bipinnate, or, rarely, by the coalition of the leaflets, almost simple. Flowers greenish, in spikes. Among the ovaries, it often happens, especially among those of the terminal flowers, that two grow together by their seed-bearing suture, which is rather villose.-De Candolle, Prodromus.

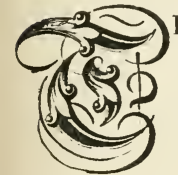

HE genus Gleditschia, in its indigenous state, appears to be confined to North America and China. It probably embraces not more than three distinct species, two American and one Chinese. The latter, Gleditschia sinensis, is distinguished by its trunk being more spiny than its branches. To the same natural family belongs the carob-tree, (Ceratonia siliqua,) which is generally considered as the locust-tree mentioned in the Bible. On this subject, Professor Martin remarks, that, the ignorance of eastern manners and natural history, induced some persons to fancy that the locusts on which Saint $J_{\text {ohn }}$ the Baptist fed, were the tender shoots of plants, and that the wild honey was the pulp of the pod of the carob; whence it is sometimes called "Saint John's bread." There is little reason to suppose, he adds, that the shells of the carob pod might be the husks which the prodigal son desired to partake of with the swine. This tree is very common in the south of Spain, where it is called algarrobo, and its seeds or beans are eaten there by man as well as by animals, as was the case in 1811 and 1812 , when they formed, at times, the principal food of the horses of the British cavalry. From the curious, horn-like pods of this tree, and the sweet fecula contained in its seeds, it well deserves to be extensively cultivated in the southern states of the union, by all who have means and conveniences for raising it. 


\title{
Gleditschia triacanthos, THE THREE-THORNED GLEDITSCHIA.
}

\author{
Synonymes. \\ Gleditschia tracanthos, \\ (Linnates, Species Plantarum. \\ De Candolle, Prodromus. \\ $\{$ Michaux, North American Sylva. \\ Loudon, Arboretum Britannicum. \\ Torrey and Gray, Flora of North America. \\ Févier d'Amerique, Févier à trois épines, France. \\ Dreidorniger Honigdorn, GEkmaNy. \\ Acacia spinosa, Gleditschia spinosa, Fava ITalx. \\ Févier, \\ Honey-shuck Locust, \\ French Canada. \\ Honey Locust, Sweet Locust, Thorny ? \\ Acacia. Three-thorned Acacia. \\ KENTUCKY.
}

Derivations. The specific name, triacanthos, is derived from the Greek treis, three, and canthos, a thorn, having reference to the disposition of the spines, which are mostly triple or compound. The French name, Ftvier, is probably corrupted from the word feve, a bean, from the resemblance which the pods of this tree bear to those of beans. The German name signifies Three-thorned Honey Thorn. The English and French Canadian names are applied to this species on account of the sweet flavour of the juice of the pods.

Engravings. Michaux, North American Sylva, pl. 79; Audubon, Birds of America, pl. xlii.; Loudon, Arboretum Britannicum, v., pl. 90 ; and the figures below.

Specific Characters. Spines simple or trifid; stout, at the very base compressed, in the upper part cylindrical, but tapered. Leaflets linear-oblong. Legumes flattish, rather crooked, many-seeded, and more than ten times as long as broad.-De Candolle, Prodromus.

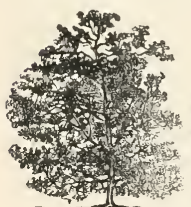

\section{Description.}

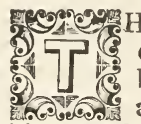

HE Gleditschia triacanthos, in favourable situations, attains a height of seventy or eighty feet, with a trunk three or four feet in diameter, clear of branches to the height of thirty feet. The bark of the trunk and branches is of a gray colour, and that of the young shoots and spines, of a purplish-brown. When the tree becomes old, the bark of the trunk detaches itself laterally, in plates three or four inches in width, and nearly a quarter of an inch in thickness. When advanced in age, the trunk and branches are armed with large prickles, which, though not ligneous, become hard, and remain attached to the bark for several years. These pricklcs are not only produced from the young wood, but occasionally

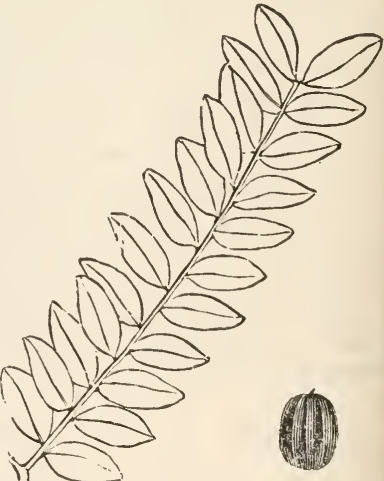
protrude themselves from the trunk, even when the tree is of considerable bulk and age. The trunk often presents a twisted appearance, and the branches proceed from it rather horizontally, than in an upright direction. The foliage is particularly elcgant, and is so thin that it scarcely obstructs the passage of the rays of the sun. The leaves are pinnated, and composed of small, oval, sessile eaflets, slightly crenulated at their summits, and of an agreeable, shining, light- 
green. They appear rather late in spring, and begin to turn yellow, and drop off early in autumn. The flowers, which open in June, are small and rather inconspicuous, the male being in the form of catkin-like racemes, of nearly the same colour of the leaves. The fruit is in the form of flat, crooked, pendulous pods, from twelve to eighteen inches in length, of a reddish-brown colour. They contain numerous hard, smooth, brown seeds, enveloped in a pulpy substance, which, for about a month after maturity, is very sweet, but which, in a few weeks after, becomes extremely sour. The pods often remain. upon the trees some time after the leaves have fallen. The seeds usually ripen in the United States towards the end of September.

Varieties. The varieties recognized under this species are as follows :-

1. G. т. Inernis, De Candolle. Spineless Honey Locust, the stem and branches of which are either entirely without spines, or sparingly so. There is a tree of this variety at Syon, near London, seventy-two feet in height, with a trunk nearly two and a half feet in diameter, and an ambitus of seventy-one feet.

2. G. т. вRachycarpos, Michaux. Short-fruited Honey Locust, with short spines, and oblong pods, much shorter than those of the species.

Geography and History. The Gleditschia triacanthos is sparingly found in une United States, from Pennsylvania to Georgia and Louisiana. It seems to belong more particularly to the country west of the Alleghanies; and it is scarcely found growing wild anywhere except in the fertile bottoms which are watered by the rivers that empty themselves into the Mississippi, and Illinois, especially in the southern parts of Kentucky and Tennessee. It is generally associated with the Juglans nigra, Carya squamosa, Ulmus rubra, Fraxinus americana quadrangulata, Robinia pseudacacia, Negundo fraxinifolium, and Gymnocladus canadensis. It is cultivated for ornament in the Atlantic cities and towns, from Schenectady, in New York, to Savannah, in Georgia.

This species was first cultivated in Britain in 1700, by Bishop Compton, in the palace garden, at Fulham; and Miller informs us that it produced pods there of full size, in 1728; but the seeds did not come to maturity.

The largest Gleditschia triacanthos in England, is at Syon, near London, which is fifty-seven feet in height, with a trunk three feet in diameter, and an ambitus of sixty-three feet.

In Renfrewshire, in Scotland, in the Glasgow botanic garden, there is another tree, planted against a wall, which is generally killed down to the ground every year; but in Haddingtonshire, at Tyningham, there is a tree which attained a height of nearly forty feet, in twenty years after planting.

This species was known in France in the time of Du Hanuel, who recommends it as an ornamental tree, but liable to have its branches broken by the wind, more especially when the trunk divides into two branches of equal size, and becomes forked at the summit. It ripens its seeds freely in France, as well as in suuthern Europe generally, from which plants are easily raised.

The largest Gleditschia triacanthos growing in France, is in the Jardin des Plantes, at Paris, which attained the height of eighty feet in one hundred years after planting, with a trunk two feet in diameter.

In Italy, at Monza, this species attained the height of thirty feet in twentynine years after planting. It was used also in Lombardy for hedges, but, like the common locust, when tried for the same purpose, was soon abandoned.

In Prussia, at Sans Souci, this tree attained a height of fifty feet in forty-five years after planting.

In Russia, in the Crimea, it ripened seeds, in 1827, from which young plants were raised.

Soil, Situation, Propagation, $\& \bullet c$. The Gleditschia triacanthos, in its natural habitat, is never found except where the soil is good, and its presence, Michaux 
observes, is an infallible sign of the greatest degree of fertility. When cultivated, it requires a deep, rich, free soil, and a situation not exposed to high winds. The climate should also be somewhat favourable, otherwise the wood of the young branches will not ripen, but will annually be killed off by the frost. In Britain, the species is always propagated from seeds imported from abroad. They are prepared for sowing, by soaking them twelve hours in warm water, as directed for those of the Robinia pseudacacia. They should be sown in March or April, and, if properly prepared, they will come up in two or three weeks. They are best transplanted to the spot where they are finally to remain, when quite young; as they make but few fibrous roots, and these, for the most part, take a downward direction. The varieties can only be insured by grafting or inarching on the species. In general, however, an abundance of plants of the Gleditschia triacanthos inermis may be selected from beds of seedlings of the species. The rate of growth of this tree for the first fifteen or twenty years, is generally about an average of a foot a year; but in favourable situations it will grow at double that rate.

Insects. One of the greatest enemies to the Gleditschia triacanthos is the Cantharis cinera, or the ash-coloured cantharis, of Harris. It usually appears in gardens in June, and often the foliage of this species is destroyed by these voracious insects. Dr. Harris remarks that they are also very fond of the leaves of the English bean, and that they are occasionally found in considerable numbers on potato vines. It is stated by Smith and Abbot, in their "Insects of Georgia," that the Phalæna concinna, or painted prominent moth, feeds upon this tree as well as upon the apple, persimon, and hickory. The whole brood most commonly come together. They form their webs about the first of June, and the perfect insects make their appearance in about fifteen days after. They likewise spin in autumn, and come out the following spring.

Properties and Uses. The wood of the Gleditschia triacanthos, when dry, weighs fifty-two pounds to a cubic foot. It is very hard, and splits with great difficulty, resembling in this, and some other respects, that of the common locust; but its grain is coarser, and its pores more open. This tree is neither used by the builder nor the wheelwright, but is sometimes employed, in Kentucky, where it is the most abundant, for rural fences, where wood of a more durable kind cannot be procured. Michaux says that the only useful purpose for which he thinks the tree fit, is for making hedges, but it has not succeeded either in Europe or in America. A sugar has been extracted from the pulp of the pods, and a beer made by fermenting it while fresh.

In general, this species, as well as all others of the genus, can only be considared as ornamental trees; but in that character, they hold a high rank. The delicate, light-green foliage, and beautifully varied, graceful, and picturesque forms assumed by this tree, together with the singular feature afforded by its spines, will always entitle it to a place in ornamental plantations. 


\section{Gleditschia monosperma, THE ONE-SEEDED GLEDITSCHIA.}

Synonymes.

\begin{tabular}{|c|c|}
\hline Gleditschia monosperma, & $\left\{\begin{array}{l}\text { WALTER, Flora Caroliniana. } \\
\text { DE CANDOLLE, Prodromus. } \\
\text { MICHAUX, North American Sylva } \\
\text { LOUDON, Arboretum Britannicum } \\
\text { ToRREY AND GRAY, Flora of North America. }\end{array}\right.$ \\
\hline $\begin{array}{l}\text { Févier monosperme, } \\
\text { Einsamiger Honigdorn, } \\
\text { Gleditschia monosperma, } \\
\text { Water Locust, }\end{array}$ & $\begin{array}{l}\text { FraNCE. } \\
\text { GERMANY. } \\
\text { ITALY. } \\
\text { BRitain AND ANGLO-AMerica. }\end{array}$ \\
\hline
\end{tabular}

Derivation. The specific name, monosperma, is derived from the Greek monos, one, and sperma, a seed, naving reference to the growing of only one seed in each pod. The French, German, and Italian names have the same signification. It is called Water Locust, on account of its growing only in large swamps that border rivers, where the soil is constantly wet, and often inundated at the season of the rising of the waters.

Engravings. Michaux, North American Sylva, pl. 80; Loudon, Arboretum Britannicum, ii., figure 364; and the figures below.

Specific Characters. Spines slender, not rarely trifid, few. Leaflets ovate-oblong, acute. Legumes flattish, roundish, 1-seeded.-De Candolle, Prodromus.

\section{Description.}

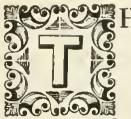

HE Gleditschia monosperma, in its natural habitat, attains a height of sixty or eighty feet, with a trunk from one to two feet in diameter. In some respects it closely resembles the preceding species. The bark, though smooth when the tree is young, cracks and scales off when it becomes old. The branches are armed with thorns, and are less numerous, and somewhat smaller than those of the Gleditschia triacanthos; and the leaves differ from it in being more diminutive in all their pro-
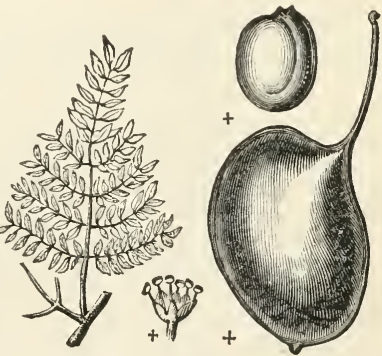
portions. The flowers, which open in June and July, are inconspicuous, of a greenish colour, and destitute of odour. They are succeeded by flat, roundish pods, of a reddish colour, about an inch in diameter, united in bunches of three, each of which contains a single, naked seed. The seeds usually come to maturity, in the United States, early in September.

Geography, History, \&॰c. The Gleditschia monosperma, along the sea-board, is found indigenous to South Carolina, Georgia, East Florida, Louisiana, and Texas; and west of the Alleghanies, it is found in Illinois. It grows only in large swamps that border the rivers, where the soil is rich and moist, or is occasionally overflowed at the season of the rising waters. In such soils it is found growing among the Taxodium distichum, Nyssa grandidentata, Acer rubrum, Quercus lyrata, Planera ulmifolia, Juglans cathartica, and other trees, requiring a deep, rich, moist soil.

This species was introduced into Britain, in 1723, by Mark Catesby, and treated in all respects like the Gleditschia triacanthos, of which it was considered, until withın a few years, only a variety 
The largest tree bearing this name in England, is at Syon, near London, which has attained a height of more than eighty feet, with a trunk two feet in diameter, and an ambitus of forty feet.

In France, where this species is not much cultivated, it is thought to be more liable to injury from frost, than the Gleditschia triacanthos, as it does not appear to produce seeds. At Scéaux, near Paris, there is a tree more than fifty feet in height.

In Hanover, in the botanic garden at Göttingen, a tree of this species attained the height of thirty feet in twenty-five years after planting.

In Austria, at Vienna, in the botanic garden, another tree of this species attained the height of thirty-six feet in twenty-two years.

Properties and Uses. The wood of the Gleditschia monosperma resembles that of the three-thorned Gleditschia, in its loose texture, and yellow colour; but as it grows in wet grounds, it is consequently inferior in quality, and is applied to no particular use in the arts. 


\section{Genus GYMNOCLADUS, Lam.}

Leguminaceæ.
Syst. Na:

Synonymes.

symnocladus, Guilandina,
Diœcia Decandria.

Syst. Lin.

Derivations. The name, Gymnocladus, is derived from the Greek gumnos, naked, and lklados, a branch, from the naked appearance of the branches. The genus Guilandina was named in honour of Melchior Guilandin, a Prussian traveller in Africa, and demonstrator of botany, at Padua.

Generic Characters. Calyx tubular-infundibuliform, the limb 5-cleft; lobes lanceolate, equal. Petals 5, oblong, somewhat longer than the lobes of the calyx, inserted into the summit of the tube. Stamens 10, included, inserted with the petals; those opposite the sepals a little longest. Legume oblong, compressed, very large, thick, pulpy within.-Torrey and Gray, Flora.

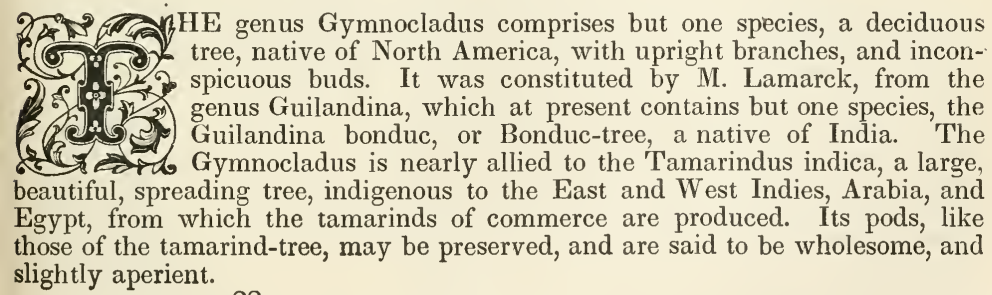




\section{Gymnocladus canadensis,}

\section{THE CANADIAN GYMNOCLADUS.}

\section{Synonymes.}

\section{Guilandina dioica,}

Gymnocladus canadensis,

Bonduc, Chiquier,

Canadischer Schusserbaum,

Gros févier,

Chicot,

Nicker-tree, Stump-tree, Kentucky Coffee-
Linndeus, Species Plantarum.

(Lamarck, Encyclopédie Méthodique Botanique.

De Candolle, Prodromus.

Michaux, North American Sylva.

Loudon, Arboretum Britannicum.

Torrey aNd Gray, Flora of North America.

France.

Germany.

French Illinols.

French Canada.

Britaln and Anglo-America

Derivation. The French Canadian name, Chicot, signifies Stump-tree. It was named Coffee-lree by the early settlers of Kentucky, who used the seeds of this tree as a substitute for the coffee of Arabia.

Engravings. Du Hamel, Traité des Arbres et Arbustes, pl. 103; Michaux, North American Sylva, pl. 50; Loudon, Arbore tum Britannicum, v., pl. 99; and the figures below.

Specific Characters. Deciduous. Branches blunt at the tip. Leaves bipinnate; flowers in racemes, with whitish petals. The leaf has $4-7$ pinnæ, the lower of which consist each of a single leaflet, and the rest each of $6-8$ pairs of leaflets.-De Candolle, Prodromus.

\section{Description.}

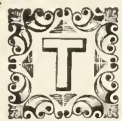

HE Gymnocladus canadensis is a lofty tree, growing to a height of

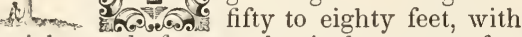
a straight trunk, from twelve inches to two feet in diameter, and is often destitute of branches for more than thirty feet. The aspect of its head in winter, is remarkable from being fastigiate, and possessing but few branches, which are large, thick, and blunt at their tips, in comparison with those of most other trees, and from being destitute of any visible buds, which latter circumstance, connected with the former, gives the tree the appearance of being dead; but in summer, when clothed with leaves, its summit forms a dense, oval or roundish mass, which has a fine effect, and may be seen at a great distance. 'The roots of this tree are few, thick,

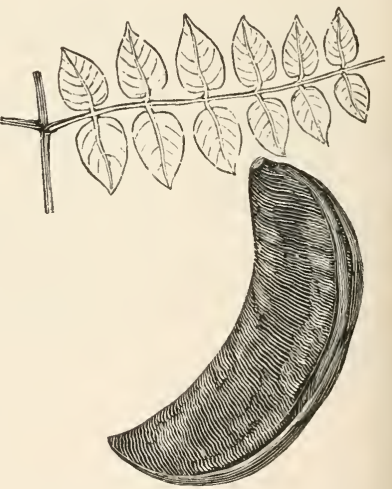
and directed downwards, in a similar manner as the branches grow upwards. The outer bark of the trunk is extremely rough, and detaches itself, after a certain age, in small, hard, transverse slips, rolled backwards at the end, and projecting sufficiently to distinguish the tree from every other. The leaves, on young, vigorous plants, are three feet long, and twenty inches in width; but on old trees, of a large size, they are not one half of these dimensions. The leaflets are oval-acuminate, from one to two inches long, of a dull, bluish-green, and the branches of their petioles are of a violet colour. The flowers, which open from May to July, occur in white spikes, of two inches or more in length, the barren and fertile ones being borne on separate trees. The fruit, which consists of large- 
bowed pods, from five to ten inches in length, and about two inches in breadth, is of a reddish-brown colour, of a pulpy consistency within, and contains several large, gray seeds, of extreme hardness, that come to maturity in September or October.

Geography and History. The Gymmocladus canadensis is sparingly found in Upper Canada, and along the borders of Lake Erie and Ontario, in the state of New York; but in Kentucky and Tennessee, it abounds on tracts which border the Ohio and Illinois rivers, and is associated with the Juglans nigra, Ulmus rubra, Liriodendron tulipifera, Fraxinus americana quadrangulata, Gleditschia triacanthos, and more especially with the Celtis occidentalis.

This tree was introduced into Britain in 1748, and was cultivated by Archibald, Duke of Argyll, at Whitton, where the original tree is said still to exist. Soon after its introduction into England, it found its way into most of the collections of France, southern Germany, and of Italy.

The largest tree of this species in Britain, is at Croome, in Worcestershire, which attained a height of sixty feet in forty years after planting, with a trunk eighteen inches in diameter, and an ambitus of thirty feet.

In France, at Paris, in the Jardin des Plantes, there is a gymnocladus which attained the height of fifty-five feet in sixty years after planting, with a trunk twenty inches in diameter, and an ambitus of forty feet. At Colombier, near Mentz, there is another tree sixty-five feet in height.

In Prussia, at Sans Souci, in Berlin, there is a tree of this species which attained the height of thirty feet in thirty years after planting.

In Austria, at Vienna, there is also a tree which attained the height of thirty feet in thirteen years after planting.

In the Bartram botanic garden, at Kingsessing, near Philadelphia, there is a Gymnocladus eighty feet in height, with a trunk five feet in circumference.

In Washington square, Philadelphia, there is a tree of this species about thirty years of age, fifty feet in height, with a trunk five feet and four inches in circumference, at a yard above the ground, and a head about fifty feet in diameter. 'There are also fine specimens of this tree in the garden of Mr. D. Landreth, of Philadelphia, and on the estate of Mr. A. J. Downing, of Newburgh, on the Hudson.

Soil, Situation, Propagation, \&ैc. The Gymnocladus canadensis, in its natural habitat, invariably grows in the very richest of soils, and thrives best in sheltered situations. The tree is generally propagated by seeds, which should be sown in March or April, and treated in the same manner as recommended in the common locust. It may also be propagated from cuttings of the roots, care being taken in planting, to keep the ends in the position in which they naturally grow.

Properties and Uses. The wood of the Gymnocladus canadensis is of a rosy hue, and is very hard, compact, tough, and strong, which render it very suitable for cabinet-making, and for building. Like the common locust, it has the valuable property of rapidly converting the alburnum into heart-wood, so that a trunk six inches in diameter, has only about half of an inch of sap-wood, and may be employed almost entirely for useful purposes. The live bark is extremely bitter; so that a morsel no larger than a grain of maize, chewed for some time, causes a violent irritation in the throat. The pods, preserved like those of the tamarind, are said to be wholesome, and slightly aperient. The seeds were employed by the early settlers of Kentucky and Tennessee, as a substitute for coffee, but their use was discontinued, as soon as the Arabian coffee could be obtained. In Europe, the only use to which this tree is applied is for the purposes of ormament and shade. Being very hardy, and remarkable for the beanty of its foliage during summer, it is highly appreciated both in Europe and its native country. 


\title{
Genus CERCIS, Linn.
} Leguminaceæ.
Syst. Nat.
Decandria Monogynia.
Syst. Lin.

Synonymes.

\author{
Cercis, Siliquastrum, \\ OF AשTHORS.
}

Derivations. Cercis, is derived from the Greek kerkis, a shuttlecock, the name given to the Judas-tree by Theophrastus. Siliqunstrum is derived from the Latin, siliqua, a pod, husk, or shell, in allusion to the fruit of the trees of this genus.

Distinctive Characters. Leaves simple, heart-shaped at the base, many-nerved, entire, protruded after the flowers; these borne in groupes, each on a pedicel proceeding directly from the trunk or branches.De Candolle, Prodromus.

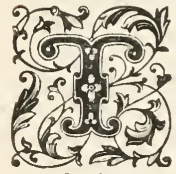

HE genus Cercis comprises two species of deciduous trees, of the third rank, natives of Europe, Asia, and North America. The Cercis siliquastrum is indigenous to the south of France, Spain, Italy, Greece, Japan, Asiatic Turkey, and more especially to Judea. It was cultivated in Britain by Gerard, in 1596, who says, "The or a little sheath. Most of the Spaniards name it algarrobo loco; that is, Siliqua sylvestris fatui (wild or foolish pod;) others arbol d'amor, for the braveness' sake. It may be called in English, Judas-tree; for it is thought to be that on which Judas hanged himself, and not upon the elder-tree, as is vulgariy said." 
Cercis canadensis, thirty-five feet in height, with a trunk three feet in circumference.

Soil, Situation, $\& \cdot c$. Like most of the Leguminacer, this tree prefers a deep, free, sandy soil, rather rich than poor. In Britain, it will only thrive, and become a handsome tree, in sheltered situations, although it is regarded in France and Germany as more hardy than the European species. It may be propagated from seeds, which should be sown on heat, early in spring, and if carefully treated, they will come up the same season.

Properties and Uses. The wood of the Cercis canadensis, like the European species, is very hard, agreeably veined, or rather blotched or waved, with black, green, and yellow spots, on a grayish ground. When seasoned, it is susceptible of a beautiful polish, and weighs nearly fifty pounds to a cubic foot. The bark and young branches of this tree are used to dye wool of a nankin colour. The French Canadians use the flowers in salads and pickles; and, from their agreeable, acid taste, they might be fried with butter or fritters, like those of the Cercis siliquastrum, and the flower-buds and tender pods may be pickled in vinegar.

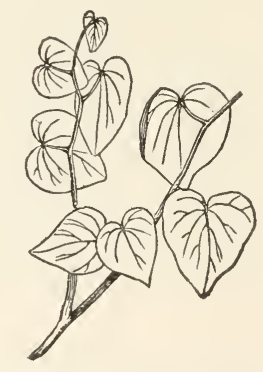




\section{Amygdalus communis, \\ THE COMMON ALMOND-TREE.}

\section{Synonymes.}

Amygdalus communis,

Amandier,

Mandelbaum,

Mandorlo,

Almendro,

Amendoéira,

Mindalnoe derevo,

Almond-tree,

\author{
Linnæus, Species Plantarum. \\ De $\mathrm{C}_{\mathrm{Andol}} \mathrm{Le}$, Prodromus. \\ Loudon, Arboretum Britannicum. \\ FRANCE. \\ Germany. \\ ITALY. \\ SPain. \\ Portugal. \\ Russia. \\ Britain and Anglo-America.
}

Engravings. Du Hamel, Traité des Arbres et Arbustes, iv., pl. 29; Loudon, Arboretum Britannicum, vi., pl. 105; and the figures below.

Specific Characters. Fruit a drupe; compressed and rather egg-shaped; the nut 2-ovuled, 1-2-seeded. Style terminal. Calyx deciduous, of a bell-shape; flowers solitary. Leaves feather-nerved, undivided, oblong-lanceolate, serrate, with the lower serratures, or the petioles glanded. Stipules not attached to the petiole.

\section{Description.}

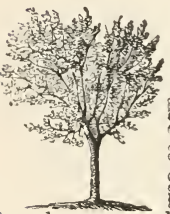

in the central parts of Europe and North America, often attains a height of twenty or thirty feet, with a trunk eight or ten inches in diameter; and even in the neighbourhood of Paris, it is met with of an elevation of forty feet, and in Spain, Italy, and the south of France, it grows still higher. It is neither a handsome-shaped tree, nor of long duration, its head being wide and spreading; but from being open, the shoots are clothed with oblong-lanceolate leaves, and pale, rose-coloured blossom-buds, to a great length, so that when the latter expand, the branches appear to be wholly covered with them. It is commonly one of the first among hardy trees to display its blossoms, which generally put forth in Barbary in January; at Smyrna, in February; near London, in March; in Germany and New York, the latter part of April; and at Christiania, in Norway, not till the beginning of June. Its contemporary flowering trees, in Britain, are the sloe, the apricot, the Cerasus pseudo-cerasus, and the myrobalan plum (Prunus domestica myrobalana.) The blossoms of all these trees appear before the leaves; and hence they produce the finest effect when planted among evergreens. It has been observed that, though vernal frosts often destroy the germs of the fruit, they do not injure the beauty of the flowers, but even increase their splendour. An avenue of 
almond-trees, quite hoary with frost, in the evening, will be of a brilliant rosecolour the following morning, and will often retain its beauty for more than a month, the flowers never falling off till the trees are covered with verdure. The fruit is not so attractive as that of the peach; because, instead of preserving the same delicious pulp, its pericarp shrivels as it ripens, and becomes a horny kind of husk, which opens of its own accord, at the end of maturity. The kernel of some varieties of the almond is not defended by so thick a shell as that of the peach and nectarine, for it is often so tender that the nuts break, when shaken together. The chief distinction between these fruits is, that the almond has a stone, covered with a coriaceous, dry, hairy covering, while that of the peach and nectarine is developed in a rich, juicy pulp, surrounded by a smooth or downy skin.

Varieties. In a wild state, the common almond is sometimes found with bitter kernels, and at other times sweet; in a similar manner as the Grammont oak, (Quercus hispanica,) which, in Spain, generally bears sweet, edible acorns, but sometimes produces only such as are bitter. For this reason we describe the bitter and sweet almond under one head, and consider them only as varieties of the same species, which are as follows:-

1. A. c. Amara, De Candolle. Bitter-kerneled Common Almond-tree ; Amandier amer, of the French; and Gemeiner Mandelbaum, of the Germans. The flowers of this variety are large. Petals pale pink, with a tinge of rose-colour at the base. Styles nearly as long as the stamens, and tomentose in the lower part. Seeds bitter. There are two forms of the bitter almond; one with a hard shell, and the other with a brittle one. The tree is cultivated in the south of Europe for its fruit, which is preferred, for some purposes in medicine and domestic economy, to that of the sweet almond, particularly for giving a flavour, and for stocks for grafting the other varieties upon, as well as the peach, apricot, and even the plum.

2. A. c. Dulcis, De Candolle. Sweet-kerneled Common Almond-tree; Amandier à petits frnits, Amande douce, of the French; and Süsser Mandelbaum, of the Germans. The leaves of this variety are of a grayish-green. The flowers put forth before the leaves; styles much longer than the stamens; fruit ovatecompressed, acuminate; shell hard; kernel sweet-flavoured. It is cultivated in the south of Europe, being generally propagated by grafting standard high on the bitter almond, or on any strong-growing seedling almonds, in order to ensure the sweetness of its fruit.

3. A. c. macrocarpa, De Candolle. Large-fruited Common Almond-tree; Amandier à gros fruits. Amandier des dames, of the French. The leaves of this variety are broad, acuminate, and slightly gray. The peduncles short, and turgid; flowers of a very pale rose-colour, large, and put forth before the leaves: petals broadly obcordate, waved; fruit large, umbilicate at the base, acuminate at the tip; shell hard, and kernel always sweet. There are two sub-varieties, one with the fruit rather smaller, commonly called, in France, amandier sultane; and the other, with fruit still smaller, called there amandier pistache. The kernels of both of these are considered remarkably delicate, and are preferred for the table. The tree of this variety is large and vigorous, of rapid growth, somewhat fastigiate, and is propagated by grafting on the common species, or on any freegrowing variety of plum. From the magnitude and beauty of its flowers, which are produced earlier than those of any other kind, it is preferred to all others for the purposes of ornament.

4. A. c. Persicöldes, De Candolle. Peach-like-leaved Common Almond-tree; Amandier-pêcher, of the French. The leaves of this variety greatly resemble those of the peach-tree. Fruit ovate, obtuse, with a slightly succulent husk: shell of a dark, yellowish colour; and the kernel sweet-flavoured. Du Hamel 
states that its fruits vary upon the same branch, from ovate, obtuse, with the husk rather fleshy, to ovate, compressed, acuminate, and the husk dry. It is cultivated in the south of Europe for its fruit. Knight considered the Tuberes of Pliny, as swollen almonds of this variety, having raised a similar one himself, by dusting the stigma of the almond with the pollen of the peach. which produced a tolerably good fruit.

5. A. c. Fragilis, De Candolle. Brittle-shelled Common Almond-tree; Amandier à coque tendre, Amandier à coque molle, of the French. The leaves of this variety are short; the petioles thick. The flowers protude at the same time as the leaves, are of a pale rose-colour, with broad, deeply-emarginate petals. The fruit is acuminate, shell soft, and kernel sweet-flavoured. Cultivated for its fruit.

6. A. c. Flore pleno, Baumann. Double-flowered Common Almond-tree.

7. A. c. folis variegatis, Baumann. Variegated-leaved Common Almond-tree.

The almond, considered as a fruit-tree, has given rise to some other varieties, which will be found treated at length in the "Nouveau Du Hamel," and the "Nouveau Cours d'Agriculture," published in France.

Geography and History. The Amygdalus communis is indigenous to Syria and northern Africa, and has become naturalized in the south of Europe, Madeira, the Azores, and the Canary Islands, and is cultivated for ornament in Britain, North America, and according to Mr. Royle, in the mountainous parts of India, in Asia.

'The beauty of this species, its flowering at a period when most other trees appear scarcely to have escaped from the icy chains of winter, and the extraordinary profusion of its flowers, doubtless attracted the early attention of aboriginal man. The first mention of the almond is found in "Holy Writ," when Moses, to ascertain from which of the twelve tribes to choose the high priest, put twelve rods into the tabernacle, and found the following day, the almond rod, which represented the tribe of Levi, covered with leaves and blossoms.

"And, behold, the rod of Aacon for the house of Levi was budded, and brought forth buds, and bloomed blossoms, and yielded almonds.'

Ningars xvii. 8

The almond is also mentioned in that sacred book as one of the choice fruits of Canaan. It was noticed by Pliny, as well as by other early Roman authors. He calls a variety of it Tuberes, which Mr. Knight considers to be the swollen or peach almond (A. c. persicöides.) In Rome, in the time of Cato, the fruit of this species was called "Greek nuts." Pownall, in his "Roman Provinces," states that the almond was brought from Grcece to Marseilles, in the Middle Agc, by the Phocæan colonists, Faulkner, in his "Kensington," says that the fruit came from the east, and was introduced into Britain in 1570 . According to other accounts, it was first brought into that country in 1548 . Turner, and also Gerard have treated of this tree, the latter of whom observes, "That though it is a tree of hot regions, yet we have them in our London gardens and orchards in great plenty, flowering betimes with the peach, and ripening their fruit in Angust." It is at present in very general cultivation in England, chiefly for its flowers; and in middle and southern Europe, northern Africa, the Canaries, and a part of Asia, for its fruit.

This species, and several of the varieties, were introduced by the late William Prince, of F'lushing, New York, previous to 1793, and they are cultivated both for ormament and their fruit in various states of the union.

Poeticul and Mythological Allusions. The following is the origin assigned by Grecian mythology to this tree, as given by Mr. Loudon, in his "Arboretum :""1)cmophoon, son of Theseus, returning from Troy, was cast by a tempest on the coast of 'T'lurace, where he was most hospitably received by the beautiful 
queen of the country, Phyllis. He won her heart, and became her husband; but scarcely were they united, when the death of his father recalled Demophoon to Athens; and he left Phyllis, promising to return to her in a month. When the given time had expired, the unfortunate queen wandered daily on the seashore, looking in vain for her Demophoon; and when, at last, winter came, and still he returned not, after gazing some time upon the sea, in an agony of despair, she fell dead on the shore, and was changed by the pitying gods into an almondtree. Demophoon shortly after returned; and, being told what had occurred, flew to the tree, and clasped it in his arms, when the strong attachment of Phyllis, unable even then to restrain himself, caused the tree, though bare of leaves. to burst forth into blossoms."

Virgil, in his "Georgics," welcomes the almond, when profusely covered with flowers, as the sign of a fruitful season.

Soil, Situation, $\mathcal{f}^{\circ} c$. The Amygdalus communis does not prosper unless the soil be dry, sandy, or calcareous, and of considerable depth; but all the varieties will succeed well in any free soil, that is not too moist, when grafted or inoculated on stocks of the domestic cultivated plum, and perhaps on those of the Prunus americana. The situation should be sheltered, on account of the liability of the branches to be broken off by high winds. In Britain, plants of the almond are seldom raised from nuts, but are generally propagated by budding or grafting. In France, it is much grown by nurserymen as a stock to graft the apricot and the peach upon. For this purpose, a vigorous-growing variety of the sweet almond is preferred near Paris, instead of a bitter variety, which was formerly employed. The kernels are sown in rows, in March, with the sharp ends downwards, and the plants are budded the following August. The great advantage of these stocks to the nurseryman is, that, as they may be budded the very first year of their growth on the spot where they are sown, a grafted tree may be obtained with them at the least possible expense. As the almond, however, sends down a taproot, exceeding two feet in length the first season, it has been found that such a tree, when taken up for sale, has few fibres, and, consequently, but little chance of growing. From this circumstance originated the practice of germinating the nuts in boxes of earth before sowing them, and pinching off the point of the radicle when about an inch in length, which causes it to throw out numerous horizontal roots (a very ingenious practice, which might be applied with advantage in many similar cases.) This mode of germinating the nuts also insures the nurseryman of having plants the first season after sowing, whereas, when it is not done, the seeds often lie in the ground two years. Plants will grow four or five feet the first year. The fruit is chiefly produced on the young wood of the previous year, or on the spurs of older wood. Almond-trees are seldom good bearers, even in France, where the fruit is cultivated as all article of commierce. A tree is considered there, on an average, only to produce a crop once in five years. It requires but little pruning, except when fruit of a large size is desired, or the duration of the tree is wished to be prolonged.

Properties and Uses. The wood of the almond-tree is hard, and of a reddish colour; and that taken from near the roots, in some respects, resembles that of lignum-vitæ (Guaicum officinale.) It is susceptible of a fine polish; but the resin which it contains, impedes its colouration by acids. At all times it takes varnish well, and in this respect differs from the lignum-vitæ, which takes it bad. It differs again, from this last-named wood, in being dryer and more brit tle. It is used in cabinet-making, especially for veneering; and is employed to make handles for carpenter and joiner's tools. The leaves of this tree are said to make an excellent forage for sheep and goats, and to fatten the former in a very short time; but it should always be mixed with other provender. The eaves are also employed, in common with those of the peach and nectarine. for 
giving a flavour to gin, whisky, and other spirits. 'The gum, which exudes from this tree, is used for the same purposes as that of the cherry, and the gum Arabic, though it is not so easily dissolved in water as the last-mentioned kind. An oil is obtained, both from bitter and sweet almonds, by maceration and expression. A liquid is also distilled from the bitter variety, which, from the quantity of prussic acid it contains, is found to be poisonous to animals. An essential oil is obtained from the expressed oil, by distillation, which is one of the most virulent poisons known. It is a singular fact, that the seeds of the bitter and the sweet almond should differ so essentially in their chemical compositions; the kernels of the bitter variety contain the deleterious principle of prussic acid, which does not exist in those of the sweet variety, although found in its bark, leaves, and flowers. On triturating almonds with water, the oil and water unite together by the mediation of albuminous matter of the kernel, and form a milky liquor, called an emulsion. The sweet almonds alone should be employed for this purpose, as the bitter ones impart their peculiar flavour. Several unctuous and resinous substances, that of themselves will not combine with water, may, by trituration with almonds, he easily mixed into the form of an emulsion; and are thus admirably adapted to pharmaceutical purposes. The Parisian milk-dealers, a few years since, resorted to the practice of adulterating their milk by means of almond emulsion. The method was so simple and cheap, that for one fifth of a dollar, the opacity and colour of milk could be imparted to nearly four gallons of water, and so far secret that no disagreeable taste was communicated to the milk; and the only corrective required was a little sugar-candy, to remove the flat taste. In domestic economy, sweet almonds, as well as the common sort, are used as a dessert, in the husk, imperfectly ripe, and also in a ripe state, with or without the husks. A preserve is also made of green almonds. After they are ripe, they are frequently brought to table without the shell, and sometimes blanched, by depriving the kernel of the thick, wrinkled skin, in which it is enveloped, by keeping them a few minutes in scalding-hot water. The kernels are much used in cookery, confectionary, and perfumery, on account of their agreeable flavour. The almond harvest takes place in the south of Europe towards the end of summer. Those which fall naturally from the tree are the largest and the best. They are first collected together, and spread out in a granary or some other convenient place, to dry, until their husks are opened, from which they are separated, and suffered to remain exposed to the air for several days more. They are then put up in sacks, casks, or boxes, where they are preserved, as free as possible from humidity, until they are exposed for sale.

Almonds form an extensive article of commerce, and may be distinguished under the following names and qualities :-

1. Amandes à la dame, of the French. This kind is known by their large, thick-furrowed shells, rounded at one end and pointed at the other. They are packed up with the external shell on, in canvass bags, with chopped straw or chaff.

2. Amandes à la princesse, (French,) are of a medium size, and of an excellent quality. 'Their shells are flat, thin, tender, of a yellowish colour, and are sometimes covered with a dust, which readily soils the fingers when slightly handled. They are packed up with the shells on, in canvass bags.

3. Amandes de Chinon, so called from the town of Chinon, in France, where they grow. This sort is of a medium size, with thick, flat, elongated shells, of a vellowish-brown, and wrinkled appearance. The pellicle which covers the kernels is very thin, and is charged with a very adhesive powder, that cannot be rubbed off with the fingers withont some pain. They are deprived of their shells, and packed up in canvass bags.

4. Amandes dures, French. This kind is smaller and more convex than any 
of the preceding, and may ie known by their thick, solid shells, of a pale-yellow colour, are difficult to break, and are marked by deep furrows. The kernels are also smaller than any of the preceding, are of a yellowish-brown colour, and sweet in their flavour. They are usually packed up in canvass bags, with the shelis on.

5. Amandes de Milhaud, (French,) distinguished by their long, flat kernels, covered with a thin pellicle, of a dirty-yellow colour, and charged with a powder which easily comes off by rubbing. They are deprived of their shells, and packed in canvass bags.

6. Amandes de Provence (sweet.) The kernels of the kind known under this name, in France, are very unequal in size, and may be distinguished, in general, by their blonde colour and slightly round form. They are sometimes covered with a reddish powder, and at others have a wrinkled or furrowed appearance. Among the Provence almonds, there are also known two other kinds, one of which, (Amandes triées à la main,) are selected with great care, having kernels of a uniform size, pale-yellow colour, rather flat, and of a regular form; and the other kind (flots de Provence) much resemble them, except in being rather larger in size, longer, and more convex, with a thicker pellicle, of a reddish colour. They are deprived of their shells, and are usually packed in straw or chaff, in canvass bags.

7. Spanish Almonds. Those from Valencia are very sweet, large, and flatpointed at one extremity, and compressed in the middle. Those from Malaga, sometimes known under the name of Jordan Almonds, are of a medium size, paleyellow colour, and of a very agreeable flavour. They are larger, flatter, less pointed at one end, and less round at the other, than the preceding. They are deprived of their shells, and packed up in mats.

8. Italian Almonds. These are not so sweet, are smaller, and less depressed in the middle than those from Valencia.

9. Bitter Almonds. This variety, as known in commerce, chiefly comes from Mogadore, and is packed in boxes.

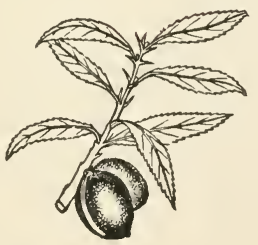




\title{
Amygdalus persica, THE PEACH-TREE.
}

Amygdalus persica,
Persica vulgaris,
Pêcher,
Pfirsichbaum,
Pesco,
Persigo, Durasno,
Peceguêiro,
Peach-tree,

Amygdalus persica,

Persica vulgaris,

Pêcher,

Prsichbaum,

Persigo, Durasno,

Peach-tree,
Synonymes.

Linneus, Species Plantarum.

(De Candolle, Prodromus.

Don, Miller's Dictionary.

Loudos, Arboretum Britannicum.

France.

Germany.

ITALY.

SPAIN.

Pontugal.

Britain, Anglo-America, \&c.

Engravings. Du Hamel, Traité des Arbres et Arbustes, 1,2-8; Noisette, Jardin Fruitier; Hoffy's, Orchardist's Cumpanion; Loudon, Arboretum Britannicum, vi., pl. 106; and the figures below.

Specific Characters. Covering of the nut very fleshy and juicy, its surface downy or smooth; nut with wrinkled furrows. Young leaves folded flatwise. Flowers almost sessile, solitary or twin, protruded before the leaves.-Loudon, Arboretum.

\section{Description.}

\author{
"And apples, which most barbarous Persia sent, \\ With native poison armed (as fame relates;) \\ But now they've lost their power to kill, and yield \\ Ambrosian juice, and have forgot to hurt; \\ And of their country still retain the name,"
}

$$
\text { Columelia. }
$$

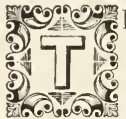

HE Amygda-
lus persica,
when grow-
ing in a natural state, is rather a small tree, with wide-spreading branches, and assumes the general form and character of the almond; but when cultivated, it sometimes attains a height of twenty or thirty feet, with a trunk fifteen to eighteen inches in diameter. Like its
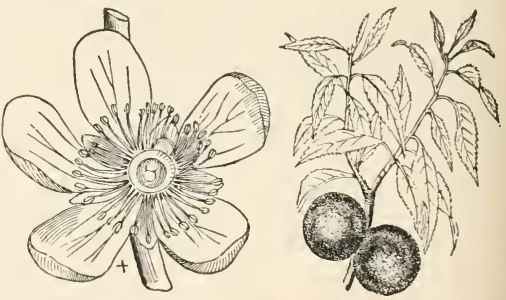
congener, the almond, its flowers appear before the leaves. They are of a very delicate colour, but of scarcely any scent. They usually appear in England early in April; at St. Mary's, in Georgia, by the middle of February; at Perth Amboy, in New Jersey, by the end of April, and ten weeks earlier at Naples, in Italy, although the two last-named places are in nearly the same parallels of latitude. The fruit is roundish, with a furrow along one side, and is covered with a delicate, downy cuticle, when ripe.

Vurieties. The varieties of the peach are exceedingly numerous, there being several hundred kinds enumerated in nurserymen's catalogues. The nectarine is considered by some botanists as a distinct species; but there can be no doubt on this point, as the peach itself is nothing more than an improved, or fleshy almond, which bears a similar relation to the peach and nectarine, as the crab does to the apple, and the sloe to the plum. To prove that the peach and nectarine are essentially the same, it may be mentioned that the fruits of both have heen found on the same branch; and even an instance is recorded, where a fruit had the smooth surface of the nectarine on one side, and the downy skin of the 
peach on the other. Peaches may be distinguished into iwo general classes, namely, those which separate easily from the stone or nut, called freestones, and those, the flesh of which adheres to the shell of the stone, and are called clingstones. This species being most frequently raised from seeds, it is easy to conceive that the fruit must be of an endless variety, scarcely two trees producing alike. Hence it would be useless even to attempt an enumeration of them. 'The following variations, however, are widely different, in respect to some of their characters, and may be described as follows:-

1. A. P. LÆVIS. Smooth-skined Peach, or Nectarine-tree. Of this variety there are two sorts, one with the fruit parting from the stone, (Pêche lisse, French,) and the other with the flesh adhering to it (Brugnon, French.) As a standard in the open garden, it forms a smaller and more delicate tree than that of the peach. In dissecting the flowers of the nectarine, the germs may readily be distinguished from those of the peach, in being smooth and shining, while those of the latter are always villous, or covered with fine hairs.

2. A. P. Flore pleno. Double-flowered Peach-tree. This variety may readily be distinguished by its double tlowers. It is also of less vigorous growth than most of the single-flowered varieties.

3. A. p. alba. White-flowered Peach-tree, known by its pure-white blossoms. 4. A. P. Follis variegatis. Variegated-leaved Peach-tree.

5. A. P. compressa. Flat-fruited Peach, a native of China, and is chiefly remarkable for the form of its fruit, and for being nearly evergreen in its leaves. 6. A. P. Saligna. Willow-leaved Peach-tree. This tree is described by $\mathrm{Mr}$ Royle in his "Illustrations of the Botany, and other branches of Natural History of the Himalayan Mountains," as growing in the district of Bissehur, and is called there, by the natives, bhemee. The fruit, though small, is represented to be juicy and very sweet.

Geography and History. It is not certain in what part of the globe the peachtree was originally produced; for, although we have early accounts of its being brought to Europe from Persia, it does not follow, from thence, that it was one of the natural productions of that country. Pliny relates that it had been stated to have possessed venomous qualities, and that its fruit was sent into Egypt by the kings of Persia, by way of revenge, to poison the natives; but he treats this story as a mere fable, and considers it the most harmless fruit in the world; that it had the most juice, and the least smell of any fruit, and yet caused thirst to those who ate of it. He expressly states that it was imported by the Romans from Persia; but whether it was indigenous to that country, or sent thither from a region still nearer to the equator, we have no information. He adds that it was not long since peaches were known in Rome, and that there was great difficulty in rearing them. He also informs us that this tree was brought from Egypt to the isle of Rhodes, where it could never be made to produce fruit; and from thence to Italy. He says, moreover, that it was not a common fruit either in Greece or Natolia. No mention, however, is made of it by Cato. Pownall, in his "Roman Provinces," makes it a Phocæan importation to Marseilles; and evidently it was cultivated in France at an early period, as Columella, in his account of this fruit, says :-

"Those of small size to ripen make great haste;

Such as great Gaul bestows, observes due time

And season, not too early, nor too late."

The peach is said to have been first cultivated in Britain about the middle of the XVIth century. Gerard describes several varieties of it as growing in his garden, in 1597. Tusser mentions it in his list of fruits in 15.57; and in all probability, it was introduced when the Romans had possession of that comntry. 
A modern writer on "Timber-trees and Fruits," remarks that, "The facility of raising the peach from the stone has probably tended to its general diffusion throughout the world. This fruit has steadily followed the progress of civilization; and man, 'from China to Peru,' has surrounded himself with the luxury of this, and of the other stone-fruits, very soon after he has begull to taste the blessings of a settled life. There are still spots where ignorance prevents portions of the human race from enjoying the blessings which Providence has everywhere ordained for industry; and there are others where tyranny forbids the earth to be cultivated, and produce its fruits. 'The inhabitants of the Haouran, who are constantly wandering, to escape the dreadful exactions of some petty tyrant, have neither orchards nor fruit-trees, nor gardens, for the growth of vegetables. 'Shall we sow for strangers?' was the affecting answer of one of them to Burckhardt." "One of the greatest blessings," continues he, "that can be conferred upon any rude people, (and it is a blessing which will bring knowledge, and virtue, and peace, in its train,) is to teach them how to cultivate those vegetable productions which constitute the best riches of mankind." 'The traveller, Burchell, rendered such a service to the Bachapins, a tribe of the interior of southern Africa. He gave to their chief a bag of fresh peach-stones, in quantity about a quart; "nor did I fail," says the benevolent visiter of these poor people, "to impress on his mind, a just idea of their value and nature, by telling him that they would produce trees which would continue every year to yield, without further trouble, abundance of large fruit of a more agreeable flavour than any which grew in the country of the Bachapins."

The peach is in general cultivated as a fruit-tree, against walls, and in hothouses, in the middle and north of Europe, and as a standard tree, in the fields and gardens of the southern parts of that country, as well as in those of northern Africa, and many of the islands of the Mediterranean, and of the Atlantic Ocean. At Montreuil, in the neighbourhood of Paris, peaches are produced of the finest flavour, the excellence of which is attributed to the exclusive attention of the people to their culture; and a single tree there, sometimes covers a space of wall sixty feet in length. The peach also abounds in various countries of the east, including China, India, and Persia, where, according to Mr. Royle, it grows both wild and in a state of cultivation. On the Himalayas, it flourishes at elevations of five thousand to six thousand feet; and in Madeira and Teneriffe, which lie in about the same latitude, it brings forth fruit of the finest quality, and in the greatest abundance, at all points below the height of five thousand feet.

The peach was introduced into North America by the first European settlers, probably towards the close of the XVIth, or early in the XVIIth century, wliere it is cultivated in extensive plantations, which often grow with such luxuriance as to resemble forests of other trees. In New Jersey, Pennsylvania, Delaware, Maryland, Virginia, and several other states, much attention is paid to its culture, and the fruit is of an excellent quality. It is no uncommon circumstance for a planter to possess a peach-orchard containing one thousand or more of standard trees. It is only in the middle states of the union where this fruit arrives at the greatest perfection. In favourable seasons, it matures in the open air, as far north as Maine, New Hampshire, Vermont, and the falls of Niagara; but its pulp is not so delicious as when grown some degrees farther south; it is also trained against walls at Montreal and Torento, in Canada, where, in some seasons, fruit of a fine quality is obtained. In the Carolinas, Georgia, and Florida, the trees make much foliage and wood; still, if well cultivated and properly pruned, the fruit grows to a large size, and is juicy and well-flavoured. On the Mississippi, particularly in Louisiana, which lies in the same latitude as that part of Asia where this species is indigenous, it grows spontaneously, but is regarded as of foreign origin, laving been introduced from Spain before that river was explored by the 
French. In the vicinity of Boston, Salem, New York, Philadelphia, and other populous cities of the United States, the peach is reared against walls and in hothouses, by numerous opulent citizens, and fruit of a large size and fine quality is produced. In some other parts of the American continent, it also readily grows, and in great abundance. Sir Francis Head, in his "Rough Notes," speaks in raptures of the beauty and luxuriance of this fruit, which was scattered over the corn-fields in the neighbourhood of Mendoza, on the east side of the Andes; and the same traveller noticed dried peaches used as an article of food on the more elevated parts of those mountains, to which they must have been carried from the plains below. On the banks of Rio de la Plata, from Montevideo to Buenos Ayres, we have seen peach-trees growing spontaneously, in the greatest perfection, and in such abundance as to form a considerable portion of the fuel of the provinces in which they grew. The fruit there is of a fine quality, large quantities of which are annually dried for domestic use, and the chief part of the remainder is consumed by cattle, or is suffered to decay upon the ground.

Soil and Situation. A sandy soil, rather poor than rich, appears to be the most favourable to the growth of good peaches; but land of moderate fertility produces the most abundant crops. This tree is also known to prosper on clayey, and calcareous loams, as well as on deep alluvial deposits. On very fertile soils, or those which have been made so by high manuring, it grows larger, and is more flourishing; but its fruit is of an inferior kind, often appearing as green as the leaves, even when ripe, and is much later than that grown on poorer soils. This defect, however, can be remedied in a measure, by depriving the tree of a portion of its foliage, after the fruit is set; but this practice is believed to shorten the life of the tree. In the middle and southern states of the union, elevated grounds, in the vicinity of water, are considered as the best for peach-trees, and the northern sides of hills as the most desirable sites; for they retard their vegetation and prevent the destructive effects of late vernal frosts; but a belt of forest is desirable on the north, to break off the cold winds. In corroboration of these views, we can aver from good authority, that the elevated tracts, not only lying along the shores of the Atlantic and the large bays adjacent thereto, but those on the borders of our western waters, are more favourable to the production of good peaches, than districts more inland. It has also been observed that peach-trees flourish in hedge-rows, and in most other places where their trunks are shaded, which preserves them from the effects of sudden transitions from heat to cold, and from cold to heat.

Propagation and Management. The peach-tree may be propagated from seeds, by grafting, or inoculation. The former mode is considered more certain, as to quickness of growth, and earlier profit, as well as economy, though it does not insure identity of species, except in a few cases; for it rarely occurs that the seeds of pomiferous fruits perpetuate the same characters and qualities. It appears, however, that the stones of the variety of peach, called "Eastburn's Choice," which originated at Philadelphia about seventeen years ago, produce fruit possessing the same properties as those of the parent tree. In Delaware, where the peach arrives at a high degree of perfection, the trees are often raised from the stone, without either grafting or budding. The mode which has been adopted there for the last century, and which is applicable to this species of culture in the middle and southern states generally, is given at length, in the "Memoirs of the Philadelphia Society for promoting Agriculture ;" and in substance is as follows:-The stones are usually cracked, with the kernels sometimes taken out, and planted two together, in hills with Indian corn, at about twenty or twenty-five feet apart, in squares. The corn is cultivated in the usual way, and the young trees grow with the crop, to a height of three or 
four feet the first season. Large orchards have thus been formed of fifty to one humdred acres at a comparatively small expense. The knife is seldom applied to standard trees, except in some instances where they have been headed down once when young, it having been found, that pruned trees, heavily laden with ice or fruit, are liable to be broken down; but when suffered to grow in a natural manner, the branches become multiplied, flexible, and tough; and often are so loaded with fruit, that its weight prostrates them to the ground unhurt. None break that are not pruned, and most of them recover their usual position when the fruit is detached. The crops are certain, abundant, and well-flavoured; and the fruit is little inferior to that grown on grafted or pruned trees; although it varies much, in size, on the same tree. In three years after planting, the orchards come to bearing; and the trees have been known to endure fifty years. All animals are excluded, except swine, which are sometimes suffered to feed and root, at pleasure, at certain periods of the year, and doubtless, are instrumental in destroying insects and vermin, and in ameliorating the soil by turning and loosening the surface. The trees are so easily propagated and renewed, that the cutting down of a peach-orchard for a course of tillage, on ground improved by this means, is of no uncommon occurrence. To insure a constant supply of this fruit, it is deemed important that a new plantation should be in progress, while that in profit is bearing and declining, and that it should be located at a distance from it, in order to be out of the reach of infection.

The following mode of propagating the peach, may be relied on as the successful result of many years' experience. Although it is attended with some labour, and requires considerable attention, let it be remembered "that the price of good fruit was fixed by the Deity himself, when he created man, and placed him in the garden of Eden ;" for, even at that early period, when the soil existed in its virgin purity, it was the condition that he should

"Dress the garden, and keep it,"

and we may venture to say, that since that time, the price has never been abated.

\section{MANAGEMENT DURING THE FIRST YEAR.}

The peach-stones, soon after they are ex tricated from the pulp, should be covered with earth to the depth of four inches, and remain in that condition till they are required for sowing, the following spring. Towards the end of March, or as soon as the ground is deprived of frost, let them be sown in good garden mould, two inches deep, and if possible, in the place where the trees are intended to stand. As soon as the young plants have risen high enough to throw out branches, which will usually take place by the first of July, the ground should be scraped over with a hoe, in order to destroy the weeds, and the side-shoots must be cut off near the main stem, care being observed not to injure the leaves which stand at the base of each shoot; for, on the preservation of these leaves, depend the health and vigorous growth of the young trees. On August 1st, or as soon as shoots of choice varieties, with good eyes of the current year, can be obtained, the trees should be budded or inoculated, within one inch, or even below the surface of the ground. The buds may be known to be ready for insertion, by the shield, or portion of the bark to which they are attached, easily parting with the wood. Let the shoots, from which the buds are to be procured for inoculation, be taken only from the outside branches of healthy and fruitful trees. The buds usually preferred, are those on the middle of young shoots, as they are not so liable to run to wood as those at the extremity, nor so apt to lie dormant as those at the lower end. Let the buds be collected in a cloudy day, or at an early or late hour of a fair one. When they are to be transported at a distance, they 
may be packed in moistened moss; or if shortly to be used, they may be put into a vessel of water; though in general, they should be used as soon as possible after gathering. Before the buds are prepared, let the stock be made ready to receive them. At the part fixed on for inoculation, which should be smooth, and rather on the northerly side of the stock, make an incision about an inch and a half in length, with a sharp knife, quite through the bark, but not into the wood, in the form of a letter I, as denoted by $(a)$, in the adjoining figure. This being done, proceed quickly and take off a bud by holding a shoot in one hand with the thickest end from you, and with the knife in the other hand, enter it about three-fourths of an inch below the bud, cutting nearly half way into the wood of the shoot, continuing it with one clean slanting cut, about three-fourths of an inch above the bud, sufficiently deep to take off part of the wood along with it, the whole to be about an inch and a half long, as represented by $(b)$; then directly
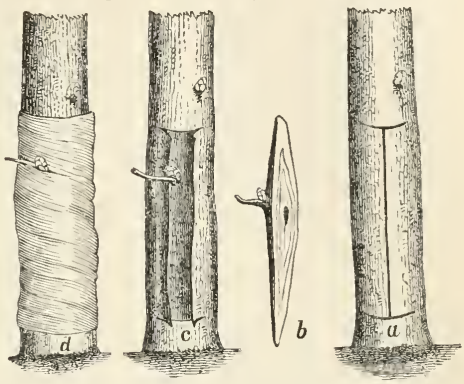
with the thumb and finger, or point of the knife, slip off the woody part remaining on the bud, and observe whether the eye or germ of the bud remains perfect; if not, and a little hole appears in that part, it is unfit for use, or, as the nurserymen say, "the bud has lost its root," and another must be prepared. This being done, place the back part of the bud or shield between your lips, and with the flat haft of the knife, or a piece of ivory or bone formed for the purpose, separate the bark of the stock $(a)$ for the admission of the bud, which must be closely inserted between the wood and bark in the aperture $(c$.$) Then cut off$ the top part of the shield containing the bud, even with the upper horizontal or cross-cut of the letter I, in order to let it completely into its place, and exactly join the upper edge of the shield with the bark of the upper transverse cut, so that the descending sap may immediately enter the back of the shield, and deposit granulated matter between it and the wood, so as to effect a living union. 'The parts are next to be imniediately bound round with a water-proof bass ligature, or some substitute, as in $(d)$, beginning a little below the incision, proceeding upwards closely round every part, except just over the eye of the bud, and sufficiently tight to keep the whole secure, and to exclude the air and moisture, without the use of grafting-wax or clay. In a fortnight, at farthest, after performing the operation, such buds as have united may be known by their fresl. appearance, and in three weeks, all those which have succeeded, must have their ligatures loosened, and in a week or two more, entirely removed. In order to guard against the borer, (Egeria,) let there be laid round each tree, in August, about a pint of coarse sand, so as to cover the roots and the tenderest part of the bark; and during the succeeding autumn, the same care should be observed, as in the early part of the season, to preserve the leaves.

\section{SECOND YEAR.}

March 1st. Cut off the tree in a slanting direction, about five inches above the point of inoculation; and let about a quart of the same kind of sand be placed cound the root of the tree, as in the summer preceding. July 1st. Clear the ground of weeds, and treat the shoot from the inoculated bud precisely as the priginal stock was the first year, with the same care to preserve the leaf at the ase of each side-shoot, taking off from time to time, as they put forth, all the 
side-shoots except four, until the tree rises to a height of about four feet. August 1st. Add a small quantity of sand to the roots, as in the season before, in order to prevent the fly, (Egeria,) from depositing her eggs.

\section{THIRD YEAR.}

March 1st. Add more sand to the roots of the tree, and wash clean its trunk with soap-suds or lye. May 15 th, or as soon as the heavy rains of spring have ceased, cut off in an oblique direction the central shoot of each tree, and leave the four lateral ones, reserved the year before, to remain for permanent branches. Loosen the ground with a strong fork, so as to admit the air without disturbing the roots, and keep the surface clear of weeds during the season. August 1st. Wash the trunk of the tree with soap-suds or lye, as in the spring before. Loosen the sand about its roots, and add more, in order to guard against the fly.

\section{FOURTH YEAR AND SUBSEQUENT TREATMENT.}

March 1st. Wash clean the body and forks of each tree with soap-suds, lye, or old urine. May 15th. Fork up the ground, and keep its surface free from weeds. August 1st. Wash the trunk and branches as in the spring before; and from this time forward, no other care will be required than to repeat these operations, to prune off all superfluous and dead branches, and to guard against the ravages of insects.

The propagation of the peach-tree by grafting has not very generally been practised, owing to the exudation of the gum at the wounded parts, and the jagging of the bark when the cleft mode is adopted. 'The latter defect, however, may be effectnally obviated by cutting through the bark with a sharp instrument, on each side of the stock, in the direction of the cleft intended to be opened. This will render the bark smooth, and enable it to meet the scion with as perfect contact as in grafting other kinds of fruit. This mode of propagation will often save a year's growth in a tree, particularly if the budding failed the autumn before; for the scions may be inserted in the roots any time from December till May, and may be brought from a distance, and used with success, at a period, too, when the cultivator is less busy than at the proper season of budding.

Insects, Accidents, \&*c. The most destructive insect which attacks the peachtree, is a species of borer, (Aggeria exitiosa, denoted in the adjoining figure, first scientifically described by Mr. Say, in the third volume of the "Journal of the Academy of Sciences, of Philadelphia," and subsequently in his "American Entomology." A history of this insect is also given by Dr. T. W. Harris, in the fifth volume of the "New England Farmer," and in his "Report on the Insects of Massachusetts injurious to Vegetation." No notice appears to have been taken of the pernicious effects of this borer before about the year 1766, when it was observed by the late Judge Peters, that, in the neighbourhood of Philadelphia, the peach-trees began, nearly at once, to fail, and finally perished. Whether their decay was caused by the borer, then undiscovered, we are at a loss to know. Many theories were advanced with regard to the nature of the evil, and that offered by Judge Peters, although among the first, perhaps was not the least rational. It was his opinion that trees, like animals, have inherent diseases, or a susceptibility to receive those peculiar to their species, and that of the peach seemed most subject to this tendency. Insects, he conceived, were the cause of many injuries to trees, but were most frequently met with in morbid parts, feculent or putrefying from previous malady, and were effects rather than causes. The borer, however, was not discovered until several years afterwards, when it was first noticed near Philadelphia, and was observed 
g madually to spread from thence in every direction, and appeared in New Hampslire, near the northern limit of the peach region, in about the year 1805, and has since extended to the southern states, and west of the Alleghany Mountains. "The eggs, from which these borers are hatched," says Dr. Harris, "are deposited, in the course of the summer, upon the trunk of the tree near the root; the borers penetrate the bark, and devour the inner bark and sap-wood. The seat of their operations is known by the castings and gum which issue from the holes

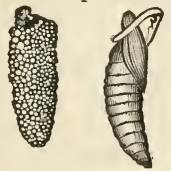

COCOON AND PUPA. in the tree. When these borers are nearly one year old, they make their cocoons either under the bark of the trunk or of the root, or in the earth and gum contiguous to the base of the trees; soon afterwards they are transformed to chrysalides, and finally come forth in the winged state, and lay the eggs for another generation of borers. The last transformation takes place from June to October, most frequently, however, during the month of July, in the state of Massachusetts. Here, although there are several broods produced by a succession of hatches, there is but one rotation of metamorphoses consummated within a year. Hence borers, of all sizes, will be found in the trees throughout the year, although it seems to be necessary that all of them, whether more or less advanced, should pass throllgh one winter before they appear in the winged state. Under its last form, this insect is a slender, dark-blue, fonr-winged moth, having a slight resemblance to a wasp or ichneumon fly, to which it is sometimes likened. The two sexes differ greatly from each other; so much so, as to have caused them to be mistaken for two distinct species. The male, which is much smaller than the female, has all the wings transparent, but bordered and veined with steel-blue, which is the general colour of the body in both sexes; the palpi or feelers, the edges of the collar, of the shoulder-covers, of the rings of the abdomen, and of the brush on the tail, are pale-yellow, and there are two rings of the same yellow colour on the shins. It expands about one inch. The fore-wings of the female are blue, and opaque, the hind-wings transparent, and bordered and veined

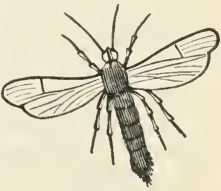

MALE. like those of the male, and the middle of the abdomen is encircled by a broad, orange-coloured belt. It expands an inch and a half or more. This insect does

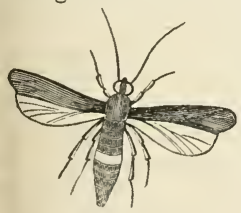

FEMALE. not confine its attacks to the peach-tree. I have repeatedly obtained both sexes from borers inhabiting the excrescences which are found on the trunks and limbs of the cherry-tree; and moreover, I have frequently taken them in connection on the trunks of cherry and of peach-trees. They sometimes deposit their eggs in the crotches of the branches of the peach-tree, where the borers will subsequently be found; but the injury sustained by their operations in such parts, bears no comparison to that resulting from their attacks at the base of the tree, which they too often completely girdle, and thus cause its premature decay and death." * Hitherto, various means have been resorted to for repelling or destroying these vile offenders, and many of them have been more or less effectual, but nowe have been attended with complete success, except in removing the earth from the base of the tree, and crushing the borers to death, und destroying the eggs and cocoons. A small quantity of leached wood-ashes, or of newly-slaked lime, added to the roots and then covered with earth, has roved advantageous, not only in warding off the borers, but in promoting the rigour of the trees. On this subject, Judge Peters remarks, in the "Memoirs of the

* See Harris' Report, p. 233. 
Phıladelphia Society for promoting Agriculture," that he had "failed in many things, in which others are said to have succeeded. Straw and bass, or paper, surrounding the tree, from the root, at all distances, from six inches, to three or four feet, white-washing, painting, urinous applications, brine, soot, lime, frames filled with sand, oil, tar, turpentine, sulphuric acid, nitrous mixtures, and almost every kind of coating. I ruined several trees, by cutting them down, and permitting the stump to throw up new shoots, and branch at pleasure. All tegnments kept the exudation from evaporating with freedom. The pores being closed, or too open, were alike injurious. Teguments of straw or bass, made the bark tender; and it threw ont, under the covering, sickly shoots. The more dense coating stopped the perspiration. The oil invited mice, and other vermin, which ate the bark thus prepared for their repast, and killed the tree. I planted in hedge-rows and near woods - I paved, raised hillocks of stone-I have suffered them to grow from the stone only, grafted on various stocks, and budded, hilled up the earth in the spring, and exposed the butt in the fall-sometimes I have used the knife freely-frequently have left the tree to shoot in every direction-I have scrubbed the stocks or trunks with hard brushes, soap-suds and sand, scraped them with proper instruments; I have, for a season or two, under various experiments, amused myself with the persuasion, that I had discovered an infallible panacea. I had temporary success, but final disappointment." "I remove the earth, a few inches round the tree in August or September, pour around the butt, beginning about one foot above the ground, a quart or more, (not being nice about the quantity,) of boiling-hot soap-suds or water. 'This kills the egg, or worm lodged in the tender bark; and of course prevents its ravages the next season. I carefully search the trees, though I seldom find worms. I do not perceive any injury from this operation. I have discovered worms in or near the roots of the smallest stocks taken from the nursery. These I frequently plunge into boiling water, before planting. I lose very few; and do not attribute the losses to the hot water."

The peach-tree also sometimes suffers severely from the attacks of leaf-hoppers, (Thrips,) as well as from those of the true plant-lice (Aphides.) They are found beneath the leaves, in small cavities produced by their irritating punctures, and are so small that they may readily escape notice. These minute insects have very slender bodies, and narrow wings, which are fringed with fine hairs, and lie close to their backs when they are at rest. 'They are exceedingly active, and appear to leap, rather than fly, when they move. The plant-lice, likewise live under the leaves of the peach, causing them, by their punctures, to become increased in thickness, to curl or form hollows beneath, and corresponding crispy and reddish swellings above, and finally to perish and drop off prematurely. The depredations of these lice is thought to be one of the causes, if not the only cause, of the peculiar malady affecting the peach-tree in the early part of summer, known under the name of "blight." * The most efficacious means employed for the destruction of the thrips and aphides are fumigations of sulphur, tobacco, or other acrid substances, and throwing into the trees, with considerable violence, warm solutions of tobacco and water, soap-suds, and eren pure water.

The fruit of the peach-tree is punctured in an early stage of its growth, by a small, rough, dark-brown beetle, (Curculio nemiphar, Herbst,) for the purpose of depositing her eggs, and thereby providing for her future progeny. When a peach is stung by these beetles, a small drop of gum may be seen oozing from its surface. The larvæ consist of little whitish grubs, which bore into the fruit, and cause it to fall before it is mature. For a further account of this insect, the

* Harris' Report, pp. 187 et 192. 
reader is referred to our article on the domestic cultivated plum, under the head of "Inscets."

The seventeen-year locust, (Cicada septendecim,) although most usually found on the oak, often resorts to other forest trees, when actuated by necessity, and not unfrequently deposits her eggs on the branches of the peach-tree, when no ther convenient shrub or tree is at hand. Peach-trees once attacked by this most pernicious insect, seldom, if ever, recover from the inflicted wounds.

Among the diseases incident to plants, there is no one involved in more mystery than that strange disorder in the peach-tree, commonly called the "yellows." It was noticed in the neighbourhood of Philadelphia, by Judge Peters, in 1790, or the year following. From perfect vcrdure, he states, the leaves of his trees turned yellow in a few days, and their bodies blackened in spots. He attributed the origin of the disease to some morbid affection of the air, which he conceived has the most to do with all vegetation, as well in its food and sustenance, as in its decay and dissolution. From Philadelphia, the malady spread, by degrees, to other parts of the country; and by 1810 , in New J $\mathbf{J}$ crsey, there were left but a few peach orchards alive, or in a flourishing state. It is said to have appeared in the vicinity of New York, in about the year 1801; in Connecticut, in 1815; and in Massachusetts, in 1S24. It is also prevalent in the southern states of the union, and west of the Alleghany Mountains.

The phenomena attending the development of this disease, are given in detail, in the second number of the "Albany Cultivator," of 1845, by Mr. Noyes Daring, of New Haven, from which we make the following condensed extracts:"There are two marks or symptoms, by which the presence of the disease is indicated. One is, the shooting out from the body or limbs of the tree, of very small, slender shoots, about the size of a hen's quill. The leaves upon these shoots are commonly destitute of green colour, as if blanched, or as if grown in dark cellar; and like the shoots which bear them, are of diminutive growth, rarely exceeding an inch in length. These shoots do not usually start from the common, visible buds at the points where the leaves join the stem, but from unseen, latent buds in the bark of the trunk or large branches. 'The other symptom is, the ripening of the frnit two to four weeks before its natural season of maturity. Most generally also, the fruit, whatever be its natural colour, is more or less spotted with purplish-red specks. If shoots, such as are above described, appear upon a tree, or without them, if the fruit upon any part of it (not wormy) ripens before the proper time, it may be certainly known that the tree has the yellows. 'T'hese are not the only marks or symptoms of the disease; but they are those which are the most readily discovered. The ordinary leaves of the tree, or at least those upon the discased portion of it, commonly undergo a slight change of colour. Instead of a bright glossy green, they take on a dull yellowish tinge. The wood also, when the disease is considerably advanced, becomes unelastic, so that its branches, when moved by the wind, instead of the graceful ivaving of health, have a stiff jerking motion. $* * * * *$ The fruit, the first season of attack, usually grows to its proper size. The second season, it is uniformly small, not more than a half or a quarter of its usual size. Whatever be he natural colour of the fruit, red, yellow, white, or green, it is more or less, when diseased, coloured with purplish-red; generally in specks, or coarse dots. The flesh, quite to the stonc, is often coloured, and most deeply around the stone. 3y the coloured specks, a person may easily distinguish by the eye, diseased, rom healthy fruit. * * * * * In the first summer of disease, it is not always hat the whole trce appears affectcd. The slender shoots may show themselves in one branch only, the rest of the trce having evcry appcarance of health. In ike manner, the fruit upon one branch may ripen four wceks too soon, upon nother two weeks too soon, and upon the rest of the tree at the natural time. 
The second season, all the fruit will ripen three or four weeks too soon. The tree sometimes dies the next year after the appearance of the disease, and sometimes lingers along with a feeble life for two or three years. ****** Soil, whether of clay or sand, whether moist or dry, whether cultivated or in grass, manured or unmanured, does not appear to me, clearly, either to increase or diminish the liability to disease. Trees standing in exposed and sheltered situations, walled and in open ground, on hills and in valleys, seem alike and equally liable. ****** When the disease commences in a garden or orchard containing a considerable number of trees, it does not attack all at once. It breaks out in patches, which are progressively enlarged, till eventually all the trees become victims to the malady. ****** i took a blossom from a diseased tree; and applied the dust (pollen) to the blossom of a young tree in my garden. The tree thus exposed to infection, showed no mark of disease, either in that or the succeeding year. ***** I took some buds from a tree, having symptoms of the yellows, and inserted part into peach, part into apricot, and part into almond stocks. Some of the inoculations took well, but all showed marks of disease the next season. The peach and almond stocks, with their buds, died the second winter after inoculation. One apricot stock lived five years, but its peach top grew, in that time, to be only about three feet high. * * * * * In an orchard or garden, containing both old and young trees, the young trees will generally be diseased first. ****** Peach-trees budded on apricots, plums, and sweet almonds, are liable to the yellows. ****** Most of the applications for the cure of the disease, have been made on the supposition that it was caused by the peach-worm. Such are ashes, scalding water, charcoal, lime, salt, saltpetre, fish-oil, and urine. All of them have more or less agency in excluding the borer, but are not all effectual, even for that purpose. Some of them have seemed to promote, for a time, the growth of the trees, and to give a deeper green to their leaves; but none that $\mathbf{I}$ have ever observed, have at at all checked the progress of the yellows." The most effectual, and the only remedy for this disease, hitherto discovered, is, on the first symptoms of decay, to grub up the trees by the roots, and convert them at once in to fuel.

The principal other accidents to which the peach-tree is liable, are the splitting of the limbs at the forks by excessive weight, or by high winds, and the bursting of the buds and bark by severe frosts in open and wet winters.

Properties and Uses. The wood of the peach-tree is hard, compact, of a roseate hue, and is susceptible of a fine polish; but owing to its inferior size and comparative scarcity, it is but little used in the arts, or for fuel, except in countries where other kinds of wood are rare. When obtained, however, of suitable dimensions, it may be employed for similar purposes as that of the almond. A colour may also be extracted from it called rose-pink. Its leaves yield, by distillation, a volatile oil, of a yellow colour, containing hydrocyanic acid. Its bark, blossoms, and kernels of the fruit, also possess the same poisonous property. From the quantity of gum and sugar contained in the delicious pulp, the peach is nutritious, and is employed as a desert, both fresh and preserved. From the malic acid contained in its juice, it is slightly refrigerant, and if eaten in moderate quantities, it is generally considered as wholesome; but if taken too freely, it is liable to disorder the bowels. When stewed with sugar, it may be given as a mild laxative to convalescents. The kernels may be used for the same purpose as those of the bitter almond. The leaves are sometimes employed by the cook, the liquorist, and the confectioner, for flavouring, and they have also been substituted for Chinese tea; but, as fatal consequences have sometimes followed these uses, they should be looked upon with precaution.

The preservation of peaches, plums, cherries, apricots, and other kinds of fruit, in syrup, occupy a prominent rank in the industry and commerce of France and 
of Majorca, and doubtless could be profitably carried on in those parts of the United States where these fruits are cultivated in abundance. To those who are desirous of entering into the business on an extensive scale, we would recommend the "Nouveau Manuel du Limonadier, du Glacier, du Chocolatier, et du Confiseur," par MM. Cardelli, Lionnet-Clémandot, et Julia de Fontenelle, published at Paris in 1838; or, what would be still better, the employment of an intelligent confiseur who is practically acquainted with all its manipulations.

As an ornamental tree or shrub, the peach, and several of its varieties, are highly deserving of culture, and group well with the double-flowered cherry, the apple, and with the plum.

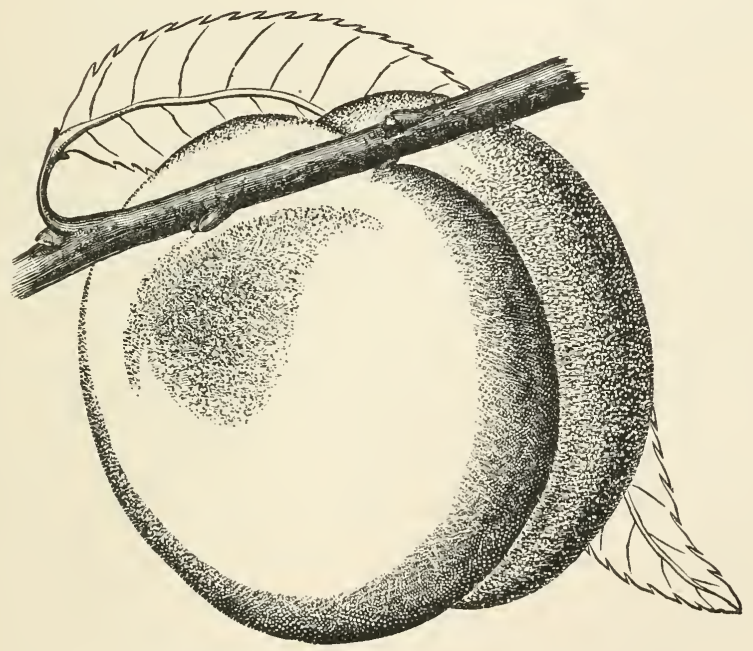




\section{Genus PRUNUS, Tourn.}

Rosaceæ.
S'yst. Nat.
Icosandria Monogynia. Syst. Lin.

Synonymes.

Prunus, Cerasus, Chamaterasus,

OF Authors.

Derivation. The name Prunus is said to have been of oriental origin, the wild plant, according to Galen, being called proumnos in Asia. The Greek name of the plum, as mentioned by Theophrastus, is proune; whence the Latin, Prunus.

Generic Characters. Drupe ovate or oblong, fleshy, quite smooth, covered with a pruinose powder. Putamen (stone) compressed, acute on both sides, somewhat furrowed at the edges, otherwise smooth. Young leaves convolute. Pedicels umbellate-fasciculate, one-flowered, evolved before or after the leaves.-De Candolle, Prodromus.

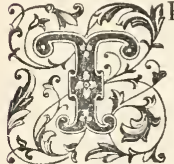

IE species belonging to this genus are mostly deciduous, low trees or shrubs, bearing edible fruit, natives of Europe, Asia, and North America. Many of them are spiny in the wild state, and all have showy flowers. The epidermis of the bark of the plum, as well as that of the birch and cherry, is readily divisible transversely, and may frequently be seen divided, in this manner, into rings on the tree. There are upwards of thirty species enumerated in catalogues; but it is a question whether one-half of them are not mere varieties. To this genus, formerly belonged the Apricot, (Armeniaca vulgaris, of 'Tournefort, De Candolle, Loudon, and others, ) and for the convenience of classification, we have retained the Linnæan name. This tree is in general cultivation throughout the temperate regions of the globe, and is distinguished, at first sight, from the almond, peach, and nectarine, by its heart-shaped, smooth, shining leaves, and white flowers. There are several wild varieties, bearing flowers of different shades of pink, and are chiefly cultivated for ornament. The great beauty of both the wild and the cultivated sorts of the apricot is, that in high latitudes, they generally come into bloom before most other trees. The most noted species of this genus proper, are the domestic cultivated plum (Prunus domestica); the sloe, or black thorn, of Europe (Prumus spinosa); the engrafted, or bullace plum (Prunus insititia); the beach-plum (Prunus maritima); and the moose or American wild plum (Prunus americana.) The latter is said to be the only species indigenous to North America which has a flat stone, groved on both margins. The other species native of this country, are somewhat intermediate in their fruit, between the cherry and the plum, the stone being slightly compressed, and the glaucous bloom wanting, except in the Prunus maritima; yet they are evidently Plums and not Cherries, in the opinion of Torrey and Gray, and cannot with propriety be separated from this genus. The beach-plum abounds along the sandy sea-coast of the United States, from Maine to Alabama. The moose-plum occurs on the banks of streams and other waters, in hedges, and on prairies, from Canada to 'Texas, and is often cultivated with success. Both of these species are said to escape the attacks of the curculio, as no warts or excrescences are found upon them, even when growing in the immediate vicinity of infested foreign trees. Hence it has been suggested that they might be propagated to advantage from the stone, for the purpose of grafting or budding other fruits upon. 


\section{Prunus armeniaca, \\ THE COMMON APRICOT-TREE.}

Synonymes.

\author{
Prunus armeniaca, \\ Armeniaca vulgaris, \\ Abricotier, \\ A prikosenbaum, \\ Albicocco, Albercocco, \\ Armellini, Pesco americano, \\ Miliaco, \\ Albaricoquero, Albaricocal, \\ Apricot,
}

\author{
Linnatus, Species Plantarum. \\ (De Candolle, Prodromus. \\ Dow, Miller's Dictionary. \\ Loudon, Arboretum Britannicum. \\ France. \\ Germany. \\ $\{$ ITALY. \\ SPAIN \\ Britain and Anglo-America.
}

Derivations. The specific name, armeniaca, is derived from Armenia, the country from which this tree was surposed origilly to have been brought to Europe. The popular English name, Apricot, was originally pracocia, and was suppcsed by some have been derived from pracox, early or precocious, from its fruit ripening sooner than most others. Some derive it from e Arabic berkoche; whence the Spanish and Italian names.

Engravings. Du Hanel, Traité des Arbres et Arbustes, i., p. 49; Loudon, Arboretum Britannicum, ii., figs. 398, 399, et , pl. 107 ; and the figures below.

pecific Characters. Flowers sessile. Leaves heart-shaped or ovate.-De Candolle, Prodromus.

\section{Description.}

HE Common Apricot, in
favourable situations,
usually attains a height
of twenty or thirty feet, ith a handsome, spreading, somewhat orbicular ead. The branches are furnished with numerus buds, and are clothed with large, hearthaped, smooth, shining leaves. The flowers, hich are white, put forth before the leaves, and re very ornamental, especially at a season when
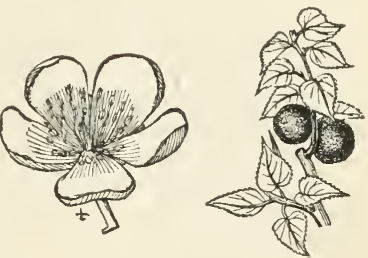

int few other trees are in bloom. They usually make their appearance at Faples, in Italy, and at Augusta, in Georgia, by the 20th of February; in Engand, by the first of April, and nearly a month later at New York. The nut or tone of the fruit is fleshy, juicy, with its surface downy, obtuse at one end, cute at the other, and furrowed at both lateral edges, but the other parts are ven.

Varieties. There are two forms of this kind of apricot, either of which may e considered as the species, and two varieties:-

1. P. A. ovalifolia. Oval-leaved Apricot-tree, the leaves of which are oval, and ie fruit small.

2. P. A. condifolia. Heart-shaped-leaved Apricot-tree, with broad, heart-shaped aves, and large fruit.

3. P. A. Folis VARIEgatis. Variegated-leaved Apricot-tree.

4. P. A. Flore Pleno. Double-flowered A pricot-tree. It is said that the Chinese ive a great number of double-flowered varieties of this tree, which they plant "little mounts for ornament, and dwarfs in pots, for their apartments.

Geography and History. The Prunus armeniaca is indigenous to Armenia, tucasus, the Himalayas, China, and Japan. From its trivial name, it is gene- 
rally supposed to have originated in Armenia, but Regnier and Sickler assign it a parallel between the Niger and Mount Atlas. Pallas considers it to be a native of the whole of the Caucasus; and Thunberg describes it as a very large, spreading, branchy tree, in Japan. Both in Caucasus and China it is more frequent on mountains than on plains, which affords a proof of its great hardiness.

This tree was cultivated by the Romans, and is described by Pliny and Dioscorides. It is said to have been brought from Greece to Marseilles by the Phocæan colonists, some time in the middle ages. It appears from Turner's "Herbal," that it was cultivated in England in 1562; and in Hackluyt's "Remembrancer," published in 1582, it is affirmed, that the apricot was brought from Italy to England by Wolfe, a French priest, gardener to Henry VIII., in 1524.

The introduction of the apricot into the United States probably dates back to the early periods of their settlements. It is at present almost as universally cultivated in both Europe and America for a fruit-tree, as the peach; and is more deserving of a place in the shrubbery than that tree, on account of its more vigorous growth, and its much handsomer general shape, independently of its more beautiful leaves.

Soil, Culture, $\& \cdot c$. Very few trees attain the appearance of maturity so soon as the apricot. A standard ten or twelve years planted, in good loamy, rich soil, will grow to a height of twenty feet, with a head twenty-five feet in diameter, presenting all the appearance of a tree of twenty or thirty years' growth: Hence the value of this tree in planting the grounds of a small villa, where unity of expression and immediate effect is desired. This tree requires very nearly the same soil and mode of culture as the nectarine and domestic plum, and is subject to the attacks of many of the same insects, and frequently loses its fruit before it arrives at maturity. The trees are generally budded on stocks of the plum, and in the higher latitudes are trained against walls. There are several varieties cultivated especially for their fruit, among which the Breda, with its brilliant scarlet buds, the Moorpark, and the Blotched-leaved Roman, stand pre-eminent. 'There is also the Peach Apricot, with large fruit, supposed to be a hybrid between the peach and apricot, which is much esteemed by some.

Properties and Uses. The fruit of the Apricot, like that of the peach and plum, is wholesome and delicious, when taken in moderate quantities, but it cannot be indulged in, to excess, with impunity. When fully ripe it may be used as a dessert at table, or may be dried, or preserved in sirup, like the peach and plım. On the African oases, it is dried, and carried to Egypt, as an article of commerce. In China, the natives employ it variously in the arts. From the wild tree, the pulp is of little value, but it has a large kernel, from which they extract an oil. They preserve this fruit wet in all its flavour; and they make lozenges of the clarified juice, which afford an agreeable beverage, when diluted in water.

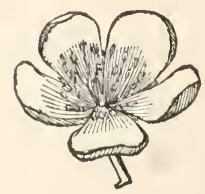




\section{Prunus domestica, \\ THE DOMESTIC CULTIVATED PLUM-TREE.}

Synonymes.

\section{Prunus domestica,}

Prunier domestique,

Gemeine Pflaume, Pflaumenbaum,

Pruno, Susino, Susino domestico,

Ciruelo,

Amexiéira,

4. Plum-tree,

\author{
(Linn xus, Species Plantarum. \\ De Candolle, Prodromus. \\ Loudon, Arboretum Britannicum. \\ France. \\ Germany. \\ ItALY. \\ Spain. \\ Portugal. \\ Britain and Anglo-America.
}

Derivation. The specific name, domestica, is derived from the Latin domus, a house, having reference to this tree as being cultivated about houses, or appertaining to home.

Engravings. London Pomological Magazine; Hoffy, Orchardist's Companion; Loudon, Arboretum Britannicum, vi., pl. 111.; and the figures below.

Specific Characters. Branches spineless. Flowers mostly solitary. Leaves lanceolate-ovate, concave on the surface, not flat.-De Candolle, Prodromus.

\section{Description.}

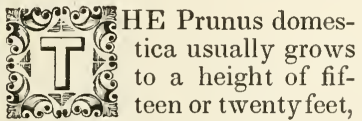
nd from to ten inches in diameter. It somewhat resembles the common sloe, (Prunus spinosa,) but larger in all its parts, and is without thorns. The bark is black, and the leaves are of a dark-green. The roots

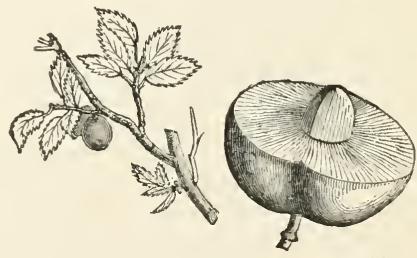
are creeping, and, in most soils and situations, throw up numerous suckers. The fowers put forth, in England and in the central parts of the United States, by the middle of April, and nearly a month later at Berlin, in Prussia, and at Boston, in Massachusetts. They are mostly solitary, and contain from twenty to thirty filaments, with yellowish anthers. 'The style is generally ouly one; but there are sometimes two. The drupe is globose, depressed at the base, or oblong-ovate, leshy, glabrous, and covered with a bloom.

Varieties. There are more than three hundred varieties and sub-varieties of the domestic cultivated plum, enumerated in catalogues, many of which, perhaps, are only dissimilar in name. It is the opinion of some authors that this species and all its variations, as well as the bullace plum, originated from the common sloe. On this point, however, botanists do not agree, and as it will be irrelevant to our purpose to undertake to refute or defend such a belief, we shall here only notice those which have some pretensions to distinctness of character, and have been cultivated either for ornament or profit.

1. P. D. armeniördes, De Candolle. Apricot-like Plum-tree; Mirabelle or Drap $d$ 'or, of the French. The leaves, the fruit, and the general habit of this variety bear some resemblance to those of the Armeniaca brigantiaca. It appears to be intermediate between the wild plum and the wild apricot.

2. P. D. claudiana, De Candolle. The Empress Claudina's Plum-tree; Green Gage, of the English; Reine-claude, of the French; and Grüne Königspflaume, 
of the Germans. This variety is regarded as one of the best of plums, and is too extensively known to require description. It was introduced into France by the wife of Francis I. Hence the name, Reine-claude. It is called Gage in England, after the name of the family who first cultivated it there.

3. P. D. myobalana, Linnæus. Myrobalan Plum-tree, Cherry or Indian Plumtree; Prunier myrobalan, or Cerisette, French; Kirschpflammenbaum or Indischer Pflanmenbaum, German. This variety appears to be first removed from the bullace plum, (Prunus insititia,) and may be distinguished by its narrow sepals, globose, depressed fruit, and small-pointed nut. It is supposed by some to be a native of North America, but it is only found in this country in a state of cultivation. It well deserves culture as an ornamental tree, on account of its very early flowering, which takes place much sooner than the fruit-bearing varieties, generally; consequently, it is liable to be injured by frost.

4. P. D. Damascena, De Candolle. Damask or Damascene Plum-tree; Prunier de damas, of the French.

5. P. D. Turonensis, De Candolle. Orleans Plum-tree; Monsieur hatif of the French. This variety is said to have been introduced into Britain from Orleans, in France, when that part of the country was in the possession of the English.

6. P. D. Juliana, De Candolle. Ste. Julienne Plum-tree, which yields the officinal prunes.

7. P. D. Catharina, De Candolle. St. Catharine Plum-tree. The fruit of this variety is a large, Jellowish plum, of an oval shape, tapering towards the base, and is distinguished for its remarkably sweet and agreeable flavour, when fresh and ripe from the tree.

8. P. D. aubertiana, De Candolle. Egg Plum-tree, or Magnum Bomum. This variety, as in the plums cultivated for their fruit, generally, has larger leaves, flowers, and fruit, and comes later into bloom than the other kinds.

9. P. D. Prunealina, De Candolle. Damson-tree, common and well known.

10. P. D. Washingtonensis. Washington or Bolmar Plum-tree. This variety may be known by its roundish, yellow fruit, of an excellent quality, vigorous growth, and pyramidal head. It is very hardy, a great bearer, and particularly deserves cultivation.

11. P. D. Flore pleno, Joundon. Double-blossomed Plum-tree, with large, handsome flowers. If the roots of this variety are not supplied with an abundance of nourishment, the flowers will degenerate into semi-double or single ones.

12. P. D. Folins variegatis, Loudon. Varieguted-leaved Plum-tree.

Geography and History. The Prumus domestica appears to be more widely diffused in its original locality than the apricot. It is believed to be indigenous to the south of Russia, Caucasus, the Himalayas, and to many parts of Europe. In England, and in some parts of the United States, it is sometimes found in hedges, but never truly wild. This species and many of its varieties are cultirated for ornament, or their fruit, in all the temperate countries of the habitable globe. Faulkner, in his "Kensington," makes the plum a native of Asia, and an introduction into Europe of the Crusaders. Gough, in his "British Topography," says, that Lord Cromwell introduced the Perdrigon plum into England in the time of Henry VII.

'The introduction of this tree into the United States dates back to the earliest periods of their settlements. Several valuable and interesting varieties have originated in this country, among which, the Bolmar or Washington plum stands conspicuous. The parent tree is said to have been purchased in a market in New York, about the end of the last century. It remained barren for several years, till, during a violent storm of thunder, the entire trunk was severed to the earth, by lightning, and destroyed. The part remaining in the ground, afterwards threw up several vigorous shoots, which were allowed to remain, and 
finally produce fruit. Trees of this variety were first sent to England in 1819, to Mr. Robert Barclay, of Bury Hill; and several others were sent to the London Horticultural Society, in 1821, by Dr. Hosack, of New York.

Soil, Situation, Propagation, $\& \bullet c$. The domestic cultivated plum prefers a free, loamy soil, somewhat calcareous, and a little inclined to clay, and a situation open, and exposed to the sun, but sheltered from the blasts of northern winds. It is almost invariably propagated by grafting or budding, and is generally performed on stocks of the most free-growing varieties; or, when the plants are intended for dwarfs, on the Mirabelle plum. 'The stocks may either be raised from seeds, or by layers. The former should be gathered when the fruit is dead ripe, mixed with sand, and turned over two or three times in the course of the winter, and being sown in March, or as soon as the ground is sufficiently open, they will come up in the May or June following. In Britain, or any other country having a humid climate, plants of this species may be very expeditiously obtained, by pegging down the shoots of the preceding year, which have risen from the stools, and covered with soil to the depth of an inch, or an inch and a half. The entire shoot being thus covered, and kept moist, each bud will produce a vertical shoot, a foot or more in length, according to the soil and the season; and each of the shoots, when separated from the stool, in the autumn following, just before the falling of the leaves, will be found to have an abundance of roots. The branches which were laid down to produce these shoots should be cut off close to the stool. This method is practised in many of the European nurseries, where stocks are raised in immense quantities, to supply the general demand of the trade. "Numerous as are the cultivated fruit-bearing varieties of the common plum," says NIr. Loudon, "it is clear that they might be increased ad infinitum; and it is also highly probable, that numerous varieties, with fruits totally different from those of the original species, might be procured by cultivating the North American species, P. maritima, and P. pubescens; if, indeed, these are anything more than varieties of $\mathbf{P}$. domestica. 'There are two forms, which every description of tree seems capable of sporting into, which are yet wanting in the genus Prunus, as at present limited; the one is with branches pendent, and the other with branches erect and fastigiate. There can be no doubt but that an endless number of hybrids, varying in their leaves, blossoms, and fruit, might be produced by fecundating the blossoms of the plum with the pollen of the almond, the peach, the apricot, and the cherry; and, though some may be disposed to assign little value to these kinds of productions, yet it must not be forgotten that almost all the cultivated plants of most value to man. have been produced by some kind of artificial process. Experiments of this kind, therefore, ought never to be discouraged. What culture has done we know; but what it may yet accomplish is concealed in the womb of time."

As in the peach-tree, the most proper time for pruning the phum, as well as for most kinds of stone-fruits, is in autumn, just as the leaves are falling, when the sap is in a downward motion, and when a more perfect cicatrization of the wound will take place, than if pruned in the winter or spring.

Insects. In America, the Prunus domestica is preyed upon by various insects or their larvæ, among which are those of the Aigeria exitiosa, that bore into its trunk or roots, in a similar manner as they do into the peach-tree; and the slugworm or slimy caterpillar, (Blennocampa cerasi, Harris,) which rests on the upper surface of the leaves of the plum, as well as upon those of the cherry and the pear, eating away their substance, and leaving only the veins and the skin beneath untouched.* But by far the most injurious insect which attacks the plum, is the Curculio nenuphar, (Rhynchanus Conotrachelus Nemuphar, Harris,)

* See Harris' Report, p. 384. 
to which allusion is made under the head of "Insects," in our article on the peach-tree. Dr. Harris describes the perfect insect as a little, rough, dark-brown, or blackish beetle, looking like a dried bud, when it is shaken from the tree, which resemblance is increased by its habit of drawing up its legs, and bending its snout close to the lower side of its body, and remaining for a time without motion, and seemingly lifeless. In stinging the fruit, before laying its eggs, it uses its short, curved snout, which is armed at the tip with a pair of very small nippers; and by means of this weapon, it makes, in the tender skin of the young plum or apple, a crescent-shaped incision, similar to what would be formed by indenting the fruit with the finger nail. Very rarely is there more than one incision made in the same fruit; and in the wound, the weevil lays only a single egg. The insect hatched from this egg is a little whitish grub, destitute of feet, and very much like a maggot in appearance, except that it has a distinct, rounded, light-brown head. It appears from some observations made by Dr. Harris and others, that the large, black, warty tumours found on the small branches of plum and cherry-trees, are infested not only by these insects, but also by another kind of grub, provided with legs, and occasionally by the larvæ of the Egeria exitiosa, or peach-tree borer. When the grubs of the plum-weevil are fully grown, which occurs at various periods from May to September, they usually fall with the punctured fruit, and go into the earth, where they are changed into chrysalides of a white colour, having the legs and wings free, and capable of motion; and finally they leave the ground in the form of a little beetle, exactly like those above described, which takes place in Massachusetts from the early part of March till towards the middle of June, according to the nature of the season and the exposure of the situation.* Among the various remedies recommended for checking the ravages of these insects, are the paving of the ground directly beneath the trees with bricks, or other materials, so as to prevent the worms from entering the earth, to transform; the pouring of boiling-hot water around the trees, towards the end of August, in order to scald the insects to death; and the shaking or jarring of the trees every evening and morning, during the time that the beetles are occupied in depositing their eggs. When thus disturbed, they contract their legs, and fall; and as they do not immediately attempt to crawl or fly away, they may readily be caught on a mat or sheet, spread under the tree, and then be crushed or burned to death. In addition to the method last described, Dr. Harris recommends that all the fallen wormy plums should be immediately gathered, and, after they are boiled or steamed, to kill the enclosed grubs, they should be given as food to swine. The diseased excrescences, he says, should be cut out, and burned, every year, before the last of June.

Properties and Uses. The wood of the Prunus domestica is hard, close, compact, beautifully veined, and susceptible of a fine polish. When dry, it weighs from forty to fifty pounds to a cubic foot, according to the age and growth of the tree. Its texture is silky, and when washed with lime-water, its colour is heightened, and may be preserved by the application of varnish or wax. Unfortunately for this tree, its wood is sometimes rotten at the heart. In France and Germany, it is much sought after by turners, cabinet-makers, and the manufacturers of musical instruments. The leaves are sometimes given to cattle for forage. The use of the fruit in domestic economy for dessert, and for making tarts and puddings, is well known. In France, plums are principally used dry or preserved, and enter extensively into commerce. The kinds usually employed for preserving, are the Brignole, the prune d'Ast, the Perdrigon blanc, the prune d'Agen, and the Ste. Catherine. In warm countries, plums or prunes are dried on hurdles by

* See Harris' Report, pp. 66, 67, 68, 351, 352. 
solar heat; but in cold climates, artificial heat is employed; the fruit being exposed to the heat of an oren, and to that of the sun, on alternate days. Table prunes are prepared from the larger kinds of plums, as the green Gage, and Ste. Catherine; those employed in medicine from the Ste. Julienne. 'The former have a very sweet and agreeable taste; and the latter are somewhat austere. Fresh, ripe plums, taken in moderate quantities, are regarded as nutritire and wholesome; but in large quantities, they readily disorder the bowels; and when immature, they still more easily excite ill effects. The medicinal prunes are employed as an agreeable, mild laxative for children, and are given during convalescence from febrile and inflammatory disorders in adults.

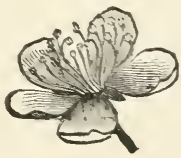




\section{Prunus chicasa, THE CHICASAW PLUM-TREE.}

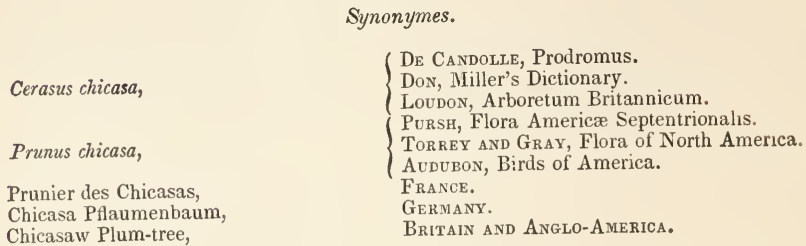

Engravings. Audubon, Birds of America, i., pl. liii ; and the figures below.

Specific Characters. Branches glabrous, becoming rather spiny. Leaves oblong-oval, acute, or acuminate. Flowers upon very short peduncles, and mostly in pairs. Calyx glabrous, its lobes very short. Fruit nearly globose. small, yellow.-De Candolle, Prodromus.

\section{Description.} heighit, indigenous to Arkansas, western Louisiana, and 'Texas, and naturalized east of the Mississippi as far north as Virginia. According to Michaux, it was brought to the Atlantic southern states, and cultivated by the Chicasaw Indians; and hence it is commonly called the Chicasaw plum. It was introduced into Britain in 1806, and plants of it are growing in many of the European collections. The flowers, which put forth in April and May, are succeeded by a yellow, or yellowishred fruit, nearly destitute of bloom, of a

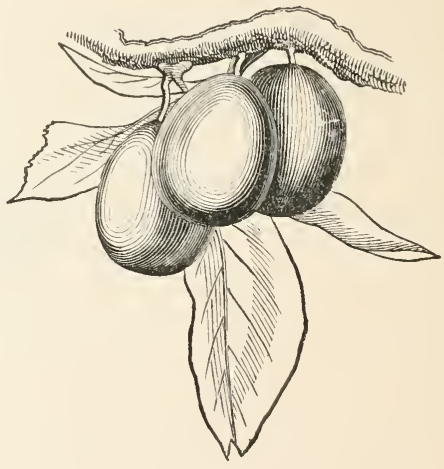
roundish form, half of an inch or more in diameter, having a thin skin, a tender pulp, and usually of an agreeable flavour, but, like all the species of the genus, it varies in its quality, sometimes being quite astringent and sour.

Variety. There is at least one variety of this species, the $P$. c. nemoralis, which may readily be distinguished by its tomentose or pubescent pedicels and leaves, and is conjectured by some, to be the original stock of the naturalized or cultivated tree. The species and variety may be propagated from seeds, by grafting, or inoculation, in a similar manner as the domestic cultivated plum.

A tree of this kind is standing in the garden of Rev. E. M. Johnson, of Brooklyn, in New York, which has attained a height of about twenty feet, with a trunk ten inclies in diameter. It is perfectly hardy, and matures fruit every year. 


\section{Genus CERASUS, Juss.}

\author{
Rosaceæ. \\ Syst. Nat. \\ Cerasus, Laurocerasus, Prunus, \\ Cerisier, \\ Kirschbaum, \\ Ciliegio, Ceriegio, \\ Cerezo, Cerezezo, \\ Cerejeira, \\ Wischnaija, \\ Cherry-tree,
}

Synonymes.
Icosandria Monogynia.
Syst. Lin.

\author{
OF Authors. \\ France. \\ Germany. \\ ITALY. \\ SPAIN. \\ Portugal. \\ Russia. \\ Britain and Anglo-America.
}

Vervations. The generic name, Cerasus, is so called from the ancient town of that name, in Asia, whence the cultivated cherry was first brought to Rome, by Lucullus. Most of the other names appear to be derived from the Latin one.

Generic Characters. Drupe globose, or with a hollow at its base; nut sub-globose, even, its covering fleshy, juicy, and with a surface glabrous, and not covered with a gray bloom. Young leaves folded flatwise. Flowers upon pedicels, either in groups resembling umbels, and produced before the leaves, or in racemes terminal to the shoots, protruded along with them.-Loudon, Arboretum.

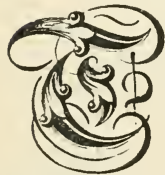

HE trees and shrubs of this genus are mostly deciduous, with smooth, serrated leaves, and white flowers. There is much confusion among botanists, in all the species, more particularly as regards those which are natives of North America. The common garden cherries, and all their varieties cultivated for their fruit, according to Linnæus, and nearly all the writers up to the time of De Candolle, have been referred to the Prunus avium and the Prunus cerasus, both of which, in the opinion of Mr. Loudon, are only varied forms of one species; the former being the mérisier of the French, and corresponding with the small, wild, black, English cherry (Cerasus sylvestris); and the latter, the French cerisier; and corresponding with the common red, sour cherry of the English (Cerasus vulgaris.) To these two species, De Candolle, in the "Flore Française," has added two others, the Cerasus juliana, which he considers as including the guigniers; and the Cerasus duracina, under which he includes the bigarreaus, or hard cherries. But as this arrangement did not appear sufficiently distinct to Mr. Loudon, he thought proper to adopt in his "Arboretum," that of the autho: of the article "Cerasus," in the "Nouveau Du Hamel," as much more simple and satisfactory, referring all the cultivated varieties of the garden clicrry to the same species as Linnæus, substituting for Prunus avium, Cerasus sylvestris ; and for Prunus cerasus, Cerasus vulgaris. Among the Asiatic trees of this genus particularly deserving of cultivation for ornament or for their timber, are the Yung-'To, or Chinese double cherry, (Cerasus serrulata,) distinguished for its double, white flowers, slightly tinged with red; the Chinese false cherry-tree, (Cerasus pseudo-cerasus,) noted for its early flowers and easy propagation; the Puddum cherry-tree, (Cerasus puddum, ) a native of Nepal, growing to a height of twenty or thirty feet, and celebrated for its rose-coloured flowers, edible fruit, and for the useful properties of its wood; also the goat-killing bird cherry, (Cerasus capricida,) native of Nepal, a handsome, showy, evergreen tree, which would probably retain its verdure in many parts of the union; and the true bird cherry-tree, (Cerasus padus,) also found in several countries in Europe, as well as the Mahaleb or perfumed cherry, and is much admired for the beauty of its 
Howers, its pendent racemes of black fruit, and its yellowish, satiny wood. To western Asia also belongs the laurel cherry, (Cerasus laurocerasus,) a beautiful evergreen tree, known at once, from all other species of the genus, by its large, smooth, yellowish-green, shining leaves, and its pale-green petioles, and young shoots. It is less hardy than the Portugal laurel cherry, (Cerasus lusitanica,) a large, evergreen tree, growing to a height of sixty or seventy feet, the branches of which, in England, are frequently killed back by the frost, and in Germany is almost everywhere treated as a green-house plant. Among the North American species worthy of culture, are the black cherry-tree, (Cerasus nigra,) a tall shrub, indigenous to Canada and the Alleghany Mountains, distinguished for its pleasing flowers, with purplish anthers, which, like those of the plum, appear before the leaves; the Cerasus mollis, a tree from twelve to twenty feet in height, a native of the subalpine hills, near the source of the river Columbia, as well as near its mouth; and the Cerasus emarginata, known by its white flowers, globose, astringent fruit, and red wood, with white spots, found wild along the same river. To these we will add the Cerasus borealis, Cerasus virginiana anc its varieties, and the Cerasus caroliniana. 


\section{Cerasus sylvestris, \\ THE WILD CHERRY-TREE, OR GEAN.}

\section{Synonymes.}

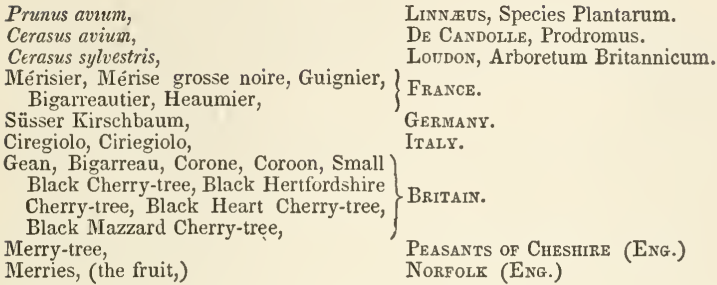

Derivations. According to Mr. Loudon, this cherry is called Corone, (a crow,) in some parts of England, in reference to ita blackness. Merisier is said to be derived from the words amere, bitter, and cerise, a cherry ; and Merry-tree and Merries, are evidently corruptions from it. Bigarreau is derived from bigarree, party-coloured, because the cherries known by this name are generally of two colours, yellow and red; and Heaumier is from the French word heaume, a helmet, from the shape of the fruit.

Engravings. Selby, British Forest Trees, pp. 53, 61, 63, 64; Loudon, Arboretum Britannicum, vi., pl. 113; and the figures below.

Specific Characters. Branches vigorous and divaricate; the buds from which the fruits are produced, oblong-acute. Flowers in umbel-like groups, sessile, not numerous. Leaves oval-lanceolate, pointed, serrated, somewhat pendent, slightly pubescent on the under side, and furnished with two glands at the base.-De Candolle, Prodromus.

\section{Description.}

MOg.920 HE Cerasus sylves8. situations, often acquires a height of sixty or seventy feet, in fifty or sixty years, with a trunk of proportionate size, and sufficiently large for the general purposes of construction. In the progress of its growth to maturity, the form of its head is pyramidal, the branches springing from the main stem, at regular intervals, or at the commencement of the annual

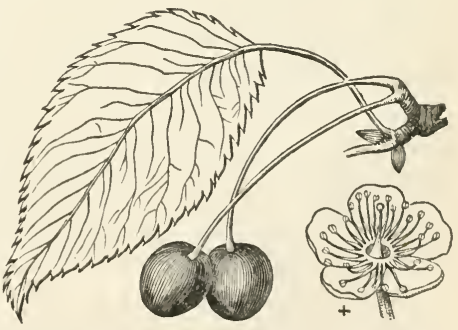
shoot; and as its spray is stiff, strong, and open in its character, it firmly resists the fury of the winds. Its foliage, though handsome and pleasing to the eye, is considered too uniform and unbroken to produce picturesque effect; yet "in autumn, when it assumes a deep purplish-red colour, it gives great richness to the landscape, and contrasts well," as Selby expresses it, "with the yellows and browns which predominate at that season." Its flowers, which are produced in profusion in A pril or May, from their snowy whiteness, blend well with those of the almond and the scarlet thorn. The fruit, well known in Britain by the name of gean, is usually of a very deep, dark-red, or black, when ripe, but sometimes it is of a bright-red; its pulp and juice is small in quantity, usually of the colour of the fruit, austere and bitter before it comes to maturity, and insipid or sweet, 
with a peculiar flavour, when perfectly ripe. The nut or stone is oval or ovate in its form, firmly adhering to the flesh, and is very large in proportion to the size of the fruit, which ripens in June or July.

Varieties. Under this species are included the following groups or races, which conform with the arrangement in the "Nouveau Du Hamel," and in Loudon's "Arboretum Britannicum :"-

1. C. s. Amara. Bitter-fruited Wild Cherry-tree, including the Merries of England, and the Mérisiers of the French, with black or yellow fruit.

2. C. s. Jullana. The Julian Wild Cherry-tree. The fruit of this group is red or black, early or late. It includes the tobacco-leaved guignier, or gean, of four to the pound.

3. C. s. Heaumiana. Helmet-shaped-fruited Wild Cherry-tree; Heaumier of the French. The fruit of this variety somewhat resembles that of the bigarreautier, but is less firm in its flesh.

4. C. S. Duracina. Hard-fruited Wild Cherry-tree; Bigarreautier of the French, with fruit white, flesh-coloured, or black, and generally heart-shaped. The trees of this race are planted for ornament rather than for their fruit, among which, is that beautiful double-flowered variety, known in France by the name of Mérisier à Fleurs doubles, or Mérisier renunculier, and in England and America, Double french White.

Geography and History. The Cerasus sylvestris is indigenous to many parts of continental Europe, and is also considered by many to be so in Britain. The first mention of this tree as growing in England, it appears, is by Gerard, in his "Herbal," published in 1597 , in which he particularly mentions the black wild cherry, with fruit of "an harsh and unpleasant taste." M. Loiseleur des Longchamps, in the "Nouveau Du Hamel," states that, "though the wild cherry is undoubtedly indigenous to France, yet it does not appear to have been so to Italy; and that even in France, only the Cerasus sylvestris, or mérisier, is found in the forests; while the Cerasus vulgaris, or cerisier, is never found in an apparently wild state in any country in Europe, except near human habitations." From this he concludes that, although the mérisier had long existed in France, it probably had escaped the notice of the Romans, and even if they had discovered the tree, they would have set but little value on its bitter, austere, and nearly juiceless fruit. This species grows wild at Portella, on Mount Æitna, at two thousand nine hundred and seventy feet above the level of the sea; but not lower, as the climate becomes too warm for it. On the Swiss Alps, at Chürwalden, where, it is said, no other kind of stone-fruit will grow, it arrives at maturity, at an elevation of three thousand nine hundred and sixty-four feet.

The largest specimen of the Cerasus sylvestris on record, is in Gloucestershire, England, standing on the northern extremity of the Cotswald Hills, on the estate of the Earl of Harrowby, which is eighty-five feet in height, with a trunk upwards of three feet in diameter.

Soil and Situation. According to Mr. Loudon, the gean will grow in any soil that is not too wet, or is not composed entirely of a strong clay. It will thrive better than most other trees in dry, calcareous, and sandy soils, attaining, even in chalk, with a thin layer of earth over it, a very large size. It was found by Du Hamel, that this species succeeds on poor sandy soils, where other trees had altogether failed. It has been further stated that, whenever the roots extend to water, the tree always decays. This tree will grow on mountains and other elevations, as may readily be supposed, from its flourishing in high northern latitudes; "but it does not attain a timber-like size," continues Mr. Loudon, "except in plains, or on low hills. It stands less in need of shelter than any other fruit-bearing tree whatever, and may often be employed on the margins of orchards, and for surrounding kitchen-gardens, to form a screen against high 
winds." It is also said to thrive best when unmixed with other trees; and suffers the grass to grow beneath its shade.

Propagation and Culture. The Cerasus sylvestris, whether grown for stocks for grafting upon, or for planting out with a view to produce timber, is almost always propagated from seeds; but, as the roots throw up an abundance of suckers, stools might be formed, and treated like those of the plum; or, cuttings of the roots might be employed for the same purpose. When plants are to be raised from seeds, Mr. Loudon recommends that the cherries should be gathered when ripe, and either be sown immediately, with the flesh on, incurring the risk of their being eaten by birds or vermin, especially mice, during the autumn and winter; or, what is preferable, they may be mixed with four times their bulk of sand, and kept in a shed or cellar, being turned over frequently, till the time arrives for sowing. As soon as the ground is sufficiently open, in the winter or spring, they may be sown in beds, and covered to the depth of one-half to threefourths of an inch, with light mould. Great care must be observed that the seeds do not sprout while in the heap; because, unlike the horse-chesnut, the acorn, and the seeds of some other fruits, the cherry expands its cotyledons at the same time that it protrudes its radicle; and when both are developed before sowing, the probability is, that the germinated seeds will not live; for the cotyledolis, in sowing, are unavoidably covered with soil, whereas nature intended them to be exposed to the light. The strongest plants, at the end of the first season, will be eighteen inches or more in height, and may be drawn out from among the others, and transplanted into nursery lines; and, after they have stood there a year, they may be grafted or budded.*

The cherry-tree, whether in a young or old state, requires but a very little pruning, and the knife should only be used for the removal of a second leading shoot, or an over-rampant branch. Whenever this becomes necessary, let it be performed in the month of August or September, or at least, àt a period when the leaves are fully expanded, "a rule which holds good," says Mr. Selby, in his treatise on 'British Forest Trees,' "and ought to be observed in regard to all deciduous trees ;" for, it has been found by experience that, when pruned in the summer season, they are not liable to bleed or exude their gum, and as the sap begins to elaborate, new wood is formed at the edges of the wounded parts, and by the time of the fall of the leaf, the injuries will be so far recovered as to be out of danger of decay, from the lodgment of wet, or the influences of the weather.

According to some experiments made by Mr. Selby, no tree bears transplanting when of considerable size, better than the gean. He removed with success plants from twenty to thirty feet in height, some of which had originated from suckers, and others from seeds. As in the case of all trees that he had removed, of a large size, they suffered a check by the operation, but from this they generally recovered in the course of two, or at most, three seasons.

Accidents, Diseases, $\mathcal{S}^{\circ}$. The foliage of the gean is seldom attacked by insects or their larvæ, though it is sometimes disfigured by the caterpillars of several species of Geometridæ; and the extremities of the young shoots are often preyed upon by a large, black louse (Aphis cerasi); but the fruit-bearing varieties of the cherry, like most other cultivated trees, seem more subject to injury from insects, than those in a wild state.

Properties and Uses. 'The wood of the wild cherry-tree is of a reddish colour, of a firm, strong texture, and close-grain, yet sufficiently soft to be easily worked, and is susceptible of a fine polish. When green, it is nearly of the same specific gravity of water, and when dry, a cubic foot weighs about fifty-five 
pounds, and in seasoning, it loses about one-sixteenth part of its bulk. In France, where mahogany is comparatively scarce, it is much sought after by cabinetmakers, turners, and the manufacturers of musical instruments. In order to heighten its colour and increase the depth of its tone, it is steeped from twentyfour to thirty-six hours in lime-water, and after being taken out, is immediately polished. This process, they say, prevents the colour from fading, when exposed to the action of the light; and the wood, when thus treated, is said strongly to resemble the more inferior kinds of mahogany. Its value, however, according to the experience of Mr. Selby, is not restricted to the uses made of it by those artisans, but it is equally applicable to the general purposes of carpentry; and where exposure to the atmosphere or the alternation of moisture and dryness is required, it is superior to most other timber, and is scarcely inferior to the best oak, or its rival, the larch.* In France, wine-casks are made of this wood, and the wine kept in them is said to be of an improved flavour. Where the tree is treated as a coppice, its shoots, from their power of resisting decay, make excellent hop-poles, vine-props, and hoops for casks, and when sufficiently large, they may be employed for posts and rails, for constructing rural fences. Like many other trees, it burns well when first cut, but if it be kept for two or three years, and is then employed for fuel, it will consume away like tinder, without producing either flame or heat.

As a tree, the gean is not only valuable for its timber, but for the food and protection which it affords to numerous species of birds. This is one reason why the cultivation of this tree is so generally encouraged in the forests of Britain, Belgium, and France; as it not only increases the number of birds by supplying them with nourishment, but is the means of destroying countless insects, which these important and useful creatures devour. In all ornamental plantations, hedge-rows, and avenues, cherry-trees are desirable objects of culture, on this account, as well as for the great beauty of their flowers and frut, which are produced in the greatest profusion in their respective seasons of the year.

In France, too, this tree is highly prized for the food it supplies to the poor; and a law was passed, as long ago as 1669, commanding the preservation of all cherry-trees in the royal forests, in consequence of which, they became so numerous, that there was no longer room for the underwood to grow; when, as usual, going to the other extreme, most of them were cut down. This measure, it was remarked, was a great calamity to the poor, who, during several months of the year, lived, either directly or indirectly, on the produce of the mérisier. Soup, made of the dried fruit, with a little bread and butter, was the common nourishment of the wood-cutters and charcoal-burners of the forest, during the winter. This fruit is much used at present, to make jelly or rob, and in the manufacture of liqueurs, such as cherry brandy, ratafia, \&c. Kirschwasser, an ardent spirit much used in Germany and Switzerland, is also made of it; and the famous liqueur Maraschino is the product of a small acid cherry that abounds in the nortl of Italy, at Trieste, and in Dalmatia.

* See Selby's British Forest Trees, p. 60.

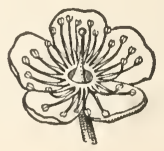




\title{
Cerasus vulgaris, \\ THE COMMON CHERRY-TREE.
}

\section{Synonymes.}

\author{
Prunus cerasus, \\ Cerasus caproniana, \\ Cerasus vulgaris, \\ Cerisier, Grottier, Cerisier de Paris, Ceri- \\ sier de Montmorenci, Cerisier à fruits \\ ronds, Cerisier du nord, Grottier franc,
Grottier des parisiens, \\ Gemeiner Kirschbaum,Saurer Kirschbaum, Germany. \\ Ciliegio, Ciriegio, Marasca, \\ Cherry-tree, Kentish or Flemish Cherry-
tree, Morello, May Duke,
}

Linnsus, Species Plantarum.

De Candolle, Prodromus.

Loudon, Arboretum Britannicum.

Derirations. The specific name, caproniana, is said to be derived from capron, the hautbois strawberry, probably from the fruit of this tree possessing much more flavour than that of the Cerasus sylvestris. Morello is either from morel, a species of fungus, (Morchelia esculenta,) the flesh of which is of a similar consistency as that of this cherry; or, perhaps, from the French word morelle, a negress. May Duke is a corruption of Medoc, the province of France where this variety is supposed to have originated. Grottier is said to be derived from aigreur, sourness, or sharpness, and is applied to this cherry, from the acidity of its fruit.

Engravings. Lindley, Pomologia Britannica ; Hoffy, Orchardists' Companion ; Loudon, Arboretum Britannicum, vi., pl. 114 ; and the figures below.

Specific Characters. Branches spreading. Flowers in subsessile umbels, somewhat stalked. Leaves ovate-lanceolate, smooth, folded together.-Loudon.

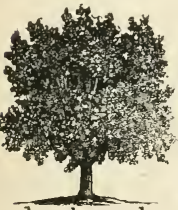
in point of general appearance, may be included under three forms:-Large trees with stout branches, and shoots proceeding from the main stem horizontally, or slightly inclining upwards; fastigiate trees of a smaller size; and small trees with weak wood, and divergent, drooping branches. The leaves vary so much, from the effects of cultivation, that it is impossible to characterize the sorts by them; but, in general, it has been observed, that those of the large trees are largest, and the lightest in colour, and those of the slender-branched varieties are the smallest, and of the darkest shade; the flowers are also the largest on the large trees. The fruit is round, melting, full of a watery juice, more or less flavoured, and almost always sensibly acid. 'The skin of the fruit separates easily from the flesh, and the flesh parts readily from the stone. It is conımonly red, but in numerous varieties it passes into all shades between that colour and dark-purple or black.

Varieties. The common cherry, like many other kinds of fruit, lıas, by long cultivation, become exceedingly multiplied in its varieties, and new races, or new names, are constantly being added to our catalognes, which number, at fresp.nt, at least three hundred. $\Lambda$ s it is impossible for us to enter, in detail into 33 
all the modifications of these races, we have thought proper to present the following arrangement, which is based upon the classification adopted by Mr. Thompson, in his "Report upon the principal Varieties of Cherry cultivated in the Garden of the London Horticultural Society," published in the first volume of the second series of the "Transactions" of that society. He appears to have founded his system principally upon the character of the edges of the leaves, the form and colour of the fruit, the firmness or aqueousness of its flesh, its sweetness or acidity, and the colour of the juice.

1. C. v. undatifolium. Waved-edged-leaved Common Cherry-tree. The leaves of this race are waved on the margin, are generally large and pendent, with sharp, prominent veins beneath, coarsely serrated, of a thinner texture, and of a more yellowish-green than those of the C.v. integrifolium. The buds are pointed, the flowers large, proceeding from wood of not less than two years' growth. The petals are loosely set, and the stamens are slender and irregular in length, some being longer and others shorter than the style. Under this form are included the following varieties, which ripen their fruit, in England, in the order they stand; but somewhat later at Philadelphia and New York, until the longest days of summer arrive, after which they ripen earlier.

a. Early Purple Guigne or Early Purple Griotte. 'This variety may be known by the long petioles of its leaves, and its very handsome, large, heartshaped, dark-purple fruit, with a rich, tender, purple pulp. It ripens from the beginning to the middle of June.

B. Werder's Early Black Heart; Werdersche frühe schwarze Herzkirsche, of the Germans. This variety originated in Prussia, prior to 1794. It is distinguished from the preceding by its shorter petioles, and large, obtuse, heartshaped, black fruit, with a firm, rich, juicy, purplish-red flesh, and ripens at about the same period.

$\gamma$. Bowyer's Early Heart, known by its obtuse heart-shaped, amber-coloured fruit, of a medium size, mottled with red, with a soft, juicy, sweet, white pulp. It ripens its fruit by the end of Jume, is a good bearer, and is regarded as one of the earliest of the light-coloured sorts.

ઈ. Knight's Early Black. 'This variety was originated by 'T. A. Knight, Esquire, in 1S10, from the bigarrean and May Duke. Its fruit is very handsome, is large, obtuse heart-shaped, black, with a rich, purplish flesh, of an excellent quality, and ripens about the end of June.

E. Black Eagle, a variety produced by Miss E. Knight, of Downton Castle, in 1806. It succeeds well as a standard, is a good bearer, and may be known by its roundish heart-shaped, black fruit, of a medium size, with a rich, tender, dark-purple pulp, and ripens early in $\mathbf{J} u l y$.

$\zeta$. Downton, a variety produced also by Miss Knight, prior to 1818 . It is a good bearer, and is distinguished by its roundish heart-shaped, pale-yellow, and red fruit, of about a medium size, having a rich, juicy, pale, amber-coloured pulp, and ripens from the beginning to the middle of July.

$\eta$. Elton, a much esteemed and productive variety, originated by the same lady as above, in 1806 . It may be known by its large size, heart-shaped, paleyellow and red fruit, with a very rich, sweet, whitish pulp, and conies to maturity at about the same period as the Downton variety.

o. Flesh-coloured Bigarrean; Bigarreau couleur de chair, of the French. This variety may be known by its pendulous branches, large, obtuse heartshaped, very shining, white and red fruit, with a tender, whitish pulp. It is regarded as a good bearer, and matures from the beginning to the middle of July.

¿. Black 'Tartarian, known also by the names of Circassian Cherry, Superb Circassim, Black Russian Cherry, Fraser's Black Heart, and Ronald's Black Heart. 'This variety is said to have originated in Spain, whence it was trans- 
mitted to Russia, and was carried from the last-named country to England by the late Mr. John Fraser. In the account given of it, however, in the "Pomona Londinensis," it is stated to have been introduced into Britain from Circassia, by Mr. John Ronalds, of Brentford, in 1791. It is distinguished for its large, obtuse heart-shaped, shining, purplish-black fruit, with an uneven surface, containing a rich, tender, juicy, purplish flesh, and differs from many other varieties in hanging in clusters, which enables it to be easily gathered. It is a cherry of great excellence, bears plentifully as a standard, and when ripe, which usually occurs early in July, it readily commands, in market, double the price of the ordinary kinds. This tree is also valuable, not only for its fruit alone, but from its vigorous growth, spreading branches, and symmetrical form, it is well adapted for the purposes of ornament, and is worthy of general cultivation.

x. Büttner's Yellow; Büttnersche gelbe Knorpelkirsche, of the Germans. This variety was originated by M. Büttner, of Halle, prior to 1803 . It succeeds well as a standard, is a good bearer, and may be known by its roundish, yellowish fruit, of a medium size, containing a sweet, pale-yellow pulp, and is ripe about the middle of July.

$\lambda$. Waterloo, distinguished by its large, obtuse heart-shaped, purplish-red fruit, with a tender, purplish-red flesh, and is ripe in July. It is but a moderate bearer, and requires to have its branches trained widely apart.

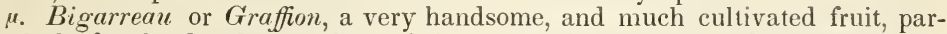
ticularly for the London market. It is an abundant bearer, and may be known by its large, obtuse heart-shaped, white and red fruit, with a firm, sweet, whitish pulp, and is usually ripe by the end of $\mathbf{J u l y}$.

$\nu$. Florence. This variety was introduced into Britain from Italy by J. A. Hublon, Esquire, in 1780. It does not bear well when young, but abundantly when the trees become older. Its fruit is large, of an obtuse heart-shape, and of a pale-amber and red colour, filled with a rich, sweet, juicy pulp. It ripens, in England, in August, and several weeks earlier at New York.

ร. Hildesheim's Late Bigarreau; Bigarrean tardif de Hildesheim of the French; and Hildesheimer späte Herzkirsche, of the Germans. This variety is the latest of all the pale-coloured cherries, often not ripening, in England, before September. It is a good bearer, and may be distingnished by its heart-shaped, red and yellow mottled fruit, of a medium size, containing a firm, sweet, paleyellow pulp.

2. C. v. integrifolium. Entire-leaved Common Cherry-tree. The leaves of this variety are generally smaller, and of a deeper green than those of the $C$. $v$. undutifolium; and have their edges plain, with the veins beneath, as they approach the margin, almost buried in the parenchyma, which is thicker than in the last-named variety. The petioles support the leaves erect, or at least from hanging loosely and pendent. The flowers expand widely, and the petals do not hang loose, but form a regular cup-shaped flower, with strong stamens, generally shorter than the style. Under this division may be recognized the following varieties, that ripen in England at the time specified below, but later or earlier in the United States, according to the circumstances under which they grow.

a. May Duke; Royale hâtive, of the French. This variety forms a mediumsized or low tree, with an erect fastigiate head. It may be known by its large, roundish, dark-red fruit, with a rich, tender, juicy, red pulp, which usually ripens about the end of June. There is another variety nearly allied to this, called Jeffrey's Duke, which was originated by Mr. Jeffrey, nurseryman, at Brompton Park, in 1780. This tree differs from the May Duke, in being of a more compact growth. 
8. Belle de Choisy or Ambree de Choisy. a rariety which originated at Choisy: near Paris, in 17010 . Its fruit is large. roundish-oblate, red, mottled with amber, and has a tender, sweet juicy pulp. It is a moderate bearer, and ripens its fruit from the beginning to the middle of July.

\%. Royal Duke; Royale tardire: of the French. The general habit of this tree resembles that of the Mar Duke. It is a good bearer, and arrires at maturity from the middle to the end of July. It may be known by its arge, oblate, dark-red fruit, with a rich. tender, juicr., reddish pulp.

8. Kentish Cherry: Montmorenci a longue queve, of the French. This rarietr forms a round-headed tree, with somewhat slender. pendulous shoots, and is rezarded as a rery productive bearer. It may be distinguished by its oblate, bright-red fruit. of a medium size, with a juicy, acid, whitish pulp; and arrives at maturity from the middle to the end of July.

E. Flemish Cherry: Montmorenci a courte quene, of the French. This variett only differs from the Kentish Cherry, in being more upright in its growth, and a less productive bearer.

Ostheim Cherry: Cerize d Ostheim: of the French. This variety originated on the Phone, in 1i50. It forms a dwarfish, weeping tree, and bears abundantly on the one-rear-old mood. It is distinguished by its globose, darkred fruit, of a medium size, with a sub-acid, claret-coloured pulp, and ripens about the end of Jult.

\%. Lute Duke; Anglaise tardire, of the French. This rariety is a great bearer, and may be known by its large, obtuse heart-shaped, dark-red fruit, with a rich, juict, arnter-coloured flesh. and is ripe in August.

6. IIorello or Milan Cherry forms a low tree, with a spreading, somewhat pendulous head. It is most prolific in flowers and fruit. the latter ripening late in Auzust or early in september. and. from not being so greedily eaten by birds, as most other kinds, it hangs on the trees for a long time. It is distinguished by its large, obtuse heart-shaped. dark-red frut. with an acid, juicy: purplish-red flesh, and by its growing on the one-year-old wood. It is excellent for preserrang. and for brandy.

The fire following varieties are particularized by Loudon; as being purely tramental :-

3. C. t. Flore semirlexo. Semi-drouble Cornmon Cherry-tree.

1. C. T. Flore pleso. Druble-floveted C'ommon Cherry-tree. "All the stamens of this rariety," Mr. Loudon says. " are changed into petals: and the pistillum into small. green leares which occupy the centre of the flower. The flower is smaller and less beautiful than that of the double mérisier: but, as the tree does not grow so high, and as it can be grown as a shrub, it is suitable for planting in situations where the other cannot be introduced." It is commonly grafted on the rerasus mahaleb. ." The flower is interesting in a physiological point of view;" continues Mr. Loudon. "on account of its central green leares; illustrating Frethe's doctrine of regetable metarnorphoses."

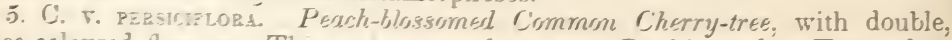
mese-coloured flowers. This variety was known to Bauhin and to Tournefort, liat at present. it is said to be very rare in collections.

6. C. r. Folits rabiegatis. Tariegated-leared Common Cherry-tree.

7. C. T. SEMPERPLSRENS. Erer-forcering Cherry-tree; Wesping Cherry-tree, Allisaints "Cherry, of the English: and Cerise de la Toussaint, Cerise de. St. Warin Cerisetardice, of the French. This rariety is distinguishable by its dronpIg branches, orate, serrated leaves, and globose, red fruit. When grafted standard high. on the cornmon wild cherry, (Cerasus sylvestris,) it forms a truly lesirable sriall tree, to stand singly in a lawn. It grows rapidly for eight or ten 
jears, and acquires a spherical head, eight or ten feet in height. and ten or twelve feet in diameter. with the extremities of the branches drooping to the ground, flowering and fruiting during almost the whole summer.

Geography and History. The Cerasus rulgaris is regarded by all ancient authors. as a tree of Asiatic crigin: but whether it is truly indicenous to ant part of Europe. several modern writers differ in opinion. Pliny states that it did not exist in Italy till after the rictory which Lucullus won orer Mithridates. king of Pontus, sixtr-eight rears before the Christian era. He tells us that, " In twentr-six rears after Lucullus planted the cherry-tree in Italr. other lands had cherries, even as far as Britain. beyond the ccean." He mentions eicht kinds of cherries as being cultivated in Italy. at the time he wrote his " Natural History." which was A. D. 70. " "The reddest cherries." sars he. " are called apronia: the blackest, actia: the Cæcilian are round. The Julian cherries hare a pleasant taste. but are so tender that ther must be eaten when garhered. as ther will not endure carriage." The Duracine cherries were esteemed the best.* but the Picardy and Portuguese cherries were most admired. The Macedonian cherries greir on dwarf trees: and one kind is mentioned br the abore-named author, which never appeared ripe. haring a hue between green. red. and black. He mentions a cherry that was grafted, in his time, on a bar stock. which circumstance gave it the name of laurea: this cherrr is described as haring an agreeable bitter fiarour. ". The cherrr-tree." continues he. "could never be made to grow in Egypt. with all the care and attention of man." According to tbbe Rosier, Lucullus brought into Italy only two superior rarieties of cherry; the species which were the origin of all those now in cultiration. being. before his time, indigenous to Italy: and to the forests of France, though their fruit was neglected by the Romans. It is affirmed br Faulkner. in his "Kensington." that the cherry was introduced into Britain about A. D. 53 . Gerard. in his "Herbal," published in 159\%, figures a double and a semi-double rarietr of cherry: and. of the fruit-bearing kinds. sars there are numerous rarienes. among which he mentions the " morello or morel." and the "Flanders or Kentish cherries." At present, the common cherry is extensirely cultirated as a fruit-tree, throughont the temperate regions of the cirilized globe: but it does not thrive in rery high latitudes. nor within the tropics. unless grown at considerable elerations. It is found in Russia as far north as latitude $55^{\circ}$ or $56^{\circ}$ : and ripens its fruit in lorwar and East Bothnia. as tar as latirude $63^{\circ}$. It is also found in the north of Africa. and on several silands in the Medirerramean. but it dies not attain so large a size in the last-named places as in higher latitudes.

The introduction of the common cherry into the Lnited states. dates back to the earliest periods of thejr settlements. Some of the oldest trees of this species. known to exist in this countr, are on the estate of Mr. Lemuel $W$. Wells in Yonkers. New Jork. and at Point Pleasant. Bristol. Rhoude Island. on the estate of Mr. Robert Rogers. Those of the latter place are said to hare been planted over two hundred years.

Noil. Nituation. Propugation, s.c. The same as recommended for the Cerasns strestris (gean.)

Accidents. Disenses. s.e. The common cherry-tree is not particularly liable to be broken by high winds. nor by exeessive weight from snow or ice: but, as a fruit-tree, its branches are frequently broken br carelessness in those who sather the fruit. Like its congener, the gean, it is subject to the slowing of sum from the wounded parts. Several species of weod-pecker. (Picus.) are said to be particularly fond of picking holes in this tree, in search of worms. (in this subject.

* It was the opinwn of Loudua that the Julıan and Durscine cherries, meationed by P'ing, were raripries of the Cersus sitres:ns. 
Mr. Loudon remarks that, "These holes, by admitting water, accelerate the decay of the heart-wood of the tree; but it is a mistake to suppose, as many do, that the decay originates with the wood-pecker, who gets the credit of making the holes out of sheer mischief, or for amusement; the truth being, that decay has commenced, and that he is only in search of his food, which consists of the larvæ which have already begun to eat the wood of the tree."

Among the insects which infest the common cherry-tree are several species of the Geometridæ, including the canker-worm, (Phulcena vernata,) and numerous wood-eating larvæ (Xylophagidæ.) The curculio, (Rhynchcenus nemuphar,) noticed under the head of "Insects, \&c.," in our article on the domestic cultivated plum, is also known to be the cause of the warty excrescences found on the small branches of the cherry, from which circumstance, it was called by Professor Peck, Rhynchanus cerasi, the cherry-weevil. These excrescences, which serve as the residence of the larvæ, are known to be produced by the punctures made in the tree by the beetles; and, according to Peck, "the sap is diverted from its regular course, and is absorbed entirely by the bark, which is very much increased in thickness; the cuticle bursts, the swelling becomes irregular, and is formed into black lumps, with a cracked, uneven, granulated surface. The wood, besides being deprived of its nutriment, is very much compressed, and the branch above the tumour perishes." The same remedies wil apply in the present case as those recommended for the excrescences found on the domestic cnltivated plum-tree.

But by far the most pernicious enemy to the common cherry-tree, is the slugfly, Blennocampa cerasi, of Harris. He describes the perfect insect, in his "Report," as being "of a glossy black colour, except the two first pairs of legs, which are dirty yellow or clay-coloured, with blackish thighs, and the hind-legs, which are dull black, with clay-coloured knees. The wings are somewhat conrex, and rumpled or uneven on the upper side, like the wings of the saw-flies generally. They are transparent, reflecting the changeable colours of the rainbow, and have a smoky tinge, forming a cloud, or broad band across the middle of the first pair; the veins are brownish. The body of the female measures rather more than one fifth of an inch in length; that of the male is smaller. In the year 1828, I observed these saw-flies, on cherry and plum-trees, on the 10th of May; but they usually appear towards the end of May or early in June. Soon afterwards some of them begin to lay their eggs, and all of them finish this business and disappear, within the space of three weeks. Their eggs are placed, singly, within little semicircular incisions through the skin of the leaf, and generally on the lower side of it. * * * * * On the fourteenth day afterwards, the eggs begin to hatch, and the young slug-worms continue to come forth from the 5 th of $\mathbf{J}$ une to the 20th of $\mathbf{J u l y}$, according as the flies have appeared early or late in the spring. At first, the slugs are white; but a slimy matter soon oozes out of their skin and covers their backs with an olive-coloured, sticky coat. 'They have twenty very short legs, or a pair under each segment of the body, except the fourth and the last. The largest slugs are about nine-twentieths of an inch in length, when fully grown. The head, of a dark-chesnut colour, is small, and is entirely concealed under the fore-part of the body. They are largest before, and taper behind, and in form somewhat resemble minute tadpoles. 'I'hey have the faculty of swelling out the fore part of the body, and generally rest with the tail a little turned up. These disgusting slugs live mostly on the upper sides of the leaves of the pear and cherry-trees, and eat a way the substance thereof, leaving only the veins and the skin beneath, untouched. Sometimes twenty or thirty of them may be seen on a single leaf; and, in the year 1797, tiey were so abundant in some parts of Massachusetts, that small trees were covered with them, and the foliage entirely destroyed; and even the air, by 
passing through the trees, became charged with a very disagreeable and sickening odour, given out by these slimy creatures. ***** * The shug-worms come to their growth in twenty-six days, during which period they cast their skins five times. Frequently, as soon as the skin is shed, they are seen feeding upon it; but they never touch the last coat, which remains stretched out upon the leaf. After this is cast off, they no longer retain their slimy appearance, and olive colour, but have a clear yellow skin, entirely free from viscidity. 'They change also in form, and become proportionably longer; and their head and the marks between the rings are plainly to be seen. In a few hours after this change, they leave the trees, and, having crept, or fallen to the ground, they burrow to the depth of from one inch to three or four inches, according to the nature of the soil. By moving their body, the earth around them becomes equally pressed on all sides, and an oblong-oval cavity is thus formed, and is afterwards lined with a sticky and glossy substance, to which the grains of earth closely adhere. Within these little earthen cells or cocoons, the change of the chrysalides takes place; and, in sixteen days after the descent of the slug-worms, they finish their transformations, break open their cells, and crawl to the surface of the ground, where they appear in the fly form. These flies usually come forth between the middle of July and the first of August, and lay their eggs for a second brood of slug-worms. The latter come to their growth, and go into the ground, in September and October, and remain there till the following spring, when they are changed to flies, and leave their winter quarters. It seems that all of them, however, do not finish their transformations at this time; some are found to remain unchanged in the ground till the following year; so that, if all the shugs of the last hatch in any one year should happen to be destroyed, enough, from a former brood, would still remain in the earth, to continue the species." Among the natural enemies to these insects, are mice, and other earth-burrowing animals, which destroy many of them in their cocoons, and it is probable that other insects and birds prey upon them, both in the larvæ and in the winged states. Professor Peck has described a minute ichneumon-fly, (Encyrtus,) which punctures the eggs of the slug-fly, and deposits in each, a single egg of its own. These minute eggs, in due time, produce little maggots, which live in the shells of the eggs of the slug-flies, devour their contents, and afterwards are changed to chrysalides, and then to flies, like the parent. Thus, by these atoms of existence, myriads of the eggs of slug-flies are rendered abortive,-an admirable illustration of the order of Providence, which prevents the earth from being overrun with ane species, by appointing another race to keep them down. Ashes or quicklime, sifted or thrown on the trees infested by these slugs, has proved effectual in checking their depredations, and Mr. Haggerston's almost universal remedy, (a solution of whale-oil soap and water,) has been found to be equally effectual. The common cherry, as well as the peach-tree, sometimes suffers severely from the attacks of the borers, produced by a large copper-coloured beetle (Buprestis divaricata, Say.)

Properties and Uses. The wood of the common cherry-tree is of a reddish hue, more or less veined with darker shades, and somewhat resembles, in its general appearance, some of the ordinary kinds of mahogany. When wel'seasoned, its weight does not usually exceed forty-five pounds to a cubic foot. It is sufficiently tender to be easily wrought, and from the openness of its grain, it is readily coloured. In those parts of Europe where mahogany is costly, it is sometimes employed in the manufacture of chairs, the frames of mirrors, and other minor works. The fruit of the cherry, although a favourite food with most persons, has ever been found more tempting than wlılesome. Pliny says, "this fruit will loosen and hurt the stomach; but when hung up and dried, lias a contrary effect." He relates that some authors have affirmed that cherries maten 
fresh from the trees, when drenched with the morning dew, and the stones being also swallowed, will purge effectually, and cure those afflicted with the gout in their feet. The hard-fleshed cherries are considered rather indigestible when eaten too freely; but the soft-fleshed kinds, such as the morellos, are esteemed sufficiently wholesome to be given in fevers, where there is a tendency to putridity. The soft-fleshed kinds are often dried, by being exposed on boards to the sun, or in an oven of moderate warmth. Ripe cherries are used for flavouring brandy; and preserves, marmalades, lozenges, and various other kinds of confectionary are manufactured from them. An oil is extracted from the kernels, which is occasionally used for emulsions, and to mix in creams, sugar-plums, etc., to impart to them the flavour of bitter almonds.

Judiciously planted in the shrubbery, the Cerasus vulgaris forms a very beautiful tree. In spring, its early white blossoms are contrasted with the sombre shades of green; and its graceful ruby and variegated balls, give a pleasing variety in summer.

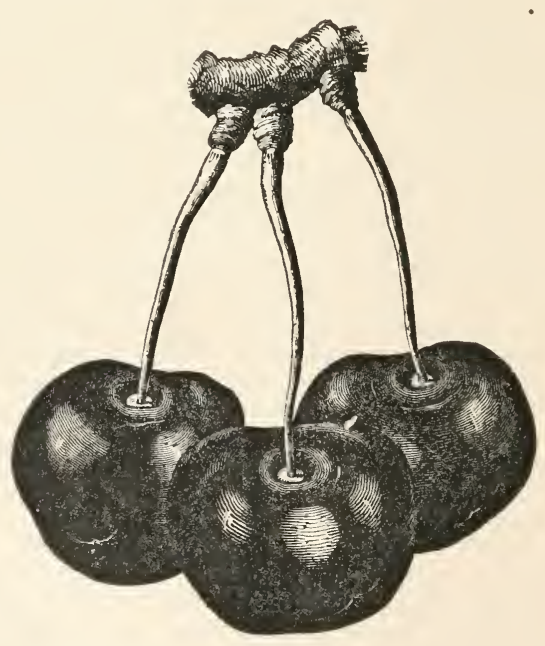




\section{Cerasus borealis,}

\section{THE NORTHERN CHERRY-TREE.}

Synonymes.

Cerasus borealis,

Cerasus pennsylvanica,

Cerisier du Canada,

Canadischer Kirschbaum,

American Bird Cherry-tree,

Small Cherry, Red Cherry-tree,

Wild Red Cherry, Bird Cherry, Choke

Cherry-tree,
Michaux, North American Sylva.

$\{$ De Candolle, Prodromus.

Loudon, Arboretum Britannicum.

Torrey and Gray, Flora of North America.

France.

Germany.

BritalN.

New England.

Other parts of Anglo-America.

Engravings. Michaux, North American Sylva, pl. 90; Loudon, Arboretum Britannicum, ii., fig. 410; and the figures keiow.

Specific Characters. Leaves oval-oblong, acuminate, membranaceous, glabrous, denticulate, and almost in an eroded manner. Flowers on longish pedicels, and disposed nearly in a corymbose manner. Fruit nearly ovate, small; its flesh red.-De Candolle, Prodromus.

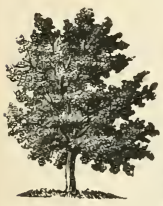

\section{Description.}

growing to a height of twenty or thirty feet, with a trunk six or eight inches in diameter, and covered with a smooth brownish bark, which detaches itself laterally. Its leaves are from two to six inches long, and somewhat resemble those of the common almond. Its flowers put forth in May or June, and occur in small, white bunches, which give birth to a small, red, intensely-acid fruit, that

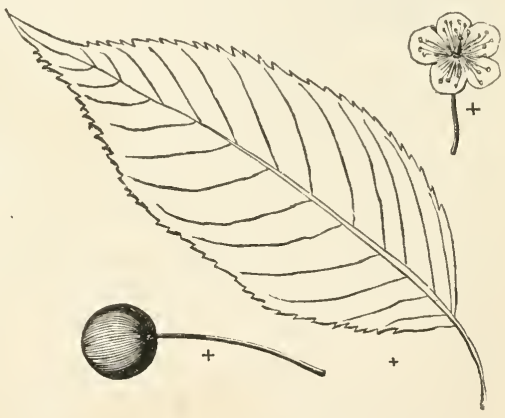
arrives at maturity in July. It is described by Pursh to be agreeable to the taste, astringent in the mouth, and hence called cholse cherry; but this name is ordinarily applied to another tree.

Geography, $\mathcal{f}^{\circ} c_{\text {. }}$ The northern cherry is found in a common soil from Newfoundland to the northern parts of the Rocky Mountains, and as far south as Virginia. It was introduced into Britain in 1822, and is growing at present in Messrs. Loddiges' arboretum, and other European collections. 'This tree, like the paper birch, is remarkable for springing up spontaneously, in old cultivated fields, or in such parts of the forests as have been burnt over by accident or design. Of all trees of North America, no one is so nearly allied to the Cerasus vulgaris as the present species; and hence it has been recommended as a suitable stock to graft that cherry upon. 'The wood of this tree is exceedingly hard, fine-grained, and of a reddish hue; but the inferior size to which it usua ly grows, forbids its use in the mechanic arts. 


\title{
Cerasus mahalel,
}

\section{THE MAHALEB, OR PERFUMED CHERRY-TREE.}

\section{Synonymes.}

\author{
Prunus mahaleb, \\ Cerasus mahaleb, \\ Bois de Sainte Lucie, Prunier odorant, \\ Mahaleb-Kirschbaum, \\ Albero (i Santa Iucia, Ciliegro canino, \\ Ciliegio malebo, \\ Perfumed Cherry-tree, \\ Linnexus, Species Plantarum. \\ (DE Candolle, Prodromus. \\ Don, Miller's Dictionary. \\ Loudon, Arboretum Britannicum. \\ France. \\ Germany. \\ ITALY. \\ Britain and Anglo-America.
}

Derarations. Mahaleb is the Arabian name of this tree. The wood of this species is perfumed, and used by the French in cabinet-work, toys, \&c., especially in the village of Ste. Lucie, whence some of the French and Italian names.

Engravings. Du Hamel, Traité des Arbres et Arbustes, v., pl. 2; Loudon, Arboretum Britannicum, vi., pl. 116; and the figures below.

Specific Characters. Leaves cordately ovate, denticulate, glanded, curved. Flowers in leafy sub-corym bose racemes. Fruit black, between ovate and round.-De Candolle, Prodromus.

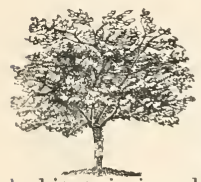
labitat, it is seldom found above twenty feet in heigh in a state of cultivation, in a good soil, it sometimes attains double that elevation, with a trunk four feet in circumference. The leaves somewhat resemble those of the common apricot, but are of a paler green. The tlowers put forth in April and May, and are succeeded by black fiuit much smaller than that of the Cerasus

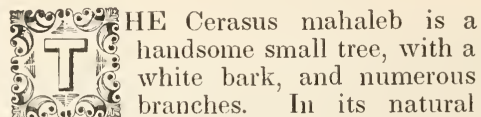
sylvestris, very bitter to the taste, though greedily eaten by several species of birds.

Varieties. Besides a tree with variegated leaves, Mr. Loudon mentions two others :-

1. C. ir. fructu flavo. Yellow-fruited Perfumed Cherry-tree.

2. C. m. Latifolium. Broad-leaved Perfumed Cherry-tree.

Geography and History. The perfumed cherry is found wild in the middle and south of France, the south of Germany, Austria, Piedmont, and in Crim Tartary; and, according to Pallas, it grows in abundance on Mount Caucasus, where it differs from the European variety, in bringing forth both flowers and leaves at the same time, and the latter in being more cordate and acuminate. The tree is very common in the mountainous districts of France, and is very generally cultivited in England for the purposes of ornament. It was introduced into the last-named country in 1714 , but was known long before, as Gerard remarks that, "the cunning French perfumers make bracelets, chains, and such like trifling toys, of the fruit, which they send to England, smeared over with some old sweet compound or other, and here sell unto our curious old ladies and gentlewomen, for rare and strange pomambers, for great sums of money."

At what period, and by whom, the Cerasus mahaleb was introduced into the United States, is uncertain. It is found in several of the American nurseries and 
collections, and a tree, bearing this name, is standing in Washington square, in Philadelphia, which has nearly attained the utmost magnitude to which this species grows.

Soil, Situation, $\mathcal{S} \cdot c$. According to Loudon, the perfumed cherry will thrive in any poor soil, that is not too dry, even in the most arid sands and naked chalks; and as it forms a low, bushy tree, which is capable of resisting the wind, it may be planted in an exposed situation. When young plants are to be raised from seeds, the fruit is sown as soon as ripe, or preserved in sand till the following spring, in the same manner as that recommended for the common cherry. The tree may also be propagated, in a moist climate, by layers, by slips from the stool, taken off with a few roots attached, by suckers, or by cuttings from the roots. In France, it is extensively raised as a stock on which to graft the different kinds of cherries, for which, it has not only the advantage of growing on a very poor soil, but of coming into sap about fifteen days later than the gean, by which means the grafting season is prolonged, and of dwarfing the plants grafted upon it. Yet, as in the case of other dwarf species of a genus which will unite with a tall, robust-growing tree, the perfumed cherry, when grafted on the Cerasus sylvestris, attains a larger size than when grown on its own roots.

Properties and Uses. The wood of the Cerasus mahaleb is of a reddish-gray, hard, compact, and is susceptible of a high polish. When green, it possesses a powerful odour, but less so, and more agreeable, when dry, in which last condition it weighs nearly sixty pounds to a cubic foot. In France, it is much sought after by cabinet-makers, on account of its fragrance, and is sold by them, green, in thin veneers, because in that state it does not crack, or at least, the slits or chinks, are less perceptible. In the Vosges, in the vicinity of the Abbey of Ste. Lucie, it is much sought after by turners, and for the manufacture of snuff-boxes and tobacco-pipes. It is also highly prized for fuel, on account of the fragrance which it sends out when burning. 'The leaves are powerfully fragrant, more particularly when dried, - are greedily eaten by cattle and sheep, and are used by cooks for giving flavour to game. The flowers and fruit, like the wood and leaves, are powerfully scented, the former being so much so, as to be alniost insupportable in $a^{\circ}$ close room, even when they have remained only for a short time. The kernels of the fruit are employed by perfumers to scent soap. In Britain and America, this species is principally cultivated as a hedge-plant, or as an ornamental shrub or low tree.

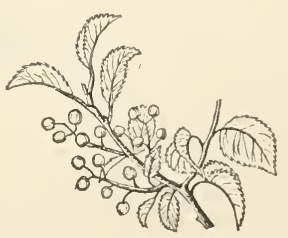




\section{Cerasus virginiana, \\ THE VIRGINIAN CHERRY-TREE.}

\section{Synonymes.}

Prunus serotina,

Cerasus virginiana,

Cerasus serotinu,

Cerisier de Virginie,

Virginischer Kirschbaum,

Ciliegio di Virginia,

Virginian Bird Cherry-tree,

Wild Cherry-tree, Black Cherry-tree,
Ehrнart, Beiträge zur Naturkund.

( Mrchaux, North American Sylva.

Loudon, Arboretum Britannicum.

TORREY AND GRAY, Flora of North America.

De Candolle, Prodromus.

France.

Germany.

ITALY.

BRITAIN.

Anglo-America.

Engravings. Mishaux, North American Sylva, pl. 88; Loudon, Arboretum Britannicum, ii., fig. 418 et vi. pl. 114 , anu the figures below

Specific Characters. Leaves (rather coriaceous) oval, oblong, or lanceolate-oblong, acuminate, glabrous, or bearded along the midrib beneath, smooth and shining above, finely serrate, with appressed, or incurved callous teeth; petioles, (or base of the leaf,) mostly with two or more glands; racemes elongated, spreading; petals broadly obovate; drupes globose, purplish-black.-Torrey and Gray, Flora.

\section{Description.}
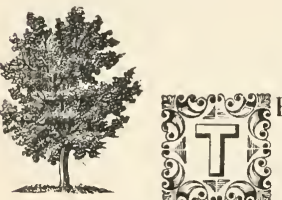

HE Cerasus virginiana, where the soil and climate are the most congenial to its growth, sometimes attains a height of eighty or one hundred feet, with a trunk three or four feet in diameter; but it varies much in size, according to the circumstances under which it grows. In England and the North American British provinces, it seldom exceeds thirty or forty feet in height, with a trunk ten or twelve inches in diameter; and in the neighbourhood of the Great Slave Lake, in latitude $62^{\circ} \mathrm{N}$., it grows only to a height of about five feet. The general surface of the bark is smooth; but it is blackish and rough, detaching itself in narrow semi-circular, hard, thick plates, which adhere for a time to the tree,

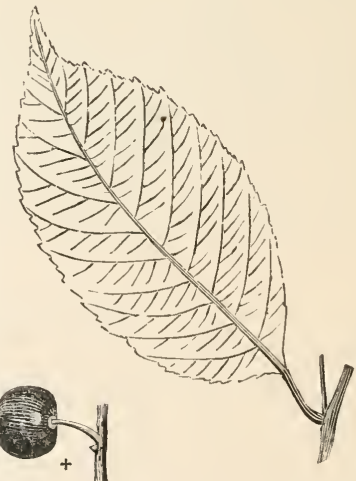
previous to dropping off. The trunk is usually straight for about one fourth of its height, where it ramifies into a spreading summit of a handsome outline; but its foliage is too thin to display that massy richness which gives so much beauty to the maples and many other trees. The leaves are usually from two to four inches long, toothed, very much pointed, and of a beautiful, smooth, shining green, with two or more small reddish glands at the base. The flowers are white, and occur in spikes, which, when fully expanded, have a beautiful effect. They put forth in Florida and the state of Georgia in the month of February, but in some parts of Canada, not before the early part of June. The fruit is about one-fourth of an inch in diameter, of a 
roundish form, purplish-black colour, and edible, but slightly bitter to the taste. It arrives at maturity at St. Mary's, in Georgia, by the first of June, but not in the northern states and Canada before August or September, when it affords great nourishment to several species of birds.

Varieties. Mnch confusion has long existed among authors with regard to the choke cherry, (Prunus virginiana, of Linnæus,) and the wild cherry (Prunus serotina, of Ehrhart.) They appear to have been confounded by Michaux and others, who mistook the latter for the choke cherry, and consequently described it under the name of Cerasns virginiana; but, as we believe that they both belong to the same species, this is to us a matter of very little consequence. By comparing the two trees in a state of cultivation, it will be difficult to discover anything like a specific distinction, or as Mr. Loudon says, even sufficient to constitute a race. The serratures, and the tufts of hairs on the under sides of the leaves, are, undoubtedly, variable; and those who are familiar with the European bird cherry, (Cerasus padus,) know how little dependence is to be placed upon its foliage, when under cultivation; and in truth, it is so nearly allied to the species under consideration, that Seringe, in De Candolle's "Prodromus," seems to doubt if it be really distinct. Admitting the above remarks to be correct, the variations of the Cerasus virginiana are as follows :-

1. C. v. PRecox. Early-fruited Virgimian Cherry-tree; Choke Cherry; Prunus virginiana, of Linnæus; Cerasns virginiana, of Torrey and Gray; Prunus serotina, of Pursh; Cerasus serotina, of Loudon. This variety differs from the species in having broadly-oval leaves, abruptly acuminated, being sometimes sub-cordate at the base, very sharply, and often doubly serrate, and generally hairy in the axils of the veins beneath; the petals are orbicular; the fruit subglobose, of a glossy scarlet-red, when ripe, sweet and pleasant, but so very astringent, that it dries the mouth and throat like the juice of spruce cones, when swallowed. In the northern states and Canada, it usually ripens its fruit several weeks earlier than the black cherry-tree; hence the name pracox.

2. C. v. Capollin, De Candolle. Capollin Bird Cherry-tree, native of Mexico, and known by its lanceolate, serrated, glabrous leaves, resembling in form, and nearly in size, those of the Salix fragilis; and the whole tree appears so much like the Cerasus virginiana, that there is but little doubt of its being only a variety of this species, but of a larger and more lixuriant growth.

Geography, Soil, \&॰c. The Cerasus virginiana is found, in greater or less abundance, along the Atlantic parts of America, from Mexico to Hudson's Bay. It especially abounds in Upper Canada, and the country west of the Alleghanies, and probably is nowhere more profusely multiplied, nor more fully developed, than in Ohio, Kentucky, and Tennessee. In the southern and maritime parts of Georgia, and the Carolinas, where the summers are intensely hot, and where the soil is generally dry and sandy, it is but sparingly produced; and on the banks of rivers, where the ground is very wet, it is rather limited in its dimensions; but in the upper parts of these states, where the climate is more temperate, and the soil is more fertile, it becomes more common, though less abundant than in the states of Pennsylvania, Virginia, and New York.

This species appears to have been among the first American trees that were introduced into England; having been cultivated there by Parkinson, in 1629, under the name of "Virginian cherry-bay." It is, at present, very common in British collections, and is growing in several of the gardens of the continent. 'The largest recorded specimen in Eingland, is at Bagshot Park, in Surrey, which is about fifty years old, and forty feet in height. In the botanic garden at Geneva, in Switzerland, there is also another tree of this species, of about the same dimensions. 
Propagation. The Virginian cherry is usually propagated from seeds, which may be treated, in all respects, like those of the Cerasus vulgaris.

Insects. It has often been remarked that the leaves of the wild cherry are more subject to the attacks of caterpillars, than those of any other tree. Among those which are regarded as its worst enemy, are the American lackey-caterpillars, Clisiocampa americana, of Harris. The eggs, from which they are hatched, are placed around the ends of the branches, forming a wide kind of rillg or bracelet, consisting of three or four hundred eggs, in the form of short cylinders standing close together, on their ends, and covered with a thick coat of brownish, water-proof varnish. The caterpillars come forth with the unfolding of the leaves. The first signs of their activity appear in the formation of a little angular web or tent, somewhat resembling a spider's web, stretched between the forks of the branches, a little below the cluster of eggs. Under the shelter of these tents, in making which, they all work together, the caterpillars remain concealed at all times, when not engaged in eating. In crawling from twig to twig, and from leaf to leaf, they spin from their mouths a slender silken thread, which is a clue to conduct them back to their tents; and as they go forth and return in files, one aiter another, their pathways, in time, become carpeted with silk, which serves to render their footing secure during their frequent and periodical journeys in various directions, to and from their common habitation. As they increase in size and age, they enlarge their tent, surrounding it, from time to time, with new layers or webs, till at length it attains a diameter of eight or ten inches. They come out together, at certain hours, to feed, and all retire at once, when their regular meals are finished; during bad weather, however, they fast, and do not venture from their shelter at all. When fully grown, they measure about two inches in length. They may be known by their black heads, and a whitish line extending along the top of the back from one end to the other, on each side of which, in a yellow ground, are numerous short and fine crinkled lines, that form a broad, longitudinal, black stripe, or rather a row of long black spots, one on each ring, in the middle of each of which is a small blue spot; below this, is a narrow, wavy yellow line, and lower still, the sides are variegated with fine, intermingled, black and yellow lines, which are lost at last in the general dusky colour of the under side of the body; on the top of the eleventh ring, is a small, blackish, hairy wart, and the whole body is very sparingly clothed with soft, short hairs, rather longer and thicker upon the sides than elsewhere. At the age of about seven weeks, they begin to quit the trees, separate from each other, wander about for a while, and finally secrete themselves in some crevice or other place of shelter, and make their cocoons. These are of a regular, oblongoval form, composed of thin, and very loosely woven webs of silk, the meshes of which are filled with a thin paste. From fourteen to seventeen days after the insects have spun, the chrysalides burst their skins, force their way through the wet and moistened ends of the cocoons, and appear in the winged or miller form. These moths are of a rusty or reddish-brown colour, more or less intermixed witl gray on the middle and base of the fore-wings, which, besides are crossed by two oblique, straight, dirty-white lines. They expand from one inch and a quarter, to one inch and a half, or a little more and appear in Massachusetts, in great numbers, in July, flying about, and often entering houses by night, at which period they lay their eggs. Many of the caterpillars, however, are unable to finish their transformations, by reason of weakness, especially those which are mable to leave with the rest of the swarm, but make their cocoons within the tent. Most of these will be found to have been preyed upon by little maggots living upon the fat within their bodies, and finally changing to small, four-winged ichnemmon wasps, which, in due time, pierce a hole in the cocoons of their vic- 
tims, and escape into the air. The American lackey caterpillar-moth selects the Virginian cherry in preference to all other trees, and next to this, the apple, a further account of which will be found in our article on that tree.**

The Virginian cherry-tree, and also the garden cherry, and peach-tree, sufter severely from the attacks of borers, which are transformed to the beetles called, by Mr. Say, in his "American Entomology," Buprestis divaricata. They are usually found under the bark, and sometimes in the solid wood of the trunks and branches of the trees, where they undergo their transformations. The beetles, or perfect insects, are copper-coloured, sometimes brassy above, and thickly covered with little punctures. They measure from seven to nine-tenths of an inch in length, and may be found sunning themselves upon the limbs of the trees during the months of June, July, and August.

Properties and Uses. The wood of the Virginian cherry-tree is of a dull, lightred tint, which deepens with age. It is compact, fine-grained, takes a brilliant polish, and when perfectly seasoned, is not liable to warp. In America, it is extensively used by cabinet-makers, for almost every species of furniture; and, when chosen near the ramification of the trunk, it rivals mahogany in beanty The wood is generally preferred to that of the black walnut, (Juglans nigra,) the dun colour of which, in time, becomes nearly black. It is also, sometimes, employed in the parts of the country where it abounds, in ship-building, and for making the felloes of wheels. The bark of the branches and of the roots, is collected by herb-venders, and bronght to market in pieces or fragments, several inches long, and from half an inch to two inches in diameter. From drying, it becomes somewhat curved laterally. That of the root is regarded as the best, is destitute of epidermis, of a reddish-brown colour, brittle, easily pulverized, and presents, when broken, a grayish surface. When fresh, the odour is prussic, which is lost, in a measure, in drying, but regained by maceration. The taste is aromatic, prussic, and bitter. It is, undoubtedly, a useful tonic, and appears to possess, in some degree, narcotic and antispasmodic properties. Dr. Barton informs us, that the leaves of this tree are poisonous to certain animals, as calves, and even the berries intoxicate different kinds of birds. The fruit is employed to make a cordial, by infusion in rum or brandy, with the addition of sugar.

In Europe, the Virginian cherry is planted solely as an ornamental tree; and as such, it well deserves a place in every collection. In America, its growth should be encouraged along the road-sides, and in the woods, in order to attract and afford nourishment to frugivorous birds.

* See Harris' Report, pp. 266, 267, 268 et 269.

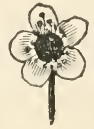




\section{Cerasus caroliniana, \\ THE CAROLINIAN CHERRY-TREE.}

\section{Synonymes.}

\section{Cerasus carolınıana,}

Cerisier du Caroline,

Kirschbaum von Carolina,

Ciliegio di Carolina,

Carolinian Bird Cherry-tree,

Carolinian Cherry, Wild Orange,
(Michaux, North American Sylva.

Loudon, Arboretum Britannicum.

Torrey and Gray, Flora of North America

FraNCE.

Germany.

ITALY.

Britain.

United States.

Engravings Michaux, North American Sylva, pl. 89; Loudon, Arboretum Britannicum, ii., fig. 423, and the thgures below.

Specific Characters. Evergreen. Leaves, with the petioles short ; and the disk lanceolate-oblong, mucronate, even, rather coriaceous, mostly entire. Flowers densely disposed in axillary racemes, that ara shorter than the leaves. Fruit nearly globose, mucronate.-De Candolle, Prodromus

\section{Description.}
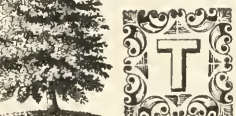
a height of twenty to fifty feet, and ramifies at a short distance from the ground, forming a tufted head. The bark of the trunk is of a dun colour, and is commonly without furrows or cracks. The leaves are smooth and shining on their upper surfaces, and are about three inches long. The flowers are white, and numerous, being arranged in little bunches, from one inch to an inch and a half long, which spring from the axils of the leaves, in the month of March or April.

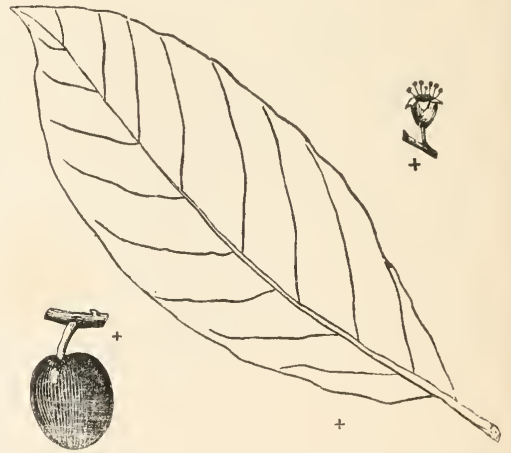

The fruit, which is oval, and nearly black, consists of a soft stone, surrounded by a small quantity of green, inedible pulp. It remains upon the branches during the greater part of the second year, so that the tree is laden, at the same time, both with flowers and fruit.

Geography and History. The Cerasus caroliniana appears to be principally confined to the Bahamas, and the islands along the coast of the Carolinas, Georgia, and Florida. On the main land, it is often found growing wild, at a distance of a thousand miles from the sea. It was first made known to Europe by Catesby, who sent seeds to Miller in 1759, under the name of "bastard mahogany." "The largest recorded specimen in Britain is at Swallowfield, in Hampshire, which, in 1833, formed a shrub ten feet in height, with a head twelve feet in diameter.

Properties and Uses. The wood of the Carolinian cherry is fine-grained, and if a roseate hue; but the scarcity, and inferior size of the tree, forbids its use in 
the mechanic arts. The bark of the roots possesses a strong prussic odour; and from it, Michaux observes, a fragrant spirituous liquor may be obtained. The leaves, according to Elliot, are very poisonous, frequently destroying cattle that are tempted to feed freely upon them, in spring. Its flowers are more sought after by bees than all others of the regions where it abounds. And the tree may be considered as one of the most beautiful vegetable productions of the south, and is generally there selected by the inhabitants, to plant near their dwellings, not only on this account, but because it grows with rapidity, and affords an impenetrable hedge. It may be propagated from seeds, and it has been suggested, that it would succeed if engrafted upon the Portugal laurel (Cerasus lusitanica.) It requires a deep, free, dry soil, and a sheltered situation.

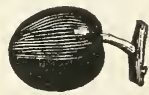




\section{Genus CRATEGUS, Lindl.}

\author{
Rosaceæ. \\ Syst. Nat. \\ Cratcgus, Mespilus, \\ Néflier, Aubépine, Alizier, \\ Mispel, \\ Cratego, Spino, \\ Thorn, Hawthorn,
}

Icosandria Di-Pentagynia.
Syst. Lin.

\section{Synonymes.}

Derivation. The name Cratogus is derived from the Greek kratos, strength, in reference to the hardness and strength sf the wood.

Generic Characters. Fruit ovate, not spreadingly open at the top. Carpels $1-5$ prismatic nuts, with bony shells, each including 1 seed. Leaves angled or toothed; in most cases, deciduous. Flowers in terminal corymbs.-Loudon, Arboretum.

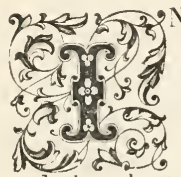

$\mathrm{N}$ viewing the various genera of hardy ligneous plants, cultivated in the gardens and shrubberies of Europe and America, not one, taken as a whole, can be compared with that of the Cratægus. It consists of small, spiny shrubs or low trees, mostly natives of Europe, Asia, northern Africa, and of North America. All the species flower and fruit freely, their wood is hard and durable, and the plants are of considerable longevity. They may all be trained, at the pleasure of the cultivator, either as small, handsome, exceedingly picturesque trees, or as beautiful gardenesque shrubs. 'Their mode of growth is orderly, neat, and characteristic, being neither so slow as to convey the idea of want of vigour, nor so rapid and robust as to be considered as coarse and rambling. Their leaves are remarkably neatly cut, and finely tufted; but are subject to considerable variation in almost every species, particularly when young. The flowers, in some kinds, appear in masses so abundant, as almost to cover the entire plant; and the fruit is produced in as great abundance as the flowers. The colour of the blossoms is generally white, more or le'ss fragrant, and in some cases, as in the double-flowered hawthorn, as they die off, are of a very fine pink. The fruit, which is usually red, and sometimes yellow, black, or green, including many varieties of shade, varies in size, from the smallness of a grain of mustardseed, as in the Cratægus spathulata, to the bigness of a large golden pippin, as in the Cratægus mexicana. The fruit of several species, such as that of the Cratægus azarolus, aronia, odoratissima, æstivalis, and tanacetifolia, is agreeable to the palate; and that of all the species is greedily devoured by singing birds. All the species may be propagated from seeds, by grafting, or inoculation, and will grow on any soil that is tolerably dry; but they will not grow vigorously in a soil that is not deep and free, and rich, rather than poor. Whether employed as small trees, or as shrubs, they are all admirably adapted for planting grounds of limited extent; and especially for small gardens in the neighbourhood of cities and large towns. Finally, were a man to be exiled to an estate without a single shrub or tree. with permission to choose only one genus of ligneous plants, to form all his plantations, shrubberies, orchards, and flower-gardens, it is probable that he could not find a genus that would afford him so many resources as that of the cratægus.*

* See Loudon's Arboretum Britannicum, ii., p. 814. 
It appears that this genus did not attract much attention in Britain until the commencement of the present century; since which period, according to Mr. Loudon, the number of sorts has been more than donbled, chiefly through the exertions of the London Horticultural Society, and Messrs. Loddiges, of Hackney. At least eighty well-marked species and varieties exist in their collections, and about the same number at Somerford Hall, in Staffordshire, made by General Monckton, and at the seat of Frederick Bourne, Esquire, at Terenure, near Dublin. The best collections in Scotland are in the Edinburgh botanic garden, and in Lawson's nursery. 'The greatest number of species in one garden, in France, is said to be in the Pepinière de Luxembourg. Good collections are also found in the nurseries of MM. Audibert, at Tarascon; and of MM. Baumann, at Bollwyller. The best collection in Belgium is at Humbeque, near Brussels; and the finest in Germany are those in the Floetbeck nurseries, at Hamburg, and in the Göttingen botanic garden. Collections have also been formed in the botanic garden at Warsaw, and in the arboretum of Count Wodzicki, at Niedzweidz, nearCracow, in Poland; and at the imperial garden of Odessa, in Russia. Among the American nurseries and collections, the finest specimens are to be found in the Bartram botanic garden, and at the Woodlands cemetery, ncar Philadelphia.

It is to be regretted that our limits prevent us from describing all the species of this genus at length; we therefore confine ourselves to a brief notice of those which are the most valuable for hedges, and the purposes of ornament; and for more detailed information concerning this interesting family of low trees, we would refer the reader to Loudon's "Arboretum Britannicum."

Under the name of hawthorns may be comprehended the numerous varieties of the Cratægus oxycantha, and the raccs nearly allied to it. They have all deeplylobed, rather glossy leaves, with but few hairs, fragrant flowers, and small, shining fruit or haws. Thirty feet is not an unusual height for a tree to attain, and fine specimens exist, in England, of an elevation of forty or fifty feet. The flowers of some varieties are double, in others bright-crimson, whilc the fruit in some is yellow, and in others black. "The hawthorn," says Lauder, "is not only an interesting object by itself, but produces a most interesting combination, or contrast, as things may be, when grouped with other trees. Whe have seen it langing over rocks, with deep shadows under its foliage; or shooting from their sides in the most fantastic forms, as if to gaze at its image in the deep pool below. Wc have seen it contrasting its tender green, and its delicate leaves, with the brighter and decper masses of the holly and the alder. We have seen it growing under the shelter, though not in the shade, of some stately oak; embodying the Idea of beauty protected by strength. Our eyes have often caught the motion of the busy mill-wheel, over which its blossoms were clustering. We have seen it growing grandly on the green of the village school, the great object of general attraction to the young urchins, who played in idle groups about its roots; and, perhaps, the only thing remaining to be recognized, when the school-boy returns as a man. We have seen its aged boughs overshadowing one half of some peaceful woodland cottage; its foliage half concealing the windows, whencc the sounds of happy content and cheerful mirth came forth. We know that lively season,-

\footnotetext{
When the milkmaid singeth blythe,

And the mower whets his scythe,

And every shepherd tells his tale

Under the hawthorn in the dale;
}

and with these, and a thousand such associations as these, we cannot but feel cmotions of no ordinary nature when we belold this beautiful tree."

Very nearly allied to the true hawthorms are the oriental thorns, which, with the exception of the various-lcaved species, (Cratigns heterophylla,) have thcir leaves deeply cut, and so closely covered with hairs, as to have a dull-gray. or 
hoary aspect. $T_{1} y$ are less graceful in their mode of growth, some of them having a round formal head; but their flowers are larger, and even more fragrant, and their large fruit renders them striking objects in autumn. The species most worthy of culture among this group, are the azarole, (C. azarolus,) distinguished for its globose, scarlet fruit, which is eaten in Italy; the sweetscented thorn, (C. odoratissima,) with its large, coral-red fruit; the tansy-leaved thorn, (C. tanacetifolia,) known by its globose, yellowish-green fruit; and the aronia thorn, (C. aronia,) celebrated for its light, orange-coloured fruit, which is sold in the markets of Montpellier, in France, under the name of Pommettes à deux closes.

The American thorns are species with leaves but little lobed, usually broad, shining, unequally toothed, often having exceedingly long spines, and having fruit of an intermediate size. They are not regarded as quite so handsome as the species of the preceding groups; but the following, nevertheless, have sufficiently ornamental features, to be well worthy of cultivation:-The cock-spur thom, (Cratægus crus-galli,) and several of its varieties; the dotted-fruited thorn (C. punctata); the Washington or heart-leaved thorn (C. cordata); Douglas' thorn, (C. douglasii,) distinguished for its dark, handsome leaves and fruit; and the small-fruited thorn, (C. microcarpa,) with graceful, pendulous shoots, and very small, beautiful vermilion-coloured fruit.

Lastly, the evergreen thorns, including the Mexican thorn, (Cratægus mexicana, and the fiery-fruited thorn (C. pyracantha.) The former is a small tree, with lance-shaped, bright-green leaves, and large, round, yellow fruit; and the latter is an inhabitant of rocks and wild places in the south of Europe, and Caucasus, and has long been cultivated for its flame-coloured berries, which remain upon the plant during most of the winter. 


\section{Cratagus punctata, \\ THE DOTTED-FRUITED THORN.}

Synonymes.

\section{Cratagus punctata,}

Néflier à fruits pointillés,

Geflecte Mispel,

Dotted-fruited Thorn, Thorn-bush,

\author{
(De Candolle, Prodromus. \\ Loudon, Arboretum Britannicum. \\ (Torrey and Gray, Flora of North America. \\ France. \\ Germany. \\ Britain and Anglo-America.
}

Engravings. Loudon, Arboretum Britannicum, ii., figs. 569 and 570, in p. 854 et vi., pl. 123; and the figures below.

Specific Characters. Leaves obovate-wedge-shaped, glabrous, serrated. Calyx a little villose; its sepals awl-shaped, entire. Fruit usually dotted.-De Candolle, Prodromus.

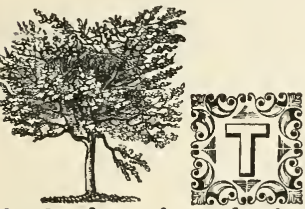

\section{Description.}

the borders of woods throughout the United States; is particularly abundant in Virginia and Carolina; and was introduced into Britain in 1746, where it is generally found in collections. Its wood is very hard, and is employed by the Indians of the west coast of America, to make wedges for splitting logs. Its
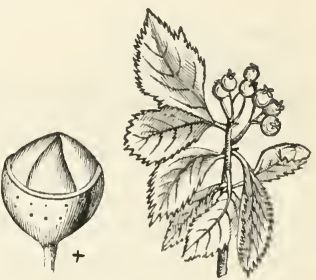
leaves are light-green, membranaceous, rather thick, firm, from two to three inches long, and when old, are usually hairy beneath. 'The flowers are white, and appear in May or June. The fruit is globose, half of an inch or more in diameter, yellowish or of a dull-red colour, dotted, rather pleasant to the taste, but tough, ripens in September, and falls with the leaves.

Varieties. In the British gardens, there are three forms of this species, designated as follows :-

1. C. P. RUBRA, Loudon. Red-fruited Dotted Thorn, a spreading tree, growing to the height of thirty feet, with red fruit, and when old, has but few spines.

2. C. p. rUbra stricta, Loudon. Red-fruited Erect-branched Dotted Thorn, differing from the above in being more fastigiate in its growth.

3. C. P. AUREA, Loudon. Yellow-fruited Dotted Thorn, a fastigiate-growing tree, with yellow fruit, and when old, with but few thorns.

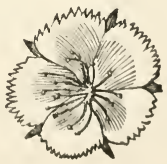




\title{
Cratcegus crus-galli,
}

\section{THE COCK-SPUR THORN.}

\author{
Synonymes.
}

C'ratagus crus-galli,

Néflier pied de coc,

Glänzende Mispel,

Lazzeruolo rosso, Lazzeruolo spinoso,

Cock-spur Thorn,
(Linnжus, Species Plantarum.

Loudon, Arboretum Britannicum.

Torrey and Gray, Flora of North America.

France.

Germany.

ITALY.

Britain and Anglo-America.

Engravings. Loudon, Arboretum Britannicum, ii., fig. 574 in p. 856, and vi. pl. 126 et 127; and the figures below.

Specific Characters. Spines long. Leaves obovate-wedge-shaped, nearly sessile, glossy, glabrous, falling off late. Stipules linear. Lobes of the calyx lanceolate, and somewhat serrated. Styles 2. Fruit scarlet.-De Candolle, Prodromus.

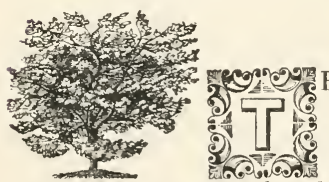
fifteen or twenty feet, found in woods and hedges, from Florida to Canada, and as far west as Missouri. It was introduced into Britain in 1691, and has been more generally cultivated in that country than any other American species. In warm, sheltered situations, it is sometimes subevergreen, retaining its leaves and fruit throughout the winter. Its branches are armed with sharp, slender spines, two or three inches long. The leaves are usually obtuse, of a shining, deep-green above, and paler and dull beneath. The flowers appear in April and May, and are succeeded by small, somewhat pyriform, scarlet fruit, which ripens in September and October.

Varieties. De Candolle and Loudon describe, under this species, the five following varieties :-

1. C. c. SPlendens. Shining-leaved Cock-spur Thorn, the leaves of which are ovate-wedged-shaped, and shining.

2. C. c. Pyracanthifolia. Yellow-spined-leaved Cock-spur Thorn. The leaves of this variety are oblong, with the upper part lanceolate, and the lower part tending to wedge-shaped.

3. C. c. Salicifolia. Willow-leaved Cock-spur Thorn, with leaves resembling in shape, those of the preceding variety, and like it, forms a beautiful low, flatheaded tree.

4. C. c. Linearis. Parallel-sided-leaved Cock-spur Thorn. This variety may be known by its linear-lanceolate leaves, shortish spines, and yellowish-red fruit. 
5. C. C. Nana. Dwarf Cock-spur Thorn, distinguished by its somewhat tomentose branchlets, oval-lanceolate leaves, paler on the under than the upper surface, and dwarfish in its growth. When trained to a single stem, it forms a beautiful miniature gardenesque tree, as denoted in the figure below.

Propagation, \&.c. In the twenty-third volume of the "Transactions of the London Society of Arts," is given the following method of raising thorns from roots, which has long been practised both in Europe and America with success :"Purchase the desired number of thorns, and when three years old, take them up and trim the roots, from each of which, ten or twelve cuttings will be obtained. Plant these cuttings in rows half a yard asunder, and about four inches from each other in the row. They ought to be about four inches long, and planted with the top one fourth of an inch out of the ground, and well fastened, otherwise they will not succeed so well. April is the best time to plant the cuttings. The thick end must be planted uppermost. The advantages of this mode are, first, in case any one has raised from haws, a thorn with remarkably large prickles, of vigorous growth, or possessing any other qualification requisite to make a good fence, he may propagate it far better and sooner, from roots, than any other way. Secondly, in three years he may raise from roots a better plant than can in six years be raised from haws, and with double the quantity of roots." 
Cratagus cordata,

\section{THE HEART-LEAVED OR WASHINGTON THORN.}

\section{Synonymes.}

Cratagus cordata,

Néflier à feuilles en cour,

Herzblättrige MIispel,

Heart-leaved Thorn, Washington Thorn,
( De Candolle, Prodromus.

Loudon, Arboretum Britannicum.

Torrey aND Gray, Flora of North America.

FRANCE.

GermanY.

Britain and Avglo-Averica.

Engratings. London Botanical Register, pl. 1151 ; Loudon, Arboretum Britannicum, ii., fig. 590 in p. 861 , et vi. pl. 137 ; and the figures below.

Specific Characters. Disks of leaves cordate-ovate, angled by lobes, glabrous. Petioles and calyxes without glands. Styles 5 in a flower.-De Candolle, Prodromus.

\section{Description.}

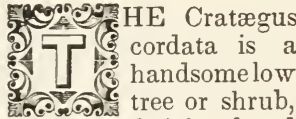

fifteen or twenty feet in height, found in greater or less abundance in rocky places, and on the banks of streams which issue from the Alleghanies, from Canada to Georgia. Its head is close and compact, with branches armed with very long, slender, sharp spines. Its leaves are of a deep, shining green, and vary, exceedingly, in size, according to the age and vigour of the tree. They are usually from one to two inches in length, and are often deeply, and nearly equally three-lobed, like those of the red-flowered maple, being sometimes

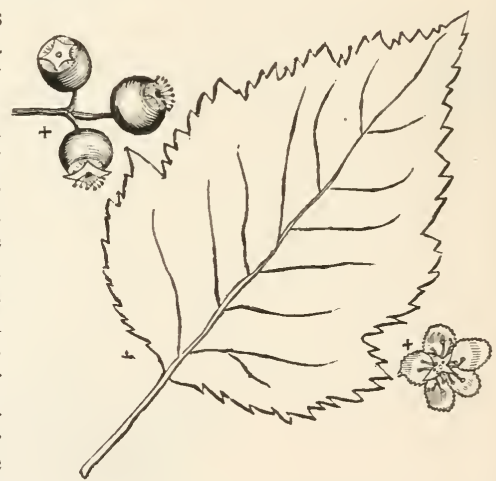
of a slightly rhombic form, and a little tapering at the base. The flowers, which appear by the end of June or the beginning of July, are produced in numerous terminal corymbs, and are succeeded by very small, depressed-globose, bright-purple fruit. This species has been cultivated in Britain since the year 1738, where several fine specimens are growing, of a height of fifteen to thirty feet. It was first cultivated in the nursery of Mr. Main, of Georgetown, in the District of Columbia, towards the close of the last century, and has since been much employed in other parts of the United States for hedges, under the name of "Washington Thorn." 


\title{
Genus AMELANCHIER, Medic.
}

\author{
Rosaceæ. \\ Syst. Nat. \\ Icosandria Di-Pentagynia. \\ Syst. Lin.
}

\author{
Synonymes. \\ Amelanchier, Mespilus, Aronia, Cratagus, Pyrus, Of Avtrons.
}

Derivations. Amelancier, according to Clusius, is derived from amelancier, the old Savoy name for the Amelanchier ruigaris The other names have been applied to the trees of this genus, from the resemblance they were supposed to bear to the medlar thorn, etc.

Generic Characters. Ovaries 5, each divided by a partition, so that there are 10 cells; ovules, 1 in each cell. Ripe pome including $3-5$ carpels. Petals lanceolate. Leaves simple, serrate, deciduous. Flowers in racemes.-Loudon, Arboretum.

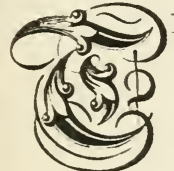

HE genus Amelanchier occurs in but two forms sufficiently distinct to be regarded as species, namely, the common amelanchier of Europe, (A. vulgaris,) and the Amelanchier canadensis, (June berry,) of North America. The former is a native of mountainous woods, among rocks, in different parts of the continent, as the Alps, the Pyrenees, Fontainbleau, Nc., and has been cultivated in Britain since 1596, where it forms a most desirable low tree, fifteen or twenty feet in height, on account of its early and numerous flowers, which cover the tree like a white sheet, about the middle of April, and, in very mild seasons, even in March. Its fruit is round, soft, eatable, and ripens in July, soon afte which, it drops off, or is eaten by birds. It may be propagated from seeds or by grafting on the hawthorn or the quilice.

To the same natural family belongs the common medlar of Europe, (Mespilus germanica,) a tree which was known to the Greeks, and has been cultivated in Britain for an indefinite period. As an ornamental shrub, it well deserves a place in every collection, from the tortuous, fantastic appearance of its branches, its large leaves, large white flowers, and rich-looking persistent calyxes, which accompany its fruit. There are several varieties of this species, among which, what is called the "Dutch medlar," is reckoned the best. The fruit, however, is not eaten till in a state of incipient decay, when it is very agreeable to some palates; though, as Du Hamel observes, it is probably more " un fruit de fantaisie," than one of real utility. 
Amelanchier canadensts,

\section{THE CANADIAN AMELANCHIER.}

\section{Synonymes}

Mespilus canadensis, Mespilus arborea,

Amelanchier c. botryapium,

Amelanchier botryapium,

Frand Amelanchier, Amelanchier de Choisy, Alizier de Choisy, Alizier France.

à grappes, Bois de flêche,

Traubenbirne,

Amelanchier di Canada,

Canadian Medlar, Snowy Mespilus,

Snowy-blossomed Amelanchier,

Wild Pear-tree, Sugar Plum, June-Berry,

Shad-blow, Shad-flower,
Linnæeus, Species Plantarum.

Michaux, North American Sylva.

Torrey and Gray, Flora of North America.

De Candolle, Prodromus.

Hooker, Flora Boreali-Americana.

Loudon, Arboretum Britannicum.

Derivations. The specific name, botryapium, is derived from the Greek botrus, a grape, in reference to the form of the fruit, and the Celtic apon, water, probably from the circumstance of this species usually growing along streams and in swampy fruit, and the Celtic apon, water, probabiy fromear. It is called June Berry, on account of the ripening of its fruit in some parts grounds. The German name signifies Grape-pear. It is called June Berry, on account of the ripening of its fruit in soment of of the country in the month of June, before that of any other tree; and it an whe of which it sometimes abounds.

Engravings. Michaux, North American Sylva, pl. 66; Audubon, Birds of America, i., pl. lx. ; Loudon, Arboretum Britannicum, ii., fig. 628 , and vi., pl. 162 et 163 ; and the figures below.

Sperific Characters. Leaves oblong-elliptical, cuspidate, somewhat villous when young, afterwards gla brous.-De Candolle, Prodromus.
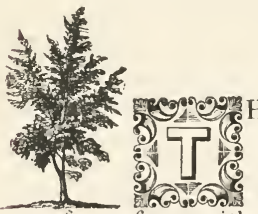

Description.

ty or forty feet, with a diameter of ten or twelve inches. Its leaves are from two to three inches long, alternate, of a lengthened oval shape, finely toothed, and, when beginning to open, are covered with a thick, silvery down, which disappears with their growth, and leaves them perfectly smooth on both sides. The flowers, which are white, and rather large, are disposed in long panicles at the extremities of the branches, and expand in the Carolinas and Georgia in February and March, and in the middle and northern states in April

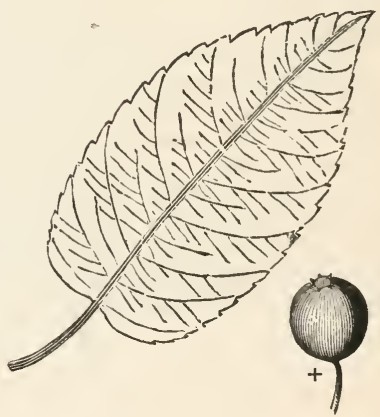
and May. The fruit is of a globular form, about one fourth of an inch in diameter, red in an immature state, and of a dark-purple when fully ripe, and is covered with a bloom. It matures at the south in the month of June, and from one to two months later in the more northern regions where it abounds. Of this fruit, the largest tree rarely yields more than half a pound. 
Varieties. As numerous forms constantly occur between the European and American types of this genus, it is difficult to determine to which species they belong. Indeed, the two trees so closely resemble each other, that they have been regarded by some botanists as belonging to the same species. There are several races, however, which appear to be sufficiently distinct, and may be described as follows :-

1. A. c. oblongifolia, Torrey and Gray. Oblong-leaved Canadian Amelanchier, a shrubby tree, with oval-oblong leaves.

2. A. с. вotundifolia, Torrey and Gray. Round-leaved Canadian Amelanchier, occurring either shrubby or arborescent, with roundish-oval leaves.

3. A. c. alnifolia, Torrey and Gray. Alder-leaved Canudian Amelanchier, also shrubby or arborescent. Its leaves are roundish, elliptical, very obtuse or retuse at each end, and only serrate near the summit.

4. A. c. Pumila, Torrey and Gray. Dwarf Canadian Amelanchier, with small, roundish-oval leaves, obtuse at both ends.

5. A. c. oligocarpa, Torrey and Gray. Few-fruited Canadian Amelanchier, a shrubby tree, with narrow oval or oblong leaves, which are mostly glabrous, even when young.

Geography, \&०c. The Amelanchier canadensis, with the exception of the maritime parts of the southern states, is spread over the whole extent of AngloAmerica, from Georgia to Hudson's Bay, and from Newfoundland to Oregon. It is most multiplied on the fertile banks of rivers, and in swampy grounds, although it sometimes occurs in dry, rocky places, where the soil is less rich. This species was introduced into Britain by Archibald, Duke of Argyll, in 1746. It is common in the European gardens and collections, where it has acquired a height of more than twenty feet, and is much esteemed in early spring, for its profusion of flowers, and in autumn, for the fine dark-red, which its leaves assume before they fall.

Properties and Uses. The wood of the Canadian amelanchier is white throughout, exhibiting no difference of colour, except in being longitudinally traversed by small red vessels, which intersect each other and run together, as in the red birch (Betula nigra.) From its inferior size, and want of durability, it is applied to no particular use in the arts. 'The fruit is of an agreeable sweet taste, and is used by the natives, in the northern regions where it abounds, as an article of food. 


\section{Genus PYRUS, Lindl.}

Rosaceæ. Syst. Nat.
Iscondria Di-Pentagynia.

Syst. Lin.

Synonymes.

$\left.\begin{array}{l}\text { Pyrus, Pyraster, Malus, Sorbus, } \\ \text { Aria, Aronia, Cratagus, Mespilus, }\end{array}\right\}$ Of Authons.

Derivations. The word Pyrus is derived from the Celtic peren, the pear; and Malus is the ancient Roman name of the apple-tree. The other names have been applied to various trees of this genus, from the analogy they were supposed to bear ta the Aria, Aronia, etc.

Generic Characters. Carpels 5, or 2-5. Seeds 2 in each carpel. Trees or shrubs. Leaves simple or pinnate, deciduous. Flowers in spreading terminal cymes or corymbs.-Loudon, Arboretum.

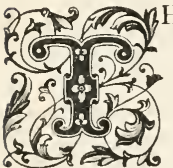

HE genus Pyrus is composed of low trees and shrubs, mostly deciduous, and natives of Europe, Asia, and of North America. Some of them are held in high estimation for their fruit; while others are cultivated chiefly for their flowers. Under this head, modern botanists have united the old genera Pyrus, Malus, and Sorbus, together with several species formerly included under Mespilus, Cratægus, Aronia, and others. Taking the generic characters from the fruit, we agree with Mr. Loudon, that this union appears strictly in accordance with the canons laid down by botanists; but we cannot help stating, with him, that, in our opinion, it would be much more convenient, in a practical point of view, in establishing genera, to take into consideration the leaves, the character of the vegetation, the physiology, and even the habit, of the plant, than merely to draw the distinctive characters from the parts of fructification. In consequence of attending only to these parts of plants, the genus Pyrus, as at present constituted, contains species, such as the apple and pear, which will not readily graft on each other; a circumstance which clearly shows that the union of these two kinds of plants, in one genus, is not a natural one. We think that no plants should be comprehended in the same genus, which will not graft reciprocally on each other, nor those of different habits or constitutions ; and, consequently, that twining plants should not be classified with trees and upright shrubs; nor deciduous trees and shrubs with evergreens. When a more perfect knowledge is obtained of all the vegetable productions of the earth, we have no doubt that it will be found necessary to remodel all of the genera, as well as to give, in many cases, new and characteristic names to the species, - a labour which, formidable as it may appear at first view, will be diminished to a degree scarcely credible, when the present chaos of names, and apparently of species, is reduced by simplification.*

Under the genus Pyrus are at present included the apple and the pear, which were formerly considered as distinct. Those authors most tanacious concerning the establishment of the two vegetables as different genera, have drawn their characters from the adherence of the lower part of the five styles to their villosity, to the spheröidal form of their fruit, and to the stem of the apple being set in a cavity,-characters which are by no means constant, and are frequently effaced. M. Turpin, in a memoir to the French Academy of Sciences, on the difference

* See London's Arboretum Britannicum, ii., p. 879. 
existing between the cellular tissues of the apple and pear, founds their distinction in the absence or presence of those stony concretions which are to be met with in the pear. These concretions he attributes to the aggregation of little globules, which by degrees become clogged with an indigestible matter, confusedly deposited in molecules, from which they receive their opaqueness, hardness, and colour.

This genus, according to De Candolle and Loudon, may be classified under eight sections, all the species of which may be propagated from seeds, and by grafting or budding on the wild varieties of each division. The sections and the most important species contained in them, we will briefly notice as follows :-

1. Pyrophorum, characterized by flat, spreading petals; five distinct styles; pome more or less top-shaped, or sub-globose, without a cavity at the base; simple umbelled pedicels; and simple leaves, without glands. This section comprehends all the pears, properly so called, and besides the Pyrus communis, and all its varieties, it includes the Chinese pear, (Pyrus sinensis,) which, according to Dr. Lindley, differs from the common pear, in having longer and greenish branches, larger, more lucid, and almost evergreen leaves; insipid, apple-shaped, warted, and very gritty fruit; and a calyx, destitute of down within. The tree is ornamental, and perfectly hardy; but as a fruit-tree, it is worthless. It also includes the Bollwyller pear, (Pyrus bollwylleriana,) a very distinct variety, witlı large, rough leaves, resembling those of the apple, with small, turbinate, orange-yellow fruit, unfit to eat; the notched-leaved pear, (Pyrus crenata,) native of Nepal, growing to an elevation of nine or twelve thousand feet above the level of the sea, and approaches to Pyrus bollwylleriana; but its leaves are crenated instead of being serrated, and its flowers are more numerous; and the variable-leaved pear, (Pyrus variolosa,) likewise a native of Nepal, distinguished by ovate, acuminated, crenate, glabrous leaves, in the adult state, situated on long petioles, but when young, clothed with yellowish tomentum beneath. Its fruit is said to be inedible until it becomes somewhat decayed; and has the property of remaining a long time on the tree, sometimes even till the flowers appear in the following spring. It forms a very handsome tree, is hardy, of tolerably rapid growth, and is well worthy of a place in every collection.

2. Malus, characterized by flat, spreading petals; five styles, more or less strictly connate at the base; pome mostly globose, depressed, and generally having a concavity at its base; flowers in corymbs; and simple leaves without glands. This section includes all the apples and crabs, and besides the Pyrus malus and varieties, it comprehends the show y-flowering apple-tree, or Chinese crab, (Pyrus spectabilis,) distinguishable by its semi-double, pale, rose-coloured flowers, the buds of which, before they expand, are of a deep-red. The stamens and pistils are much more numerous than in the other species; the former sometimes exceeding forty and the latter twenty in number. The fruit is small, irregularly round, angular, about the size of a cherry, and when ripe, is of a yellow colour, but without flavour, and is only fit to eat in a state of incipient decay. From the beauty of its flowers in early spring, when but few other trees are in bloom, it is well worthy of cultivation, and no garden, whether large or small, should be without it.

3. Aria, characterized by flat, spreading petals; from two to three styles; globose pome; flowers with racemose corymbs, and branched peduncles; simple leaves, whitely tomentose beneath, and without glands. 'This section comprehends the white beam-tree, (Pyrus aria,) and its varieties of Europe and Asia, which vary much in a state of culture, and consequently cause great confusion among amateurs and botanists. As a useful and an ornamental tree, the white beam has some valuable properties. Its wood is universally enployed on the continent for cogs to the wheels of machinery, and is appropriated to a variety of other uses. From the moderate size of the tree, and the definite shape of its 
summit, and thus bearing the character of art, it is adapted for particular situations where the violent contrast exhibited by trees of picturesque forms would be inharmonious. In summer, when clothed with leaves, it forms a compact green mass, till it is ruffled by the breeze, when, like the abele, it suddenly assumes a mealy whiteness. From its hardy nature, it will withstand the fiercest and the coldest winds, and yet will never fail to grow erect, and produce a regular head; and for this reason, it is well adapted for sheltering houses and gardens where the situations are much exposed.

4. Torminaria, characterized by flat, spreading petals, with short claws; from two to five connected glabrous styles; pome top-shaped at the base, and truncate at the tip, with but little juice; sepals deciduous; leaves angled, with lobes, glabrous when adult; flowers in corymbs, with the peduncles branched. In this section is included the griping-fruited or common wild service-tree, (Pyrus torminalis,) native of various parts of Europe, and of western Asia; and in its general character, in regard to constitution and habit, greatly resembles the trees of the division Aria.

5. Eriolobus, characterized by flat, spreading petals, with short claws, and with about three teeth at the tip; styles, five in number, long at the base, very hairy, and somewhat connected; pome globose, glabrous, crowned with the lobes of the calyx, which are tomentose upon both surfaces; leaves palmately lobed, and glabrous; flowers upon unbranched pedicels, disposed in corymbs. This section includes the three-lobed-leaved pear-tree, (Pyrus trilobata,) a native of Mount Lebanon, which grows to the height of twenty feet.

6. Sorbus, characterized by flat, spreading petals; from two to five styles; globose, or top-shaped pome; impari-pinnate, or pinnately-cut leaves; and flowers occurring in branched corymbs. The trees comprehended in this division, are natives of northern and western Asia, Europe, the Himalayas, and North America, and like those of the section Aria, are much confounded, and bear a great variety of names. Besides the mountain ash, or fowler's service-tree, (Pyrus aucuparia,) and its varieties, this section includes the auricled service, (Pyrus auriculata,) a native of Egypt; the pinnatifid-leaved service, (Pyrus pinnatifida,) indigenous to Gothland, 'Thuringia, and Britain; and the true servicetree, (Pyrus sorbus,) a native of Europe, western Asia, and northern Africa, cultivated for ornament, and celebrated for being the hardest and the heaviest of all European woods.

7. Adenorachis, characterized by spreading petals, each with a claw, and a concave limb; from two to five styles; globose pome; simple leaves, with the midribs bearing glands on the upper surface; and the flowers occurring in branched corymbs. This section is so unlike the others in habit and general appearance, that, at some future time, it will probably form a distinct genus, and perhaps will be classified with the common haw thorn, (Cratægus oxycantha, ) as the trees in the two divisions will probably prove to graft reciprocally upon each other. Among the trees of this section, are inclinded the arbutus-leared aronia, (Pyrus arbutifolia,) and its varieties, which consist of deciduous shrubs, natives of North America, growing to a height of four or five feet, and distinguished for their prolific flowers, and red, dark-purple, or black fruit; the downybranched aronia, (Pyrus pubens, ) and the large-leaved aronia, (Pyrus grandifolia,) both of which are also natives of North America, and well deserve a place in every collection.

S. Chamamespilus, characterized by upright, conniving, concave petals; two styles; ovate pome; simple, glandless leaves; and flowers occurring in capitate corymbs. 'This section comprehends the European dwarf medlar, (Pyrus chamæmespilus, ) a compact bush, bearing an abundance of flowers, and orange-coloured fruit, grafts readily on the common hawthorn, and deserves to be extensively introduced in collections. 


\title{
Pyrus communis, \\ THE COMMON PEAR-TREE.
}

Synonymes.

Pyrus sommunis,

Poirier,

Gemeine Birne, Birnenbaum,

Pero,

Perêira,

Gruschka,

Pear-tree, $\int$ Linnzers, Species Plantarum.

De Candolle, Prodromus.

Loudon, Arboretum Britannicum.

France,

Germany.

Italy and Spain.

Portugal.

Russia.

Britain and Anglo-America. Engravings. Lindley, Pomologia Britannica ; Hoffy, Orchardists' Companion ; Loudon, Arboretum Britannicum, vi., p.
'66, 167, et 168; and the figures below.

Specific Characters. Branches and buds glabrous. Leaves ovate, serrated, glabrous upon both surface Flowers corymbose.-De Candolle, Prodromus.

\section{Description.}

\author{
"The juicy pear \\ Lies in soft profusion scattered round. \\ A various sweetness swells the gentle race, \\ By nature's all-refining hand prepared, \\ Of tempered sun and water, earth and air, \\ In ever-changing composition mixed."
}

midal shaped head, with thorny branches, at first erect, and afterwards pendulous or curved downwards. When cultivated under favourable circumstances, it will sometimes attain a height of fifty or sixty
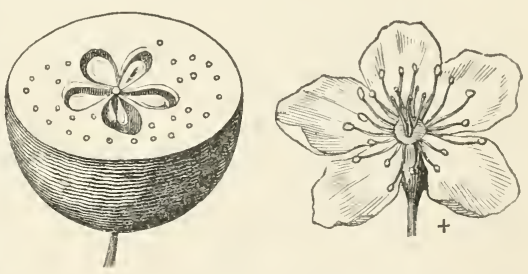

feet, and a diameter of eighteen to thirty-six inches. The roots, which are not numerous, descend perpendicularly, and liave but few lateral ramifications, except in shallow and rich soil. The leaves vary exceedingly in different soils, and in different parts of the globe. In Britain, and in the temperate regions of North America, they are gencrally green, slightly tomentose, and do not greatly vary in size; but in the woods of Poland, and in the vast steppes of Russia, those of the wild pear-trees are commonly white with down, and vary so exceedingly in their size and forms, as to include what are called the "willow-leaved," the "sage-leaved," and the "narrow-leaved" varieties, which, by many, are regarded as species. The blossoms of the pear, which are scentless, and of a pure white, appear in the warmer parts of Britain, and in the southern counties of Ohio, by the middle of April ; in Sweden, and in Massachusetts, by the 20th of May; at Perth Amboy, in New Jersey, the 10th of May, and at Naples, in Italy, six weeks earlier. The fruit, in a wild state, is seldom more than a fourth part of the size of the ordinary cultivated varieties; and is also austere and unfit to eat. For a comparison of this fruit with the apple, the reader is referred to our description of the latter, under the liead of "Pyrus malus."

Varieties. De Candolle describes two forms of the wild species, comparatively 
permanent; to which Mir. Loudon added several others, the result of cultivation, and which he considers as more or less accidental or temporary. To these we have subjoined a group of wild pears, with hoary leaves, which may be regarded as varieties or races, though commonly treated as species :-

1. P. c. Achras. The Spiny-leaved Pear-tree. This variety may be known by its spiny, ovate, acuminate, entire leaves, with long petioles. The leaves and the tube of the calyx are woolly, when young, but afterwards glabrous. Pome with its basal part long.

2. P. c. Pyraster. The Wild Acerb-frnited Pear-tree, distinguished by its spiny branches, roundish, acute, sharply-serrated leaves, glabrous even when young, as is the tube of the calyx. Pome rounded at the base, gritty, sour, bitter, and harsh to the taste.

3. P. c. Folis variegatis. Variegated-leaved Pear-tree.

4. P. c. fructu variegato. Variegated-fruited Pear-tree, the skin of the fruit of which is variegated with yellow and white.

5. P. c. Sangunolenta. The Sanguinole Pear-tree, the flesh of the fruit of which is red or reddish; and, though small and gritty, is edible when ripe.

6. P. c. flone pleno. Double-flowered Pear-tree; Poirier de l'Arménie, of the French, distinguished for its double flowers.

7. P. c. Jaspida. The Jasper-barked Pear-tree; Bon Chrétien à bois jaspé, of the French, having the bark of the wood striped with yellow.

8. P. c. Sativa. The Spineless cultivated Pear-tree, from which originated the numerous sub-varieties growing in gardens, with edible fruit. Their number at present amount to several thousand, and it is to be regretted that the speciality of this work will not permit us to treat of them in detail, after the manner of describing the different varieties of the common cherry.

9. P. c. Salvifolia, (P. salvifolia, De Candolle,) Sage-leaved or Aurelian Peartree, with thick branches; tomentose buds; entire lanceolate leaves, tomentose all over when young, but glabrous on the upper surface when adult. Its fruit is thick, long, and suitable for making perry. It occurs both wild and cultivated, about Aurelia, in France.

10. P. c. Nivalis ( $P$. nivalis, De Candolle.) Snowy-leaved Pear-tree, with leaves oval, entire, obtuse, white and silky beneath; corymbs terminal; fruit globose, very acid, except when ripe, and beginning to decay, when it becomes sweet. It is a native of the Austrian Alps.

11. P. c. salicifolia (P. salicifolia, De Candolle.) Willow-leaved Pear-tree. The buds of this variety are whitely tomentose; the leaves linear-lanceolate, acute, entire, hoary, particularly upon the under surface, with their disks three times as long as the petioles; the flowers occur upon short pedicels, disposed in corymbs. It is a native of Siberia, Caucasus, and Persia, and is generally accompanied by the Cratægus oxycantha, and Prunus spinosa.

12. P. c. amygdaliformis, ( $P$. amygdaliformis, De Candolle,) Almond-shaped Pear-tree, the branches of which are spiny; the buds tomentose; the leaves oblong, acute, entire, tomentose all over when young, but glabrous on the upper surface when adult, with disks six times longer than the petioles; the flowers occur in corymbs. It grows wild in rough places in Provence, Dauphiny, and Languedoc, in France, and when cultivated, forms a tree with a very irregular, picturesque head, with many of the side-branches sweeping the ground.

Geography and History. The common pear-tree is indigenous to Europe, western Asia, the Himalayas, and to China; but not to Africa nor America. It is found wild in most of the counties of Britain, as far north as Forfarshire; on the continent of Europe, from Sweden to the Mediterranean; and in Asia, as far east as China and $\mathbf{J}$ apan. It is always found on a dry soil, and more frequently on plains than on hills or mountains; and solitary, or in small groups, rather 
than in woods and forests. The varieties cultivated for their fruit succeed botll in the temperate and transition zones of the two hemispheres, and it has been remarked that this tree, as well as the apple and the cherry, will grow in the open air, wherever the oak will thrive.

The earliest writers mention the pear as growing abundantly in Syria; Egypt, and in Greece; and it appears to have been brought into Italy from these places about the time that Sylla made himself master of the last-named country, although there is but little doubt that the Romans had several kinds of this fruit long before that time. Among the trees which Homer describes as forming the orchard of Laertes, the father of Ulysses, we find the pear. Theophrastus speaks of the productiveness of old pear-trees; and Virgil mentions some pears which he received from Cato. Pliny describes the varieties in cultivation, in his time, as being exceedingly numerous, and says that a fermented liquor was made of the expressed juice. "Both apples and pears," he says, "have the properties of wine, on which account the physicians are careful how they give them to their patients ; but when sodden in wine and water, they are esteemed as wholesome." Again, he observes, - "All pears whatsoever are but a heavy meat, even to those in good health, and the sick are debarred from eating them; and yet, if they are well boiled or baked, they are exceedingly pleasant, and moderately wholesome; when sodden or baked with honey, they agree with the stomach." According to Pownell, the cultivated pear was imported into Marseilles by the Phocæan colonists, sometime during the middle ages; and Whitaker thinks that it was introduced into Britain by the Romans, but at what period, although it is mentioned by all the early writers of that country, we have no account. It was the opinion of Mr. Loudon, that all the wild pears growing in England, originated from the seeds of the cultivated sorts, accidentally disseminated by birds.

The pear-tree is of great longevity, and all writers on the subject, from Theophrastus to the present day, agree that, as the tree grows old, it increases in fruitfulness, which is indeed the case with many other trees. In corroboration of these views, Mr. Loudon states that, "In Nottmghamshire, at Old Baseford, ihere is a pear-tree, of the kind known as the brown dominion, which, in 1826 , was upwards of a century old. It is forty feet high, with a head fifty-four feet in diameter, and a trunk two feet three inches in diameter. From 1806 to 1826 , the produce of this tree, on an average, was fifty pecks of pears a year. In the year 1823, it bore one hundred and seven pecks, each peck containing four hundred and twenty pears; and in 1826, it produced one hundred pecks of two hundred and seventy-nine pears each; which, when gathered, weighed twenty pounds each peck; making a total of a ton weight of pears in one year. As the tree grows older, the fruit becomes larger and finer; so that it requires more than one hundred pears less to fill the peck now, than it did twenty-six years ago. The increase in the size of the fruit is doubtless, owing to the field in which the tree stands being frequently top-dressed with manure.'

In Duncumb's "General View of the Agriculture of the County of IIereford," published in 1805 , there is recorded a very extraordinary tree, growing on the glebe land of the parish of Hom-Lacey, that more than once filled fifteen hogsheads with perry in the same year. When the branches of this tree, in its original state, became long and heavy, their extreme ends successively fell to the ground, and, taking fresh root at the several parts where they touched it, each branch became a new tree, and in its turn, produced others in the same way, covering at that time nearly half of an acre of land. "Being anxious to know the present state of this celebrated tree," observes Mr. Loulon, "we wrote to a highly valued friend, residing at Hereford, respecting it, and we have been favoured with the following reply:-I lave been this morning to see the farfamed pear-tree. It once covered an acre of land, and would have extended 
much further, had nature been left to her own operations. It is now not a quarter the size it once boasted; but it looks healthy and vigorous, and when I saw it, it was covered with luxuriant blossoms. The original trunk is still remaining; and there are young shoots which are only yet approaching the ground, but which seem nearly ready to take root in it. The tree would completely have covered the vicarage garden, if it had been allowed to remain. It is said to have been in its greatest perfection about 1776 or 1777 . There is another tree of the same kind in the neighbourhood.-Hereford, May 18, 1836."

In Scotland, at Restalrig, near Edinburgh, in a garden adjacent to what was the house of Albert Logan, who was attainted in the reign of James VI., (of Scotland, and First of England,) there is a pear-tree, which was probably planted before his forfeiture. It is of the kind called "Golden Knap," which, in that part of the country, is generally considered as the best variety to plant for timber. At two and a half feet from the ground, in 1836, it was four yards in circumference. Dr. Neill has mentioned a number of very old pear-trees, standing in the neighbourhood of Jedburgh Abbey, and in fields known to have been formerly the gardens of religious houses in Scotland, which were destroyed at the time of the "Reformation." Such trees are, for the most part, in good health, and are abundant bearers; and as some of them must have been planted when the abbeys were built, they are probably from five to six hundred years old.*

The introduction of this fruit-tree into the North American colonies, probably dates back to the early periods of their settlements. 'There are at present existing in this country, many aged trees, celebrated for the improved excellence of their fruit, among which may be mentioned a venerable old tree, standing at the corner of the Third avenue and Thirteenth street, in the city of New York. It is said to have been planted in about the year 1646, by Peter Stuyvesant, then governor of New Netherlands, and has been a living witness of all the changes and political struggles through which this city has passed, for a period of nearly two hundred years. Although its trunk and larger branches are signally marked by the effects of time, it amnually bears an abundance of delicious fruit, and at the present date, (April 17, 1845,) it is covered with a profusion of fiowers. It is about forty feet in height, with a trunk one hundred inches in girth, at a yard above the ground.

Soil and Situation. The common pear-tree naturally requires a dry soil, and where it is intended to grow to a large size, and be productive, it should be deep and fertile. It has been remarked that a somewhat clayey soil is more favourable to the longevity of the tree than one that is loose and sandy, in consequence of the resistance it offers to the larvæ of insects, which attack its fruit, leaves, and wood, and which usually burrow below the surface, to transform. The same remark, it is said, holds true with regard to the apple, the mountain ash, (Pyrus aucuparia,) and other trees of this genus. "In respect to situation," Mr. Loudon observes, "where the pear-tree is grown for timber, or its effect in landscape scenery, it may either be planted at regular distances, as in an orchard, in lines in a hedge-row, or in scattered groups. There are few trees better adapted for being grown in hedge-rows than the fastigiate-growing varieties of the pear, because their roots descend perpendicularly, and can, therefore, never interfere with the plough; and the heads, whether fastigiate or spreading, it is known from experience, do very little injury to pasture. If, therefore, fastigiategrowing trees, producing excellent sorts of fruit, were planted in all hedges, a very great benefit would result to the proprietors or to the public."

Propagation and Culture. The wild pear may be continued by seed; but the

* See Loudon's Arboretum Britannicum, ii., p. 888. 
varieties cultivated for their fruit are usually propagated by grafting and budding ou stocks of its own kind, of the mountain ash, the quince, and those of several other trees. For the poorer soils, and exposed situations, stocks of the wild pear, the medlar, and several species of thorn, of the given locality, are thought to be best, on account of their hardihood; but it is found from experience, that, on good soils, or where the pear is to be cultivated entirely as a fruit-tree, both the tree and the fruit will grow larger when the stock is a seedling-pear of some vigorous-growing variety. Such stocks also throw the scions sooner into bearing than the wild ones, though they tend more to shorten the longevity of the trees. If grafted on the stocks of the quince, the medlar, the thorn, the mountain ash, or any species of sorbus, fine divarf-trees may be obtained, which may be trained en quenouille, a mode much adopted at present, by the amateurs of Europe, and is also becoming common in the United States. The pear grows remarkably well on the common hawthorn, but if the graft is not made under ground, it does not form a very safe and durable tree; because, as the diameter of the scion increases faster than that of the stock, it is liable to be blown off by the wind. When the graft, however, is made close to the ground, or directly below its surface, the stock swells in nearly the same proportion as the scion, and there is but little danger of the tree being blown down, or of its not advancing to a considerable age: Whenever the grafted part of a tree has long been buried at some distance below the surface of the soil, the scion or upper part throws out new roots, which acquire, in time, so much vigour and strength, that those of the primitive stock gradually become decomposed, and serve for the nourishment of the future tree. "This "re-rooting," as it is termed, is of great advantage to trees occupying a soil not well adapted to their longevity or vigour, in which case, art should assist in the operation in the following manner, which we quote from the "Revue Horticole," as translated in Hovey's "Magazine of Horticulture," for A pril, 1845, by Mr. A. J. Downing, of the botanic garden and nursery, at Newburgh, New York:- "At the time of planting the trees, the graft should be inserted a few inches below the surface of the soil ; two or three years afterwards, **** $*$ at the time when the descending sap is most abundant, which is usually in July, the earth should be removed at the foot of each tree, so as to lay bare the swelling of the graft; after which, several incisions should be made with a sharp gouge, raising up from below several tongues of the thickness of the bark and alburnum; this operation will give them a concave form, of which the length will be at least double the width; these incisions should be multiplied, according to the size of the trees upon which the operation is performed; but more than a quarter of the bark should never be removed. These wounds should be immediately covered with the richest soil; one fourth cow-manure, to three-fourths of fresh loam, well mixed, are, in my opinion, the best and the simplest application; one or two shovels full of this mixture are sufficient to cause the tree to throw out a large quantity of roots, which, shooting down into the natural soil, sustain the life of the trees during a considerable time." On this subject, Mr. Downing remarks, that, "generally speaking, it is a dangerous practice to plant a tree several inches lower than it stood in the nursery, so as to cover the union of the stock and graft. Many trees would languish and die, under such treatment, unless speedily re-established on the new roots. But this suggests a very excellent mode of grafting, that obviates all this difficulty, and which may indeed be considered the most perfect of all modes, viz., that of grafting on pieces of the root, instead of the whole stock; or cutting down small stocks quite to the root, and grafting considerably below the surface. This is now practised to some extent by many American nurserymen, in working the apple, and it might be carried further with success, as the re-rooting of grafts so inserted would, perhaps, generally take place without assistance." 
From the pyramidal, and often fastigiate form of the pear, its summit requires much less space than the apple or the clierry. In the more fertile soils, the distance at which the trees may be planted apart, need not exceed twenty feet; and those of a poorer soil may be much less. The quenouilles, or dwarfs, trained in the form of a distaff, with their branches reaching nearly or quite to the ground, are found to succeed even at a distance of four or five feet apart, and produce abundant crops.

The pear-tree is liable to be much injured if pruned by those who do not understand the nature of its growth. The blossoms are commonly produced from buds at the extremity of the last year's shoots, and as these are often cut off by the unskilful pruner, it prevents them from producing fruit, and causes the boughs to send out new branches, which overfill the tree with wood. For reasons assigned on the subject of pruning in our articles on the cherry and plum, July and August is the best time to look over the pear-trees, and to remove all superfluous and foreright shoots, which would too much shade the fruit.

'The rate of growth of the cultivated pear-tree, in Britain, is considered, on an average, as from two to three feet per annum, for the first six or seven years; in ten years it will acquire the height of twenty feet; and in thirty years, it will attain an elevation of fifty feet, with a trunk from one foot to eighteen inches in diameter. Its development or rate of growth, in America, under favourable circumstances, is equal to that of Europe, and in some instances, even surpasses it.

Accidents, Diseases, and Insects. "The pear, as a standard tree," says Mr. Loudon, "is not liable to have its branches broken off or disfigured by the wind; nor is it nearly so liable to canker as the apple-tree. It is liable to the attacks of insects, but certainly not so much so in fields as in gardens, and perhaps nowhere to the same extent as in the other edible fruit-bearing Rosaceæ. On a large scale, there is, perhaps, no cure worth attempting, for insects, or mildew on the leaves; but shallow planting, surface manuring, and regrafting, are excellent preventives and correctives for these and all other evils to which the pear, and all other Rosaceæ, are liable." In Britain, the leaves of the pear-tree are affected by a species of fimgus, (AEcidium cancellatum, Sowerby,) which, in moist seasons, and in close situations, sometimes appears to so great an extent, as to occasion them to fall prematurely. There seems to be no remedy, except that of increasing the airiness of the situation, which may always be done, to a certain extent, by thinning out the branches of the tree. The trunks of cankered trees, in Europe, are sometimes perforated in every direction by the larvæ of the lesser stag-beetle (Dorcus parallelopipedus, Stephens.) In Europe, also, the larvæ of the wood leopard-moth, ('Keuzera asculi, Latreille,) also perforate longitudinally the trunk of the peartree, as well as that of the apple, the service, the quince, and probably those of all the Rosaceæ, as it is known to do in the horse-chesnut, lime, walnut, beech, birch, and oak.

In America, the pear-tree is subject to a peculiar malady, called the blight, which shows itself during midsummer, by the sudden withering of its leaves and fruit, and the discolouration of the bark of one or more of the limbs, followed by the immediate death of the part affected. From a communication in the fifth volume of the "New England Farmer," by the late Judge Lowell, of Roxbury, in Massachusetts, it appears that this malady is caused by the larvæ of an insect, named by Professor Peck, Scolytus pyri. They eat their way inward through the alburnum, into the hardest part of the wood, beginning at the root of a bud, (behind which, Dr. Harris thinks the eggs are deposited,) following the course of the eyes of the buds towards the pith, around which it passes, and part of which it also consumes; thus forming, after penetrating through the alburnum or sap-wood, circular burrows or passages, "not exceeding the size of a knittingneedle," in the heart-wood. contiguous to the pitli which they surround. By 
this means, the central vessels, or those which convey the ascending sap, are divided, and the circulation cut off. This takes place when the increasing heat of the atmosphere, producing a greater transpiration from the leaves, renders a large and continued flow of sap necessary to supply the evaporation. For the want of this, or trom some other unknown cause, the whole of the branch above the perforated part, suddenly withers and perishes, during the intense heat of the season. The larvæ, which are changed to pupæ, and subsequently to little beetles, in the bottom of their burrows, make their escape from the tree in the latter part of June, or the beginning of July, and probably deposit their eggs before the end of August. These beetles are about one tenth of an inch in length, are of a deep-brown colour, with their antennæ and legs rather pale, or of the colour of iron rust. The remedy suggested by Mr. Lowell and Professor Peck, to prevent other branches and trees from being subsequently attacked in the same way, consists in cutting off the blasted limb below the seat of injury, and burning it before the perfect insect has made its escape. It will therefore be necessary, carefully to examine the trees daily, during the month of June, and watch for the first indication of disease; otherwise the remedy will be applied too late to prevent the dispersion of the insects among other trees.*

The pear-tree is also perforated by a species of borer, (Egeria pyri, Harris,) which lives under the bark of the trunk, where, towards the end of summer, it forms its cocoon. The perfect insect appears in autumn, and like all its congeners, leaves its chrysalis skin projecting from the orifice of the burrow which it has previously made. Its wings expand rather more than half an inch, are transparent, but veined, bordered and fringed with purplish-black, and across the tips of the fore-wings is a broad, dark band, glossed with coppery tints. The prevailing colour of the upper side of the body is purple-black; but most of the under side is golden-yellow, as are the edges of the collar of the shoulder-covers, and of the fan-shaped brush on the tail; and there is a broad yellow band across the middle of the abdomen, preceded by two narrow bands of the same colour. $\dagger$

Among other insects that infest the pear-tree, may be mentioned the pigeon tremex, (Tremex columba, Harris,) described under the head of "Insects, Lc.," in our article on the Ulmus americana; also a species of bark-louse, (Coccus *****) occurring in considerable numbers, in two different forms and sizes, and adhere to the bark of the trees in autumn, and during the winter, in a dormant state. Those of the largest size are less than a tenth of an inch in length, and resemble in their form the common oyster-shell, being broad at the posterior end, and tapering towards the other, which is surmounted by a little oval, brownish scale. The small ones, which are about half of the length of the large ones, are of a very long oval shape, or almost four-sided, rounded at the ends, with one extremity covered by a minute, oval, dark-coloured scale. For a description of the general habits of the genus coccus, the reader is referred to the remarks under the head of "Insects," in our article on the orange.

The leaves of the pear-tree are particularly subject to the attacks of the goldsmith beetle, (Areodalanigera, Harris,) and the larvæ of the slug-fly, (Blennocampa cerasi,) the latter of which is described under the head of "Accidents, \&c.," in our article on the common cherry-tree.

Properties and Uses. The wood of the common pear-tree is heavy, strong, compact, of a fine grain, and slightly tinged with red. In common with that of all the Rosaceæ, it is liable to have its natural colour changed by steeping in water, which, therefore, ought to be avoided, when intended for particular purposes in the arts. When green, it weighs nearly eighty pounds to a cubic foot and from forty-nine to fifty-three pounds, when dry. According to Du Hamel,

* See Harris' Report on the Insects of Massachusetts, pp. 75, 76. † Ibid. p. 235. 
it is next to the true service, (Pyrus sorbus,) the best wood that can be employed in wood-engraving, for which purpose, however, it is far inferior to that of the box. Yet, it is allowed to be very hard and homogeneous, easy to cut, and when perfectly dry, is not liable either to crack or warp. For the coarser kinds of engraving; such as large plans or diagrams, show-bills, \&c., it serves a very good purpose. When it can be obtained, in Europe, it is much used by turners and pattern-makers; also for joiners' tools; and, as it can readily be stained, it is sometimes made into various articles, dyed black, in imitation of ebony. As fuel, the wood of this tree is excellent, producing a vivid and durable flame, accompanied by an intense heat. According to Withering, the leaves afford a yellow dye, and may be employed to impart a greenish shade to blue cloths. But the most important uses of the pear-tree, are those which arise from its fruit. When ripe, it is employed at the table as a dessert, eitlier raw, stewed, or preserved in syrup, and occasionally it is used in tarts. In most of the countries where it grows, this fruit is very generally dried in ovens, or in the sun, in which state, when stewed, it is excellent, either as a substitute for puddings and pies, or as forming part of the dessert. In the "Nouveau Cours d'Agriculture," published in 1809, it is stated that pears, in France, are dried two ways,-one, for family use, by puttiug them into an oven, without being pared, after the bread is withdrawn, either on bricks, or on raised frames of tin or boards. They are put in two, three, and even four times, according to their size, and to the degree of heat contained in the oven. 'The only things necessary to be observed, are, to see that the oven is not so hot as to burn the pears, and that they are not left in so long as to become hard. Melting sugary pears, of a inedium size, are the best for this purpose; and when properly prepared, they may be kept in bags, in a dry place, for several years. The second mode, is that used for preparing the fruit sold in boxes, at the shops; and for this purpose, rather small pears are considered the best. They must be gathered before they are quite ripe, and care taken to preserve their stems. They are then parboiled in a very little water, peeled, and placed on dishes, with the stems upwards. In this state, a kind of syrup runs from them, which must be carefully poured off, and set aside. They are next placed on raised frames, and put into an oven, after the bread has been withdrawn, or heated to a similar degree, and left there twelve hours; after which they are taken out and steeped in syrup, sweetened with sugar, to which there have been added a little cimnamon, mace, and a small quantity of the best brandy. The pears, when taken out of the syrup, are again placed in the oven, which should not be made quite so hot as it was the first time. The operations of alternately steeping and drying are repeated three times, and are finished by putting the pears, for the fourth time, into the oven, and leaving them there till they are quite dry; when, if they have been properly treated, they will be of a clear, pale-brown, with fine translucent flesh. They are then arranged in boxes, garuished with white paper, and kept in dry places, or offered for sale. 'They will remain good, in this state, for three years, but are considered best the first year.* Another purpose to which tle pear is applied, is for making perry. It is extensively cultivated for this object in various parts of Britain, France, and Germany, where the trees are sometimes planted in rows eighteen or twenty yards apart, in order to admit a free access of light and air. Perry is made in the same mamner as cider. The pears should be gathered before they begin to fall, and should be ground as soon after as possible. Should the perry not be sufficiently clear, when racked off, it may be fined in the usual manner of clarifying cider, by isinglass, in the proportion of about half an ounce to a barrel. 'The kinds of pears used for making this liquor in Herefordshire, are such as liave

* See Nouv. Cours d'Agr., xii., p. 146 ; al.o Loudon's Arboretum, ii., p. 853. 
an austere juice, as the "Squash," the "Oldfield," the "Barland," the "Huff-cap," the "Sack," the "Red," and the "Longland" varieties. Pears were considered by the Romans, as all antidote to the effect of eating poisonous mushrooms; and up to the present time, perry is said to be the best remedy that can be employed for the same purpose. In Britain and France, an agreeable wine is made from a mixture of crab-apples and pears, which, in the latter country is called piquette. Pears, in general, produce flatulency, and consequently are unfit for weak stomachs; but when they are quite ripe, and contain a sweet juice, they seldom prove noxious, unless eaten to excess.

Pears that are to be kept for winter use, should hang as long on the trees as the state of the weather will admit. They should then be kept in heaps, in an open, dry situation, for about ten days, then wiped with a dry woollen cloth, and lastly packed up close from the air and moisture. But to keep the fruit in its greatest perfection, small earthen jars may be selected, abont the size of the pear, which should be packed separately, in clean oat chaff or wheaten bran, then tied down with oiled paper or skin, and cemented tight with wax or pitch. These jars should then be packed in a cask, chest, or some other secure place, with their bottoms upwards, where they should remain until required for use.

From their picturesque forms as well as the beauty of their blossoms and fruit, several varieties of the pear-tree are appropriate objects in landscape gardening. Those particnlarly worthy of culture for ornament, as well as for producing fruit of first-rate excellence, are the "Beurré Diel," the "Benvie," the "Golden Knap," the "Elcho," and the "Swan's Egg" varieties, for conical forms; the "Busked Lady," and "Pow Meg," for orbicular forms; and the "Beurré de Rans," the "Glont Morceau," the "Bezi de la Motte," the "Napoleon," the "Dunmore," the "Monarch," the "Seckle," the "Andrews," and the "Bartlett," for other considerations.

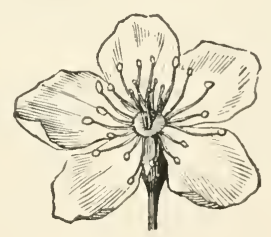




\section{Pyrus malus, \\ THE COMMON APPLE-TREF.}

Synonymes.

\author{
Pyrus malus, \\ Pomier commun, \\ Gemeiner Apfelbaum, \\ Melo, \\ Manzano, \\ Maceira, \\ Iablon, \\ A pple-tree,
}

\author{
(Linneus, Species Plantarum. \\ De Candolle, Prodromus. \\ Loudon, Arboretum Britannicum. \\ France. \\ Germany. \\ ITALY. \\ SPain. \\ Portugal. \\ Russia. \\ Britain and Anglo-America.
}

Engravings. Lindley, Pomologia Britannica ; Hoffy, Orchardist's Companion ; Loudon, Arboretum Britannicum, vi., pì. 173 et 174 ; and the figures below.

Specific Characters. Leaves ovate, acute, crenated, woolly on the under surface. Flowers in corymbs. Tube of calyx woolly. Styles glabrous.-De Candolle, Prodromus.

\section{Description.}

\footnotetext{
"The fragrant stores, the wide projected heaps

of apples, which the lusty.handed year,

Innumerous o'er the blushing orchard shakes;

A various spirit, fresh, delicious, keen,

Dwells in their gelid pores; and, active, points

The piercing cider for the thirsty tongue."
}

Tномson.

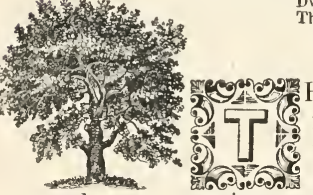

\section{HE Com- mon Apple- tree, in an indigenous} state, when young, is generally more or less furnished with spines, which gradually disappear, as it advances in age; when growing wild, however, in a very fertile soil, this tree, as well as the crab, and the common hawthorn,
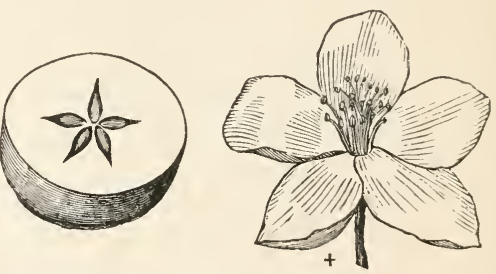
sometimes occurs without thorns. Under favourable circumstances, it usually attains a height of thirty or forty feet, with a trunk from one foot to eighteen inches in diameter. The trunk is naturally crooked, and the branches, when young, generally take a horizontal direction; but when old, they droop or become pendulous. The diameter of the head is often greater than the height of the tree,-its growth, in this respect, being quite different from that of the pear, which is lofty and upright, while that of the apple is low and spreading. 'The leaves of the apple are commonly wider in proportion to their length, less obviously serrated, and somewhat more hairy and whitish underneath than those of the pear. Their vascular system too, is very different, being loose in the apple, and very close in the pear. Hence the leaves of the latter are much stouter, and more permanent than those of the former. They usually fall, in England, by the 20th of November, five weeks later at Naples, and a month earlier at New York. The blossoms of the apple are tinged with red, and are fragrant; while those of the pear are of a pure white, and scentless. They usually appear a* Naples by the 20th of March, a month later in England, two months later at Perth Amboy: but not in Sweden before the 1st of June. The fruit of the appl. 
and pear is not less different than the leaves and flowers. The apple is generally concave at the insertion of the peduncle, depressed at the top, of a softer texture, less astringent, but more acid than the pear; whereas, the latter, which may vary in shape, size, colour, taste, \&c., by cultivation, is generally convex, and lengthened out at the base. The apple has woody threads passing throigh it to the peduncle, ten of which are regularly disposed round the capsules, tending towards the calyx; and it is said that the fruit decays when these are broken. The pear also has these threads, but less distinet, on account of the gritty matter which prevails in many of the varieties, and especially in wild pears. The cells of the two fruits are likewise differently shaped. Those of the apple are narrow, and pointed at both ends; while in the pear, they are obovate, broad exteriorly, and drawing to a point at the centre of the fruit.

Varieties. 'The common apple-tree, by itself, or conjointly with other species or races, is the parent of innumerable varieties or sub-varieties, generally termed by the British and Anglo-Americans, "cultivated apple-trees," and by the French, "pommiers doux," or "pommiers à couteau." Many of them are not only derived from the wild apple or crab, of Europe, but from the crabs of Siberia and Astrachan. As it is utterly impossible to trace the multitude of cultivated sorts to the wild forms from which they have been obtained; and as it appears very doubtful to us whether the wild crabs of Europe, northern and western Asia, and of North America, are specifically distinct, we have considered them only as varieties of the Pyrus malus. We are aware that objections will be made to this mode of classification, as it deviates from what is considered as established authority. Those, however, who differ from us in opinion, will find no difficulty in recognizing the names, as given by De Candolle, Loudon, and others, and will be enabled to know under what head they are described.

1. P. m. acerba, Loudon. Sour-frnited Apple or Common European Crabtree; Pyrus acerba, of De Candolle; Pommier sauvageon, of the French; Holzapfelbaum, of the Germans; and Melo sylvatico, of the Italians. This form is a native of woods and way-sides, in Europe, and may be known by its ovate, acute, crenated leaves, glabrous even when young, as is the tube of the calyx. The flowers occur in corymbs; and, according to De Candolle, there are many sub-varieties, with sour fruit, commonly called cider apples in Britain, and pom mes à cidre in France.

2. P. M. Coronaria. The Garland-flowering scented Crab; Pyrus coronaria, of De Candolle, Torrey and Gray, and Loudon; Malus coronaria, of Michaux; Pommier samvage, of the French; and Amerilianischer Holzapfelbaum, of the Germans. This variety is a native of North America, from Canada to Louisiana, and was introduced into Britain in 1724, where it is common in collections, and has also been naturalized. It is found in fertile soils, in cool, moist places, near the borders of woods, where it usually grows to a height of fifteen to eighteen feet, with a trunk six or seven inches in diameter, and under very favourable circumstances, it sometimes attains nearly double these dimensions. In some parts of Britain, as at White Knights, and at Pepper Harrow, near Godalming, it has become naturalized in the woods; and plants of various ages are found wild, which have sprung up from sceds

Apple-tree or American Sweet-

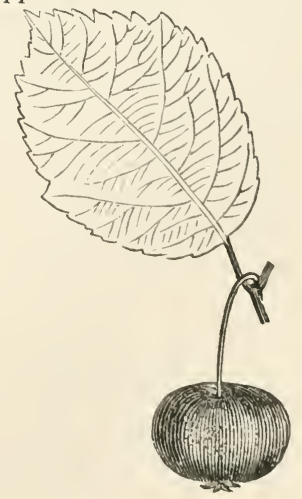


dissemninated by birds. The largest trees at the latter place are about thirty feet in height, and are said to preserve all the distinctive features of the species or race. The leaves are broadly ovate, rounded at the base, subangulate, smooth on the upper surface, and when fully developed, are distinctly toothed. While young, they have a bitter, and slightly aromatic taste; whence Michaux thinks that, with the addition of sugar, they would make an agreeable tea. The flowers, which put forth in Harch, April, and May, are white at first, and gradually change to a purplish hue before they fall. They are very large, and occur in corymbs, with smooth peduncles; and, during the blooming season, they perfume the whole air with the scent of violets. The fruit is flatly orbiculate, from an inch to an inch and a half in diameter, of a yellowish-green when ripe, which occurs in September, and gradually becomes more yellow, and somewhat translucent, with age. It is of a firm texture, extremely acid, and has sometimes been employed in the manufacture of cider, and in the making of preserves, with the addition of sugar equivalent to its own weight. Successful experiments have been made of uniting this tree, by grafting and budding, with the common apple; but the time is so long in bringing it to perfection, that no particular advantage can be derived from such a union. It has been suggested, however, that new and valuable varieties might be obtained from seeds produced by fertilizing the flowers with the pollen of the vigorous-growing pippins, or those of the Siberian crabs. Setting aside all other considerations, this tree, from the beautiful character of its leaves, the fragrance of its blossoms, together with the lateness of their appearance, and the deep-green, and depressed form of its fruit, is a most desirable object of culture, and no shrubbery should be without it.

3. P. m. angustifolia. Narrou-leaved American Crab Apple-tree; Pyrus angustifolia, of De Candolle, Torrey and Gray, Loudon, and others. 'This variety is also a native of North America, is found from Pennsylvania to Louisiana; flowers in March and April; and differs from the preceding race, in having narrower leaves, much smaller and narrower fruit, lead-coloured and speckled branches, and in being sub-evergreen, which last circumstance, together with its sweet-scented flowers, entitles it to a place in collections.

4. P. m. Prunifolia. The Plum-leaved Apple-tree or Siberian Crab; Pyrus prunifolia, of De Candolle and London, a native of Siberia; was introduced into Britain in 1758; and, according to Mr. Knight, some of the finest varieties raised by him were produced from cultivated apples fecundated with the blossoms of this tree. He found that the progeny formed more hardy trees than any other kinds, and that they produced earlier and more highly flavoured fruit. The leaves are ovate, acuminate, serrated, and glabrous; the peduncles pubescent; the tube of the calyx glabrous; the styles woolly at the base, and twice as long as the stamens. The fruit is sub-globose, of a yellowish colour, and of an austere taste.

5. P. м. вaccata. The Berry-like-fruited Apple-tree or Siberian Crab; Pyrus baccuta, of De Candolle and Loudon, native of Siberia and Dahuria, and only differs from the preceding sort in not having a persistent calyx. From this variety originated the cultivated "Cherry Crab," a spreading tree, with drooping branches, bearing an abundance of fruit, about the size and colour of a large cherry.

6. P. м. Dloica. The Diocious-sexed Apple-tree; Pyrus dioica, of De Candolle and London, occasionally cultivated in the gardens of Europe. Its leaves are oval, serrated, and tomentose beneath; the flowers, in many instances, solitary; the sexes diccious by defect; the calyx tomentose; the petals linear, of the length of the sepals; and the styles are glabrous.

7. P. m. astracanica. The Astrachan Apple-tree; Pyrus astracanica, of De Candolle and Loudon. This form is said to be indigenous about Astrachan. Its leaves are oval-oblong, acute, partially doubly serrated, pale beneath, where the 
nerves are villose, but glabrous above, except in being slightly downy on the midrib. From this race originated the cultivated "Red Astrachsn Crab," a medium-sized tree, with a branchy head, bearing a bright-red fruit, covered with a fine bloom, like that of the plum; also the "IVhite Astrachan," or "Transparent Crab," of Moscow, a tree resembling the Red Astrachan, except in its branches tending upwards, when young, and afterwards becoming pendulous. Its fruit is of a wax colour, almost transparent, and covered with a fine bloom.

From the preceding forms, it may be safely presumed, that all the apples cultivated for the dessert, or the kitchen, have been obtained, either by selections from seedlings, or from cross-fecundation. The number of varieties and subvarieties, at present known, amounts to several thousand, about fifteen hundred of which have been collected in the garden of the London Horticultural society, and distinct sorts are being added every year. Hence, as the varieties are so numerous, and are rapidly becoming more multiplied, it is impossible for us, within our limits, to present an account of them, or even to enumerate their names. This branch of knowledge, however, forms a very important feature in practical horticulture; and one of the most valuable objects to which individuals and societies for the encouragement of experiments in cultivation, can direct their attention, would be to diminish the embarrassing list of varieties, by confining themselves to the best sorts alone.

Geography and History. The Pyrus malus, or some of its varieties, grows spontaneously in almost every part of the northern hemisphere, except in the torrid and frigid zones, and some of the islands in the ocean. It is found throughout western Asia, China, Japan, North America, and in the north of Europe, as far as West Finland, in latitude $62^{\circ}$; in Sweden, in latitude $55^{\circ}$ or $59^{\circ}$; and central Russia, to $55^{\circ}$ or $60^{\circ}$. The crab of Europe, however, is wanting in Siberia, where its place is abundantly supplied by the P. m. prunifolia, and the P. m. baccata. In Britain, Ireland, and North America, the common apple-tree occurs wild, in hedges, and on the margins of woods. It is cultivated for its fruit, both in the temperate and transition zones of both hemispheres, even in the southern parts of India, on the Himalayas, and in China and Japan.

'That the apple-tree is a native of the eastern part of the world, we have the authority of the carliest writers in "Holy Writ," as well as of the naturalists of ancient Greece and Rome. The prophet Joel, where he declares the destruction of the products of the earth, by a long drought, mentions the fruits which were held in high estimation, and among them, he names the apple.

\footnotetext{
"The vine is dried up, and the fig-tree languisheth ; the pomegranate-tree, the palm-tree, also, and the apple-tree, even all the trees of the field are withered."

JoEI i. 12
}

Apples are also mentioned by Theophrastus, Herodotus, and Columella; and the Greeks, according to Pliny, called them Medica, after the country whence they were first brought, in ancient times; but others conjecture that the term "Medica," was more probably applied to the citron and the peach, both of which are supposed to have been introduced from Media into Greece. That the Epirotica, from Epirus, were what we call apples, there can be no doubt; as they are described by Pliny, as a fruit with a tender skin, that can easily be pared off; and besides, he mentions "crabs" and "wildings," as being smaller, "and for their harsh somrness they have many a foul word and shrewd curse given them." The cultivated apple, however, probably was not very abundant at Rome, in his time; for he states that, "there were some trees in the villas near the city, which yielded more profit than a small farm, and which brought about the invention of grafting." "'There are apples," continues he, "that have ennobled the countries from which they came; and our best varieties will honour 
their first grafters forever; such as took their names from Matius, Cestius, Manlius, and Claudius." He particularizes the "quince apples," that came from a quince grafted upon an apple stock, which smelled like the quince, and were called Appiana, after Appius, of the house of Claudius. It must be confessed, however, that Pliny has related so many particulars as facts, concerning the apple, (such as changing the fruit to the colour of blood, by grafting it on the mulberry; and the tree in the Tyburtines country, "grafted and laden with all manner of fruits," which are regarded by modern grafters as physiological impossibilities,) it would seem that very little confidence could be placed in his statements of any kind. But what reason have we to doubt the authority of a man. whose life was spent to the benefit of mankind, and whose death was caused by his perseverance in search of truth? Instances of grafting trees of different families upon one another, are also mentioned by other old authors, and even our Evelyn, of more recent times, states that he saw, in Holland, a rose engrafted upon the orange. Columella, a practical husbandman, who wrote some years before Pliny, describes three methods of grafting, as handed down to him, by whom he calls the "ancients," besides a fourth method of his own, and a mode of inarching, or grafting by approach, "whereby all sorts of grafts may be graffed upon all sorts of trees." It would appear, however, that the art of grafting, at the period in which he flourished, was comparatively a modern invention, as it is not mentioned by Moses, in his directions to the Israelites when they

\footnotetext{
" ***** shall come into the land, and shall

have planted all manner of trees;"
}

neither by Hesiod nor Homer, although forming a part of the subjects on which they wrote.*

Whitaker, in his "History of Manchester," conjectures that the apple was brought into Britain by the first colonies of the natives, and by the Hædui of Somersetshire in particular; hence Glastonbury was distinguished by the title of "Avellonia " or apple orchard, previously to the arrival of the Romans. Before the IIIrd century, this fruit had spread over the whole island, and so widely, that, according to Solinus, there were large plantations of it in the "Ultima Thule." The manufacture of wine from the apple, appears to have occurred in Norfolk, at the beginning of the XIIIth century; for it is stated by Bloomfield, that, in the sixth year of King John, (1205,) Robert de Evermere was found to hold his lordship of Redham and Stokesly, in Norfolk, by petty sergeantry, the annual payment of two hundred pearmains, and four hogsheads of wine of pearmains, into the exchequer, at the feast of St. Michael. The making of cider was introduced into Britain by the Normans, who, it is said, obtained the art from Spain, where it is no longer practised. This liquor is supposed to have been first known, however, in Africa, from its being mentioned by the two African fathers, Tertullian and Augustine, and was introduced by the Carthaginians into Biscay, a province unfriendly to the vine, on which account it became the substitute in other countries.

Many of the better varieties of the apple were probably introduced into Britain from the continent, as the greater part of their names are either pure or corrupted French. Thus the "Nonpareil," according to old herbalists, was brought from France by a Jesuit, in the time of Queen Mary, and first planted in Oxfordshire. On the other hand, the celebrated "Golden Pippin" is considered as of British origin; and is noticed as such by French and Dutch authors. It is described bv

* The art of grafting, as well as that of pruning, has been ascribed to accidental origin. The occasional natural union or inarching of the boughs of distinct trees in the forests, is thought to have first suggested the idea of grafting; and the more vigorous shooting of a vine, after a goat had broused on it, is said to have given rise to the practice of pruning. 
Du Hamel under the name of "Pomme d'or," "Reinette d'Angleterre," and "Grosse Reinette d'Angleterre." Pippins were probably very little known in England until towards the close of the XVIth century. Fuller states that one Leonard Maschal, in the sixteenth year of the reign of Henry VIII., brought them from over sea, and planted them at Plnmstead, in Sussex. 'They were called pippins because the trees were raised from the pips or seeds, and bore the apples which gave them celebrity, without grafting.

The fine cider orchards of Herefordshire began to be planted in the reign of Charles I. The adaptation of the trees to the soil was soon discovered, and they spread over the face of the whole country. The cider counties of England lie something in the form of a horse-shoe, round the Bristol channel, the best of which are in Worcester and Hereford, on the north of the channel, and Somerset and Devon on the south. Of the varieties of the cider apples, the "Redstreak," and the "Sline," were formerly the most prized; and the cider of these apples, and the perry of the "Squash Pear," were celebrated throughout the kingdom. Some of the orchards occupy a space of forty or fifty acres, the produce of which is very fluctuating, and the growers seldom expect an abundant crop oftener than once in three years; and in a good year, an acre of orchard will produce about six hundred bushels of fruit.*

The introduction of the common apple-tree into the North American colonies, dates back to the earliest periods of their settlements. In the middle, northern, and some of the western states, no branch of rural economy has been pursued with inore zeal, and few have been attended with more successful and bencficial results, than the cultivation of orchards. It was not undertaken on an extensive scale, however, until about the commencement of the present century, when experience had taught the hardy yeomanry of the soil, that "the moderate use of cider, as a common beverage, was highly conducive to sound health and long life." It appears from Dodsley's London "Annual Register," that in the year 1768, the Society for promoting Arts, \&c., at New York, a warded a premium of ten pounds to 'Thomas Young, of Oyster Bay, for the largest nursery of apple-trees, the number being twenty-seven thousand one hundred and twenty-three. Between the years 1794 and 1808, Mr. William Coxe, of Burlington, New Jersey, enriched hị lands in that vicinity with extensive orchards, containing in the aggregate several thousand trees, which occupied a space of seventy or eighty acres; and within and since that period, numerous other orchards have been planted in various parts of the country, equaling, and even surpassing them in extent. Among the largest, and perhaps the most select, are those of Mr. Robert L. Pell, of the county of Ulster, New York, which have been planted about twenty years, and are said to contain twenty thousand trees. Anerica, too, has given birth to several valuable varieties of apples, which enter extensively both into her foreign as well as her domestic commerce, and are eagerly sought after in almost every civilized country of the globe. The most celebrated, and unquestionably the best variety extant, for shipping and for winter use, is said to have been the spontaneous production from a seed, more than a century and a half ago, in Newtown, on Long Island, near New York, and is well known by the name of "Newtown Pippin." The original tree stood " on the estate swned at present by Mr. John J. Moore, of that town, and for a long time its fruit was called "Gershom Moore Pippin," in honor of its former proprietor. After enduring for more than one hundred years, it died, in about the year 1805, from excessive cutting and exhaustion. Its scions were in great request by all the principal amateurs and orchardists of the day, and engrafted trees of it are still to be met with in the neighbouring towns, which have stood

\footnotetext{
* See Library of Entertaining Finowledge, article, "Apple."
} 
beyond the "memory of nan."* It is to be regretted, howevar, that the trees bearing this excellent variety of fruit, in many parts of the country, begin to manifest symptoms of decline; and it is believed by many, that the period has arrived, in which nature is to terminate their existence, and like their parent stock, are about to pass into decrepitude and final decay.

Is the longevity of the apple-tree is comparatively limited, which is obvious from the perishable nature of its wood, there are but few very aged individuals to be met with, either in Europe or in America. The oldest trees of which we have received any accomnt, are said to be growing near Plymouth, in Massachuselts, and are represented as being upwards of two cellturies old. An ancient tree of the "Pearmain" variety also stands on the Charter Oak Place, in Hartford, Connecticut, which was brought from England by Mr. George · Wyllis, previous to the year 1645 , and consequently must be more than two hundred years of age. Its trunk, though much decayed, still sends forth several thrifty bonghs, which annually produce from two to three pecks of excellent fruit.

On the authority of Dr. James Mease, of Philadelphia, there is a mammoth appletree at Romney, in Virginia, which grew spontaneously from seed, and is estimated to be fifty years old. It has attained a height of forty-five feet, with a trunk more than a yard in diameter, and a spread of branches of fifty-five feet. It is said to be in a flourishing condition, and continues to increase in size. In 1835 , it produced one hundred and eighty bushels of large fruit, besides four or five bushels left under its bonghs as damaged, and several bushels, which, it was calculated, had been taken by visitors, in the course of the season; so that the total produce, in the opinion of Dr. Mease, amounted to nearly two hundred bushels.

The greatest quantity of fruit borne on a single tree, in England, in one year, that we have heard of, is recorded in Dodsley's "Annual Register," for 1777. It grew in the orchard of Mr. Hackman, of Littlefield, in Sussex, and produced seventy-four bushels of fruit, which, on being weighed, was found to average fourteen pounds to each peck, and consequently the total product of the tree was nearly two tons.

The largest recorded apple-tree in Britain, is at Herbert's farm, near Hereford, which, in 1836, was forty-eight feet in height, with a trunk five feet in diameter, and a spread of branches of forty-eight feet.

Legendary and Mythological Allusions. The apple-tree, so singularly connected with the first transgression and fall of man, the fruit of which, as has long been supposed was eaten by Eve in Paradise, is distinguished alike in the mythologies of the Greeks, Scandinavians, and the Druids. The golden fruits of the Hesperides, which it was one of the labours of Hercules to procure, in spite of the sleepless dragon which guarded them, were believed by the pagans to be apples. Hercules was worshipped by the Thebans under the name of Melius; and apples were offered at his altars. The origin of this custom was the circumstance of the river Asopus having, on one occasion, overflowed its banks to such an extent, as to render it impossible to bring a sheep across it which was to be sacrificed to Hercnles; when some youths, recollecting that an apple bore the same name as a sheep in Greek, (mélon:) offered an apple, with four little sticks stuck in it, to resemble legs, as a substitute for a sheep; and after that period, the pagans always considered the apple as especially devoted to Hercules. In the Scandinavian "Edda," we are told that the goddess Iduna had the care of apples which had the power of conferring immortality; and which were consequently reserved for the gods, who ate of them when they began to feel themselves growing old. The evil spirit Loke took away Iduna and her apple-tree, and hid them in a forest, where they could not be found by the gods. In consequence of this malicious

* On the estate of Mr. Gardner G. Howland, at Flushing, there are several old trees of this description which bear abundantly every other vear, and are supposed to he one hundred vears of age. 
thett, everything went wrong in the world. The gods became old and infirm: and, enfeebled both in body and in mind, no longer paid the same attention to the affairs of the earth; and men, having no one to look after them, fell into evil courses, and becamc the prey of the evil spirit. At length the gods, finding matters getting worse and worse every day, roused their last remains of vigour, and combiniug together, forced Loke to restore the tree.

The Druids paid particular reverence to the apple-tree, because the mistletoe was supposed to grow only on it and the oak; and also on account of the great usefulness of the fruit. In consequence of this feeling, the apple was cultivated in Britain from the earliest ages of which we have any record; and Glastonbury, as has already been observed, was distinguished by the title of "Avellonia," or the apple orchard, previous to the arrival of the Romans. Many old rites and ceremonies arc therefore connected with this tree, some of which are practised in the orchard districts even at the present day. Apple-trees were sprinkled with a libation of cider and toast, for a fruitful crop, on 'Twelfth eve or Christmas day; and new apples were blessed by the priest on St. James' day, July 25th. Divinations were also practised with the pairing and seeds. T'ossing an apple to a girl was a token of love. As a symbol of Venus, it is modern. 'The custom of bobbing for apples on All-Hallow E'en and on All Saint's day, which was formerly common over all England, is still practised in some parts of Ireland. Throwing up little apples, and catching them on the points of knives, were favourite accomplishments of the Troubadours.

Soil and Situation. The apple-tree, to attain its greatest perfection and productiveness, requires a soil more or less calcareous, or one that rests upon strata abounding in marls, marly clays, or calcareous sandstone. It has been observed that the best apple orchards in England, are sitnated on the marls of the old red sandstone of Herefordshire; and those of the new red sandstone, the marly clays of the lias, and the calcareous and often marly beds of the inferior oolite, in the counties of Worcester, Gloucester, Somerset, and Devon. It has also been observed in Ireland, that the apple-tree flourishes best on limestone gravel; and in Scotland, that the few orchards which exist in that country, are to be found on soils more or less calcareous. On the continent of Europe, the two districts most famous for the apple, are Normandy and the vale of stutgard, in both of which, the soil is well known to abound in lime or marl. It has also been observed, that early fruits attain their greatest perfection in light, moderately rich, sandy soils; and that the late fruits succeed best when pianted in a soil that is strong and clayey. Trees will sometimes grow luxuriantly on deep gravels and grauwacke slate, without bearing apples. It has been found by experience that the above-named principles will hold good in the various parts of the United States. Within the last few years, much light has been thrown upon the adaptation of soils to particular plants, and it is now regarded as an established fact, that the apple-tree requires alkaline and probably earthy bases, as an indispensable condition to the perfection of its fruit. It has been shown by several enlightened chemists that the acids generated in plants are always in union witl alkaline or earthy bases, and caunot be produced without their presence, that all deciduons trees require a considerable portion of potash for the claboration of the juices in their leaves, and that they are prosperous or otherwisc, in proportion to the scarcity or abundance of that substance in the soil. It is well known that all clays contain potash, and that marls are principally composed of clay and carbonate of lime, and also contain potash, besides sulphate and plosphate of lime. Hence the presence of alkaline and earthy bases, particularly potash and lime, affords a satisfactory solution of the adaptation of marly soils to the production of apples, even withont taking into account the part which phospliate and sulphate of lime play in their formation.* 
With regard to the aspect best adapted to orchards, the surface, in general, should be more or less undulating, and at the same time, sheltered from the extremes of heat and cold; and it has often been remarked, that abrupt acclivities, which are too steep for tillage by the plough, or for the pasturage of heavy cattle, have been more certain in the production of fruit. Very open, or very elevated, exposed situations, as well as the bottoms of deep-sunk valleys, are alike unfavourable to the perfection of orchards. The former, from the low temperature and the violence of the winds, and the latter, from the liability to cold fogs and late vernal frosts, at the time the trees are in blossom, often, in one fatal night, utterly destroy the husbandman's hopes. A severe frost in early autumn, in a single night, may prove equally fatal to the tender flower-buds, in the latter situation, or, if not fatal, sufficiently injurious to impair their vitality, and render them unfit to withstand the cold of the ensuing winter; and, should they escape and put forth the following spring, the fruit will be knotty, blotched, and unfair. In planting an orchard, therefore, in Britain, or in the northern parts of AngloAmerica, the site should not be chosen

"In lowly vale, fast by a river side,'

wor, on the contrary, at an elevation too much exposed, but on moderately sheltered southern slopes, and where choice will further permit, inclining rather to the east than to the west. Planting the rows in a northerly and southerly direction, is thought to be advantageous, in order that the trees may derive the greatest benefit from the sun. But in the middle and western sections of the United States, more especially if the locality be in the region of large bodies of water, a northern exposure has proved to be decidedly more certain in producing fruit, than slopes inclining towards the south.

Propagation and Management. The Pyrus malus, and all its varieties, may be propagated from seeds, by grafting, or inoculation, and by cuttings and layers. It is a prevailing opinion in England, that the hardiest and best stocks are those which are raised from the seeds of the wild crab, (P. m. acerba,) and Mr. Knight recommends that the pips should be taken from the fruit before it is pressed. The mode practised in the Goldworth nursery, where fruit-tree stocks are raised on a more extensive scale than anywhere else in Britain, is to gather the crabs when they are fully ripe, and to lay them either in a heap to rot, or to pass them between two fluted rollers, and then to press out the juice, which is thus converted into an inferior kind of cider, and afterwards to separate the seeds from the pomace by maceration in water, and sifting. It is the opinion of many persons, both in Europe and in America, that it is of little consequence whether they are particular in the selection of seeds for sowing, from the fact that the fruit of trees raised from pips of the same apple differ both from the parent tree and from each other. But let it be considered that, when these variations take place, they may not always tend to deteriorate the fruit, but may often result in an exchange of one good quality for another, or may perhaps even exhibit improvements in the qualities. For instance, we may, at least, expect to obtain eariy fruit from the seeds of that which is early, and from those of late fruit the reverse; and by parity of reason, from sweet or sour, from juicy or dry fruit, we may also expect to obtain seedlings that will, in a considerable degree, correspond to their origin-a result, which it may often be an object for the cultivator to secure. Indeed, if it be true, that it is of "little consequence" what lind of pips we employ, there certainly can be no detriment in sowing seeds of good fruit; and this, we conceive, will be a sufficient hint for the prudent nurseryman to observe The pomace, therefore, should be obtained from the apples of healthy and vigorous trees, and should be thickly strewed, and covered with earth, in shallow renches about eighteen inches apart, so as to admit of the young plants being 
well hoed and weeded by hand in the following summer. Immediately after the fall of the leaf, in the ensuing autumn, the strongest and the most vigorous plants may be drawn, and planted in rows eighteen inches apart, and the same distance from each other, in a soil previously trenched, manured, and cultivated for garden produce. The remaining plants should be similarly managed in the following year. During their second and third year's growth, the ground should be kept perfectly free from weeds by repeated hoeings, and the plants would be greatly benefitted by a light forking between the rows. No knife should be allowed to touch them in this stage, unless it be to shorten an over-rampant shoot, which may be making too strong a diversion from the stem, and not even then, if it be more than a foot from the ground, particularly when it is intended to graft the stem; for every twig and every leaf contributes to the growth of the root and stem. When the stems of the plants have acquired half an inch or more in diameter, at a foot from the ground, the head should be cut off, and the operation of grafting or inoculation performed.

In order to insure the most desirable sorts by means of grafts, the trees from which they are intended to be taken, should be carefully inspected and marked, in the autumn previous, or at the time the fruit is in the greatest perfection. A month or six weeks before the season of grafting arrives, cut your scions, and keep them buried, at length, in dry earth or clay, out of the reach of moisture and frost, until required for use, in order that the stocks may advance over them in forwardness of vegetation. Select your scions from the outside branches of healthy trees, just in their prime, or at full bearing, about midway in their heaćs, and rather on their sunny sides, where the juices of the wood have been properly digested by sun and air. If the trees from which they are to be taken be young and vigorous, let the shoots consist of the last summer's growth; but if the trees be old or sickly, take them from the most healthful branches in the centre of their tops, or what is still better, the young shoots which spring from their trunks near the ground. Grafting may also be performed with the shoots of the current year, as well as with those of several years' growth. The proper time for grafting; is when the sap of the stocks is in brisk motion, which occurs in deciduous trees a few weeks before they put forth their leaves; but re-productive evergreer:s may be grafted during summer as well as spring. After making choice of the proper season, and all things are in readiness, let the operation of grafting be performed as quickly as possible. For dwarf trees, head down the stocks to within a few inches of the ground, or even below the surface. For standard trees, or those designed to attain their full height, engraft on vigorous branches, situated about midway in their summits, and well exposed to the sun and air. Ordinarily, the scions may be from one fourth of an inch to one inch in diameter; but, if necessity requires, they may be much larger or smaller. 'The middle portion of the scion is best; but where there is a scarcity, both the top and bottom-parts may be used. Take off a little of the lower end of the scion first, and then cut it of such a length as to leave from two to five eyes or buds for the production of new shoots, always taking care to cut off the top in a slanting direction. T'wo eyes will be sufficient for a standard tree, but four or five are better for dwarfs which are intended to be trained. Let the stocks and scions, if possible, be of the same thickness, in order that the inner barks of both will exactly unite and facilitate the flow of the sap, the immediate object being to bring the bark and young wood of both, into close and permanent contact, by which means the vessels of the one, will be enabled to communicate with those of the other. This operation is effected by several different methods, each of which have their adroates, and are adopted in various countries, according to the preference or caprice of the nurserymen. The modes which appear to be most generally approved of. in grafting young apple stocks, are what are called "Whip," or "splice-graft- 
ung" for scions less than a half of an inch in diameter, and "saddle-grafting" for those which are larger. Grafting upon old stocks and full-grown trees is usually performed by what is termed cleft-grafting.

In whip-grafting, cut the stock $(a)$ with a sharp knife, in an oblique direction without starting or bruising the bark, and the scion (b) in like manner of a corresponding angle. And then, with as little delay as possible, place the inner barks of the stock and scion in perfect contact, at least on one side, and bind them fast together with a riband of bass or guana, as indicated at $\left(c_{.}\right)$In this part of the process, take particular pains and see that the junction of the two barks is not in the least displaced. To protect the grafted parts from drought, air, and moisture, a layer of green cow-dung and fresh loam, well mixed in equal proportions, should be applied, with a trowel or spatula, one inch thick on every side, and a little above and below the union of the stock and the scion. A mixture of three parts fine clay, and one part fresh horse-droppings, well incorporated together, may also be applied with success. A bandage of moss or tow is sometimes wound round the clay or mixture, to prevent it from

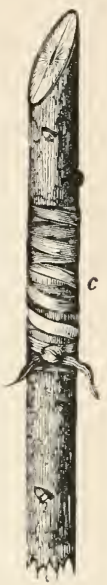

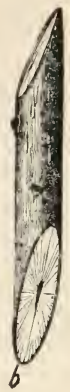

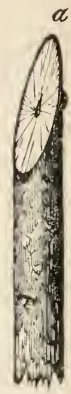
cracking by the heat of the sun, and from washing away by rains. In making the incision in the side of the stock which is to receive the scion, the knife ought, if possible, to be entered at the base of a bud, and pass upwards. The reason of this is, that the vital principle is more powerful there; and that the germs, both of buds and roots, are, in most plants, confined to the joints of the stems; though in some, as in several varieties of the elm, they appear to be distributed equally over every part of the stem and roots.

In performing saddle-grafting, cut, with a sharp drawing-knife or other instrument, the stock $(d)$ so as to leave the top in the form of a wedge. Split the lower end of the scion $(e)$ and pare each side of the cleft, so as to fit, when seated, exactly on the top of the stock, with the inner barks of both in perfect contact. And then, with a bass riband, bind the parts strongly together, as at $(f$,$) and perform the operation of clay-$ ing as in the preceding method. In three months or more after grafting, remove the clay, and partially loosen the bass ribands which are bound round the grafts, in order that the scions may have more room to expand. In a few weeks more, when the parts have been partialiy inured to the air, and when there is no danger of the scion being blown off by the winds, the whole of

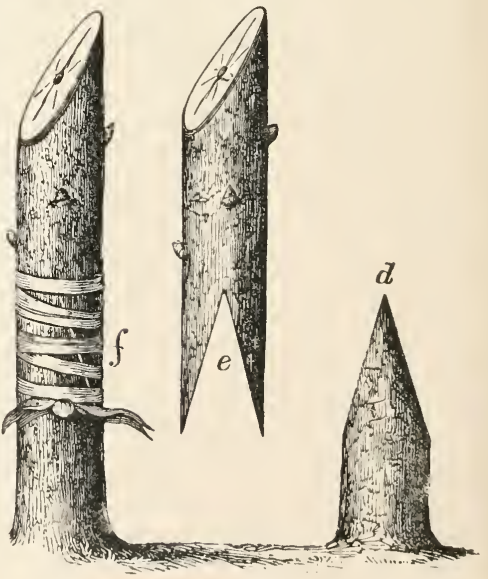


the ligature may be removed. Should the grafts have much lateral motion, caused by the wind, they should be secured to a stake or a frame.

In grafting, as well as in transplanting trees, particularly those which are liable to be affected by the change of situation, as the magnolias, walnuts, dc., they should always be planted or inserted, in the same position, with reference to the sun as that in which they grew previous to their removal.

When the grafts have grown about two feet in heiglit, the plants should be removed, or planted out in land similarly prepared as in the nursery beds, in rows four feet apart, with an equal distance between each, where they are to remain until finally removed. Before the plants are drawn from their graftingsites, no side-shoots should be cut off, except those below the graft. On their removal to open rows, any overgrown branch may be shortened, and two or three of the lowermost cut off close to the stem. After this, the stronger side-shoots only should be moderately shortened, in order to encourage the upward growth until a good head is formed, about six or seven feet above the ground. The side-shoots may then be removed close to the stem, in two successive years, while the head is left to its unrestricted growth. It is a very common, and at the same time, a very bad practice, to cut off all the side-shoots early, leaving only two or three twigs at the top, by which means the plant is very much checked in its growth, and instead of producing a firm and tapering stem, it becomes almost cylindrical, and tortuous, instead of upright. Those who treat plants in this way, are undoubtedly ignorant of the true nature of their growth, and the important office of their leaves; and, therefore, in attempting to assist nature in promoting the growth of the head, most injuriously interfere with her operations. If such persons had equal facility of witnessing the growth of the roots, they would no doubt think it their duty to cut part of them away, with a view of promoting the growth of the stem; at least, such a proceeding would be no less absurd. Every leaf is a feeder of the plant, as well as every rootlet; and no interference with the progress of the tree should be allowed, except for the purpose of preventing any side-brancl becoming a rival to the head. When, however, the tree has attained the required height of stem, and the head has pushed forward strong shoots above that height, the whole of those on the stem may be finally cut away, as before directed, the stem having by this time gained sufficient substance and strength, to preserve its erect position, and to support the head.*

The subject of grafting necessarily involves that of the selection of the best varieties, whether they are new, or in the vigour of their bearing, or are intended for the cider-mill, the table, or the kitchen; but it would be quite incompatible with the speciality of this treatise to notice, even in a tabular form, one half of the apples recommended in nurserymen's catalogues; and there are many other points connected with the management of orchards, which, for the same reason, must necessarily be omitted; but there is one particular connected with this subject, which we here beg leave to introduce.

A theory was advanced many years ago in England, and has lately been revived in that country, and is gaining ground in America, that the "chance of life in a scion is affected by the chance of life in the original seedling which began the species ;" that is, when the natural period for the decline of the parent tree lias arrived, the scions taken from it will also be found in a declining state, though growing upon stocks in other respects vigorous. 'The advocates of this theory contend, that each particular variety of apple has its period of vigour and decline, and its duration canuot be protracted by grafting beyond a certain limit; and what they conceive to be very remarkable, is, that within that natural limit, the grafts

* See Journ. Roy. Agr. Soc. of England, vol. iv., p. 384 . 
partake both of the vigour and decrepitude of the parent tree or variety. Although the period of duration is not known with any precision, it is thought to be longer in some varieties than in others. It is generally supposed, however, that it never much exceeds two hundred years. It seems that this opinion has chiefly arisen from the fact, that many kinds of the most celebrated Enropean varieties have long since disappeared from their catalognes, and can now no longer be found; while many others, which were much esteemed in their "palmy days" of bearing, are fast approaching to extinction, and will soon no longer exist. Although the above hypothesis may seem plausible enough in itself, we cannot but remark, that the want of durability of the varieties in question, does not apply to every set of scions; for many sorts of apple, as well as several other kinds of fruit, appear to have been readily propagated by means of successive scions, from the times of our forefathers. For instance, the New town pippin, the parent stock of which has been dead for forty years, has been successfully cultivated for at least one hundred years from before that period, and is still to be met with in the highest perfection in the markets, both at home and abroad. Furthermore, experience has shown, that niany of the scions of deteriorated varieties, have flourished for a time after grafting, and afterwards, have appeared to die, not from old age, but from disease. Thus Sharrock, who wrote in 1672, inquired "whether the canker in pippins arose not from incongruous grafting;" and Miller and Knight, of more recent times, each complained that pippins became cankered from a similar cause. Nevertheless, we do not wish to be understood, that the age of a tree is of little moment in the selection of scions; for, when a tree is evidently on the decline, an experienced nurseryman would not cull scions from it by choice, lest they should prove sickly and diseased; neither would he take them from a young tree, before it had arrived at its proper period of bearing. For every cutting taken from the apple, and probably from many other trees, will be affected by the state of the parent stock. If too young to produce fruit, it will grow with vigour, but will not blossom before it has passed through its successive periods of ripening wood; and if too old, it will immediately bring forth fruit, but will never make a healthy tree. It may further be stated, that stocks often so much influence the scions engrafted upon them, by habit, if from no other cause, that their fruit is essentially different from that borne on the parent tree; and both stocks and scions, in being transferred to different soils or situations, often improve or deteriorate in the character of their fruit, sometimes becoming more healthfil, and at others more sickly and diseased. That most ingenious and thoroughly practical people, the Chinese, have long siice been familiar with the practice of grafting scion upon scion, one above another, several deep; but in order to secure the agreement between the stocks and scions, they engraft each stock and each scion from its own respective branches.

The propagation of the apple by budding or inoculation is also practised to a considerable extent, but it is thought by many to possess fewer advantages than by grafting. In this part of vegetable economy, it may be proper to remark, that every fruit-tree must have a certain age before it will produce fruit. For example, the peach will bear the third or fourth year from the stone; but an appletree from the seed, must be twelve or fifteen years old, to produce fruit in perfection. And it is remarkable, that scions or shoots from the top branches of a bearing tree are essentially of the same age as the tree itself, and those growing from the roots or trunk near the earth, are no older in point of maturity, than the tree was when of the height of the parts from which they spring. For a detailed description of the process of budding or inoculation, which will apply equally well to most fruit-bearing trees, the reader is referred to our articles on the orange and the peach, linder the head of "Propagation," \&c.

The apple, like the pear, may be grafted or inoculated on the common thorn: 
vut it does not form so desirable a tree. When intended to be grown as a divarf, it may be inserted on stocks of the Siberian crab, the "Wise Apple," (court pend" plat, of the French,) or on paradise stocks. It may also be propagated by inarching or grafting by approach; that is, by uniting a scion to a stock standing near by, without being separated from its parent tree.

Preparatory to the planting of an orchard, it is desirable to determine the quality of the fruit of seedlings at as early an age as possible, and to know whether they are to be cut off at the gromind and grafted, or to be preserved entire. In order to do this, the following devices have long been practised, and have usually been attended with success. Any time within the month of May or Jume, select a horizontal branch of the tree designed to be rendered fruitful, and remove from the part near its junction with the trunk, a ring of bark from one fourth to one half of an inch in breadth, taking precaution, at the same time, to rub off, within the space operated upon, every part of the bark, quite to the sap-wood, in order to obstruct the descending juices in the succeeding antumn. Another expedient employed for the same purpose, is, to make two turns of a copper wire closely round the bark, with a repetition of the operation at some distance below, and leave it to be incorporated by the growth of the tree. Should either of these devices prove insufficient, or shonld the healing of the wounded parts follow too quickly, the operations may be repeated in the same, or in the following season. The total removal of a ring of bark produces the desired effect, sooner, by a whole year, than a mere stricture upon it, although the pressure from the wire, of itself, finally kills the bark underneath. Alkaline, or ammoniacal preparations have also been applied to young trees, as well as to old ones, for the purpose of stimulating their growth, and accelerating their fruitfulness, such as white-washing their trunks and branches, rubbing them with soap-suds, and spreading round their roots lime, gypsum, charcoal, ashes, \&c.; and, "human urine," says Columella, "which yon have let grow old for six months, is well fitted for the shoots of young trees. If you apply it to vines, or to young apple-trees, there is nothing that contributes more to make them bear an abundance of fruit; nor does this only produce a greater increase, but it also improves both the taste and the flavour of the wine, and of the apples."

Apple-trees are generally fit for planting out in the orchard at about the age of seven years, at which time, if they have been properly treated in the nursery, they will be about an inch and a half in diameter at the middle of the stem. The particular age, however, at which they should be removed to their final destination, after they have formed a good head, is not very important, provided they do not much exceed the above-named size; and the objection to a larger size, is the difficulty of taking them up with a due proportion of roots, so as to prevent them from receiving too great a check. If trees are to be purchased from a 11 ursery, either as seedlings, or ready grafted, and the sorts camnot be relied ıpon, they should be inspected in the previons summer while in leaf; and those selected which give the greatest promise of making good and healthy trees, and the most likely to be good bearers. They should have full and flourishing heads; and broad, roundish leaves, as such generally bear the largest fruit, and the most abundant crops. In winter, such trees will present a larger and fuller bud than those the leaves of which are small and pointed; but though these are favourable indications of the size of the fruit, and the productiveness of the tree, they are by no means so with regard to other qualities; as the trees may be early or late bearers, and the fruit red, yellow, or green; and whether they will produce cither good cider-apples, or those better adapted to the table, can only be known when they produce their first fruit. If they then prove not such as are desired, or there be too great a proportion of one sort, grafting or budding in the head should be had recourse to. 'This will, it is true, protract the time of bearing a year or two; 
but it is much better to submit to two or even three'years' delay, than for a hundred years to have bad fruit. 'The most proper time for planting out, is soor after the trees have shed their leaves. They should be taken up with their lateral roots at least two feet in length, and planted as soon as possible. In planting orchards, the ground, for the space of at least six feet in diameter, should be trenched two spades deep, the lowermost of which should be cast away, and the other well broken with a spade or otherwise, and the place of the former supplied with turf, or a compost of stable-dung, a small portion of leaf-mould $0 ;$ : peat, well mixed with newly-slacked lime, ashes, soda, or almost any other alkaline substance. It is of some importance that the tree, when planted, should stand in the same position with regard to the sun, as that in which it grew in the nursery; and, in order to insure this, the south or north side of each tree should be marked before it is removed, and this might be done at the time of selection. Care should be taken to surround the roots with the finest part of the mould, and to plant the trees at precisely the same depth as that at which they before grew. 'The ragged or lacerated ends of the roots should be taken off with the knife; and the hole, after being duly prepared as above, opened wide enough to admit the longest of them. If the ground at the time of planting be dry, and water can be conveniently procured, two or three bucketfuls, applied to each of the trees, will be of essential service in securing its growth. The tree, being temporarily fixed in its proper position by a single stake, the hole should be nearly filled with mould, and the water poured itpon it. After a few hours, the remaining mould may be added, and well trodden down. If, in the ensuing spring, a thick dressing of a well-mixed compost of lime and earth be laid over the space that has been opened round each tree, and afterwards dug in, it will be highly beneficial to it; and digging or forking round the trees should be repeated for three or four years in succession. After this period, it is probable that the leaves falling from the trees, will be nearly or quite adequate to the supply of all the organic or gaseous substances required for the perfection of their fruit; therefore, it is in the mechanical state, and to the inorganic constitution of the soil that we are to look for those conditions which are either favourable or unfavourable to the growth and productiveness of such trees. It is not enough that the soil be neither too open nor too retentive for the supply of a due degree of moisture; it must also contain those inorganic or mineral substances which the tree and its fruit require. When the defects are known, the remedies are obvious. By draining and trenching only, a stiff soil may probably be rendered favourable to the production of fruit; and, if this operation fail to produce the desired effect, it is evident that mineral manures are wanting, which may be supplied by heavy dressings of lime, or peat ashes, or both. If the soil be too porous, a heavy dressing of marl is the best remedy; and when this cannot be procured, clay, with lime, and peat or other ashes, will supply its place.

When young trees have been carefully planted, and well fenced, they will require but little attention, except that of keeping up the fences, and to see that they are not shaken by the wind. The mode of fencing must be suited to the kind of stock kept in the orchard. If sheep only are depastured, each tree may be closely surrounded by strong thorns stuck in the ground, enclosed and sustained by thick stakes, firmly driven, and reaching nearly to the forks. These stakes should be strongly bound to ether by bands or withes; and, as a further precaution against damage from the gnawing of sheep, at any exposed place, the tree should be washed or smeared with a mixture of creamy lime and green cow-dung, which should be renewed, from time to time, as occasion may require. If it be indispensable to stock the orchard occasionally with large cattle, each tree must be fenced by two or three strong rough posts, firmly fixed in the ground, and united 
by s: rong battens or short rails, nailed to each. In some situations, where suitable stones abound, the trees are sometimes surrounded by circular walls.*

In answer to the question often asked, "Whether orchards ought to be ploughed?" we would reply, that it is an old and prevalent opinion, that fruittrees of every kind are improved and rendered better, by having the ground stirred round them, in order to let in the dews and air to their roots. And with this view, orchards have often been tilled for potatoes, grain, and other crops, to which there are two striking objections; first, they require the light of the sun, and will not well flourish under the shade of trees; and second, that being exhausting crops, they impoverish the soil, which is so far injurious to the apples, both in quantity and quality. But the Jerusalem artichoke, (Helianthus tuberosus, ) which is extensively cultivated on the banks of the Rhine, rather prefers the shade, and would, therefore, thrive well under the trees; and, so far from exhausting the land, will, it is said, bear abundantly for ten or more years in succession, without manure, even upon poor soils. It has been furtler stated, that it does not require much tilling after it has once been planted; for, it is only necessary to draw the tops ont of the ground, when ripe, the remaining roots being sufficient to produce the next year's crop, without fresh setting, and thus they continue from year to year until they die of old age. All these properties seem to render this plant suitable for orchards; the pulling it up will open the ground, while the avoidance of digging, after once set, will spare the roots of the trees many a wound. It also possesses the rare property of absorbing nitrogen largely from the atmosphere, which is probably the reason of its thriving so well without manure, and consequently improves the condition of the soil. It is planted in drills similar to potatoes, and like them, its roots are employed for food for man and animals. It has been observed that orcliards, when ploughed, often rapidly advance to a certain point, and then cease to flourish; but this is believed to be caused by planting the trees too near each other, and by ploughing between them, hurries their roots towards each other until their interference checks their future growth. The chief objection to ploughing an orchard is, that, in a hilly country, having a soil easily carried off by water, such a soil, if kept bare and loose, will, in time, become sensibly diminished, where horizontal furrows are insufficient to remedy the evil. But this circumstance ought to forbid the use of the plough, not only in an orchard, but for any object whatever, in such a situation. ' In ploughing an orchard, care must also be observed not to go too deep amongst the roots, which would greatly damage the trees by the wounds they would receive.

The distance at which trees should be planted in an orchard must be from forty to sixty feet apart, according to the richness of the soil; for it should be always remembered that the roots extend far beyond the branches; or another mode may be adopted that will answer for the present generation and for posterity. This may be effected by planting what may be called principal trees, at the distances which their full growth will require, and placing between them, either as standards, or as dwarfs, supernumerary trees, to remain until the principal ones shall require them to be removed. 'The supernumeraries, in this case, will have a peculiar value; since, if they be dwarfs, they will immediately come into bearing, and will ripen their fruit early in the season, which can be gathered witl great facility; and if it falls to the ground, will often escape from being bruised. Dwarfs, too, may easily be pruned, and very conveniently thinued of their superfluous fruit; or, they may be readily cleansed from every offending thing, or supplied with nutritious washes. On the other liand, if the supernumeraries be seedlings or grafts, they will be ready for the supply of such vacancies as will

* See Journ. Roy. Agr. Soc. of England, vol. iv., pp. 390, et seq. 
have occurred amongst the standards, from accident or disease, at the time of removal. Among other advantages resulting from the wide planting of orchards, may be mentioned the healthful and invigorating influence of the sun on every part of the trees, and thereby causing them to bring forth more fruit, and that which is larger, fairer, and better flavoured; for an apple, of a globular form, three inches in diameter, contains twenty-seven times more bulk, than one of an inch in diameter, (globes being to each other as the cubes of their diameters.) Hence apples are not to be valued by their number only, but by their size; and indeed, by their weight; for most weight must be expected where there is most juice, and juice will follow health and vigour.* Another important advantage is, that trees planted at wide intervals from each other, have more room to spread, without the interference of their roots and branches, and consequently will bear a greater quantity of fruit. A tree witlı a hemispherical head, fifty feet in diameter, will have twenty-five times as much fruit-bearing surface, as one of the same formed head ten feet in diameter. In other words, circumstances being equal, it would produce as much fruit as twenty-five of the smaller trees, although it would occupy but little more than one half as much ground.

The usual mode of planting out trees in an orchard, is the square-form; but the system most esteemed and adopted by the ancients, was to plant them in quincuncem, that is, in the form of the Roman nunieral V., which answers to four asterisks placed in the corners of an oblong square, with a fifth midway between them. The two modes may be illustrated by the following diagrams:-

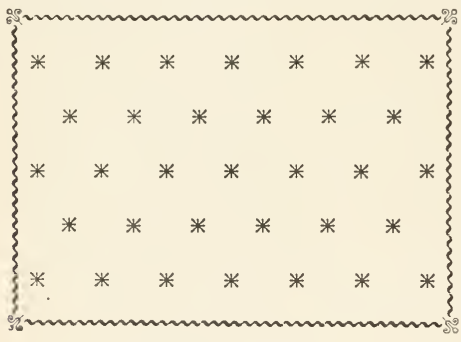

QUINCUNX-FORM.

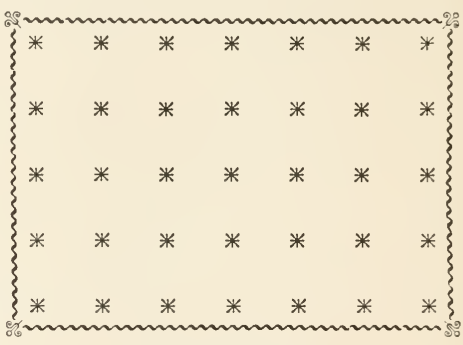

SQUARE-FORM.

The quincunx, when compared with the square-form, saves one eighth of the ground, and has the advantage of disposing the trees at equal distances apart in every direction. $\dagger$ The vacant spaces which will be left at the ends of every other row of standards, may be filled with supernumerary dwarf trees, and allowed to remain permanently. To plant temporary trees between the principal ones, so as to divide the distances into halves, will require about two supernumeraries for every principal one, by the square-form, and a less number by the quincunx-

* Papers of Mass. Agr. Soc., 1804, p. 85.

$\dagger$ The following is a practical method of laying out an orchard by the quincunx-form :-First, deter mine the points for the centre of each tree in the outer row, by setting stakes at equal distances apartsay fifty feet. Take a line one hundred feet in length, with a knot or mark in its middle, and place its two ends at two contiguous stakes; then extend the knot or mark till the whole line becomes stretched in two equal lengths, and the knot or mark will indicate the place for a tree in the next row, where there should be driven another stake. Repeat the same operation with a second pair of stakes in the outer row, and another point will be determined in the next row, where there must also be inserted a stake. In like manner, continue with all the other stakes, checking, in the mean time, each of the stations by oblique, cross, and longitudinal sights, till the whole be completed. Every tree in such an orchard, will be fifty feet from each of its neighbours; but the rows will be only forty-three and three-tenths feet apart : and this distance is to fifty feet nearly as seven is to eight. Consequently, one eighth of the ground ai... ve sived, as intimated above. In order to show the distance of the rows apart by the quincunx-firm, the 
form, if $d$ warf standards are allowed to remain in the vacant spaces which occur at the ends of every other row. 'This will be more clearly understood by an inspection of the diagrams below, in which the asterisks denote the standard trees, (D) the permanent dwarfs, and (s) the supernumary trees.

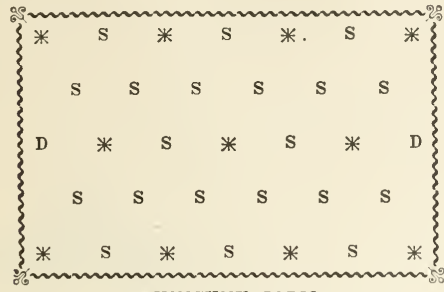

QUINCUNX-FORM.

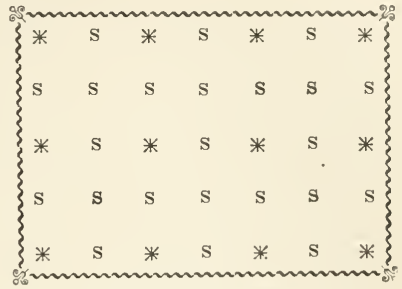

SQUARE-FORM.

distance of the trees from each other being given, the subjoined table has been constructed from Euclid i., 37. which may be applied with advantage to other species of cuiture :-

\begin{tabular}{|c|c|c|c|c|c|c|c|}
\hline 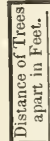 & 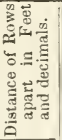 & 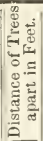 & 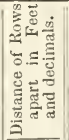 & 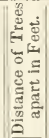 & 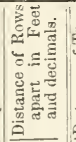 & 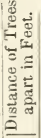 & 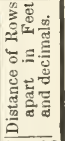 \\
\hline$\frac{1}{2}$ & $\overline{0.433}$ & 16 & $\overline{13 \cdot 856}$ & $\overline{31}$ & $\overline{26.847}$ & $\overline{47}$ & $\overline{40 \cdot 703}$ \\
\hline & $0 \cdot 866$ & $16 \frac{1}{2}$ & $14 \cdot 289$ & 32 & $27 \cdot 713$ & 48 & \\
\hline 2 & $1 \cdot 732$ & $17^{\circ}$ & .722 & 33 & 28. & 9 & \\
\hline 3 & $2 \cdot 598$ & 18 & & 34 & $29 \cdot 445$ & $49 \frac{1}{2}$ & \\
\hline 4 & $3 \cdot 464$ & 19 & .454 & 35 & & 50 & \\
\hline 5 & $4 \cdot 330$ & 20 & & 36 & 31 . & 51 & \\
\hline 6 & & 21 & & 37 & & 52 & \\
\hline 7 & & 22 & & 38 & & & \\
\hline 8 & & 23 & & 39 & & & \\
\hline 9 & & 24 & & 40 & & & \\
\hline 10 & & & & 41 & 35 . & 56 & \\
\hline & & & & 42 & & 57 & \\
\hline & & & & 43 & & & \\
\hline 13 & $11 \cdot 258$ & & & 44 & & & \\
\hline 14 & $12 \cdot 124$ & & & 45 & & & \\
\hline 15 & & & & 46 & 837 & & \\
\hline
\end{tabular}

The following table may also be useful for readily pointing out the number of trees and other plant required for a statute acre of land, when planted at any of the under-mentioned distances apart :-

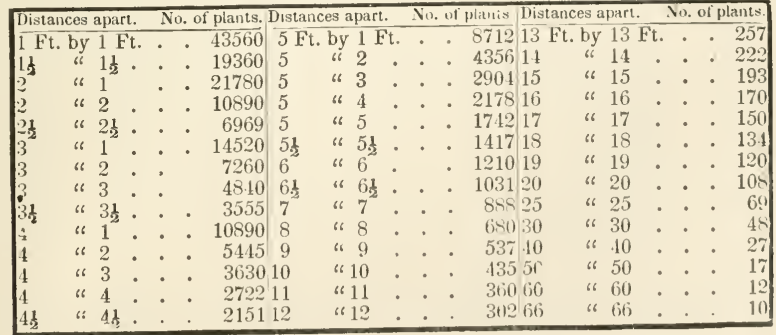


In pruning apple-trees, it is alike important to regard the general form of their heads, as it is the management of their individual branches. A system which has long been practised in Europe, and has been adopted for many years in the United States, is to lead out of the upright stem, at a given height, a series of horizontal branches, each series comprising four limbs, situated at proper intervals, till the tree can bear no more of them. The advantages resulting from this mode are, that the boughs can be made capable of producing fruit at an earlier age; the strength of such branches, at the place of their insertion into the stem, is much greater than of those which grow at more acute angles; and that the flat or semi-spherical heads of such trees seem designed not only to lessen the hold of the wind, but to diminish the influence of the shade on the crops around them, as well as to admit light, heat, and ventilation within them. It has been recommended that the head of the tree be somewhat hemispherical, with a hollow space left in the line of its central parts; for these parts are more secluded from the light and air, than the rest of the tree, and consequently are not adapted to the production of fruit. In forming the head of a tree in the Atlantic

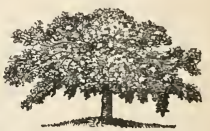
parts of the United States, it has also been recommended to diminish the weight and quantity of boughs on its east or north-east side, (the side opposite to the prevailing winds, ) as trees generally incline that way; and to enconrage the branches on the opposite side to screen the sun from the trunk, in order to prevent its powerful rays in summer from killing the bark, and causing canker and ruin to the tree. Mr. Knight recommends most attention to be paid to the lateral branches, which, if unchecked by occasional pruning, are apt to load the tree too much at the extremities. Mr. Joseph Cooper, of New Jersey, entertained a similar opinion. "Young fruit-trees," said he, "should not have the side-shoots cut close to the stem, which forces the growth the whole way up the top; which becomes so weighty, as to bend and spoil the trees. I have found it better to cut the ends of the side-shoots $* * * * *$ which will encourage the growth of the stem or trunk, till it acquires strength to support a good top." After the head of the tree is properly formed, nothing more is necessary than to cut out all the branches that cross each other, or are likely to be in the way within three years. As the trees produce their fruit upon crrsions, or spurs, care must be observed not to cut off or destroy them, as they continue to be fruitful for several seasons. It has also been recommended to "prine at a fork," or at least, "at a bud ;" on the ground that a wound is best protected when covered by bark from without; and as the bark never spreads over the end of a long stump, but only over the place from which it has been taken, the new cover must be supplied by the extension of the bark of another branch, and such a branch, even a bud may become in time. Till this extension of bark be effected, however, an artificial covering should be substituted, by shaving the wounded surface close and smooth, and applying immediately a plaster composed of

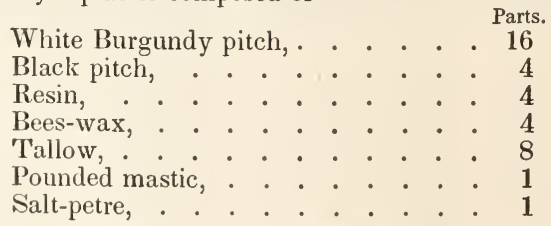

This mixture should be warmed over a slow fire for three fourths of an hour; and when melted, but not too hot, be put on with a brush to a depth of one sixteenth to one half of an inch in thickness, according to the size of the wound. 
In performing these operations, particular care must be observed not to injure the remaining branch or bud; and should a cut accidentally be made, the wounded part should by no means be removed, but be pressed fast together, and a coat of the composition immediately laid over it. The bearing capabilities of apple-trees of considerable age may be much improved by judicious pruning, in removing decayed branches, and old, unprofitable boughs, where the head is too much crowded. These should, in all cases, be taken off by a clean cut, close to the branch from which they are separated, or at least to a lateral shoot, so that the part nay heal over. as soon as possible. The proper season for pruning is about mid-summer, or about the time the downward motion of the sap commences, and when a more perfect cicatrization of the wounded parts take place, than if pruned in the winter or spring. Another important rule in pruning is, to remove every part of the tree "incurably diseased;" not only because the disease may be contagious, but because rottenness of itself occasions increased evils, from the weather, from insects, and other causes. When the adjoining wood and bark are pruned to the quick, and properly sheltered, room is given, as we have pointed out, for a natural cover to be made for the wound. But we must repeat, that the wound, if possible, must be protected, or the evil may be made worse, from various causes. When consistent, the wound occasioned by pruning should be on the lower side of the branch, rather than on the upper side; especially where no composition is intended to be applied, as the lower side is least exposed to the sun and rain. It is a good rule to have no reliance on boughs which are kept continually damp by the drippings of other boughs, or upon those which are kept constantly screened from the sun. "The general shape of an old tree" should be kept substantially the same, in order that the ascending juices may continue as nearly as possible in their established channels; or if changes are aimed at, they should be gradıal. Hence, care must be taken not to cut off "too many large limbs at a time," lest the sap of some of the roots, and particularly those corresponding to these limbs, should be too suddenly checked in its ascent. Sometimes trees, which at first were good bearers, become stag-lieaded and unfruitful. It is more than probable that this condition is owing to some defect in the soil. The proper remedy to be resorted to in this case is, what is called "heading down ;" that is, removing all the branches to within a foot or two of the main forks, or the stem of the tree, in order to encourage the formation of a liealthy and vigorous head. This operation should be accompanied by a heavy dressing of compost, formed of lime, ashes, and loam, extending for a considerable distance round the tree, which should be dug in with the turf. According to the opinion of some orchardists, pruning, after the head of the tree is properly formed, is to be avoided as much as possible, as it creates numerous useless slıoots, and prevents the production of fruit. A very important advantage, however, may be derived from this principle, by provoking young shoots to appear by skilfully wounding the bark in the vacant spaces of a branch, and thereby regulate the symmetry of the tree.

Accidents, Diseases, and Insects. The apple-tree, as a standard, is more liable to accidents, the attacks of insects, and to diseases, than the pear-tree. Its branclies are more frequently broken by tempestuous winds, whereby their wounded parts, in being exposed to the vicissitudes of the weather, sooner decay, and tend greatly to lessen the productiveness and the duration of the tree. When sitnated near the borders of woods, orchards are often injured by the American grouse, or partridge, (Tetrao umbellus, ) which greedily devours the flower-buds, in winter, when the ground is covered with snow. The apple-tree is also subject to canker; more especially when planted deep, or in a soil which is annually dug romnd it to some depth, and cropped with vegetables. In some soils, also, particularly those which contain much oxide of iron, the tree is liable to canker under any mode of cul- 
cure; and the remedy, or palliative, in such soils, is liming abundantly, to neu. tralize the oxide; and planting on the surface, without digging the ground, but only hoeing, or keeping it entirely in pasture. The trunk and branches, in some soils, and in moist situations, are liable to be infested with lichens and moss, which must be scraped off; and in others, the mistletoe is apt to take root, which must be cut out. 'The fungus, Ecidium cancellatum, which also grows on the leaves of the pear-tree, and produces what is called mildew, is not unfrequent on those of the apple-tree.

The leaves, flowers, fruit, and wood of the apple-tree are subject to the attacks of numerous insects, or their larvæ, against which there are few or no remedies. One of the most common enemies to this tree, in Europe, particularly in England, is the cotton insect, or woolly aphis (Aphis lanigera, of Linnæus, and Eriosoma mali, of Leach.) 'This insect was first described by Hausmann, in 1801, as infesting the orchards of Germany; but it was noticed in England as early as the year 1787 , and has since acquired in that country, though improperly, the name of "American blight," from the belief that it had been imported from America. Although it exists in the United States, it is exceedingly rare; but it is thought not to be indigenous, but was brought to this country on fruit-trees from Europe. It appears to have been known, also, by the French gardeners for a long time previous to either of the above-named dates; and according to Mr. Rennie, it is found in the orchards in the vicinity of Harfleur, in Normandy, and is very destructive to the trees in the department of Calvados. The eggs of this insect are so small that they cannot be distinguished without the aid of a microscope. They are enveloped in a cotton-like substance, furnished by the body of the insect, and are deposited in the forks of the branches, and in the chinks of the bark, at or near the surface of the ground, especially if there are suckers springing from that place. The young, when first hatched, are covered with a very short, fine down, and appear, in the spring of the year, like so many little specks of mould. As the season advances, and the insects increase in size, their downy coats become more distinct, and grow in length daily. This down is very easily removed, adheres to the fingers, when touched, and appears to issue from all the pores of the skin of the abdomen. When fully grown, the insects of the first brood are one tenth of an inch in length, and, when the down is rubbed off, the head, antennæ, sucker, and shins, are found to be of a blackish colour, and the abdomen of a honey-yellow. The young are produced alive during the summer, are buried in masses of the down, and derive their nourishment from the sap of the bark and of the alburnim or young wood directly under the bark. The adult insects, it is said, never acquire wings nor honey tubes, but from time to time, they emit drops of an adhesive fluid from the extremities of their bodies. Although destitute of wings, they are conveyed from tree to tree by means of their long down, which is so plentiful and so light, that they are easily wafted by the winds of autumn, and thus the evil will gradually spread throughout an extensive orchard. The numerous punctures of these insects produce on the tender shoots a cellular appearance, and wherever a colony of them is established warts or excrescences arise on the bark; the limbs thus attacked, become sickly, the leaves turn yellow and drop off; and, as the infection spreads from limb to limb, the whole tree becomes diseased, and eventually perishes.* A writer in the London "Entomological Magazine" describes the mode of propagation of this insect, and gives a method of destroying it as follows :- "These blights wander wherever it pleases the wind to carry them; and, if bad luck should drive one of them against the branch of an apple-tree, there it will stick, creep into a crack in the bark, bring fortl its young, and found a colony. The white cotton soon

* See Harris' Report, p. 193. Also Illiger's Magazine, i., p. 440 ; and Rennie's Insect Miscellanies,
p. 180. p. 180 . 
appears in large bunches; branch after branch becomes infected; the tree grows cankery, pines, and dies. How this is effected, no one knows, though the cause and effect are too evident to escape the notice of the commonest clown. In large orchards, it is vain to hope for a cure; but not so in gardens. Directly you see the least morsel of cotton, make up your mind to a little trouble, and you will get rid of it. In the first place, get a plasterer's white-washing brush; then get z large pot of double size; make your man heat it, till it is quite liquid; then go with him into the garden, and see that he paints over every patch of white, though not bigger than a sixpence; the next morning have the size-pot heated again, and have another hunt; and keep on doing so every morning for a fortnight. Your man will tell you it's no use-tell him that's your business, not his. Your neighbours will laugh at you for your pains-do it before they are up. I have tried it, and know it to be effectual. Spirit of tar has been used with partial effect; so also has resin. White-washing has been often tried, and, as it contains some size, is not entirely useless; and some horticulturists think it ornamental-I do not." *

The apple-tree, as well as the quince, mountain ash, June berry, and various species of thorns and aronias are attacked by the larvæ of the two-striped saperda, (Saperda bivittata, Say,) denoted by the adjoining figure. The upper side of the body of the perfect insect is marked with two longitudinal white stripes between three others of a light-brown colour, while the face, the antennæ, the under side of the body, and the legs, are white. This beetle varies in length from a little more than one half to three fourths of an inch. It comes forth from the trunks of the trees early in June, making its escape in the night, during which time only it uses its ample wings in passing from one tree to another in search of companions and for food. In the day-time, it keeps at rest among the leaves of the plants on which it feeds. In the months of June and $\mathbf{J} n$ ly, the females deposite their eggs upon the bark of the trees, near the roots, and the larvæ or borers hatched from them consist of fleshy whitish grubs, without legs, nearly cylindrical in their form, and tapering a little from the first ring to the end of the body. The head is small, horny, and of a brownish colour. The first ring is much larger than the others, the next two very short, and, like the first, are covered with punctures and very minute hairs. This grub, with its strong jaws, cuts a cylindrical passage through the bark, and pushes its castings backwards out of the hole, while it bores upwards into the wood. It continues in the larva state two or three years, during which it penetrates eight or ten inches into the trunk of the tree, its burrow at the end approaching to, and being covered only by, the bark. It is in this situation that its transformation takes place, which is completed about the first of June, when the beetle gnaws through the bark that covers the end of the burrow, and comes out of its place of confinement in the night. One of the oldest, safest, and most successful modes of destroying this borer is, to thrust a wire into the hole it has made; or, what would probably answer as well, to plug it up with soft wood.

Young apple-trees, and the extremities of the limbs of older trees, are very much subject to the attacks of a small species of bark-louse, (Coccus *****?) The limbs and smooth parts of the trunks are sometimes completely covered with these insects. They measure about one tentl of an inch in length, are of an oblong-oval shape, gradually decreasing to a point at one end, and are of a brownish colour, very near to that of the bark of the tree. 'There is also another speries of coccus, which inhabits the apple-tree, differing from the one above men-

* See London Gardener's Magazine, ix.. p. 335. † See Harris' Report, p. $\$ 9$. 
tioned in several important particulars. It is one of the kind in which the body of the female is not large enough to cover her eggs, for the protection whereof, provision is made, consisting, in this species, of a kind of menibraneous shell, of the colour and consistence almost of paper. In autumn, and during sinter, these insects are seen in a torpid state, and of two different forms and sizes, on the bark of the trees. The larger ones measure less than a tenth of an inch in length, and are in the shape of a common oyster-shell, being broad at the hinder extremity, but tapering towards the other, which is surmounted by a little oval, brownish scale. The small ones, which are not much more than half the length of the others, are of an oblong-oval shape, or almost four-sided, with the ends rounded, and one extremity is covered by a dark-coloured, minute, oval scale. For a description of the general habits of this family of insects, the reader is referred to our article on the orange-tree, under the head of "Insects."*

The tender buds and young leaves of the apple-tree are sometimes attacked, in May and June, by multitudes of small caterpillars, described by Dr. Harris, under the name of the eye-spotted penthina (Penthina oculann.) They are of a pale and dull-brown colour, warty and slightly downy, with the head and the top of the first ring of a dark shining brown. They usually acquire their growth by the middle of June, at which time they transform, and come out in the winged state early in July. These caterpillars live singly in the buds or opening foliage, which they fasten together and devour. The only sure mode recommended to destroy them is, to crush the withered clusters of leaves containing them or their chrysalides, and thus "nip them in the bud." But one of the greatest pests to the American orchards, as well as to the foliage of the elm, and sometimes of the cherry, plum, linden, and other trees, is the canker-worm, first described by Professor Peck under the name of Phalcena vernata. According to Dr. Harris, the canker-worm moths begin to make their appearance after the first hard frost in the autumn, usually towards the end of October, and they continue to come forth, in greater or smaller numbers, according to the mildness or severity of the weather after the frosts have begun. Their general time of rising, however, is in the spring, beginning about the middle of March, but sometimes before, and at others, after this time; and they continue to come forth for the space of about three weeks. It has been observed that there are niore females than males among those that appear in the autumn and winter, and that the males are the most abundant in the spring. The sluggish and wingless females instinctively make their way towards the nearest trees, and creep slowly up their trunks. In a few days afterwards they are followed by the winged and active males, which flutter about and accompany them in their ascent, during which, the two sexes pair. Soon after this, the females lay their eggs upon the branches of the trees, placing them on their ends, close together in rows, forming clusters of sixty to one hundred eggs or more, which is the number usually laid by each. The eggs are glued to each other, and to the bark, by a grayish varnish, which is impervious to water; and the clusters are thus securely fastened in the forks of the small branches, or close to the young twigs and buds. The eggs are usually hatched between the first and the middle of May, or about the time that the red currant is in blossom, and the young leaves of the apple-tree begin to expand. 'The little canker-worms, upon making their escape from the eggs, gather upon the tender leaves, and, on the occurrence of cold and wet weather, seek shelter in the bosom of a bud, or into the flowers, when the latter appear. The leaves, when first atta ked, will be found pierced with small holes, whiclı become larger and more irregular as the worms increase in size, until nearly all the pulpy parts are consumed. A very great difference of colour is observable among these 
worms of different ages, and even among those of the same age and size. Wher very young, they have two minute warts on the top of the last rings, and they are then generally of a blackish or dusky-brown colour, with a yellowish stripe on each side of the body; there are two whitish bands aeross the head; and the belly is whitish. When fully grown, these individuals become ash-eoloured on the back, and black on the sides, below which, the pale, yellowish line remains. Some are found of a dull greenish-yellow, and others of a clay-colour, with slender interrupted blackish lines on the sides, and small spots of the same colour on the back. The head and feet partake of the general eolour of the body; the belly is paler. When not eating, they remain stretched out at full length, and resting on their fore and hind legs, beneath the leaves. When fully grown and well fed, they measure nearly or quite an inch in length. They cease fceding when about four weeks old, at which time they begin to quit the trees. Some creep down by the trunks, but great numbers let themselves down by their slender threads from the branches, their instinets prompting them to get to the ground by the easiest and most direct course possible. After reaching the ground, they immediately burrow into the earth, to the depth of two to six inehes, unless prevented by weakness, or by the hardness of the soil. In the latter case, they die, or undergo their transformations on the surface. In the former, they make little cavities or cells in the ground, by turning round repeatedly, and fastcning the loose grains of earth about them with a few silken threads; and, within twentyfour hours afterwards, they are changed into chrysalides, and in due time, emerge from these retreats in their perfect form. In order to protect the trees from the ravages of the canker-ivorm, the only thing that would seem necessary would be to prevent the wingless femalcs from aseending the trunks to deposit their eggs. The expedients usually resorted to for this purpose, are, to fit a close collar of lead, tin, wood, or other materials, around the trunks of the trees, or a circular trough filled with oil. The application of belts of tar, liquid Indian rubber, and other viscid substances, to the bodies of the trees have been employed with partial success.

The apple-tree is also infested by the larvæ of the white-marked orgia, or tussock-moth (Orgia leucostigma, Harris.) 'These small, slender eaterpillars are of a bright-yellow colour, and are sparingly clothed with long and fine yellow hairs on the sides of their bodies. The females, in the adult state, though secmingly wingless, have two little scales or stinted wings, while the males have large ashen-gray wings, the upper pair of which are crossed by dark wavy bands, with a small black spot near the tip, and a minute whitc crescent near the outer hind angle. The body of the male is small and slender, with a row of little tufts along the back, and the wings expand one inch and three eighths. 'The females are of a lighter gray than the males, and their bodies are much thicker, and are of an oblong-oval shape. Different broods of these insects appear at various times in the course of the summer, but the greater number comc to maturity and lay their eggs in the latter part of August and the beginning of September, which are not hatched before the following spring. It is stated by the late Mr. B. H. Ives, of Salcm, Massachusetts, in vol. i., p. 52, of Hovey's "Gardener's Magazine," that on passing through an apple orchard in February, he "perceived nearly all the trees speckled with oecasional dead leaves, adhering so firmly to the branches as to require considerable force to dislodge them. Liaeh leaf covered a small patch of from one to two hundred cggs, united together, as well as the leaf, by a gummy and silken fibre, peentiar to the moth." In the March following, he visited the same orchard, and as an experiment, cleared three trees, from which he took twenty-one bunches of eggs. 'The remainder of the trees he lcft untonched until the 10th of May, when he found the caterpillars were hatchcd from the egg, and had commenced their slow, but sure work of 
destruction. He watched them from time to time, until many branches had been spoiled of their leaves, and in the antumn were entirely destitute of fruit; while the three trees, which had been cleared of the eggs, were flush with foliage, each limb, without exception, ripening its fruit. In addition to a brief notice of the American lackey caterpillar, (Clisiocampa americana,) in our article on the Virginian cherry-trees, under the head of "Insects," it may be proper here to state, that, where proper attention has not been paid to prevent its ravages, it prevails to such an extent as almost entirely to strip the apple orchards, as well as the cherry-tree of their foliage. This insect, from its abundance in all parts of the country, and being known almost exclusively in common language, by the name of the caterpillar, requires no further description. Various methods have been recommended to destroy this insect, such as burning and crushing the nests, early in the morning or evening while the vermin are at their repose, and the collection and destruction of their eggs in the winter or early part of spring. If a liberal bounty for the collection of the eggs were to be offered, as was suggested by the late Judge Lowell, and continued for the space of ten years, this destructive caterpillar would be nearly exterminated at the end of that time. Another insect, which may be called the tent-caterpillar of the forest, (Clisiocampa sylvatica, Harris,) very much resembling the preceding in its habits, preys upon the leaves of the oak, the hickory, and more rarely upon those of the apple-tree. Two other species of gregarious caterpillars, Notodonta concinna, and Pygara ministra, of Harris, also swarm on the apple, cherry and plum-trees, towards the end of summer, stripping whole branches of their leaves. The caterpillar of the American lappet-moth, (Gastropacha americana, Harris,) appears in September, and makes the leaves of the apple its food, which it only eats in the night. A large green caterpillar, (Attacus cecropia, Harris,) also makes its appearance on the apple-tree in the months of July and August, as well as upon the currant, the berberry, the cherry, and the plum.*

Among the insects which create the greatest havock in orchards, in Europe, are the larvæ of the Tinea padella, of Linnæus, which congregate in such vast numbers, that the leaves vanish before them, and by mid-summer, the trees are often completely defoliated by them.

Apples often fall off prematurely, both in Europe and in America, from being worm-eaten. The cause of this is a beautiful little insect, called the apple-worm moth, Tinea pomonella, of Linnæus; Pyralis pomana, of Fabricius; and Carpocapsa pomonella, of modern entomologists. The habits and economy of this moth have been satisfactorily pointed out by a writer in the London "Entomological Magazine," and a good account of it is also given by Dr. Harris, in his "Report on the Insects of Massachusetts injurious to Vegetation," p. 353. The larvæ of this insect leave their chrysalides from the middle of June to the first of July, or at the time the young apples become well set. The moth now lays her eggs in the eye of the apple, one only in each, by introducing its long ovipositor bet ween the leaves of the calyx, which form a tent above it, that effectually shields it from the inclemeucy of the weather, or other casualties. "As soon as the egg hatches," says the writer above referred to, "the little grub gnaws a hole in the crown of the apple, and soon buries itself in its substance; and it is worthy of remark, that the rind of the apple, as if to afford every facility to the destroyer, is thinner here than in any other part, and, consequently, more easily pierced. ****** The grub, controlled by an unvarying instinct, eats into the apple obliquely downwards, and, by thus avoiding the core and pips, in no way hinders its growth. At first, it niakes but slow progress, being little bigger than a thread; but, after a fortnight, its size and its operations have much increased. It has now eaten half-way down the apple; and the position of the hole at the top, if the apple continue upright, or nearly so,

* See Harris' Report, pp. 261, 269, 273, 279, 307, 312, 332, et 348 . 
is convenient for a purpose it has up to this time been used for, that is, as a pass to get rid of its little pellets of excrement, which are something like fine saw dust, or coarse sand. Another communication with the outer air is therefore required; and it must be so constructed as to allow the power of gravity to assist in keeping it clear. It is accordingly inade directly downwards, towards that part of the apple which is lowest; and thus the trouble of thrusting the pellets upwards through the eye of the apple is saved, and a constant admission given to a supply of air without any labour. The hole now made, is not, however, sufficiently open for an observer to gain by its means any knowledge of what is going on within; this is only to be obtained by cutting open a number of the apples, as they gradually advance towards ripeness; the hole is, however, very easily seen, from its always having adhering to it, on the outside, an accumulation of the little grains which have been thrust through. Having completed this work, the grub returns towards the centre of the apple, where he feeds at his ease. When within a few days of being full fed, he, for the first time, enters the core, through a round hole gnawed in the hard horny substance which always separates the pips from the pulp of the fruit; and the destroyer now finds himself in that spacious chamber, which codlings, in particular, always have in their centre. From this time, he eats only the pips, never again tasting the more common pulp, which hitherto had satisfied his unsophisticated palate; now nothing less than the highly-flavoured aromatic kernels will suit his tooth; and on these, for a few days, he feasts in luxury. Somehow or other, the pips of an apple are connected with its growth, as the heart of an animal with its life. Injure the heart, an animal dies-injure the pips, an apple falls. Whether the fall of his house gives the tenant warning to quit, I cannot say, but quit he does, and that almost immediately. He leaves the core, crawls along his breathing and clearing-out gallery, the mouth of which, before nearly closed, he now gnaws into a smooth round hole, which will permit him free passage, without hurting his fat, soft, round body; then out he comes, and, for the first time in his life finds himself in the open air. He now wanders about on the ground till he finds the stem of a tree; up this he climbs, and hides himself in some nice little crack in the bark. I should remark that the fall of the apple, the exit of the grub, and his wandering to this place of security, usually take place in the night-time. In this situation he remains without stirring for a day or two, as if to rest himself after the uncommon fatigue of a two yards' march; he then gnaws away the bark a little, in order to get further in out of the way of observation; and, liaving made a smooth chamber, big enough for his wants, he spins a beautiful little milkwhite silken case, in which, after a few weeks, he becomes a chrysalis, and in this state remains throughout the winter, and until the following June, unless some unlucky black-headed tit, running up the trunk, peeping into every cranny, and whistling out his merry see-saw, happens to spy him; in which case, he is plucked without ceremony from his retreat, and his last moments are spent in the bird's crop. But, supposing no such ill-fortune betide him, by the middle of June he is again on the wing, and hovering round the young apples on a midsummer evening as before. By burning weeds in your garden, at this time of the year, you will effectually drive away this little moth. If you have trees, the crops of which you value, make a smoking fire under each. It will put you to some inconvenience if your garden be near your house; but the apples will repay you for that." As the apple-worm instinctively leaves the fruit soon after it falls from the trees, it has been recommended to gather up all wind-fallen fruit daily, and give it to cattle or swine, in order to kill these insects, before they have time to escape. Mr. Joseph Burrelle, of Quincy, Massachusetts, in vol. xviii. of the "New England Farmer," says tlıat, "if any old cloth is wound around or hung in the crotches of the trees, the apple-worms will conceal themselves therein. 
and by this means thousands of them may be obtained and destroyed, from the time when they first begin to leave the apples, until the fruit is gathered."

Properties and Uses. The wood of the apple-tree, in a wild state, is finegrained, hard, and of a brownish colour; and that of the cultivated tree is believed to be of a still finer and closer grain, which is a result of cultivation contrary to what is usual. The weight of the wood of this species varies much according to the locality in which it grows. In a green state, it weighs from forty-eight to sixty-six pounds to a cubic foot; and it loses from one eighth to one twelfth of its bulk in drying, and about one tenth of its weight. The wood of the cultivated varieties weighs more than that of the wild tree, in the proportion of about sixty-six to forty-five. In Britain, apple-tree wood was formerly much used in turnery, and as cogs for wheels, for which latter purpose it was found to be durable, when kept dry; but if exposed to the alternations of moisture and dryness, it did not last long in any situation. The bark of this tree affords a yellow dye; and the leaves are eaten by horses, cows, sheep, and goats. In France and some parts of Germany, the thorny wild-apple, or crab, is formed into live hedges, the branches of which, according to Agricola, were inarched into each other, in order to give them more strength to resist cattle. In some of the forests of France, its fruit is a great resource for the wild boar, and it is also given in that country to swine and cows. Apples, for the various purposes in domestic economy, recommend themselves to our choice by very different qualities; though some few varieties are almost equally well adapted to all purposes. In those for the table, we require sweetness, with a subdued and pleasant acidity, and a delicate, aromatic flavour. In the kitchen-apple, size, the quality of keeping, and considerable acidity are the principal requisites; and those intended for boiling and for making sauce, acidity is an indispensable property. The best apples for cider, are those which yield a juice of the greatest specific gravity; and it is said that cider made from trees grown on a strong clayey soil, has more strength, and will keep better than that made from trees on a sandy soil. The red and yellow colour of the rind is considered as good indications of cider fruit, and apples of the various degrees of these colours are decidedly preferable to those of which the rind is green. The pulp should be yellow, the taste rich, and somewhat astringent. Apples of a small size, if equal in quality, are always to be preferred for cider to those of a larger size, in order that the rind and kernel may bear the greatest proportion to the pulp, the latter of which, affords the weakest arıd the most watery juice.

With regard to the preservation of apples, it is a practice, with many persons, to gather them in October, and first spread them on the floor of an upper room, in order to let them dry, and then to pack them in casks or boxes, and store them away in a cellar; bnt experience has shown that this mode of treatment causes them to wither, and lose their flavour, withont xcquiring any additional dura bility. The apples intended to be preserved for winter and spring use, should remain on the trees until quite ripe, which will usually take place at the coming of the first heavy frost. They should then be plucked from the trees by hand, in a fair day, and packed up immediately in casks, in alternate layers of dry sand, plaster, chaff, saw-dnst, or bran, and conveyed to a cool, dry place as sooll as possible. The sand or saw-dust may be dried in the heat of summer, or may be baked in an oven at the time required to be used. The peculiar advantages arising from packing apples in sand, are explained and commented upon as follows, by the late Mr. Webster, author of the "American Dictionary of the English language;"- "1st, the sand keeps the apples from the air, which is essential to their preservation; $2 d$, the sand checks the evaporation or perspiration of the apples, thus preserving in them their full flavour-at the same time any moisture yielded by the apples is absorbed by the sand-so that the apples are kept dry, 
and all mustiness is prevented. My pippins in May and June, are as fresh as when first picked. Even the ends of the stems look as if just separated from the twigs; $3 d$, the sand is equally a preservative from frost, rats, \&c. But after the extreme heat of June takes place, all apples speedily lose their flavour, and become insipid."

The uses of the apple, as an eatable fruit, are very numerous. They are equally good for the kitchen and the dessert; and may not only be used in various dishes by themselves, but enter into numerous combinations with other fruits. In confectionary, apple-jelly forms a most beautiful medium for preserving Siberian crabs, and many other kinds of fruit; and dried apples (beaufins) are prepared in great numbers in some parts of England, by drying them slowly in bakers' ovens after the bread has been drawn, and occasionally taking them out and flattening them with the hand, till they are perfectly soft, and of a rich deep-brown colour. In France, a kind of jam or rob, called raisiné composé, is prepared by boiling apples in unfermented wine. The must or wine should be diminished by boiling to one half of its bulk, to be continually skimmed as fresh scum arises, and afterwards strained through a cloth or a fine sieve. The apples are then pared, cut into quarters, and put into this liquor, (raisiné,) and left to simmer gently over a fire, with a continual stirring with a wooden spatula, till the apples become thoroughly amalgamated with the liquor, and the whole forms a species of marmalade, which is extremely agreeable to the taste. When prepared in the northern departments, the raisiné, after the first boiling, skimming, and straining, should be set in a cool place for twenty-four hours, when a saline liquor, like a scum, will appear on the surface. This must be removed, and the liquor strained, before it is mixed with the apples, as above. This scum consists principally of tartaric acid, which would spoil the rasiné, and prevent it from keeping siveet, but which is not perceivable when the grapes have ripened in a sonthern climate. The raisiné, when properly prepared, is sweet, but with a slight flavour of acidity, like lemon juice mixed with honey. The best raisine is made in Burgundy. In Normandy, a similar marmalade is composed of cider and pears, much resembling the "apple-butter" or "apple-sauce," of the United States; but it is not so good as the raisiné, being apt to ferment. In some cases, the pears are put into an earthen vessel without water, and placed in a baker's oven after the bread has been drawn, previously to mixing with cider. The best raisiné is considered very wholesome, particularly for children, who eat it spread on bread, and for persons in delicate health, whose stomachs will not bear butter. In Italy, the raisine is eaten with preparations either of Indian corn, or of maccaroni, to give a flavour to these dishes.*

A kind of wine is also made from apples with water and sugar; but it is by no means so good as the better classes of cider, from which a spirit is extracted equal to brandy, for preserving fruit. In some parts of England and France, a drink called boisson, is made from the wild crab; and verjuice is a well known vinegar, produced from the most austere of this fruit. In the United States, a liquor is made from cider by distillation, which is called cider brandy; and a very agreeable, and at the same time, a very strong liquor, is obtained by allowing cider to freeze, and drawing off the unfrozen part, which, of course, includes all the spirit the cider contained. A liquor is also made in America, called pomona wine, by adding one gallon of brandy to six gallons of new cider after it is racked off, whicli, when eight or twelve months old, is a very good substitute for wine.

Apples are stated, by persons who have made exact experiments, to yield about seventy per cent. of their weight of juice; or nearly seven imperial gallons, or eighıt and thirty-five hundredths wine gallons of juice to one hundred pounds of apples

* See Nouv. Cours d'Agr., xiii., p. 14. 
which may serve as some sort of guide to those who may wish to purchase apples for the purpose of making cider. It has also been stated that the quantity of apples required to make a hogshead of cider, in England, is from twenty-four to thirty bushels; and from eight to twelve bushels to make a barrel of that liquor, in the United States. As the strength of cider alwa-js depends upon the weight of the juice, there is no surer way of determining its value than by its specific gravity. The specific gravity of the juice of the best quality of apples should vary from 1.080 to 1.095 .

Medicinally, apples are considered particularly cooling, and excellent in all inflammatory disorders; and apple-water is a most refreshing drink in fevers. Dr. Short, in speaking of the properties of cider, says, "Long observation assures us, that such as chiefly drink cider, are more healthy and strong, and have better complexions than those that are accustomed to wine and ale." Both Lord Bacon and Dr. Baynard tell us of several persons nearly a hundred years of age, and some more, who seldom drank any other liquor, and were very active and vigorous at that age.

The apple-tree, as an object in landscape scenery, cannot be recommended as harmonizing well with other forms; but, as it has a character of its own, and as it affords an agreeable variety to the husbandman's hopes and pursuits, and no inconsiderable addition to his domestic comforts and enjoyments, it deserves a place in every garden and in every hedge-row. In the latter, it is more especially desirable, as it does very little injury to the surrounding crops by its shade; and, on the authority of Mr. Loudon, it may be added, that, in nurseries and market-gardens, particularly in the former, it gives protection to the young trees. And indeed, in viewing a "heaven-showered" orchard, whether covered in spring with a profusion of blossoms, or laden in autumn with fruit of rich and varied flavour, more beautiful than the grape, and yielding a juice scarcely less agreeable to the palate, our admiration is excited with the prodigal bounty and beauty of nature.

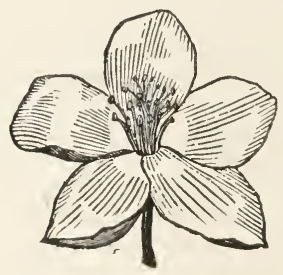




\title{
Pyrus aucuparia, THE MOUNTAIN ASH.
}

\section{Synonymes.}

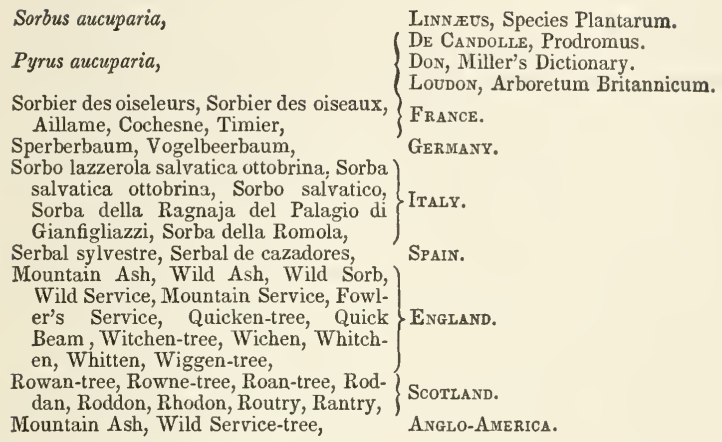

Derivations. The specific name aucuparia is derived from the Latin aucupor, to seek or get by cunning; having reference to the use made of the berries of this tree in all countries where it grows, and from time immemorial, to bait birds with Whence the French names, Sorbier des oiseleurs, the Bird-catcher's Service-tree, and Sorbier des oiseaux, the Bird Servicetree. The German name signifies the Bird's Berry-tree. This species is called Mountain Ash, from its growing on mountains, and the pinnæ of its leaves bearing some resemblance to those of the common ash. Witchen, and all its derivatives, bear rela. tion to the supposed power of this tree, as a protection against witches and evil spirits.

Engravings. Audubon, Birds of America, iv., pl. ccclxiii.; Selby, British Forest Trees, pp. 76 et 80; Loudon, Arboretum Britannicum, vi., pl. $183 \mathrm{et} 184$; and the figures below.

Specific Characters. Petals spreading, flat. Styles 2-5. Pomes globose. Buds softly tomentose. Leaves impari-pinnate, serrated, and slightly glabrous. Flowers in branched corymbs. - De Candolle, Prodromus.

\section{Description.}

\author{
"But what is higher beyond thought than thee? \\ Fresher than berries of a mountain-tree?"
} KEATS.

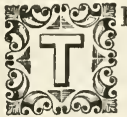

HE Mountain Ash forms an erect-stemmed tree, sometimes growing to a height of twenty or thirty feet, with 2 trunk a foot or more in diameter. When fully grown, like most of its congeners, it assumes a somewhat formal character, having an orbicular head; but in a young state, its branches are disposed in a more loose and graceful manner. The bark is smooth and gray on the old wood, but when young, it is of a purplish-brown. The leaves are composed of eight or nine pair of leaflets, which are spear-shaped, notched at the edges, except at the base, and terminated by an odd one. They are smooth above, and nearly so beneath, with channelled midribs, but no foot-stalks.

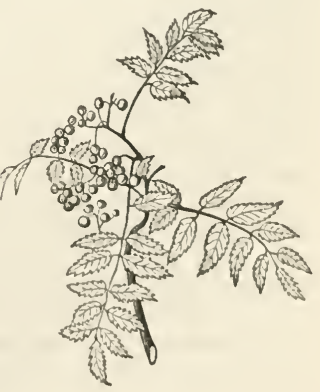


The flowers, which put forth in May and June, occur in large white corymbs, of an almond-like scent, and are succeeded by brilliant scarlet, or purplish berries of a sour or bitterish taste. They usually begin to ripen in September, and ofter. remain upon the trees until the following spring.

Varieties. The varieties of the mountain ash are as follows:-

1. P. A. Fructu lutea, Loudon. Yellow-fruited Mountain Ash, which may be continued by grafting.

2. P. A. Folin Variegatis, Loudon. Variegated-leaved Mountain Ash.

3. P. A. Fastiglata, Loudon. Fastigiate-branched Mountain Ash, having rigid and upright branches.

4. P. A. americana. American Mountain Ash; Pyrus americana, of De Candolle and Loudon; and Sorbus americana, var. $\beta$, of Michaux. The leaflets of this race are acute, almost equally serrated, glabrous, as is the petiole. Although a native of Canada, Newfoundland, Labrador, and the most northern parts of America, it closely resembles the European variety, being, apparently, a more robust-growing tree, with larger leaves, shining above, and smooth beneath. The young shoots are of a dark purplish colour, and are thought to be more tender than those of the common cultivated variety. The fruit is of a dark purplishred, approaching to the colour of copper, and like the European variety, is of a globose form. This tree may be propagated from seeds, or by grafting on the Pyrus aucuparia; and, from the brilliant colour of the fruit, and the large size of the bunches, it well deserves a place in collections.

5. P. A. Microcarpa. Small-fruited Mountain Ash; Pyrus microcarpa, of De Candolle and Loudon; and Sorbus aucuparia, var. $\alpha$, of Michaux. This variety, which is indigenous to the mountainous parts of the United States, particularly to the whole range of the Alleghanies, may be distinguished from the preceding, by the young branches being covered with a dark-brown gloss, and by having small scarlet berries. 'The leaflets are unequally incisely serrated, with the teeth tipped with a bristle-like mucro.

Geography and History. The Pyrus aucuparia is a native of most parts of Europe, from Iceland to the Mediterranean Sea. It is found in Asia from Russia and Siberia, as far as the Eastern Ocean; and from the cold woody region of the north, to the Alpine parts of Caucasus and Mount Libanus. In the former situations it is a low shrubby bush, and in the latter, a handsome tree of the third rank. It also occurs in Japan, and probably on other islands of the Indian Ocean; and, as stated above, two of its varieties are indigenous to North America. In Britain, it is common in woods and hedges, and in almost every cool and mountainous part of the island, as well as in Ireland. In France, Germany, and Switzerland, it occurs wild in the woods, and in the higher and colder regions of the mountains of Sicily, Italy, and Spain.

This tree was known to the Greeks and Romans, and frequent mention is made of it by their poets and historians. Thus they tell us that the Amazons of ancient mythology formed their spears of its wood; and Virgil was a ware that it was susceptible of being grafted upon the pear, and that its fruit was sure to attract the thrush and the black-bird to any grove where it grew. Pliny considered it as a species of ash; and Matthiolus, an Italian physician who wrote about the middle of the XVIth century, describes it under the name of Sorbus sylvestris. And to come down to more recent times, Evelyn, in speaking of this tree, says, that "ale and beer brewed with these berries, being ripe, is an incomparable drink, familiar in Wales." They form, continues he, a tempting bait for the thrushes; so that, "as long as they last in your woods, you will be sure of their company." "Besides the use of it for the husbandman's tools, goads, \&c., the wheelwright commends it for being all heart; our fletchers commend it for bows, next to the yew, which we ought not to pass over, for the glory of our once 
English ancestors. In a statute of Henry VIII., you have it mentioned; and there is no churchyard in Wales withont a mountain ash tree planted in it, as the yew trees are in the churchyards of England. So, in a certain day in the vear, everybody in Wales, religionsly wears a cross made of the wood; and the tree is, by some authors, called Fraxinus cambro-britannica."

The largest tree of this species on record, in Britain, and probably on the globe, is at Old Montrose, in Forfarshire, which, at sixty-five years after planting, had attained a height of fifty feet, with a trunk two feet and ten inches in diameter, and an ambitus or spread of branches of forty feet.

The introduction of the Pyrus aucuparia into the British colonies of North America, probably dates back to the early periods of their settlements. It is much cultivated for ormament within the environs of Boston, New York, Philadelphia, and other places in the United States, where there are trees to be found from twenty to thirty feet in height, which have been planted from forty to sixty years; but owing to the depredations of several species of borers hereafter mentioned, this tree does not often surpass that age.

Poetical and Legendary Allusions. In ancient days, when superstition held that place in society which dissipation and impiety hold in the more advanced stages of civilization, the monntain ash was regarded as an object of great vener. ation. Gilpin, in his "Forest Scenery," in speaking of this tree, says, that often in his time, "a stump of the monntain ash was found in some old burying-place, or near the circle of a Druid's temple, the rites of which were formerly performed under its shade." On this passage, Sir 'Thomas Dick Lauder observes that, "a branch of the roan-tree is still considered good against evil influences in the high. lands of Scotland, and in Wales, where it is often hung up over doorways, and in stables and cow-houses, to neutralize the wicked spells of witches and warlocks." And Lightfoot, in his "Flora Scotica," says, "It is probable that this tree was in high esteem with the Druids; for it may to this day be observed to grow more frequently than any other in the neighbourhood of those Druidical circles of stones, so often seen in the north of Britain; and the superstitious still continue to retain a great veneration for it, which was undoubtedly handed down to them from early antiquity. They believe that any small part of this tree, carried about them, will prove a sovereign charm against all the dire effects of enchantments and witchcraft. Their cattle, also, as well as themselves, are supposed to be preserved by it from evil; for the dairy-maid will not forget to drive them to the shearlings, or summer pasture, with a rod of the rowan-tree, which she carefully lays up over the door of the sheal-boothy, or summer-house, and drives them home again with the same. In Strathspey they make, on the 1st of May, a hoop with the wood of this tree, and in the evening and morning cause the sheep and lambs to pass through it." 'That a belief in the supernatural virtues of this tree still prevails in some parts of Yorkshire, as appears from the following anecdote, related by Waterton, author of the celebrated "Wanderings," in the Magazine of Natural History, we have not the slightest doubt:- "In the village of Walton," says he, "I have two small tenants. The name of one is James Simpson, and that of the other Sally Holloway; and Sally's stands a little before the house of Simpson. Some three months ago, I overtook Simpson on the turnpike-road, and I asked him if his cow was getting better, for his son had told me that she had fallen sick. 'She 's coming on surprisingly, sir,' quoth he; "the last time the cow-doctor came to see her, "Jem," said he to me, looking earnestly at old Sally's house; "Jem," said he, "mind and keep your cow-house door shut before the sun goes down, otherwise I won't answer for what may happen to the cow." 'Ay, ay, my lad,' said 1, 'I understand your meaning; but I am up to the old slut, and I defy her to do me any harm now !' And what has old Sally been doing to you, James? said I. 'Why, sir,' replied he, 'we al) 
к110w too well what she can do. She has long owed me a grudge; and my cow, which was in very good health, fell sick immediately after Sally had been seen to look in at the door of the cow-house, just as night was coming on. The cow grew worse, and so I went and cut a bit of wiggin, (mountain ash,) and I nailed the branches all up and down the cow-house; and, sir, you may see them there, if you will take the trouble to step in. I am a match for old Sally, now, and she can't do me any more harm, so long as the wiggin branches hang in the place where I have nailed them. My poor cow will get better in spite of her.' Alas ! thought I to myself, as the deluded man was finishing his story, how much there is yet to be done in our country by the school-master of the nineteenth century." The author of "Woodland Gleanings," says, "The mountain ash, so esteemed among our northern neighbours as a protection against the evil designs of wizards and witches, is propagated by the Parisians for a very different purpose. They are used as one of the principal charms for enticing the French belles into the public gardens, where they are permitted to use all the spells and witcheries of which they are mistresses; and certainly this tree, ornamented by its brilliant scarlet fruit, has a most enchanting appearance when lighted up with lamps, in the months of August and September." Miss Kent, in her "Sylvan Sketches," in alluding to this tree, says, "In former times, this tree was supposed to be possessed of the property of driving away witches and evil spirits; and this property is recorded in one of the stanzas of a very ancient song, called The Laidley Worm of Spindleston Heughs,-

\footnotetext{
'Their spells were vain; the hags return'd

To the queen in sorrowful mood,

Crying that witches have no power

Where there is.roan-tree wood.'
}

The last line of this stanza leads to the true reading of a line in Shakspeare's tragedy of Macbeth. The sailor's wife, on the witch's requesting some chesnuts, hastily answers, 'A rown-tree, witch!' but all the editions have it 'Aroint thee, witch!' which is nonsense, and evidently a corruption." If the phrase "Aroint thee," had occurred but once in Shakspeare, we night be disposed to adopt the above explanation; but as it is to be found twice, we have reason to suppose that it is of Saxon origin, and signifies away! run! The Saxon glossaries supply ryne for running; and the old Icelandic munka, signifies to agitate, or to move. Hone, in his "Religious Mysteries," gives a fac-simile of an old drawing called the Descent into Hell, in which our Saviour is represented with a roan-tree cross in his left hand, while with the right he appears to draw a contrite spirit from the jaws of hell.* It is remarkable, that nearly the same superstitions should exist also in India, as may be seen by perusing Bishop Heber's "Journal," \&c. And it is no less remarkable than true, that the American mountain ash is regarded by our native Indians as an object of veneration and awe. From time immemorial, they have made offerings to the spirits of their departed heroes, by casting round it the boughs of other trees. Ask them why they do this, and they will tell you that its branches "are eloquent with the ghosts of their warrior-sires, who will come at evening, in the chariot of cloud, to fire the young to deeds of war." 'Their offerings, or their remains, are frequently to be found at the foot of this tree, and in some cases, mounds have been formed from the immensity of their numbers, which have passed into decay.

Soil and Situation. The mountain ash will grow in any soil, and in the most exposed situations, as it is found near the sea-shore, and on the tops of mountains in various parts of the globe. Hence it is an excellent tree for plantations intended to resist the sea-breeze, or to be placed in situations exposed to the fury of th.e 
winds; but, wherever it is wanted to attain a large size, it ought to be planted in a free soil in a moist climate, or near water, and in a situation that is open and dry. Few trees suffer more from extreme heat and drought than the mountain ash.

Propagation and Culture. This species, and most of its varieties may be propagated from seeds, which should be gathered as soon as ripe, to prevent their being eaten by birds. When gathered, the fruit should be macerated in water till the seeds are separated from the pulp, after which, they may be immediately sown; but, as they will remain, in that case, eighteen months in the ground, before coming up, the common mode adopted by nurserymen is, to mix the berries with light sandy soil, and spread them out in the rotting-ground, in a layer ten or twelve inches in thickness; then to cover this layer with ashes or sand to a depth of two or three inches, and allow them to remain in that state for a year. They are then separated from the soil by sifting, and sown in beds of light, rich soil, being covered to the depth of a quarter of an inch. The seeds should not be dropped nearer together than two inches, which will allow the plants to come up with sufficient strength, and without the interference of their leaves. They may be sown late in autumn or very early in spring, which will cause them to come up in the June or July following; and, by the end of the season, the strongest plants will be eighteen inches high, and fit to separate from the others, and to plant out in nursery lines. They will grow rapidly for the first three or four years, and in five years will acquire a height of eight or nine feet. At this period they will be ready to plant out in the situations where they are permanently to remain, after which, they will begin to form their heads, and in ten years more will attain the height of twenty feet. Each head will continue to increase slowly, though the tree seldom grows higher than twenty-five or thirty feet in a hundred years. This tree will not bear lopping, but grass and herbage will grow well under its shade.*

Insects. The trunk and roots of the mountain ash are perforated by several species of borers, among which are the larvæ of the beetles called Saperda bivittata and Saperda vestita, both of which are described in our articles on the common apple, and the European lime-tree, under the head of "Insects," and neer" no further notice here.

Properties and Uses. The wood of the mountain ash, when dry, weighs fiftyone pounds to a cubic foot, is homogeneous, fine-grained, hard, capable of being stained any colour, and is susceptible of taking a high polish. It is much used in Europe in the small manufactures, such as the handles of knives and forks, wooden spoons, \&c. ; and for musical instruments, and various articles of turnery. When of sufficient dimensions, it is also used for axle-trees, naves, and felloes to wheels, carpenter and husbandman's tools, cogs to the wheels of machinery, and for a variety of other purposes. In Britain, the tree forms excellent coppice-wood, the shoots being well adapted for poles, and for making excellent hoops; and the bark is used in tanning. In Livonia, Sweden, and Kamtschatka, the berries of this tree are eaten, when ripe, as a fruit, and a very good spirit is distilled from them; and in various other parts of northern Europe, these berries are dried and ground into flour, and used as a substitute for the flour made of wheat, in times of great scarcity. Infused in water, the berries make an acid drink, somewhal resembling perry, which is much used in $\mathrm{W}$ ales by the poor, who call it diorl-graviole. In the island of Java, the juice of these berrics is used as an acid for punch. In Germany, the fowlers bait springes, or nooses of hair with the berries of this tree, which they hang in the woods to entice the red-wings and ficld-fares.

As an ornamental trec, the mountain ash is well adapted for small gardens, and 
also deserves a place in every plantation, where the harbouring of singing birds is an object. "In the Scottish Highlands," observes Gilpin, in his "Forest Scenery," "it becomes a considerable tree. There, on some rocky mountains, covered with dark pines and waving birch, which cast a solemn gloom over the lake below, a few mountain ashes, joining in a clump, and mixing with them, have a fine effect. In summer, the light-green tint of their foliage, and, in autumn, the glowing berries which hang clustering upon them, contrast beautifully with the deeper green of the pines; and, if they are happily blended, and not in too large a proportion, they add some of the most picturesque furniture with which the sides of those rugged mountains are invested." One great advantage of the mountain ash, in all situations, is, that it never requires pruning, and never grows out of shape. 


\title{
Genus CYDONIA, Tourn.
}

\author{
Rosaceæ. \\ Syst. Nat. \\ Icosandria Di-Pentagynia. \\ Syst. Lin.
}

Synonymes.

Pyrus, Sorbus, Cydonia,

Of Authors.

Derivations. The genus Cydonia is so called from Cydon, in Candia, its native place. It was formerly classified with the genera Pyrus and Sorbus, from the resemblance of its fruit to that of the service and the pear.

Generic Characters. Fruit a pome. Carpels 5, each including many seeds. Testa mucilaginous. Caly 5 -parted, with leafy divisions.

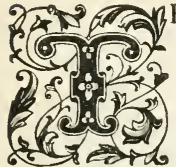

HE genus Cydonia consists of low, deciduous trees or shrubs, natives of Europe and Asia, which are easily propagated by layers, and by grafting on the common thorn. The species most worthy of culture are the Cydonia vulgaris, hereafter described, and the Cydonia japonica, commonly known by the name of Pyrus japonica. The latter is a shrub, native of China and Japan, growing to a height of five or six feet, and flowering a great part of the year, more especially if supplied with water during the hottest months. It is one of the most desirable deciduous shrmbs in cultivation, whether as a bush in the open lawn, trained against a wall, or treated as an ornamental hedge plant. It has also been trained up with a single stem as a standard; and, in this character, its pendent branches ard numerous flowers, give it a rich and striking appearance, particularly in early spring. It has ripened fruit in Europe and America, both as a bush, and when trained against a wall; which, even when ripe, is unfit to eat, though it has so fragrant an odour as to induce some persons to keep it among their clothes. Miss Twamley, in her "Romance of Nature," in speaking of this shrub, calls its flowers "fairy fires,"

\footnotetext{
"That gleam and glow amid the wintry scene,

Lighting their ruddy beacons at the sun,

To melt away the snow. See how it falls

In drops of crystal from the glowing spray;

Wreathed in deep crimsoned buds-the fairy fires."
}

To the same natural family belong the following genera:-

1. Photinia, embracing evergreen trees, with undivided, coriaceous, serrated, or entire leaves, and, in most cases, with corymbose flowers, and small fruit. They are natives of China, India, Japan, and California.

2. Cotoneaster, consisting of several species of very desirable garden shrubs or low trees, natives of Europe and India. The C. frigida and affinis, in particular, from the abundance of intense scarlet-coloured fruit they bear, which remains on the trees a greater part of the winter, well deserve a place in every collection.

3. Raphiolepis, a genus, the species of which are evergreen trees or slumbs, native of China, with crenulated, coriaceous, reticulated leaves.

4. Eriobotrya: a genus of Japanese trees, evergreen in their foliage, which is large, and independently of their flowers, are strikingly picturesque and ornamental. The species the most worthy of cultivation is the E. japonica.

5. Kageneckia, a genus of evergreen trees, native of Chili and Peru, the leaves 
of which are intensely bitter, and are sometimes used by the Chilians to cure intermittent fevers.

6. Margyricarpus, one species of which, (M. setosus,) is a native of arid hills in Brazil, with white, pearl-like fruit, resembling that of the mistletoe, but different from it, in having a grateful acid taste.

7. Cercocarpus, a genus conıprising the $\mathbf{C}$. fothergillöides, a tree native of Mexico, with elliptic, coriaceous, glabrous leaves, and conspicuous flowers and fruit. 


\section{Cydonia vulgaris, THE COMMON QUINCE-TREE.}

Synonymes.

Pyrus cydonia,

Cydonia vulgaris,
Coignassier, Coigner, Coignier, Coudounier Quittenbaum,

Cotogno, Melo cotogno, Pero cotogno,

Membrillo, Membrillero,

Marmeleiro,

Armud,

Quince-tree, Quince Bush,
Linnaus, Species Plantarum.

$\int$ De Candolle, Prodromus.

Don, Miller's Dictionary.

Loudon, Arboretum Britannicum.

r, France.

Germany.

ITALY.

Spain.

Portugal.

Russia.

Britain and Anglo-America.

Engravings. Lindley, Pomologia Britannica; Loudon, Arboretum Britannicum, vi., pl. 188; and the figures below.

Specific Characters. Leaves ovate, obtuse at the base, entire, tomentose beneath. Calyx tomentose; tis lobes serrulated, and a little leafy. Stamens in one row.-De Candolle, Prodromus.

\section{Description.}

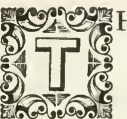

HE Common Quince is a low tree, seldom exceeding fifteen or twenty feet in height, with a crooked stem, and tortuous, rambling branches. The bark is smooth and brown, approaching to black. The leaves are roundish or ovate; dusky-green above, and whitish underneath. The flowers, which put forth in England by the middle of April, and in the middle and northern parts of the United States, in May and June, are large, with the petals pale-red or

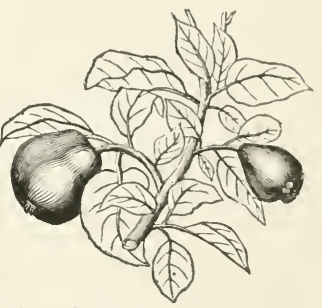
white, and the sepals of the same length as the petals. The flowers are succeeded by large fruit of a globular, oblong, or pear-shaped form, of a rich yellow or orange-colour, when ripe, of an austere taste, and emitting a peculiar and rather pleasant smell.

Varieties. In nursery catalogues, and also in botanical works generally, there are designated five or more varieties of this species; but Mr. Thompson of the London Horticultural Society's garden, has judiciously remarked that there are, in reality, only the three following :-

1. C. v. PYRIformis. Pear-shaped Quince; Coignassier pyriforme, of the French, which may be considered as the normal form of the species. For ornamental purposes, this variety, and the apple-shaped quince, are mnch to be preferred to the Portugal quince.

2. C. v. MaLiformis. Apple-shaped Quince; Coignassier à fruit pomiforme, Coignassier mâle, of the French. This variety requires to be continued by extension; because it is found that seedling plants of both this and the preceding variety are not quite true to their kinds. They most frequently produce pearshaped fruit.

3. C. v. Lusitanica. Lusitanian or Portugal Quince; Coignassier de Portugal, of the French. This variety has broader leaves, and larger fruit, than the 
two preceding, and being of a more vigorous growth, it is better adapted for stocks to graft upon. It is not so good a bearer as either of the other two varieties; and the fruit is not of so deep an orange; but it is considered the best for marmalade, as its pulp turns to a fine purple or crimson, when stewed or baked, and becomes much softer, and less austere.

Geography and History. The quince is supposed to have been originally a native of Sidon, a city of ancient Crete, now the island of Candia; but it is much more probable that it was only first brought into notice in that city. It is considered, at present, as indigenous to the south of France, particularly on the borders of the Garonne, and to Germany, on the banks of the Danube. By some, the tree is thought to be indigenous to Britain; and Phillips states, in his "Pomarium Britannicum," that quinces grow in such abundance in some parts of the Wealds of Sussex, as to enable private families to make quince wine in quantities of from one hundred to two hundred gallons in a season."

The quince was known to the Greeks and Romans, and both nations held it in high estimation. Columella says, "Quinces not only yield pleasure, but health." He speaks of three kinds-the "Struthian," the "Must Quince," and the "Orange Quince." Pliny mentions many kinds, some growing wild in Italy, and others in cultivation, so large that they weighed the boughs, on which they grew, down to the ground. He also says that some were of a green, and others of a golden colour, the latter of which were called chrysomela. The only kind that was eaten raw, he states to have been raised by grafting the large quince upon the stock of a small variety, called struthla. "All kinds of this fruit," continues he, "are grown in boxes, and placed within the waiting-chambers of our great personages, in which men wait to salute these personages as they come forth, every morning." It appears from the same author, that quinces were used to decorate the images of the gods, which were placed, in sleeping-chambers, round the beds; whence it follows, that the Romans did not think that there was anything either injurious or unpleasant in their smell. He gives directions for preserving the fruit, by excluding the air from them, or boiling them in honey; or, by plunging them in boiling honey, a practice in use with this, and other fruits, in Genoa, at the present day. He also writes much on the medicinal qualities of this fruit. "Quinces," says he, "when eaten raw, if quite ripe, are good for those who spit blood, or are troubled with hemorrhage." The juice of raw quinces, he states to be a sovereign remedy for the swollen spleen, the dropsy, and difficulty of taking breath, particularly to those who cannot conveniently breathe, except when in an upright position. The flowers of the quince, either fresh or dried, he tells us, are good for inflamed eyes. The root of the tree was used, not only as a medicine, but as a charm against scrofula.

The date of the introduction of the quince into Britain is unknown. Gerard mentions it as growing in gardens and orchards, and as being "planted oftentimes in hedges and fences belonging to gardens and vineyards ;" from which we may infer, that it was by no means rare in his time; and, indeed, in all probability, it has existed in England from the time of the Romans.

The largest recorded tree of this species in Britain, is in Radnorshire, at Maeslough Castle, which is twenty-one feet in height, with a trunk ten inches in diameter, and an ambitus, or spread of branches, of twenty-two feet.

The quince, like most of our orchard fruits, was probably introduced into the North American colonies at the early periods of their settlements. It is very generally cultivated for its fruit, and is usually planted in clumps of bushes, t.ther than as individual trees or shrubs. Of late, however, orchards of it have been formed on the rich loamy spots of Long Island, and other parts of the country, and donbtless, in time, their owners will derive a handsome profit.

Mythological and Legendary Allusions. The quince was considered by the 
ancrents, to be the emblem of love, happiness, and fruitfulness. It was dedicated to Venus, and the temples of that goddess at Cyprus and Paphos were decorated with it. The nuptial chambers of the Greeks and Romans were adorned with the fruit; and the bride and bridegroom also ate of it as soon as the marriage ceremony was performed. The learned Goropius maintains that quinces were the "golden apples of the Hesperides," and not oranges, as some commentators have supposed. In support of his argument, he says that it was a fruit much revered by the ancients; and he assures us, that there has been discovered at Rome, a statue of Hercules, that held in its hand three quinces. "This," he says, "agrees with the fable which states, that Hercules stole the golden apples from the gardens of the Hesperides." The Farnese Hercules, however, has apples in his hand, but not quinces. It has also been alleged, that the golden fruit thrown by Hippomenes to Atalanta were quinces, and that the fruit of the "forbidden tree," which the Jewish traditions describe as "golden," was the quince.

Soil and Situation. The quince prefers a moist but free soil, near water, and a situation rather open, but sheltered. In dry soils, neither the tree nor the fruit will attain a large size; and in situations exposed to high winds, the fruit is liable to fall before mature. The finest specimens of quince-trees, in Britain, are said to be found in old orchards adjoining ponds; it being customary, formerly, to plant a quince-tree in every apple orchard. If the soil be too dry or meagre, an artificial one may be prepared, as recommended for the Gordonia lasianthus; or, a hole may be excavated for each tree to a depth of ten or twelve feet, and then filling it with loose stones to within two or three feet of the surface, and tlie remainder with rich loamy earth or mould. Such a preparation is well worthy of the expense in every garden where this tree will not otherwise grow.

Propagation and Cullure. The quince may be as readily propagated from seeds as the apple and pear; but the quickest mode of raising plants is by layers. It will also grow by cuttings, planted in autumn in a moist, sandy soil. 'The trees, when planted as standards, should be situated about ten feet apart, and once set out, require but little attention, beyond that of removing the suckers from the roots, and the side-shoots from the main stems. To have the fruit of a large size, the head of the tree should be kept open by thinning out the shoots; and the fruit ought also to be thinned out, leaving no more on the tree than it can well mature. The tree is of moderately rapid growth, when young, acquiring, in four or five years, a height of six or eight feet; and in ten or twelve years, it attains an elevation of fifteen feet, after which, it continues to increase chiefly in the width of its head.

Insects. The greatest enemy to the quince-tree is the borer, or larva, of the Saperda bivittata, described in our article on the common apple-tree. It perforates the stems, in a similar manner as it does the trunks of the apple, the hawthorn, the June berry, and the mountain ash, and may be destroyed by the same modes recommended for the apple-tree.

Properties and Uses. The wood of the quince, when found of sufficient dimensions, is applied to the purposes of turnery; but from its small size, this tree is almost entirely cultivated for its fruit, or as stocks on which to graft the mountain ash, and the pear. In Frallce, however, this tree is sometimes grown for hedges. 'The fruit is seldom eaten by itself, but is generally preserved in syrup, or is niade into marmalade, or mixed with apples in tarts. In France, it is manufactured into "marmelades," "pâtes," and "gelées," known by the general name of cotignac; and a very agreeable liquor is extracted from it, called euu de coings. According to Gerard, quinces are hurtful to the head, by reason of their strong smell; and, when eaten from the tree, they have "a kind of choking aste." Medicinally, they are considered as cooling, astringent, and stomachic. The expressed juice of this fruit, taken in small quantities, is of service in uallsea, 
vomiting, \&c.; and a syrup made of the juice may be taken to strengthen the stomach. Quince wine is made with sugar and water, in a similar manner as other fruit wines. The fruit should first he deprived of their cores, (as the seeds impart an unpleasant flavour to the wine,) then mashed or ground to a pulp, and mixed in equal proportions, by measure, with water. After standing from twenty-fou to thirty-six hours, separate the juice from the pulp by straining; add to each gallon of the liquid three pounds and a quarter of muscovado sugar, and put it up in air-tight casks, and let it remain until the March or April following. 'Then, rack it off; cleanse the cask of sediment; put back the liquor again; and a year after bottle it up. It will be greatly improved by age, and is much esteemed by asthmatic persons. The rind of the quince imparts to wool a yellowish-brown; and, when mixed with the salts of iron, it gives a blackishgreen. A mucilage prepared from the seeds of this fruit was formerly much in use, but is now supplanted by the simple gums.

Independently altogether of its value as a fruit-tree, or of the young plants for stocks, the quince richly deserves a place in ornamental plantations, on account of the velvety surface of its leaves, its fine, large, pale-pink flowers, and, above all, its splendid golden fruit, which, when ripe on the tree, reminds us of the orange groves of Italy and of the torrid zone, and may very well justify the con. jecture that it was the true "golden apple" of the Hesperides. 


\section{Genus PUNICA, Tourn.}

Granatacex.
Syst. Nat.
Icosandria Monogynia.
Syst. Lin.

Synonymes.

Punica, Malus,

OF Authors.

Nervation. According to the "Nouveau Du Hamel," Punica is said to be derived either from puniceus, scarlet, in allu. sion to the colour of the flowers; or from the same word, or punicus, both signifying "of Carthage;" near which city, Pling
tells us, it was first found.

Generic Characters. Calyx with its tube top-shaped; its limb with $5-7$ lobes; their xstivation valvate. Petals 5-7. Stamens numerous, with distinct filaments, which bear the anthers on their inner side. Style 1. Stigma 1. Fruit spherical, crowned with the upper part of the calyx, the lower part of which, forms the rind. The fruit does not open, but is divided into two parts by a horizontal diaphragm. The upper portion consists of 5-9 cells; the lower one is smaller, and consists of 3 cells only. In both, the cells are separated by membraneous partitions; in the upper ones, fleshy placentæ extend from the sides of the fruit to the centre, and in the lower, irregular processes arise from the bottom. Seeds very numerous, surrounded by a transparent, shining pulp. Embryo oblong; its radicle short and straight ; its cotyledons leafy, and spirally convolute. Leaves deciduous, opposite, more rarely whorled or alternate; in many instances in groups in the axils; oblong and entire. Flowers scarlet, $2-5$ together, almost sessile, and almost terminal upon the branchlets.-De Candolle, Prodromus.

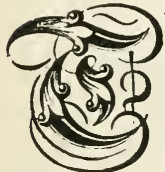

HE genus Punica was separated from the order Myrtaceæ by Professor Don, in 1826. It consists of small trees or shrubs, with branchlets imperfectly square, and becoming spiny with age. There are several species described by botanists, but we have regarded them only as varieties of the same tree.

Nearly allied to the natural family to which this genus belongs, is the order Calycanthaceæ, including two genera, Calycanthus and Chimonanthus. "In the stems of all the plants belonging to this order, there is the usual deposit of concentric circles of wood around the pith, and, in addition, four very imperfect centres of deposition on the outside next the bark; a most singular structure, which may be called, without much inaccuracy, an instance of exogenous and endogenous growth combined in the same individual."* The species belonging to these genera, most worthy of note, are the Carolina allspice, (Calycanthus floridus,) American allspice, (Calycanthus lævigatus,) and the fragrant-flowered chimonanthus, (Chimonanthus fragrans,) the latter of which is a native of Japan.

* Lindley's Introduction to the Natural System of Botany, p. 160. 


\section{Punica granatum, THE POMEGRANATE-TREE.}

\section{Synonymes.}

\author{
Punica granatum, \\ Grenadier, Balaustier, Miouganier, \\ Grenadier, Granatbaum, \\ Melograno, Granato, \\ Granado, \\ Romeira, \\ Pomegranate-tree, Carthaginian Apple-
tree, \\ Pomegranate-tree,
}

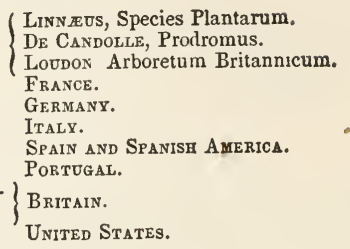

Derivations. The specific name granatum, is derived from the Iatin granum, a grain, on account of the numerous grains o seeds in its fruit. Most of the European names are derived from the botanical one.

Engravings. Sims, Botanical Magazine, pl. 1832; Loudon, Arboretum Britannicum, ii. fig. 664; Encyclopædia of Plante, fig. 7019; and the figures below.

Specific Characters. Stem arboreous. Leaf lanceolate.-De Candolle, Prodromus.

\section{Description.}
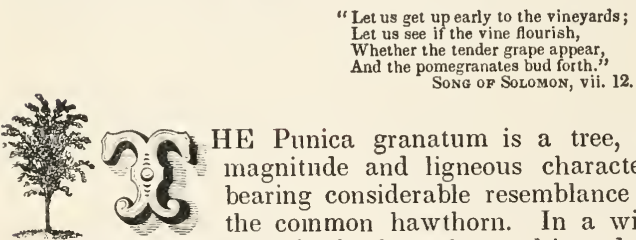

HE Punica granatum is a tree, in magnitude and ligneous character, bearing considerable resemblance to the coinmon hawthorn. In a wild state, it forms a thorny bush; but when cultivated in gardens and in plantations, under favourable circumstances, it often attains a height of fifteen or twenty feet. 'The leaves, which are of a beautiful green, stand opposite, and are about three inches long, and from half an inch to an inch broad in the middle. The flowers, which are somewhat in the shape of a bell, and of a brightscarlet colour, come out at the ends of the branches,

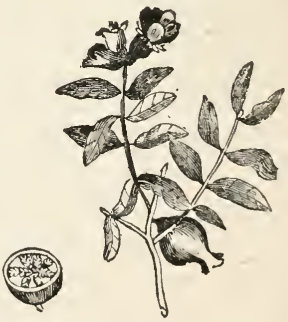
sometimes occurring in clusters of three or four, and the times of their blooming are so irregular, that the succession is often continued for months. Their petals are handsome, very thick and fleshy, and their odour is as fragrant as their colour is bright. The fruit, which is very beautiful to the eye and pleasant to the taste, is nearly round, encircled at the end opposite the stem, with something resembling a crown, and is covered with a thick, hard rind, that is easily broken. When fully grown, it is about as big as a large-sized orange, sometimes weighing a pound, and when perfectly ripe, varies in the colour of its rind, from brightyellow or green, to a dark-red, and is often blended with all of these tints.

Varieties. The varieties recognized under this species are as follows:-

1. P. g. Rubrum, Loudon. Red-flowered Pomegranate-tree; Grenadier des bois, of the French, known by the reddish tinge of the pulp of the fruit, and as growing wild in Mauritania, and in the south of Europe. 
2. P. g. rubrum flore pleno, Loudon. Double-flowering Red-flowered Pomegranate-tree, distinguished by its red double flowers, and reddish pulp.

3. P. G. aldescens, Loudon. White-petalled Pomegranate-tree, known by the white petals, and slightly yellowish calyx of its flowers, and by the pale-red tinge of the pulp of its fruit.

4. P. G. albescens flore pleno, Loudon. Double-flowering white-petalled Pomegranate-tree, distinguished by its double flowers, which are nearly white.

5. P. g. Flavum, Loudon: Yellow-flowered Pomegranate-tree, has the flowers yellow, but very rare in gardens.

6. P. G. nana, Loudon. Dwarf Pomegranate-tree; Grenadier nain, of the French. This variety, which is usually treated as a species, is a native of the Caribbee Islands, and of South America, in the neighbourhood of Demerara. It may be distinguished by its shrubby stem, linear leaves, red flowers, and dwarfy habit, usually not exceeding five or six feet in height.

Geography and History. The Punica granatum is indigenous to Barbary, Persia, Japan, and various parts of Asia; and has long been naturalized in the south of Europe, the West Indies, Mexico, and in South America. In the Himalayas, Mr. Royle informs us that the pomegranate grows wild; and, also, that it is planted near villages. It forms quite a wood in Mazanderan, whence the dried seeds are exported for medical use. The famous seedless pomegranates are grown in the rich gardens lying under the snowy hills near the river Caubul. They are also described as delicious about Hadgiabad, and throughout Persia. "Though grown in most parts of India," says Mr. Royle, "large quantities, of superior quality, are yearly brought down by the northern merchants from Catlbul, Cashmere, and Boodurwar."

The pomegranate-tree, which partakes of the antiquity of the vine, the fig, and the olive,-and which, in point of utility, is numbered with the-grain-bearing plants, and with honey, all constituting the principal food of the eastern nations, in the early stages of civilization,--must possess no small degree of historical interest. It is mentioned by Theophrastus under the name of roa; the Phœnicians called it sida; the Greeks, cytinos; and the Romans, according to Pliny, malus punica. The Jews appear to have held the tree in grcat veneration, and still employ the fruit in their ceremonials. It is mentioned, in the Old Testament, as one of the fruits discovered in the "Promised Land:"-

\footnotetext{
"A land of wheat, and barley, and vines, and pomegranates; a land of oil olive, and honey ;
}

DeUteronomy, viii. 8.

and, while the Israelites sojourned in the wilderness, it was selected as one of the ornaments to the robe of the ephod. The two large pillars of brass, made by Hiram for the porch of Solomon's Temple, were ornamented with carvings of the pomegranate. In the Canticles, Solomon speaks of "an orchard of pomegranates, with pleasant fruits;" and, from other passages of Holy Writ, a wine appears to have been made from this fruit. In the ancicnt island Eubœa, now Negropont, there was a statue of Juno, holding in one hand a sceptre, and in the other a pomegranate. Pliny speaks of extracting a colour from the flowers for dyeing cloth a light-red. He mentions nine varieties; including the sweet, the sour, the temperate, the austere, and the wine-flavourcd. The rind of the sour kind, he says, is the best for tanners and curriers to dress their lcather with. The celebrated kingdom of Granada is supposed to have derived its name from the trees planted in it by the Moors; which is rendered highly probable, by the arms of their capital being a split pomegranate.

The earliest mention of the pomegranate in Britain, is in 'Turner's "Herbal," in 1548; but it was probably introduecd long before that time by the monks, and planted in the gardens of the religious louses. For a long period, it was kent 
exclusively in houses, along with orange-trees, and we find, accordingly, that it fruited in the orangery of Charles I., as Parkinson informs us, under the care of Tradescant, when he was that king's gardener. At present, it is found in most collections as an ornamental wall tree, and, in fine seasons, in the neighbourhood of London, frequently ripens its fruit, or at least, produces it of the full size; but the varieties most generally cultivated, are those with double flowers. The largest tree of this species, in England, is supposed to be that trained against the walls of Fulham Palace, which is said to be forty feet in height and fifty feet broad.

In the south of Europe, the pomegranate is cultivated for its fruit; and, in sume places, as a hedge plant. It is also grown as an ornamental tree, the stem being trained to a height of six or eight feet, and the head afterwards allowed to spread, and droop down on every side. In the orange nurseries about Nice and Genoa, young trees are grown in boxes, in which they are exported to various parts of the world. In the conservatories in the neighbourhood of Paris, and in France generally, the double-flowered varieties are planted in large boxes, and treated like the orange-tree; but, at Paris and Versailles, they will not bear exposure to the open air too early in the spring, although they may be removed from the house eight or ten days before the orange. At the two last-named cities, there are specimens of the pomegranate, which are known, with certainty, to have existed nearly two hundred and fifty years. Both the single and doubleflowered varieties are very frequeutly trained against walls, in Italy, as well as in France; and the more ingenious cultivators intermingle the branches of one sort with those of the other, so as to make a display of both double flowers and fruit, apparently on the same tree.

The discovery and settlement of the Spanish colonies of the West Indies and of South America, led to the early introduction of this tree into all the warmer parts of those countries, where it is much cultivated for ornament in gardens, and along the avenues of plantations, and where it is greatly admired, both for its flowers and its fruit. In the southern states of North America, too, it is frequently to be met with in gardens, and about houses and plantations, and is much esteemed as an ornamental tree. It is also cultivated as a wall tree, or as a conservatory plant, in various parts of the middle and northern states of the union, where it is highly prized.

Poetical, Mythological, and Legendary Allusions. The pomegranate is mentioned by the poets of all ages. Ovid tells us that when Ceres discovered that Pluto had stolen her daughter Proserpine, she implored Jupiter so earuestly to restore her, that he consented, provided she had eaten nothing during her residence in the infernal regions. Unfortunately, however, while walking the Elysian Fields, Proserpine had gathered a pomegranate, and eaten several grains of it, which had been observed by Ascalaphus, who, ou informing Pluto of what had been done, was turned by Ceres into an owl, for his interference. Rapin, in his poem entitled "Les Plasirs du Gentilhomme Champêtre," published in 1583, gives the following origin of this tree :-A young girl of Scythia, having consulted the diviners to know her fortune, was told by them that she was destined one day to wear a crown. This rendered her so proud and vain, that she was easily seduced by Bacchus, on his promising to give her a crown. He soon grew tired, and abandoned her; and, when she afterwards died of grief, he metamorphosed her into a pomegranate-tree, on the fruit of which, he affixed a crown; thus tardily and ambignously redeeming his promise. In the language of poets, this shrub is regarded as the symbol of democracy; "probably," says Loudon, "from its fruit consisting of numerous seeds, which form its valuable part, and a worthless crown. In allusion to the latter circumstance, Queen Anne, of Austria, had for a device a pomegranate, with the motto, "My worth is not in my crown;" and 
Phillips, in his "Pomarium Britannicum," says that, the French, in the island of St. Vincent, had a riddle on the pomegranate, which was "Quelle est la reine qui porte son royaume dans son sein?" alluding to the same properties. "The nightingale," says Russell, in his account of Aleppo, "sings from the pomegranate groves in the day-time."

Soil, Situation, Propagation, \&॰c. The single wild pomegranate will grow in almost any soil; but the double-flowered varieties, and the species, when intended to bear fruit, require a rich, free soil. The double-flowering trees, grown in boxes by the French gardeners, are planted in the very richest soil that can be composed; and a portion of this soil is renewed every year. The plant is easily propagated by cuttings of the shoots of the roots, by layers, or by grafting one kind on another. It also rises freely from seeds; but these ought to be sown immedidiately on being removed from the fruit; because they very soon lose their vital powers. In pruning this tree, the head should be thinned out in such a manner as to multiply as much as possible, short, slender shoots, on the points of which alone, the flowers are produced. In training it against a wall, it is necessary to keep this constantly in view; for, if these slender shoots are cut off, no flowers will be produced. In very rich soils, an advantage is derived by annually pruning the roots.

Properties and Uses. The general diffusion of the pomegranate throughout the climates suited to its growth, implies that it possesses highly valuable properties. In hot countries, its utility is incontestable; for its juice is most grateful to the palate, and assuages thirst in a degree quite peculiar to it, from its pleasant acid - an acid so soft, that it may, in truth, be said to be "full of melting sweetness," as Moore expresses himself. The pulp, however, which encloses the seeds, is sometimes acid, sometimes sweet; and in some cases, vinous, astringent, and always refreshing. A syrup is made from the pulp by the druggists, as well as from the dried flowers, which is employed as an astringent and detergent. The rind of the fruit, on account of its astringent properties, is sometimes employed in materia medica as well as in the veterinary art. It has also been used as a substitute for galls, in the manufacture of black ink, and is said to be still employed, in some parts of Germany, in dyeing leather red, in imitation of morocco. In the Himalayas, Mr. Royle informs us, the rind of the fruit, called naspal, "being very astringent, is used in medicine, as well as in dyeing. The employment, by the natives of India, of the bark of the root for the expulsion of the tape-worm, being now well known, since the subject was communicated by Drs. Hamilton and Fleming, is a remarkable instance of the oblivion into which even a valuable medicine may fall, as this property was well known to Dioscorides." Lord Bacon recommends the juice of pomegranates as good for liver complaints; and Dr. Woodville says, it is preferable to that of oranges, in cases of fever. From the flowers, with the addition of alum, there may be obtained a fine red ink. The flowers, also, were formerly used to dye cloth a light-red

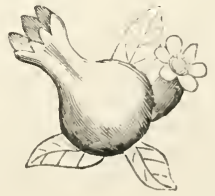




\title{
Genus MYRTUS, Linn.
}

\author{
Myrtaceæ. \\ Syst. Nat. \\ Icosandria Monogynia.
}

\author{
Synonymes. \\ Myrtus, Eugenia, Caryophillus, Calyp-
tranthes, Pimenta, OF Adthors.
}

Derivations. The word Myrtus, according to some lexicographers, is derived from the Greek muron, a perfumed oil'; in anusion to the grateful perfume of the leaves, flowers, and fruit of most of the species of this geaus. The other names belong to genera which were supposed by some botanists to include species more properly coming under the head of Myrlus.

Generic Characters Calyx 5-cleft. Petals 5. Berry 2 or 3-celled, many-seeded. Radicle and cotyledens distinct.-Loudon, Enc. of Plants.

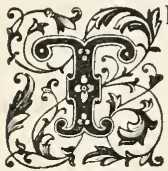

HE genus Mytrus belongs to that natural group of woody plants, which, in general, may be recognized by their opposite, entire leaves, full of transparent dots, which indicate the presence of a fragrant, aromatic, pungent, volatile oil. Hence, the grateful perfunie of the leaves, flowers, and fruit, of the greater part of the trees and shrubs belonging to this order. Like most highly aromatic woody plants, the species are chiefly inhabitants of warm climates. The common myrtle, however, is a native of Europe; but all the other kinds belong to North or South America, Africa, Asia, or Australia. All the species may be propagated by cuttings, and many of them, from their being evergreen, and from the beauty of their foliage and flowers, are very appropriate for hedges, in a mild climate, or for conservatory walls, in a cold one.

To the same natural family belongs the common guava, (Psidium pyriferum,) of the tropics, so much esteemed by all classes, both when formed into a jelly, and when eaten raw; also the Florida guava, (Psidium buxifolium,) the excellent flavour of the fruit of which has been compared to that of strawberries and cream. Nearly allied to the genus myrtus are the common clove of commerce, (Caryophyllus aromaticus,) a native of the Molucca Islands; and the Jamaica pepper, or allspice (Pimenta vulgaris.) This order also includes the Jambolana or Java plum-tree, (Calyptranthes jambolana,) bearing a black esculent berry; the forked calyptranthes, (Calyptranthes chytraculia,) indigenous to the West Indies and Southern Florida; the Malay apple, (Eugenia malaccensis,) cultivated between the tropics, for its fruit; the Eugenia dichotoma, procera, and buxifolia, of Southern Florida, Cuba, Jamaica, \&c. ; and the pitanga, (Myrtus braziliensis, ) the latter of which is much cultivated in Brazil for its highly delicious, sub-acid fruit, from which there is manufactured an excellent jelly.

Among other ligneous plants nearly allied to this group, and which are hardy, are the Tamarix gallica, indica, and dioica, and the Myricaria germanica. The former is interesting, from its ascending, spreading stems, numerous slender branches, abundant, minute foliage, and its splendid panicles of racemes, of pale rose-coloured flowers. From its bitter and highly astringent properties, it is occasionally employed as a tonic in medicine; and, in Denmark, it is sometimes substituted for hops in making beer. When grown near the sea, its ashes contain a large proportion of sulphate of soda. By means of the puncture of the Coccus manniparius, a species of manna is produced, known in conımerce by the name of Arabian, to distinguish it from the Persian manna, which is the produce of the Alhagi maurorum. The Myricaria germanica is interesting from its close upright habit of growth, and the glaucous hue of its persistent foliage. To the foregoing may le added the common syringa or mock orange, (Philadelphus coronarius,) a native uf the south of Europe; Philadelphus verrucosus, laxus, and hirsutus, of North America: and the Philadelphus tomentosus, of Nepal. 


\title{
Myrtus communis, \\ THE COMMON MYRTLE-TREE.
}

\section{Synonymes.}

\author{
Myrtus communis, \\ Myrte, Meurthe, Herbe du lagui, \\ Myrthe, \\ Myrter, \\ Myrten, \\ Mirto, \\ Mirto, Arrayan, \\ Myrta, Murta, \\ Myrtle,
}

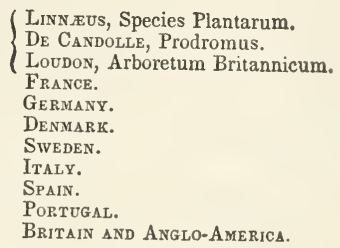

Derivations. This species was called murtos by the Greeks, and it is remarkable that from this word originated the names
of this tree in all the languages of Europe. Engravings. Loudon, Arboretum Britannicum, ii. fig. 706 and figs. 2469 et 2470 ; Encyclopædia of Plants, fig. 6971 ; and the
figures below. Specific Characters. Flowers solitary, white. Involucre 2-leaved.-Loudon, Enc. of Plants.

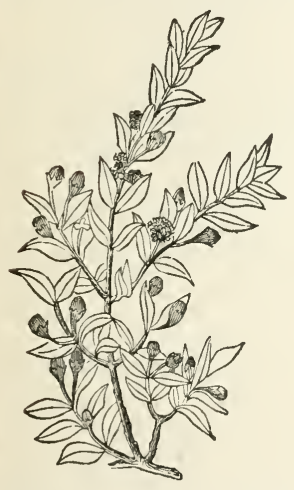

when cultivated under favourable circumstances, it attains four or five times that elevation. When trained as a tree with a clear stem, the head is thickly crowded with small branches, which only bear leaves at their extremities, and it

\section{Description.}

"In the hollow breast of Appenine,

Beneath the shelter of encircling hills,

A myrtle rises, far from human eye,

And breathes its balmy fragrance o'er the wild."

THomson.

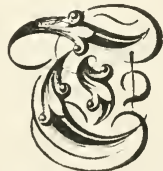

HE Myrtus communis is a beautiful evergreen shrub, growing to a height of five or six feet, in a wild state, and presents, when the eye is beneath it, a meagre appearance, "looking," as is observed in the "Nouveau Du Hamel," "more like a magpie's nest, or a dead bush placed on a pole, than a living tree;" but, when trained against a wall, or formed into groves or hedges, perfuming the air in the montlis of July and August, with its elegant green leaves and snow-white flowers, it forms one of the most beautiful objects of the vegetable kingdom.

Varieties. The following forms, or varieties of myrtle, the first of which may be considered as the species, are given in Don's Miller's Dictionary:-

1. M. c. Ronana. Common Broad-leated or Roman Myrtle; Myrte romain, of the French, with ovate leaves, long pedicels, and black fruit. 'I'his kind is 
sometimes called the "Flowering Myrtle," because it flowers in England more than any other variety.

2. M. c. Tarentina. Tarentum or Box-leaved Myrtle; Myrte de Tarente, of the French. 'The leaves of this variety are small and ovate. Flowers small, and opening late in autumn. Berries round and black.

3. M. c. ITALica. Italian or Upright Myrtle, the leaves of which are ovatelanceolate, and the branches erect. Fruit black.

4. M. с. BEтICA. Andalusian or Orange-leaved Myrtle; Myrte d'Andalusie, of the French, the leaves of which are lanceolate and acuminate. Fruit black.

5. M. c. Lusitanica. Portugal Myrtle, with black fruit.

6. M. c. Belgica. Broad-leaved Dutch Myrtle; Myrte de Belgique, of the French, the leaves of which are lanceolate, acuminated, crowded together, and of a dark-green. Fruit black.

7. M. c. Mucronata. Sharp-pointed-leaved or Thyme-leaved Myrtle; Myrte pointu, of the French, the leaves of which are linear-lanceolate, and acuminated. Fruit black. 'This variety and all the preceding ones are frequent in the south of' Europe, and comprise several sub-varieties with double flowers and variegated leaves.

8. M. c. LEUCocarpa. White-berried Myrtie, a native of Greece and the Belearic Islands. The fruit, which is white, is rather large, and edible, with a grateful taste and smell.

All of the above-named varieties are constant; but there are many others growing in gardens, which are more variable. The following are the names of most of these :-

$\alpha$. Gold-striped Broad-leaved Myrtle.

$\beta$. Broad-Leaved Jews' Myrtle, having leaves frequently in threes, on which account it is said to be in esteem among the Jews in their religious ceremonies.

\%. Gold-striped Orange-leaved Myrtle.

$\delta$. Silver-striped Italian Myrtle.

8. Striped-leaved Myrtle.

5. Silver-striped Rosemary or Thyme-leaved Myrtle.

$\eta$. Silver-striped Nutmeg Myrtle, apparently a sub-variety of the "Portugal Myrtle."

0. Cock's-comb or Bird's-nest Myrtle.

¿. Spotted-leaved Myrtle.

«. Double-flowered Myrtle, apparently a sub-variety of the "Broad-leaved Dutch Myrtle."

Geography and History. The Myrtus communis is indigenous to the south of Europe, and is found wild in abundance in France, about Marseilles, and from that city, along the coast to Genoa, growing in thickets, even within the spray of the sea, and throughout Italy. It is cultivated as a standard or for hedges in collections and gardens in most of the warm and temperate countries of the globe; and in climes less congenial to its growth, it is made to ornament the conservatory or to grace the garden wall.

Although the myrtle is now common as an underwood, in Italy, Pliny tells us that it was not a native of that country; and that the first myrtle seen in Europe was planted near the tomb of one of the companions of Ulysses at Circeii; and he adds that it still retained its Greek name murtos. He mentions eleven sorts of myrtle, and says that the most odoriferous grew in Egypt. Cato only speaks of two kinds.

'The first cultivation of the myrtle in Britain is assigned, in the "Hortus Kewensis," to the year 1629; when Parkinson informs us that he had three sorts in his garden, namely, the broad-leaved, and two varieties of the box-leaved myrtle. Gerard, however, in 1597, says that "myrtles never bear fruit in England;" 
which surely implies that it was cultivated in that country before that period. Bradley, who wrote a treatise on British husbandry and gardening, states that myrtles were introduced by Sir Frances Carew and Sir Walter Raleigh, in 155.5. When they returned to England, after a residence in Spain, just before the invasion of the armada, one of these myrtles was planted by Sir Francis at Beddington. In the environs of London, the broad and narrow-leaved myrtles stand out, in dry, warm situations, as bushes, sometimes having the extremities of their shoots killed down by frost, but more frequently by the direct influence of the sun after a frosty night, accompanied with snow and sleet. Both double and single varieties of the common myrtle cover large spaces of a wall in the Horticultural Society's garden.

At Cobham Hall, in Kent, England, there are several trees against the house, thirty feet high. In the isle of Wight and in Devonshire, the myrtle forms hedges to gardens.

At the Willows, near Swansea, in Glamorganshire, Wales, there were, in 1828, two myrtles fifteen feet high, grown in the open ground as standards, the branches of the largest of which covered a space of ninety feet in circumference.

In East Lothian, Scotland, more especially at Biel, the myrtle grows against a wall with very little protection.

In Ireland, in Trinity College botanic garden, at Dublin, all the varieties, except the orange-leaved, have stood out against a wall with a southern aspect; and at Youghall, near Cork, there was a plant in the open garden twenty feet high, which, in 1835, never had been protected.

In the neighbourhood of Paris, in France, the myrtle will not stand out against a wall, without a good deal more protection than it requires at London; but in the southern states of the American union, it grows in great perfection in the open air, without protection, in the severest winters.

Poetical, Mythological and Legendary Allusions. The name "Myrtus," is said to have been taken from that of Myrsine, an Athenian maiden, a favourite of Minerva, who, suffering love to overpower her wisdom, was changed into a myrtle by her offended mistress, and taken pity on by Venus. Others say that Venus, when she first sprang from the bosom of the sea, had a wreath of myrtle on her head. The temples of this goddess were always surrounded by groves of myrtle; and in Greece, she was adored under the name of Myrtilla. According to Pliny, the Romans and Sabines, when they were reconciled, laid down their arms under a myrtle-tree, and purified themselves with its boughs. Wreaths of myrtle were the symbols of authority worn by the Athenian magistrates. 'The weapons of war of the Greeks were also formed of this tree; and sprigs of nyrtle were entwined with the laurel wreaths worn by those conquerors during their triumphs, who had gained a victory without blood-shed. 'The victors in the Olympic and other games were also adorned with myrtles. In Rome, two myrtles were placed before the temple of Romulus Quirinus, to represent the plebeian and patrician orders, which were predicted to be in the ascendency according to the state of the trees. The Roman ladies put the leaves of the myrtle into their baths, persuaded that the plant of Venus must be favourable to beauty. The branches and berries were steeped in wine to give it a flavour; and the fruit was used in cookery, as the entire plant was in medicine. The ancient poets made the myrtle their favourite theme; and Virgil represents Aneas discovering it to be the metamorphosed Polydorus. In modern times it lias been frequently noticed by British poets. Thus, Spencer says in his "Faerie Queene,"-

\footnotetext{
"Right in the midlest of that Paradise,

There stool a stately moutt, on whose round top

A gloomy erove of myrte trees did rise,

Whose shady bonghs sharp steel diul never lop, 44

Nor wicked beasts their temder boughts disl crop,
} 
But, like a girland compassed the height,

And from their fruitful sides fresh gum did drop,

That all the ground with precious dew bedight,

Threw forth most dainty odours, and most sweet delight."

And Thomson, in those beautiful lines, beginning "The lovely young Lavinia once had friends," \&c., compares her to a myrtle. Milton places this tree in the bower of Eve.

Propagation, Culture, $\& \bullet c$. All the varieties of the common myrtle are readily propagated by cuttings; and those which ripen their fruit, as the Roman myrtle, come up in abundance from seeds. Cuttings may either be made of the ripe wood, or of that which is in a growing state; the latter take root the soonest, but require the most care, and success will be the most certain when they are planted in sand, and covered with a bell-glass. The finer varieties might be grafted on the common and more hardy sorts; and perhaps something might be gained in rendering the Australian Myrtaceæ more hardy, by grafting them on the common myrtle. Perhaps, also, something might be done in the way of cross-fecundation between the genera Myrtus, Psidium, \&c. Whenever the myrtle has been exposed to cold, snowy, or frosty nights, it should either be dashed all over with water, to thaw the frost; or covered with a mat, to prevent it from thawirig too suddenly by the rays of the sun. The safest mode in such weather is, to cover the plants with mats at night; because, though frost may not kill them, yet it will always injure the foliage.

Properties and Uses. The wood of the common myrtle is very hard, and is used for various purposes in turnery. The leaves and bark are aromatic and slightly astringent, and are sometimes employed as a tonic or stimulant. From the leaves and flowers a cosmetic is distilled, called, in France, ean d'ange. In some parts of Italy, the leaves are also used in the preparation of skins. In Tuscany, the berries are used as a substitute for pepper; and in Germany they serve to make a slate-coloured dye. In Provence, the myrtle is employed for garnishing arbours, bowers, and hedge-rows, and is not only formed into hedges, but is sometimes trained as a tree with a clear stem.

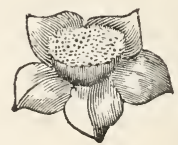




\section{Genus CORNUS, Linn.}

Cornaceæ.
Syst. Nat.
Tetrandria Monogynia. Syst. Lin.

Synonymes.

Cornus,

Cornouiller,

Hartriegel, Hornstrauch, Kornel-Kirschbaum,

Corniolo, Corgnolo,

Cornizo,

Dogwood, Cornelian Cherry-tree,
OF AUthors.

France.

Germany.

ITALT.

Spain.

Britain and Anglo-America.

Lerivations. The word Cornus is derived from the Latin cornu, a horn; the wood of some of the trees of this genus being thought to be as hard and as durable as horn. The French, Spanish, and Italian names have the same meaning as the botanic one. The German name Hurtriegel signifies hard rail, or hard wood; Hornstrauch, means Horn-bush; and the other Gernan name signifies Cornelian Cherry-tree. The name Dogroood is applied to this genus, because, as Parkinson says in his " Para. disus," the frut of most of the species is not fit even for dogs; but it is more likely to have been given to it, from the astringeri properties of the bark and leaves, a decoction of which was formerly used as a wash for curing the mange, \&c., in dogs.

Generic Characters. Tube of the calyx adhering to the ovarium. Limb small, 4-toothed. Petals 4 , oblong, sessile; valvate in rstivation. Stamens 4. Style 1. Pome baccate, marked by the vestiges of the calyx, containing a 2-celled, rarely 3-celled, nut. Seed solitary, pendulous. Albumen fleshy. Radicle of embryo shorter than the cotyledons.-Don, Miller's Dict.

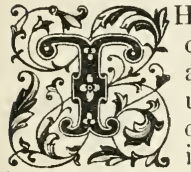

$\mathrm{HE}$ genus Cornus consists of deciduous trees and shrubs, all with opposite leaves, (except those of the Cornus alternifolia,) entire and feather-nerved. The flowers are sometimes capitate and umbellate, involucrated; sometimes corymbose and panicled, without an involucre, with petals white, and rarely yellow. They are in general very hardy, and may be easily propagated from seeds, by suckers, or by cuttings and layers. Beside the Cornus florida, hereafter described, the following species and varieties are well worth the attention of amateurs, as being particularly suitable for small suburban gardens, in which several of them will form fit associates for small trees of Cratægus, Berberis, Rhamnus, Euronymus, Hamamelis, \&c. :-

1. Cornus alternifolia. Alternate-leaved Dogwood; a native of North America, from Canada to Carolina, in shady woods on river banks, where it forms a tree, fifteen or twenty feet in height, and flowers from May to July. This spe cies is known from every other, by the horizontal umbelliferous character assumed by the branches, which are also dichotomous, with clusters of leaves at the joints ; and the general colonr is that of a lively green. The fruit, when ripe, is purple, and about the size of a grain of pepper.

2. Cormus purpurea. Purple-fruited Dogwood; Cornus sanguinea, of Linnæus, Don, Loudon, and others; Cornouiller femelle, Cornouiller sanvage, Bois de chien, Bois sanguin, Savignon, Puine noire, or Bois punais, of the French; Rother Hartriegel, of the Germans; Sanguinella, of the Italians; F'male Cornel, Wild Cornel, Dogberry-tree, Hound-tree, Prickwood, Gatten-tree, Gatter-tree, and Calleridge-tree, of the British and Anglo-Americans. 'This species is incligenous to Northern Africa, and is plentiful in hedges and thickets, especially on chalk and limestone soils, in most of the temperate parts of Europe. It has been introducell into the United States, and is found wild in New York, New Jersey, Pennsylvania, and other parts of the country. There is also a variety of this species, described by Don and Loudon, under the name of Cornus sangninea purshii, indigenous in New York, from Long Island to the lakes, which only 
dıffers from that of Europe, in having the leaves pubescent, and i.s bri.1s if a taller stature. The Cornus purpurea grows to a height of from four to fifteen feet, flowering in June and $\mathbf{J u l y}$, and ripening its dark-purple fruit in August and September. It is easily known trom all its congeners by its dark-red branches, dark-purple fruit, and the intensely dark-red of its leaves before they fall in autumn. This species is called "Female Cornel," because it bears fruit when very young; whereas, the Cornus mas. is barren for many years after it shows flowers. The wood of this species, which is not quite so hard as that of the Cornus mas. was formerly much used in Europe for mill-cogs, and for various purposes in rustic carpentry; and is still made into skewers for butchers, toothpicks, and other small articles. It makes excellent fuel, and the very best charcoal for gunpowder. The fruit, like the bark and leaves, is bitter and styptic; and, when treated like that of the olive, it yields thirty-four per cent., by weight, of an oil, that is used, in France, for lamps, and in the manufacture of soap.

3. Cornus alba. White-fruited Dogwood; Cornouiller à fruit bleu, of the French; Weisser Hornstrauch, of the Germans, is a native of North America, from Virginia to Canada and Newfoundland, on the banks of streams and lakes; and, if we take into account the Cornus stricta, paniculata, sericea, and some states of Cornus circinata, all of which are considered, by Sir W. J. Hooker, to be too nearly allied to be made separate species, it is also a native of Siberia, Oregon, Texas, Mexico, and California. The Cornus alba, when wild, grows to a height of from four to ten feet, and to donble these heights in a state of cultivation. In summer, it is particularly interesting from its fine large leaves, and white flowers; in autumn, from its bluish-white fruit, which is about the size and colour of that of the mistletoe; and in winter and spring, from the fine red colour of its young branches or shoots.

4. Cornus mascula. Nale Dogwood; Cornouiller mâle, Cornouiller des bois, Cornier, Cuernier, Caneulè, Aournier, of the French ; Kornel-Kirsche Hartriegel, of the Germans; Corniolo maschin, Sanguine maschio, Corgnolo, of the Italians; Cornel-tree, Cornelian Cherry-tree, Long Cherry, of the English. This species is a native throughout Europe, Britain excepted, and the north and west of Asia, in woods and hedges. In a wild state, it is seldom found above ten or twelve feet in height; but in a state of cultivation, it often attains double these elevations. It has ash-coloured, pubescent shoots, ovate-lanceolate leaves, and yellow flowers, which, in mild winters, come out in January or February; and the greater part of which, in trees not exceeding twelve or fifteen years of age, have only stamens, and drop off withont producing fruit. The fruit, which ripens in September or October, is about the size of a small acorn, and of a fine, rich, transparent scarlet. It remains a long time on the tree after it is ripe, and is very orna= mental. The wood of this tree has been celebrated in all ages, for its hardness and durability. In a dry state, it weighs sixty-nine and a quarter pounds to a cubic foot. The heart-wood is of a brownish tint, and the sap-wood white, with a slight tint of red. In ancient times, it was much in repute as shafts for javelins; and both Homer and Virgil mention its use for these weapons. Pliny, also, informs us, that it was nearly equal to iron in hardness, and was used by the Romans for making wedges and pins, and the spokes of wheels. In France, when it can be procured of sufficient size, it is employed for mill-work, especially as cogs to wheels. The small branches are made into ladder rongs, or spokes, forks for turning hay, hoops, vine-props, butchers' skewers, \&c. 'The wood of the cornel, like that of all the species of the genus, makes excellent fuel and charcoal; and the young shoots form a good substitute for those of the willow, in making baskets, and tying up packages of various kinds. The leaves, small branches, and fruit, may be employed for tanning skins; or may be used for dyeing a yellowish-brown. The fruit, when perfectly ripe, is somewhat sweet, and not disa- 
greuable to eat; and, on the continent of Europe, it is frequently used in confectionary, and for making marmalades, robs, and liqueurs. It is mixed with apples, and pears in making cider; and, gathered in an unripe state, and preserved in salt and water, it is used as a substitute for pickled olives. When mature, and treated like ripe olives, it yields an oil, which may be used for various purposes, but not for the table. As an ornamental tree, the cornel is not only valuable on account of its early flowering, and the fine display made by its ripe fruit, but because it is a low tree, and one which, after it has attained a height of ten or twelve feet, is of slow growth, and of very great duration. For these last reasons, it is particularly suitable for small suburban gardens, or for situations of limited space.

The order Cornacæ includes but one other genus, the Benthamia, which embraces the strawberry-bearing benthamia, (Benthamia fragifera,) a native of Nepal, where it grows to a small tree, approaching, in the general appearance and character of its leaves and flowers, to the Cornus florida, but differing from that species in its fruit. Allied to the same natural family are the various species of currants and gooseberries, (Ribes); the Virginian itea, (Itea virginica); several species of Escallonia, sub-evergreen, half-hardy shrubs, natives of South America; the Carolinian angelica-tree, (Aralia spinosa); the Chinese guilder rose, (Hydrangea hortensia,) well known by its ample corymbs of snowball-like flowers, which are of a whitish-green when they first appear, but which afterwards become of a fine rose-colour, and finally die off with a purplish tinge; the shrubby bupleurum, or hare's ear, (Bupleurum fruticosom,) a beautiful evergreen shrub, a native of the south of Europe, with smooth, shining foliage of a glaucous hue; and the common ivy, (Hedera helix,) well known to the classical ancients as well as to the amateurs and cultivators of the present day. And still more nearly allied to the genus Cornus is the witch-hazel, (Hamamelis virginica,) a curious shrub, native of North America from Canada to Florida; sometimes growing to a height of twenty or thirty feet; and putting forth, late in autumn or early in winter, small yellowish flowers. The male plant sometimes shows a few female flowers; but no male flowers have been observed on a female plant. The male blossoms usually appear in October, and continue throughout the winter; and the female flowers, which are very ornamental, begin to open by the 1st of November. This shrub is much esteemed by the American Indians for its medicinal virtues; and it was formerly held in high repute by the superstitious, for its supposed divining powers. 


\title{
Cornus florida, THE FLOWERY DOGWOOD.
}

\author{
Synonymes. \\ Cornus florida,
Cornouiller à grandes fleurs, Cornouiller
fleuri, Bois de chien,
Blühender Hartriegel, Blühender Horn-
strauch, \\ (Linnæus, Species Plantarum. \\ $\{$ Michaux, North American Sylva. \\ Lounon, Arboretum Britannicum. \\ France. \\ Germanx. \\ Florida Dogwood, Virginian Dogwood, Britain.
Dogwood, New-England Box-wood,
}

Derivations. The specific name florida, is derived from the Latin floreo, to blossom, in allusion to the profusion of flowers which this tree puts forth. The French and German names are derived from the botanic one.

Engravings. Michaux, North American Sylva, pl. 48; Bigelow, Medical Botany, il., pl. 28; Audubon, Birds of America, i., pl. viii. et lxxiii.; Loudon, Arboretum Britannicum, ii., fig. 769; and the figures below.

Specific Characters. Branches shining. Leaves ovate, acuminated, pale beneath, beset with appressed hairs on both surfaces. Flowers umbellate, protruded after the leaves. Leaves of involucre large, roundish, retuse, or nearly obcordate. Pomes ovate. Leaves of involucre white. Flowers greenishyellow, and very large. Pomes scarlet, about half the size of those of C. mas.-Don, Miller's Dict.

\section{Description.}

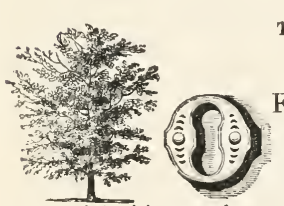

\author{
"Cropp'd the fair bloom with which young Spring adorn \\ The flow'ring Cornus." \\ Tratts of the ABorigings.
}

natural habitat, when grown under favourable circumstances, it forms a tree, attaining a height of thirty to thirty-five feet, with a trunk nine or ten inches in diameter; but, in general, it does not much exceed one half of these dimensions. The trunk is covered with a blackish bark, chopped into many small portions, which are often in the shape of squares more or less exact. 'The branches, which are not so numerous as on most other trees, are regularly disposed, with their young twigs inclining upwards in a semi-circular direction. 'The leaves are opposite, about three inches in length, ovate, acuminated, of a dark-green above, and whitish beneath, with the upper surface very dis-

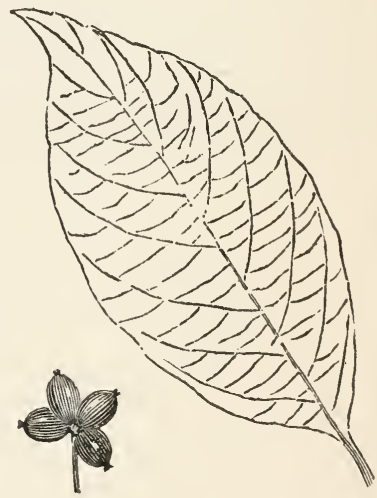
tinctly sulcated. T'owards the close of summer, they are often marked with black spots; and at the approach of winter they change to dull-red. 'The flowers, which appear in Florda in March, and in New York in May, are small, yellowish, and connected in bunches, surrounded with a very large involucre, composed of four white floral leaves, sometimes inclining to violet. This fine involucre constitutes the chief beauty of the flowers, which are verr numerons and whinh 
in their season, "robe the tree in white, like a full-blown apple-tree, and render it one of the fairest ornaments of the American forests." The fruits, which are of a vivid glossy red, and of an oval shape, are always united, and remain upon the trees till the appearance of the first autumnal frosts, when, notwithstanding their bitterness, they are devoured throughout the winter, in the southern states, by the mocking-bird (Turdus polyglottus,) and the American robbin, or redbreasted thrush, (Turdus migratorius,) the latter of which, about this period, arrives from the regions of the north.

Geography and History. The Cornus florida is first met with at the north, on the Columbia River, near its confluence with the Pacific, and on the Atlantic coast, in New Hampshire and Massachusetts, between the parallels of forty-two and forty-three degrees of north latitude. In proceeding southward, it is uninterruptedly found throughout the country east of the banks of the Mississippi, and in some situations, is one of the most common trees. It particularly abounds in New Jersey, Pennsylvania, Maryland, and Virginia, where the soil is moist, gravelly, and somewhat uneven; but further south, in the Carolinas, Georgia, and Florida, it is found only on the borders of swamps, but never in the pine-barrens, where the soil is too dry and sandy to sustain its vegetation. In the most fertile districts of Ohio, Kentucky, and Western Tennessee, it does not appear in the forests, except where the soil is gravelly, and of a middling quality.

This fine tree was first noticed by Rev. John Bannister, in Ray's "Historia Plantarum," published in 1680; and afterwards by Catesby, in his "Natural History of Carolina," \&c. It was cultivated in Britain by Mr. Thomas Fairchild, in about the year 1731 ; by Miller, in 1739 ; and has since been introduced and propagated into most of the European collections. In England, this tree does not thrive so well as in its native country, seldom being found, in the neighbourhood of London, higher than seven or eight feet, although there is a fine specimen at Syon Hill, exceeding twenty feet in lieight, and others at White Knights, which flower freely every year. Miller, however, in 1752 , says tliat "the tree is common in British gardens under the name of 'Virginian Dogwood,' that it is as hardy as any of the other species; and that, though it produces abundance of large leaves, it is not plentiful of flowers ;" nor had he seen any plants of it which had produced fruit in Fngland. Catesby, in describing this tree, says, that "the blossoms break forth in the begiming of March, being at first not so wide as a sixpence, but increasing gradually to the breadth of a man's hand; being not of their full bigness till about six weeks after they begin to open." And Mr. William Bartram, in his "Travels in Georgia and Florida," published in 1791, gives the following glowing account of its appearance near the banks of the Alabama: - "We now entered a remarkable grove of dogwood-trees, (Cornus florida,) which continued nine or ten miles unaltered, except here and there by a towering Magnolia grandiflora. The land on which they stand is an exact level; the surface a shallow, loose, black mould, on a stratum of stiff, yellowislı clay. These trees were about twelve feet high, spreading horizontally; and their limbs meeting, and interlocking with each other, formed one vast, shady, cool grove, so dense and humid as to exclude the sumbeams, and prevent the intrusion of almost every other vegetable; affording us a most desirable slelter from the fervid sunbeams of noonday. This admirable grove, by way of eminence, has acquired the name of the Dog Woods. During a progress of nearly seventy miles through this high forest, there were constantly presented to view, on one hand or the other, spacious groves of this fine flowering tree, which must, in the spring season, when covered with blossoms, exhibit a most pleasing scene; when, at the same time, a variety of other sweet shrubs display their beauty, adorned in their gay apparel."

Soil, Situation, Propagation, $\mathcal{S}^{\circ} c$. The Cornus florida thrives best in a peat 
soil, which must be kept moist; and the situation should be sheltered, though the foliage of the plants must be fully exposed to the influence of the sun, otherwise they will not flower freely. They may be propagated from seeds, and by cuttings or layers.

Properties and Uses. The wood of this tree is hard, compact, heavy, and finegrained, and is susceptible of a brilliant polish; from which circumstances, it may be substituted for numerous purposes to which box-wood is applied. The sap-wood is perfectly white, and the heart-wood is of the colour of chocolate. In the United States, it enters into the construction of many articles both for utility and ornament, such as the handles of light tools, mallets, toys, \&c. It is sometimes used by farmers for harrow teeth, for the hames of horse-collars, and also for shoeing the runners of sleds; but to whatever purpose it is applied, being liable to split, it should never be wrought till it is perfectly seasoned. The shoots, when three or four years old, are found suitable for the light hoops of small casks; and in the middle states, the cogs of mill-wheels are made of them, and the forked branches are converted into the yokes which are put upon the necks of swine, to prevent them from breaking into inclosed fields. In the parts of the country where it abounds, it serves for excellent fuel. The inner bark of this tree is extremely bitter, and has proved an excellent substitute for the Peruvian bark.* The bark, also, may be substituted for galls in the manufacture of ink; and from the bark of the more fibrous roots, the American Indians obtain a good scarlet dye. An infusion of the flowers of this tree is also used by them in the cure of intermittents. The fruit is sometimes taken as a tonic, in the form of a spirituous impregnation; and it likewise affords a favourite repast for various species of birds. In England, the sole use of this species is an ornamental shrub; and, from its large white flowers, "emulous of the purity of snow," which finely contrast with the "forest green," it richly deserves a place in every collection wherever it will thrive.

* Dr. Walker of Virginia, in an inaugural dissertation on the comparative virtues of the Cornus florida, Cornus sericea, and Cinchona officinalis, of Linnæus, after detailing a great number of experiments, remarks :- "A summary recapitulation of these experiments shows, that the Cornus florida, sericea, and Peruvian bark, possess the same ingredients; that is, gum, mucilage, and extracts; which last contain the tannin and gallic acid, though in different proportions. The florida has most of the gum mucilage and extracts; the sericea the next, which appears to be an intermediate between the florida and cinchona; while the latter possesses most of the resin. Their virtues appear similar, and equal, in their residence. The extract and resin possess all their active powers. The extract appears to possess all their tonic powers. The resin, when perfectly separated from the extract, appears to be purely stimulant; and probably the tonic powers of the extract, are increased when combined with a portion of the resin, as in the spirituous tincture."

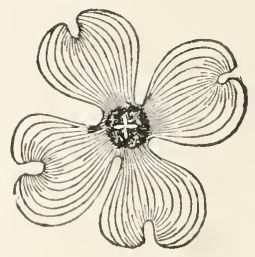




\section{Genus PINCKNEYA, Mich.}

\author{
Rubiaceæ. \\ Syst. Nat.

\begin{abstract}
Synonymes.
\end{abstract}
Pinckneya, Pincneya, Cinchona, Mussanda,
Pentandria Monogynia.
Syst. Lin.

Dervations. The name Pinckneya was so called by Michaux, in honour of Mr. Charles Pinckney, of South Carolina, a gentleman who was engaged in the cause and advancement of botanical science. The other names have been applied to the trees of this genus, from the resemblance they were supposed to bear to the Cinchona, and Mussænda.

Generic Characters. Sepals unequal, one or two of them foliaceous. Corolla a long tube. Filaments in the base of the tube. Capsules 2-valved, valves bearing the divisions in the middle.-Loudon, Enc. of Plants.

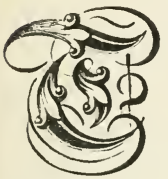

HIS genus is nearly allied to Mussænda, and embraces but one species, a native of North America. To the same order belong a great number of genera; but a few of the species of which are sufficiently hardy to withstand the climate of Britain, and the middle and northern parts of the United States, even when protected by garden walls. The only truly hardy kind is the button-bush, (Cephalanthus occidentalis,) a shrub growing to a height of six or eight feet, in the margins of ponds and of streams leading from them, from Canada to Florida. Allied to the same natural family are the mistletoe (Viscum album); the various species of elder (Sambucus); the European guilder rose. (Viburnum opulus): the cranberry-fruited guilder rose, (Viburnum oxycoccus,) a native of elevated lands from New Jersey to the Rocky Mountains and Hudson's Bay; and the edible-fruited guilder rose or tree-cranberry, (Viburnum edule,) found from New York to Canada, and celebrated for its subglobose red berries, of an agreeable acid taste, and when completely ripe, are frequently employed as a substitute for cranberries; also, the various species of woodbine and honeysuckle (Lonicera): and the beautiful Leycesteria, (Leycesteria formosa,) much admired for the deepgreen hue of its stems and leaves, and its beautiful, large bracteas of flowers and fruit. To these may be added the coffee-tree, (Coffea arabica,) which produces the coffee of commerce, and may be distinguished by its conical-shaped head; light-brown bark; opposite, oblong, wavy, shining, light-green leaves, with clusters of white, fragrant flowers at their base; and its bright-red berries, when fully grown, but black, when perfectly ripe. 


\title{
Pinckneya pubescens, \\ THE PUBESCENT PINCKNEYA.
}

\section{Synonymes.}

\author{
Pinckneya pubens, \\ Pincneya pubescens, \\ Pincneya pubescent, \\ Behaarte Pincneya, \\ Pinckneya, \\ Georgia Bark, Pinckneya,
}

\author{
\{ Michaux, North American Sylva. \\ Loudon, Arboretum Britannicum. \\ Persoon, Enchyridium Botanicum. \\ France. \\ Germany. \\ Britain. \\ United States.
}

\begin{abstract}
Derivations. The word pubescens is derived from the Latin pubesco, to become downy, in allusion to the down which grows Derivations. The word pubescens is derived frem. Pubescens signifies an incipient state of becoming covered with hair or upon the flowers, leaves, and branches of this tree. Pown. The. French and German names have the same signification as the down; and pubens implies fully grown with hair or down. The from its abounding in the state of Georgia, it is called Georgia botanic

Bark.

Engravings. Michaux, North American Sylva, pl. 49; Audubon, Birds of America, ii., pl. clxv.; Loudon, Arboretum Brı tannicum, ii., fig. 830 ; and the figures below.

Specific Characters. Branches and leaves tomentose. Flowers rather large, pubescent, white, and tinred with red.
\end{abstract}

\section{Description.}

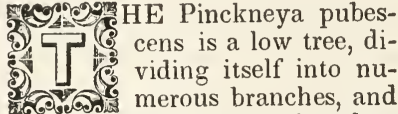
rarely exceeds the height of twenty-five feet, with a stem five or six inches in diameter. Its leaves are opposite, four or five inches long, of a light-green colour, and downy beneath. The flowers, which put forth in May and June, are white, with longitudinal rose-coloured stripes, and occur in panicles at the extremity of the branches. Each flower is accompanied by a floral leaf, bordered with rose-colour, near the upper edge. The capsules are round, compressed in the middle, and contain a great number of small winged seeds.

Geography, $\& \circ c$. The Pinckneya is indigenous to the southern parts of the United States, and particularly abounds on the borders of

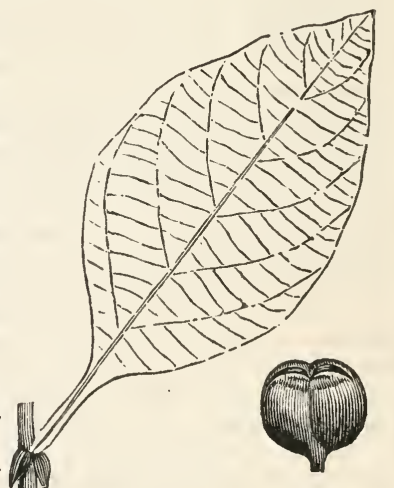
swamps in Georgia and Florida, where the soil is deep and fertile, and where the situation is rather cool and shady. In England, the plant is generally kept in green-houses or cold-pits; but it will thrive much better if planted in the free ground, and trained against a wall with a southern exposure. It requires a shady situation, and is said to thrive best in a mixture of sand and peat.

Properties and Uses. The wood of the Pinckneya is soft, which, together with its diminutive size, renders it unfit for use in the arts. The inner bark is extremely bitter, and appears to partake of the febrifugal virtues of the Cinchona officinalis; for, the inhabitants of the southern parts of Georgia successfully employ it in the cure of the intermittent fevers, which, during the latter part of "nmer and in autumn, prevail in that countrv. 


\title{
Genus LYONIA, Nutt.
}

Ericaceæ.
Syst. Nat.
Decandria Monogynia.

Syst. Lin

\section{Synonymes.}

\author{
Lyonia, Andromeda,
}

Of Authors.

Derivations. This genus was named Lyonia, in commemoration of Mr. John Lyon, an indefatigable English collector of North American plants, who fell a victim to a dangerous epidemic amidst those savage and romantic mountains which had so often been the theatre of his labours. Andromeda was the name of the daughter of Cephalus, king of Ethiopia. She was tied naked to a rock, and exposed to be devoured by a sea-monster to appease the wrath of Neptune; but was delivered by Perseus, who afterwards inarried her, and they had many children. The following reasons for the application of the name of Andromeda to this genus of plants are extracted from Linnæus" "Lachesis Lapponica":- "Andromeda polifolia," says Linnæus, "was now (June 12,) in its highest beauty, decorating the marshy grounds in a most agreeable manner. The flowers are quite blood-red before they expand; but, when full grown, the corolla is of a flesh-colour. Scarcely any painter's art can so happily imitate the beauty of a fine female complexion; still less could any artificial colour upon the face itself bear a comparison with this lovely blossom. As I contemplated it, I could not help thinking of Andromeda, as described by the poets: and the more I meditated upon their descriptions, the more applicable they seemed to the little plant before me; so that, if these writers had it in view, they could scarcely have contrived a more apposite fable. Andromeda is represented by them as a virgin of most exquisite and unrivalled charms; but these charms remain in perfection only so long as she retains her virgin purity, which is also appli. cable to the plant now preparing to celebrate its nuptials. This plant is always fixed on some little turfy hillock in the midet of the swamps, as Andromeda herself was chained to a rock in the sea, which bathed her feet, as the fresh water does the roots of this plant. Dragons and venomous serpents surrounded her, as toads and other reptiles frequent the abode of her vegetable resembler, and, when they pair in the spring, throw mud and water over its leaves and branches. As the distressed virgin cast down her blushing face through excessive affliction, so does this rosy-coloured flower hang its head, growing paler and paler till it withers away. Hence, as this plant forms a new genus, I have chosen for it the name of Andromeda." Our great mas. ter has drawn this fanciful analogy still further in his "Flora Lapponica." "At length," says he, "comes Perseus, in this shape of summer, dries up the surrounding water, and destroys the monsters, rendering the damsel a fruitful mother, who then carries her head (the oapsule) erect."

Generic Characters. Calyx 5-parted. Carolla ovate or tubular, with a contracted, 5-toothed mouth. Filaments short, fiat, downy. Anthers with membranous cells that open lengthwise. Style 5-cornered. Stigma obtuse. Capsule 5-cornered. Flowers for the most part terminal, disposed in racemose panicles.-Loudon, Arboretum.

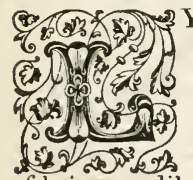

YONIA embraces evergreen and deciduous shrubs, and also one tree, natives of North America, and bearing the common character of the plants of the order Ericaceæ, both in respect to beauty, soil, situation, propagation, and culture. All the species which compose this family have hair-like roots, and require a peat soil, or a soil of a close, cohesive nature, but which is yet susceptible of being readily penetrated by their finest fibrils. They all may readily be propagated from seeds, by cuttings, or by layers. 


\section{Lyonia arborea, THE TREE LYONIA.}

\section{Synonymes.}

Andromeda arborea,

Lyonia arborea,

Andromède en arbre, Arbre à l'oseille,

Sauerampferbaum,

Albero dell' Andromeda, Albero dell' acetosa,

Sorrel-tree,
(Linvæשs, Species Plantarum.

Michaux, North American Sylva.

Don, Miller's Dictionary.

Loudon, Arboretum Britannicum.

France.

Germany.

ItraLy.

Britain and Anglo-America.

Dernvations. The specific name arborea is derived from the Latin arbor, a tree; on account of the large size which this e pecies attains. It is called Sorrel-tree from the acidity of its leaves. The French, German, and Italian names signify Andromeda-tree and Sorrel-tree.

Engravings. Michaux, North American Sylva, pl. 85; Catesby, Natural History of Carolina, i., pl. 71; and the figures below.

Specific Characters. Branches taper. Leaves deciduous, oblong, acuminate, serrate, with mucronate teeth, glabrous, acid. Flowers in terminal panicles of many racemes. Corollas white, ovoid-cylindrical; downy.-Don, Miller's Dict.

\section{Description.}

$F$ all the species of the genus, the Lyonia arborea is the only one which rises to a sufficient height to be ranked among trees. In favourable situations, it usually grows to a height of from forty to sixty feet, with a trunk from twelve to eighteen inches in diameter; but, in dry and gravelly soils this tree is observed to be so much stinted that it presents itself only in the form of a shrub. The bark of the trunk is very thick, and deeply furrowed. The leaves, which are downy in the spring, and become smooth and glabrous in acquiring their growth, are alternate, oval-acuminate, finely denticulated, and from four to five

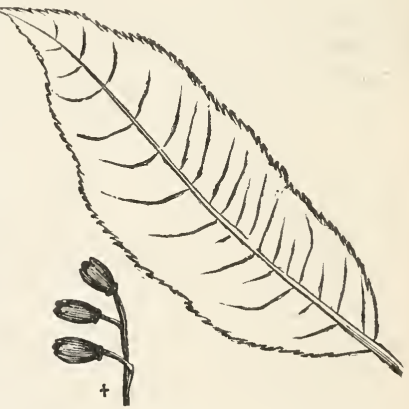
inches long. The flowers, which put forth from June to August, occur in white spikes five or six inches in length, and are succeeded by small capsules containing a number of exceedingly minute seeds. United in groups, the flowers have a fine effect, which renders this tree very proper for the embellishment of gardens and ornamental plantations.

Geography and History. This species is indigenous to the United States, from Pennsylvania to Florida; and is found in the valleys of the Alleghanies from Virginia to their termination in Georgia; but, in advancing either eastward or westward from these mountains, it becomes more rare, and ceases entirely in the maritime parts of the southern states. It was introduced into Britain in 1752, where it is found in several collections, from fifteen to twenty feet in height, and ripens seeds every year, from which an abundance of plants have been raised. 
Propagation, \& $\bullet$. The Lyonia arborea, like all the plants of the order Ericaceæ, requires a very fine loamy or sandy soil, which must be kept equally moist, or one that is mixed, more or less, with leaf-mould, or with well-rotted peat. When propagated from seeds, they must be thinly covered in pots, as they are small, and would rot, if buried deep. When the young trees are about an inch high, they should be carefully planted out in other pots, where they will acquire strength, in time; and, when large enough, may be planted in open ground.

Properties and Uses. The wood of the Lyonia arborea is very soft, of a pale rose-colour, and is totally rejected in the arts and for fuel. The leaves have a very pleasant acid taste, and are frequently made use of by hunters, in the mountains, to allay their thirst. They are sometimes employed, in the form of a decoction, as a refreshing beverage for fevers, in the parts of the country where this tree abounds. The branches and bark produce a black dye, with the addition of the salts of iron. In Tennessee, the inhabitants prefer this plant to sumach, in imparting colour to wool. 


\section{Genus RHODODENDRON, Linn.}

Ericaceæ.

Syst. Nat.
Penta-Decandria Monogynia.

Syst. Lin.

Synonymes.

$\begin{array}{ll}\begin{array}{l}\text { Rhododendron, Rhododendrum, Rhodora, } \\ \text { Chamarhododendros, Azalea, }\end{array} & \text { OF Authors. } \\ \text { Rhododendron, } & \text { France. } \\ \text { Alpbalsam, } & \text { Germany. } \\ \text { Rododendro, } & \text { Spain AND Itraly. } \\ \text { Rhododendron, Rose Bay-tree, } & \text { Britain and ANglo-America. }\end{array}$

Derivations. The word Rhododendron is derived from the Greek rhodon, a rose, and dendron, a tree, having reference to the terminal bunches of flowers, which are red, or rose-colour, in many of the plants of this genus.

Generic Characters. Calyx 5-parted. Corolla somewhat funnel-shaped, 5-cleft. Stamens 5-10. Anthers opening by terminal pores. Capsule 5-celled, 5-valved, opening at the tip.-Don, Miller's Dict.

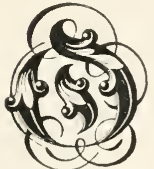

$\mathbf{F}$ all the genera in existence, the Rhododendron, including the Azaleas, comprises the most handsome, the most elegant, and the most showy shrubs which grace the lawns and shrubberies of both hemispheres. Although these plants are cultivated in Europe and America almost exclusively for ornament, yet, from their stimulant and even deleterious properties, in many parts of the globe where they grow wild, they are not without their other uses. Thus, the Rhododendron ponticum, maximum, ferrugineum, and the Rhododendron chrysanthum are poisonous to cattle which feed on their leaves; and yet, they are used in moderate doses in medicine, for the cure of rheumatism, \&c. The former was known to the ancient inhabitants of Pontus, who were well acquainted with the poisonous qualities of its flowers, which had such influence on the honey of that country, that the Romans would not receive it in tribute, but obliged the Greeks to pay them a double portion of wax in lieu of it. Both this rhododendron and the Azalea pontica were abundant in the neighbourhood of Trebisond in the time of Xenophon, who reports that, when the army of ten thousand Greeks, in their celebrated retreat, approached that city, his soldiers, having eaten the honey which they found in the environs, were seized with a violent vomiting and purging, followed by a species of delirium, so severe, that those :east affected resembled drunken persons, and the others madmen. The ground was strewed about with bodies of the soldiers, as it is after a battle. No one died, however, and the malady disappeared in twenty-four hours after it had commenced, leaving only a sensation of great weakness. According to Mr. Royle, the Himalayan species, Rhododendron arboreum, is more remarkable for its uses as a timber-tree; but its flowers are eaten by the hill people, and are formed into a jelly by European visitors. The leaves of the Rhododendron campanulatum, being used as a snuff by the natives of India, are imported from Cashmere, under the names of hoolas-kasmeeree, (Cashmere snuff,) and burg-itibbut, (Thibet lecf,) though easily procurable within the British territories. And it is not a little remarkable that the American aborigines employ the dust which adheres to the petioles of the kalmias and rhododendrons for a similar purpose.

The shrubs and trees of the genus Rhododendron, are usually evergreen, but in the azalea division they are almost entirely deciduous, with quite entire alterIlate leaves, terminated by a withered tip, or yellow gland; and with terminal, corymbose, showy flowers. They may all be cultivated in sandy peat, kept rather moist. and propagated by layers, seeds, or by cuttings. 


\section{Rhododendron maximum, THE AMERICAN ROSE BAY-TRFE}

Synonymes.

\begin{tabular}{|c|c|}
\hline Rhododendron maximum, & $\begin{array}{l}\text { Linnæed, Species Plantarum. } \\
\text { MichaUx, North American Sylva. } \\
\text { Don, Miller's Dictionary. } \\
\text { Loudon, Arboretum Britannicum. }\end{array}$ \\
\hline $\begin{array}{l}\text { hododendron maximum, Rhododendron } \\
\text { d'Amerique, }\end{array}$ & France. \\
\hline $\begin{array}{l}\text { rican Rose Bay-tree, } \\
\text { Bay-tree, Dwarf Rose Bay-tree, }\end{array}$ & $\begin{array}{l}\text { Germany. } \\
\text { Britain. } \\
\text { United States. }\end{array}$ \\
\hline
\end{tabular}

Dervation. The specific name maximum is derived from the Latin magnus, great, and signifies "the largest $;$ " in reference to the laige size of this tree when compared with the minor species of this genus.

Engravings. Michaux, North American Sylva, pl. 67; Audubon, Birds of America, ii., pl. ciii.; Loudon, Arboretum Bri. tannicum, ii., fig. 932; and the figures below.

Specific Characters. Arborescent. Leaves elliptic-oblong, acute, convex, bluntish at the base, whitish or rusty beneath, glabrous. Calycine segments oval-obtuse. Segments of corolla roundish. Flowers pale-red, in umbellate corymbs, studded with green, yellow, or purple protuberances.-Don, Miller's

Dict.

\section{Description.}
"Pleased with their toil, the healers sought the cell, Where Rhododendron, like some drooping maid, Timid and beauteous, hides its golden locks; Or lur'd her statelier sister's aid, to bribe Relentless Chronic Rheumatism to loose The rigid sinew."

Traits of the A Borigings.

shrub, less than ten feet high; but it sometimes attains a height of twenty or twenty-five feet, with a stem four or five inches in diameter. When the leaves are beginning to unfold themselves they are rose-coloured, and are covered with a reddish down. When fully expanded, they are smooth, five or six inches long, of an elongated-oval form, and of a thick, coriaceous texture. Although the tree is HE Rhododendron maximum generally presents itself in the form of a evergreen, it renews its leaves once in three or

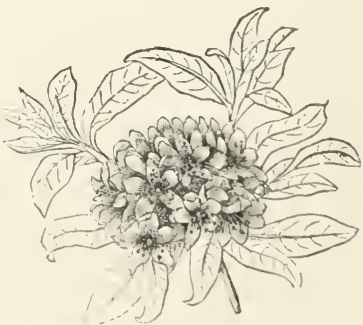
four years. It puts forth flowers from Jume till August, which are commonly rose-coloured, with yellow dots on the inside, and sometimes they are perfectly white. 'They always occur at the extremity of the branches in beautiful groups, which derive additional lustre from the foliage that surrounds them. 'The seeds are extremely minute, and are contained in capsules which open in autumn, for their escape.

Varieties. The varieties recognized in this species are as follows :-

1. R. M. album, Loudon. White-flowered Rose Bay-tree, with pure white flowers, and is comparatively rare.

2. R. м. hybridum, Loudon. Mybrid Rose Bay-tree, supposed to have been produced by fertilizing the ccmmon white glaucous-leaved Azalea with the pol- 
len of the Rhododendron maximum. The flowers of this variety are very tragrant, which circumstance alone, entitles it to a place in collections.

3. R. M. Purpureun, Loudon. Purple-flowered Rose Bay-tree. This variety, which has large purple flowers, grows to an immense size, its stem being often found eighteen inches in diameter, and its folıage triple the size of that of any other species. It is a native of Virginia and Carolina, on the highest mountains, near lakes, where it forms a large shrub, or low tree, growing to the height of twenty-five feet, flowering in the months of May and June.

Geography, \& $\bullet$. The Rhododendron maximum is found on Long Island, and on the banks of the Hudson below the Highlands, in the state of New York, and rarely as far north as Massachusetts; but these places may be considered far beyond the limits where this tree ceases to be an inhabitant of the forests. It frequently occurs in the middle and southern states of the union, particularly in the mountainous tracts of Carolina and Georgia. It is almost exclusively seen on the borders of rivers and creeks, and is observed to be more multiplied in approaching the Alleghanies, till, in the midst of these mountains, especially in Virginia, it becomes so abundant on the sides of the torrents, as to form impenetrable thickets. Deeply-shaded situations, in the vicinity of cool and crystal waters flowing among rocks, where the atmosphere is charged with vapour, are the most congenial to the growth of this tree.

This species was introduced into Britain by Peter Collinson, in 1736; but it did not flower in England, as Miller informs us, until 1756; and the only person who then succeeded in raising it, was Mr. James Gordon, at Mile End. It has also been introduced into many of the gardens and collections on the continent of Europe; but as it is not nearly so easy of cultivation as the Rhododendron ponticum, it does not grow to so large a size. In Derbyshire, England, at Shipley Hall, there is a specimen of the Pontic rhododendron exceeding sixteen feet in height, the branches of which cover a space nearly sixty feet in diameter. In the Bartram botanic garden, at Kingsessing, near Philadelphia, there is a Rhododendron maximum fifteen feet in height, with a top forty-five feet in circumference.

Propagation and Culture. The Rhododendron maximum, like all its congeners, may be propagated by cuttings of the young shoots, taken off in a growing state, when their lower ends have begun to ripen, and planted in pure sand, and covered with a bell-glass, or by layers; but the best plants of this, and all the other species, are procured from seeds. They are ripe in August or September; and, though they will retain their vital principle for upwards of a year, it is considered safest to sow them soon after they are gathered. They should be sown in peat soil, or very fine sandy loam, in pots or boxes, or in a border shaded from the direct influence of the sun; and kept in a uniform state of moisture, and protected from the frost. In sowing, the surface of the soil should previously be made quite smooth, and gently pressed down, or watered till it has settled to a level surface; and, after the seeds have been equally distributed over this surface, they should be covered with no more soil than is barely requisite to conceal them from the eye. Seeds sown in autumn will germinate in the following spring, and will be fit for transplanting by the next autumn, or by the spring of the following year. After seedling plants have been a year in pots, or in the seedbed, they may be planted into nursery lines, and removed every year, or every second year, and placed at greater distances, till they have acquired the size at which it is considered desirable to sell them, or to plant them where they are finally to remain. At whatever age or size they are removed from the nursery, they require, in common with all hair-rooted plants, to have a small ball of earth attached to their roots, and to have these carefully protected from drought by mats. In consequence of almost all the rhododendrons and azaleas being remov- 
able with balls, they may be transplanted at every seasoll of the year, though antumn and spring are the periods generally made choice of. In consequence, also, of peat soil readily adhering to the fibrils of the plants of this genus, and, indeed, of all the Ericaceæ, it becomes less necessary to grow them in pots for the convenience of removal, than is the case with most other rare and valuable trees and shrubs.

Properties and Uses. The wood of the American rose bay is hard, compact, and fine-grained; but, from its diminutive size and comparative scarcity in the more populous parts of the country where it grows, it has not, hitherto, been appropriated to any particular use in the arts. The leaves are sudorific and narcotic, and have been successfully employed in the cure of rheumatism. "The alinost entire use to which this species is applied, both in Europe and in America, is for ornament; and, from its delicately-coloured flowers, of the beautiful red and white tints of the apple blossom and of the rose, which strikingly contrast with its smooth, evergreen leaves, it richly deserves a place in every collection.

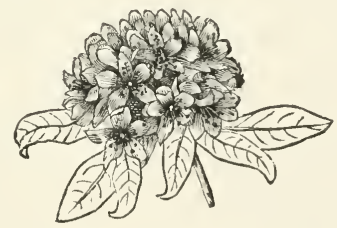




\title{
Genus KALMIA, Linn.
}

\author{
Ericaceæ. \\ Syst. Nat. \\ Decandria Monogynia. \\ Syst. Lin.
}

Derivation. Named by Linnzeus in honour of Peter Kalm, professor at Abo, in Sweden; author of "Travels in America," in 1753 .

Generic Characters. Corolla of the shape of a wide-spread bell, and with 10 cavities on the inside, in which the anthers of 10 stamens repose before shedding their pollen. Capsule 5-celled. Dissepiments marginal.-Don, Miller's Dict.

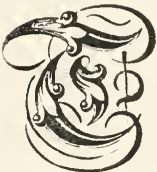

HE genus Kalmia consists of low evergreen shrubs, highly ornamental in their foliage and flowers; natives of North America; of easy culture in peaty soil, and propagated by layers, seeds, or by cuttings. Most, if not all the species are accounted poisonous, and honey collected by bees from their flowers is of a deleterious nature. The leaves of the shrub called "Lamb-kill," or "Sheep Laurel," (Kalmia angustifolia,) is highly poisonous to sheep and lambs, often causing their death when eaten by them, particularly the latter. Hence the name.

To the same natural family belong the various species of heath (Erica, Gypsocallis, Calluna, etc.); also the several kinds of stra wberry-trees (Arbutus); whortleberries (Vaccinium); and several genera of procumbent and trailing shrubs, among which are the common bearberry, (Arctostaphylos uva-ursi,) the partridgeberry or winter-green, (Gaultheria procumbens,) the Labrador tea, (Ledum latifolium, and the common marsh cranberry (Oxycoccus palustris.) 


\section{Kalmia latifolia, \\ THE BROAD-LEAVED KALMIA.}

Synonymes.

Kalmia latifolia;

(Linvaus, Species Plantarum.

Michadx, North American Sylva.

$\{$ Bigelow, Medical Botany.

Don, Miller's Dictionary.

Loudon, Arboretum Britannicum.

Kalmia à larges feuilles,

Breitblättrige Kalmia,

Broad-leaved Kalmia,

France.

Germany.

Baurel, Mountain

Bush, Calico-tree, Calico Flower,

Derivations. The specific name latifolia is derived from the Latin latus, broad, and folium, a leaf, having reference to the broad leaves of this species. The French and German names have the same signification as the botanic one. It is called Calicotree, Calico Flower, \&c., on account of its beautiful spotted flowers.

Engravings. Nichaux, North American Sylva, pl. 68; Catesby, Natural History of Carolina, ii., pl. 98; Audubon, Birds of America, i., Iv.; Loudon, Arboretum Britannicum, ii., fig. 959; and the figures below.

Specific Characters. Leaves on long petioles, scattered, or 3 in a whorl, oval, coriaceous, smooth, and green on both surfaces. Corymbs terminal, downy, and viscid.-Don, Miller's Dict.

\section{Description.} of fifteen or twenty feet, in favourable situations, with a stem three or four inches in diameter; but ordinarily it does not attain more than one half of these dimensions. Its leaves are of a coriaceous texture, oval-acuminate, entire, and about three inches long. The flowers, which put forth from May to July, are sometimes of a pure white, tinted with palepink, delicately spotted; but, in general, they are of a beautiful rose-colour, and are destitute of odour. They are disposed in corymbs at the extremity of the branches; and, as they are always numerous, their brilliant effect is heightened by the richness of the surrounding foliage. The seeds are very minute, and are contained

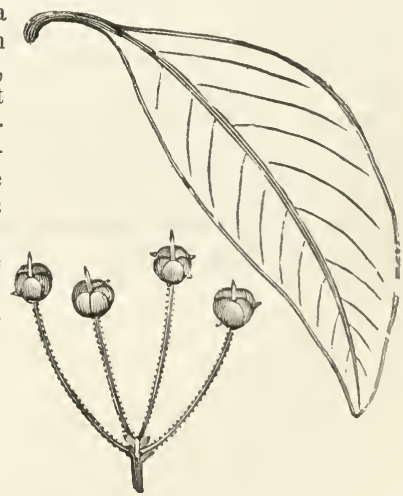
in small, globular capsules.

Geography and History. The Kalmia latifolia is indigenous to North Ame1ica, from Canada to Carolina. It rarely occurs, however, north of the forty-second or forty-third degrees of north latitude, and is but sparingly produced in Kentucky and western Tennessee, and disappears entirely in the southern states wherever the rivers enter the low country, or where the pine-barrens begin. Although it is comparatively abundant along the rivers of the middle and somtherr. states, it is nowhere seen more profusely multiplind, nor of a greater height, 
and of more luxuriant vegetation, than in North Carolina, on the loftiest parts of the Alleghanies. It there occupies large tracts, and forms thickets upon their summits, and for a third of the distance down their sides, which are rendered almost impenetrable by the crooked and unyielding trunks, crossed and locked with each other. As the shrubs which compose these copses are nearly of the same height, and richly laden with evergreen foliage, they present, at a distance, the appearance of verdant meadows, surrounded by tall trees.

This species was introduced into Britain in 1734, by Peter Collinson, who procured it from Pennsylvania, and planted it in Catesby's garden, at Fulham, where it flowered for the first time in England, in 1741. It was introduced into France, by the elder Michaux, in about the year 1790, and is to be found in many of the European collections.

Soil, Situation, \&॰c. The Kalmia latifolia, in its natural habitat, usually occurs on the sides of stony hills, near water, where the soil is sterile; but when cultivated, it flourishes best in a soft, loose, and cool soil, with a northern exposure. For propagation and culture, the reader is referred to our article on the Rhododendron maximum.

Properties and Uses. The wood of the Kalmia latifolia, particularly that of the roots, is very compact, fine-grained, and marked with red lines. When green, it is of a soft texture, and is easily wrought; but, when well seasoned, it is very hard, and more nearly resembles the European box, (Buxus sempervirens, ) than any other American wood. Consequently it is worthy of the attention of mathematical instrument-makers, and of engravers on wood. It is sometimes employed in the United States for the handles of light tools, for screws, boxes, \&c.; and it is said, also, to make good clarionets. It is used by the American Indians for making small dishes, spoons, and other domestic utensils. The whole plant is regarded as poisonous to young cattle, and sheep, but not to goats and deer. A decoction of the leaves of this tree was formerly taken by those miserable natives who had determined on self-destruction. But modern enterprise has successfully enlisted it in the service of medicine, and it is applied, in a pulverized form, internally, in fevers, or topically, for the relief of cutaneous affections. A few drops of the tincture poured upon the body of a large and vigorous rattlesnake, killed the reptile in a short time. The powder which covers the leaves is popularly employed in some parts of the country where it grows, for snuff. The honey collected from the flowers by bees, is accounted deleterious, which, with other noxious qualities of this elegant shrub, lessens that esteem which its beauty claims.

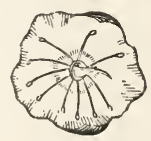




\title{
Genus HALESIA, Ellis.
}

\author{
Halesiaceæ. \\ Syst. Nat. \\ Dodecandria Monogynia. \\ Syst. Lin.
}

Derivation. Named by Ellis in honour of the learned and venerable Stephen Hales, D. D. F. R. S., author of "Vegetable Statics," \&c., published in 1727.

Generic Characters. Corolla monopetalous, ventricosely campanulate, with a 4-lobed erect border. Stamens 12 to 16 . Filaments combined into a tube at the base, and adnate to the corolla. Anthers oblong, erect, 2-celled, dehiscing lengthwise. Ovarium inferior. Style 1. Stigma simple. Drupe dry, corticate, oblong, with 2-4-winged angles, terminated by the permanent style, containing a 2-4. celled putamen, which is acute at both ends. Cells 1-seeded. Seeds attached to the bottom of the cells. Testa of seeds simple, very thin. Enbryo the length of albumen, with linear-oblong cotyledons, and a long, linear, compressed, inferior radicle. Albumen fleshy. Trees, with alternate serrated leaves, and lateral fascicles of pedicellate, drooping, white flowers.-Don, Miller's Dict.

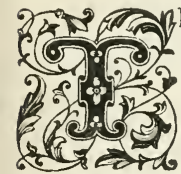

HE genus Halesia embraces but two species, natives of Carolina and Georgia, both of which are highly ornamental and sufficiently hardy to withstand the climate of Britain and the temperate parts of the United States. The Halesia diptera, a native of Georgia, has leaves which closely resemble those of the Styrax grandifolium, but differ from them in not being downy beneath, and is frequently sold for it in nurseries. Indeed, in affinity, as well as in general appearance, this genus approaches near to that of styrax; and there is so close a resemblance among all the allied species of styrax, that they may possibly be only varieties of one form. To the last-named genus belongs the officinal storax of apothecaries, (Styrax officinale,) much used at the present day in Catholic countries to burn as incense. The common storax of commerce differs from that of the shops, and is a liquid balsam, said to be obtained from the Liquidambar styraciflua. 


\title{
Halesia tetraptera, THE COMMON SNOWDROP-TREE.
}

\author{
Synonymes.
}

\section{Halesia tetraptera,}

Halesia tetraptera, Snowdrop-tree, Silver Bell-tree, Wild Olive-tree,
Linveus, Species Plantarum.

Don, Miller's Dictionary.

Loudon, Arboretum Britannicum.

France and Germany.

Derivations. The specific name tetraptera is derived from the Greek tetra, four, and pteron, a wing, in allusion to the fou wings of the fruit of thie tree. It is called Snowdrop-tree, from the resemblance which its flowers bear to those of the snowdrop. Engravings. Curtis, Botanical Magazine, pl. 910 ; Audubon, Birds of America; Loudon, Arboretum Britannicum, ii., fig. 1012 and vi., pl. 196 et 197 ; and the figures below.

Specific Characters. Leaves ovate-lanceolatc, acuminated, sharply serrated. Petioles glandular. Fruit with 4 wings. Leaves acuminated, with the middle depressed. Flowers pure white, $9-10$ in a fascicle. drooping, resembling those of the snowdrop.-Don, Miller's Dict.

\section{Description.}

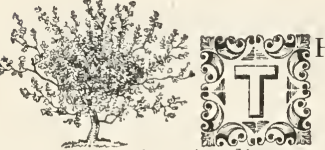

HE Halesia tetraptera is a beautiful low tree or large shrub, growing from fifteen to thirty feet in height, with a trunk from five to eighteen inches in diameter. The bark of the trunk is of a darkish colour, with many irregular fissures. The leaves are ovate-acuminate, serrate, with the middle depressed. The flowers, which are of a pure white, put forth in April and May, and are succeeded by an acid fruit, of a rhomboidal form, with four wings. Its flowers are produced in great abundance; and, from their shape, colour, and pendulous appearance, they are considered as resembling those of the snowdrop (Galanthus nivalis.)

Variety. H. т. Parviflora. Small-flowered Four-winged-fruited Halesia, uฯ Snowdrop-tree; Halesia parviflora, of Pursh, Michaux, and others. This variety, though usually considered as a distinct species, differs from the Halesia tetraptera, chiefly in having the leaves downy and glaucous beneath.

Geography, $\mathscr{f}^{\circ} \mathrm{c}$. The Halesia tetraptera is found in shady woods, on the banks of streams, from Carolina to Texas. It was introduced into Britain in 1756 , and is to be met with in most of the European collections. The largest recorded trees of this species in Britain, are at Purser's Cross, and at Syon House, near London, which exceed thirty feet in height, with trunks about eighteen inches in diameter. At Schwöbber, in Hanover, Germany, there is another tree of about the same dimensions.

This species may be propagated from seeds which often remain in the ground more than a year without vegetating. It may also be increased by cuttings or by layers.

Properties and Uses. The wood of the Halesia tetraptera is hard, brittle, and veined; but owing to its small size, and comparative scarcity, it is appropriated to no particular use in the arts. The fruit, when ripe, is eaten in a crude state, by some people; and, when green, it is sometimes employed as a pickle. As this species is one of the most ornamental of the American deciduous trees, it richly deserves a nlace in everv collection. 


\section{Genus DIOSPYROS, Linn.}

Ebenaceæ.

Syst. Nat.

Diospyros, Ebenus, Guaiacana,

Plaqueminier,

Dattelpflaume,

Diospiro,

Date Plum-tree,
Polygamia Diœcia.

Syst. Lin.

Synonymes.

OF Authons.

France.

Germany.

ITALY.

Britain and Anglo-America.

Derivation. The word Diospyros is thought to be corrupted from the Greek Diospuros, (dios, divine, and puros, wheat, s name given by the ancients to the Lithospermam officinale. Its application to the date plum is supposed to have arisen by confounding the Greek puros, wheat, with the Latin pyrus, a pear-tree, to the fruit of which the date plum may have been thought to bear some resemblance.

Generic Characters. Flowers polygamous. Calyx deeply 4-cleft, sometimes 3 or 6-cleft. Corolla urceo late, 4-cleft; sometimes 3 or 6 -cleft. Male flowers having the stamens inserted by pairs into the base of the corolla, twice the number of its segments, with double or twin filaments, and the rudiment of a pistil. Hermaphrodite flowers having fewer and sterile stamens. Ovarium 8-12-celled: cells 1seeded. Berry globose, with a spreading calyx which is at length reflexed. Albumen horny._Don, Miller's Dict.

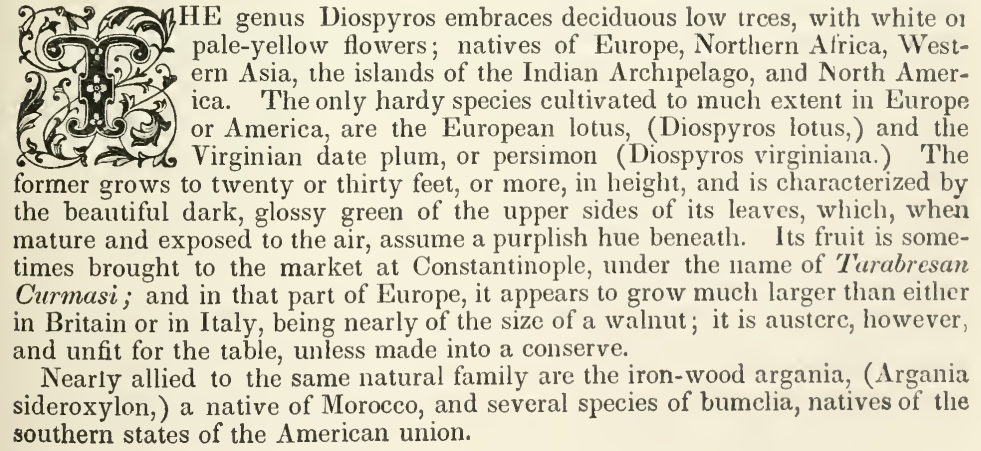




\title{
Diospyros virginiana, \\ THE VIRGINIAN DATE PLUM OR, PERSIMON-TREE.
}

\section{Synonymes.}

Diospyros virginiana.

Plaqueminier de Virginie, Virginische Dattelpflaume, Diospiro di Virginia,

Virginian Date Plum-tree, Persimon-tree, Britain and Anglo-America.
(Linneus, Species Plantarum.

$\{$ Michaux, North American Sylva.

Loudon, Arboretum Britannicum

France.

Germany.

ITALY.

Engravings. Michaux, North American Sylva, pl. 93; Audubon, Birds of America, 1., pl. 1xaxı.. , Loucor, arnoletum Britannicum, vi., pl. 200 et 201 ; and the figures below.

Specific Characters. Leaver ovate-oblong, acuminated, glabrous, shining above, and paler beneath, reticulately veined. Petioles short and curved, and, as well as the branchlets, downy. Leaf buds glabrous Flowers quadrifid, rarely quinquefid. Flowers pale-yellow.-Don, Miller's Dict.

\section{Description.}

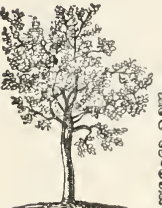

\author{
"If Fever's fervid rage \\ Glow'd in the boiling veins, with care they sought \\ The firm Diospyros."
}

Traits of the Aborigines

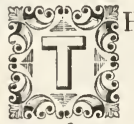

HE Virginian Date Plum, when grown under favourable conditions, sometimes attains a height of sixty or seventy feet, with a trunk eighteen or twenty inches in diameter; but, under ordinary circumstances, it does not usually exceed one half of these dimensions. The trunk of a fullgrown tree is covered with a deeply-furrowed blackish bark, from which exudes a greenislı gum, without taste or odour. This tree is readily distinguished from the European date plum, by its leaves being nearly of the same shade of green on both surfaces; while those of the latter are of a dark purplish-green above, and much paler, and furnished with a somewhat pinkish down beneath. Those of the Virginian date plum are from four to six inches in length, oblong, entire, of a fine green above, glaucous beneath, and often, in autumn, are variegated with black spots. The terminal shoots are observed to be usually accompanied, at the base, by small rounded leaves. This species belongs to that class of vegetables, the sexes of which are confined to different trees. Both the barren and fertile flowers are of a greenish-yellow, but not strikingly conspicuous. They put forth in June and $\mathbf{J} u l y$, and are succeeded by a round fruit, about the size of a bullace plum, of a reddish complexion, with a fleshy pulp, containing six or eight semi-oval stones, slightly swollen at the sides, and of a dark-purple colour. The fruit is not palatable till it has been softened by frost, when it becomes sweet, though still astringent. In the southern states of the union it adheres to the branches long after the leaves have dropped; and when it falls; it is eagerly devoured by wild and domestic animals. 
Varieties. The varieties recognized under this species are as follows:-

1. D. v. Pubescens. Pubescent-leaved Virginian Date Plum-tree; Diospyrns pubescens, of Pursh, Don, and others. The chief distinction between this variety and the Diospyros virginiana is, in its fruit having fewer seeds, and the downiness of its leaves on their under sides, which are also slightly different in their shape. Michaux makes this only a variety of this species, occasioned by difference of climate; which, he observes, exerts an extraordinary influence on the development of all trees that are common to different parts of the United States.

2. D. v. Dulcis, Prince. Sweet-frnited Virginian Date Plmm-tree, characterized in having sweeter fruit than that of the species.

Geography and History. The Diospyros virginiana is found wild in the United States from the forty-second degree of north latitude to T'exas. It is quite common in New Jersey, still more so in the middle and southern states, and abounds also in the west. When it was introduced into Britain is nncertain; but it has been in cultivation, in England, though not very common, ever siuce the time of Parkinson.

The largest tree of this species in Britain, is in the arboretum at Kew, which exceeds forty feet in height.

In France, Germany, and Italy, there are specimens of about the same height as at Kew.

The largest recorded tree of this kind on the globe, is in the Bartram botanic garden, at Kingsessing, near Philadelphia, which exceeds seventy feet in height, with a trunk two feet in diameter.

Soil, Situation, Propasgation, $\mathcal{S}^{\circ} c$. The Diospyros virginiana seems to prefer a soft, black soil, rather moist, and requires a sheltered situation. It is usually propagated from seeds; but may be increased either by grafting or by layers.

Properties and Uses. The fresh sap-wood of the Virginian date plum, is of a greenish colour, which it preserves after it is seasoned; and the heart-wood is brown, hard, compact, strong, and elastic, but liable to split. At Baltimore, screws and mallets have been made of it; at Philadelphia, shoe-lasts; and in Carolina, wedges for splitting trees. Michaux says that he was assured by the coach-makers in Charleston, that they had employed it for the shafts of chaises, and found it preferable to the ash, and all other species of wood, except the lancewood of the West Indies. The inner bark, which is exceedingly bitter, is said to have been employed with success, not only by the American Indians, but by the inhabitants of the regions where this tree abounds, in the cure of intermittent fevers. The bark of the root has also been considered a tonic favourable to the treatment of dropsies. A greenish gum exudes from the tree, but in very small quantities, which never has, as yet, been applied to any useful purpose either as a medicine or in the arts. In the middle and western states, the fruit is sometimes collected, pounded up with wheaten bran, formed into cakes, which are dried in an oven, and kept to make beer. For this purpose, they are dissolved in warm water, with the addition of lops and yeast. 'The fruit itself, bruised and fermented, yields an ardent spirit, which is said to improve witl age. It has been asserted by the farmers of Virginia that, grass grows more vigorously beneath the persimon than bencath any other tree, and this fact is attributed to the speedy decay of its leaves, as well as to those of the common locust, which form an excellent manure.

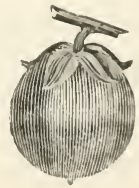




\section{Genus CHIONANTHUS, Linn.}

Oleaceæ.

Syst. Nat.
Diandria Monogynia. Syst. Lin.

Derivation. From the Greek chiōn, snow, and anthos, a flower, in reference to the snow-white flowers of the species.

Generic Characters. Calyx small, 4-parted, or 4-toothed. Corolla with a short tube and a 4-parted limb; segments of the limb long and linear. Style hardly any. Stigma 2-lobed. Anthers almost sessile Drupe baccate, containing a striated nut. Seeds albuminous.-Don, Miller's Dict.

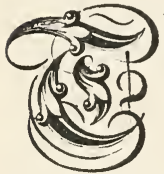

HE order to which this genus belongs embraces trees and shrubs, natives of both hemispheres, and for the most part are deciduous. Some of them are timber-trees; others medicinal, which, in general, are bitter. One genus, (Olea,) produces a valuable oil; and from others, (Ornus and Fraxinus,) is obtained the sweet purgative manna. The Syringa supplies some of the most beautiful deciduous shrubs, and the Ligustrum and Phillyrea some useful evergreens. As most of the species of this order may be grafted on one another, it is probable that their flowers might be reciprocally fecundated; in which case, some curious hybrids might be produced between the privet and the lilac, the privet and the olive, the lilac and the ash, \&c. 


\section{Chionanthus virginica, THE VIRGINIAN SNOW FLOWER-TREE.}

Synonymes.

$\begin{array}{ll}\text { Chionanthus virginica, } & \begin{array}{l}\text { Linnaus, Species Plantarum. } \\ \text { Don, Miller's Dictionary. } \\ \text { Loudon, Arboretum Britannicum. }\end{array} \\ \text { Arbre de neige, Chionanthe de Virginie, } & \text { France. } \\ \text { Schneeblume, } & \text { Germany. } \\ \text { Albero di neve, } & \text { ITALY. } \\ \text { Virginian Snow flower-tree, Fringe-tree, Britain. } \\ \text { Virginian Snow flower-tree, Snowdrop-tree, UnITEd States. }\end{array}$

Engravings. Catesby, Natural History of Carolina, i, pl. 98; Loudon, Arboretum Britannicum, ii., figs. I029 et 1030; and the figures below.

Specific Characters. Racemes terminal. Peduncles 3-flowered. Flowers pedicellate. Leaves lanceolate, glabrous, resembling those of a deciduous magnolia. Drupe purplish._Don Miller's Dict.

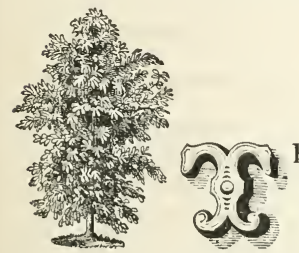

\section{Description.}

troduced into Britain in 1796 ; flowing from July; and requires to be sandy peat or sandy loam, and in a sheltered situation. It may be propagated by layers, or by grafting on the ash, which, if done standard high, would, from its large leaves and the singular appearance of its snow-white flowers, form a splendid tree. The leaves are often a

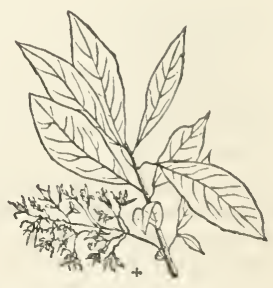
foot long, and nearly half as broad; but neither the leaves nor the flowers will attain any degree of perfection, unless the soil be kept moist. The bark of the root, bruised, is sometimes employed in healing wounds.

Varieties. Under this species are recognized the following varieties :-

1. C. v. Latifolia, Loudon. Broad-leaved Virginian Shon flower-tree, with broad coriaceous leaves, a native of Carolina, \&c.

2. C. v. Angustifolia, Loudon. Narrow-leaved Virginian Snow flower-tree.

3. C. v. maritima, Loudon. Sea-side-inhabiting Virginian Snow flower-tree, a native of North America, growing in boggy woods by the sea-side. 


\section{Genus OLEA, Linn.}

\section{Oleacex. \\ Syst. Nat. \\ Diandria Monogynia.}

Derivation. The word Olea is derived from the Greek elaia, the olive-tree; and, in its turn, as De Theis conjectures, from the Celtic olew, oil.

Generic Characters. Corolla quadrifid, with the segments nearly ovate. Drupe a monospermous plum

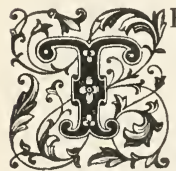

HE genus Olea embraces more than twenty species, either indigenous or cultivated in the temperate parts of Europe, Asia, Africa, and America. Besides the Olea europæa and americana, hereafter described, may be noted, as worthy of cultivation, the Olea excelsa, a native of Madeira, and sufficiently hardy to withstand the climate of Britain and the temperate parts of the United States; the Olea emarginata, indigenous to Madagascar; the Olea capensis, a native of the Cape of Good Hope; and the Olea fragrans, of China and Japan, where it is much cultivated for the sake of its sweet-scented flowers; which, it is said, are used for giving flavour to schulang tea. The scent of this plant, Messrs. Loddiges observe, "is astonishing; and so diffusive, that we distinctly noticed it, when in bloom, on the back wall of our green-house, at considerable more than one hundred yards' distance." 


\section{Olea europaa, \\ THE EUROPEAN OLIVE-TREE.}

Synonymes.

Ulea europaa,

Olivier,

Oehlbaum, Olivenbaum,

Olivo, Ulivo,

Olivo,

Oliveyra,

Olive-tree,
(Linv五Us, Species Plantarum.

$\{$ Michaux, North American Sylva.

Don, Miller's Dictionary.

Loudon, Arboretum Britannicum.

France.

Germany.

ITALY.

SPAIN.

Portugal.

Britain and ANglo-America.

Engravings. Michaux, North American Sylva, pl. 87; Loudon, Arboretum Britannicum, ii., fig. 1032; and the figurea oelow.

Specific Characters. Leaves lanceolate, pointed, entire, hoary beneath. Branches angular, not spiny.Loudon, Enc. of Plants.

\section{Description.}

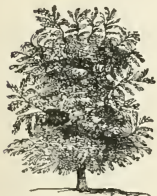

$$
\begin{aligned}
& \text { "The trees went forth on a time to anoint a king over them; } \\
& \text { and they said to the olive-tree, reign thou over us." Judges, ix. } 8 .
\end{aligned}
$$

ble resmblan wow becos bearing considerabe remmon willow, which has been lopped, and acquired a new summit of three or four years' growth. It seldom exceeds thirty feet in height, with a trunk two feet in diameter, and frequently it does not attain one half of these dimensions. It ramifies at a small height from the ground, and forms a compact summit. The bark of the trunk and branches, when young, is smooth, of an ashy hue, and when the epidermis is removed, the cellular integument appears of a

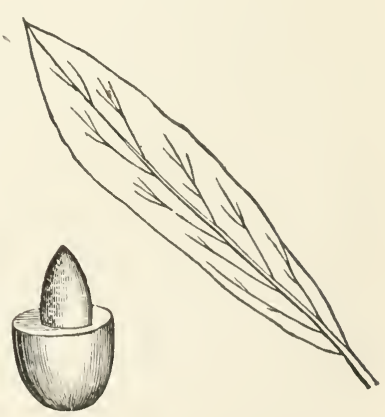
light-green. On old trees, the bark upon the trunk, and upon the base of the principal limbs, is brown, rough, and deeply furrowed. In spring and autumn, when the sap is in motion, the bark is easily detached from the body of the tree. The main limbs are numerously divided, with their branchlets opposite, and in pairs, alternately placed upon conjugate axes. The foliage is of a pale, impoverished evergreen verdure, but a part of it turns yellow, and falls in the summer, and in three years it is completely renewed. In spring or early autumn, when the vegetation of this tree is in its greatest activity, the young leaves put forth directly above the cicatrix of the former leafstalks, and are distinguished by their suppleness, and by the freshness of their tint. The colour of the leaves varies in the different varieties of this species, but they are generally smooth, of a light-green above, and whitish or glaucous and somewhat downy, with a prominent midrib, beneath. On most of the cultivated varieties, they are from an inch and a half to two inclies long, and from 
half of an inch to an inch broad, narrow, with both ends acute, even, and entire at the edge, joined to the main stem by very short foot-stalks, and opposite, after the manner of the branchlets. The flower-buds begin to appear about the middle of April, but the bloom is not full before the end of May or the beginning of Jume. The flowers, which are borne by the shoots of the preceding year, are small, white, slightly odoriferous, and are disposed in axillary racemes, some of which are almost as numerous as the leaves, and garnish the tree with wanton luxuriance, while other bunches are thinly scattered over the branches, or are seen only at their extremities. A week after the expansion of the flower, the corolla fades and falls. If the calyx remains behind, a favourable presage is formed of the fruitfulness of the season; but the hopes of the husbandman are liable to be blasted, at this period, at the slightest intemperateness of the elements, which causes the germ to fall with the flower; whereas, warm weather, accompanied by gentle breezes that agitate the tree and facilitate the fecundation, is most propitious to his wishes. The fruit of the olive is egg-shaped, pointed at the extremity, and is usually from a half to three-fourths of an inch in diameter, in one direction, and from three-fourths of an inch to an inch and a half in the other; but, on wild trees, it scarcely exceeds the size of a common currant. The skin is smooth, and generally of a violet colour, when ripe; but in certain varieties, it is of various shades of red, yellow, and black. The pulp is greenish, containing an oblong, pointed stone, divided into two cells, one of which is usually void. The oil of the olive is furnished by the pulp, which is a characteristic almost peculiar to this fruit, and that of the Cornus mas. and purpurea, being extracted from the seeds of other oleaginous vegetables. The young olives set in June; increase in size, and remain green during the summer; begin to change colour early in October; and are ripe at the end of November, or by the beginning of December. On the wild olive, five or six fruits are ripened upon each peduncle; but on the cultivated tree a great part of the flowers prove abortive, and the green fruit is cast at every stage of its growth, so that rarely more than one or two germs upon a cluster arrive at maturity.

Varieties. The olive, like many other kiuds of fruit, has, by long cultivation, become exceedingly multiplied in its varieties, which may be considered as more or less accidental or temporary. From the extensive distribution and long cultivation of this tree, it is utterly impossible to trace the multitude of cultivated sorts to their original form. The wild, thorny olive, (Olea oleaster,) indigenons to Spain, Portugal, the south of France, and Italy is thought by some, to bear the same relation to the cultivated olive, as the crab does to the apple, and the pyraster to the pear. The following varieties, however, appear to be suffiiently distinct, the first of which, may be considered as the normal form of the species :-

1. O. E. Longifolia, Loudon. Long-leaved European Olive-tree; Olea europaa, of Michaux; Olivier $d$ Europe, of the French; Langblattriger Oehlbaum, of the Germans. This variety is that which is principally cultivated in France and Italy, and answers to the general description at the commencement of this article.

2. O. E. latifolia, Loudon. Broad-leaved European Olive-tree; Olea hispanica, of Blackwell, in Miller's Dictionary; Olivier d'Espagne, of the French; Breitblätriger Oehlbaum, of the Germans. 'This variety is chiefly cultivated in Spain, the fruit of which is nearly double the size of the common olive of Provence or Italy; but the oil made from it is too rank in flavour for most palates.

3. O. e. ferruginea, Loudon. Ferruginous-leaved European Olive-tree, a native of the Cape of Good Hope, and, according to Mr. Royle, of the Himalayas, with the leaves narrow, acute at both ends, and rusty beneath.

4. O. E. curvifolia. T'wisted-leaved European Olive-tree; Olivier à feuilles inrses, of the French, with oblong leaves bent obliquely, and pale beneath. 
5. O. E. Buxifolia, Loudon. Box-leaved European Olive-trce; Olivier à fenilles de buis, of the French, with oblong-ovate leaves, and divaricate branches.

6. O. E. LAURIfolia. Laurel-leaved European Olive-tree; Olivier à fenilles de laurier, of the French.

7. O. E. umbracula. Umbrella European Olive-tree; Olivier en parasol, of the French.

8. O. E. Pendula. Pendulous-branched European Olive-tree; Olivier à rameaux pendans, of the French.

9. O. e. polymorpha. Many-formed-fruited or Weeping European Olive-tree; Olivier pleureur or Olivier de grasse, of the French. This variety is one of the largest and finest trees. Its branches are numerous and pendant, like those of the weeping willow. Its fruit is good for the table, and yields a pure and abundant oil. It should be grown in valleys rather than on elevated ground, as there is more to be feared from drought than cold. It is said there are individuals of this kind, in Languedoc, that have three times survived the general destruction of the olive, in France, by frost.

10. O. E. MacrocarPa. Large-fruited European Olive-tree; Olivier à gros fruit, of the French.

11. O. E. мinima. Small-fruited European Olive-tree; Olivier à petit fruit rond or Olivier de salon, of the French. 'This variety produces a small round fruit, good for oil, and prefers dry and elevated grounds.

12. O. E. rotundata. Round-fruited European Olive-tree; Olivier à fruit rond, of the French. This variety is among the less hardy kinds, and requires moisture, a good soil, and an abundance of manure. Its fruit yields an oil of superior quality.

13. O. E. UVARIA. Grape-like-fruited European Olive-tree; Olivier à grappe, of the French.

14. O. E. Amygdalina. Almond-like-fruited European Olive-tree; Olivier amygdalin, of the French, much esteemed about Montpellier, for its fine and abundant oil.

15. O. E. oblonga. Oblong-fruited European Olive-tree; Olivier à fruit oblong, of the French.

16. O. E. Fructu Longo. Long-frnited European Olive-tree; Olivier à fruit long or Olivier a olives picholines, of the French. This variety yields the kind of olives most celebrated for pickling, and is not very particular in the choice of soil and climate.

17. O. e. Nigerrima. Black-fruited European Olive-tree; Olivier à fruit noir, of the French, a variety common in Palestine.

18. O. E. BIFLorens. Semi-annual-Flowering European Olive-tree; Olivier de deux saisons, of the French.

19. O. E. SEMPERfonens. Ever-flowering European Olive-tree; Olivier de tous les mois, of the French.

20. O. E. PRÆcox. Early-flowering European Olive-tree; Olivier précoce, of the French.

21. O. E. serotina. Late-flowering Enropean Olive-tree; Olivier tardif, of the French.

Geography and History. The Olea enropæa is found indigenous in Syria, Greece, northern Africa, on the lower slopes of Momit Atlas, and is naturalized in different parts of France, Spain, and Italy, where it is found growing wild in hedges and woods; but its fruit is small and unfit for use. 'The cultivated olive grows spontaneously in the temperate parts of $\Lambda$ sia and $\Lambda$ frica, by the sea-coast; and it promises, also, to be a valuable tree in Anstralia. It abounds in many parts of Syria, particularly about Aleppo and Mount Libanus; and is casily reared in all parts of the shores of the Levant that are not visited by frosty 
winds. The beautiful plain of Athens, as seen towards the north-west from Mount Hymettus, it is said, appears entirely covered with olive-trees. Tuscany, the sonth of France, and the plains of Spain are the places in Europe in which this species was first cultivated. The Tuscans were the first who exported oliveoil largely, and thus it has obtained the name of "Florence oil." The particular departments of France, in which the olive is most successfully cultivated, are those of the mouths of the Rhone, of the Var, of the Gard, and some others; but it does not ripen its fruit to the north of a line drawn from the Pyrenees, near Narbonne, to the foot of the Tittle St. Bernard in the Alps; nor in that part of France which niay be considered as forming a portion of the basin of the Mediterranean, and which is enclosed between that sea and the mountains of Cevennes and the Alps. The province of Suse, in Morocco, particularly in the neighbourhood of Mersa, produces a great abundance of olive oil, which is stated to be equal, in quality, to the best Florence oil. 'The olive grows in Britain; but, from the severity of the climate, its character is changed. In its native country it is an evergreen; but in England, it loses its leaves. Indeed, it needs protection even in the mildest winters; and it is only in the very warmest summers that it will produce fruit at all, which then does not ripen, and is of a very poor flavour. 'T'hus Italy, south of the Apennines, and 'Turkey, south of the Hæmus, or a line running directly westward from the Black Sea to the Atlantic Ocean, in about latitude forty-four degrees, appears to be the general northern limit of the culture of this tree in Europe; while on the Atlantic coast of North America, it scarcely reaches thirty-four degrees of latitude. Near Charleston, in South Carolina, the olive is usually rendered barren by the vernal frosts; and in the southern parts of Florida and Louisiana, where it would be secure in winter, it languishes through the sultry heats of summer, for the want of those refreshing breezes which invigorate this tree on the shores of the Mediterranean. But, doubtless, there are tracts in this country, uniting the conditions necessary for its growth, which have been demonstrated by several experiments-one in particular, we here beg leave to reiate. While the Floridas were held by the English, in 1769, one Dr. Turnbull, a famous adventurer of that nation, brought over from Smyrna, a colony of fifteen hundred Greeks and Minorcans, chiefly of the former, and founded the settlement of New Sinyrna, on Mosquito River. One of the principal treasures which they brought from their native land, was the olive. Mr. William Bartram, who visited this colony in 1775 , describes that place as a flourishing town. Its prosperity, however, was of momentary duration. Driven to despair by hardships, oppression, and disease, and precluded from escape by land, where they were intercepted by the savages of the wilderness, a part of these unhappy exiles died, while others conceived the hardy enterprise of embarking for Havana in an open boat, and in three years their number was reduced to five hundred. The rest removed to St. Augnstine, when the Spaniards resumed possession of the country; and, in 1783, a few decaying huts, and several large olive-trees, were the only remains to be seen of their wearied industry. In New California, on the Pacific, they cultivate the olive with success along the canal of Santa Barbara, in latitude thirty-four degrees north; and at Quito, in South America, near the equator, this tree, for eight thousand feet up the Andes, often attains the magnitude of the oak, but seldom or never bears fruit.

The olive, which is called by Colımella, the first among trees, has constituted, from the remotest antiquity, the pride of some of the most celebrated regions of the globe; and, aside from the commercial value of its products, it is invested, both in sacred and profane history, with a thonsand interesting associations. It appears to have been cultivated very early; for we read of oil in the time of Jacob; and the patriarch Noah had sent out a dove from the ark, but she returned without any token of hope. Then 
"A gain he sent forth the dove out of the ark: and the dove came in to him in the eveming; and, lo, in her mouth was an olive leaf pluckt off."

Gengsis viii. 10, 11.

That the olive was anciently very mueh esteemed by the Hebrews, is evident from the parable of Jotham,- "The trees went forth on a time to appoint a king," \&c.; and David, also, seems to have considered this tree as a blessing, when he says, "Thy children, like the olive branches round abont thy table; Lo! thus shall the man be blessed that feareth the Lord."

The ancient Greeks appear to have thought no less of the olive and of its fruit, than the Israelites; and the great duration of the tree is apparent from the history of one in the Acropolis at Athens. Dr. Clarke, in his "Travels," in speaking of the temple of Pandrosus says, "Within this building, so late as the second century, was preserved the olive-tree mentioned by Apollodorus, which was said to be as old as the foundation of the citadel." A contribution of olives was given by all the Greeks who attended the Panathenca, a festival held at Athens in honour of Minerva. Those who excelled in any of the games during this festival, were crowned with a wreath of olives, which grew in the grove of Academus, a place near the city, with spacious and shady walks, belonging to a man of that name.

The olive, it is said, was first planted in Italy, in the thirteenth year of the reign of Servius Tullius, the VIth king of Rome; and during the reign of 'Tarquinius Priscus, which was about the one hundred and eighty-third year from the foundation of that city, there were no olive-trees, either in Italy, Spain, or Africa, a strong presumption that they grew originally only in Syria. Theophrastus states that, in the four hundred and fortieth year of the city, there were no olive-trees in Italy, except on the coast, and within forty miles of the sea; but Pliny says, in his time, they were to be found in the very heart of France and Spain, and that the olives of Syria, although smaller, produced the best oil. $\mathrm{He}$ also informs us, that in the five hundredth year of the city, when Appius Claudius and L. Junius were consuls together, a pound of oil was sold for twelve asses; that in the year $6 \mathrm{S0}$, ten pounds sold for one ass; and that in twenty-two years after that time, Italy was able to furnish the provinces with oil; and that it was much used by the Romans at their baths, possessing, as they supposec'. the property of warming the body, and defending it against the cold. Virgil speaks of but three kinds of olives. Columella mentions ten varieties, and says he believes they were much more numerous.

As the wood of the olive-tree is very compact and durable, it is not surprising that it should furnish instances of extraordinary longevity. "In comparative youth," says a writer in the "North American Review," "the stem increases in diameter only at the rate of an eighth of an inch in a year. Therefore, the olive at Pescio, mentioned by De Candolle, having a truuk of twenty-four feet in girth, should be seven hundred years old; even supposing it to have grown, throughout, at the ordinary rate for young trees; while the still larger tree at Beaulieu, near Nice, described by Risso, and recently measured by Berthelot, doubtless the oldest of the race in Europe, should be more than a thousand years old. Although now in a state of decrepitude, it still bears an abundant crop of fruit, or at least did so, as late as the year 1S28. It is not improbable, therefore, that those eight venerable trees, which yet survive upon the Mount of Olives, may have been in existence, as tradition asserts, at the time of our Saviour's passion." MIr. Loudon mentions some plantations of olive-trees, in Italy, at Terni, which he passed through, in 1819 , on his way to the Falls of Marmora, that were supposed to have existed from the time of Pliny.

Mythological and Legendary Allusions. The olive has been the emblem of peace among all nations; perhaps, becanse the olive-leaf, brought by the dove to Noah in the ark, was the first sign which he received of peace restored between 
heaven and earth, after the bursting forth of God's awful wrath in the waters of the flood. It was also the symbol of wisdom, abundance, and of prosperity of every kind. The oil likewise became the emblem of joy and gladness. It appears to have been of great utility to the ancients, since Aristæus, son of Apollo, was regarded as a rural deity, from having taught mankind to extract it, as well as to make honey, butter, and cheese. It was also employed by the ancient Greeks in pouring ont libations to the gods, while the branches formed the wreaths of the victors of the Olympic games. They have a very instructive fable in their mythology, on the origin of the olive. The gods having been called on to settle a dispute between Neptune and Minerva, arising from the desire of each to give a name to the new city of Cecrops, determined to give the preference to the one who should produce the most beneficial gift to mankind. Neptune, with his trident, struck the shore, out of which sprang a horse; but Minerva, by causing an olive-tree to spring from the earth, gained her point, and from her was the city called Athenæ, now Athens; since, the olive, the emblem of peace or agriculture, was much preferred to a horse, the symbol of war and bloodshed. Minerva and the graces are also represented as crowned with olive branches.

Three statues of Minerva were preserved in the citadel of Athens, which admirably exemplified the progress of the art of sculpture. The first, made of olivewood, and of rude workmanship, was said to have fallen from heaven; the second, of bronze, was consecrated after the victory of Marathon; and the third was made of gold and ivory, which was one of the miracles of the age of Pericles.

Soil and Situation. The olive flourishes with the most advantage on land that is rather barren, sandy, and dry; and delights in schistous calcareous steeps, not very elevated, nor at a great distance from the sea; yet it is found in the centre of Spain, and in Mesopotamia, at the distance of a hundred leagues from the shore. The best oil is produced from fruit grown in calcareous soils.

Propagation and Culture. The olive may be multiplied by all the modes that are in use for the propagation of trees, and requires but little care in cultivation. In some parts of Italy it is multiplied by cuttings, and by what are called uovoli, (little eggs,) and in other parts by seeds. The novoli are knots, swellings, or tumours in the wood, caused by the sap not returning freely to the roots, but swelling through the bark of the trunk, and thus forming wens or excrescences containing embryo buds. They are separated from the tree by introducing a sharp knife between them and the trunk; but the parent plant suffers no injury from the operation. Solnetimes, however, an old tree is cut down, and the ceppo, or stock, is divided into pieces of nearly the size and shape of a mushroom, and which, from that circumstance, are also called uovoli. Care is observed that each uovolo shall contain a small portion of bark. After being dipped in manure, the uovoli are thickly planted in a bed, and covered with earth to the depth of three inches; they soon throw up shoots, and are transplanted at the end of one year, and in three years more are fit to be finally removed to the plantation. When raised from the seed, the fruit should be treated like that of the hawthorn or the holly; and, though some will come up in October, if sown in spring, yet a greater number will not make their appearance till the May of the second year. Seedling plants have the advantage of never throwing up suckers; and in Tuscany, where this mode of propagation is generally practised, it is said to produce invariably the largest and strongest trees.

Properties and. Uses. The wood of the olive is heavy, compact, fine-grained, and brilliant. The sap-wood is white and soft, and the heart-wood hard, brittle, and of a reddish or yellowish tint, with the pith nearly effaced, as in the box. It is employed by cabinet-makers to inlay the finer species of wood, which are contrasted with it in colour, and to form light articles of ornament, such as dressing- 
cases, snuff-boxes, \&c. The wood of the roots, which is agreeably marbled, is preferred to that of the trunk. On account of its hardness and durability, the wood of this tree was anciently used for the hinges of doors; and, before metal became common, it was selected by the Greeks for the images of their gods. From its resinous and oleaginous nature, the wood of this tree is exceedingly combustible, and burns as well before, as after it is dried. There exudes from its wood a gum, which is sometimes sold for gurn-elemi. There is also extracted from this tree a substance called olinine. The bark contains a bitter principle, and is regarded as tonic and febrifugal. The leaves are astringent.

But the chief value of this tree is the oil produced from its fruit, which is used as a substitute for butter, in all the countries where it grows. It is contained in the pulp only, as before observed, whereas, most other fruits have it in the nut or kernel. The proper time for gathering olives for the press is the eve of their maturity. If delayed too long, the next crop is prevented, and the tree is productive only in alternate years. At Aix, where the olive harvest takes place early in November, it is annual; but in Languedoc, Spain, and Italy, where it is delayed till December or January, it produces fruit but once in two years. The quality of the oil, also, depends upon the gathering of the fruit in the first stage of its maturity. It should be carefully plucked by the hand; and the whole harvest completed if possible in a day. To concoct the mucilage, and allow the water to evaporate, it is spread out, during two or three days, in beds three inches deep. The oil is obtained by simple pressure, in the following manner :- The olives are first bruised by a mill-stone, sufficiently hard as not to break the kernels, and are then put into sacks of coarse linen, feather-grass, or of wool, and subjected to heavy pressure, by which means the most fluid and the best liquor is forced out, and is called virgin-oil. It is received into vessels half filled with water, from which it is skimmed, and put up into tubs, barrels, and bottles, for use. Several coarser kinds of oil are afterwards obtained, by adding hot water to the bruised fruit. The best olive oil is of a bright pale-amber colour, without smell, and bland to the taste. Kept warm, it becomes rancid, and at $35^{\circ} \mathrm{F}$. it congeals. It is of the same nature as all mild expressed vegetable oils; of these, the most fluid are preferred, and hence the oils of olives and almonds are those chiefly used in medicine. One of the most esteemed kinds of oil is that produced at $\mathrm{Aix}$ (Huile d'Aix en Provence.) Florence Oil is also a fine kind, imported from Leghorn in flasks surrounded by a kind of network, formed of the leaves of a monocotyledonous plant. These are the kinds of olive oil in most frequent use at the tables for salads (hence they are called Salad Oils.) Lucca Oil is imported in jars holding about nineteen gallons each. Genoa Oil is a fine kind. Gallipoli. Oil is imported in casks; and constitutes the largest portion of the olive oil imported into England. Sicily Oil is of an inferior quality. Spanish Oil is the worst. The foot deposited by olive oil is used for oiling machinery, under the name of Droppings of Sweet Oil. Olive oil consists of

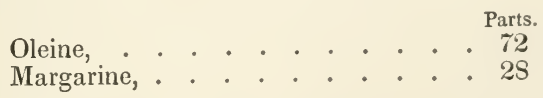

In cold weather, the latter constituent congeals in the form of white or yellowish globules.* Oily substances do not unite with the contents of acid stomachs; but to healthy persons they afford much nourishment, and medicinally are supposed to correct acrimony, to lubricate, and relax. Olive oil is applied externally to bites and stings of poisonous animals, and to burns alone, with

* See Pereira's Treatise on Food and Diet, p. 86. 
chalk, or in liniments and poultices. The ancients rubbed their bodies with it in dropsies, and for various purposes; but it is now little used as a medicine, excepting for coughs, burns, and a few other cases.

Another important advantage afforded by this tree, is its fruit in a pickled state. It is gathered unripe, and suffered to steep in water for some days, and is afterwards put into a lye of water and barilla, or kali, with the ashes of olivestones, or with lime. It is then put up in earthen bottles, or in barrels, with salt and water, and in this state, is ready for use. Olives are eaten before, as well as after meals, and are believed to excite appetite and promote digestion. The finest kind of prepared fruit is known in commerce by the name of Picholines, after one Picholini, an Italian, who first discovered the art of pickling olives.

The fruit of the olive is of a pleasant taste, and is eaten by the modern Greeks, during Lent, in its ripe state, without any preparation, except with the addition of a little pepper, salt, and oil.

From the value of its products, in a commercial point of view, aside from other considerations, the culture of the olive strongly claims the attention of the American agriculturist, and the trial should be made in every place where its failure is not certain, and for this purpose, young grafted trees of hardy and choice varieties should be obtained from Europe, and the formation of nurseries immediately begun. A portion of Texas, Louisiana, the islands of Georgia, and chosen exposures of the interior of the last-named state, as well as of some of the western states, California, or of Oregon, will be the scene of this species of culture, if ever attended with success in North America. 


\section{Olea americana, \\ THE AMERICAN OLIVE-TREE.}

\author{
Dlea americana, \\ Olivier d'Amerique, \\ Amerikanischer Oehlbaum, \\ Olivo americano, \\ American Olive-tree, \\ American Olive-tree, Devil-wood,
}

Synonymes.

Engravings. Michaux, North American Sylva, pl. 86; Loudon, Arboretum Britannicum, ii., fig. 1034; and the figuree

( Linnæus, Mantissa.

Michaux, North American Sylva.

Loudon, Arboretum Britannicum.

France.

Germany.

ITALY.

Britain.

United States. below.

Specific Characters. Leaves elliptic-lanceolate. Bractes all persistent, connate, ovate. Racemes sub. compound, narrow.-Loudon, Enc. of Plants.

\section{Description.}

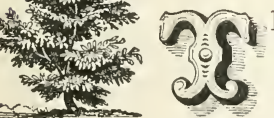

HE Olea americana is a large evergreen shrub or low tree, sometimes growing to a height of thirty or thirty-five feet, with a trunk ten or twelve inches in diameter; but usually it does not attain one half of these dimensions. The bark which covers the trunk is smooth, and of a grayish colour. The leaves are four or five inches long, opposite, entire, smooth, and brilliant on the upper surfaces, and of an agreeable light-green. The fertile and barren flowers grow on separate trees. They are very small, strongly scented, of a pale-yellow colour, and axillary. They put forth at St. Mary's, in Georgia, by the last of March, and a month later in Virginia. 'The fruit, which is round, is about the size of a small grape, of a purple colour, approaching to blue, and contains a hard stone, thinly coated

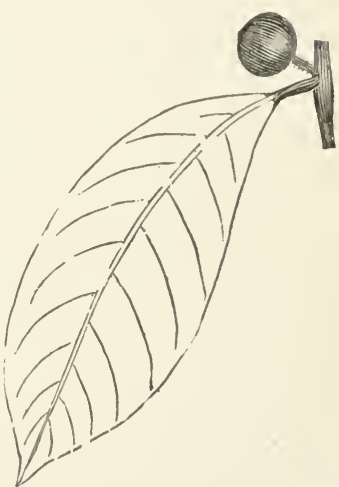
with pulp. It ripens in October, and remains attached to the branches during a part of the winter, forming an agreeable contrast with the light-green leaves.

Geography, \&•c. The Olea americana, which belongs exclusively to the soutllern states of the American union, is not often found north of Norfolk, in Virginia; and, like the live oak and cabbage-tree, is confined almost exclusively to the sea-shore. It grows in soils and exposures extremely variable. In the maritime parts of Carolina, Georgia, and.Florida, it springs up with the live oak in the most barren spots; and in other places it is associated with the Magnolia grandiflora, umbrella-tree, \&c., in cool, fertile, and shady situations. 'This tree was introduced into Britain in 1758, and is considerably more hardy than the European olive. It is said there is a very handsome flourishing plant against the wall of the arboretum of Messrs. Loddiges, at Hackney, which receives no protectior: whatever. It may be propagated by layers, by seeds, or by cuttings. 
Properties and Uses. The wood of the Olea americana is compact, of a fine grain, and when perfectly dry, is excessively hard and difficult to cut and split. Hence, the provincial name of devil-wood. From its small size, and difficulty of being wrought, it is appropriated to no particular use in the arts. On laying bare the cellular integument of the bark, its natural yellow hue :mmediately changes to a deep-red; and the wood, by contact with the air, soon assumes a rosy complexion. 


\section{Genus FRAXINUS, Tourn.}

\section{Oleaceæ.}

Syst. Nat.
Polygamia Diœcia.
Syst. Lin.

Synonymes.

\author{
Fraxinus, \\ Frêne, Fresne, \\ Esche, \\ Frassino, \\ Fresno, \\ Freixo, \\ Jas, Jasen, \\ Ash,
}

Of Authors.

France.

Germany.

ITALY.

Spain.

Portugal.

Russia.

Britain and Anglo-America.

Derivations. The derivation of Fraxinus, given by Don, in Miller's Dictionary, is from the Greek phrasso, to enclose; the ash having been formerly used for making hedges. Linnæus derives it from the Greek phraxis, a separation; because the wood splits easily. Others derive it from the Latin frangitur, because the young branches are easily broken; or which may have been applied ironically, in allusion to the extreme toughness of the wood. The English name Ash, may be derived either from the Saxon word asc, a pike; or from the colour of the bark of the trunk and branches, which resembles that of wood.ashes.

Generic Characters. Flowers polygamous. Calyx none, or 4-parted, or 4-toothed. Corolla none. Stamens 2, in the male flowers. Anthers sessile, or on short filaments, dehiscing outwardly. Female flowers the same, except that they have no stamens, but have each a pistil, that has a bifid stigma. Fruit, or samara, 2-celled, compressed, winged at top. Cells 1-seeded.-Don, Miller's Dict

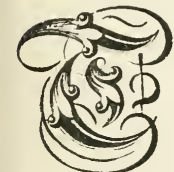

HE genus Fraxinus consists of deciduous trees, witlı spposite, impari-pinnate, rarely simple leaves, and lateral racemes of greenish-yellow flowers; and natives of Europe, northern Africa, a part of Asia, and of North America. They are raised from seeds, or by grafting on the Fraxinus excelsior. In all the species, there is a great tendency to sport into varieties; and most of those which are described by botanists as species, do not appear to be entitled to that distinction. Indeed, with two or three exceptions, the trees belonging to this genus bear so close a resemblance to each other, when young, that it is difficult to determine which are species and which are varieties; and, in pursuance of the idea advanced by Mr. Loudon, that, "no plant can be truly a species, that is $\mathrm{nut}$ readily distinguished from every other, in every stage of its growth, and at every season of the year," we are inclined to believe that there are no more than two species of ash hitherto discovered, either in Europe or America, viz. :-Fraxinus excelsior, and americana. We have accordingly, for the salie of brevity, and convenience of classification, brought them all under these two heads, and liave considered them only as varieties. Those, however, who difler from us in opinion, will find no difficulty in recognizing among our synonymes, the names as given by Michaux, Don, Loudon, and others, and will be enabled to know under what head they are described in the works of these authors. 


\title{
Fraxinus excelsior,
}

\section{THE EUROPEAN ASH-TREE.}

\section{Synonymes.}

\author{
Fraxinus excelsior, \\ Frêne élevé, Frêne commun, Grand \\ frêne, \\ Esche, Aesche, \\ Frassino, Frassine, Nocione, \\ Ash, \\ European ash,

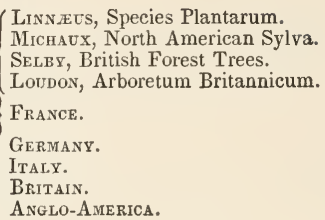

Derivation. The specific name excelsior is derived from the Latin ex, from, and cello, to lift up, and signifies taller, or more elevated, from the superior height which this species attains.

Engravings. Michaux, North American Sylva, pl. 121; Selby, British Forest Trees, pp. 84, 86 et 101; Loudon, Arboretlm Britannicum, ii., figs. 1044 et 1045 and vi., pl. 202, 203 et 204 ; and the figures below.

Specific Characters. Leaflets almost sessile, lanceolate-oblong, acuminate, serrated, cuneated at the base.

Flowers naked. Samara obliquely emarginate at the apex.-Don, Miller's Dict.

\section{Description.}

"The ash asks not a depth of fruitful mould,

But, like frugality, on little means

It thrives; and high o'er creviced ruins spreads

lts ample shade, or in the naked rock,

That nods in air, with graceful limbs depends."

BIDLAKE

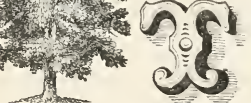

HE Fraxinus excelsior is one of the noblest trees of the European forests. In a close grove, and in a free, deep soil, it becomes a lofty tree, from eighty to one hundrcd feet in lieight, with a trunk free from branches for more than half its length. Standing singly, it throws sut large limbs, which divide into numerous branches, forming a full spreading

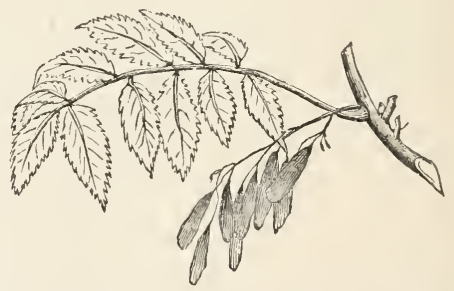
head, with a short, but very thick trunk. In some situations, particularly on rocky steeps, the branches of old trees become pendent; but, in most cases of old trees of this species, there is a tendency in the extremities of the lower branches to curve upwards. The bark is of a dark-gray, when young, and ash-coloured as the tree advances in age. The roots, which are numerous and take a horizontal direction, are furnished with more fibres than those of most other forest trees. Both fibres and roots are white, which, indeed, is the case in all the oleaceæ. The buds are short, oval, obtuse, and constantly black; and, by this last circimstance, this tree is easily distinguished from the American species. The leaves are opposite, and are composed of from five to thirteen leaflets, slightly pedicellate, smooth, oval, acuminated, and serrated. The common petiole is semi-cylindrical, with a channel on the upper side. The flowers, which put forth in March and April, are produced in long, loose spikes, from the sides of the branclies. On some there are only female flowers; on others, hermaphrodite 
ones; while on some there are only male flowers, and frequently trees are to twe met with containing flowers in two of these states, and eveu in all of them. Thie: seeds, which are included in what are commonly called keys, or botanically samaræ, are generally ripe in October; and, like those of the aceraceæ and the ailantus, from their wedge-like shape, they are liable to fix themselves in the crevices of rocks, ruins, walls, and even in the clefts of old trees, where they often vegetate and grow.*

Varieties. These are very numerous; but we shall first give those which are universally allowed to be varieties, and are described as such by Don and Loudon ; and afterwards indicate those which are treated by botanists as species.

1. F. e. pendula. Pendulous-branched European Ash; F'rêne pleureur, F'rêne parasol, of the French; Trauer Esche, of the Germans. 'This singular and beantiful variety was discovered about the middle of the last century, in a field belonging to the vicar of Gamlingay, near Wimpole, in Cambridgeshire. The tree was standing as late as $\mathbf{1 8 3 . 5}$, but comparatively in ruins. There are many individuals growing in England, which have been propagated from it; some in Scotland, Ireland, France, and Germany, and a few in America. In a list of trees planted in the government gardens at Odessa, by M. Descemet, is an ash with pendent branches, found in a bed of seedlings, which may possibly be somewhat different from the English variety. The weeping ash is commonly grafted standard high; and, as it is very hardy, and grows with great rapidity, it is a valuable tree for forming arbours, or for covering seats more especially in public gardens.

2. F. E. Kincairniz. Kincairney Ash, with the spray alternately pendulous. and rigidly upright, and thus forms a tree of fantastic shape. 'The original specimen grows on the estate of Mr. Mungo Murray, in Kincairney, in the parish of Caputh, near Dunkeld, Perthshire, in Scotland.

3. F. E. Aurea. Golden-barked European Ash; Frêne doré, of the French. This variety has the bark of the trunk and branches yellow and dotted; and the leaflets sessile, lanceolate, unequally scrrated, acuminated, cuneated at the base, and glabrons. It is particularly conspicnous in winter, not only from the yellow colour of its bark; but from the curved, contorted character of its branches, which somewhat resemble the horns of an animal.

4. F. e. aurea pendula. Pendulous-branched Golden-barked European Ash, which is of as vigorous growth as the F. e. pendula.

5. F. E. CRISPA. Curled-leafleted European Ash. The darkness of the green of the leaves of this variety is remarkable, which, with their crumpled appearance, combined with the rigid stunted character of the whole plant, renders it a striking object.

6. F. E. Jaspidea. Striped-barked European Ash ; Frêne jaspé, of the Freuch. The bark of the trunk and branches of this variety, is streaked witl reddishwhite.

7. F. e. purpurascens. Purple-barked European Ash, with the bark purple. It was found in a bed of seedlings, by M. Descemet, who had plants of it under his care at Odessa.

\footnotetext{
* On the piers of the entrance to Blenheim Park from Woodstock, in England, there were, in 1 1431 , a sycamore established on one pier, and an ash on the other, each about five leet high. "On the rums of Sweetheart Abbey, in Dumfriesshire," Mr. London observes, "there is a large tree of the common syca more on the top of a wall, which, in 1806, when we last saw it, had sent down a fibrous root on the out side of the wall, completely exposed to the air, for the height of ten or twelve feet, till it reached th. round. This fibre soon afterwards acquired considerable thiekness, and now constitutes, as we ait informed, the main stem of the tree." Gilpin quotes an instance from Dr. Plot, of an ash establishing" itself on, and finally destroying a willow. A similar eiren mstance also fork place with a weeping willuw. in the botanic garden of Carlsruhe; and the same thing not unfrequently happens with the oak and other trees. In the city of New York, where the ailantus is much cultivated for ornamenting the streets, 11 is not uncommon to see small plants of it from two to three feet high, growing on the rools amil gutfers of houses, where they have taken root from seets.
} 
8 F. e. Folis argenteis. Silver-striped-leafleted European Ash; F. e. argentea, of Loudon; Frêne argenté, of the French, with leaflets variegated with white.

9. F. E. LuteA. Yellow-edged-leafleted European Ash, with the leaflets edged with yellow.

10. F. E. ERosa. Erose-leafleted European Ash, with the leaflets erosely toothed.

11. F. e. horizontalis. Horizontal-branched European Ash; Frêne horizontal, of the French, with the branches spreading horizontally.

12. F. E. verrucosa. Warted-barked Emropean Ash; Frênevermqueux, of the French, with its branches warty.

13. F. E. verrucosa Pendula. Pendulons-branched Warted-barlied Enropean Ash.

14. F. E. Nana. Dwarf Erropean Ash, which seldom exceeds a yard in height. The leaves of this variety resemble those of the species, but the leaflets are much smaller and closer together.

15. F. E. Fungosa. Fungous-barked Enropean Ash.

16. F. e. verticillata. WWhorled-leaved Enropean Ash; Frêne à feuille verticillées, of the French.

17. F. E. villosa nova. Villous-leafleted Enropean Ash, a new seedling, accidentally discovered by M. Descemet, of which there are plants in the Odessa collection.

1S. F. e. heterophylla. Varions-leaved European Ash; Fraxinus heterophylla, of Don, Loudon, and others; Frêne à une feuille, of the French; Verschiedenblittrige Esche, of the Germans. The leaves of this variety are trifoliate, dentately serrated, usually simple, but sometimes with three or five leaflets, three or four inches long, ovate, sub-cordate, or acuminate at the base and apex. The samaræ are oblong-lanceolate, one inch in length, obtuse and emarginate at the apex. The branches are dotted, and the buds are black. Some botanists consider this kind as a species; but Sir 'T. Dick Lauder states that Mr. McNab, of the Edinburgh botanic garden, sowed seeds produced by the tree in that garden, supposed to have been originally planted by Southerland, and found that the plants had pimnated leaves; and M. Sinning, garden inspector of Poppilsdorf, near Boun, sowed seeds of the common European ash, which he gathered in a distant forest, many of which came up with simple leaves. Nearly one thousand of these plants were transplanted, and left to become trees; when they were about eight feet high, nearly twenty of them were observed to have simple leaves, and almost as many to have only three leaflets; though occasionally they showed a greater number.

19. F'. E. heterophylla veriegata. Variegated Various-leaved Enropean Ash, discovered in 1830, in the gromnds of Captain Moore, of Eglantine, near Hillsborough, in the county of Down, in Ireland. The variegation appeared in summer, on the point of one of the shoots of a tree of fifteen years' growth; and Captain Moore marked it, and had the portion of shoot which showed the variegated leaves taken off, and grafted the following spring. The parent tree, it is said, never has since shown the slightest tendency to variegation, but the grafted plants continue true.

20. F'. e. ANGustifolia. Narrow-leaved European Ash; Frêned feuilles étroites, of the French; Schmalblättrige Esche, of the Germans. The leaflets of this variety are sessile, lanceolate, remotely denticulated, occurring in three or four pairs, from an inch and a half to two inches long. The peduncles below the leaves are solitary, and about two inches in length. The flowers, which put forth in May are naked; and the samaræ are entire at the apex, and acute at the base. 'I'he branchlets are green, dotted with white, and the buds brown. This tree is a natıve of Spain. 
21. F. e. Parvifolia. Small-leaved European Ash; F'axinus parvifolia, of Don, Loudon, and others; Frêne à petites fenilles, of the French; Kleimblitli ige I'sche, of the Germans. This variety is a native of the I,evant, liaving from five to seven pairs of leaflets, which are sessile, roundish, ovate, and oblong. 'They are attenuated, and quite entire at the base, bnt mucronate and sliarply serrated at the apex. The flowers are naked, and put forth in April and May. And the branches are purplish, and trigonal at the top.

22. F. E. ARgentea. Silvery-leaved Europeau Ash; Fraximus argentea, of 1)on. Loudon, and others; Frêne du Corse, of the Frencl.. The leaves of this variety are of a silver-gray, and usually have three pairs of rather coriaceous, ellipticovate, shortly-cuspidate, bluntly-toothed leaflets, on short petiolules. It is a native of the island of Corsica, in the fissures of rocks.

23. F. E. oxycarpa. Sharp-fruited Europeun Ash; Fraxiuns oxycurpa, of Don, Loudon, and others; Frêne à fruits pointu, of the French. The leaves of this variety are of a dark glossy green, and are produced in tufts at the ends of the branches. They have from two to three pairs of leaflets, almost sessile, which are lanceolate, acuminated, serrated, and glabrous. The flowers are naked. The samaræ lanceolate, attemuated at both ends, and mucronate. The branchlets are green, with white dots; and the buds are brown. This tree is a native of Caucasus.

24. F. E. PAllida. Pale-barked European Ash; Fraximus pallida, of Don, London, and others. The leaves of this variety have three pairs of leaflets, which are glabrous, almost sessile, ovate-lanceolate, and toothed. The branches are yellow.

Geography and History. The Fraxinus excelsior is indigenous to most parts of Europe, northern Africa, and Japan. It nowhere arrives at greater perfection han in Britain, where it is found from the county of Ross to Cornwall. It Ilso abounds in the forests of France, Germany, Sweden, Norway, and of Russia.

The ash was known to the Greeks, whose name for it was melia, or boumelia ; and to the Romans, who, it is said, named it Fiaxinus, quia facile fraugitur, to express the fragile nature of the wood, as the boughs of it are easily. broken; and both the Greeks and Romans made their spears of its wood. By the Roman agricultural writers it is recommended as peculiarly fit for making implements of husbandry, to which purpose it is chiefly applied in modern times. In Britain, it ranks amongst the most beautiful of their trees, although, in the ancient history of that country, it was very little regarded; indeed, some idea of the value set upon it may be formed, from the fact, that in the laws of the celcbrated Howel Dda, while a branch of mistletoe was valued at thirty shillings, the ash was ummentioned, and therefore must be ranked with trees after the thorn, and rated at fourpence. Druidical superstition, however, has vanished, and now, while the mistletoe is but little valued except by the birl-catcher, for the mannfacture of his lime, the ash is styled by way of eminence, the "husbandman's tree," on account of its celebrity for the formation of agricultural implements and for purposes of domestic economy.

Among numerous ashes of extraordinary size, recorded as growing in Britain, may be mentioned those spoken of by Evelyn, "lately sold in Fissex, in lengtl one hundred and thirty-two feet," and the celebrated tree which formerly stood in the churchyard of Kilmalie, in Lochaber. 'The latter was considered the largest and the most remarkable tree in the Highlands. I oochicl, and his mumerous kindred and clan held it in great veneration for generations, which is supposed to have been the cause of its destruction; it being burnt to the gromud by the brutal soldiery, in 17.16. In one direction, its diameter was seventeen feet and three inches, and the cross diameter twenty-one foet; its circumference at the ground was fifty-eight feet. 
At Cobham Hall, in Kent, there is a tree of this species, one hundred and twenty feet in height, with a trunk six feet and eight inches in diameter, straight, and without a branch, for a great height.

In Ayrshire, at Kilkerran, there is an ash, which, at thirty years after planting, had attained the height of sixty feet, with a trunk nine feet in diameter, and an ambitus or spread of branches of seventy-five feet.

In Fermanagh, at Enniskillen, Ireland, there is an old tree, with a trunk twelve feet in diameter, three feet from the ground. And, in Limerick, at Adare, there is an ash of unknown age, under which the family treasure of the ancestors of the Earl of Dunraven lay concealed during the troubles of $168 \mathrm{~s}$.

In France, at the Jardin des Plantes, in Paris, there is a Fraxinus excelsior, which in sixty years after planting, had attained the height of fifty-six feet.

At Monza, in Italy, there is a tree, which, at the age of forty years, was sixty feet high.

At Sans Souci, near Berlin, in Prussia, there is an ash, which, in forty years after planting, had attained the height of fifty feet.

In Russia, in the government garden at Odessa, there is a tree of this species, which acquired the height of twenty-three feet, in eleven years after planting.

The Fraxinus excelsior was introduced into the North American colonies in about the year 1740 , and the original tree, which has attained the height of fifty feet, with a trunk four feet in girth, is yet standing in the Bartram botanic garden, at Kingsessing. There are also specimens of the Fraxinus e. aurea and pendula, in the nursery of Mr. D. Landreth, in Philadelphia, fifteen years planted, and twenty-five feet in height.

Poetical, Mythological and Legendary Allusions. The ash is mentioned both by Hesiod and Homer; the latter of whom not only speaks of the ashen spear of Achilles, but informs us that it was by a spear of this wood that he was slain.

\footnotetext{
"The noble ash rewards the planter's toil;

Noble, since great Achilles from her side

Took the dire spear by which brave Hector died."
}

In heathen mythology, Cupid is said to have made his arrows first of ash, though they were afterwards made of cypress. According to Virgil, the disciples of Mars insed ashen poles for lances.

\footnotetext{
"A lance of tough ground Ash the Trojan threw, Rough in the rind and knotted as it grew."
}

'The Scandinavians also introduce this tree into their mythology. It is stated in the "Edda," or sacred book of the Northmen, that the court of the gods is held under a mighty ash, the summit of which reaches to the heavens, the branches overshadow the whole surface of the earth, and the roots penetrate to the infernal regions. An eagle rests on its summit to observe everything that passes; to which a squirrel constantly ascends and descends, to report those things that the exalted bird may have neglected to notice. Serpents are twined round the trunk; and from the roots there spring two limpid fountains, in one of which lies concealed wisdom, and in the other a knowledge of the things to come. Three virgins constantly attend on this tree, to sprinkle its leaves with water from the magic fountains; and this water, falling on the earth in the form of dew, produces honey. Man, according to the "Edda," was formed from the wood of this tree; and Hesiod, in like manner, deduces his brazen race from

\footnotetext{
"The warlike Ash, that reeks with human blood."
}

Ancient writers of all nations state that the serpent entertains an extraordinary respect for the ash. Pliny says that, if a serpent be placed near a fire, and both surrounded by ashen twigs, the serpent will sooner run into the fire than pass over 
tne preces of ash; and Dioscorides asserts that the juice of ash leaves, mixed with wine, is a cure for the bite of serpents. Evelyn mentions that, in some parts of England the country people believe that, "if they split young ash-trees, and make ruptured children pass through the chasm, it will cure them ;" and the Rev. W. $\mathrm{T}$. Bree relates an instance, within his personal knowledge, of this extraordinary superstition having been practised within a few years in Warwickshire. Another superstition is that of boring a hole in an ash-tree, and imprisoning a shrew mouse in it. A few strokes with a branch of a tree thus prepared, is supposed to cure lameness and cramps in cattle, all of which the poor mouse is accused of having occasioned. There is also a proverb in the midland coumties of England, that, "if there are no keys on the ash-trees, there will be no king within the twelvemonth;" in allusion to the ash never being totally destitute of keys. Lightfoot says that, in many parts of the Highlands of Scotland, "at the birth of a child, the nurse or midwife puts one end of a green stick of this tree into the fire, and, while it is burning, gathering in a spoon the sap, or juice, which oozes out at the other end, administers this as the first spoonful of food to the newlyborn baby." Gilpin, in his "Forest Scenery," calls the oak the Hercules of the forest, and the ash the Venus. The Romans called the seed of the ash linguu avis, from its supposed resemblance to a bird's tongue. In marshy situations, the ash strikes its roots deep into the ground. Hence arises the proverb in some parts of England,_- "May your foot-fall be by the root of an ash" - may you get a firm footing.

Soil and Situation. The Fraxinus excelsior always grows best in a good soil, somewhat calcareous, and which, though not boggy, is generally adjoining water. Its most favourite situations are on the steep, rocky banks of rivers, or on the sides of glens, where the soil is generally of a great depth, and a stream not very far distant. The ash, however, agrees with a greater variety of soil aud situation, perhaps, than any other tree producing timber of equal value; and, differing from many other trees, its value is increased, rather than diminished, by the rapidity of its growth. Wherever its growth is stumted, the wood is brittle, and soou affected by the rot; but where it has been vigorous, the compact part of the several layers bears a greater proportion to the cellular or spongy parts, and the timber is very tough, elastic, and durable. Mr. Sang, who is considered the very best modern authority in all matters respecting the hardier forest trees, observes, that the ash "is found in the highest perfection on dry, loamy soils. On such it spontaneously grows. In moist, but not wet soils, it grows fast, but soon sickens. It will grow freely on most kinds of soils, if the situation be tolerably good, except on retentive clays or tills. In wet soils, it soon sits up, (ceases to increase either in girth or height,) languishes, and dies. In rich lands, its wood is short and brittle; in sandy soils it is tough and reedy; qualities which, for several purposes, very much enhance it value. In loam, mixed with decomposed rock, at the bottom of a mountain, the ash arrives at a greater size." Dr. Walker, a close observer of nature, and an ardent lover of trees, says, in his "Highlands of scotland," that, "The ash should be planted on dry banks, in glens and gullies, in places incumbered with large, loose stones, and in all rocky places, wherever there is shelter ;" but, "the largest trees," continues he, "will always be found where they have running water within reach of their roots." And he adds, "There is no situation too high, or too cold, for the ash, provided it has shelter; but without shelter it never makes a considerable tree at a great height, even though standing in a good soil." The most proper situation for the ash, according to Nicol, is the forest or the grove. Marshall recommends it to be planted alternately with the oak; because, as the ash draws its nourishment from the surface, and the oak from the sub-soil. the ground would thins be finlly and profit. ably employed 
Propagation and Culture. The species is always propagated by seeds, and the varieties by grafting or budding on the species. The seeds should be gathered as soon as they are ripe, and taken to the rotting-ground, where they should be mixed with light, sandy earth, and laid in a flat heap, not more than ten inches thick, in order to prevent them from heating. Here they should be turned over several times in the course of the winter; and, as early as the ground will pernit, in the spring, they may be removed, freed from the sand by sifting, and sown in beds in a middling soil. The richness or quality of the soil, Sang observes, is of little consequence; but it should be well broken by the rake, and the situation should be open, to prevent the plants from being drawn up too slender. The seeds may be deposited at the distance of half an inch every way, and covered about a quarter of an inch deep with soil. The plants may be taken up at the end of the first season, and planted in nursery lines; and at the end of the second year, they may be renioved to where they are finally to remain. If planted in a good soil, they will grow rapidly when young, attaining a leeight of fifteen feet and upwards, in ten years. When cultivated as a coppice-wood, the ash will continue throwing up shoots from stools or pollards for more than a century. The most profitable age for felling its timber, appears to be from eighty to one hundred years. The drip of the ash is injurious to the vegetation of almost every other plant; and, when planted in cultivated fields, from its numerous fibrous roots, which run close to the surface, a certain portion of the land around it is rendered unproductive. The use of the ash in plantations, therefore, has been objected to on this account; although, it is admitted that this, and its love of shelter, constitute a decided reason why it should not be planted in hedge-rows, or where it is expected to derive profit from plants growing under its shade, yet it affords no argument against planting it in masses, where the object is the production of timber or coppice-wood. As the tree, when standing singly, forms a most ornamental object on a lawn, and, though it may impede the growth of grass, yet does not destroy it, there is no reason why the ash should not be admitted into pleasure-grounds, as well as the cedar, or any other dense evergreen, under which grass will not thrive. It has been observed, that female and hermaphrodite trees, from the quantity of seeds which they produce, never exhibit such a handsome clothing of foliage as the nole trees; and hence, in some situations, where ornament is required, it may be desirable to make sure of a male by grafting.

Accidents, Diseases, and Insects. When standing alone, the far-extended branches of the ash, are liable to be broken off by high winds; but, except on insuitable soils, it is not subject to the canker, or many other diseases. From . 0 quick an ascent of the sap; or, as some imagine, from the puncture of an unknown insect in the tender twigs, which diverts the sap from its usual course, the branches of the ash sometimes become twisted and curled into a beautiful ficiated form, resembling a ram's horn, or a crosier. 'These wreathed excrescences or facia are sometimes also found in other trees, as the willow, and particularly in the holly. As the ash comes late into leaf, it is by no means so liable to the attacks of insects as t'le various species of orchard fruits, which put forth early; at l ast, this is the case in Britain; but, in France, its leaves are liable to be destroyed by the Cantharis vesicatoria, denoted by the adjoining figure; and also by bees, ants, and birds, in the middle of summer. "If nature had produced the ash for no other purpose than for the embellishment of forests," says a writer in the "Nouveau Du Hamel," "we might almost say

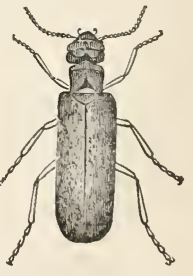
that she had failed in her end, or had opposed herself to her own views, in ciestining the leaves of that tree to be the food of an insect, Cantharis vesi- 
catoria, a beetle of a beautiful golden-green, with black antennæ, which devours them with avidity. The ash is no sooner covered with leaves, than they are attacked by such a number of eantharides, or Spanish flies, that the trees, during the remainder of the summer, have a dismal appearance; and, lhough the: insect which devours the leaves may please the eye by its elegant form, and its colours of green and gold, yet it spreads abroad a smell which is so disagrecable, that it causes the common ash to be excluded from our forests, where the fluwering ash, and some of the American species, are alone introduced." M. Pirolle, in the "Bon Jardinier," states that, "even when the cantharides are dead on the trees, they become dried to a powder, which it is difficult to pass without inhaling. The particles of this powder, being parts of those flies that canse the blistering of the skin when a blister-plaster is applied, are, of course, dangerous to persons who inhale them; and, on this account, ash-trees are seldom planted near villages in France." Mr. Mumby, in a paper in the London "Mlagazine of Natural History," states that he saw "an ash-tree overhanging the road wear" Dijon, so crowded with the Cantharis vesicatoria, that the excrement of the insects literally blackened the ground." On passing underneath the tree, he felt his face as if bitten by gnats, and smelt a most disagreeable sickening odour, "which extends," says he, "twenty or thirty yards from the tree, according to the direction of the wind." 'These insects make their appearance, in the sonth of Europe about mid-summer, more particularly on the ash, privet, and lilac, on the leaves of which they feed. Fortunately, they are not very numerous in England; but in Russia, according to Pallas, the cantharides abound on the Lonicera tatarica, and are collected from that plant in great quantities for the apothecaries. In a living state, the young branches of the ash are frequently attacked by a small scaly insect, (Chermes,) which, feeding on the sap, often throws the tree into a decline. The decayed wood of the ash, as well as that of many other trees, is devoured by the larvæe of the Dorcus parallelopipedus, and the sinodendron cylindricum. It has been observed, that, when wood-peckers are seen tapping the ash and other timber-trees, they ought to be cut down, as these birds never attempt to make holes in a tree, till it is in a state of decay.

Properties and Uses. The timber of the ash is exceedingly elastic; so much so, according to Tredgold, that a joist of it will sustain more weight before it will break, than one of any other European tree. When green, it weighs about sixty-four and a half pounds to a cubic foot, and about forty-nine and a lialf pounds when dry. The value of the timber is increased by the rapidity of its growth; and, as in the case of the Castanea vesca, (sweet chesnut,) the wood of the young trees is more esteemed than that of old ones. The texture of the wood is alternately compact and porous; and, where the growth has been vigorous, the compact part of the annual layers bears a greater proportion to the porous, and the timber is comparatively more tough, elastic, and durable. In durability, however, and also in rigidity, it is inferior to that of the oak; but it is superior to that wood, in toughness and elasticity; and hence its miversal employment in all those parts of machinery which have to sustain sudden shocks; such as the circumference teeth, and spokes of wheels, beams, plonghs, Ic.* Fince the use of iron has become so general in the mannfacture of implements and machines, the value of the ash is somewhat diminished; still, however, it ranlis next in ralue to the oak, and is held even to surpass it for some purposes. It is much in use by the coach-maker, the wheel wright, and the manufacturer of agricultural implements; and is also much used for making oars, blocks for pulleys, ic. It is highly valued for kitchen tables, as it may be better scoured thin any other wood, and is not so liable to run splinters into the fingers of the seourer. For the same reason, it was formerly much used in Fingland for staircases and, in 
many parts of that country, milk-pails are made of thin boards, sawed lengthwise out of this tree, by rolling them into hollow cylinders, and then affixing a bottom to each. From the sonorous properties of the timber of the ash, combined with strength and elasticity, it is preferred by watchmen, for staves, to any other wood. The roots and knotty parts of the trunk of this tree are in demand by cabinet-makers, on account of the curious dark figures formed by their veins, which make a singular appearance when wrought and polished. 'There are also certain knotty excrescences in the ash, called brusca and mollusca. which, when cut and polished, are remarkably beautiful. Evelyn remarks in his "Sylva," that "some ash is so curiously cambleted and veined, that skilful cabinet-makers prize it equally with ebony, and call it green ebony." The ash makes excellent fuel, burning, even when newly cut, with very little smoke; and it is said to be the best of all woods for smoke-drying herrings. Few other timber trees in England become useful so soon after planting, it being fit for walking-canes at four or five years' growth; and for handles to spades and other implements, at nine or ten years of age. "An ash pole," observes Nicol, "three inches in diameter, is as valuable and durable, for any purpose to which it may be applied, as the timber of the largest tree." It is particularly valuable for hoppoles, hoops, crates, handles to baskets, rods for training plants, forming bowers, for light hurdles, and for wattling fences. In Staffordshire, in the neighbourhood of potteries, the ash is cultivated to a great extent, and cut every five or six years for crate-wood. In Kent, and in varisus places in the neighbourhood of London, the most profitable application of the young ash is for walking-canes, plant-rods, hoops, and hop-poles. For the latter purpose, coppice-woods are cut over every twelve or fourteen years, according to the nature of the soil; and, for the former purposes, every five or seven years. The ashes of the branches and shoots of this tree afford a very good potash. The bark is used for tanning nets and calf-skins. With the sulphate of iron, it imparts a green or greenish-black; with the salts of alum, a yellow; and with the acetate of copper, a clear olivegreen colour. In many parts of continental Europe, the ash is formed into hedges, and its lea ves serve for feeding cattle in autumn, winter, and spring. The leaves and shoots, eaten by cows, are said to give the milk and butter a rank taste; but this does not appear to have been considered a great evil by the Romans, as they recommend the leaves of this tree for fodder next to those of the elm; and Mr. Sydney, of Cowpen, near Morpeth, in Northumberlandshire, who lives in a country where the ash is more abundant than any other tree, says, in a communication to Mr. Loudon, that, "The statement made by several writers, that butter made from the milk of cows which have eaten ash leaves has a disagreeable taste, is certainly not founded in fact." Medicinally, the leaves, bark, seeds, and wood of this tree, are sudorific, diuretic, and febrifugal; the bark having acquired the name of the "cinchona of Europe." The Arabian, as well as the Greek and Roman physicians, highly extolled the medicinal virtues of the seed, which, it is said, is good for the dropsy, stone, and many other diseases. M. De Perthuis states that the sap of the ash is an excellent remedy for the gangrene. For this purpose it is extracted from the leaves by maceration; and from the green wood by putting one end of a branch or truncheon into the fire, and gathering the sap in a spoon as it oozes out from the other end. A decoction of the bark, or of the leaves, has been used as a tonic; and an infusion of the leaves as an aperient, and as a purgative. They have also been employed in England in adulterating tea. The ash keys, which have an aromatic, though rather bitter flavour, were formerly gathered in a green state, and pickled with salt and vinegar, to be sent to the table as a sauce, or, as Evelyn expresses it, "as a delicate salading." In Siberia, the keys are infused in the water used for drinking to give it what is there considered an agreeable flavour. The leaves 
and bark of the Fraxinus e. heterophylla, in that country, distil a monnu, a very gentle purgative, considerably used in materia medica, as well as in the veterinary art. This manna, when freshly gathered, serves as a good substitute for sugar. From the ash, as before observed, are obtained the cantharides of the shops, commonly known by the name of Spanish flies.

This tree, with reference to its picturesque beauties, is characterized by that beautiful writer, Bernard Gilpin, in the following manner:- "The ash generally carries its principal stem higher than the oak, and rises in an easy, flowing line; but its chief beauty consists in the lightness of its whole appearance. Its branches, at first, keep close to the trunk, and form acute angles with it; but as they begin to lengthen, they generally take an easy sweep; and the looseness of the leaves corresponding with the lightness of the spray, the whole forms an elegant depending foliage. Nothing can have a better effect than an old ash hanging from the corner of a wood, and bringing off the heaviness of the other foliage with its loose pendent branches; and yet, in some soils, I have seen the ash lose much of its beauty in the decline of age. Its foliage becomes rare and meagre; and its branches, instead of hanging loosely, often start away in disagreeable forms. In short, the ash often loses that grandenr and beauty in old age which the generality of trees, and particularly the oak, preserve till a late period of their existence. The ash also, on another account, falls under the displeasure of the picturesque eye. Its leaf is much tenderer than that of the oak, and sooner receives impression from the winds and frost. Instead of contributing its tint, therefore, in the wane of the year, among the many-coloured offspring of the woods, it shrinks from the blast, drops its leaf, and, in every scene where it predominates, leares wide blanks of desolated boughs, amidst foliage yet fresh and verdant. Before its decay, we sometimes see its leaf tinged with a fine yellow, well contrasted with the neighbouring greens. But this is one of nature's casual beauties; much oftener, its leaf decays in a dark, muddy, unpleasing tint; and yet, sometimes, notwithstanding this early loss of its foliage, we see the ash, in a sheltered situation, when the rains have been abundant, and the season mild, retain its green, when the oak and the elm in its neighbourhood have put on their autumnal attire." And the ash is no less beautifully characterized by Strutt, in his " Sylva Britannica," "waving its slender branches over some precipice which just affords it soil sufficient for its footing, or springing between crevices of rock; a liappy emblem of the hardy spirit which will not be subdued by fortune's scantiness. It is likewise a lovely object by the side of some crystal stream, in which it views its elegant pendent foliage, bending, Narcissus-like, over its own charms."

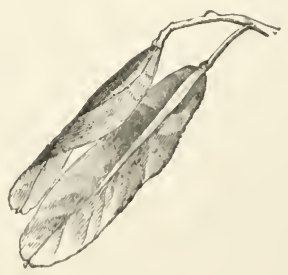




\section{Fraxinus americana,}

\section{THE AMERICAN ASH-TREE.}

Synonymes.

\author{
Fraxinus amencana, \\ Frêne d'Amerique, Frêne blanc, \\ Amerikanische Esche, \\ Frassino americano, \\ American Ash, \\ White Ash, Green Ash,
}

(Willdenow, Linnæi Species Plantarum.

Michaux, North American Sylva.

Lovdon, Arboretum Britannicum.

France.

Germany.

ITALY.

Britain.

Anglo-America.

Derivations. This species is called Frêne blanc, or White Ash, from the superior whiteness of its wood, over every other species of the genus.

Engravings. Michaux, North American Sylva, pl. 118; Loudon, Arboretum Britannicum, ii., fig. 1055, and vi., pl, 209; and the figures below.

Specific Characters. Leaflets 7, petiolate, oblong, acuminate, shining above, quite entire, glaucous beneath. Flowers calyculate.-Don, Miller's Dict.
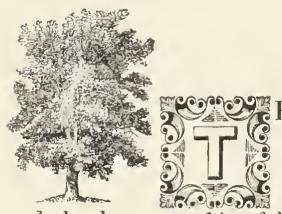

\section{Description.} and the beauty of its foliage, is one of the most interesting among American trees. In favourable situations, it sometimes attains the height of eighty feet, with a trunk three feet in diameter, and often is undivided for more than half of its length. 'The bark is deeply furrowed, with the ridges crossing each other in such a manner, as to give the spaces between, the shape of a lozenge, or what is usually called diamond form. When grown in an open field or lawn, the branches diverge from the central stem, in a double curve, like those of a chandelier, diminishing in length, with great regularity as they proceed upwards. The twigs are thick,

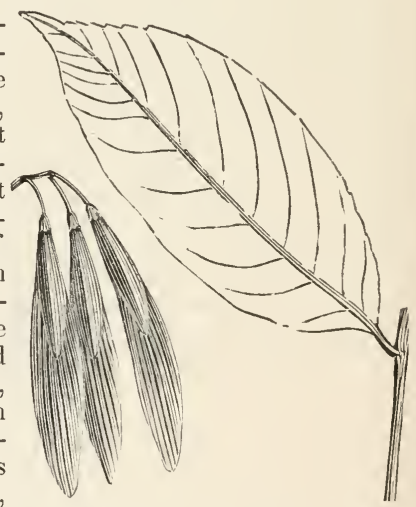
and do not taper to a point, but end abruptly, in spring, with a large terminal bud. 'The shoots of the first two years' growth are of a bluish-gray colour, and are perfectly smooth. 'The buds, which are intensely bitter, are large and broad, and are of a pale-brown colour, by which latter circumstance this tree is easily distinguished from the European species. The leaves are from twelve to fourteen inches long, opposite, and composed of three or four pairs of leaflets, surmomnted by an odd one. They are borne on short petiolules, are three or four inches long, about two inches broad, oval-acuminate, rarely denticulated, of a delicate texture, with an undulated surface. Early in the spring, they are covered with a light down, which gradually disappears, and at the approach of summer, they are perfectly smooth, of a light-green colour above, and whitish beneath. This difference in the colour of the surfaces of the leaflets is peculiar to this spe- 
cies, from which circumstance, it las been called by some botanists, Fraximus discolor. The flowers, which put forth in the month of May, are of a light-green colour, and are succeeded by keys about an inch and a half in length, cylindrical near the basi, and gradually flattened into a wing-like form, with their extremities slightly notched. They are usually united in bunches, four or five inclies long, and are ripe early in autumn.

Vurieties. For reasons stated in our remarks at the commencement of this genus, we have considered all the alleged species of the American ash, only as varieties, which will be found to be no more numerons than those of the European species; and not half so much so as those of the Quercus cerris, ilex, and other species of oak, of which very little notice is taken, because they camnot be readily propagated by grafting. The variations in the American ash may be characterized as follows; but those who differ from us in opinion will find no difficulty in recognizing their names as given by Michaux, London, and others, and will thus be enabled to know under what head they are described in the works of these authors :-

1. F. A. Latifolia, Loudon. Broad-leaved American Ash, having broader leaves than the species.

2. F. A. Pubescens. Pubescent American Ash; Fraxinus tomentosa, of Michaux; Fraxinus pubescens, of Don, Loudon, and others; Frêne pubescent, Frêne rouge, of the French; Red Ash, of the Anglo-Americans. This variety is a beantiful tree, sometimes attaining a height of sixty feet, with a trunk fifteen or eighteen inches in diameter. The bark of the trunk is of a deep-browil; and the wood, which is of a reddish hue, is somewhat harder, but less elastic, than that of the white ash, and is applied to similar uses in the arts. It is inferior to that tree, both in size, and in the rapidity of its growth; the length of the annual shoots, and the distances between the buds being only about one half as great. 'The leaves are from twelve to fifteen inches .ong, and are composed of three or four pairs of very acuminate leaflets, terminated by an odd one. The lower surface of the leaflets, as well as the shoots of the same season, are covered with a thick down, which, on insulated trees, at the approach of autumn, becomes red,

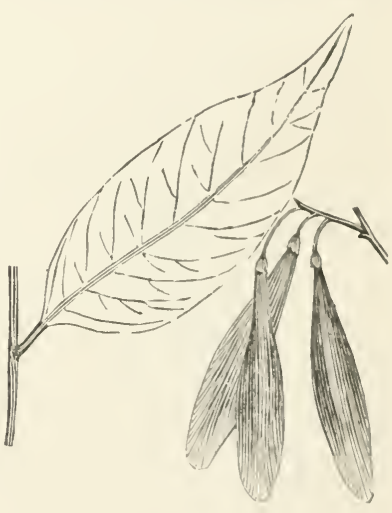
whence, probably, is derived the name of the tree; but by others it is thought to be derived from the reddish colour of its wood. The flowers, which put forth in May, are succeeded by samaræ similar in form and arrangement to those of the white ash, but differing from them in being not quite so long. and in having a short mucro at the apex. This variety is most abundant in Penusylvania, Maryland, and Virginia; where it prefers swamps and places frequently inmudated, or liable to be covered with water by copions rains. In these situations, it is accompanied by the shell-bark hickory, (Carya alba,) bitter-11ut hickory, (('arya amara,) swamp white oak, (Quercus prinus discolor,) red maple, (Acer rubrum,) sweet gum, (Liquidambar styraciflua,) and the tupelo-tree (Nyssa biflora.) This variety was introduced into Britain in 1S11, where it can only be considered as an ornamental tree.

3. F. A. sub-Pubescens. Slightly-pmbescent American Ash, having its leaflets petiolate, elliptic-oblong, acuminated, sliarply serrated, downy beneath, with the common petioles glabrous. 
4. F. A. Sambucifolia. Eller-leaved American Ash; Fraxinus sambucifolu, of Michaux, Don, Loudon, and others; Frêne à feuilles de sureau, Frêne noir, of the French; Black Ash, Brown Ash, Water Ash, of the Anglo-Americans. This tree, in favourable situations, frequently attains a height of seventy or eighty feet, with a trunk from two feet to two feet and a half in diameter. It is easily distinguished from the white ash by its bark, which is more inclined to a yellowish cast, is smoother, with the furrows, in old trees, parallel and perpendicular, often infested with bunches of moss, and may, in some degree, be peeled off in small thin plates, or laminæ. It may also be distinguished by its buds, which are of a deep-tlue, or nearly black, and by the colour of its heart-wood, which is of a fine bistre-brown. The young shoots are of a bright-green, beset with black dots, which disappear as the season advances. The leaves at their unfolding are accompanied by stipulæ which fall after two or three weeks, are from $\mathrm{t}$ welve to fifteen inches long, when fully devel-

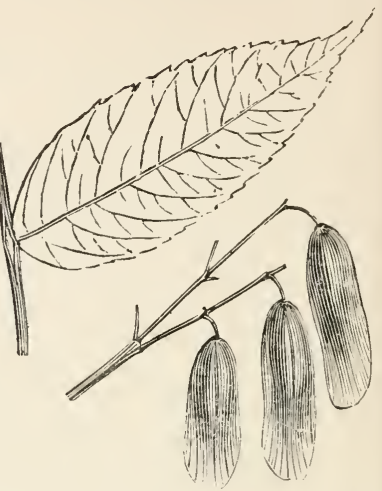
oped, and are composed of three or four pairs of leaflets, with an odd one. The leaflets are sessile, oval-acuminate, denticulated, of a deep-green colour, smooth on the upper surface, and coated with a reddish down upon the main ribs, beneath. When bruised, they emit an odour like that of the leaves of the elder. 'This variety is among the last trees which put forth in spring, and the earliest that lose their leaves in autumn. The vory first hard frost that comes, not only causes its leaves to fade and become yellow, as those of the other trees, but blackening and shrivelling them up, so that they fall in showers, with the least breath of wind. It is often completely denuded, in the northern parts of the United States by the 20th of September. 'The flowers, which put forth in May or June, are succeeded by flat samaræ,or keys, disposed in bunches four or five inches long, that are nearly as broad at the base as at the summit. This variety is found chiefly in the middle and northern parts of the United States, and also abounds in the British colonies of North America, particularly in the forests of Nova Scotia and New Bruıswick, where it is generally found in a moist soil, or one that is exposed to inundations, and is usually accompanied by the red maple, (Acer rubrum,) yellow birch, (Betula excelsa,) black spruce, (Abies nigra,) and the American arbor vitæ (Thuja occidentalis.) In the middle states of the union, this tree associates with the Fraxinus a. pubescens, and the Acer rubrum. Its wood is tougher and more elastic than that of the white ash, but less durable when exposed to the vicissitudes of moisture and dryness, for which reason it is less extensively used. Like the European ash, the value of its timber is increased by the rapidity of its growth; and, as in the case of that species, the wood of young trees is more esteemed than that of old ones. The sap-wood of this variety is very white, tough, and compact, when compared with its heart-wood, which, as before observed, is of a fine bistre-brown, and from this circumstance the tree derives its name. In the parts of the country where this variety abounds it is split into rails for rural fences, which rank next to the cedar for durability, but are far more heavy and difficnlt to move. It has also been employed with advantage in the construction of dams, wharves, canals, and other works, particularly in the parts above the ordinary flow of the waters and streams, where strength and durability are required. It is not employed by coach-makers nor mill-wrights, nor is it ever wrought into oars, pulleys, or hand- 
spikes, as the annual layers readily separate, by repeated blows, or by frequent bending. In Nova Scotia, New Brunswick, and the northern states of the union, it is preferred to the white ash for hoops; and, as the concentric layers readily yield by malling, they are separated into long strips, often as thin as a wafer, which are much used in the country in the manufacture of baskets, corn-riddles, and sometimes for the bottoms of chairs. The wood of this variety is more liable than any other to be disfigured with knobs or wens, which are sometimes of considerable size, and are detached from the body of the tree, and made into trays or bowls. The wood of these excrescences has the advantage of superior solidity, and when carefully polished, exhibits very singular undulations of fibre, and might be profitably employed by cabinet-makers and other manufacturers of fancy work. 'This sort, like most other kinds of ash, is particularly prolific in potash.

5. F. a. sanbucifolia CRisPa. Crisp-leaved Elder-leaved American Ash, having curled leaves.

6. F. A. QUadrangulata. Quadrangular-branched American Ash; Fraximus quadrangulata, of Michaux, Don, Loudon, and others; Frêne quadranguluire, Frêne bleu, of the French; Blue Ash, of the Anglo-Americans. 'This variety, in favourable situations, often attains a height of sixty or seventy feet, with a diameter of fifteen or twenty inches. 'The bark of the trunk cracks and separates into thin plates much in the same manner as that of the white oak (Quercus alba.) The leaves are from twelve to eighteen inches long, and are composed of from two to four pairs of leaflets, terminated by an odd one. The leaflets are almost sessile, elliptic-lanceolate, distinctly toothed, smooth on the upper surface, and downy beneath. The branches are quadrangular; and the young shoots to which the leaves are attached, are distinguished by four opposite membranes, nearly one third of an inch broad, that are of a greenish colour, and extend through their entire length. This character disappears in the third or fourth year, leaving only the traces of its existence. The flowers, which put forth in May, are succeeded by samaræ that are flat from one extremity to the other, and blunt at both ends, but a little narrowed towards the base. 'The blue ash is chiefly found in Tennessee, Kentucky, and the southern part of Ohio, where the climate is mild, and the soil fertile in an extreme degree. 'This fertility seems to serve as a substitute for that degree of moisture, which, in the Atlantic states, appears to bo indispensable to the growth of the ash. The wood of this tree possesses the characteristic properties of the genus; and, of all the varieties of the western states, it is the most extensively employed, and the most highly esteemed. Besides the habitual use that is made of it for the frames of carriages, and for the felloes of wheels, agricultural implements, lc., it is generally selected for the flooring of houses, and frequently for their exterior covering; and, where the tulip-tree, (Liriodendron,) does not abound, it sometimes serves for the shingles of their roofs. It is said that a blue colour may be extracted from the bark of this tree; from which circumstance, probably, it derives its common name. It was introduced into Britain in 18\%3, and is to be met with in many of the European and American collections.

7. F. a. Quadrangulata nekvosa. Comspicums-nerved-leared Quadrangulurbranched American Ash. 
8. F. a. juglandifolia. Walnut-leaved American Ash; Fraxinus viridis, of Michaux; Fraxinus juglandifolia, of Don, Loudon, and others; Frêne à feuilles de noyer, Frêne vert, of the French; Gieen Ash, of the Anglo-Americans. This tree, in its natural habitat, usually attains a height of twenty-five or thirty feet, with a trunk four or five inches in diameter; but in a state of cultivation, it has exceeded more than double of these dimensions. It is easily recognized by the brilliant green colour of its young leaves; and by its leaves being nearly of the same colour on both surfaces. From this uniformity, which is rarely observed in the foliage of trees, Dr. Mühlenberg applied the specific name, concolor; and Michaux gave this tree the popular name of the "Green Ash." The branches are glabrous, and, like the buds, are of a grayishbrown. The leaves vary in length from six to fifteen inches, with from two to four pairs of leaflets, and an odd one, according to the vigour of the tree, and to the coolness of the soil in which it grows. The leaflets, which are about

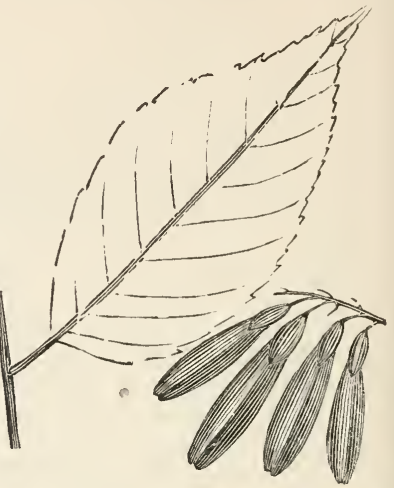
three inches long, are membranous, glabrous, but not shming, sometimes canescent or glancous beneath, downy in the axils of the veins, stalked, elliptic-lanceolate, distinctly denticulated, with glabrous petioles. The flowers, which put forth in May, occur in pendulous corymbs, and are succeeded by linear samaræ; similar in form to those of the white ash, but only abont one half as large. 'This variety is a native of wet, shady woods, from Canada to Carolina; but is more common in the western parts of Pennsylvania, Maryland, and Virginia, than in any other sections of the United States. It is also found in abundance on the banks of the Monongahela and of the Ohio. Its wood is distinguished by similar properties as that of the other trees of the genus, and is applied, in the regions where it abounds, to similar purposes; but as the white ash and the brownhearted variety are more common where it grows, which are much superior in size, the green ash is only incidentally employed. It was introduced into Britain in $1 \% \% 4$, where it is only considered as an ornamental tree. The finest specimen, probably existing in the known world, is on Pope's Villa, at 'Twickenham, in England, which has attained a height of nearly seventy feet, with a trunk three feet in diameter, and an ambitus or spread of branches as great as its height. This splendid tree, which retains its foliage until Christmas, flowers, but never matures its seeds. This variety was introduced into France in 1775, and is cultivated for ornament in many of the European gardens and collections.

9. F. A. Juglandifolia subserrata. Willdenow. Slightly-toothed Walmutleaved American Ash.

10. F. A. caroliniana. Carolina Ash; Fraxinus platycarpa, of Michaux; Fraximus caroliniana, of Don, Loudon, and others; Frêne de la Caroline, of the French. This is a very remarkable variety, readily distinguished by the large size of its leaflets, which are nearly round, but acuminated, petiolate, serrated, glabrous and shining above, and seldom consists of more than two pairs of leaflets, with an odd one. In spring, the lower surface of the leaves, and the young shoots, are covered with down, which disappears as the summer advances. The stature of this tree seldom exceeds thirty feet; and it often flowers and fruits at half of this height. The branches are glabrous, and, like the buds, are of a brownish hue. The flowers, which put forth in May, as in the other varieties, are small, and not very conspicunus. 'They are succeeded by samaræ which are 
vialike those of any of the preceding sorts; being flat, oval, and often almost as broad as they are long. This tree is a native from Pennsylvania to fieorgia, abounding chiefly on the river of Cape Fear, in North Carolina, and upon Ashley and Cooper Rivers, in South Carolina. From its inferior dimensions, this variety is not much used in the arts; although it possesses properties of eminent ntility. It was introduced into Britain in 1783 , and is cultivated in many parts of Europe, solely as an ornamental tree.

11. F. A. Eplptera. Wing-topped-seeded American Ash; Fraxinus epiptera, of Don, Loudon, and others. This variety may be distinguished by its lanceolate-elliptic leaflets, which are subserrated, opaque, and downy beneath, on the veins. 'The samaræ are cuneated, obtuse, and emarginate at the apex, and terete at the base. The young branches are green, and covered with white dots; the bark chinky; the buds brown; and the flowers calyculate, which put forth in May. A tree thirty feet high, native of North America, from Canada to Carolina, and was introduced into Britain in 1823.

12. F. A. platycarpa. Broad-fruited American Ash; Wraxims platycarpu, of Don, Loudon, and others. The leaflets of this variety are almost sessile, very distinctly serrated, elliptic-lanceolate, two inches long, and one inch broad; having the larger veins villous beneath. The samaræ are elliptic-lanceolate, two inches long, and acute at both ends. A tree from thirty to fifty feet high; native. of Virginia and Carolina; introduced into Britain in 1721; and flowers in May. It is very easily known from all other American varieties, by the leaves dying off, in autumn, of a fine purple.

13. F. A. expansa. Expanded American Ash; Fraxims expansa, of Don, Loudon, and others. The leaflets of this variety occur in five pairs, three inches long, ovate-oblong, unequally serrated, acuminated, glabrous, but not shining, and petiolate. The branches are glabrous, smooth, and green, when young, with the buds brown. A tree from thirty to fifty feet in height; native of North America; introduced into Britain in 1824, and flowers in May.

14. F. A. pulverulenta. Powdery-petioled American Ash; Fraxiuns mulvernlenta, of Don, Loudon, and others.

15. F. A. rubicunda. Reddish-veined American Ash; Fraxims rubicmula, of Don, Loudon, and others.

16. F. A. Longlfolia. Long-leaved American Ash; Fraximus longifolia, of Don, Loudon, and others.

17. F. A. vinıDis. Green-branched American Ash; Fraximus viridis, of 10n, Loudon, and others (but not $\mathrm{F}$. viridis of Michaux.)

19. F. A. Cinera. Gray-budded American Ash; Fraximus cinera, of Don, Lolldon, and others.

19. F. A. Nigra. Black-branched American Ash; Fraximus nigra, of Don Loudon, and others.

20. F. A. Fusca. Browon-branched American Ash; Fraximus fusca, of 1 on. Loudon, and others.

21. F. A. ruFA. Rufons-haired-leafleted American Ash; Fraximns rufa, of Don, Loudon, and others.

22. F. A. Pannosa. Cloth-like-leaved American Ash; Fraximus pamnosa, of Don, Loudon, and others. A tree with fulvons buds, native of Carolina, introduced into Britain in 18:0).

23. F. A. TRIPTERA. Three-winged-frnited American Ash; Fraxiuns tripterl. of Nuttal, a native of the oak forests of Soutl Carolina.

Geography and History. The Fraximus americana is a mative of North America from Labrador to Carolina; is particularly abmulant in Canada itud New Brunswick; and, as a cold climate is more congenial to its cromiln than a varm one, it is found in greater numbers north of the river Iludson Ilian 
south of it. In the upper part of New Hampshire, it is always accompanied by the white elm, (Ulmus americana,) yellow birch, (Betula excelsa,) white maple, (Acer eriocarpum, heinlock spruce, (Abies canadensis,) and the black spruce (Abies nigra); and in New Jersey, it is mingled with the red maple, (Acer rubrum,) shell-bark hickory, (Carya alba,) and the sycamore-tree (Platanus vccidentalis.)

T'lin species was first introduced into Britain by Mark Catesby, in 1723; and, in about the year 1826, when Cobbett became a nurserynan, and strongly recommended various kinds of American trees, several plantations of the white ass: were formed, in different parts of England; but a sufficient time has not yet elapsed to judge of the value of the tree, as compared with the common European ash. In the neighbourhood of London, young trees are generally more or less injured by the spring frosts; nevertheless, in Surrey, at St. Ann's Hill, there is a specimen, which, in thirty-six years after planting, had attained the height of thirty-three feet.

In France, at Clairvanlt, there is a tree of this species, which had attained the height of thirty feet, in thirty years after planting.

In Russia, the American ash, and several of its varieties, are planted in the government garden, at Odessa, and it is stated by M. le Chevalier Descemet, conseiller de cour, that they have the great advantage of prospering in soils where the European ash will languish. "'They are not," says he, "like Fraxinus excelsior, subject to lose their leaves by the ravages of the insect Cantharis vesicatoria, in the middle of summer, and may, consequently, be planted in the neighbourhood of dwelling-houses. They resist the burning heats of summer much better than the European ash-tree, and maintain a deep-green foliage during the hottest weather, when that of the common ash becomes pale, and very frequently withers and drops." "In short, the American ash-trees," he adds, "deserve to be extensively cultivated in forests, in lines for bordering roads, and in smalI groups in parks and pleasure-grounds."

It is stated by Mr. John Pearson, in a communication to Dr. James Measi, in the "Memoirs of the Philadelphia Society for promoting Agriculture," for the year 1897 , that, in Wayne county, Pennsylvania, there were white ash-trees five feet in diameter, and from fifty to eighty feet in length.

Soil, Situation, Propagation, $\& \cdot c$. The most favourite situations of the Fraxin us americana are the banks of rivers and streams, the edges or acclivities of sivamps, where the soil is deep and fertile, and intermingled with the fragments of rocks. The propagation and culture of this tree is the same as that of the European species.

Insects, Accidents, $\&^{*} c$. The Fraxinus americana, like its European congener, is but little subject to accidents and to the attacks of insects. The only insects that prove particularly injurious to this tree, are the larvæ or borers of the 'Trochilium denudatum, described by Dr. Harris, in "Silliman's Journal of Science," and also in his "Report on the Insects of Massachusetts injurious to Vegetation." These borers perforate the bark and the sap-wood of the trunk of the ash, from the roots upwards, and are also found in all the branches of any considerable size. The trees thus infested soon show symptoms of disease, in the death of the branches near the summit; and when these insects become numerous, the trees no longer increase in size and height, and premature decay and death ensue. These insects assume the chrysalis form in June and July, when they may be seen projecung half way out of their round holes in the bark of the trees, during which months, their final transformation is effected, when they burst forth, and escape in the winged state.

Properties and Uses. The wood of the white ash, in young, thrifty trees, is very white from the bark to the centre: hut in large, old trees, the heart-wood is 
of a reddish tinge, and the sap-wood white. When the annual layers are thick and coarse, it is exceedingly tough and elastic, and may be applied to all the various purposes for which the Fraxinus excelsior is used in Europe. In America, the wood of this tree is highly esteemed for its strength and suppleness, and is advantageously employed for a great variety of uses, of which we shall mention only a few of the most common. It is selected by coach and wagon-makers for the felloes of wheels, for shafts, and for the frames of carriage bodies, and for those of light wagons. It is also in very general use for agricultural implements and domestic wares, particularly for the handles of spades, hoes, shovels, forks, rakes, scythes, \&c. In Canada, and the northern parts of the United States, it is extensively used for hoops and staves, the latter of which are of a quality between those of the white and red oaks, and are esteemed best for casks containing salted provisions and flour. It has also been admitted into the lower frames of vessels, but is considered inferior to that of the yellow birch, (Betula excelsa,) and to the heart of the red beech. For the blocks to pulleys, particularly those used in ships, and the pins for belaying the cordage, this wood is very appropriate; and, on account of its strength and elasticity, it is esteemed as superior to every other species of timber for oars. It is extensively exported to Europe, especially to England, in the form of planks, and the oars of this wood are used in all the navies of the world. The inner bark of this tree imparts a very permanent yellow to skins, and may be used with advantage in dyeing wool.

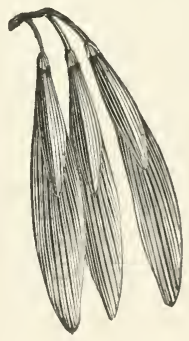




\section{Genus ORNUS, Pers.}

Oleaceæ.

Syst. Nat.

Ornus, Fraxinus,
Diandria Monogynia.
Syst. Lin.

Synonymes.

Of Authors.

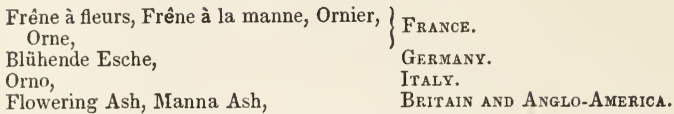

Derivations. The word Ornus is derived from the Greek oros, a mountain, having reference to some of the trees of tl.1s genus as growing on hills and mountains. The species were classified under the head of Fraxinus of the old authors.

Generic Characters. Flowers hermaphrodite, or of distinct sexes. Calyx 4-parted or 4-toothed. Corolla 4-parted; segments long, ligulate. Stamens with long filaments. Stigma emarginate. Samara 1celled, 1-seeded, winged.-Don, Miller's Dict.

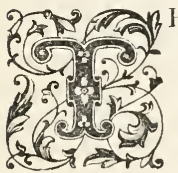

HIS genus embraces trees natives of Europe, Asia, and of North America; with impari-pinnate leaves, and terminal or axillary panicles of flowers, distinguished from those of the common ash, by having corollas. They may all be propagated from seeds, by grafting or budding, or by cuttings and layers.

Several, if not all the species of both the genera Fraxinus and Ornus, extravasate sap, which, when it becomes concrete, is mild and mucrlaginous. This sap is produced more abundantly by the Ornus europæa, and some of its varieties, than by any other species; and, when collected, it forms the manna of commerce. This substance is chiefly collected in Calabria and Sicily, where, according to the "Materia Medica" of Geoffroy, the manna runs of itself" from the trunks of some trees, while it does not flow from others unless wounds are made in the bark. Those trees which yield the manna spontaneously grow in the most favourable situations; and the sap runs from them of its own accord only during the greatest heats of summer. It begins to ooze out about mid-day, in the form of a clear liquid, which soon thickens, and contimues to run until the cool of the evening, when it begins to harden into granules, that are scraped off the following morning. When the night has been damp or rainy, the mauna does not harden, but runs to the ground, and is lost. This kind is called mamma in tears (manna lagrima, of the Sicilians); and it is as pure and white as the finest sugar. About the end of July, when the liquid ceases to flow of itself, incisions are made through the bark and soft wood; and into these incisions slender pieces of straw or twig are inserted, on which the manna runs, and, in hardening, entirely coats them over. This is the common manna of the shops, which is thus collected in the form of tubes; and is called by the Sicilians, manna in cannoli, or manna cannoli. Another sort, which is inferior to the two precediug, is procured by making an oblong incision in the trees, in July or August, and taking off a piece of the bark about three inches in leugth, and two inches in breadth. This kind, wlich is called manna grassa, is the coarsest of all; but, as it is obtained with the least trouble, and in great abundance, it is also the cheapest. Sometimes, instead of cutting out a piece of bark, and leaving the wound open, two horizontal gashes are made, one a little above the other; in the lupper of which is inserted the stalk of a maple leaf, the point of the leaf being fixed in the lower gash, so as to form a sort of a cup to receive the manna 
and to protect it from dust and other impurities. The greater part of the manna of commerce is procured in the latter manner; and it is imported in chests, in long pieces, or granulated fragments, of a whitish or pale-yellow colour, and in some degree transparent. The inferior kind, which is of a dark-brown colour. comes in adhesive masses, and is moist and unctuous to the touch. Manna from the ash has a peculiar odour, and a sweetish taste, accompanied with a slight degree of bitterness. It is considered as aperient, and was formerly much used in medicine; but it is now chiefly employed to disguise other drugs in administering them to children, and is used as a purgative in the veterinary art. This: kind of manna, however, must not be confounded with that mentioned in the Holy Writ, which is supposed to be identical with the manna produced by the Alhagi maurorum, a low shrub two or three feet high, native of the deserts of Egypt, Syria, Mesopotamia, and other eastern countries. The Arabians have a tradition that, this manna fell from the clouds upon this plant to feed the Israelites in the desert. This, however, is contrary to what is recorded in the sicriptures, namely, that the miraculous manna appeared only on the rocks, and on the sand, and hence the surprise of the Israelites, who would not have been astonished if they had seen small portions of it on the shrubs; but who, finding it in such immense quantities on the ground, where they had never seen it before. could hardly believe it to be the same thing, and exclaimed in Hebrew, "Man"? that is to say, "What is it?" whence, possibly the name. The manna produced by the alhagi is a natural exudation from the leaves and branches, which takes place only in very hot weather. At first, it resembles drops of honey; but granulates on exposure to the atmosphere, into particles of different sizes, but seldom larger than a coriander seed. Another species of manna is obtained in Arabia from the tamarisk-tree, (Tamarix gallica,) by the puncture of the Coccus manniparus. A similar substance is also obtained from the larch, (Larix europæa.) in the south of France, where it is known by the name of manne de Briançon. This substance is a kind of sap of a sweetish, but insipid taste, which, towards the end of May, and during the months of June and July, exudes, according to some, only during the night, from the bark of the young shoots; but whicl. according to others, transpires from the buds and leaves, on which it coagulates in the form of little white glutinous grains, that are easily scraped off. In the morning, young larch-trees, before they are struck with the rays of the sum, will be found covered with it; but the grains, if not gathered, will soon disappear. It resembles the manna of the flowering ash, (Ornus europæa rotundifolia,) but is less purgative. The rhododendron, the walnut, the beech, and the Norway maple, also yield an analogous substance, ns probably, do various other trees: for the sap of most ligneous plants is more or less sweet and mucilaginous; and, consequently, when collected in any quantity, is susceptible of becoming concrete by evaporation. The manna of Lebanon is the gum mastic obtained from the Pistacia lentiscus; and the manna of Poland is composed of the seeds of the Glyceria fluitans. 


\section{Ornus americana, \\ THE AMERICAN FLOWERING ASH.}

\author{
Fraxinus americana, \\ Ornus americana, \\ Ornier d'Amerique, \\ Amerikanische Blühende-Esche, \\ Orno americano, \\ American Flowering Ash,
}

\section{Synonymes.}

\author{
Linnæus, Species Plantarum. \\ $\int$ Pursh, Flora Americæ Septentrionalis. \\ Don, Miller's Dictionary. \\ Loudon, Arboretum Britannicum. \\ France. \\ GERMany. \\ ITALY. \\ Britain and Anglo-America.
}

Engravings. Loudon, Arboretum Britannicum, ii, fig. 1070; and the figures below.

Specific Characters Leaves with $2-5$ pairs of oblong or ovate-acuminated, shining, serrated leaflets, each $3-5 \mathrm{in}$. long, and $2 \mathrm{in}$. broad, and having the larger veins rather villous, glaucous, and paler beneath, the odd one rather cordate. Flowers with petals, disposed in terminal panicles. Branches brownish. gray. Buds brown. Samara narrow, obtuse, mucronate.-Don, Miller's Dict.

\section{Description.}
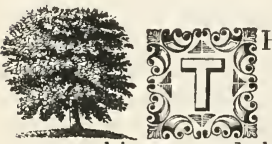

HE Ornus americana is a beautiful tree, growing to a height of thirty or forty feet, and flowering in May. The difference between this sort and the manna ash of Europe is so very slight, that donbts are entertained by some, of there being but one species. It is a native of North America, and was introduced into Britain in 1820, where it is cultivated for ornament, and is highly prized. There are plants of it in the Horticultural Society's garden, at London, and in

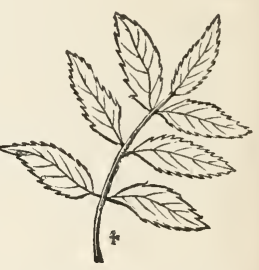
the arboretum at Kew, where, in the last-named place, it is grafted on the Fraxinus excelsior; and the point where the scion was inserted in the stock, is said to have enlarged nearly as much as the stock itself, a proof that the American flowering ash is a more robust-growing tree than the Ornus europæa, which was also engrafted in a similar manner, but did not increase in the same ratio with the stock. When no other mode can be obtained of rendering a tree gardenesque, Mr. Loudon suggests, that, in order to give the trunk an architectural base, a slowgrowing species may be grafted on one that is more vigorous; and that the application of the art of grafting might be worth adopting for certain ornamental trees to be planted in exposed situations; for an architectural base to a tree is strongly expressive of its stability.

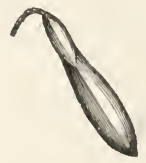




\section{Genus CATALPA, Juss.}

Bignoniacex. Syst. Nat.
Diandria Monogynia. Syst. Lin.

Synonymes.

Catalpa, Bignonia,

Of Authors.

Derivations. The word Catalpa is supposed to be corrupted from an Indian name of a tree belonging to this genus; and Bignonia was so called by Tournefort, in compliment to the Abbé Bignon, librarian to Louis XIV.

Generic Characters Calyx 2-parted. Corolla campanulate, with a ventricose tube, and an unequal 4 lobed limb. Stamens 5, 2 of which are fertile, and 3 of them sterile. Stigma bilamellate. Capsule silique-formed, long, cylindrical, 2-valved. Dissepiment opposite the valves. Seeds membranous y margined, and pappose at the base and apex.-Don, Miller's Dict.

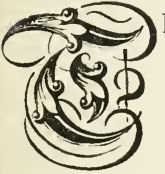

HE genus Catalpa was constituted by Jussieu from the Bignoniu catalpa of Tournefort, and comprises but one species, native of North America. Nearly allied to the same natural family is the order Scrophulariaceæ, which embraces that magnificent tree, the Paulownia imperiaiis, so called by Sieber, in honour of the Hereditary Princess of the Netherlands, who was daugliter to the Emperor of Russia. The leaves of the Paulownia are cordate, deeply serrated, and slightly ciliated, having the general appearance of those of a gigantic sun-flower. The flowers, which put forth in April or May, are blue, resembling those of the Gloxinia caulescens, and have an agreeable odour, somewhat like that of the mock orange, (Philadelphus coronarius,) but less powerful. This tree is a native of Japan, and was introduced into Britain in 1840, and into France two or three years before that date. It has proved quite hardy in the Jardin des Plantes, at Paris, where it withstood the winter of 1838-9 without any covering, and in 1842, had acquired the height of twenty feet, producing leaves two feet in diameter. The plants at Trianon have been much more rapid in their growth, having made shoots from twelve to fourteen feet in length in a single year. This species was introduced into the United States, in 1843, by Messrs. Parsons, of Flushing, near New York, where it remained in the open air, without any covering, during the last eight years. It has since been propagated in several nurseries in the union, and bids fair to be a great addition to our shrubberies and ornamental plantations, particularly in situations where immediate effect is the object. It is easily propagated by cuttings of the roots, put into thumb-pots, and will grow in any commor garden soil; but it thrives best in one that is dry, and somewhat loamy. 
Catalpa syringafolia,

\title{
THE LILAC-LEAVED CATALPA-TREE.
}

\section{Synonymes.}

\author{
Bignonia catalpa, \\ Catalpa syringafolia, \\ Catalpa, \\ Bois Shavanon, \\ Trompetenbaum, \\ Catalpa, Catawba-tree. Bean-tree,
}

Derivations. The word Catalpa is supposed to be a corruption of Catavba, the name of an Indian tribe that formerly occupied a great part of Georgia and the Carolinas. The French of Louisiana call this tree Bois Shavanon, from its being found in goundance on the banks of the Shavanon, now called Cumberland River. The German name signifies Trumpet-tree, from the form of its flowers.

Engravings. Michaux, North American Sylva, pl. 64; Loudon, Arboretum Britannicum, vii., pl. 215 et 216 ; and the figures below.

Specific Characters. Leaves cordate, flat, 3 in a whorl, large, and deciduous. Branches strong. Panicles large, branchy, terminal. Corollas white, speckled with purple and yellow.-Don, Miller's Dict.

\section{Description.}

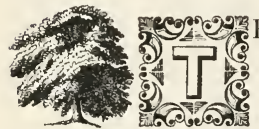

HE Catalpa syringæfolia, in its natural habitat, frequently exceeds fifty feet in height, with a trunk from eighteen to twenty-four inches in diameter. It is easily recognized by its bark, which is of a silver-gray colour, and but slightly furrowed; and by its wide-spreading head, disproportioned in size to the diameter of its trunk. It also differs from most other trees in the fewness of its branches, and the fine, pale-green of its very large leaves, which are late in coming out in spring, and are among the first to shrink at the approach of autumn. They are heart-shaped, petiolated, often six or seven inches in width, glabrous above, and downy beneath, particularly on the principal ribs. The flowers, which put forth in July or August, occur in large bunches, at the extremity of the

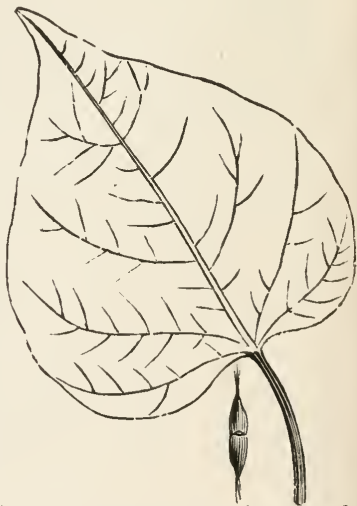
branches, and are white, marked with purple and yellow spots. In favourable: seasons, they are succeeded by capsules or seed-pods, which somewhat resemble those of the common cabbage, but on a larger scale; being frequently two feet long, and curved upwards, resembling horns. They are cylindrical and pendent, of a brownish colour, when ripe, and contain thin, flat seeds, developed in a long, narrow, membranous wing, terminated by a hairy tuft. Each seed with its wing, is about an inch long, and one eighth of an inch broad.

Geography and History. The Catalpa syringæfolia is indigenous to the south- 
ern states of the Ameriean union, and is first met with, in a wild state, on the Atlantic coast, on the banks of the river Savamnah, and west of the Alleglianies, on those of the Cumberland, between the thirty-fifth and thirty-sixth degrees of latitude. Further south, it is more common, and abounds near the borders of all the rivers which empty into the Mississippi, or water the westerly part of Florida. In a cultivated state, it is to be met with, as an ornamental tree, in most of the cities and large towns, from New Orleans, in Louisiana, to Newburyport, in Massachusetts; but in the latter place, it dwindles down to a mere shrub, and is often killed back by the frost.

This species was introduced into Britain, by Mark Catesby, in 1\%26, and is frequently to be met with in gardens and collections, both in that country, and on the continent of Europe.

The largest recorded tree of this species in Britain, is at Syon, whieh is fiftytwo feet in height, with a trunk three feet in diameter, and an ambitus or spread of branches of fifty feet.

The largest catalpa in France is at the Seéaux, which, in thirty years after planting, had attained the height of fifty feet, with a trunk two feet in diameter, and that of the head thirty feet.

At Sehwöbber, in Hanover, Germany, there is a tree of this species, exceeding thirty feet in height.

In Austria, at Vienna, in the university botanic garden, there is a catalpa, which, in twenty-six years after planting, had attained the height of forty feet, with a trunk eighteen inches in diameter, and an ambitus or spread of branehes of twenty-four feet.

In various parts of Italy and the south of France, particularly in the neighbourhood of Milan and Montpellier, the eatalpa is planted as a road-side tree, and along the avenues to houses in the country, where, with the Melia azedarach, and the tulip-tree, (Liriodendron,) and in some places, where the soil is moist, with the Magnolia acuminata, and other species, it forms a scene of splendour and beauty, worthy of a climate so eongenial to vegetation.

About the first tree of this species, which was introduced into New England, is said to stand in front of the late residence of Major Babeoek, in Washington street, Hartford, in the state of Conneeticut. It is represented as being of a large size, and when in bloom, appears like one solid mass of elegant flowers. It is believed to exceed fifty years of age.

Propagation, $\&^{\circ} \cdot$. The catalpa is generally propagated by seeds; but it will grow readily from cuttings of the root; and, when thus raised, it will flower much sooner than when propagated by seeds. The tree is of rapid growth till it reaches the height of twenty feet, whieh, in a deep, free soil, it will usually attain in ten years. Seedling plants generally begin to flower, under favourable circumstanees, in twelve or fifteen years; and in soils and situations where the wood is well ripened, they continue flowering every year, making a splendid appearance, not only from the large size and lively colour of the blossoms, but from the fine pale-green of their leaves.

Properties and Uses. The wood of the catalpa is remarkably light, of a very fine texture, and is susceptible of a brilliant polish. Its colour is of a grayishwhite; and, when properly seasoned, it is very durable. It resembles the wood of the sycamore, (Platanus,) with this exeeption, that the latter is of a reddisl hue, and is less durable when exposed to the alternations of moisture and dryness. It is sometimes used for posts to rural fences, and in eabinet-making. If a portion of the bark of the catalpa be removed in the spring, a vellomous and offensive odour is exhaled. In a thesis, read at the medical eollege of Philadelphia, the bark of this tree was maintained to be tonie, and more powerfully 
antiseptic than that of the Cinchona officinalis. It is considered to be a good antidote for the bite of snakes. It is stated that the honey collected from the flowers is poisonous, and that its effects, though less alarming, are analogous to those produced from the honey of the yellow jasmine (Gelsenium nitidum.) The flowers are extolled as being a sovereign remedy against asthma.

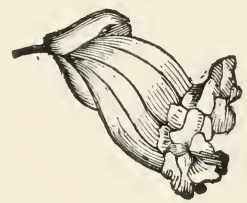




\section{Genus LAURUS, Plin}

Lauraceæ.
Syst. Nat. $\underset{\text { Enneandria Monogynia. }}{\text { Syst. Lin. }}$

Synonymes.

Laurus, Persea, Borbonia,

OF AUthors.

Derivation. The word Laurus is derived from the Latin laus, praise, in reference to the ancient custom of crowning the Roman conquerors with laurel, in the triumphal processions.

Generic Characters. Sexes polygamous or diœcious. Calyx with 6 sepals. Stamens 9 ; 6 exterior, 3 interior, and each of them having a pair of gland-like bodies attached to its base. These have been deemed imperfect stamens. Anthers adnate; of 2 cells in most of the species, of 4 unequal ones in the others; each cell is closed by a vertical valve, that opens elastically, and often carries up the pollen in a mass. Fruit a carpel that is pulpy externally, and includes 1 seed. Cotyledons eccentrically peltate, or, in other words, attached to the remainder of the embryo a little above the base line.-Loudon, Arboretum.

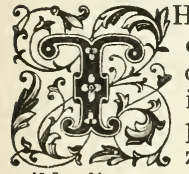

HE genus Laurus has been divided by modern botanists, and several genera formed out of it; but, for the sake of brevity, and the convenience of classification, we have retained the Linnæan names in all the species which we have noticed. There are only three perfectly hardy kinds, namely, Laurus nobilis, sassafras and benzoin; but there are several species that will live in the open air in mild climates, or with little protection, which are well worthy of cultivation. The Laurus benzoin, (spice bush,) is a beautiful deciduous shrub, a native from Virginia to Canada, growing from three to twelve feet in height, and is readily distinguished by its highly pungent and aromatic bark, which is regarded as a stimulant and tonic, and is extensively used in the regions where it abounds, in the cure of intermittent fevers; and hence, is sometimes called fever bush. 'The Laurus cinnamomum and cassia, which are natives of Ceylon, Malabar, CochinChina, Sumatra, \&c., and which are cultivated in India, Mauritius, Jamaica, Brazil, and other places, produce the cinnamon and cassia of commeree. What are called cassia buds, are not obtained from the Laurus cassia, but are the lexangular, fleshy reeeptacles of the seeds of the true cinnamon-tree. Cassia bark and buds are used for the same purposes as cinnamon bark, but they are consid.. ered as inferior in value, on account of containing a greater proportion of mucilage. From the present genus we also derive a portion of the camphor of commerce, which is the product of the Laurus camphora, hereafter considered. 'The Laurus indica is indigenous to Madeira and the Canary Islands, the wood of which is highly esteemed in eabinet-making. It can lardly be distinguished from mahogany, except that it is somewhat less brown in its colour. Hence it is imported into England under the name of Madeira mahogany.

To the same natural order belong the California bay-tree, (1)rimophyllum pauciflorum,) and the Californian umbellularia, (Umbellularia californica,) both elegant evergreen trees, natives of Upper California, the former growing to a height of twenty or thirty feet, and the latter from forty to one hundred and twenty feet, with a trunk from two to four feet in diameter. Its foliage, according to Mr. Nuttall, gives out, when bruised, a most powerful camphorated odour, which, from its pungency, is capable of exciting sueezing. "The volatile oil," observes the same writer, "obtained from some species of Laurus found in the vast forests between the Oronoko and the Parime, is produced in great abundance by merely making an incision into the bark with an axe, as deep as the liber or young wood 
It gushes out in such quantities, that several quarts may be obtained by a single incision." **

Nearly allied to the same natural family are the genera Tectona and Vitex, the latter of which embraces several species of deciduous shrmbs and trees, natives of the south of Europe, India, China, and of North America. The only hardy kind is the Vitex agnus-castus, indigenous to Sicily. The teak-tree, (Tectona grandis,) which is justly called the "oak of the east," abounds in the vast forests of Java, Ceylon, Malabar, Coromandel, \&c., more especially in the Birman and Pegu empires. Its timber is considered superior to all others for ship-building. It is easily wrought, and at the same time is both strong and durable. This tree, Mr. Royle informs us, has been planted as far north as Saharunpore, in India, in about the same latitude as the northern parts of Old California, and of the Canary Islands; where, from their mountainous character, it is highly probable it might be cultivated with success.

* See Nuttall's North American Sylra, p. 89. 


\section{Laurus nobilis, \\ THE NOBLE LAUREL-TREE.}

Synonymes.

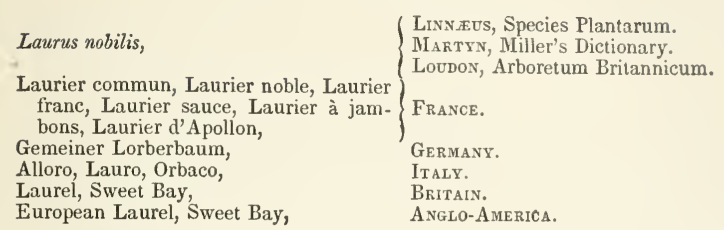

Derivation. The specific name nobilis was so called by Linnæus, because this tree was consecrated to priests, sacrifices, ano heroes, in the ages of antiquity, and has been celebrated accordingly.

Engravings. Blackwell, Herbal, pl. 175; Loudon, Arboretum Britannicum, vii., pl. 217; and the figure helow.

Specific Characters. Evergreen. Flowers 4-cleft. Sexes dicecious. Leaves lanceolate, veiny.-Willdenow, Linnai Species Plantarum.

\section{Description.}

\footnotetext{
"Deep in the palace, of long growth, there stood A laurel's trunk, a venerable wood;

Where rites divine were paid; whose holy hair Was kept and cut with superstitious care.

This plant, Latinus, when his town he wall'd,

Then found, and from the tree Laurentum call'd;

And last, in honour of his new abode,

He vow'd the laurel to the laurel's god."

VIRGL.
}

mo6ecos of sixty or seventy feet but always displaying a tendency to throw up suckers; and rarely, if ever, assuming a trec-like character, without the aid of art. The leaves, which are evergreen, are of a firm texture, and are of an agreeable smell, with an aromatic, sub-acid, slightly bitterish taste. The flowers, which put forth in April or May, are dicecious, or the male and female on different trees, and are disposed in racemes shorter than the leaves. 'The male tree is the most showy, from the greater proportion of yellow in the flowers. 'The berries are ovate, fleshy, and of a very dark-purple, approaching to black, and are about the size of a small olive. In winter, they are greedily devoured by the European

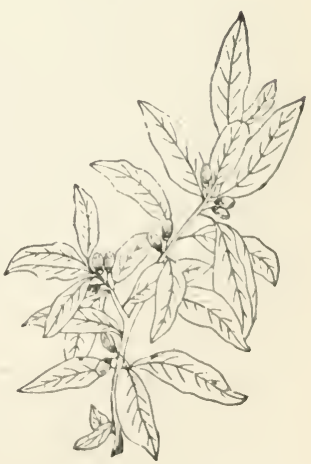
black bird.

Varieties. The varieties recognized under this species, are as follows:-

1. L. N. Latifolia, Loudon. Broad-leaved Noble Laurel; Laurier d lurges fenilles, of the French. This variety has leaves much broader and smoother than those of the species. It is indigenous to Spain, Italy, and $\mathbf{A s i a}$, but is less hardy than several other kinds. 
2. L N. Parvifolia. Small-leaved Noble Laurel; Laurier à petites feuilles, of the French, indigenous to the Caribbee Islands, where its leaves are used for seasoning food.

3. L. N. Salicifolia, London. Willow-leaved Noble Laurel, a shrub six or eight feet high, with long, narrow leaves, not so thick as those of the species, and of a lighter green.

4. L. N. undulata, Loudon. Undulated-leaved Noble Laurel, a low shrub, seldom growing higher than from four to six feet, with leaves waved on the edges, and is said to be more hardy than the species.

5. L. N. CRISPA, Loudon. Crisped-leaved Noble Laurel, with leaves somewhat curled.

6. L. N. variegata, Loudon. Variegated-leaved. Noble Laurel.

7. L. N. Flore Pleno, Loudon. Double-flowered Noble Laurel.

Geography and History. The Laurus nobilis is a native of the south of Europe, and northern Africa; and, according to St. Pierre, remarkably fine trees of it were found on the banks of the river Peneus, in Thessaly, which, probably. might have given rise to the fable of the nymph Daphne, (supposing the Greek daphne to be this tree,) the daughter of that river.

The exact date of the introduction of this species into Britain is unknown, but it must have been previous to 1562, as it is mentioned by Turner, in his "Herbal," published in that year; and we find that, in the reign of Elizabeth, the floors of the houses of distinguished persons were strewed with its leaves.

The largest recorded tree of this species in Britain, is at Margram, in Glanorganshire, on the seat of C. P. Talbot, M. P., about twelve miles from Swansea. It is upwards of sixty feet in height, with a magnificent bell-shaped summit, about sixty feet in diameter.

At Cypress grove, near Dublin, in Ireland, there is a laurel fifty feet in height, with a trunk two feet in diameter, and an ambitus or spread of branches of twenty-five feet.

Throughout Germany, the Laurus nobilis is a green-house plant. In Russia, in the Crimea, it requires protection during winter.

In Italy and Spain, it attains a larger size than in any other part of Europe, forming immense bushes from fifty to sevellty feet in height.

In the northern parts of the United States, it is only cultivated as a greenhouse plant; but in the southern sections of the union, where the climate is more mild, it grows in great perfection in the open air.

Mythological and Legendary Allusions. This tree is celebrated in mythology, as having once been Daphne, the danghter of Peneus, who, flying from the embraces of A pollo, and reaching the banks of her parent stream, called on the river god for protection, was changed into a laurel. In the age of Roman greatness, this tree was considered as the emblem of victory, and also of clemency. The victorious generals were crowned with it in their triumphal processions; every common soldier carried a sprig of it in his hand, and even the dispatches announcing a victory were wrapped up in, and ornamented with, its leaves. The aromatic odour of this tree was supposed by the ancient Romans to have the power of dispelling contagion; and, during a pestilence, the Emperor Claudius removed his court to Laurentum, so called from the bay-trees which grew within its walls. Theophrastus tells us that the superstitious Greeks would keep a bay leaf in their mouths all day, to preserve themselves from misfortunes. The Greeks, also, had diviners who were called Daphnephagi, because they chewed laurel leaves, which they pretended inspired them with the spirit of prophecy. The laurel was dedicated to Apollo, and the first temple raised to that god at Delphi, was formed of the branches of this tree. It was the favourite tree of the poets; and we are told that Maia, the mother of Virgil, dreamed that she was delivered of 2 
bay-tree; and that one of these trees sprang from Virgil's ashes, and is still growing over his tomb. In more recent times, the laurel was supposed to be a safeguard against lightning; and Madame de Genlis mentions the device of the Count De Dunois, which was a bay-tree, with the motto, "I defend the carth that bears me." It was a custom, in the middle ages, to place wreaths of laurel, with the berries attached, on the heads of those poets who had particularly distinguished themselves; hence the expression, "poet laureate." The crowns, which have for a long time encircled the heads of the young students in the European sehools of divinity, law, and of medicine, who have taken their degrees, are made of the branches of this tree, garnished with the berries, and thus indicate the title of bachelor or baccalaureate, from the Latin bacce laurea, laurel berries. These students, formerly, were not allowed to marry, lest the duties of husband and father should take them from their literary pursuits; and, in time, all single men were called bachelors. The statues of Fisculapius, crowned with sprigs of laurel, announced the great confidence in which the ancients held the medicinal virtues of this tree. The laurel is mentioned by Chaucer as the crown of the Knights of the Round Table.

Soil, Propagation, $\& \cdot c$. The Laurus nobilis requires a good free soil, and it will not thrive in the open air, in a climate much colder than that of London, in England, or of Charleston, in South Carolina. It is generally propagated by layers or cuttings, particularly the varieties; but the species may readily be increased from seeds. As it forms a dense conical bush, when not trained to a single stem, it is well adapted for hedges. This tree is very tenacious of life, and a root or stump of it will often send up suckers two years after it has appeared to be dead.

Properties and Uses. The wood of this tree, from its inferior size, is not much used in construction, nor in the arts. The young branches are sometimes enployed for the hoops of small casks. Both the leaves and berries were formerly considered medicinal, being highly aromatic and stomachic; they are also astringent and carminative. An infusion of them was not only considered benefieial, when taken internally, but it was used in fomentations, \&c. From the berries, there is extracted a particular principle, called laurine. The kernels of the fruit yield an emollient and resolutive oil, called oil of laurel, which is employed as an embrocation in materia medica, and in the veterinary art. 'The essential oil is used in perfumery, and for scrubbing wainscots in chambers, in order to drive away flies. The leaves impart a yellow colour to wool. The principal use of this tree, however, is for hedges, and other purposes of ornament, though the leaves are much employed for flavouring custards, blanc-mange, sc. The flowers afford the best kind of honey, and are numerously frequented by bees.

As an evergreen shrub, the laurel is not only beautiful in itself, but conneeted as it is with many classical and interesting associations, it well deserves a place in every collection. 
Laurus carolinensis,

\section{THE CAROLINA LAUREL-TREE.}

Synonymes.

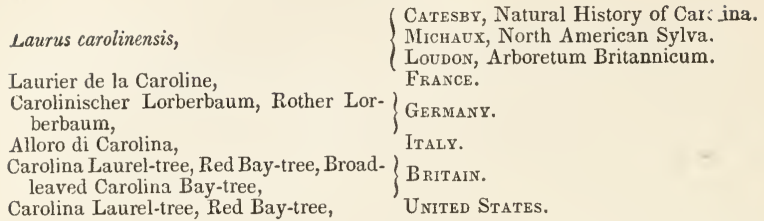

Engravings. Catesby, Natural History of Carolina, pl. 63; Michaux, North American Sylva, pl. 82; Loudon, Arboretum Br. tannicum, iii., fig. 1168; and the figures below.

Specific Characters. Evergreen. Leaves oval, lanceolate, slightly glaucous beneath. Flowers in pedun cled axillary groups.-Sprengel, Syst. Veg.

Description.

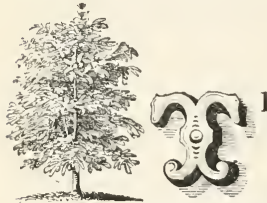
ral habitat, with a trunk fifteen or twenty inches in diameter, rarely exhibits a regular form; its stem generally being crooked, and divided into several thick limbs, eight, ten, or twelve feet above the ground. Upon the trunks of old trees, the bark is thick, and deeply furrowed; but on young stocks and branches, it is smooth, and of a beautiful green colour. The leaves are about six inches long, alternate, oval-acuminate, glaucous on the lower surface, and evergreen. The male flowers come out in April or May, in long clusters from the axils of the leaves; and the female flowers occur in loose bunches, on rather long, red peduncles. The berries, which are of an oval form, and of a rich, darkhlue, grow in red cups, and occur two, and sometimes three together.

Varieties. Michaux states that this tree differs exceedingly in its character, according to the latitude in which it grows. Laurus borbonia, of Linnæus, is probably the form which it assumes in the southern states; and $\boldsymbol{L}$. carolinensis, the one in which it appears in the more northern states. The three following varieties appear to be distinctly marked, all of which were introduced into Britain, in $1806:$

1. L. C. Glabra, Pursh. Glabrous-leaved Carolina Laurel, with leaves slightly glabrous.

2. L. c. Pubescens, Pursh. Pubescent-leaved Carolina Laurel, having slightlv pubescent leaves.

3. L. с. овтusa, Pursh. Olstuse-leaved Carolina Laurel, with the leaves ovate-

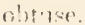


Geography, $\mathcal{f} \cdot c$. The Laurus carolinensis is indigenons to the lower part of Virginia, and is found more or less abundantly throughout the maritime districts of the Carolinas, Georgia, Florida, and of Louisiana. It occurs in the broad swamps which interseet the pine-barrens, and is there associated with the tupelo, (Nyssa biflora,) red maple, (Acer rubrum,) and the water oak (Quercus aquatica.) A cool and humid soil appears to be essential to its growth; and it is remarked, that the further south it grows, the more vigorous and beautiful is its vegetation.

This species was discovered by Mark Catesby, and was first described and figured by him, in his "Natural History of Carolina." It was cultivated in Britain, by Miller, in 1739. In France, Plumier constituted it a genus, to which he gave the name of Borbonia, in honour of Gaston de Bourbon, son of Henry IV., and uncle to Louis XIV.

Propagation, \&.c. The Carolina laurel may be propagated by cuttings or layers, or from seeds. In its native country, the seeds vegetate freely, and the old trees are often surrounded by hundreds of young plants.

Properties and Uses. The wood of the Laurus carolinensis is very strong, and of a beautiful rose-colour, with a fine, compact grain, and is susceptible of a brilliant polish, having the appearance of watered satin. Before mahogany became in general use in cabinet-making, in the United States, the wood of this tree was much employed in the regions where it abounds in the manufacture of articles of furniture of the highest degree of beauty. It miglit also be employed in ship-building, and for other purposes of construction, as it unites the properties of strength and durability; but its trunks are rarely found, of late, of sufficient dimensions to render it available for these purposes. When bruised, the leaves diffuse a strong odour, resembling that of the sweet bay, (Laurus nobilis, ) and may, like them, be employed in cookery.

In Europe, this species is solely considered as an ornamental tree; and as it is more tender than the sweet bay, it is only suitable for warm and sheltered situations, or for being placed against a wall.

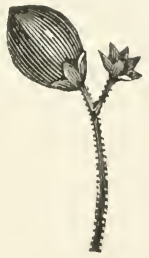


Laurus sassafras,

\title{
THE SASSAFRAS-TREE.
}

\begin{tabular}{|c|c|}
\hline Laurus sassafras, & $\left\{\begin{array}{l}\text { Linneus, Species Plantarum. } \\
\text { Michatx, North American Sylva. } \\
\text { Loudon, Arboretum Britannicum. }\end{array}\right.$ \\
\hline $\begin{array}{l}\text { Laurier sassafras, Laurier des Iroquois, } \\
\text { Sassafras-Lorberbaum, } \\
\text { Sassofrasso, } \\
\text { Sassafras-tree, Saxifax-tree, }\end{array}$ & $\begin{array}{l}\text { France. } \\
\text { Germany. } \\
\text { ItaLy. } \\
\text { Britain and ANglo-AMerica. }\end{array}$ \\
\hline
\end{tabular}

Derivation. The specific name sassafras, is an alteration of the Spanish word salsafras, or saxifras, which is afplied to a species of Saxifraga, the virtues of which are attributed by the Spanish Americans to this tree.

Engravings. Michaux, North American Sylva, pl. 81; Bigelow, Medical Botany, pl. 35; Audubon, Birds of America, iii. pl. cxliv.; Loudon, Arboretum Britannicum, vii., pl. 218 et 219 ; and the figures below.

Specific Characters. Sexes diœcious. Habit arborescent. Both leaves and flowers are produced from the same buds. Buds, younger branches, and the under surface of the leaves, pubescent. Leaves entire, or with 2-3 lobes. Veins prominent on the under side. Flowers in corymbose conglomerate racemes. Anthers with 4 unequal cells. In the female flower, additionally to the pistil, are 6 glandlike bodies, like those of the male flowers.-Nuttall, Genera.

\section{Description.}

\author{
"If Fever's fervid rage \\ Glowed in the boiling veins, with care they" ***** \\ $* * * * *$ "Freely urg'd \\ The cool aperient from the fragrant bark \\ Of Sassafras " ***** \\ $* * * * *$ "To supply \\ The place of fam'd Cinchona, whose rough brow \\ Now ruddy, and anon with paleness mark'd, \\ Drinks in its native bed, the genial gales \\ Of mountainous Peru."
}

Traits of the Aborianers.

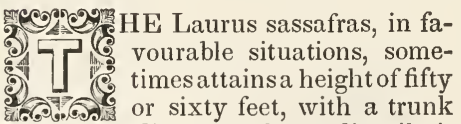
from one to two feet in diameter; but ordinarily it does not much exceed one half of these dimensions. The bark of the trunk is of a grayish colour, and is deeply furrowed; and that of the young branches is smooth, and of a beautiful reddish-green. On cutting into the cortex or true bark, it exhibits a dark, dull-red, much resembling the colour of the Peruvian bark. 'The trees, when old, often give birth to numerous suckers, that spring up at little distances from their trunks, which rarely rise higher than six or eight feet. The leaves of the sassafras are four or five inches in length, alternate and petiolated. At their unfolding, in spring, they are downy, and of a tender texture; but become smoother, and

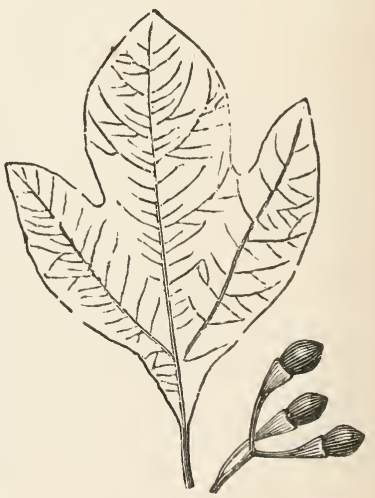
more firm by age. They are remarkable for the variety of their forms on the same tree. "Those which proceed first from the bud, are usually oval and entire; the next have the same form, with a lobe on one side; and the last, and 
most numerous, have regularly three lobes."* It has been further remarked, that the lobed leaves are the most numerous on the upper part of the tree. The flowers, which put forth before the leaves, nsually appear in Carolina and Georgia, from the middle to the last of March; but in the vicinity of Philadelphia and New York, not before the beginning of May. They are disposed in short, slender racemes, of a pale-green colour, and protrude from the sides of the branches below the leaves, having the scales of the former bud for their floral leaves. In this species, as with the Laurus nobilis, the sexes are confined to different trees. The fruit, or seeds, is of an oval form, of a deep-blue colour, and is contained in small, bright-red cups, supported by peduncles from one to two inches in length. These seeds, when ripe, are eagerly devoured by birds, and soon disappear from the tree.

Varieties. Nuttall states in his "Genera of North American Plants," that the mhabitants of Carolina distinguish two kinds of sassafras, the "Red," and the "White," calling the latter, also, the "Smooth." The red variety he identifies with his sub-genus Euosmus; and the white or smooth kind, he considers as belonging to the same sub-genus, which he calls Laurus Euosmus albida, and of which he has adduced the following characteristics:-Its buds and young branches are smooth and glancous; its leaves are everywhere glabrous and thin. and the veins are obsolete on the under surface; the petiole is longer. The root is much more strongly camphorated than the root of the red sort, and is nearly white. This kind, he says, is better calculated to answer as a substitute for ochra, (Hibiscus esculentus,) from its buds and young branches being much more mucilaginous. It is abundant in North and South Carolina, from the Catawba Mountains to the east bank of the Santee, growing with the red variety, which, in North Carolina, is less abundant.

Geography and History. The Laurus sassafras is said to be indigenous to every section of the United States, east of the Rocky Mountains, and to Upper Canada, where, in the last-named country, it is found between Niagara and Hamilton, in forty-three and a half degrees of north latitude; but there it dwindles down to a tall shrub, though healthy in its appearance, not exceeding twenty feet in height. In the neighbonrhood of New York and Philadelphia, however, it grows to a height of forty or fifty feet, and attains a still greater elevation in the southern states. Indeed, it abounds from the state of New Hampshire to the banks of the Mississippi, and from the shores of the Atlantic, in Virginia, to the remotest wilds of Missouri, comprising an extent in one direction, of more than a thousand miles, and more than double that distance in the other direction.

The sassafras, from the peculiar forms of its foliage, and the properties of its bark, wood, and leaves, is rendered a prominent object of notice, and it appears to have been one of the earliest trees of the North American forests to attract the attention of Europeans. Monardez, in 1549, and after him Clusius, treat of its uses. Gerard calls it the "ague-tree," and says that a decoction of its bark will cure agues and other diseases. And Bigelow states that, "Its character, as an article of medicine, was at one time so high, that it commanded an extravagant price, and treatises were written to celebrate its virtues." "It still retains a place," he adds, "in the best European pharmacopœias." The most interesting historical recollection connected with this tree is, that it may be said to have led to the discovery of America; as it was its strong fragrance, smelt by Columbus, that encouraged him to persevere when his crew were in a state of mutiny; and enabled him to convince them that land was nigh.

The largest recorded tree of this species, in Britam, is at Syon, which is fortysix feet in height, with a trunk three feet in diameter, and an ambitus or spread of branches of thirty-four fect. There is another tree at Cobham Hall, in Kent. 
which, in thirty years after planting, had attained the height of fifty feet, with a trunk eighteen inches in diameter.

In France, in the neighbourhood of Nantes, there is a sassafras, which, in twenty-four years after planting, had attained the height of thirty feet, with a trunk two feet in diameter.

Soil, Propagation, \&॰c. The Laurus sassafras will grow in any free soil, rather moist than dry, and is generally propagated from seeds, which should be sown or put into a rot-heap, as soon as received, as they remain a year, and sometimes two or three years, in the ground, before they vegetate. The sassafras may also be propagated by cuttings of the roots, or by suckers thrown up by old trees. The sitnation where the tree is to be finally planted, should be sheltered; and, in the northern parts of Britain, as well as in Canada, in order to insure fine foliage, it should be planted against a wall.

Insects. The Laurus sassafras is inhabited by the larvæ of various species of insects, among which, are those of the black swallow-tail butterfly, (Papilio ilioneus, of Smith and Abbot,) and of the (Attacus promethea, of Harris.) The latter usually come to their full size by the beginning of September, when they measure two inches or more in length, and about half of an inch in diameter. The body of this caterpillar is very plump, and but slightly contracted on the back between the rings. It is of a clear, and pale bluish-green colour; the head, the feet, and the tail are yellow; there are about eight warts on each of the rings; the two uppermost warts on the top of the second and third rings are almost cylindrical, much longer than the rest, and of a rich, coral-red; all the rest of the warts are very small, and of a deep-blue colonr. Before entering into its chrysalis state, the caterpillar instinctively fastens to the branch, the leaf that is to serve for a cover to its cocoon, so that it shall not fall off in autumn, and then proceeds to spin on its upper side, bending over the edges to form a hollow, within which lies concealed its cocoon. These brown and curled leaves may be frequently seen hanging upon the trees during winter, when all the rest of the foliage has fallen. If one of these leaves be examined, it will be found to be retained by a quantity of silken thread, which is wound round the twig to the distance of half an inch or more on each side of the leaf-stalk, and is thence carried downwards around the stalk to an oval cocoon, that is wrapped up by the sides of the leaf. The cocoon itself is about an inch long, of a regnlar oval shape, and consists of two coats. So strong is the coating of silk that surrounds the leaf-stalk, and connects the cocoon with the branches, that it cannot be severed without considerable force; and consequently, the chrysalis swings securely within its leaf-covered hammock, through all the storms of winter.* The sassafras, as well as the balsam poplar, the elm, the dogwood, and the leaves of clover and of Indian corn, are fed upon by the Io caterpillar (Saturnia io.)

Properties and Uses. The wood of the Laurus sassafras, in young trees, is white and tender; but in those which exceed fifteen or eighteen inches in diameter, it is of a reddish cast, and of a more compact grain. It is not, however, in the latter respect, to be compared with the oak, as a piece of considerable size may be broken with a slight effort. Consequently, the sassafras is of little value as a timber-tree, where strength is the object in view. Experience has showl, that the wood, stripped of its bark, resists, for a considerable period, the progress of decay; and it is on this account employed for the posts and rails of rural fences. It is also sometimes used for joists and rafters in the construction of houses; and is said to be secure from the attacks of insects, an advantage attributed to its odour. On this account, it has been employed for trunks, bedsteads, \&c. ; but a property of this kind is wrongly attributed to this wood, since it is nearly devoid of smell after a few months' drying.

* See Harris' Report, pp. 280 et 281. 
But for these purposes, the timber of this tree is not in habitual use, being only occasionally employed. 'The wood is of very little esteem for fuel; and the bark contains a considerable portion of air, and snaps while burning, like that of the chesnut. The wood imparts to wool a very durable orange-colour.

Medicinally, the wood, bark, and roots of the sassafras, are considered to be an excellent stimulant and sudorific, and may be advantageously employed in materia medica, and in the veterinary art. They were formerly much celebrated in the cure of various complaints, particularly in rheumatism, dropsy, and cutaneous eruptions; but, by modern practitioners, they are only recognized as forming a warm stimulant and diaphoretic. The wood is slightly aromatic and somewhat acrimonious, depending on a resin and an essential oil; but the smell and taste, which are peculiar to this vegetable, are more sensible in the young branches, and comparatively more so in the bark of the roots. A decoction of the sassafras chips, sold by druggists, is well known as a remedy for scorbutic affections. The bark and pith of the young twigs, as well as the tender leaves, abound with a pure mucilaginous principle resembling that of the Hibiscus esculentus (ochra.) Mucilage of sassafras pith is peculiarly mild and lubricatory, and has been used with much benefit in dysentery and catarrh, and particularly as a lotion in the inflammatory stages of ophthalmia. From the bark of the roots the greatest quantity of essential oil is extracted, which, after long exposure to the cold, it is said, deposits very beautiful crystals. The flowers of this tree, which have a weak aromatic odour, when fresh, are considered as stomachic and efficacious in purifying the blood; and for this purpose, during a fortnight in the spring, an infusion of them is drunk with a little sugar, in the manner of tea. In Louisiana, the leaves are used to thicken pottage; and in various parts of the United States, an agreeable beverage is formed with the aid of the young shoots, and of the bark of the roots, usually known by the name of "Root Beer," which is considered as very salutary during the months of summer. The fruits of the sassafras are much in quest by perfumers, who convert them into powder, which they put up in small sachets; but what are known by druggists under the name of "sassafras nuts," are the fruit of the Laurus pucheri, a native of Peru.

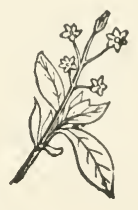




\section{Laurus camphora, THE CAMPHOR-TREE.}

\author{
Laurus camphora, \\ Camphrier, \\ Campherbaum, \\ Albero di canfora, \\ Camphor-tree, Camphire-tree,
}

\section{Synonymes.}

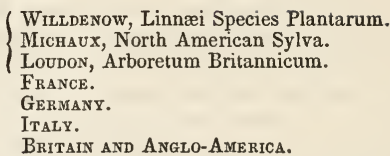

Derivation. The word camphora is an alteration of the Arabic kânfour, the name of the camphor-tree in that language. Engravings. Michaux, North American Sylva, pl. 83; Loudon, Arboretum Britannicum, iii., fig. 1174; and the figures below.

Specific Characters. Leaves triple-nerved, shining above, glandular in the axils of the veins. Panicles axillary and terminal, corymbose, naked.-Pereira, Materia Medica.

\section{Description.}

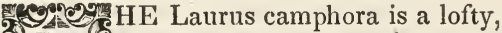
evergreen tree, growing to a height of fifty or sixty feet, with a trunk of a proportionate diameter. The young branches are of a yellowish-green, and smooth. The leaves are oval, acuminate, attenuate at the base, of a bright-green colour, shining above, and paler beneath, with petioles from one inch to an inch and a half in length. The flowers, which are small, and of a yellowish-white, are succeeded by round, dark-red berries, about the size of a black currant, each containing a solitary seed.

Geography and History. The Laurus camphora is indigenous to China, Japan, and Cochin-China, and has been introduced into Java, and other islands of the same group.

"The ancient Greeks and Romans," observes Pereira, "do not appear to have been acquainted with camphor. C. Bauhin, and several subsequent writers, state that Aëtius speaks of it; but I have been unable to find any notice of it in his writings; and others have been equally unsuccessful in their search of it. Avicenna and Serapion speak of it; the latter calls it kaphor, and erroneously cites Dioscorides. Simeon Seth, who lived in the XIth century, describes it; and his description is considered, both by Voigtels and by Sprengel to be the earliest record." "This tree, Michaux remarks, possesses a high degree of interest for the United States, and should especially engage the attention of the inhabitants of Florida, the lower parts of the Carolinas, and of Louisiana. Its multiplication, in these climates, he says, would be so easy, that after a few years, it might be abandoned to nature.

Properties and Uses. The wood of the camphor-tree, which is of a whitish colour, is strongly impregnated with camphor, and is sometimes employed for making trunks and boxes, that are liable to be infested with insects or worms. 
Every part of the tree, particularly the flowers, possess the smell and taste of camphor in a high degree; but, it is especially from the roots, that this substance, so useful in medicine, is obtained. According to Kæmpfer and Thunberg, the method of extracting camphor in the provinces of Saltzuma and the islands of Gotha, in Japan, is to chop up the roots and wood of the tree, and boil them in water in an iron vessel, with an earthen head, containing a quantity of straw, adapted to it, on which the camphor condenses, or sublimes. But the method practised in China, from the statements of the Abbe Grosier, Dentrecolles, and Davies, appears to be somewhat different. The chopped branches are steeped in water, and afterwards boiled, until the camphor begins to adhere to the stick, or spatula, used in stirring. The liquid is then strained, and by standing, the camphor concretes. Alternate layers of dry earth, finely powdered, and of this camphor, are then placed in a copper basin, to which another inverted one is luted, and by this means sublimation is effected.

There are two kinds of crude camphor known in commerce, namely, the Dutch or Japan camphor, and the China, Formosa, or ordinary crude campleor. The former is brought from Batavia, and is said to be the produce of Japan. It is imported in tubs covered by mating, and each surrounded by a second tub, sezured on the outside by hoops of twisted cane. Each tub contains from one hundred to one hundred and fifty pounds. It consists of pink-coloured grains, which, by their natural adhesion, form various-sized masses. It differs from the ordinary crude camphor in having larger grains, in being cleaner, and in subiming, usually at a lower temperature. The ordinary crude camphor is imported from Singapore, Bombay, \&c., in square chests, lined with lead foil, and containing from one hundred and forty to one hundred and seventy pounds. It is chiefly produced in the island of Formosa, and is bronght by the Chin-Chew junks in very large quantities to Canton, whence foreign markets are supplied. It consists of dirty grayish grains, which are smaller than those of Dutch camphor. Its quality varies-being sometimes wet and impure, but occasionally it is as fine as the Dutch kind.

Liquid camphor and Sumatra or Borneo camphor, are obtained from the Dryobalanops aromatica, a large tree growing in Sumatra and Borneo. The liquid camphor or camphor oil is obtained by making deep incisions in the tree, from which the liquid oozes out, and is received in bamboos, or other convenient utensils. It is occasionally imported in tin canisters, and sometimes consists of a perfectly limpid, transparent fluid, but most usually it is more or less tinged with yellow or brown. Its odour is somewhat analogous to that of the oil of cajuputi, combined with the odour of camphor and cardamoms. Sumatra or Borneo camphor, called by the natives Kapurbarus, is found in the natural fissures or crevices of the wood, and occurs in small, white, transparent fragments of crystals, of a camphoraceous odour, and a hot taste. It is much esteemed by the Chinese; but, from its exorbitant price, it rarely enters into their foreign commerce.*

Camphor is also found in numerous herbs, especially peppermint, rose-mary, thyme, lavender, \&c. The quantity, however, thus produced, is too small to yield a commercial supply.

* See Pereira's Materia Medica, ii., pp. 243, 244 et 655. 


\title{
Genus NYSSA, Linn.
}

\author{
Santalacex. \\ Syst. Nat. \\ Polygamia Diœcia. \\ Syst. Lin.
}

Derivation. The genus $N y s s a$ was so called by Linnæus, from a water nymph of that name, who educated Bacthus; because several of its species grow in water or moist places.

Generic Characters. Flowers bisexual and male; the two kinds upon distinct plants, and without petals. Calyx of bisexual flower connate, with the ovary in its lower part, having a free, 5-parted limb. Stamens 5. Ovary ovate, containing 1 pendulous ovule, and in some instances, 2. Style simple, revolute, curved inwards. Stigma acute. Fruit a roundish drupe. Nut elliptical, acute, angular, somewhat irregular, grooved lengthwise, containing 1 seed, which is albuminous, and has an embryo that has large, leafy cotyledons, and a superior radicle. Calyx of male flower 5-parted, spreading. Stamens $5,8,10$, and 12 ; surrounding a shield-shaped gland. Leaves alternate, entire. Inflorescence axillary, peduncled, of 1 flower, or several aggregate flowers. Fruit red or blackish-purple, suffused with a frosty appearance.-Loudon, Arboretum.

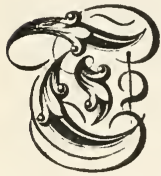

HE genus Nyssa embraces deciduous trees, natives of North America, and, though several sorts have been described by botanists, they are all, probably, referable to two, or at most, three species; namely, Nyssa biflora, candicans and grandidentata, the two latter being so nearly allied, that we have considered them as belonging to the same species.

To the natural family of hardy trees next preceding Santalaceæ belong the genera Daphne and Dirca, the former of which contains the mezereon, (Daphne mezereum,) a well-known shrub, much valued in gardens and shrubberies, both for the beauty of its flowers and its fruit. It produces its agreeably fragrant flowers in early spring, before the leaves; when, as is beautifully expressed by Cowper, its branches are,

\footnotetext{
"Though leafless, well attired, and thick beset

With blushing wreaths, investing every spray."
}

The marsh dirca, or leather-wood, (Dirca palustris,) sometimes also called wickoby, is a native from Maine and Canada to Georgia, and is noted for the extreme toughness of its inner bark, which is so strong that the stoutest man could not break, by pulling, a strip an inch in width, taken from the main stem. The wood, when deprived of the bark, is remarkably soft and brittle, snapping with the slightest effort. Like the mezereon, it blossoms before leafing. 


\section{Nyssa biflora, \\ THE TWIN-FLOWERED NYSSA.}

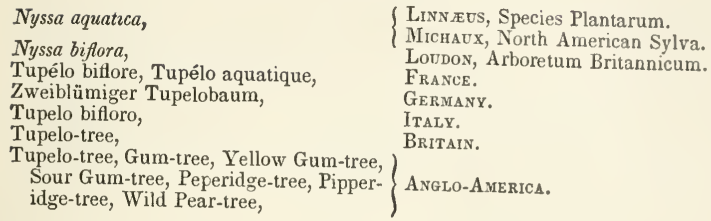

Derivation. The specific name biflora is derived from the Latin binus, by couples, and floreo, to blossom, having refer is wholly misapplied, as no self-condensing in pairs. Tupelo appears to be the aboriginal name of this species. Gum-lre is wholly misapplied, as no self-condensing fluid distils from the tree. The French, German, and Italian nanes have the same
signification as the botanical one.

Engravings. Michaux, North American Sylva, pl. 111 ; Catesby, Natural History of Carolina, i., pl. 41; Audubon, Birds of America, ii., pl. cxxxiw ; Loudon, Arboretum Britannicum, iii., figs. 1195 et 1196, and vii., pl. 220; and the figures below.

Specific Characters. Leaves ovate-oblong, entire, acute at both ends, glabrous. Female flowers two upor
a peduncle. Drupe short, and obovate, with the nut striated.

\section{Description.}

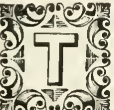

HE Nyssa biflora, in an uncultivated state, seldom rises above forty or fifty feet, with a trunk fifteen or twenty inches in diameter. Its branches spring from the main stem, five or six feet above the ground, usually affecting a horizontal direction; and the young shoots of the first two years are commonly simple, and widely divergent from the branches. The trunk, while it is less than ten inches in diameter, has nothing remarkable in its appearance, but on fullgrown and vigorous stocks, the bark is thick and deeply furrowed, which, unlike that of most other trees, is divided into hexagons, that are sometimes very regular. The leaves are about three inclies long, ovate-oblong, entire, slightly glaucous beneath, alternate, and are often united in bunches

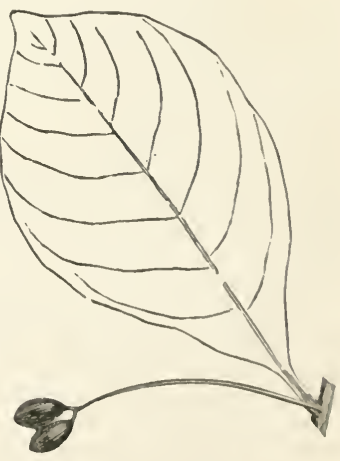
at the extremities of the young shoots. The flowers, whiclı put forth in $A$ pril or May, are small, and scarcely apparent; but the fruit, which is usually abundant, and attached in pairs on peduncles one or two inches in length, is about the size of a pea, of a deep-blue colour, and is highly ornamental. It is ripe m ()ctober, and, remaining upon the trees after the falling of the leaves, it serves for a part of the food of the American robins, (Turdus inigratorius,) in their annul migrations to the south. 'The stone of the fruit is compressed on one side, slightly convex on the other, and longitudinally striated.

Variety. N. B. villosa, Loudon. Hairy-leaved Nyssa; Nysssa sylintica, of Michaux; T'upélo des terrains secs; T'upélo de montagrne, of the French; Huari- 
yer Tupelobaum, of the Germans; Mountain Tupelo-tree, Sour Gum-tree, Black Gum, Yellow Gum, of the Anglo-Americans. This variety, which attains a height of sixty or seventy feet, is a native of Maryland, Virginia, and of the western states, where it grows on high and level ground, associated with oaks and walnuts; but in the lower parts of Carolina and Georgia, it is found only in moist or wet places, with the Magnolia glauca, Laurus carolinensis, (red bay,) Gordonia lasianthus, (loblolly bay,) and the Quercus aquatica (water oak.) In the latter situations, it exhibits a very remarkable singularity of vegetation, often having a trunk eighteen or twenty feet in height, with a diameter of seven or eight inches, at the surface of the ground, and only two or three inches at a foot above; but the proportions vary in different individuals. This tree appears to differ but a very little from the species, except in its greater height, and in the downiness of the petioles of the leaves. The fruit is of about the same shape, size, and colour, generally produced in pairs on similar peduncles, and the wood is of the same description, fine-grained, and tough. The alburnum of the trunks of trees growing upon dry and elevated lands, is yellow; and this colour, being considered by wheelwrights as a proof of the superior quality of the wood, has probably given rise to the name of "yellow gum," which is sometimes applied to the species. Throughout the greater part of Virginia, this wood is employed for the naves of coach and wagon wheels. At Richmond, Baltimore, Philadelphia, \&c., it is preferred for hatters' blocks, to any other wood, being but little liable to split. In the southern states, it is employed for the cylinders which receive the cogs of rice mills. It is also sometimes chosen by shipwrights for the caps or pieces that receive the topmasts.

Geography and History. The Nyssa biflora begins to appear in the lower part of New Hampshire, where the climate is tempered by the ocean; and, in progressing southward, it is found most abundantly in the easterly parts of New York, New Jersey, and Pennsylvania; but in Virginia and Carolina, it is more sparingly produced, and, as in the north, it always occurs in moist ground or in watery places.

This species was introduced into Britain in 1739 , and is not unfrequent in European and American collections. The largest recorded tree in Europe, is at the Countess of Shaftesbury's villa, in Richmond, England, which, in 1836, was forty-five feet high, with a trunk sixteen inches in diameter.

At Schwöbber, in Hanover, Germany, there is another specimen, which, in sixty years after planting, had attained the height of forty feet, with a widespreading head, and branches drooping to the ground. It is planted in a low, moist situation, and the roots, which extend to a great distance, send up innumerable suckers. In autumn, the leaves, before dropping off, become as red as blood.

On the seat of the late Mr. Astor, near Hurl-gate, New York, there is a tree of this species, which has attained a height of more than forty feet, with a trunk a foot in diameter.

Propagation, $\& \cdot c$. The Nyssa biflora may be multiplied by seeds, and by cuttings or layers; and, to insure the prosperity of the tree, it ought always to be planted in moist peat, near water. A splendid specimen at Strathfieldsaye, on the estate of the Duke of Wellington, as well as the tree above referred to, at 
Sch wöbber, are grown in moist meadows, on a level with the waters of the adjoining rivers.

Properties and Uses. The Nyssa biflora holds a middle rank between soft and hard-wooded-trees. When perfectly seasoned, the sap-wood is of a slight reddish tint, and the heart-wood is of a deep-brown. Of trees exceeding fifteen or eighteen inches in diameter, frequently more than half of the trunk is hollow. The ligneous fibres, which compose the body of most other trees are closely united, and usually ascend in a perpendicular direction. But, on the contrary, the trees of this genus exhibit a constant peculiarity of organization, the fibres being united in bundles, and are interwoven like a braided cord. 'This property gives it a decided superiority for certain uses. In the parts of the country where it abounds, it is employed for the naves of wheels destined for heavy burthens. It is also employed for the heads of the shafts of wind-mills, and, sawn into boards, it is used for lining carts. Wooden bowls are made of it, which are heavier than those made of the tulip-tree, (Liriodendron,) and are less liable to split. From this irregularity of fibre, the "gum-tree" is not admitted as evidence in the courts of Pennsylvania, in establishing boundaries to lands, \&c., from the number of years which have elapsed since the trees have been blazed. As fuel, this wood burns slowly, and diffuses a great heat.

In British gardens, it does not appear that much pains have been taken to encourage the growth of this, or any other species of Nyssa; nor are there but very few specimens of a tree-like form to be seen either in the European or American pleasure-grounds; but, from the singularity of the fruit, and the beauty of the foliage, which dies off of an intensely deep scarlet, this tree deserves a place in every collection. 


\section{Nyssa candicans, WHITISH-LEAVED NYSSA.}

Synonymes.

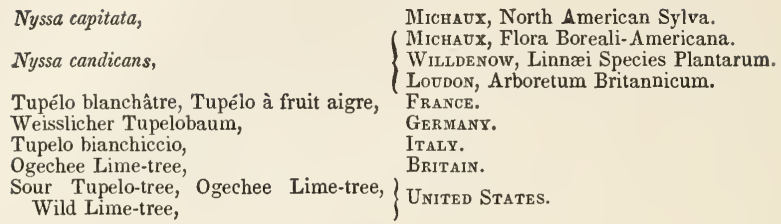

Derivation. The specific name candicans is derived from the Latin candeo, to be white, having reference to the whutish colour of the leaves on their under surface. The word capitata is derived from caput, the head, on account of the male flowers being grouped in little heals. It is called Sour Tupelo, Lime-tree, \&c., from the agreeable acid juice contained in the fruit.

Engravings. Michaux, North American Sylva, pl. 113; Loudon, Arboretum Britannicum, iii., fig. 1199; and the figures below.

Specific Characters. Leaf with the petiole very short, and the disk oblong, wedge-shaped at the base, nearly entire, whitish on the under surface. Female flowers one upon a peduncle.-IVilldenow, Linnei Spec. Plant.

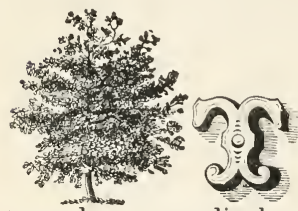

\section{Description.}

HE Nyssa candicans, in its natural habitat, rarely exceeds thirty feet in height, with a trunk seven or eight inches in diameter. The branches of the male trees are somewhat compressed about their trunks, and tend towards a perpendicular direction; while those of the female trees diffuse themselves horizontally, and form a larger and rounder summit. The leaves are five or six inches in length, oval, rarely denticulated, of a light-green ahove, and whitish beneath. The male flowers are grouped in little heads, and appear in April or May. The bracteas attending the female flowers are short, the calyx tomentose, with its lobes short. And the sexes are borne by separate trees. The fruit is supported by long peduncles, and is about an inch and a half in length, of a light-red colour, and of an oval shape. It is thick-skinned, intensely acid, and contains a large, oblong stone, deeply channelled on both sides.

Variety. N. c. Grandidentata. Deeply-toothed Whitish-leaved Nyssa; Nyssa grandidentata, of Michaux and Loudon; Tupélo à grandes dents, Grand Tupélo, of the French; Grossgezähnter Tupelobaum, of the Germans; Large Tupelo-tree, Wild Olive-tree, of the Anglo-Americans. This variety, for height and diameter, is the most remarkable tree of the genus. In favourable situations, it attains a height of seventy or eighty feet, with a diameter of eight or nine feet at the surface of the ground, fifteen or twenty inches at six or seven feet above, from which point its size continues uniform to an elevation of twenty-five or thirty feet. The leaves are commonly five or six inches long, and two or three inches broad; but on young and thriving plants they are double of these dimensions. 'They are of an oval shape, and garnished with two or three large teeth, which are irregularly placed, and generally only on one side of the leaf, as denoted 
in the adjoining figure. When the leaves unfold in spring, they are downy; but as they expand, they become smooth on both sides. 'The flowers, which appear in April or May, are numerous, though single, and are succeeded by fruit of considerable size, and of a deep-blue colour, of which the stone is depressed, and very distinctly striated. The wood is extremely white and soft, when unseasoned, but light and hard when dry; and, as in the arrangement of its fibres, it resembles the other trees of the same genus, it is employed for making bowls and trays. The roots are also tender and light, and are used by fishermen to buoy up their nets, instead of cork. This variety is described in Miller's "Dictionary," as the Virginian water tupelo-tree, rising, with a strong, upright trunk, to a height of eighty or one hundred feet, and dividing into many branches towards the top. The drupes are represented as being nearly the size and shape of small olives, and, like that fruit, is preserved by the French inhabitants of the Mississippi, where this tree greatly abounds, and is there called the "Olive-tree." It grows chiefly in the southern parts of the United States; and Michaux observes that it is always found in company with the long-leaved pine, (Pinus palustris,) and the cypress (Taxodium distichum.) In South Carolina and Georgia, it is constantly found growing with the over-cup oak, (Quercus lyrata,) the water locust, (Gleditschia monosperma,) the cotton-woods, (Populus canadensis,) the Carolinian poplar, (Populus angulata,) and the water bitter-nut hickory (Carya aquatica); intermixed with which it composes the dark impenetrable forests that cover the miry swamps on the borders of the rivers, to the distance of one or two hundred miles from the ocean. The presence of these trees is considered as an infallible proof of the depth and fertility of the soil, and, consequently, of its fitness for the culture of the vine.*

Geography, \&.c. The Nyssa candicans makes its first appearance, according to Michaux, on the river Ogechee, near the road from Savannah to Sudbury, and, in proceeding southward, it is seen in every favourable situation. This appears to be the species which is said to be described by Marshall, from Bartram's catalogue, " as a tree of great singularity and beauty, rising to the height of thirty feet: the fruit of which is of a deep scarlet colour, and of the size of a loanascene plum. It has an agreeable acid taste, whence it is called the lime-tree." Bartram calls it Nyssa coccinea, and says that there is no tree which exhibits a more desirable appearance than this, in autumn, when the fruit is ripe, and the tree is partly divested of its leaves; for then, "the remainder looks as red as scarlet, and the fruit is of that colour also." "The most northern habitation of this tree yet known," he adds, "is on the Great Ogechee, where it is called the Ogechee lime, from its acid fruit being about the size of limes, and being sometimes used in their stead."

Uses, \&॰c. The wood of this tree is soft, and unfit for any particular use in the arts. Its fruit is sold in the Savannah market, under the name of "Ogechee Limes," for the purpose of preserving in sugar, which, when properly prepared, is said to possess a most delicate and delicious flavour. 


\title{
Genus SHEPHERDIA, Nutt.
}

\author{
Elæagneæ. \\ Syst. Nat.
}

Diœela Uctandria.
Syst. Lin.

Synonymes.

Shepherdia, Hippophae,

OF Authors.

Derivations. The genus Shepherdia was named by Nuttall, in honour of the late Mr. William Shepherd, curator of the Liv. erpool botanic garden, a scientific horticulturist, to whose exertions that institution is greatly indebted for its success.

Generic Characters. Flowers diœcious. Male calyx 4-cleft, much larger than that of the female. Corolla, none. Stamina 8, alternating with a torus of 8 glands. Female flower with a small, 4-cleft, superior, campanulate calyx, and 8 glands. Style 1; stigma oblique, sub-capitate. Berry juicy, 1-seeded, globose, invested with the fleshy calyx.-Nuttall, Sylva.

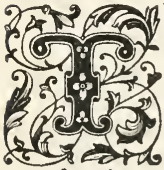

HE trees of this genus, as characterised by Mr. Nuttall, are small, spinescent or unarmed, with the general aspect of Elæagnus. The leaves are entire, opposite, clothed with silvery and ferruginous scales; the berries pulpy, diaphanous, of a scarlet colour, and subacid taste. There are two species indigenous to North America, the Shepherdia argentea, hereafter considered, and the Shepherdia canadensis, a thornless shrub, growing to the height of six or eight feet, bearing brilliant scarlet berries, of a sweetish, though unpleasant taste, and principally abounding throughout the British possessions, from Newfoundland to the northwest coast of America.

To the same natural order belong the oleaster, or wild olive-tree, (Elæagnus hortensis, ) and the sea buckthorn, (Hippophae rhamnöides,) both of which are common throughout Europe, and a considerable portion of Asia. The former, called in the south of Europe the "Tree of Paradise," is remarkable for the silvery whiteness of its foliage, and the fragrance of its blossoms, which are produced in great abundance, in the month of May, perfuming the air for a considerable distance around; and hence, is rendered a most desirable tree for a lawn or shrubbery. When cultivated in a good soil, it sometimes attains the height of thirty feet, with a head nearly as wide as it is high. The sea buckthorn, in Europe, as it throws up suckers freely from the roots, and endures the sea-breeze, is sometimes formed into hedges, and woody scenery, in marine situations, where but few other trees or shrubs will grow. Its berries are much eaten by the Tartars, who make a jelly or preserve of them; and the fishermen of the Gulf of Bothnia, prepare a rob, or jam from them, which imparts a grateful flavour to fresh fish; but in some parts of France and Switzerland, they are considered as poisonous. Rousseau, in his "Rêverie du Promeneur Solitaire," relates a curious story, of his having made an excursion in the neighbourhood of Grenoble, with a local botanist, who, though he saw him eating the fruit, which he believed to be poisonous, was so polite, or regarded Rousseau with so much respect, that he dared not presume to warn him of his danger.
\end{abstract}


Variety. S. A. FRuctu Luteo. Yellow-fruiled Silvery-leaved Shepherdia, said to be found in the Rocky Mountains by Mr. Wyeth.

Geography and Hislory. The Shepherdia argentea, in its native state, is wholly confined to the northerly and western regions of North America. Dr. Richardson observed it on the banks of the Saskatchewan, in latitude fifty-four degrees; Major Long's party saw it growing near Rainy Lake, in about latitude forty-nine degrees; and Mr. Nuttall found it on the borders of Ia Platte, on the banks of the Missouri, which he considered as its southernmost limit.

This species was first propagated east of the Rocky Mountains, in about the year 1826, by Messrs. Winships, of Brighton, near Boston, in Massaçusetts, by a few seeds sent them from the banks of the Missouri, by Colonel Snelling. From this source, probably, originated most, if not all, the cultivated plants at present existing, both in Europe and in the United States. One of the original trees is now growing in their nursery, which has attained a height of nearly twenty feet, and is still vigorous, and increasing in size. 'These gentlemen have continued to cultivate this plant for the purpose of forming hedges, and rows of them may be seen at this time, on many of the seats in the vicinity of Boston, and in many other places in the northern states, where it thrives well.

This tree was first introduced into Britain, in 1815, by Mr. Thomas Nuttall, and kept in the green-house of the Liverpool botanic garden; but, for the want of proper management, it soon after died. It has since been re-introduced, and fine specimens of it are to be met with in the London Horticultural Society's garden, in the Twickenham botanic garden, and in numerous other European gardens and collections.

Soil, Propagation, $\&^{\circ} c$. The Shepherdia argentea is perfectly hardy in every part of Europe and of America, south of the fifty-fourth parallel of north latitude; and it will grow in any soil where our common orchard fruits will thrive. It may be propagated from seeds, by cuttings, or suckers; and when trained to a small tree, it is particularly well adapted for suburban gardens. When employed as a hedge-plant, and kept down by the shears, it becomes close and compact, and has the advantage of being thorny, green, or rather silvery, till late in autumn; and is not attacked by insects, nor is subject to any disease or blight. If cultivated for fruit, a male tree should be planted by the side of the female.

Properties and Uses. Independently of the use of the shepherdia for the purposes of ornament, its fruit makes an excellent jelly or preserve. Although small, it is juicy, but not watery, is of a pleasant, subacid taste, mixed with a sweetness, which renders it highly agreeable. Made into sweet jelly, in the manner of currants, these berries are thought to be preferable to that fruit by most persons who have tasted them.

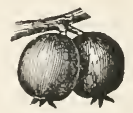




\section{Genus BUXUS, Tourn.}

Euphorbiaceæ.
Syst. Nat.
Monœcia Tetrandria.

Synonymes.

Buxus,

Buis,

Buchsbaum,

Bossolo, Bussolo,

Buxo,

Box,
OF AUthors.

France.

Germany.

ItaLY.

Portugal.

Britain, Spain, and Anglo-A uierica.

Derivations. The word Buxus and its derivatives, come from the Greek puknos, close or firm; in reference to the harlness and closeness of the wood of the box-tree.

Generic Characters. Flowers in axillary groups; unisexual in effect, but the male flowers have a rudi ment of a pistil ; those of both sexes borne on one plant. Calyx of male flowers with 4 minute leaves Stamens 4, inserted under the rudiment of a pistil. Female flowers singly, at the tip of groups of male ones. Calyx as in the male. Ovary sessile, roundish, of 3 cells, and 2 ovules in each cell. Styles 3 . Stigmas 3. Fruit a regma, leathery, beaked with the styles; consisting of 3 incomplete cells, that open down the centre, and divide the style, and of 3 valves that bear the incomplete dissepiments in their centres. Seeds 2 in a cell, pendulous, both enclosed in the endocarpial lining of the cell, which, after the seed is ripe, disparts elastically, to admit of, and conduce to, their dispersion.-Nees Von Esєnbeck, Genera.

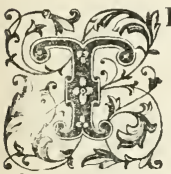

HE genus Buxus embraces low evergreen trees or shrubs, with shining coriaceous leaves, and greenish-yellow flowers; natives of Europe, and the temperate parts of Asia; of easy culture in any soil that is tolerably dry; and propagated freely from cuttings, or hy seeds. There are two species indigenous to Europe, namely, Buxus sempervirens, and balearica, the latter of which is a native of the Balearic Islands, where, according to the "Nouveau Du Hamel," it sometimes grows to the height of eighty feet. It is also found in great abundance on all rocky surfaces both of Europe and Asiatic Turkey. It forms a very handsome tree, with a straight, smooth trunk. Its leaves, which are three times as large as those of the Buxus sempervirens, when fully exposed to the air, are of a much paler green than that species; but when they are grown in the shade, they are of an intensely deep-green. The wood, which is of a brighter yellow colour than that of the common box, is imported into Europe and America, from Constantinople, for the use of wood-engravers; but its grain is coarser, and less compact, and consequently of less value. It has been asserted that the honey of Corsica is rendered poisonous from the bees feeding on the flowers of this tree.

To the same natural order belongs the celebrated tallow-tree, (Nillingia sebifera,) a native of China, and introduced into Carolina, in 17\%:, together with the upland rice, by Mr. John Bradley Blake, of Canton. 'T'he seeds, which were planted by Dr. Alexander Garden, of Charleston, flourished, and from that source were obtained all the trees of this description now growing in the southern states of the union. An oil may be expressed from the kernels of the fruit, which hardens by cold, to the consistence of common tallow, and by boiling, becomes as hard as bees'-wax. 


\title{
Buxus sempervirens.
}

\section{THE EVERGREEN BOX-i REE.}

\author{
Synor.yines.

\begin{tabular}{|c|c|}
\hline Buxus sempervirens, & $\begin{array}{l}\text { Linnsus, Species Plantarum. } \\
\text { Smith, English Flora. }\end{array}$ \\
\hline $\begin{array}{l}\text { Buis toujours vert, Buis commun, Bois } \\
\text { bénit, Ozanne, }\end{array}$ & France. \\
\hline $\begin{array}{l}\text { Buchsbaum, Immergrüner Buchsbaum, } \\
\text { Bussolo verde, Busso, Bosso, } \\
\text { Box-tree, }\end{array}$ & $\begin{array}{l}\text { Germany. } \\
\text { Italy. } \\
\text { Britain and Anglo-America. }\end{array}$ \\
\hline
\end{tabular}

Derivation. The specific name is derived from the Latin semper, continually, and virens, flourishing; in reference to the persistency of the leaves of this tree.

Engravings. Smith, English Flora, pl. 1341 ; Loudon, Arboretum Britannicum, iii., fig. 1215; and the figures below.

Specific Characters. Disk of leaf ovate, convex; footstalk slightly downy at the edges. Anthers ovatearrow-shaped.-Smith, Eng. Flora.

\section{Description.}

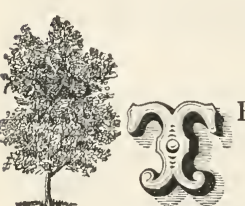

"Nor box, nor limes, without their use are made,
Smooth-grained, and proper for the turner's trade;
Which curious hands may carve, and steel with ease invade."

HE Buxus sempervirens is a well-known hardy evergreen tree or shrub, which, in its natural habitat, seldom exceeds a height of twelve or fifteen feet, with a trunk from six to eight inches in diameter; but, in a state of cultivation, it sometimes attains double of these dimensions. The thickness of the trunk is very considerable in proportion to its height; and the bark on young wood is of a yellowish hue, but on old trees, it is rough and gray. The leaves, which are opposite, oval, and

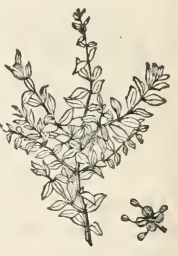
almost sessile, are of a coriaceous texture, and of a shining, yellowish-green, when they grow in a situation fully exposed to the light; but of a fine, deep, glossy-green, when shaded by other trees. The flowers, which put forth in April or May, are of a greenish-yellow colour, and are disposed in little tufts in the axils of the leaves. The capsules, which contain two small, pendulous seeds, burst their cells, at maturity, with an elastic force, and thereby conduce to their dispersion.

Varieties. The varieties recognized in this species are as follows:-

1. B. S. ARborescens, Loudon. Arborescent Evergreen Box; Buis arborescent, of the French; Baumartiger Buchsbaum, of the Germans. This is the most common form of the species, being arborescent, with ovate leaves.

2. B. s. angustifolia, Loudon. Narrow-leaved Evergreen Box; Buis à feuilles étroiles, of the French; Schmalbläıriger Buchsbaum, of the Germans; arborescent, with lanceolate leaves.

3. B. s. myrtifolia, Loudon. Myrlle-leaved Evergreen Box; Buis à feuilles de myrte, of the French; Myrte-Buchsbaum, of the Germans; dwarfy, with small, oblong, narrowish leaves. A pretty little plant, generally quite low, but, under favourable circumstances, grows to a considerable size.

4. B. s. suffruticosa, Loudon. Suffruticous Evergreen Box; Buis suffru- 
tescent, Buis nain, Petit buis, Buis à bordures, Buis d'Artois, Buis de Ilollumle. of the French; Staudenartiger Buchsbaum, Zwerger Buchsbaum, of the Germans; dwarfy, with small obovate leaves. 'This is the kind usually cultivaterl for edging beds in gardens.

5. B. s. argentea, Loudon. Silver-leaved Evergreen Box; Buis argenté, of the French; Silber-Buchsbaum, of the Germans; arborescent, with ovate leaves, variegated with a silvery colour.

6. B. s. AUREa, Loudon. Golden-coloured-leaved Evergreen Box; Buis à feuilles dorées, of the French; Goldgelber Buchsbaum, of the Giermans; arborescent, with ovate leaves, variegated with a golden colour.

7. B. s. marginata, Loudon. Golden-edged-leaved Evergreen Box; Buis marginé, of the French; Eingefasster Buchsbaum, of the Ciermans; arborescent, having ovate leaves, with a margin of a golden colour.

8. B. s. Variegata, Loudon. Variegated-leaved Evergrcen Box; Buis à fenilles variées, of the French; arborescent, with lanceolate variegated leaves.

Geography and History. The Buxus sempervirens is found wild on monntains, and spreading as undergrowth among other trees, throughout birrope and Asia, between the thirty-seventh and fifty-second degrees of north latitude; bnt never forming forests entirely of itself. It grows plentifully upon Box Hill, near Dorking, in Surry, mixed with a few juniper bushes not higher than itself, but not among deciduous trees, and shaded by them, as it does in its native habitat, in France, and in other parts of the continent. The box-tree is found abundantly in Turkey, and on the shores of the Black Sea; but a great portion of the boxwood of commerce, sold in the European and American markets as "Turkey box," is grown in Circassia and Georgia, whence it is bronght to Odessa for shipment. It is also found in various parts of Persia, China, Cochin-China, and, from some statements, in Japan. This tree, which is of great longevity, and subject to but few diseases, is rarely attacked by insects, and is so extremely hardy, that there are but few other non-resiniferous evergreens that will stand in the open air, without protection, during winter, in the gardens of Paris, Berlin, Vienna, and of New York.

The box appears to have been first mentioned by Theophrastıs, who ranks its wood with that of ebony, on account of the closeness of its grain. Both Virgil and Ovid allude to its use for musical instrmments, and employ the word $6 o x$, as if synonymous with that of fute. Pliny describes the wood as heing as hard to burn as iron, producing no flame, and as being totally unfit for charcoal. He distinguishes three kinds, which he calls the "larger, the smaller, and the Italian box;" and speaks of the use of the tree for topiary gardens, and of the wood for musical instruments. Vitruvius also recommends the box for topiary-work, and uses the word topiarius to express the art of the gardener. This tree appears to have been much employed in verdant sculpture, and close-clipped hedges, in the gardens of Roman villas in the Augustan age. Pliny describes his 'l'usculau villa as having a lawn adorned with figures of animals cut out in box-trees, answering alternately to one another. This lawn was again surromelerd by a walk enclosed with evergreen shrubs, sheared into a variety of forms. lieyond this was a place of exercise, of a circular form, ornamented in the midelle with boxtrees, sheared, as before, into numerous figures of various forms: and the whole surrounded by a sloping bank, covered with box, rising in steps to the top. In another part of the grounds of the same villa, the box is mentioned as being cut into a variety of shapes and letters; some expressing the name of the master, and others that of the artificer, \&c. The same practice is followed in sereral lioman gardens at the present day; and, in that of the latican, the name of the Pepe. the date of his election, Ec., may be read from the windows of the palace, in letters of box. In more modern times, in Britain, it is mentionerl by 'l'urner 
Gerard, Parkinson, and other writers on gardening and rural affairs; and previously to the XVIIIth century, it was in great repute for ger metric gardens, from the facility with which it could be made to assume any shape that the caprice or ingenuity of the gardener might devise. It was also extensively employed for that purpose both as a tree and as a shrub throughout Europe, from the earliest times. As a tree, it tormed, when clipped into shape, hedges, arcades, arbours, and, above all, the figures of animals. As a shrub, it was used to border beds and walks, and for the execution of numerous curious devices, such as letters, coats of arms, \&c., on the ground; but of all the uses to which the dwarf box was applied, the most important, in the ancient style of gardening, was that of forming parterres of embroidery; it being the only evergreen shrub susceptible of forming the delicate lines which that kind of work required, and of being kept within the narrow limits of its lines for a number of years. In those days, when the flowers used in ornamenting gardens were few, the great art of the gardener was to distinguish his parterres by beautiful and curious artifical forms of evergreen plants. All the dark parts of the figures, when formed of box, in no part were allowed to grow higher than three inches from the ground, and the finer lines not to exceed two inches in width. The spaces between the lines or figures, in the more common designs, were covered with sand all of one colour; but in the more choice parterres, different coloured sands, earths, shells, powdered glass, and other articles were used, so as to produce red, white, and black grounds, on which the green of the box appeared to advantage, at all seasons of the year. The beauty of these parterres was most conspicuous when they were seen as a whole from the windows of the house, or from a surrounding terrace-walk. Sometimes, however, they were placed on a sloping bank, to be seen from below. The embroidered style of parterre is still occasionally to be met with adjoining very old residences, in France and Italy, and even in a few places in England; and, as affording variety, it is at least as worthy of revival as the architectural style of building of the age in which it most extensively prevailed. About the middle of the XVIIth century, the taste for verdant sculpture was at its height in England; and, about the beginning of the XVIIIth century, it afforded a subject of raillery for the wits of the day, soon afterwards beginning to decline. The following lines, by West, will give a good idea of a topiary garden :-

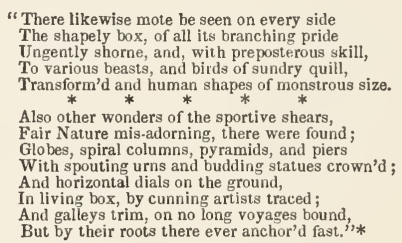

The art of engraving on wood was invented before that of printing with movable types; and it is supposed to have been first practised in the early part of the $X V$ th century. The first objects to which it was applied were very different in their character, namely, books of devotion and playing cards. The mere ontlines of the figures were rudely cut in the wood with knives, in the direction of the grain, and the impressions were taken off by friction, without the aid of a press. The earliest specimen of wood-engraving now extant, in England, is said to be in the collection of the Earl of Spencer, and represents St. Christopher carrying the infant Saviour; bearing the date of 1423 . A very curious work was published

* See Loudon's Arboretum, iiı., pp. 1334 et seq. 
between 1430 and 1450, entitled "Biblia Pauperum," the Bible of the poor. This work consisted of about forty pages printed from wood-cuts, illustrated by texts of scripture, which is supposed to have given the first idea of printing with the movable types, soon after invented by Guttemburg. In 11S0, Wohlgenuth, an engraver on wood, at Nuremberg, is said to have been the first who attempted to introduce shade into wood-engravings. His pupil, Albert Duer, carried the art to a very high degree of perfection; and in his time, the wood-cutters, (formschneider.) of Germany, became so numerous, that they were incorporated into a body distinct from that of the letter-printers or writers (briefmaler.) Holbein succeeded Duer; but soon afterwards, the art of engraving on copper having been discovered, wood-engraving was comparatively neglected, and fell into disuse till the time of Bewick, when a taste for the art was revived. 'The first engravers on wood, and up to the time of Bewick, or nearly so, were accustomed to have the trunks of the trees on which they were to engrave, sawn up into planks, and to cut out the figures with a knife or other tools, on the side of the grain; but since his time, or before, the practice of cutting the trunk in to cross sections, about an inch in thickness, was adopted; and the engra vings were cut out on the wood across the grain. The advantages of this mode over the other are, that much finer lines can be produced, and the engraved block, from which a greater number of impressions can be taken, will be far more durable. 'The followers of Bewick produced some beautiful engravings; but from the mode of printing from them, though they were mixed with the type, they were almost as expensive as if they liad been worked from separate plates. By the more modern practice, however, wood-cuts are printed from, with the same facility as from movable types; and as specimens of unsurpassable beauty, extraordinary force, and delicacy of execution, the reader is referred to several illustrated works recently published in London, by Van Voorst, and others, among which we would particularize the "History of British Forest Trees," by Selby; "Sporting Scenes and Country Characters," by Martingale; and the late volumes of the "Penny Magazine."*

The largest box-trees in Britain, probably, are two at Fyford House, near Stow, in the Wold, in Gloucestershire, both of which exceed thirty-two fect in height, with trunks rather more than two feet in circumference, and a diamcte: of space covered by the branches, of about twenty feet.

The largest box hedge in England, is at Pentworth, which is fifteen fect high, forty yards long, twelve feet broad at the base, and is supposed to be more than two centuries old.

In France, in the Jardin des Plantes, at Paris, there is a box-trce, upwards of one hundred years planted, which has attained a height of more than thirty feet.

The introduction of this species into the North American colonies probably dates back to the early periods of their settlements. One of the oldest specimens known to exist in this country, is growing on the estate of Mr. I cemuel W. Wells. at Yonkers, near New York, which, it is said, was planted about two hundred years ago, by Frederick Philipse, who formerly lived on the place of its present proprietor.

In the Bartram botanic garden, at Kingsessing, near Philadelplia, there is a Buxus s. variegata, which has attained the height of twenty-five feet, with a trunk two feet and a half in circumference.

Poetical Allusions, $\mathcal{S}^{\circ} \mathrm{c}$. The box is sometimes substituted for the holly in decorating the churches at Christmas; and in a note to Wordsworth's poems, we are informed that, in several parts of the north of Fingland, when a funcral talies place, a basinful of sprigs of box is placed at the door of the house of the deceased, and that each attendant takes one of these sprigs, and throws it into the

* See Loudon's Arboretum, iii., pp. 1335 et 1336. 
grave. The common box is the badge of the Highland clan M'Intosh; and the variegated kind, of the clan M'Pherson.

Propagation and Culture. The box may be propagated from seeds, by cuttings, and layers. When allowed to grow freely, this tree produces an abundance of seeds; but where it is closely clipped in, they seldom arrive at maturity. They should be gathered as soon as the capsules appear ready to open, and should be sown immediately in light, rich earth, consisting chiefly of vegetable mould, which is well drained. Autumn is the proper time for planting cuttings, which may be from four to six inches in length. They should be set in a sandy soil, and a shaded situation, and in a year after they will be fit to transplant into nursery lines. Layers may be made either in the spring or autumn, both of the young and the old wood. The dwarf box used for edgings is best propagated in the spring, by being taken up, divided, and replanted. 'They may be clipped at almost any season except in mid-winter; but June is considered as the most appropriate time for this operation, as well as that of hedges or other ornaments, when the plants have nearly completed their year's growth; because they will afterwards make shoots of half of an inch to an inch in length, or, at all events, put forth a few leaves, and thus, in a few weeks, will conceal all appearance of the use of the shears. When this practice is followed, it is necessary to go over the edgings or hedges in July, in order to cut neatly off, with the knife, any shoots that may have been protruded too far, taking care not to cut the leaves. Box edgings, when kept low, if they are wanted to endure many years, require occasionally to be cut in, almost to the ground; and this operation should only be performed on one side of the edging in one year, and not on the other side till two years after. When treated in this way, both edgings and hedges will, on good, loamy soil, endure for a long tine; whereas, if they be continually clipped on the surface only, a network of shoots is formed there, which, by excluding the air from the stem within, occasions decay, and the edging or hedge becomes unsightly and naked below. The form of the cross section of a box edging or hedge, should always be that of a truncated triangle, with the broadest end next to the ground. In the case of edgings to walks, or to flower-beds, their breadth at the ground may be three inches, their height four inches, and their width at the top two inches; or one half of these dimensions may be adopted. In every case, both of edgings and hedges, the base ought always to be broader than the summit, in order that the rain may fall on the sides, and the light of the sun strike on them with more force. In clipping the box into artificial forms, it is usual to enclose the tree in a slight frame of wirework of the intended form; and, for the sake of durability, the wire should be of copper, and painted green, which would also render it less conspicuous.

Properties and Uses. The wood of the box is remarkably heavy, weighing, when newly cut, nearly eighty pounds and a half to a cubic foot, and when perfectly dry, sixty-eight and three-fourths pounds; being the only European wood that will sink, in that state, in water. It is of a yellowish colour, of a very hard, compact grain, and is susceptible of a fine polish; and, when well seasoned, it expands and contracts, by heat and cold, moisture and dryness, less than any other kind of wood. Hence, it was formerly much used in England, in cabinetmaking and inlaying, as it still is in France; and also, in most countries in Europe and America, for musical and mathematical instruments, combs, and various articles of turnery. But one of the principal uses to which this wood is applied, is, for wood-engraving; and for this purpose, it forms an important article of commerce.

In France, the box-wood used by cabinet-makers and turners, is chiefly that of the root. The town of St. Clande, near which there is one of the largest boxgroves in Europe, is almost entirely inhabited by turners, who make snuff-boxes 
rosary-beads, forks, spoons, buttons, and numerous other articles. The wood of some roots is more beautifully marbled, or veined, than that of others; and the articles manufactured from them, as well as from the warty excrescences, vary in price accordingly. Articles formed of the trunk, are easily distinguished from those of the root, when the wood is cut transversely, by that of the trmin alway. displaying a beautiful and very regular star, which is never the case with that of the root. Box-wood is very apt to split in drying; and, to prevent this, the French turners put the wood, designed for their finest works, into a dark cellar, as soon as it is cut, where they keep it from three to five years, according to circumstances. At the expiration of the given time, they cut off the sap-wood with a hatchet, and place the heart-wood again in the cellar till it is wanted for the lathe. For the most delicate articles, the wood is soaked for twenty-four hours, in very clear, fresh water, and then boiled for some time. When taken out of the boiling water, it is wiped quite dry, and then buried, till wanted for use, in sand, or bran, so as to completely exclude it from the light and air. Articles made of the wood thus prepared, resemble, in appearance, what is called, in Ingland, 'Tunbridge ware. Olivier de Serres, in the "Théâtre d'A griculture," recommends the branches and leaves of the box, as by far the best manure for the grape: not only because it is very common in the south of France, but because there is no plant, that by its decomposition, which affords a greater quantity of vegetable mould. The spray of the box, though it burns very slowly, is much esteemed, also, in France, as fuel for lime-kilus, brick-kilns, ovens, Nc., where a great and lasting heat is required.

The other uses of the box, in former times, were various; but many of them, doubtless, are forgotten. The bark and leaves are bitter, and have a disagreeable smell; and a decoction of them, when taken in large doses, is said to be purgative; and, in small doses, sudorific. An empyreumatic oil is extracted from them, which is said to cure the toothache, and some other disorders. A tincture was once made from them, which was a celebrated specific in Germany for intermittent fevers; but, the secret having been purchased, and made public by Joseph I., the medicine fell into disuse. The box is said to enter into the composition of various medicated oils, for strengthening and increasing the grow th of th hair; and Parkinson says that "the leaves and saw-dust, boiled in lye, will change the hair to an auburn colour." It is stated in Dodsley's "London Amnual Register," that, in the year 1762, "A young woman of Grunburg, in Lower silesia, had a malignant dysentery, and lost her hair. She washed her head, and accidentally her face and neck, with a decoction of box-wood, and her whole face and neck were soon covered with red hairs." Pliny affirms that no animal will eat the seeds of the box; and it is said that its leaves are particularly poisonous to camels. It is also asserted by many authors that box-trees are never cropped by cattle.

In modern gardening, the Buxus sempervirens forms a most valuable evergreen shrub or low tree. It is more particularly eligible as an undergrowth in ornamental plantations; where, partially shaded by cther trees, its leaves assume a deeper green, and shine more conspicuously. Next to the holly, it has the most beautiful appearance in winter, more especially when the ground is covered with snow. The variegated sorts are admissible as objects of curiosity; but, as they are apt to lose their variegation when planted in the shade, and as in the full light, their green is frequently of a sickly, yellowish luue, they certainly cannot be recommended as ormamental.

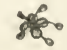




\section{Genus MORUS, Tourn.}

\begin{abstract}
Urticaceæ.
Syst. Nat.
\end{abstract}

Monœeia Tetrandria.
Syst. Lin.
Morus,

Mûrier,

Maulbeerbaum,

Moro,

Moral,

Amoréira,

Mulberry-tree,

\section{Synonymes.}

Of Authors.

France.

Germany.

IrALY.

Spain.

Portugal.

Britain and Anglo-America.

Derivations. Several derivations have been given of the word Morus. Some suppose it to be taken from the Greek morea, or moron, signifying a mulberry or blackberry; but others derive it from the Greek mauros, dark, or more remotely from th Celtic mor, which signifies black; from the dark colour of the fruit of the black mulberry, supposed originally to have grown in Persia.

Generic Characters. Flowers unisexual; those of the two sexes, in most species, upon the same plant. Male flowers disposed in a drooping, peduncled, axillary spike. Calyx of 4 equal sepals, imbricate in zstivation, expanded in flowering. Stamens 4, with a rudiment of a pistil. Female flowers in ovate, erect spikes. Calyx of 4 leaves, in opposite pairs, the outer pair the larger, all upright and persistent, becoming pulpy and juicy. Ovary of 2 cells, one including a pendulous ovule, the other devoid of any. Stigmas 2, long. In the state of maturity, each ovary is a fleshy and juicy utricle, and is covered by the fleshy and juicy calyx.-Nees Von Esenbeck, Genera.

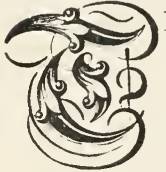

HE genus Morus embraces deciduous trees, natives of Europe, Asia, and of America, remarkable for their large leaves, which are mostly lobed, and which, in a state of cultivation, are liable to a great variation in point of magnitude, form, and texture. They are all easily propagated from seeds, by cuttings, and layers, and by truncheons. All the species will serve to nourish the silkworm; but the white mulberry, (Morus alba,) and its varieties, are considered much the best. In warm climates, such as Persia, the leaves of the black mulberry, (Morus nigra,) are sufficiently succulent for the purpose; but in colder countries they do not answer equally well. The leaves of the red mulberry, (Morus rubra,) are thick, rough, and hairy, even while they are young, and are also improper for the food of silkworms, which feed with advantage only on foliage that is thin, tender, and succulent. Various attempts have been made to discover some substitute for the natural food of these insects, which may be readily procured at all seasons, and in sufficient abundance to render the silk culturist independent of the chances that attend the growth of the mulberry-tree. It is probable that the leaves of most plants which contain a milky juice, will, if they are appropriate in point of texture, afford nourishment to the silkworm, from the common property of their juice containing caoutchonc; but, notwithstanding the partial success so frequently proclaimed, as the substitution of the tender leaves of the fig, the maclura, the slippery-elm, and the Norway and 'Tartarian maples, among trees; and those of the lettuce, endive, beet, spinach, nettle, viper-grass, (Scorzonera hispanica,) \&c., anıong herbaceous plants, all practical cultivators of silk are convinced that it would be unprofitable to feed their worms on anything save their natural nourishment. None of these substitutes are of any real use, unless we except the maclura, the viper-grass, and the lettuce. 


\title{
Morus nigra, THE BLACK-FRUITED MULBERRY-TREE.
}

Synonymes.

\author{
Morus nigra, \\ Mûrier noir, \\ Schwarzer Maulbeerbaum, \\ Moro nero, More nere, \\ Moral negro, \\ Black Mulberry-tree,
}

\author{
(Linnedes, Species Plantarum. \\ Poiret, Encyclopédie MIéthodique. \\ Loudon, Arboretum Britannicum. \\ France. \\ Germany \\ ITALY. \\ Spain. \\ Britain and Anglo-Anerica.
}

Derivation. The specific name nigra is derived from the Latin niger, black; referring to the colour of the fruit of thia tree. Engravings. Nouveau Du Hamel, iv., pl. 22; Loudon, Arboretum Britannicum, iii., fig. 1222, and vii., pl. 223 et 241 ; and
the figures below.

Specific Characters. Sexes monœcious, sometimes diœcious. Leaves heart-shaped, bluntish, or slightly lobed, with about 5 lobes; toothed with unequal teeth, rough.-Willdenon; Linnæi Spec. Plant.

\section{Description.}

\author{
"But cautiously the Mulberry did move, \\ And first the temper of the skies would prove; \\ What sign the sun was in, and if she might \\ Give credit yet to winter's seeming flight; \\ She dares not venture on his first retreat, \\ Nor trust her fruit and leaves to doubtful heat \\ Her ready sap within her bark confines, \\ Till she of settled warmth has certain signs ! \\ Then, making rich amends for the delay, \\ With sudden haste she dons her green array; \\ In two short mont hs her purple fruit appears, \\ And of two lovers slain the tincture wears. \\ Her fruit is rich, but she doth leaves produce \\ Of far surpassing worth, and noble use."
}

$$
\text { Cowley. }
$$

arow arms near the ground, and forming an extremely large head, with numerous branches. 'The bark is thick and rough, and in this respect alone, this species may be readily distinguished from the Morus alba,

HE Morus nigra is generally a low tree, seldom exceeding twenty or thirty feet in height, the bark of which is light. The leaves of the black

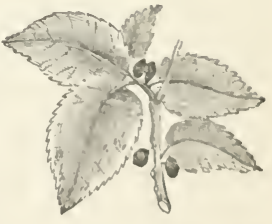
mulberry, which are very rough, are broad, heart-shaped, unequally serrated, and are among the last to appear in the spring. This species is sometimes perfectly dœcious, and very frequently partially so; the stamens being in greater perfection in most flowers of one tree, and the pistils in those of another; but, as in the case of most other monocious trees, it often prodnces male blossoms for many years after it is planted, and yet afterwards becomes fruitful. 'I'he flowers, which put forth in May or June, are succeeded by large, dark-purple fruit, very wholesome and agreeable to the palate.

Variety. M. n. Laciniata, London. Cut-leuved. or Jagged-leaved Bluck Mulberry, with leaves jagged, rather than cut.

Geography and Mistory. The Morus nigra is generally supposed to be a native of Persia, where there are still masses of it fomd in a seemingly wild state; and, although the date of its introduction into Europe is mnknown, it is occusion- 
ally to be met with in Italy, apparently wild. This tree, however, is so frequently confounded with the white mulberry, by the earlier writers, as to render it next to an impossibility to ascertain the countries of which it is truly indigenous. It has been known from the earliest records of antiquity, being mentioned in "Holy Writ," in the second book of Samuel, and in the Psalms. Ovid evidently points out the black mulberry as the one introduced in the story of Pyramus and Thisbe; and Pliny seems to allude to it, where he observes that there is no other tree that has been so much neglected by the wit of man, either in grafting or giving it names; "an observation," as Mr. Loudon remarks, "which holds good to the present day respecting the black mulberry, as it has only one trifling variety, or rather variation, and no synonyme, whereas, there are numerous varieties of the Morus alba." Pliny adds, "Of all the cultivated trees, the mulberry is the last that buds, which it never does until the cold weather is past; and it is therefore called the wisest of trees. But when it begins to put forth buds, it dispatches the bussiness in one night, and that with so much force, that their breaking forth may be evidently heard." On Mount Aitna, the black mulberry is grown at an elevation of two thousand five hundred feet, for the food of the silkworm, to the exclusion of the Morus alba, probably on account of the tenderness of the latter tree in that elevated region.

The black mulberry, it is said, was introduced into Britain by the Romans; but at what period, there is no record which throws any light on the subject. It is mentioned in Turner's "Names of Herbes," published in 1548, when there were some trees planted at Syon, one, at least of which is still in existence. The tree is mentioned by 'Tusser, who wrote in 1.557 , also by Gerard, who describes both the black and the white mulberry as being cultivated in his time. The royal edict of James I., about the year 1605 , recommending the rearing of silkworms, and offering packets of mulberry seeds to all who would sow them, no doubt rendered the tree fashionable, as there is scarcely an old garden or gentleman's seat throughout England, that can be traced back to the XVIIth century, in which a mulberry-tree is not to be found. It is remarkable, however, that, though these trees were doubtless intended for the food of silkworms, they nearly all belong to the Morus nigra, as very few instances of old trees of the white mulberry exist, at the present time, in any part of that country. Shakspear's mulberry is referable to this period, as it was planted in 1609 , in his garden, at New Place, in Stratford.

One of the most remarkable trees of this species in Britain, is at Battersea, on the estate of the late Earl of Spencer. It is from thirty to forty feet in height, having fourteen trunks, averaging about one foot in girth at a foot above the ground, with a head fifty feet by seventy in diameter, and is supposed to be over three hundred years of age.

In Suffolk, at Finborough Hall, there is a black mulberry, which, in seventy years after planting, had attained the height of forty feet, with a trunk two feet in diameter, and an ambitus, or spread of branches of forty-t wo feet.

In France, at Nantes, in the nursery of M. De Nerrières, there is a specimen, which, in sixty years after planting, had attained the height of forty-nine feet, with a trunk two feet and a half in eircumference.

The introduction of the black mulberry into the North American colonies, as with most of our foreign trees bearing edible fruit, it is highly probable, dates back to the early periods of their settlements; but, as it produces only a moderately sized fruit, at best, and requires some attention to bring it to perfection, it has fallen into neglect. 'There are trees, however, of considerable size and age, to be met with, in all the middle and eastern states of the union, which are regarded as comparatively worthless, either for fruit or ornament.

Poetical, Legendary, and Mythological Allusions. The mulberry was dedi- 
cated by the Greeks to Minerva, probably because it was anciently considered as the eniblem of wisdom, from the slowness of its putting ont its leaves; and Jupiter, the Protector, in their language, was called after it, Morea. From Ovid we learn that the fruit of the mulberry derives its fine colour from the blood of those two unfortmnate lovers, Pyramus and Thisbe. He says, that it was formerly snow-white, but that, when Pyramus, in despair at the supposed death of his mistress, fell upon his own sword, it was under the shade of this tree. Ihisbe, shortly after, finding him dead, killed herself in the same way, and their blood mingling together, was absorbed by the roots and imparted its colour to the fruit.

\footnotetext{
"Dark in the rising tide the berries grew,

And, white no longer, took a sable hue;

But brighter crimson, springing from the root.

Shot through the black, and purpled o'er the fruit."
}

Cowley, in the fifth book of his poem on plants, has given a very plain and accurate description of the apparently cautious habits of this tree. He also alludes to the fable just named. The Norea, in the Levant, is said to have been so called, from a supposed resemblance of the shape of that peninsula to the leaf of the mulberry. The roots of this tree are so wonderfully tenacious of life, that an instance is recorded of their sending up shoots after having lain dormant in the ground for twenty-four years.

Soil, Situation, Propagation, $\& \cdot c$. The Morus nigra will grow in almost any soil or situation that is tolerably dry, and in any climate not much colder than most parts of Britain and the United States. It is very easily propagated by truncheons or pieces of the branches, eight or nine feet in length, and of any thickness, being planted half their depth in tolerably good soil; when they will bear fruit the following year. As it is extremely tenacious of life, every part of the root, trunk, boughs, and branches may be converted into plants by separation; the rootlets, and small shoots, or spray, being made into cuttings, the larger boughs into stakes, the arms into truncheons, and the trunk, stool, and roots, being cut into fragments, leaving a portion of the bark on each, and planting them after the Italian mode of propagating the olive-tree. The mulberry may also be increased from seeds, by layers, or by grafting and budding. This tree, from its slowness of putting out its leaves, being rarely injured by spring frosts, and its leaves being seldom or never devoured by any insect, except the silkworm, and never touched with mildew, very seldom fails to produce a good crop of fruit. 'This fruit, however, though excellent and exceedingly wholesome, does not keep, and is so far troublesome, that it is only good when it is quite ripe, and is beșt when it is suffered to fall from the tree itself. For this reason. mulberry-trees are generally planted on a lawn or grass-plot, to prevent the fruit that falls from being injured by the gravel or dirt. This practice, however, is objectionable, as no tree, perhaps, receives more benefit from the spade and the dung-hill than the mulberry, and it ought, therefore, to be frequently dug about the roots, and occasionally assisted with manure. The ground under the tree should be kept free from weeds throughout the summer, particularly when the fruit is ripening, as the reflected light and heat from the bare surface of the soil is thus increased. In a cool, moist climate, like that of Britain, the fruit is also very fine if the tree be trained as an espalier, with the reflection of the south side of a building or wall. As a standard tree, whether for ormament or fruit, the mulberry requires very little pruning or attention of any kind, other than that which is given above. As it increases in age, it increases in productiveness, and in full-grown trees the fruit is much larger and better flavoured than in those which are young.

Properties and Uses. The wood of the Morus nigra is less compact than even that of the white mulberry, and when perfectly dry, weighs only about forty 
pounds to a cubic foot. It is said to be durable, and has been employed in England for various purposes 'of carpentry, for hoops, bows, wheels, and even ribs for small vessels, instead of oak. In France, this wood is considered of but little value, except for fuel. In some parts of Spain, in Sicily, and in Persia, the leaves of this species are said to be preferred to those of the white mulberry for the food of silkworms. The leaves are also eaten by cattle, sheep, and goats. The roots have an acrid, bitter taste, and are considered as an excellent vermifuge, when taken, in a powder, in doses of half a drachın. The tree, in every part, contains a milky juice, which, being coagulated, is found to form a coarse kind of elastic gum.

The fruit of this tree is of an agreeable acid and aromatic flavour, and is eaten raw, as a dessert, or may be formed into an agreeable preserve; and Evelyn says that, mixed with the juice of cider apples, it makes a very strong and agreeable wine. Dr. Clarke observes, that he saw some Greeks, in the Crimea, employed in distilling brandy from mulberries; which he describes as "a weak, but palatable spirit, as clear as water." A wine is also made from it in France; but it requires to be drunk immediately, as it very soon becomes acid. The fruit, when ripe, is regarded as cooling and laxative, allaying thirst, and being grateful in cases of fever. When made into a syrup, it is considered excellent for a sore throat. Like the strawberry and raspberry, it is said to undergo the acetous fermentation in the stomach, and therefore may be safely eaten by persons afflicted with the rheumatism or gout. All kinds of poultry are excessively fond of this fruit. and devour it with aviditv, whenever within their reach.

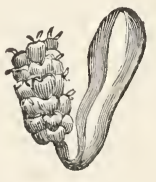




\section{Morus alba, \\ THE WHITE-FRUITED MULBERRY-TREE.}

\section{Synonymes.}

\author{
Norus alba, \\ Mûrier blanc, Mûrier du ver-a-soie, \\ Weisser Maulbeerbaum, \\ Gelso, Gelso moro, Moro bianco, Moro \\ gelso, \\ Morera \\ White Mulberry-tree,
}

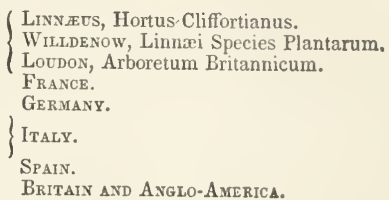

Derivation. The specific name alba is derived from the Latin albus, white; in reference to the colour of the fruit of tnıs species.

Engravings. Loudon, Arboretum Britannicum, iii., fig. 1223, and vii., pl. 225 et 226 ; and the figures below.

Specific Characters. Leaves with a deep scallop at the base, and either heart-shaped or ovate, undivided or lobed, serrated with unequal teeth, glossy, or, at least, smoothish; the projecting portions on the two sides of the basal sinus unequal.-Willdenow, Linnai Spec. Plant.

\section{Description.}

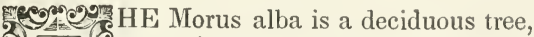
8.5 sometimes growing to a height of
thirty or forty feet, with a trunk eter. It is readily distinguished from the black mulberry, even in winter, by its more numerous, slender, uprightgrowing, and white-barked shoots. It is a tree of much more rapid growth than that species, and its leaves are not only less rough and more succulent, but they contain more of the glutinous, milky substance, resembling caoutchonc,

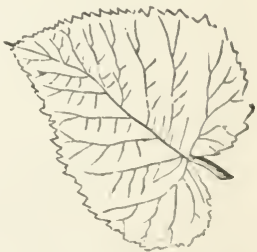
which gives tenacity to the silk produced by the worms that feed on then. They are generally cordate and entire, but sometimes lobed, and always deeply serrated. The flowers, which put forth in May, are generally succeeded by ari abundance of white fruit, but in some varieties, it is ash-coloured, purple, and even black.

Varieties. The Morus alba, like the apple, the pear, and the peach, when propagated from seeds, is liable to sport, and produce varieties differing, in many cases, more from one another than they do from other species. These variations are very numerous; but many of the sorts enumerated in catalogues, in diflerent countries, perhaps are only dissimilar in name. 'The following, however, are some of those most generally cultivated for their leaves, in Lurope and Anerica, as affording food for the silkworm :-

1. M. A. MACrophylda, Loudon. Large-leaved White-fruited Mulberry; Wurier à grandes feuilles, Mûrier d' Espagne, F'cuille d' Espugne, of the French; Cirossblattriger Maulbeerbaum, of the Germans. 'This variety produces strong and vigorous shoots, with large leaves, sometimes measuring eight inches long, and six inches broad, resembling in form those of the Morns nigra, but are smooth, glossy, and succulent. The fruit is white. If grown in rich soil, this sort, 
according to the "Nouveau Cours d"Agriculture," is apt to produce leaves which are so exceedingly succulent, that they cause the worms that feed on thein, to burst. It is a valuable variety for poor soils, particularly in calcareous, rocky situations. There is a sub-variety of this kind, cultivated in France, under the name of La grosse Reine, with very deep-green leaves, and black fruit, instead of white. The celebrated Alpine Mulberry, also, introduced into the United States a few years since, from the south side of the Alps, by Mr. Samuel Whitmarsh, of Massachusetts, is believed to be only a sub-variety of the Morus a. macrophylla. When planted on elevated land, even when exposed to cold, dry winds, or in a light, sandy soil, it produces a most healthy and nutritious food to the worms, which produce, when fed upon its leaves, the largest quantity of strong silk, of the purest and finest quality.

2. M. A. Rounana, Loudon. Roman White-fruited Mulberry; Mûrier romain, of the French. This variety bears a close resemblance to the M. a. macrophylla.

3. M. A. nervosa, Loudon. Thick-nerved-leaved White-fruited Mulberry ; Morus nervosa ("Bon Jardinier," of 1836.) The leaves of this variety are strongly marked with thick, white nerves on the under side. There is a sub-variety with larger leaves, called $M$. a. nervosa longifolia.

4. M. A. ITALica, London. Italian White-fruited Mulberry; Mûrier d'Italie, of the French; with lobed leaves. In 1825, and for a few years before and after, while attempts were making to re-introduce the culture of silk into England and Ireland, this variety was principally planted.

5. M. A. Rosea, Loudon. Rose-leaved White-fruited Mulberry or Small-leaved White Mulberry; Mûrier rose, Feuille rose, of the French. 'This tree is classified by M. Castelet, in his "Traité sur les Mûriers blancs," among the wild varieties. The fruit is small, white, and insipid; and the leaves resemble the leaflets of a rose-tree, but are larger. This kind is said to produce remarkably strong silk.

6. M. a. Columbassa, Loudon. Mûrier columba, of the French, having small, delicate leaves, and flexible branches. It is considered the most tender of all the kinds.

7. M. a. nembranacea, Loudon. Membranous-leaved White-fruited Mulberry; Mûrier à fenilles de parchemin, of the French, with large, thin, dry leaves.

8. M. A. sinensis, Loudon. Chinese White-fruited Mulberry; Mûrier de Chine, of the French; Chinese White Mulberry, of the Anglo-Americans, having large leaves, and is considered as one of the best varieties in the United States, for the production of silk.

9. M. A. PUMILA, Loudon. Dwarf White-fruited Mulberry; Mûrier nain, of the French; a shrub seldom exceeding ten feet in height. Its leaves, when young, are nearly as large as those of the M. a. macrophylla.

10. M. A. Fenina. Female White-fruited Mulberry; Mûrier femelle, of the French; a spiny tree, classed by M. Castelet, among the wild varieties. It sends forth its fruit before the leaves, which are trilobate.

11. M. A. Moretrtana, Loudon. Moretti's Black-fruited White Mulberry; Mûrier de Moretti, Mûrier de Dandolo, of the French; Dandolo's Mulberry, of the English. This variety, the fruit of which is black, has very large, flat, deepgreen, shining leaves, that are thin, and perfectly smooth on both surfaces. They rank high, as food for silkworms, and the silk made by the worms fed on them, has a beautiful gloss, and is said to be of a finer quality than any other. It is not so hardy as the Morus a. multicaulis, but is much more valuable for the purpose of raising silk. It was brought into notice, in Italy, in 1S15, by Signore Moretti, professor in the university of Pavia; whence its name. It was also named in honour of Count Dandolo, who has not only devoted much time to the improvement of the culture of silk, but has written a work on the subject. 
12. M. a. constantinopolitana. Constentinople White-finited Mulberry; Murus constantinopolitana, of Loudon and others; Murier de Constantimople, of the French. This is a low-branehing tree, seldom exeeeding a height of ten or fifteen feet; a native of Greee, 'Turkey, and the Crete, and lias long been enltivated in the Jardin des Plantes, at Paris, but which was not introdnced into Britain before 1818. This variety or race, may readily be recognized by its rough, furrowed, stunted trunk; its thiek and short branches; its leaves, which are always entire; and its solitary, and very white fruit.

13. M. a. multicaulis, Loudon. Many-stalked Black-firited White Mílberry; Mûrier multicaule, Mûrier à tiges nombrenses, Mûrier Perroltet, M trier des I'hilippines, of the Freneh; Vielstieliger Maulbeerbaum, of the Gernans; Morodelle Filippine, of the Italians; Morus multicaulis, Many-stallied Mulberry, Chinese Black Mulberry, Perrottet Mulberry, of the British and Anglo-Amerieaus. 'This variety, or race, is a small, many stemmed-tree, or rather gigantic shrub, of rapid growth, with vigorous shoots, and large, pendulous leaves, which, even in poor, dry soils, are often six inehes long, and eight or nine inches broad; and which, in rieh, humid soils, are often a foot in length, and fifteen or sixteen inches ju breadth. They are eonvex on the upper surface, cordate-rounded, being neither oblique nor lobed, crenate, acute, somewhat rough, when very large, but thin, and generally of a beautiful glossy-green. Its fruit is long, black, and of a flavour somewhat resembling that of the eommon black mulberry (Morus nigra.) 'This variety of mulberry differs from all the others in throwing up snckers freely from the crown of the roots, growing in clusters or bushes, like the lilac, the hiazel, the berberry, \&c.; hence the name multicaulis (many-stalked.) It also strikes root more readily by cuttings, either of the young or old wood, than any other variety. It was introduced into France in 1821, by M. Perrottet, (agricultural botanist and traveller of the marine and colonies of the French,) from Manilla, the capital of the Philippine Islands; into which country it had been brought some years before from China, as an ornamental tree. It was introdueed into the United States by the late M. André Parmentier, of Brooklyn, l.ong Island, previous to 1828 , when, in June of that year, it was brought into publie notice by the American Institute, at New York, at the suggestion of the late 10r. Felix Pas calis. It has since been extensively propagated in France and Italy, where it is still considered one of the best varieties for cultivation, as food for the silliworm : but in America, we regret to say, after all the enloginm and attention it has received, it is generally regarded as illy adapted to the production of silk, and the "Brousa," the "Chinese," and the "Alpine" varieties, are taking its place. It still has its advocates, hovever, among whom is Mr. Gideon B. Smith, of Baltimore, who took special pains to bring this plant into publie favour, through the columns of the "American Farmer," in 183:, and who doubtless possesses more practical knowledge of its nature and applieation than any other one in the enmtry. He states that, "The Morus multicanlis is perfectly hardy, when grown on its own peculiar and natural soil, which is light, lry, and not over rich. (1) low, rich soils, the growth of the plants is protracted to so late a season, that they do not ripen their wood, and of course they are killed to the gromnd in winter. I have uniformly grown them on high, dry, rather saudy soil, and never lost a branch or a bud; while others, who planted them on low, alluvial, rich soils. have lost them every winter." "I estimate the comparative value of the Murns. multicaulis, and the best white or Italian variety, as one to two; that is, I consider the Morus multicaulis worth one liundred per eent. more than the white Italian. It saves nine-tenths of the lahour in gathering the leaves, on account of their being at least ten times the size of those of the white. Onc pound of Morus multicaulis leaves contains one third more nutritive mitter than a poume of the best white mulberry leaves; the reason of this being, there is very little wouly 
fibre in the Morus multicaulis leaves, and in the best white, there is a very largo portion, all of which passes off in the form of excrement." On the contrary, it is contended by others, that there is an excess of moisture in the leaves of the Morus multicaulis, which is peculiarly productive of disease to the worm, and a disproportionate deficiency of the gummy matter, so essential to the formation of silk; yet, it is conceded by both parties, that, when this variety is used at all, it should be planted on a light, dry soil, which will do much to reduce the proportion of water, and increase that of the resinous matter of the leaf.

14. M. A. Tatarica. Tartarian Black-fruited White Mulberry; Morus tatarica, of Loudon and others; Mûrier de Tartarie, of the French. A deciduous tree, growing to the height of twenty feet, in places inundated by the waters of the rivers Wolga and Tanais, or Don, in Tartary. Its fruit is generally black, resembling that of the Morus nigra; though Pallas speaks of it as reddish or pale, of no good flavour, though eaten raw by the Tartars, as well as dried, or made by them into a sweetmeat. A wine is also prepared from it, and a very wellflavoured spirit. Its leaves are reported as being esteemed in China for the food of silkworms. Fine samples of silk have also been made from them in the United States. This variety appears to be very nearly allied to the Morus a. multicaulis, and by some is considered to be the same plant.

M. Castelet, in his "Traité sur les Mûriers blancs," describes three varieties which we are not able to identify with any of the preceding, viz.:-1. La Reine ¿âtarde, a wild variety, with leaves twice as large as those of the Morus a. rosea, and deeply toothed. This is probably the same as the Foglia zazola, of the Italians. 2. La Reine, a grafted variety, which has shining leaves, and ashcoloured fruit. 3. La Feuille de flocs, also a grafted variety, with very deepgreen leaves, growing in tufts at the extremities of the branches. The fruit, he says, is produced in abundance, but never arrives at maturity. This appears to agree with the Foglia doppia, or double-leaved variety, of the Italian gardeners.

Geography and History. The Morus alba is only found truly wild in China, in the province of Seres, or Serica; it is, however, apparently naturalized in many parts of Asia Minor, and of Europe. It does not embrace so great a geographical range as the Morus nigra, being unable to resist either very great extremes of heat or of cold. In a cultivated state, it is found, as a road-side pollard tree, in many parts of France, Spain, Italy, and in Germany as far north as Frankfort, on the Oder. In England, it is not very common; and it is scarcely to be found in Scotland, even against a wall. As a silk-growing tree, the white mulberry is propagated with tolerable success throughout a great part of Asia and Australia; in all the principal countries of Europe south of the forty-ninth degree of north latitude, including most of the islands of the Mediterranean; in a portion of northern Africa, the Azores, Madeira, and Canary Isles; in nearly all the states of the American union; in California, Mexico, Chili, Peru, Buenos Ayres, Brazil, Ca racas, Jamaica, and other parts of the West Indies, the Sandwich Islands, \&c. In the south of Europe, the vhite mulberry is grown in plantations by itself, like willows and fruit-trees; also in hedge-rows, and as hedges; but in all cases the plants are kept low, for the convenience of gathering the leaves, without injuring the trees; the greatest height they are suffered to attain being that of a pollard of six feet, which is annually lopped.

The culture and manufacture of silk, like many productions of nature and art, are difficult to trace from their origin. All that we know concerning them, is, that they have flowed to us from the east in a comparative state of perfection. The Seres are mentioned in the oldest Sanscrit books, as a gentle race, who shunned the rest of mankind, and whose occupation was to attend silkworms. It seems to have been in Asia that silk was first known; and it was from thence that the ancients obtained it, calling it Serica, from the name of the country whence it was supposed to be brought. 
T'he Chinese appear to have been the first to cultivate the mulberry for feeding silkworms; and they are supposed to have discovered the art of making this dolicate luxury 2700 B. C., in the reign of Emperor Hong, whose Empress, si-lingchi, is said to have first observed the operations of the silkworm on wild mulberrytrees, and applied their labours to the production of silk. She collected them from the trees, and, with the aid of the females attached to her household, atiended them with much care, in the imperial apartments, supplied them with mulberryleaves, and kept them very clean. It was soon found that they thrived much better in this manner than in the open air, where they were constantly exposed to their natural enemies, serpents, spiders, $\mathbb{N c}$., and to the ill effects of clianges of temperature. The cocoons, produced in rooms, were more numerous, larger, and of better quality, than those gathered from the trees. Care was afterwards taken to hatch the eggs in rooms, and the superiority of this artificial mode of culture soon became more and more manifest, which was followed by the successive sovereigns of that empire, and all the rich and affluent were dressed in garments of silk. Subsequently, it became an article of exportation, and a source of great wealth. The traders of Serica first carried the silken stuffs over the whole breadth of Asia. Their caravans performed long journeys of two hundred and forty-three days, from the "far coasts" of China to those of Syria. The culture spread from China to India, Persia, and Arabia, and was for many centuries, as $\mathrm{t}$ is at the present day, a great source of wealth to these countries.

The expedition of Alexander the Great into Persia and India, first introduced the knowledge of silk to the Greeks, about 350 years B. C.; and, with the increase of wealth and luxury in the Grecian court, the demand for silken goods prodigiously augmented. The Persians engrossed, for a time, the trade of Greece, and became rich from the commerce of silk, which they procured from China. Among the most active traders of that epoch were the Plıœnicians, who were also engaged in the traffic of silk, and carried it to the east of Europe; but for a long time, even those who were concerned in its commerce, knew not what it was, how it was produced, nor where was situated the country of Serica, from which it originally came. Some, supposing it to be grown on trees, as hair grows on animals; others, that it was produced by a shell-fish, similar to a mussel, which is known to throw out threads for the purpose of attaching itself to rocks; others, that it was the entrails of a sort of spider, which was fed for four years with paste, and then with the leaves of a kind of green willow, till it burst with fat; and others, that it was the product of a worm which built nests of clay, and collected wax. But Aristotle, with more truth, thought it was unwound from the pupa of a large horned caterpillar.

From Greece, the use of silk passed into Rome; and, though the exact year of its introduction is unknown, it was probably about the time of Pompey and Julius Cæsar; the latter, we find, having used it in his festivals. In the reign of Tiberius, an edict was passed, prohibiting the nse of silk as effeminate. Among all the articles of elegance belonging to the luxurious Cleopatra, none seemed more to excite admiration and astonishment, than the silken sails of her pleasure barge. in which she visited Alexandria. Heliogabalus, in the year 2:20 of our cra, is said to have been the first emperor who wore a robe made entirely of silk; which then, and for some time afterwards, sold for its weight in gold. Anrelian, in the year 280, is said to have denied his Empress, Severa, a robe of silk, becanse it was too dear.

About the beginning of the VIth century, after the seat of the Roman empire had been transferred to Constantinople, two monks arrived at the court of the Limperor Justinian, from a mission into Clima, bringing with them the seeds of the mulberry, and communicated to him the discovery of the mode of rearing silliworms. Although the exportation of the insects from China, was prolibited, on 
pain of death, yet, by the liberal promises, and the persuasions of Justinian, they were induced to undertake to import some from that country; and they returned from their expedition through Bucharia and Persia, to Constantinople, in the year 555 , with the eggs of the precious insect, which they had obtained in the "far country," concealed in the hollow of their canes, or pilgrim-staves. Until this time, the extensive manufactures of Tyre and Berytes had received the whole of their supply of raw silk from China, through Persia. The eggs thus obtained, were hatched in a hot-bed, and, being afterwards carefully fed and attended to, the experiment proved successful, and the silkworm became very generally cultivated throughout Greece.

The silkworm and the black mulberry were introduced simultaneously into Spain and Portugal, by the Arabs, or Saracens, on their conquest of Spain, in 771. In the XVth century, the silk culture of the last-named country, is universally allowed to have been in a highly flourishing state; but it has been in a declining condition ever since; so much so, that, in the year 1833, at the time we visited that unfortunate country, it was one of the most neglected branches of agriculture in the kingdom; being almost entirely confined to a few of the southern provinces.

The white mulberry was for a long period confined to Greece; but when Roger, king of Sicily, in 1130, ravaged Peloponnesus, he compelled the principal artificers of silk, and breeders of silkworms, to remove with him to Palermo, with the determination to try the culture of this tree in that country. The Morus alba was accordingly transplanted from Greece to Sicily, and, flourishing in its fine climate, that island became the great mart of nearly all the raw silk required for the manufactures of Europe.

In 1204, the conquest of Constantinople, by the Venetians, led to the introduction of the silkworm into Venice, from which, in the course of a short time, it extended to Genoa, and other parts of Italy. The white mulberry was introduced into upper Italy, in 1440 , since which time, up to the present day, the culture and manufacture of silk have constitnted a very important part of the commerce both of Italy and Sicily.

The white mulberry was introduced into France by Seigneur d'Allan, under the reign of Charles VII.; and it is said that the original tree still exists at the gates of Montelimart. Silk manufactures were first established at 'Tours, in 1 180, by Lonis XI., who invited workmen from Italy to settle in his kingdom. 'These manufactures, however, were supplied, entirely, at first, with the raw material, from Sicily and Piedmont. In 1494, several of the great landed proprietors who had followed Charles VIII, in his Italian wars, bronght with them, on their return from Naples and Sicily, an additional supply of the white mulberry, which they planted in Provence, in the vicinity of Montelimart. In 1520, Francis I., having taken possession of Milan, prevailed on some artisans of that city to estabtish themselves at Lyons; and, to encourage them to remain there, he granted them special privileges and immunities. Henry II., and Charles IX., appear to have been the next sovereigns who endeavoured to promote the culture of silk in France; and, in the reign of the latter monarch, in 1564, François Traucat, a gardener at Nismes, formed a large nursery, expressly for raising white mulberry plants, from which he supplied all the south of France. Henry IV. was no sooner established on the throne, than he exerted himself to promote this branch of industry throughout his dominions; and, by his desire, Olivier de Serres, seigneur de Pradel, in 1601, formed a plantation of white mulberry trees in the garden of the 'Tuileries, where was erected a large building for rearing the silkworms. In 1603, an edict was passed for encouraging the planting of mulberrytrees thronghout France; promising to reward with patents of nobility, such manufacturers as had supported and pursued the trade for twelve years. Under 
Louis XIII., the silk manufactures fell into neglect; but under the reign of his successor, Louis XIV., the subject attracted the attention of government, and Colbert, one of the public ministers, seeing the advantages that might be derived from the culture of mulberry-trees, resolved to enforce it by every means in his power. He reëstablished royal nurseries; gave plants to all who desired them: and even planted, by force, the lands of proprietors who would not voluntarily cultivate the trees. This arbitrary measure caused so much dissatisfaction and disgust, on the part of the proprietors, that the mulberry plantations were soon suffered to decay. Colbert next tried more gentle means, offering a premium of twenty-four sous for every mulberry-tree that had stood in a plantation for three years. This plan was crowned with success; and, in the course of at few years, mulberry plantations were general throughout the kingdom, and have so continued up to the present day. Soon after Algiers came into possession of the French, in 1830 , a public nursery, occupying eighty acres, was there established, which is said to contain twenty-five thousand trees and plants for the purpose of experiment in naturalization, among which are the Morus alba and several of its varieties.

In Germany, the culture of silk was first introduced by Frederick II., who had mulberries planted extensively in different parts of his dominions; and the example was soon after followed in Saxony, Austria, and in some of the smaller states. In Bavaria, this species of culture was commenced under the auspices of government, and of the Munich Agricultural Society, in about 1820, at the recommendation of M. Hazzi. Since that time, a great number of mulberry plants have been raised in the government nurseries, and distributed throughout the provinces; but, on the whole, neither in this part of Germany, nor in any other, has the culture of silk ever been very considerable. In several of the southeru states, however, pollard trees may be seen bordering the highways, and in some of the cities, goods are made from German silk; but the chief establishments of this kind are at Vienna, at Rovedero in the Tyrol, at Creveldt, at Berlin, and at Cologne.

The culture of silk has been introduced into Belgium with some prospect of success; and the mulberry has also been planted in the southern parts of Denmark. In Sweden, an attempt has been made to establish its culture in the southern provinces; but the experiment has proved unprofitable.

In Russia, the silk culture has been commenced in the Crimea, and all the best varieties of the Morus alba have been planted in the government garden at Odessa; where, according to M. Descemet, they perfectly succeed.

In Egypt, the culture of silk was introdnced some years since, by the P'açha Ibrahim, and is said to be in a prosperous state. In Persia, the silkworm is nourished almost exclusively on the leaves of the black mulberry. The cultivators, from a motive of economy, are accustomed to feed the worms with the boughs of the tree, with the foliage upon them, instead of using the leaf separately, as is adopted in most other silk-growing countries.

In India, the culture of the mulberry and the rearing of silkworms continue to be practised; but how far it will be influenced by the progress of this culture in Europe and America, remains to be proved. In Australia, the culture of silk has been undertaken to a considerable extent, and from the milchess of its climate, and the cheapness of labour, it appears likely to be attended with snecess.

The first record of silk in Britain, is of a present sent by Charlemagne, to Offia. king of Mercia, in the year 708 , consisting of a belt and two silken vests. Silk is also mentioned in a chronicle of the date of 1:26ti, in which we are told that some ladies wore silk mantles at a festival, in Kenilworti, abont that perton: and by other records, we find that this article was worn by the linglish clergy. in 15.3. Henry VIII. had the first pair of silk stoekings that were ever sectl in 
England, sent to him from Spain; and Edward VI., "had a pair of long silk hose," from the same country, presented to him by Sir Thomas Gresham, " a present which was thought much of." They were cut out of a piece of silk, and sewed together, like the cloth hose that were tvorn previously to the reign of Elizabeth. James I., when lking of Scotland, was forced to beg the loan of a pair of silk stockings of the Earl of Mar, to appear in before the English embassador, enforcing his request with the cogent appeal, "For ye would not, sure, tha your king should appear as a scrub before strangers"-a circumstance which probably led him to promote the cultivation of silk, both in England and in America. The manufacture of silk was introduced into Britain in the XVth century; but it did not appear to make much progress till the time of Elizabeth, the tranquillity of whose long reign, and the influx of the Flemings, occasioned by the disturbances in the Low Countries, gave a powerful stimulus to the manufactures of England. In 1605, James I., probably in imitation of Henry IV., passed his famous edict for introducing the culture of silk into Britain; and from the "Issues of the Exchequer," \&c., of his reign, it appears that, by the year 1608, he planted largely himself. Hartlib, in his "Legacy," \&c., printed in 1652, quotes some passages from Bonoeil's work on mulberries, \&c., issued in 1609; and among other letters from King James to his lords lieutenants, recommending the planting of mulberrytrees, and offering them at two farthings each. Though this attempt to rear silkworms in England proved unsuccessful, the manufacture of the raw materiai supplied by other countries, was in an extremely flourishing condition. The silk-throwsters of London were united into a fellowship, in 1562; and were incorporated in 1629. Though retarded by the civil wars in the time of Charles I. and the commonwealth, the manufacture continued gradually to advance; and so flourishing had it become, that it is stated in a preamble to a statute passed in 1666 , that there were at that time no fewer than forty thousand individuals engaged in the trade. A considerable stimulus was given to the English silk manufacture by the revocation of the edict of Nantes, in 1685; when about fifty thousand French artisans took refuge in Britain. At this period, the consumption of silk goods was so great in England, that, besides the quantity manufactured in the country, there were annually imported an amount exceeding six hundred thousand pounds sterling. After the failure of the attempts of James I., to establish the culture of silk in Britain, another trial appears to have been made in the year 1629. This may be inferred from a grant having been made to Walter Aston, of the custody of the garden, mulberry-trees, and silkworms, near St. James', in the county of Middlesex; although this may possibly have been a continuation of the project of the year 1605. In 1718, the scheme was again renewed, and a patent granted to John Appleton, Esquire, for producing raw silk of the growth of England. To accomplish this undertaking, he was authorized to raise a fund by joint-stock subscription. This he accomplished, dividing the capital into shares of five pounds each. A deed of trust was executed, and enrolled in the court of chancery; directors for managing the concerns of the company were chosen by the subscribers, and Chelsea Park, being conveniently situated, and possessing, as was supposed, a soil favourable for the purpose, was fixed upon as the theatre of their operations. A lease of this place for one hundred and twenty-two years was obtained, and two thousand mulberry-trees were soon actually planted; this forming but a small part, however, of the vast quantity which the company contemplated raising. Many large edifices were erected at a great expense, upon the spot, the remains of which, at the present day, are said to be entirely obliterated. Mr. Henry Barham, who probably was a member of this company, published, at this tine, an essay on the sillkworm, wherein he laboured to prove that all objections and difficulties raised against the prosecution of what lie calls "this glorious undertaking," were mere phantoms. The 
event however proved him to be wrong; and showed that difficulties did exist of an insurmountable description; for, although it was confidently predicted that in the ensuing year, a considerable quantity of raw silk would be prodnced, the expectation was disappointed, and the company soon sunk into oblivion. I 18.25, a company was established in England, under the naine of "The British, Irish, and Colonial silk Company," with a large capital, and under the direction of the celebrated Count Dandolo, whose treatise on the management of the silkworm, \&c., is considered the best work extant on the subject, in Italy. 'This company formed extensive plantations in England and Ireland, particularly near Slough, and in the vicinity of Cork; and Mr. John Heathcoat, of 'Tiverton, Devonshire, one of the most influential members, invented a method of reeling, whicl was attended with the most complete success. 'The company also forned plan. tations in the county of Devon; but, after numerous trials, it was found that the climate of the British lsles was too humid for the production of good silk; and the company was finally broken up, and its plantations destroyed, in 1-29.*

The first introduction of the silk culture into the British North American colonies was made by James I., who, on several occasions, urged the Virginian Company to promote the cultivation of mulberry-trees, and the breeding of silkworms. In 1622, he addressed a letter to them expressly on this subject, conveying to them strict injunctions that they should use every exertion for this purpose, and should stimulate the colonists to apply themselves diligently and promptly to the breeding of silkworms, and the establishment of silk works. The company, thus incited, showed inuch zeal in their endeavours to accomplish the king's wishes 'They lost no time in transmitting his majesty's letter to the governor and council of Virginia, together with particular instructions how the colonists might best apply their labours in the production of silk. For the furtherance of this object. their instructions were accompanied by several copies of Bonoeil's "'Treatise on the Art of Making Silk," Sc., and a quantity of mulberry-trees and silkworms eggs, which had been sent from England to that colony. Mr. Bonoeil, who was a member of the Virginian Company, engaged warmly in the undertaking; and was so fully convinced of its practicability, as to assert that. with an adequate number of hands, such a quantity of silk nnight be produced in Virginia, as in a very short time, would sufficiently supply all Christendom. 'The inisfortunes soon after this time experienced by the colony of Virginia, and which involved the dissolution of the conıpany, materially checked the execution of this project. A considerable number of mulberry-trees were planted, and tlourished; but little silk was produced. In the year 1654 , the rearing of silkworms again became a subject of interest in Virginia. This revival was principally owing to the exertions of Mr. Edward Diggs, who confidently asserted that he had conquered all the main difficulties attending the experiment. He endeavoured to persuade the Virginians that, in a short time, a great quantity of silk might very profitably be obtained. About this period, it was also enacted by the British government that every planter in Virginia, wlio should not have raised at least ten mulberry-trees for every hundred acres of land in his possession, should be fined ten ponnds of tobacco. Five thousand pounds of tobacco were promised to any onc who should produce one thousand ponnds of wound silk in one year. In litil, Mr. Wallier. a member of the legislature, stated that he had seventy thonsand mulberry-trees on his estate. In 1666 , all statutory provisions were repealed, becanse, it is said. the business was in so thriving a condition as no longer to require protection. 'This branch of industry, however, was soon after suffered to decline: and it does not appear that the production was ever earried to any great extent in that colony. The decline was probably owing to new immigriuts, who hrouglit witls 
them new views and habits. As they brought with them their slaves, it became necessary that an immediate retırn should be realized. Hence the culture of rice, indigo, and tobacco, froin which an immediate profit could be derived, took precedence to that of silk, which would have required a steady perseverance for a course of years.

In the earliest infancy of the settlement of Georgia, in the year 1732, a piece of ground belonging to government, was allotted as a nursery plantation for white mulberry-trees, and the attention of some of the settlers was soon engaged in rearing silkworms. 'The trustees of the colony not only transmitted mulberrytrees, but the seeds of this tree, and silkworms' eggs. And this branch of rural economy was considered to be nearly brought to perfection, and was of so much national importance, that the public seal of the colony represented silkworms in the various stages of their growth; and liad for its inscription, "Non sibi sed ahiis." In the year 1736 , a quantity of raw silk was raised in that colony, and was manufactured at Derby, in England, by Sir Thomas Lombe, into a piece of stuff, which he presented to the queen. 'The culture of silk gradually, though slowly increased, both in Georgia and Carolina; and as it was desirable on the part of Britain to be enabled to draw supplies from its colonies, rather than be dependent upon foreign states for a material of continual and increasing demand for its manufacturers, an act of parliament was passed in 1749 , for encouraging the growth of colonial silk, under the provision of which, all that was certified to be the productions of Georgia and Carolina, was exempted from the payment of dity on importation into the port of London. Encouraged by the increasing growth of raw silk in these colonies, which induced a belief, that, by the adoption of more judicious plans, an abundant supply might be drawn from them, sufficient to answer all the demands of the English manufacturers, a bounty was uffered for the production of silk, and a man named Ortolengi, from Italy, was engaged, at a suitable salary, to proceed to Georgia, and instruct the colonists in the Italian mode of management. Although, for a tinie, hopes were entertained that the Georgians might find in this pursuit a valuable branch of industry; yet, in consequence of one or two unfarourable seasons, and still more from the quality of the silk, in most instances, proving very indifferent, its culture soon began to decline, and the reduction of the bounty became a signal for its abandonment by the planters. A few years, however, before the war of independence, considerable quantities of raw material began to be raised, which was said to be equal, in some cases, to the best Piedmont silk, and worked with less waste than the Chinese article. In the year 1766, more than twenty thousand pounds of raw silk were imported into England from Georgia. After the revolution, this branch of business gradually declined, and by the end of the last century, the production of silk was wholly discontinued, as an article of commerce, not only in Georgia, but in all the states of the union, except Connecticut.

The rearing of silkworms had also been an object of interest in Carolina as early as the year 1732. It was undertaken by the small farmers, many of whom produced from forty to fifty pounds of silk in a season. 'The endeavours to increase and perfect its production in this colony were long persevered in. In April, 1764, Rev. Mr. Gilbert formed a settlement of French protestants in the township of Hillsborough, called New Bourdeaux, where, among other branches of rural industry, he attended to the rearing of silkworms. In the year 1765, he raised six hundred and thirty pounds of cocoons on the plantation of Mr. David Manigauld, called "Silk Hope." In 1766, the House of Assembly of this province voted the sum of one thousand pounds currency towards establishing a silk filature in Charleston, under the direction of Mr. Gilbert. In 1771, M. Louis de St. Pierre, of New Bourdeaux, made a representation to the government, that, at the expense of his whole fortune, he had brought to perfection the art of making 
wine and the production of silk. His samples of wine and silk, which were transmitted to England, were thought deserving of notice by the Patriotic Society for the Encouragements of Arts, who awarded him a gold medal, accompanied with a premium of fifty pounds. In January, 17\%2, the commissioners of the silk manufacture, at Charleston, shipped for England, four hundred and fiftyfive pounds of raw silk, of more than an ordinary quality of the growth of Perrysburgh, in that province. Notwithstanding this stimulus to further efforts, the quantities afterwards raised by the colonists were very small, and the cost of production proved too great for successful competition with the silk of other countries.

In the year 1 69, on the recommendation of Dr. Franklin, through the American Philosophical society, a filature of raw silk was established, by private subscription, in seventh street, between Market and Arch streets, Philadelphia. It was placed under the direction of an intelligent and skilful Frenchman, who, it is siid, produced samples of reeled silk, "not inferior in goodness to the best from France and Italy." Between the 25th of June and the 15th of August, 17\%1, there were bought by the managers, two thousand three hundred pounds of cocoons, all the products of Pennsylvania, New Jersey, and Delaware. Nothing further, of importance, appears to have followed from this undertaking, having been put to an end by the American revolution. A similar enterprise was again attempted in Philadelphia, in 1830, under the direction of M. J. D'Homergue, and cocoons were brought in abundance to the establishment, from all parts of the union, and so continued for some time afterwards; but, for the want of capital the undertaking failed.

In Connecticut, attention was first directed to the rearing of silkworms, in $\mathbf{1 7 6 0 .}$ Dr. Aspinwall, of Mansfield, urged on by patriotism, used his best exertions, to introduce this important branch of rural economy. He succeeded in forming extensive nurseries of the mulberry at New Haven, Long Island, Pennsylvania, and other places, with the aid of a warm and zealous coadjutor, the Rev. Dr. Stiles, at that time president of Yale College. One half of an ounce of mulberry seeds was sent to every parish in the colony, with such directions as their knowledge of the business cnabled them to impart. Through the exertions of these gentlemen, the legislature of Connecticut, in 1783, was induced to grant a bounty on mulberry-trees and raw silk. From some cause or other, in a few years, the bounty was withdrawn, the business languished, and in 1793, the town of Mansfield produced only two hundred and sixty-five pounds of silk. It may be said, however, to the honour of Connecticut, that she is the only state in the union, which has continued the business, without suspension, and probably produced more silk from the time of her commencement, up to the year 1830 , than all the rest of the states together.

In about the year 1530 , the project of rearing silkworms, and establishing filatures of silk, was renewed in various parts of the union, and the subject was deemed to be of so much importance, that it not only attracted the attention of congress, but has since received encouragement from the legislatures of several states, by offering bounties for all the raw silk produced within their limits, for certain periods of time. But, instead of tracing the progress of this branch of industry, for the last fifteen years, in the United States, and entering into the subject in detail, we are compelled for the want of space, to refer the reader to a work entitled "The Silk Question Settled;" containing the testimony of one hundred and fifty witnesses, being the Report of the Proceedings of the National Convention of Silk-growers and Manufacturers, held at the American Institute, in the city of New York, in October, 1543. According to the Report of the commissioner of the United States Patent Office, however, for the year 1844, the amount of silk cocoons produced in that year, in the several states in the union, 
ras as follows:-Connecticut, 176,210 pounds; Massachusetts, 37,690; Pennsylvania, 33,100; Ohio, 31,500; 'Tennessee, 25,090; Vermont, 10,990; Alabama, 7.170; Maryland, 8,530; North Carolina, 8,050; Virginia, 7,720; Georgia, 7,660; South Carolina, 6,930; New York, 6,540; Kentucky, 5,810; New Jersey, 5,2100; Delaware, 4,580; Illinois, 4,250 ; Michigan, 1,730; Louisiana, 1,310; District of Columbia, 1,250; Rhode Island, 1,140 ; New Hampshire, 1,100; Indiana, 1,05ก, Maine, S.50; Florida, 510; Mississippi, 270; Arkansas, 270; Missouri, 260, Wisconsin, 30.-Total, 396,790.

The largest white mulberry-tree in Britain, is at Syon, which has attained 8 height of forty-five feet, with a trumk nearly two feet in diameter, and an arnbitus, or spread of branches, of about sixty feet. It bears an abundance of fruit every year.

In France, in the Jardin des Plantes, at Paris, there is a tree of this species, which, in thirty-five years after planting, had attained the height of thirty-twc leet, with a trunk one foot in diameter, and an ambitus of thirty-six feet.

In Italy, at Monza, there is a Morus alba, two hundred years old, forty feet in height, with a trunk three feet in diameter, and an ambitus of fifty feet.

Soil, Situation, Propagation, and Culture. 'The white mulberry is more ten der than the Morus nigra, and requires more care in the choice of a situation. A calcareous soil is said to produce the best silk, and situations that are humid, or those in which the roots of the tree can have access to water, produce the worst. A gravelly or sandy loam is very suitable; and trees grown on hilly surfaces, and poor soils, always produce silk superior to those grown in valleys, and in rich soils.

This species may be propagated from seeds, by cuttings, or layers, and by grafting. To obtain seeds, the berries must be collected from trees known to produce male catkins the preceding spring. The berries may either be gathered when quite ripe, and left to become dry before the seeds are separated from them; or they may be put into water as soon as they are gathered, and rubbed sufficiently hard to disengage the seeds, which may be cleansed from the pulp in the water, and then rubbed dry on a linen cloth, and sown immediately, or mixed with sand, and kept till wanted for use. In the south of France, the seeds are sown as soon as the fruit is gathered, and the plants come up the same autumn; but in colder climates, they are kept till spring, when they generally come up in three or four weeks, and require some protection, at fisst, during cold nights. In Germany, and in the northern parts of the United States, the young plants are commonly covered during the first winter, with dry leaves or straw; and this covering is often continued on the ground for three or four years, till the plants are thoroughly established, to protect their roots from the cold. Young plants are generally taken up and replanted the second spring, in rows four or five feet apart, or sufficiently far for the convenience of gathering the leaves. The Morus a. multicaulis, and several other varieties, are always propagated by layers or cuttings; the layers being made in spring or at mid-sinmmer, and separated from the parent plant in autumn; or by cuttings of branches, or truncheons, which will readily take root, and produce leaves for the worms the following year. Count Dandolo recommends grafting the species with the large-leaved varieties, near the ground, the third spring; but most writers on the silkworm appear to prefer seedling plants, or plants raised from layers or cuttings, to grafted ones. It has been asserted that trees raised from seeds are not only more hardy and of greater longevity, than those propagated by the other modes, but a given weight of their foliage will produce a greater quantity of silk. M. Pomier, in a treatise which he has written on this subject, recommends that the white mulberry be grafted on the Morus nigra; and the reason urged for the adoption of this plan is, that the white species commonly decays first at the root, while the black mul- 
berry is not subject to any disease. In pruning, cutting in, or lieading down, the trees, the great object is to preserve the equilibrium of the heads, so that the sap may be equally distributed through the branches on every side. (On this depends the production of the crop of leaves of equal quality on every part of the tree, which is alike important both for the first crop, given to the worms, and fin the second crop, which is required for the nourishment of the tree itself. I)u Halde, in his "History of China," relates that the Chinese are so particular m pruning their mulberries, that the leaves may be gathered in the easiest mamuer, and without risk or damage to the trees. This is accomplished by cutting the head of the tree in a hollow form, without any intersecting branches in the middle; so that a person going round the tree, may gather all the outside leaves, and afterwards, by standing within the summit, and merely turning ronnd to the different parts, may pluck the leaves growing in the interior. 'The trees are not allowed to grow to any great height, each forming a sort of dwarf, or round hedge, that may be reached in every part without climbing on its branches. In China, and also in India, the mulberry plantations are made much in the manner as those of the singar-cane, and other agricultural plants. A field is laid ont into squares of five or six feet on a side, and in the centre of each square a hollow is formed, into which are planted in a group, five or six mulberry cuttings, after the soil has been stirred and manured. These plants are never allowed to grow higher than three or four feet; being cut down to the ground every year, in the same manner as a raspberry plantation. Mulberry-trees, when planted out, should be kept clear of grass and herbage, and the ground loosened about their roots. They should never be touched with fresh barn-yard manure, as it will do them no immediate benefit, but often will prove fatal to them. 'The only manure that can be applied to advantage, is well-rotted vegetable mould, containing a due proportion of lime, potash, and ammonical salts, and the leaves and branches of the tree itself, or the excrement and litter of the silkworms, which should always be preserved, as far as convenient, for this purpose.

Insects and Diseases. The leaves of the Morus alba are believed to be eaten by no other insect but the silkworm (Bombyx mori.) M. Pullein, however, made experiments with various kinds of insects, but they all rejected the mulberry leaf for food, except "a green worm, about an inch long, and as thick as an oat straw." Although he found it upon a mulberry, it was his belief that it was not peculiar to that tree alone, but found its way there by accident. 'The white mulberry, however, is attacked by numerous diseases, occasioned partly, no doubt, by the unnatural manner in which it is treated, by being stripped of its foliage. One of these diseases is brought on by any sudden check given to the transpiration of the leaves, which turn yellow, and fall off, shortly after causing the tree to die. Another is the death of the roots, which is accompanied by the formation on them of parasitic fungi. The leaves are also apt to be attacked with honey-dew, mildew, rust, and other diseases, which render them infit for the food of the silkworm. Those leaves covered with honey-dew may be washed, and, when thoroughly dry, may be given to the insects without injury; but the other diseased leaves should be thrown away. If leaves covered with honeydew are employed without washing, they cause dysentery and death to the worms. As it is not our intention to treat of the whole art of the rearing and management of the silkworm, we are compelled to refer the reader to a "I'reatise on the Origin and Progressive Improvement of the silk Manufacture," being the twenty-second volume of the London Cabinet Cyclopachia; also to the work of Count Dandolo, entitled "Dell' Arte di governare i Bacehi da Reta ;" Kenrick's "American Silk-Grower's Guide;" and to most of the agricultural journals of the day.

Properties and Uses. The wood of the Morus alba, when dry, weighs forty- 
four pounds to a cubic foot. In France, the principal uses of that of the trunk, is for various purposes of turnery, and carpentry, and for the making of winecasks, for which it is highly valued, as it is said to impart an agreeable, violetlike flavour to white wines. The branches are used for vine-props, posts and rails to rural fences, and for fuel. The bark may be converted into linen, of the fineness of silk. For this purpose, the young wood is gathered in August, during the second ascent of the sap, and imnersed for three or four days in still water. It is then taken out, at sunset, spread on the grass, and returned to the water at sunrise. After repeating this process daily for some time, it is finally taken out, dried, and prepared like flax. The bark is also used like that of the European lime-tree, for making bast for mats, \&c. The bark, and more especially the leaves of the white mulberry, abound in a milky juice, which is found to possess more or less of the properties of caoutchouc, according to the climate in which the tree is grown. It is doubtless owing to this property in the leaves of the mulberry, that the cocoons of the silkworm have so much more tenacity of fibre than those of any other insect that feeds on the leaves of trees. Hence, also, the silk, like the tobacco and wine of warm climates, and of poor, dry soils, is always superior to that produced in colder climates, and from rich and moist soils. To verify this opinion, we quote the following very judicious observations from the "Journal d'Agriculture des Pays-Bas," which will not only show the impracticability of profitably raising silk in the higher latitudes, but will serve as an infallable guide in the choice of a soil and climate for this species of culture :"The mulberry-tree is found in different climates; but the juice of the leaves grown in the north is much less suitable for the production of good silk, than that of the leaves of the south. In this respect, mulberry leaves and silk differ as much as wines, according to the climate and soil in which they are produced. In general, every climate and soil that will grow good wheat will produce large, succulent mulberry leaves; but these leaves will, in many cases, be tóo nutritive; that is, they will have too much sap, and too much substance and succulency. The wild mulberry, with small leaves, answers better, for such a soil, than the grafted mulberry, with large leaves. A general rule, and one to be depended on, is, that the mulberry, to produce the best silk, requires the same soil and exposure that the vine does to produce the best wine. Experience has proved that silkworms nourished by leaves gathered from a dry soil, succeed much better, produce more cocoons, and are less subject to those diseases which destroy them, than those which have been nourished by leaves produced by an extremely rich soil." The fruit of the white mulberry is less acid than that of the black species, and that of some of the varieties, particularly of the Morus a. multicaulis, is used for making robs and syrups, and is said to be remarkably good to eat, in warm climates.

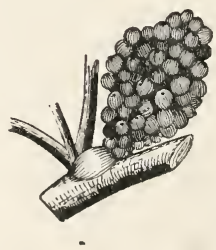




\section{Morus rubra, THE RED-FRUITED MULBERRY-TREE.}

Synonymes.

\begin{tabular}{|c|c|}
\hline Morus rubra, & $\left\{\begin{array}{l}\text { LiNN玉Us, Species Plantarum. } \\
\text { MichaUx, North American Sylva. } \\
\text { Loudon, Arboretum Britannicum. }\end{array}\right.$ \\
\hline Mûrier & France. \\
\hline $\begin{array}{l}\text { Iaulbeerbaum, } \\
\text { sso, }\end{array}$ & $\begin{array}{l}\text { Germany. } \\
\text { ItALY. }\end{array}$ \\
\hline $\begin{array}{l}\text { ed Mulberry-tree, Virginian Mulberry- } \\
\text { iree, }\end{array}$ & Britain and Anglo-America. \\
\hline
\end{tabular}

Lerivations. The specific name rubra is derived from the Latin ruber, red; having reference to the colour of the fruul of this species. The other names have the same signification as the botanical one, except Virginian Mulberry, which is so called because this tree was originally found in great abundance in the colony of Virginia.

Engravings. Michaux, North American Sylva, pl. 116; Loudon, Arboretum Britannicum, vii., pl. 227; and the figures below.

Specific Characters. Sexes polygamous, or diœecious. Spikes of female flowers cylindrical. Catkins of male flowers of the length of those of the Betula alba. Leaves heart-shaped, ovate, acuminate, 3-lobed, or palmate; serrated with equal teeth, rough, somewhat villous; under surface very tomentose, and soft.
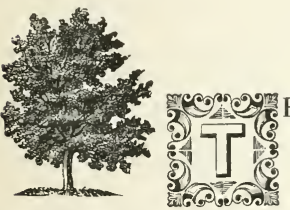
HE Morus rubra, when
growing in its native
forests, among other
trees, sometimes attains a height of sixty or seventy feet, with a trunk two feet in diameter; but, in open situations, its stature is low, and the thickness of the stem proportionably increased. The bark of the trunk of old trees is of a grayish colour, and is more deeply furrowed than that of the oak. The leaves, which are often nine or ten inches in length, and three-fourths as broad as they are long, are sometimes entire, and at others divided into two or three lobes, rounded, cordiform, denticulated, of a dark glossy-green colowr, with a thick texture, and a rough, uneven surface. The sexes are usually separate, though they are sometimes found on the same trees, which, it is

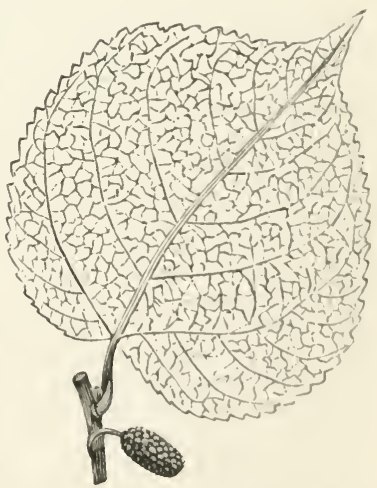
even stated, vary in their sexes every year. The male flowers, which put forth in Pennsylvania in May, form pendulous, cylindrical aments, about an inch in length; but those of the opposite sex are small, and scarcely apparent. 'The fruit, which is generally of a deep-red colour, is of an oblong form, an agreeable, acidulous, sugary taste, and is composed by the union of a great number of small utriculi, each of which contains a minute seed.

Varieties. The Morus rubra appears to have the same tendency to spert, and form new varieties or races, as its easten congeners, the white, and black-fruited species. The following variations we insert principally on the anthority of liaf- 
inesque, which are generally treated by him as species; but, from observations of our own, as well as the opinion of others, we regard them only as varieties :-

1. M. R. Pallida. Pale-fruited Red-fruited Mulberry; with fruit of a pale-red colour.

2. M. R. heterophylla. Various-leaved Red-fruited Mulberry; with all the leaves unlike.

3. M. R. RIPARIA. River-bank-inhabiting Red-fruited Mulberry; Water Mulberry, Wild Black Mulberry, of the Pennsylvanians. This variety differs from the species in having longer petioles, ovate, deeply cordate leaves, which are seldom laterally lobed, quite smooth, and thin, crenate, serrate, acute, but neither acuminate nor oblique at the base. It forms a handsome tree, growing on the banks of the Susquehannah, in the Alleghany Mountains. The leaves are from three to five inches long; and the fruit is of a dark-red.

4. M. R. Canadensis. Canadian Red-fruited Mulberry; called Rock Mulberry, when growing on rocky steeps. The leaves of this variety are ovate, oblique, rounded at the base, but not cordate, serrate, acuminate, and smooth. It is a native of Canada, the northern parts of Maine, New Hampshire, Vermont, New York, and the Alleghany Mountains.

5. M. R. Parvifolia. Small-leaved Red-fruited Mulberry; called Indian Mulberry, by the inhabitants of the Alleghanies. The leaves of this variety are from one to two inches long, are smooth, ovate, acute or obtuse, not lobed, equally sub-crenate, truncate at the base, often oblique, and supported by long, slender petioles. The fruit is very small, oblong-ovate, of a very pale-red colour, and sweet taste. It is a native of the Alleghany and Apalachian Mountains, and is said to have been cultivated by the Indians.

Geography and History. The Morus rubra is found near the northern extremity of Lake Champlain, and at the head of Lake Winnipisiogee, which may be assumed as the northern limits of this tree. As a temperate climate is favourable to its increase, as we progress southward it becomes more multiplied; but along the Atlantic, it is proportionably less common than many other trees which do not form the mass of the forests. In the lower parts of the southern states, it is much less frequently seen, than at a distance from the ocean, where the soil and vegetable productions wear a different character. It is most frequently met with in Pennsylvania, Virginia, Ohio, Kentucky, and Tennessee, and particularly abounds on the banks of the Wabash, the Illinois, and the Missouri, which is attributable to the superior fertility of the soil.

This species was cultivated in Britain, according to Parkinson, early in the XVIIth century. He says, in his "Paradisus," "it grows quickly with us to a large tree," and that "the fruit is long, red, and pleasantly acid." Miller mentions a tree of this species in the garden at Fulham Palace, which, in 1731, had been there many years without producing any fruit; but which, at some seasons, bore a great number of catkins, much like those of the hazel-nut; which caused Ray to give it the name of Corylus. Almost the only plants of the Morus rubra, of much magnitude, in the environs of London, are those mentioned by Mr. Loudon, as growing in the garden of the Horticultural Society, and in the arboretum of Messrs. Loddiges, at Hackney. In 1836, these trees were from eight to sixteen feet high.

In France, in the Jardin des Plantes, at Paris, there is a tree of this species, which, in fifty years after planting, had attained the height of forty-five feet, with a trunk a foot and a half in diameter, and an ambitus or spread of branches of thirty-eight feet.

In Italy, at Monza, there is a Morus rubra, which, in sixty years after planting, had attained the height of twenty-six feet, with a trunk two feet in diameter, and an ambitus of thirty feet. 
In the Bartram botanic garden, at Kingsessing, near Philadelphia, there is a red mulberry-tree, forty feet in height, with a trunk four feet in circunference.

Propagation, $\mathcal{f}^{\circ} \mathrm{c}$. The Morus rubra, like the white, and black-fruited species, may be propagated from seeds, by cuttings and layers, or by grafting; and, in general, will thrive with similar treatment. Its growth. however, is more slow, and it requires a richer soil, and succeeds best in sheltered valleys, at a considerable distance from the sea.

Insects. It has frequently been asserted, and is generally believed, that the leaves of this species are not fed upon by any insect but the silkworm. In simith and Abbott's work on the "Insects of Georgia," however, a specimen of the red mulberry is given, with the small ermine moth, (Phalæula punctatissima,) feeding on it.

Properties and Uses. The perfect wood of the Morus rubra, which is finegrained, and compact, though light, is of a yellowish hue, approaching to lemoncolour. It possesses strength and solidity; and, when properly seasoned, it is almost as durable as that of locust, to which, by many persons, it is esteemed equal. In the dock-yards at Philadelphia, Baltimore, and the more southern ports, it is employed in the construction of both the upper and lower frames of vessels, for knees, floor-timbers, \&c.; and is preferred to every other kind of wood for trenails, except that of the locust. In Charleston, South Carolina, it is sonetimes selected for the ribs of large boats. It is also used in the parts of the country where it abounds, for the posts of rural fences, which, from their durability, are as much esteemed as those of the locust. As the leaves of this species are thick, rough, and hairy, while young, they are improper for the food of silkworms, which feed with advantage, in a cold climate, only on the Norus alba, or some of its varieties. The red mulberry is well deserving of cultivation, both from its thick and shady foliage, and the agreeable flavour of its dark-red fruit. 


\title{
Genus BROUSSONETIA, L'Hérit.
}

Urticacex.
Syst. Nat.

\begin{abstract}
Synonymes.
\end{abstract}
Diœcla Tetrandria.

Syst. Lin.

\begin{abstract}
Broussonetia, Morus, Papyrus,
Derivation. The genus Broussonetia was so named in honour of M. P. N. V. Broussonet, a French naturalist, who wroto numerous works on natural history.

Generic Characters. Flowers unisexual; those of the two sexes upon distinct plants. Male flowers in pendulous cylindrical catkins; each flower in the axil of the bractea. Calyx shortly tubular, then 4parted. Stamens 4, elastic. Female .flowers in peduncled, axillary, upright, globular heads. Calyx tubular, its tip with $3-4$ teeth. Ovary within an integument that arises from the bottom of the calyx. Style lateral, prominent. Fruit club-shaped, proceeding from the bottom of the calyx, and extended much beyond its tip; and consisting of the integument in which the ovary was enclosed, and now becomes very juicy; and of a 1-seeded oval utricle, with a crustaceous integument, and enclosed within this juicy integument.-Du Hamel, Traité de Arbres.
\end{abstract}

OF AUthors.

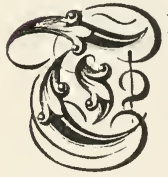

HE genus Broussonetia was constituted by L'Héritier from the Morus papyrifera, and is said to comprise but one species, native of Japan, and the Islands of the Pacific Ocean. It consists of a vigorous-growing shrub or low tree, with large-lobed, hairy leaves, variously shaped, and differing so much from each other on the tunct species. male and female plants, that they might be easily taken for dis-

To the same natural order belong the fustic-trees of the tropics, which are more nearly allied to this genus than to morus. They differ from the true mulberries by having the female catkins globular, the flowers distinct, calyx scariose, 4-parted; the sepals unequally obovate, obtuse, the ovary obovate-compressed; the style single, terminal, smooth, filiform, and flexuose; and the fruit a globular, compound berry or syncarpe; whereas the true mori have double styles and stigmas, and oblong fruits. There are several kinds of fustic-trees, which might be formed into a peculiar group, from their baccate seeds. The true fustic of dyers, (Morus tinctoria,) is a large tree, sixty feet in height, bearing sweet, edible fruit, about the size of a nutmeg, and is a native of Central America, Yucatan, Cuba, Jamaica, \&c. The whole plant abounds in a slightly glutinous milk, of a sulphureous colour. The wood is yellow, and is much used in dyeing, for which purpose it is chiefly imported into Europe and the United States, under the name of fustic-wood. There is a variety of this species, called Bastard Fustic, a tree smaller in stature, and less valuable as a dye, and is found from Yucatan to the southern parts of Florida and the Bahama Islands. 


\title{
Broussonctia papyrifera,
}

\section{THE PAPER MULBERRY-TREE.}

Synonymes.

\author{
Morus papyrifera, \\ Broussonetia papyrifera,
}

Linnzus, Species Plantarum.

\{ Dos, Miller's Dictionary.

Loudon, Arboretum Britannicum.

Broussınetia à papier, Mûrier à papier,

Mûrier de la Chine, Papyrier,

Papier-Maulbeerbaum,

Moro papirifero, Moro della China,

Paper Mulberry-tree,

\author{
France. \\ Germany. \\ ITALY. \\ Britain and Asglo-America.
}

Derivations. The specific name papyrifera is derived from the Latin papyrus, paper, and fero, to bear ; referring to the us ot the bark of this tree in the manufacture of paper. Most of the other names have the same signification as the botanical one

Engravings. Nouveau Du Hamel, ii., pl. 7; Loudon, Arboretum Britannicum, vii., pl. 223; and the figures below.

Specific Characters. Female calyx tubular, 3-4 dentate; style lateral; seed clavate. Leaves 3-5. lobed, acuminate, serrated, scabrous.

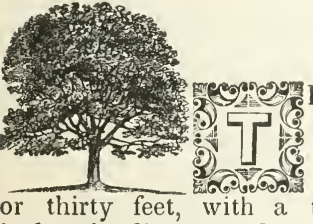
inches in diameter; but in favourable situations, it sometimes attains nearly double of these dimensions. Its trunk ramifies at a small height above the ground, into numerous branches, which form a wide, though regular summit. The bark of the trunk, when young, is rather smooth, and of a grayish colour. Its leaves are large, hairy, and canescent; and are either heartshaped, ovate, acuminate, or cut into deep, irregular lobes. The flowers, which appear at New York early in Nay, before the leaves, are succeeded by an oblong, dark, scarlet-coloured fruit, of a sweetish, but rather insipid taste, when ripe, which occurs at New York, in July or August.

Varieties. The varieties recognized under this species are as follows:-

1. B. P. cucullata, Loudon. Cowled-leaved Puper Mulberry; a sport, founa on a male plant by M. Camuset, foreman of the nursery, in the Jardin des l'lantes, at Paris, with leaves curved upwards, like the hood of a Capmchin, or the sides of a boat.
2. B. P. Fructu albo, Loudon.
White-fruited Paper Mullorry.

Geography and History. The Broussonetia papyrifera, is a native of Chma, Japan, and Polynesia, and is now cultivated, as an ormamental tree thronghout the chief countries of Europe, and in most of the states of the Ameriean minu.

This tree was introdnced into Britain, from Japan. by Mr. Peter ('olinson. in 17.51; and specimens varying from ten to thirty fect in height, are to be met with in most of the gardens and collections in Fingland and sootland. Buth the male and female plant have long been cultivated in the Iondon Horn- 
cultural Society's garden, at Turnham Green, and in the arboretum of Messrs. Loddiges, at Hackney.

The largest recorded tree of this species in France, is in the botanic garden, at Avranches, which, in 1835, forty years after planting, had attained the height of forty feet, with a trunk two feet and a half in diameter, and an ambitus or spread of branches of thirty feet.

In Italy, at Monza, there is a paper mulberry, which, in twenty-four years after planting, had attained the height of forty feet, with a trunk a foot in diameter, with an ambitus of twenty feet.

The male plant of the Broussonetia papyrifera was introduced into the United States, from Europe, in 1784, by Mr. William Hamilton, of the Woodlands, near Philadelphia, who had, at one period, the most complete collection of foreign trees of any one in America. The paper mulberry, was also cultivated, either from seeds or importation, by the late William Prince, of Flushing, Long Island, prior to 1820. To this gentleman we are indebted for three female trees, standing opposite No. 3, in Abingdon square, in the city of New York, all of which matured their fruit early in July and August of the years 1843 to 1845 .

This species is among the most common of ornamental trees in New York, Brooklyn, Philadelphia, and other parts of the union, where there are specimens frequently to be met with, varying from twenty to forty feet in height, with trunks from ten inclies to two feet in diameter.

Propagation, $\mathcal{S}^{\circ} c$. The paper mulberry may be propagated either from seeds, by suckers, or by cuttings; but the latter mode is nsually adopted, as the cuttings of the branches, whether large or small, readily take root and thrive, in any soil, consisting of a moderately rich sandy loam, that is not too dry, nor sur charged with moisture. The tree is perfectly hardy in Britain, and will with stand the climate, without injury, of any part of the United States south of Con. necticut; but eastward of that state, it is frequently killed back by frosts, and as far north as Montreal, in Canada, it will barely live without protection.

Properties and Uses. The wood of the paper mulberry, which is soft, spongy, and brittle, is of little value except for fuel. 'The leaves are too rough and coarse, in their texture, for the food of silkworms; but they are found to be excellent fodder for cattle; and as the tree will grow rapidly in ahmost every soil, and throw out numerous tufts of leaves, it has been suggested that it might be valnable to cultivate, in some situations and climates, for that purpose. The juice of this tree is sufficiently tenacious to be used in China as a glue, either in gilding leather or paper. The finest and whitest cloth worn by the inhabitants of Otaheite, and of the Sandwich Islands, is made of its bark. But the principal use, however, to which this tree appears to be applied, is for the manufacture of paper. The following is an abridgment of Kæmpfer's account of the process of making this article in Japan, as quoted from the fifth volume of the London "Pen" Cyclopædia":- "The branches of the current year, being cut into pieces about a yard long, are boiled until the bark shrinks from the wood, which is taken ont, and thrown away; and the bark, being dried, is preserved till wanted. In orde. to make paper, it is soaked for three or four hours in water; after which, the external skin, (epidermis,) and the green internal coat, are scraped off, and the strongest and finest pieces are selected; the produce of the younger shoots being of an inferior quality. If any very old portions present themselves, they are on the other hand rejected as too coarse. All knotty parts, and everything which might impair the beauty of the paper, are also removed. The chosen bark is boiled in a lixivium till its downy fibres can be separated by a touch of the finger. The pulp, so produced, is then agitated in water till it resembles tufts of tow. If not sufficiently boiled, the paper will be coarse, though spongy; if too much, it will be white, indced, but deficient in strength and solidity. Upon the various 
degrees and modes of washing the pulp, much also depends as to the quality and beauty of the paper. Mucilage obtained from boiling rice, or from a root called oreni, one of the mallow tribe, is afterwards added to the pulp. The paper is finished much after the European mode, except that stalks of rushes are used, instead of brass wires." The article thus made, constitutes the India or China paper used by engravers for taking proofs, and by chemists for filters.

In Europe and America, this species is solely considered as an ornamental tree; and, from its hardihood and rapidity of growth, and its singularly beantiful, light, open foliage, which is attacked by no insect, it is rendered a most desirable object for shading streets and avenues. 


\section{Genus MACLURA, Nutt}

Urticaceæ.
Syst. Nut.

Maclura, Toxylon,
Diøcia Tetrandna.

Syst. Lin

Synonymes.

Derivation. This was named by Nuttall, in honour o: the late Mr. William Maclure, of Philadelphia, a celebrated natural ist, and patron of science.

Generic Characters. Flowers diœcious. Male flowers with the calyx 4-cleft. Stamens 4, exserted. Eemale flowers in globular aments; the calyx fleshy, 4-parted, with the bases ingrafted together. Corolla none. Style 1, filiform, villous. Germs numerous, each 1-seeded, coalescing into a compound globular berry of many cells, the cells 1 -seeded. Seed obovate.-Nuttall, Sylva.

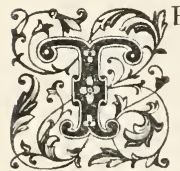

HE genus Maclura embraces but one species, indigenous to North America, a lactescent tree, intermediate between the fustic, (Morus tinctoria,) and the bread-fruit tree (Artocarpus incisa.) The latter is a native of the South Sea Islands, growing to the height of thirty feet, and abounding throughout, in a very tenacious milky juce. Its fruit, when fully ripe, is nearly round, from twelve to twenty inches in girth, with a rough, reticnlated surface, and is covered with a thin skin. The eatable part, which is of a snowy whiteness, lies between the skin and a core, and has somewhat the consistency of newly-made bread; hence the name.

Closely allied to the maclura, is the celebrated Arbol de la Vaca, or cow-tree, (Galactodendrum utile,) of South America, sometimes growing to the height of one hundred feet, with a trunk six feet in diameter, and having leaves resembling those of the laurel. It yields a profuse supply of nutritions milk, by making an incision in the bark, which tastes somewhat like that of a cow, but slightly bitterish to the taste, and producing a disagreeable clamminess on the lips.

To the same natural order belongs the Jamaica bread-nut, (Brosium alicastrum,) a native of the woods of Cuba and Jamaica, the leaves and younger branches of which are full of gum, and afford an excellent fodder for cattle. The nuts or fruit, when roasted, are sometimes used instead of bread, and have a taste not unlike the European chesnut. Boiled with fish or flesh, they are also eaten as food in times of scarcity, by the poor, and prove nutritious and pleasant to the taste. 


\section{Maclura aurantiaca, \\ THE OSAGE ORANGE-TREE.}

Synonymes.

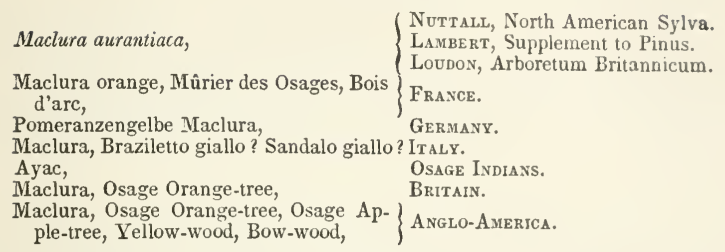

Derivations. The specific name aurantiaca is derived from the Latin aurum, gold; from the colour of the fruit of this apecies. It was called Bois d'arc, (bow-wood,) by the French Canadians, on account of being used by the Osages for making hunting-bows.

Engravings. Nuttall, North American Sylva, pl. 38; Loudon, Arboretum Britannlcum, iii., fig. 1226, 1227 et 1228 ; and the figures below.

Specific Characters. Leaves smooth, lucid, ovate-acuminate, petiolate, entire, with a recurved spine near the base. Flowers axillary, peduncled, and occurring in small umbels. Fruit an axillary berry, subsessile, drooping, yellow, and about the size of an orange.

\section{Description.}

ciduous tree, usually growing to a height of twenty-five or thirty feet, with a trunk from twelve to eighteen inches in diameter; but, in very favourable situations, it sometimes attains double of these dimensions. The branches, which are covered with a smooth, grayish bark, are somewhat inclined to spread, when old, though, at first, the tree presents an elegant, roundish summit. "But at all times, it strikes the beholder as something remarkable, in the northern forest, by the beauty and splendour of its dark and shining foliage, which, in appearance, strongly resembles that of the orange, and the numerous spines, which the branches present, seem to confirm the comparison."* The leaves, which are broad, and from two to four inches long, are alternate, ovate, acnminate, having a cuspidate point, smooth, entire, of a bright, shining green on the upper surface, with the petioles and nerves beneath, pubescent, when yonng; bnt, on the branches bearing fruit, they are somewhat larger, and heart-shaped at the base. 'The spines, which are produced in the upper axils of the leaves, are simple, rather strong,

* Nuttall, North $\Lambda$ ncrican Sylva, p. 127. 
and an inch or more in length. The male flowers, which put forth in April or May, are inconspicuous, nearly green, with a slight tinge of yellow, and occur in small, pedunculated, axillary umbels. "The female capitulum consists of a congeries of flowers united into a globular form, about the size of a cherry; they consist also in a calyx of four divisions, but less regular than the male. The styles and stigmas, one to each germ, are three-fourths of an inch long, giving to the ament the appearance of a tuft of long, pubescent threads."* The fruit, which matures at Philadelphia, in September or October, is of the size and general appearance, at a distance, of a large Seville orange. It consists of numerous, radiating, somewhat woody fibres, terminating in a verrucose, reticulated surface, resembling that of a truffle, or the bread-fruit; and contains, when perfect, numerous, obovate, depressed seeds (or nuts, as they are botanically termed,) about the size of those of an orange, and a considerable quantity of a sweetish, lacteous fluid, which, when exposed to the action of the air, coagulates like milk.

Geography and History. The Maclura aurantiaca is indigenous to Arkansas, Texas, and upper Missouri, and is cultivated for oruament or use, in most of the collections and gardens, both in Europe and in America. It is perfectly hardy in the climate of London, and of New York, and has ripened its fruit at Lyons, at Clairvaux, near Chatellerault, and at Montpellier, in France; at Monza, in Italy; and in the United States, as far north as Philadelphia; but as we proceed eastward or northward of that city, although the tree survives the winters in the vicinity of Boston, without much protection, it begins to dwindle, and at Montreal, in Canada, it will barely live.

This species was first noticed by the travellers, Hunter and Dunbar, on the banks of Red River, and in the deep, fertile bottoms of the adjacent valley. It was also observed along the rivers Arkansas and Canadian, by Dr. James, in Major Long's expedition, the banks of the former being considered as its northernmost limit, as an indigenous tree. It was first cultivated among the white settlers of the west, in about the year 1800, in the garden of M. Chouteau, at St. Louis, on the Mississippi, where it was propagated from some seeds procured from a village of Osage Indians; whence it obtained its popular name. It was subsequently planted in the nursery of the late Mr. M'Mahon, of Philadelphia, from seeds collected by Lewis and Clarke, on their western expedition, in 1803 to 1805 ; and shortly after, in the garden of Mr. Landreth, in Federal street, of the same city, where, one of the original trees still exists, and has attained the height of thirty feet, with a large, round head, and a trunk two feet in diameter. This tree annually produces fruit, which has been rendered perfect, by tying on the branches, when in bloom, stameniferous flowers, obtained from a distant tree. The trees propagated by Mr. M'Mahon, were planted two and two, each pair being about four hundred feet apart. In the year 1831, it was discovered that one of these trees produced larger fruit than the others, and that this fruit contained perfect seeds. Two of the other trees produced smaller fruit, but the seeds they contained were abortive; while one of the trees was entirely barren. The next year, it was further discovered, that the barren tree was a male plant; and that the one by its side that had produced perfect seeds, was a female. $\dagger$

At Beaver Dam, in Virginia, a female tree of this species, with a large, globular head, yielded, in 1835, one hundred and fifty fruits, many of which weighed eighteen or nineteen ounces each.

There is also a cultivated tree of this sort, in the Bartram botanic garden, at Kingsessing, which has attained the height of twenty feet, with a trunk ten inches in diameter, and fruits freely every year.

* Nuttall, North American Sylva, p. 129.

† A merican Gardener's Magazine, ii., p. 77. 
In about the year 1818, seeds of this tree were sent to England by Senhor Correa de Serra, a Portuguese botanist and diplomatist; and, subsequently, plants of both sexes, were imported by the London nurserymen, and trees are to be met with in various parts of the kingdom, varying from ten to twenty-five feet in height, with trunks of proportionate diameters.

In France, in the Jardin des Plantes, at Paris, there is a tree of this species, which, in ten years after planting, had attained the height of eighteen feet. At Lyons, in the nursery of M. Sidy, there is another specimen, which has fruited. exceeding twenty-five feet in height.

Propagation, $\mathcal{S} \cdot c$. The Machura aurantiaca may readily be propagated from seeds, by cuttings of the roots, by layers, and by grafting or inoculation; and it will grow in any common soil in which the Morus alba will thrive. As the male plant appears to be constitutionally weaker, more delicate, and shorter-lived than its opposite sex, and as its presence is absolutely necessary to produce perfect srieds, it has been suggested that it be grafted or inoculated on the branches of the female tree, in order to add to the size and beauty of the fruit, and to facilitate in the dissemination of the species. When propagated from cuttings or layers, and if cut down to the ground after two or three years' growth, it will throw up shoots or suckers six or eight feet in height, and not more than half of an inch in diameter, with fine, broad, shining, succulent leaves. In the United States, where the surface of the ground is exposed to the extremes of heat and cold, the maclura, like the vine, the mulberry, and many other trees, should be planted deep in the earth, otherwise its roots will often be injured by drought or frost.

Properties and Uses. The wood of the maclura is of a bright-yellow colour, somewhat resembling that of the fustic, (Morus tinctoria,) and, like the wood of that tree, it is said, affords a yellow dye. It is solid, heavy, durable, uncommonly fine-grained, and elastic; and, on account of the latter property, it is used for bows by all the tribes of Indians of the regions where it abounds. When wrought, it receives a beautiful polish, of the appearance and brilliancy of satinwood, and might be employed for inlaying the finer kinds of furniture. The sap of the young wood and leaves is of a milky consistency, and soon dries, on exposure to the air. It is insoluble in water, and contains a large proportion of an elastic gum. The bark, like that of the paper mulberry, (Broussonetia,) yields a fine, white fibre, which might be converted into a beautiful hinen. The fruit, when ripe, abounds in a sweetish, lacteous fluid, somewhat acrid and insipid to the taste, which renders it unpalatable both to man and animals. The maclura is also advantageously employed for hedges or live fences, for which purpose it appears to be admirably adapted, as its branches grow close, are armed with strong, sharp-pointed spines, will endure the shears, and for a long time retain their foliage, which is free from the attacks of insects, and the blight. The maclura has likewise been used as a stock on which to engraft the nulberry, and its leaves have been employed, in France, with partial success, as food for silkworms. M. Bonafous, visiting the botanic garden, at Montpellier, in 1835, and observing the luxuriance with which this tree grew, conceived that it might be substituted for the mulberry in the culture of silk. He had a number of the leaves gathered, on which he fed eighteen silkworms, as their only food, and it is said they produced very beautiful cocoons. A second experiment was made by M. Raffeneau De Lile, directeur of the same garden, in 1536, by giving fifty silkworms the leaves of this tree, during only the latter stages of their existence. They were not fed on the maclura till the 19th of May, when they cast their second skins. It is said they never seemed to eat the leaves greedily, although they increased in size as much as those that were fed on the leaves of the mulberry. In the course of feeding, fifteen of the worms wandered away, and were lost; and during the time of spinning, twenty more died, the latter beconing 
black, rotten, and reduced to a liquid. The cocoons were not formed till some days after those of the worms which fed on the mulberry; only five of them being quite perfect, and several of them tolerably so, from all of which, the silk reeled freely, and was of an excellent quality.* Other experiments have since been made in Italy and other places, but with still less favourable results.

The maclura, from its general form, its beautiful shining foliage, which it retains longer than almost any other deciduous tree, and from its fine, large golden fruit, well deserves a place in every collection wherever it will grow.

* Otto, Garten Zeitung, iii., p. 292. 


\section{Genus FICUS, Tourn.}

Urticacex.
Syst. Nat.
Polygamia Dicecia.
Syst. Lin.

\section{Synonymes.}

Ficus,

Figuier,

Feigenbaum,

Fico,

Figuera, Higuera,

Figueira,

Fig-tree,
OF Adthors.

France.

Germany.

ITALY.

Spain.

Portugal.

Britain and Anglo-America.

Derivation. The word Ficus, according to some lexicographers, is derived from the Latin focundus, fruitful; on accouns of its abundant bearing; but others derive it from the Greek sukos, or more remotely from the Hebrew, fag, the names of the fig-tree in these languages.

Generic Characters. Flowers inserted upon the interior surface of a hollow, globular or pear-shaped, fleshy receptacle, in the tip of which is an orifice, closed with small scales; minute, many within a receptacle; those in the upper part male, the rest female; or the flowers of each sex occupy distinct receptacles upon distinct plants. Calyx of male 3-parted. Stamens 3 . Calyx of female flower 5cleft, having a tube that invests a thread-shaped stalk that bears the pistil. Stalk adnate to the ovary on one side, and extending to the base of the style; the style is inserted rather laterally. Ovary with 1 cell and 1 ovule. Stigmas 2. Fruit a utricle. Seed pendulous. Embryo falcate, in the centre of a fleshy albumen.-Nees Von Esenbeck, Genera.

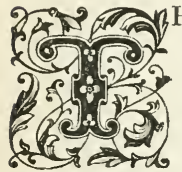

HIS genus consists of trees and shrubs occurring in the warmer regions of both hemispheres, remarkable, in a popular sense, for having their flowers concealed by the fleshy receptacle known as the fruit. There are only two species which bear edible fruit, the common fig, (Ficus carica,) hereafter considered, and the sycamore, (Ficus sycomorus,) mentioned in "Holy Writ," a native of Egypt, holding a medium rank among timber trees.

Among the numerous species of this genus described by botanists, may be mentioned the famous banian-tree, (Ficus benghalensis,) held sacred with the Hindoos in the East Indies, from the vast size that it attains, and from the singularity of ite growth. This tree is described by Pliny with an accuracy, which has been confirmed by more recent observations, and which has been rendered almost literal by the poet Milton, in the following beautiful lines :-

\footnotetext{
"Branching so broad along, that in the ground

The bending twigs take root; and daughters grow

About the inother tree; a pillared shade,

High over-arched, with echoing walks between."
}

The fruit of the banian does not exceed a hazel-nut in size; but the lateral branches send down shoots which take root, till, in the course of time, a single tree extends itself to a considerable grove. From this, as well as most other species of ficus, may be extracted an elastic gum, resembling the cuuntchouc of commerce, which is principally obtained from the Hevea guianensis, a native of the equatorial regions of America. 


\section{Ficus carica, THE COMMON FIG-TREE.}

\section{Synonymes.}

Ficus cari:a,

Figuier cultivé, Figuier commun, Bou, Gemeiner Feigenbaum, Fico,

Fig-tree, Common Fig-tree,
(Linneus, Species Plantarum.

Du Hames, Traité des Arbres et Arbustes.

Loudon, Arboretum Britannicum

Frané.

Germany.

ItALY.

Britain and Anglo-America.

Derivation. The specific name carica is supposed to be derived from Caria, in Asia; whence this species is said originally to have been brought.

Engravings. Du Hamel, Traité des Arbres et Arbustes, pl. 53; Loudon, Arboretum Britannicum, vii., pl. 229; and ths aigures below.

Specific Characters. Leaves palmate and sub-trilobate; rough above, pubescent beneath.

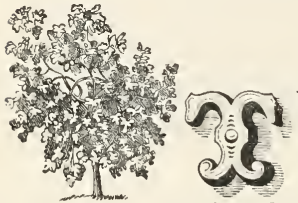

\section{Description.}

$\mathrm{HE}$ Ficus carica is a large shrub or low tree, sometimes growing, under favourable circumstances, to a height of twenty-five to thirty feet, with a trunk from a foot to a foot and a half in diameter; but usually it does not much exceed one half of these dimensions. The branches, when young, are clothed with short hairs, but become smoother with age; and the bark of the trunk is of an ash-colour, or greenish-gray. The leaves, which are annual in the temperate zones, and perennial within the tropics, are comparatively small, in a wild state, entire, or not much cut; but, in the

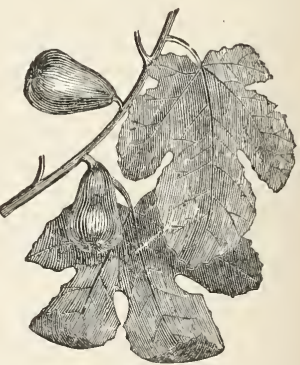
cultivated varieties, they are very large, cordate, deeply cut, with from three to five lobes, thick, rough on the upper surface, and pubescent beneatl. The fruit consists of a pulp, containing a number of seed-like pericarps, enclosed in a blue or black, red or purple, green or yellow, or white rind. Botanically, it is a turbinate berry, hollow within, and is produced chiefly on the upper part of the shoots of the former year, in the axils of the leaves, on small, round peduncles. It first protrudes from the branches, without any visible flower, in the form of little buds, with a perforation at the end, but not opening or showing anything like petals, or any of the common organs of fructification. The flowers come to maturity in concealment, in what is considered as the fruit; that is, an ordinary calyx or receptaçle, which is usually, but not always, entire and connivent; for, there : $r$ re some few sorts, in which the fruit constantly opens when it approaches maturity, commonly dividing into four parts, that expand like the petals of a flower, to such an extent, that each division becomes perpendicular to its stem.* The !nale flowers, which are comparatively few, are inserted near the perforation at the extremity of the receptacle, or fruit; but the female flowers are very numer-

* The varieties which exhibit this singularity, are called, in the "Nouveau Du Hamel," Barnissotes and Verdales 
ous, and fill the remainder of the hollow space within. The greater part of the latter prove abortive, either with, or without, the process of caprification. The fig, in warm, temperate climates, as in many parts of the east, unlike almost every other tree, bears two, and sometimes three successive crops of fruit in the same year, each crop being generally produced on a distinct set of shoots.

Varielies. The varieties of this species are very numerous. Besides the common wild fig, (Caprificus,) there are noticed in the "Nouveau Du Hamel," thirty-six choice kinds, several of which are figured. In nurserymen's catalogies there are enumerated upivards of one hundred sorts, exclisively of synonymes. The following are a few of those most celebrated:-

1. F. c. CANDida. White-fruited or Marseilles Fig; Fignier blanc, of the French. The leaves of this variety are very large, but not very deeply lobed. It produces an excellent fruit, known in commerce by the name of figues marseillaises. It forms a very desirable tree, when treated as a standard, and is well adapted for the climate of London, and of the sonthern parts of the United States.

2. F. c. Lutea. Yellow-finited Fig; Figuier jaune, of the French. The fruit of this variety is known in France, by the names of figues angéliques, or figues grasses.

3. F. c. PYriforuis. Pear-shaped Fig; Fignier pyriforme, of the French, producing the figues de Bordeanx.

4. F. c. violacea. Violet-coloured-fruited Fig; Fignier violet, of the French.

Geography and History. The common fig is indigenons to the west of Asia, and the shores of the Mediterranean, both in Europe and in Africa. In no country is it found at a great distance from the sea, and rarely in very elevated situations. Hence its abundance in the islands of the Grecian Archipelago, the Azores, Madeira, and the Canary Isles, and on the adjacent continent.

According to the traditions of the Greeks, the origin of the fig may be traced back to the remotest antiquity. It was probably known to the people of the east before the cerealia, and stood in the same relation to the primitive inhabitants of society, as the banana does to some of the present tribes of Africa, or the Indians of South America. With little trouble of cultivation, it supplied their principal necessities; and afforded, not only an article of occasional luxury, but of constant food, either in a fresh or in a dried state. As we proceed to a more advanced stage of civilization, we still find the fig an object of general attention. It is often mentioned both in the Old and in the New 'Testament, in a manner to induce us to conclude that it formed a principal part of the food of the syrian nation. The want of a blossom on the fig-tree was considered as one of the most grevious calamities of the Jews. It is also a fruit that appears to have been highly esteemed by the Israelites, who brought figs out of the land of Canaan, when they were sent by Moses to ascertain the produce of that country. Calies of figs were included in the presents of provisions by which Abigail, the wife of Nabal, appeased the wrath of David. King Hezekiah's boil was cured by a lump or pouitice of figs, applied according to the direction of Isaiah, and which, a learned doctor observes, is the first poultice we read of in history.

Among the Greeks, we find, by the laws of Lycurgns, that figs formed a part of the ordinary food of the Spartans. It would seem that the Athenians were so choice of their figs, that they did not allow them to be exported; for, by a law of Solon, no production of the Attican lands, except oil, was allowed to be sold to strangers; and therefore, it is not improbable, what some aflirm, that the exportation of figs was forbidden, and that the informers against the delinquents were called sukophantai (from the Greek sukon, a fig, and phuino, to show, or give proof of); and as they sometimes gave malicious information, the term was after- 
wards applied to all informers, parasites, liars, flatterers, imposters, \&c.; hence the modern word sycophant.

The fig was a fruit much admired by the Romans, who brought, it from most of the countries they conquered, and had so increased the varieties in Italy, by the commencement of the Christian era, that Pliny has furnished us with a description of twenty-nine sorts. He says, "figs are restorative, and the best food that can be taken by those who are brought low by long sickness, and are on the recovery." He adds, "that figs increase the strength of young people, preserve the elderly in better health, and make them look younger, and with fewer wrinkles. They are so nutritive as to cause corpulency and strength; on which account, professed wrestlers and champions were in times past, fed with figs." This naturalist mentions the African figs, as being admired; but says, "it is not long since they began to grow figs in Africa." These appear to have been of an early kind; for, we find that, when Cato wished to stimulate the senators to declare war against Carthage, he took an early African fig in his hand, and then addressing the assembly, he said, "I would demand of you how long it is since this fig was plucked from the tree?" and when they all agreed that it was freshly gathered, "Yes," answered Cato, "it is not yet three days since this fig was gathered at Carthage; and by it, see how near to the walls of our city we have a mortal enemy." "With this argument, he prevailed upon them to begin the thrrd Punic war, in which Carthage, that had so long been a rival to Rome, was utterly destroyed. "The Lydian figs," continues Pliny, "are of a reddish-purple colour; the Rhodian, of a blackish hue; as is the Tiburtine, which ripens before the others. 'The white figs were from Herculaneum; the Chelidonian figs are the latest, and ripen against the winter; some bear twice a year, and some of the Chalcidian kinds bear three times a year." The Romans had figs from Chalcis and Chios, and many of their varieties, it appears, were named after those who first introduced or cultivated them in Italy. For instance, the "Livian Fig" was so called after Livia, wife of the Emperor Augustus, who; it is said, made the unnatural use of it to poison her husband.

The fig-tree is said to have been first brought from Italy into Britain, in 1525, by Cardinal Pole; though probably it was introduced long before, by the Romans and the monks. The specimens, which were of the Marseilles kind, were planted against the walls of the archiepiscopal palace, at Lambeth, and bore excellent fruit. In the course of their long existence, they attained a size far exceeding the standard fig-tree in its natural habitat, being fifty feet in height, with trunks from twenty-one to twenty-eight inches in circumference, and a spread of branches of forty feet. These trees were much injured by the severe winter of 1813-14; but the main stems, being cut down, they recovered, so as to be in tolerable vigour, in 1817; but some years since, while the palace was under repair, they were destroyed. The "Pocock Fig-tree" was once supposed to have been the first of the white Marseilles figs, introduced into England. The tradition is, that it was brought from Aleppo by Dr. Pocock, the celebrated traveller, and planted in the garden of the Regius Professor of Hebrew, at Christ-Church, Oxford, in the year 1648. Some of the figs of this tree were exhibited at a meeting of the London Horticultural Society, in August, 1819; and others gained a premium as the best white figs, at a meeting of the Oxford and Oxfordshire Horticultural Society, in August, 1833. In the year 1806, this tree was twenty-one feet high, with a trunk three feet and a half in circumference at its upper part. It received considerable damage from the fire that happened at Christ-Church, on the $3 \mathrm{~d}$ of March, 1809, some time previous to which, its trunk had been covered with lead to preserve it from the injuries of the weather; but at the time of the fire the lead was stolen, and, soon after, the trunk itself decayed, and was principally removed. In 1833 , at the time Mr. Loudon visited this tree, there were 
but slight remains of the old trunk to be seen, which had thrown ont a number of branches, perhaps of twenty or thirty years' growth, and upwards of twenty. five feet in length. The fig-tree, though introduced so early, appears for a long time, not to have been extensively cultivated in England, which is thought by Professor Burnet to be owing to a popular prejudice that existed against this tree, as once having been a common vehicle for poison, - a singular contrast to the ideas expressed in "Holy Writ" respecting this fruit; the best blessing of heaven being typified by

"Every man sitting under his own fig-tree."

The fig is in general cultivation in first rate British gardens, usually against walls; but in some parts of the southern counties, as along the coast of sinssex, and in Devonshire, icc., it is propagated as a standard. In scotland, it is never grown as a standard; but, in some parts of East Lothian, and in Wigtonshire, it ripens its fruit against a south wall, without the aid of artificial heat.

The largest fig-tree, as a wall fruit, in England, is at Farnham Castle, where, in twenty-five years after planting, it had attained the height of forty feet.

The largest standard tree of this species in England, is at Armolel Castle, in Sussex, and exceeds twenty-five feet in height, with a trunk a foot in diameter.

In France, the culture of the fig-tree was not carried to any degree of perfection till the time of Olivier de Serres; but it is now general thronghout the whole country. In the southern departments, its fruit is grown for drying, as an article of commerce, but in the northern districts, it is only used for the table. In the neighbourhood of Nantes, the tree, as a standard, seldom exceeds eighteen feet in height; but at Avignon, it attains an elevation of twenty or twenty-five feet.

In Italy, at Monza, there is a fig-tree, which, in sixty years after planting, had attained the height of thirty feet, with a trunk eighteen inches in diameter, and an ambitus of sixty feet.

In the east, as well as in Italy and Spain, the fig forms a considerable article of commerce, as well as a considerable part of the sustenance of the population.

In the sonthern states of the American union, the fig-tree is planted as a standard, and prodinces fruit of an excellent quality. In the middle and northem states it is propagated as a conservatory or wall tree, and necessarily requires protection during winter.

Mythological and Legendary Allusions. The Egyptians and Greeks held the fruit of this tree in great estimation; it being the custom to carry a basket of figs next to the vessel of wine used in the Dimnysia, or festival in honour of Bacchus. The Romans, also, carried the fig next to the wine, in their processions, in honour of the same god, as a patron of joy and plenty; and Bacchus was supposed by them, to have derived his corpulency and vigour from this fruit, and not the grape. Saturn, one of the Roman deities, was represented crowned with new figs; he being supposed to have first taught the use of agriculture in Italy. There was a temple in Rome, dedicated to this got, before which grew a large fig-tree. The fig is related to have been the favourite fruit of Cleopatra; and the asp, with which she terminated her life, was conveyed to her in a basket of figs. The story of Romulus and Remus being suckled by a wolf muder a fig-tree, is familiar to every one conversant in ancient history. 'l'imon, of Athens, who was called Misanthrope, from his aversion to mankind and all socicty, once went into a public place, where his appearance, as an orator, soon collected a large assembly, when he addressed his countrymen, by informing them that he had a fig-tree in his garden, on which many of the citizens had ended their hre's with a halter; and that, as he was going to cut it down, he advised all those that were inclined to leave the world, to hasten to his garden and hang themselves. It 
would seem, from some of the old English writers, and indeed from a common expression even of the present day, that, from some association of ideas, the fig was an object of contempt. " "Figo for thy friendship," says Pistol, in Henry IV Steevens, the commentator on Shakspeare, thinks that the "fig of Spain," mentioned by many of the old British poets, alluded "to the custom of giving poisoned figs to those who were the objects of Spanish or Italian revenge;" and hence, probably, a vulgar prejudice against this fruit.

Propagation, Management, $\mathcal{S}^{\circ} \mathrm{c}$. 'The common fig-tree is easily propagated by cuttings of the shoots or roots, (not one of which will fail,) and also by suckers, layers, and seeds. In France, more particularly about Marseilles, where the fig is extensively grown as an article of commerce, an open situation is made choice of, for a plantation, near the sea, and exposed to the south and east. T'Te ground is trenched two or three feet deep, and richly manured; and the trees are planted in squares, or in the quincuux-form, at from twelve to fifteen feet apart. The plants are watered frequently during the first summer, and left without any pruning whatever; but in the winter of the second year, they are cut down to the ground. The third year, they throw up vigorous shoots, five or six of which are retained to form a bush; and in the following, or fourth year, the tree is suffered to ripen fruit. In some cases, the trees are trained to single stems; and this is also generally the case in Italy and Greece, where the climate is milder, and the tree attains a larger size than in France. In the subsequent management, the trees require but little pruning, except when they become too much crowded with branches. In the south of France, they always suffer more or less, during very hot summers, for the want of water, which they require in abundance, on account of the excessive transpiration that takes place from their large leaves, and very porous, thinly-covered bark. Hence in seasons of very great drought, the branches are sometimes completely scorched and killed by the powerful rays of the sun. Severe frost has a similar effect on the branches in winter, even at Marseilles, as extreme drought has in summer. In all countries, which may properly be called fig climates, two crops are produced in a year. The first is from the old wood, and corresponds with the crops of England and some parts of the United States; and the second from the wood of the current year, the figs produced by which, in the last-named comntries, are never ripened except in hothouses. In Greece, Syria, and Egypt, a third crop is sometimes produced. 'The first crop is ripened, in the south of France and in Italy, in May; and the second crop in September. Those which are to be dried, are left on the tree till they are dead ripe, which is known by a drop of sweet liquid that appears hanging from the eye. The figs, being gathered, are placed on wicker hurdles, in a dry, airy shed; and, when the dew is off, they are exposed every morning to the sun, during the hottest part of the day. 'To facilitate the progress of drying, the figs are occasionally flattened with the hand; and in moist, dull weather, they are placed in rooms warmed by stoves. When they are thoroughly dried, they are packed in rush baskets, or in boxes, in layers, alternately with long straw and laurel leaves, and in this state they are sold to merchants. In some parts of the solth of France, figs are prepared by dipping them in hot lye, made from the ashes of the fig-tree, and then dried; the nse of the lye being to harden their skins.

In the north of France, except in the gardens of amateurs, where the fig is generally trained against walls, as in Britain, and in some parts of the United States, there are only two or three places where it is grown for its fruit as a standard: and the principal of these is at Argentenil, in the neighbourhood of Paris. The trees are kept as low bushes, and the shoots are seldom allowed to acquire more than three or four years' growth; because it is necessary to bend them down to the ground, and retain them there, by means of stakes or stones, or 
a mass of soil, to proteet them from the effeets of the frost. It is observed in the "Nouveaı Cours d'Agriculture," that the figs of Argenteuil, are never brought to such a degree of perfeetion as to please the palates of those who have been acenstomed to the figs of Marseilles. 'They are, according to the writer, always either insipid or half rotten; and, even to bring them to this state, it is necessary to pinch off the points of the shoots, in the same way as is done with the vine when early grapes are wanted; or with the pea, to aecelerate the maturity of the pods. An additional process is requisite in cold seasons, and at the latter end of every season; and that is, the insertion of a small drop of oil, by means of a straw, into the eye of the fruit; which has the effect of destroying the vital principle, and causing the fig to part readily from the shoot, like ripe fruit; after which it soon begins to deeay.

In British and American nurseries, the fig is generally propagated by layers; though these do not ripen their wood the first season, so well as cuttings. When the fig is to be planted as a standard tree, constant attention must be paid to remove all the suekers from the collar, and all side shoots from the stem. When trained against a wall in a eold climate, the branehes should proeeed from a single stem, and not from the collar, as is generally the case; because the plant, when so treated, produees shoots which are less vigorous, and, cousequently, more likely to ripen their wood.

The process of caprification, which has been in use from time immemorial, in the Levant, is described by Theophrastus, Plıtarch, Pliny, and other authors of antiquity, and more recently by Tournefort; and though it is laughed at by many of the French physiologists of the present day, it is thought by many that it must be of some important use. We think it too curious a eireunstance, however, in a notice of this species, to be omitted, as it furnishes a convinciug proof of the reality of the sexes of plants. The operation eonsists in indueing a certain species of insect of the gnat kind, (Cynips,) which abounds on the wild fig, (Caprifieus,) to enter the fruit of the cultivated varieties, for the purpose of pumcturing its pericarp, in order to deposite its eggs, and thereby hasten its maturity. By this means, the fertile flowers in the interior of the fruit beeome fecundated by the farina of the barren ones near the orifice; but, without this operation, though the fruit may ripen, but few effeetive seeds are procluced. It is alleged by Bosc, that there is no other object in this practice than that of hastening the maturity of the erop; but others are of opinion that, by iusuring the feemudation of the stigma, it tends to inerease the size of the fruit, and, by filling it wilh inature seeds, to render it more nourishing; as appears to be the case with the Osage orange. Olivier, the botanieal traveller, asserts, that, after a long residence in the islands of the Arehipelago, he is convinced of the inntility of the practice; and Bose, though he allows that it may hasten the maturity of the figs, as the larva of the Pyralis pomona aceelerates the maturity of the apple, in France. yet, he believes that it has no effeet in improving either the size or the flavour of the fruit. M. Bernard, the autlıor of a "Mémoire sur le F"ignier," and of the article of that tree in the "Nouveau 1) Hamel," goes further, and asserts that the" figs, which have undergone the process of eaprification, are inferior to the others, in size, flavour, and the property of keeping. In ligypt, where the Fieus syeomorus is the prevailing speeies, an operation is performed on the fruit, which is said to answer the purpose of caprifieation, as fit as respects early ripurums. When the fruit has aequired a third part of its size, a slice is cut ofl the cuct of it, of a sufficient depth to remove all the stamens, which have unt hy this tume matured the fertilizing dust. 'The womnd is immediately covered with sat?, which thickens, and forms a mass that excludes the air from the interior of the fruit ; and the consequence is, that it ripens or becomes ready to drop ofl. Im halt the time usually taken by nature, without losing any of its size or of its flavour. 
Insects, Accidents, and Diseases. The fig-tree, in hot countres, and in dry seasons, especially when at a distance from the sea, is apt to have its leaves and fruit scorched and shrivelled up by the sun. It is scarcely subject to any diseases; but is liable to the attacks of several species of the coccidæ, as the cochineal, the kermes, \&c. In British gardens, it is very seldom injured by insects, in the open air; but it is very liable to the attacks of the red spider, the coccus, and the !oney dew, under glass. An abundance of water, and a moist atmosphere, like that of its indigenous habitat, the sea-shore, are perhaps the best preventives.

Properties and Uses. The sap-wood of the fig-tree, which is extremely light and tender, and of a white colour, is used in France, for making whetstones, from its facility of receiving and retaining the emery and the oil that are employed in sharpening smith's tools. The heart-wood, which is yellow, loses a great deal of its weight in drying; but, by that process, it acquires so much strength and elasticity, that the screws of wine-presses are made of it. When used as fuel, it does not afford a very intense heat; but its charcoal has the valuable property of consuming very slowly. The leaves and bark abound in a milky, acrid juce, which may be applied as a rennet, for raising blisters, and fo: destroying warts. From this milky juice, which contains caoutchouc, India rubber might be made if desirable; and, on account of the same property, the very tenderest of the young leaves might be given as food to the larvæ of the silk-moth. The fruit of the fig-tree, as has already been observed, serves as an article of food for a great part of the inhabitants of the regions where it abounds. In the northern parts of Europe and of America, it also enters into the desert, either fresh or dried. Medicinally, it is considered demulcent and laxative, and has long been used for emollient cataplasms, and for restoring persons debilitated by fevers, \&c. In Portugal, the Grecian Archipelago, and the Canary Islands, a kind of brandy is distilled from fermented figs. All the species of the genus ficus, and also of the allied genus carica, are said to have the singular property of rendering raw meat tender, when hung beneath their shade. On what chemical principle this depends, we are ignorant, but the fact seems undoubted.

As a fruit tree, the fig is valuable for growing and ripening fruit in situations unfavourable in regard to light, air, and soil; such as against walls, in court-yards, the walls of houses in crowded cities, on the back-walls of green-houses and forcing-houses, comparatively in the shade, \&c. It also bears better than any other fruit tree whatever, in pots; and, with an abundance of liquid manure and heat, this tree will produce under glass, three, and sometimes even four crops in a year.

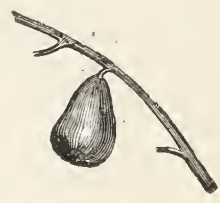




\title{
Genus ULMUS, Linn.
}

\author{
Uimaceæ. \\ Syst. Nat. \\ Pentandria Digynia. \\ Syst. Lin.
}

\section{Synonymes.}

Ulmus,

Orme,

Ulme, Rüster,

Olmo,

Olmo, Ulmo, Ulmêyro,

Elm,
OF Authors.

France.

Germany.

Spain and Italy.

Portugal.

Britain and Anglo-America.

Derivations. The word Ulmus is supposed to be derived from the Saxon $e l m$, or $u l m$; a name which is applied, with very - light alterations, to the Ulmus campestris, in all the dialects of the Celtic tongue. Ulm is still one of the German names fur wis tree; and the city of Ulm is said to have derived its name from the great number of elms that are growing near it.

Feneric Characters. Flowers, in most species, protruded earlier than the shoots and leaves of the year; disposed in groups, each group lateral, and proceeding from a bud peculiar to it ; the flowers of the group situated each upon a peduncle, or each upon a pedicel, and disposed a few together upon short peduncles, or situated.in both modes; and sometimes they are disposed in racemes, composed of several clusters of 2 to 4 together, extending to a considerable length, and furnished with 1 or 2 small, though perfect leaves, before the opening of the terminal buds. Flowers bisexual, or a few of them male; both kinds upon one plant. Calyx reddish, distinct from the ovary, top-shaped, or bell-shaped, of one piece, but having $4-8$ segments, which are imbricate in æstivation; remaining until the fruit falls. Stamens as many, as the segments; inserted into the lower part of the calyx, oppositely to the segments, and prominent beyond them. Anthers opening lengthwise, outwardly or inwardly. Ovary elliptic-oblong, compressed, cloven at the summit, having 2 cells, and a pendulous ovule in each. Style very short, or there is none. Stigmas 2, acuminate, villous on the inner face. Fruit a samara, and this compressed, more or less round or oval, and having the wing-like part membranous, broad, and present all round, except in a notch, the base of which is the place of the attachment of the stigmas. Seed 1, in a samara, pendulous; in many instances it is not perfected. Embryo unattended by albumen, straight, its radicle uppermost. Flowers small. Leaves alternate, in 2 ranks, featherveined; in most, unequal at the base, annual, serrate, and harsh to the touch. Stipules oblong, deciduous. Leaves within the bud folded lengthwise, in 2 portions, upright, with scales between leaf and leaf.-Adapted, from Nees Von Esenbeek and others.

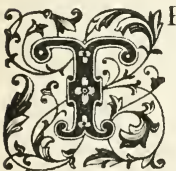

HE genus Ulmus embraces deciduous trees, often of great size and age, with rugged or corky bark, hard wood, twiggy branches, and growing wild in Europe, Africa, North America, India, and China. The roots of young plants, in some of the species, are of a leathery toughness, very strong, of considerable length and suppleness. The more common, and perhaps all the kinds increase rapidly in the number and the size of their roots and branches. All have strong, uprightgrowing trunks; but these vary, in several kinds, in their diameters and lengths. The disposition of the branches, relatively to the trunk and to the head which they constitute, also varies exceedingly; and considerable difference of character prevails in the spray. Although the character of the foliage is nearly the same in all the kinds, it varies in time of leafing and falling; and, in its size, colour, and form. The flowers, in most of the species, are protrnded before the leares, and are disposed in small groups, which give a knotted appearance to the leafless branches, before they are fully developed; but which, afterwards, from their colour, and their being supported on peduncles, look like little tufts of fringe. The trees are generally of easy culture, rapid growth, and will thrive in almost any soil that is not too moist, or excessively dry and barren.

The species of this genus have a remarkable aptitude to vary from seeds; so much so, that it is extremely difficult to determine which are species and which 
are varieties; or even to what species the varieties belong. Mr. Loudon was of an opinion that there are only two kinds truly distinct; namely, Ulmus campestris, and montana. The Ulmus americana he would consider as allied to U. campestris, from an assertion made by Mr. Masters, of Canterbury, in England, who has paid great attention to this genus, and has raised many sorts, both from Imerican and European seeds. He assured him that the American species is identical, or apparently so, with what is called the "Huntingdon Elm," (U. montana vegeta, of Lindley,) a variety raised at Huntingdon, from seeds gathered from trees in that neighbourhood, about a century ago. To us, it appears more probable that the Ulmus montana belongs to U. campestris, and that Ulmus americana, and most, if not all, other American elms, form a distinct species; their variations being cansed by the difference of soil and climate, or by hybridation. Therefore, for the sake of brevity, and convenience of classification, as in the genera tilia, fraxinus, \&c., we have brought the elms all under two heads; namely, Ulmus campestris, and americana, and have considered the kinds, which are ustally treated as species by botanists, only as varieties. Those, however, who differ from us in opinion, will find no difficulty in recognizing among our synonymes, the names as given by Willdenow, Michaux, Loudon, and others, and will be enabled $\mathrm{t}: \mathrm{know}$ under what heads they are described in the works cf these autho:s. 


\section{Ulmus campestris, \\ THE EUROPEAN OR FIELD ELM.}

\section{Synonymes.}

\begin{tabular}{|c|c|}
\hline Ulmus campestris, & $\begin{array}{l}\text { LinNeUs, Species Plantarum. } \\
\text { MichaUx, North American Sylva. } \\
\text { Loudon, Arboretum Britannicum. } \\
\text { SELBX, British Forest Trees }\end{array}$ \\
\hline $\begin{array}{l}\text { Orme champêtre, Orme des champs, } \\
\text { Orme blane, Ormeau, Ormille, Arbre } \\
\text { à pauvre homme, }\end{array}$ & $\left\{\begin{array}{l}\text { FELBY, British Forest Trees. } \\
\text { FraNCE. }\end{array}\right.$ \\
\hline $\begin{array}{l}\text { Landlicher Ulmenbaum, Ulme, Rüster, } \\
\text { Olmo, Olmo piramidale, }\end{array}$ & $\begin{array}{l}\text { Germany. } \\
\text { Italy. }\end{array}$ \\
\hline $\begin{array}{l}\text { English Elm, Field Elm, Common Small- } \\
\text { leaved Elm, }\end{array}$ & Britain. \\
\hline English Elm, European Elm, & ANGLO-A MERICA. \\
\hline
\end{tabular}

Derivations. The specific name campestris is derived from the Latin campus, a field; having reference to this tree as grow ing in open fields and in hedges. Most of the European nanes have the same signification as the botanical one. Engravings. Michaux, North American Sylva, pl. 129; Loudon, Arboretum Britannicum, ii., fig. 1233 et 1239 and vii., pl
230 et seq. ; Selby, British Forest Trees, pp. 104, 105 et 106; and the figures below. Specific Characters. Leaves doubly serrated, rough. Flowers nearly sessile, 4-cleft. Samara oblong,
deeply cloven, glabrous.-Smith, English Flora.

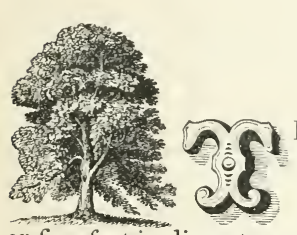
or five feet in diameter, when fully grown, and attaining a height of from sixty to seventy feet, or upwards. The branches, which are rather slender, are densely clothed with small, deep-green leaves, somewhat shining on the upper surface, though rough to the touch. The leaves are broad in the middle, and contracted toward the ends; being, like those of most other kinds of elm, unequal at the base, and doubly dentated, and having a strongly-marked midrib, with other lateral ribs, equally prominent, proceeding from it, on each side. 'They unfold at Naples, in Italy, by the first of February; at Paris, in March; in Fingland by the middle of April; and at New York early in May. They fall at Paris, and at New York, in the beginning of November, and three or four weeks later in England; but in Naples they often remain upon the trees until the end of the year. The flowers, which put forth just before the leaves, vary in colour from a dullpurple to a dark-red; and are succeeded by oblong, deeply-cloven samarie, containing each a seed, that ripens in a month after the appearance of the leaves.

Varieties. The varieties of this species are very numerous, both in Britain and on the continent; and most of them have been selected by unrserymen from their seed-beds. As remarked at the commencement of this genus, from the 
aptitude of the different kinds of elm to vary from seeds, ther 2 is, in truth, no ce: tainty as to what are species and what varieties. On this subject, M. Baudrillart observes, in the "Dictionnaire des Eaux et Forêts," that, "Any one who has ever observed a bed of seedling elms, must have noticed that some have large leaves, and some small ones; some are early, and some late; some have smooth bark, and some that which is rough; and some soft leaves and others very rough ones. Some varieties are higher than others. The branches take now a vertical and again a horizontal direction. In short, while botanists describe, and cultivators sow, they will find that nature sports with their labours, and seems to delight in setting at fault alike the science of the one and the hopes of the other. This is always the case with plants that have long been submitted to the cultivation of man. The cares that are bestowed upon them, the different situations in which they are placed, and the different kinds of treatment which they receive, appear to change their native habits." The quality and size of the timber of the several varieties differ as much as the size of the leaves and the habit of their growth. For instance, the timber of the Ulmus c. viminalis is of but little value, from the slenderness of the trunk; while, in other varieties, the trees are subject to decay at the joints of the branches, their bark splits into long, thin strips, and the interior of their trunk decays. We shall first notice the principal varieties of the common English elm, which are found in British nurseries; and next, the kinds most nearly allied to them, and which are usually treated, by botanists, as species.

1. U. c. vulgaris, Loudon. Common Field Elm. This variety, when grown in an open space, is very twiggy, with a smooth, pale bark, and is sometimes of an irregular growth, with almost horizontal branches. In some soils it is very subject to decay at the joints. The bark, which is lead-coloured, while young, splits into long, thin strips with age. A bad variety to cultivate for timber,

2. U. c. Latifolia, Loudon. Broad-leaved Field Elm, with broader leaves than the species, which expand early in the spring.

3. U. c. ALBa, Loudon. Whitish-barlied Field Elm. The growth of this variety is upright; the old bark cracks in long irregular pieces, and becomes very pale with age. The bark of the shoots, as are the foot-stalks of the leaves is tinged with red. The leaves, which are shining, and doubly and deepl $j$ serrated, bear a very near resemblance to those of the Ulmus c. effusa. This variety forms a valuable timber tree.

4. U. c. ACUTIFolia, Loudon. Acute-leaved Field Elm. 'The growth of this tree, during its early stages, very nearly resembles that of the last-named variety, but is stronger. The leaves, in old specimens, are more tapering, and the branches more pendulous. Also a good timber tree.

5. U. c. stricta, Loudon. Upright-growing Field Elm or English Red Elm. This variety is of a very rigid growth, and forms one of the most valuable timber trees of the small-leaved kinds. The poles are of equal diameter throughout.

6. U. c. virens', Loudon. Sub-evergreen Field Elm or Kidbrook Elm. This variety is almost evergreen in 'a' mild winter; and, as such, it is the most ornamental tree of the genus. The' bark is red, and the tree is of a spreading habit. This, like the last-mentioned kind, grows well upon chalky soils; but it is not to be depended upon as a timber tree, because, in some autumns, the shoots are killed by frost.

7. U. c. connubiensis, Loudon. Cornish Field Elm, an upright-branched tree, with small, strongly veined coriaceous leaves. The branches are bright-brown, smooth, rigid, erect, and very compact. It attains a very great height, with a somewhat narrow head; and in the climate of London, it is a week or two later in oming into leaf than the species. Dr. Inindley mentions a sub-rariety, with 
smaller leaves, which he ealls U. stricta parvifolia; and Messrs. Loddiges, two others, under the names of $\mathbf{U}$. strieta aspera, and U. stricta crispa.

8. U. c. SARniensis, Loudon. Jersey F'ield Elm, a free-growing variety, differing but very little from the species.

9. U. c. Tortuosa, Loudon. Twisted-woorled Ficld Elm; Orme tortillurd, of the Freneh. This variety, which is very distinet, frequently eomes true from seeds. Its leaves are of a very deep-green, and about a medium size. The trunk is marked with alternate knots and hollows; and the fibres of the wood are all twisted and interlaeed together. This tree presents a very singular appearance when it becomes old, as a number of knots (bosses) appear to surround its trunk. It produees but few seeds, and some years not any. It is considered, in France, as the best of all the varieties of elm for the use of wheelwrights; and particularly for the hubs of wheels. On the road from Paris to Meaux, there are to be seen a great number of these trees.

10. U. c. Folis variegatis, Loudon. Variegated-leaved Field Elm; silver-leaved Elm, having leaves striped with white, and, in spring, is very ornamental.

11. U. c. Betuleffolia, Loudon. Birch-leaved Field Elm, with leaves somewhat resembling those of the Betula alba.

12. U. c. vmmnalis, Loudon. T'wiggy-branched Field Elm, having small leaves, and numerous slender twig-like branches. It is a very distinct and elegant variety, and is easily recognized both in summer and in winter. In some stages of its growth, its foliage is frequently mistaken for a variety of birch. It is quite useless for timber, but forms an ornamental tree, with a eharacter of its own.

13. U. c. Parvifolia, Loudon. S'mall-leaved Field Eilm; Ulmus parvifolia, of Jacquin, Willdenow, and others; a tree, according to Pallas, who mentions several varieties of it, very eommon in all the woods of the south of Russia, and varying in height from that of a middle-sized tree to that of a diminutive shrub, aceording to the soil and elimate in which it grows. It is very plentiful about Caucasus; and, in passing through Siberia, it gradually becomes less nuultiplied; but oceurs again about Lake Baikal, where the inhabitants use the leaves as a substitute for tea. The wood of this variety, when it assumes a tree-like form, is said to be very hard and tough; and is veined with transverse lines. The root is also beautifully variegated, and is used by the turner and cabinet-maker. One of the sub-varieties, mentioned by Pallas, has the bark somewhat fungous or eorky; another has the branehes slender, wand-like, and of a whitish-gray eolour. In rocky, monntainous surfaces, the branches are thiek and short; but, in sandy soils, the trees are all small, with slender shoots.

14. U. c. Planifolia, Loudon. Plane-leared F'ield Elm, a handsome, small tree, elosely resembling the last-named variety.

15. U. c. chinensis, Loudon. Chinese Field I:lm; Ormenain, Thé de l Abbe Gallois, of the French. 'This variety forms a low bush, introduced into Britain from China, but when is uncertain. "Notwithstanding," says Mr. L.oudon, "the eircurnstanee of its being kept in green-houses in some eases, and retaining its loaves there through the winter, we cannot consider it as anything else than a variety of U. eampestris. We are eonfirmed in this opinion by Mr. Main, who brought home some plants of this sort from China, and found them to stand the rigour of our winters in the garden of his friend, the Rev. Mr. Norris, of (irove street, Hackney. We believe it to be the same sort which is sometimes imported from (hina. in the form of a miniature old tree, planted in a China vase. While retaned in these vases, and sparingly supplied with nourishment, it maintins its stunted figure; but planted out in a free soil, in a favourable situation, in a year or two, it will make shoots five or six feet long, as may be seen in the garden of the London Horticultural society. The manner in which the Chinese procure these miniature trees is, by ringing the extremitics of the branches of old trees, anl 
then applying a ball of loam, kept moist by water and moss, till roots are thrown out from the callosity formed at the ring, when the sinall branch is cut off, and planted in a porcelain pot, 'either,' says Mr. Main, 'round, or, most commonly, of an elongated square, twelve or fourteen inches long, eight inches wide, and about five inches in depth. Along with the tree they place pieces of stone, to represent rocks, among which moss and lichens are introduced. The tree, thus planted, is not allowed to rise higher than about a foot or fifteen inches; no greater supply of water is given than just sufficient to keep it alive; and, as the pot soon acts as a prison, its growth is necessarily impeded; at the same time every means are used to check its enlargement. The points of the shoots, and the half of every new leaf,.are constantly and carefully cut off; the stem and branches, which are allowed to extend only a certain length, are bound and fantastically distorted, by means of wire; the bark is lacerated to prodnce protnberances, asperities and cracks; one branch is partly broken through, and allowed to hang down, as if by accident; another is mutilated to represent a dead stump; in short, every exertion of the plant is checked by some studied violence or other This treatment produces, in course of time, a perfect forest tree in miniature. Stunted and deformed, by the above means, it certainly becomes a curious object, bearing all the marks of extreme old age. Its writhed and knotty stem, weather-stained and scabrous bark; its distorted and partly dead branches, its diminutive shoots and leaves; all give it the aspect of antiquity." "The French name, Thé de l'Abbé Gallois, was so called from M. Gallois, who, under the reign of Louis $\mathrm{XV}$., imported this variety into France, supposing it to be the real Chinese tea-tree. Grafted standard high on the common English elm, the Ulmus c. chinensis would form a very handsome small tree.

16. U. c. nana, Loudon. Dwarf Field Elm, a very distinct variety, growing in the London Horticultural Society's garden, which, in ten or twelve years, attained only a height of about two feet. When taken up to be removed, it was found to have a root running along the surface of the ground seven or eight feet in length.

17. U. c. cucullata, Loudon. Hooded-leaved Field Elm, a tree with curious leaves, curved something like a hood.

18. U. c ConcaVæfolia, Loudon. Concave-leaved Field Elm, somewhat resembling the preceding kind.

19. U. c. Folis aUreIs, Loudon. Golden Variegated-leaved Field Elm, having leaves variegated with yellow.

20. U. c. suberosa. Cork-barked Elm; Ulmus suberosa, of Willdenow, Lindley, Loudon, and others; Orme fongeux, Orme-liège, of the French; a very marked kind of elm, but evidently a variety of the Ulnıus campestris. It varies exceedingly in the character of its bark; being sometimes deeply furrowed, and at other times much less so. It also varies much in the character of its head, being sometimes low, loose, and spreading, and at others tall and narrow. The bark, when a year old, is covered with very fine, dense cork; hence the name suberosa. The leaves are rough on both sides, are more rounded, and twice or three times as large as in the common English elm. They are very unequal at the base, strongly, sharply and doubly serrated, hairy beneath, with dense, broad tufts at the origin of the transverse ribs. The flowers are much earlier than the foliage, stalked, reddish, with four or five rounded segments, and as many stamens, with dull-purple anthers. The samaræ are nearly orbicular, with deep sinuses reaching to the place of the seed. It is propagated by suckers, and layers, or by grafting on the Ulmus c. montana. The tree is of large and rapid growth, and is highly valued on account of its thriving well upon chalkv soils, and in keeping in leaf till late in autumn. 
21. U. c. suberosa rolis variegatis, Loudon. Variegruted-leaved Cork-burlied Field Elm; a tree precisely like the preceding, except in its variegation.

22. U. c. suberosa Ar.ba, Loudon. White Corked-bark Field Elm; a low tree, of more compact growth than the two preceding; and often growing into an oval, or rather cone-shaped head. The young shoots are pubescent; the foliage thickly set, and the bark much wrinkled, becoming white with age.

23. U. c. suberosa erecta, Loudon. Eirect Cork-brarked Field Flin; a tree with a tall, narrow head, resembling that of the Cornish elm; but diflering from that variety in having much broader leaves, and a corky bark.

24. U. c. MaJor. Greater Field Elm; Ulmus major, of Smith, Lindley, Lolldon and others; Great Dutch Corked-barked Elm, of the British and AngloAmericans. The branches of this variety spread widely, in a drooping manner, and their bark is rugged, and much more corky than even that of the Ulmus c. suberosa. The leaves, which are on short, thick stalks, are larger and more bluntly serrated than those of that variety; they are rongh on both sides, especially beneath; but the hairy tufts at the origins of the transverse ribs are very small. The segments of the calyx are short and rounded; the stamens four in number; and the samaræ obovate, with very small rounded sinuses, not reaching half so far as the seeds. This appears to be the elm which was carried into Britain, from Holland, by William III. From its quick growth, it was, at first, much used for hedges, and formal rows of clipped trees; but when the Dutch taste in gardening declined in England, the tree was no longer cultivated, as its wood was fonnd to be very inferior to that of most other kinds of elm. 'This variety may be propagated in the same manner as the Ulmus c. suberosa.

25. U. c. effusa. Spreading-branched Field Elm; Ulmus effusa, of Willdenow, Loudon and others; Orme pédonculé, of the French. The colour of the young wood, the buds, and the size, colour, and serrature of the leaves of this variety, are remarkably like those of the "Huntingdon Elm" (Ulmus c. montana glabra vegeta.) Its leaves are large, and of a beautiful light, shining green. The trunk more nearly resembles that of the Ulmus c. montana than that of the common elm; its head is more spreading, and its bark, instead of being furrowed, is smooth. The buds are long, sharply pointed, and greenish, while, in the common elm, they are short, obtuse, and covered with grayish hairs. 'The tree is usually more rapid in its growth, and comes fifteen or twenty days earlier into leaf. It is a native of Europe, chiefly in the south of France, and in the Caucasus; flowers in April and May, and is propagated in British nurseries by grafting on the Ulmus c. montana. According to Pallas, the wood is very hard and durable, and is used in Russia for all the purfoses for which the common elm is employed in other parts of Europe. It is said that this variety is very common by the road-side, between Villars-Cotterets and Paris, in France; and also between that city and Cressy.

26. U. c. montana. Mountain Field Elm; Ulmus montana, of Smith, Lindley, Loudon, and others; Scotch Elm, Wych Elm, Wych Hazel, of the Britisil. The trunk of this variety is not so upright as that of the English elm; and soon divides into long, widely-extended, and somewhat drooping branclies, forming a large, spreading summit. Its wood is of quicker growth than that of the Ulmus campestris, and consequently, is far inferior in hardness and compactuess, and is more liable to split. The branches, in some individuals, are quite pendulous, like those of the weeping willow, the bark of which is even and downy, when young. The leaves, which are quite large, are broadly elliptical, having a long, copiously serrated point; rongh on the upper surface, with minute callous, bristly tubercles, but less harsh than those of many other varieties, and pale and downy beneath, with straight, parallel, transverse ribs, that are copiously hatiry it theit origins and subdivisions. From their resemblance to those of the hazel, (ieraril 
tells us that, in Hampshire, "it is commonly called the witch hazell." The flowers are paler, rather larger, and occur in looser tufts, than those of most other varieties. They have each from five to seven oblong-acute segments, and as many broad, and rather heart-shaped, dark anthers. The samaræ are broadly obovate or elliptical, and almost orbicular, with shallow notches at the ends, not extending half way to the seeds. 'This variety, although the most common elm in Scotland and Ireland, and grows spontaneously in numerous places in England and other temperate parts of northern Europe, appears to be almost unknown in France and Germany, as it is not mentioned by any of the dendrological writers of the two last-named countries. It is only within the present century, however, that this tree has been much planted in England, though in Scotland and Ireland its timber has long been considered as next in value to that of the oak; and it has, accordingly, been extensively introduced into artificial plantations. Its wood weighs less than that of the Ulnuus campestris, and is of a coarser grain. Nevertheless, it is used by the ship-builder, the boat-builder, the pump and block-maker, the cartwright, the cabinet-maker, and the coach-maker. The timber, according to Matthews, has great longitndinal toughness; but, from the great quantity of sap-wood, and want of lateral adhesion, it splits considerably when dry. The summit of this variety, which has a peculiar fan-like spread of branches, often tends, probably from the effects of the prevailing winds, to one side, which is most perceptible in young trees. Hence, when fully grown, the stem is generally slightly bent, which renders it very appropriate for the floor-timbers of vessels, being the only part of a ship, except the bottom planks, to which it is applicable, as it soon decays above water. "The tree," continues Matthews, "when it comes to some size, and the primary branches being lopped off, like the common elm, and the oak, often throws out a brush of twigs from the stem; and these twigs impeding the transit of the sap, the brush increases, and the stem thickens considerably, in consequence of a wart-like deposit of wood forming at the base of the twigs. This excrescence, when of size, after being seasoned in some cool, moist place, such as the north re-entering angle of a building exposed to the dripping from the roof, forms a richer veneer for cabinet-work than any other timber." But, even without this process, the wood has often a curious laced appearance, which renders it fit for dressing cases and other fancy works. The wood of this tree is said to be suitable for the naves, poles, and shafts of gigs and other carriages; and from its not splintering, as is the case with the oak and ash, in time of battle, it is used for the swingle-trees of the carriages of cannon. It is also employed for the rollers of printers and dyers; for making wheel-barrows; and for the handles of spades, lorks, and other implements of husbandry. And, according to Gerard it was applied to various uses in ancient times. It was not only made into bows, but its bark, which is so tough that it will strip or peel off from the wood from one end of a bough to the other, without breaking, was made into ropes. Gilpin, in speaking of this tree, says, that it " is, perhaps, generally more picturesque than the common sort, as it hangs more negligently, though, at the same time with this negligence, it loses, in a good degree, that happy surface for catching masses of light, which we admire in the common elm. We observe, also, when we see this tree in company with the common elm, that its bark is of a somewhat lighter hue." On this passage, Sir Thomas Dick Lauder observes, "We are disposed to think that Mr. Gilpin hardly does justice to this elm. For our own parts, we consider the wych, or Scottish elm, as one of the most beautiful trees in our British sylva. The trunk is so bold and picturesque in form, covered, as it frequently is, with huge excrescences; the limbs and branches are so free and graceful in their growth; and the foliage is so rich, without being leafy or clumpy, as a whole; and the head is generally so finely massed, and yet so 
well broken, as to render it one of the noblest of park trees; and, when it grnw' wildly amid the rocky scenery of its native scotland, there is no tree, which assumes so great or so pleasing a variety of character."* "The scotch elm," Sang observes, "accominodates itself, both in a natural state and when planted, to many different soils and situations. The soil, in which it most luxuriates, is a deep, rich loam; but that in which it becomes most valuable, is a sandy loam, lying on rubble stone, or on dry rock. It is frequently found flourishing by the sides of rivers or streams, whicli sometimes wash part of its roots; yet it will not endure stagnant moisture." "In a mixture of loam and clay schistus, incumbent on whinstone rock, as at Alva," continues he, "it arrives at a large size within a century." The most ready mode of propagating this tree is from seeds, which are produced in great abundance, and are ripe in Britain about the iniddle of June. They should be gathered by hand before they drop, as from their lightness and winged appendages, they are very apt to be blown a way by the wind. They may either be sown as soon as gathered, in which case, inany plants will come up the same season; or they may be thinly spread out to dry in the shade, and afterwards put up into bags or boxes, and kept in a cool, dry place, till the March or April following. Sang directs the seeds to be chosen from the tallest, most erect, and healthy trees; on the sound principle, that plants, like animals, convey to their progeny their general appearance, whether good or bad. Trees, therefore, though having an abundance of seeds, if they be either visibly diseased, or ill-formed, should be passed over by the collector. When sown, the seeds of this tree, and those of all its sub-varieties, ought to be deposited in light or friable rich soil, and very thinly covered, in order that the plants, that rise from them, may be strong and vigorous. The best form in which the seeds can be sown is in beds; and the covering of soil should not exceed half of an inch in depth. The plants may be removed into nursery lines, at the age of one or two years; or they may be grafted in the following spring. If not intended to be grafted, they may go through a regular course of nursery culture, till they have acquired the desired height for final transplanting, which should not exceed twenty or twenty-five feet. This variety, like the Ulmus campestris, may also be increased by layers, by cuttings from the roots, and by inoculation.

27. U. c. Montana Rugosa. Crumpled-barked Monntuin Field Elm; Ulmms $m$. rugosa, of Loudon; a tree of spreading growth, and moderate size, with reddish-brown bark, which cracks into short, regular pieces, similar to that of the Acer campestre.

2S. U. c. Montana Major. Larger Mountain Field Elm; Ulmus m. major, of Loudon; a tree of upright, rapid growth, with but few branches; and, in some stages, approaching the habit of the common Scotch elm, but of a more tapering form. Its leaves fall almost a month earlier than those of most of the allied races.

29. U. c. montana Minor. Smaller Mountain Field Elm; Ulmms m. minor, of Loudon. This tree, as compared with the preceding, is of a more branching and spreading habit, and of lower growth, with more twiggy shoots, which are more densely clothed with leaves.

30. U. c. montana cebenNensis. Cevennes Elm; Ulmus m. cebennensis, of Loudon. The habit of this tree is somewhat like that of the Ulmus c. montana; but it appears to be of much less rapid growth.

31. U. c. Montana nigra. Black-barked Mountain Field Elm; Ulmus m. nigra, of Loudon; Irish Black Llm, of the Finglish; a spreading tree, with the habit of the Ulmus c. montana, but with mitch smaller leaves.

32. I. c. montana australis. Sonthern Monntain I'ield Lim; Ulmus m. ans-

* Lauder's Gilpin, 1., p. 91. 
tralis, of Loudon. This tree has rather smaller leaves, and a more penduious habit of growth than that of the Ulmus c. montana; but it does not appear to be different in any other respect.

33. U. c. montana pendula. Pendulous.branched Mountain Field Flm; Ulmus m. pendula, of Loudon; which forms a beautiful, highly characteristic tree, generally spreading its branches in a fan-like manuer, and stretching them out sometimes horizontally, and at other times almost perpendicularly downwards, so that its summit exhibits great variety of shape. By some, this tree is considered as belonging to an American species of elm; but from its large, rough leaves, its vigorous young wood, and large buds, and, above all, from its flowering at the same time as the Ulmus c. montana, and, like it, ripening an abundance of seeds, which no American elm whatever does, in Britain, we have not a doubt that it is a sub-variety of the Ulmus c. montana. For particular situations in artificial scenery, it is admirably adapted; for example, for attracting the eye, and fixing it, in order to draw it away from some object which cannot be concealed, but which is not desirable to be seen.

34. U. c. montana fastiglata. Fastigzate Mountain Field Elm ; Ulmus m. fastigiata, of Loudon; Exeter Elm, Ford's Elm, of the English; a very remarkable tree, with peculiarly twisted leaves, and a very fastigiate habit of growth. The leaves, which are very harsh, feather-nerved, and retain their deep-green till they fall off, enfold one side of the shoots. Its foliage is darker than that of any other variety, save that of the Ulmus c. virens; and the singular cup-shaped form of its summit, cannot be mistaken for that of any other tree. It is of less vigorous growth than the preceding; but, being of a marked character, it well deserves a place in collections.

35. U. c. montana glabra. Smooth-leaved Mountain Field Elm; Ulmus m. glabra, of Loudon; Smooth-leaved Wych Elm, Feathered Elm, of the English. This variety forms an elegant tall tree, with spreading, rather drooping, smooth, blackish branches, scarcely downy, even in the earliest stages of their growth. The leaves, which are small, and quite oblong, are strongly serrated, very unequal at the base, but not elongated at the extremity, and are of a rather rigid, firm substance. The surface of both sides is very smooth to the touch, and without hairs beneath, except the axillary pubescence of the ribs, which often forms a narrow, downy line along the midrib. The flowers are nearly sessile, with fine, short, bluntish, fringed segments, and as many long stamens, the anthers of which are roundish heart-shaped. The samaræ, which are smaller than those of most other varieties, are obovate, cloven down to the seeds, smooth, and often of a reddish hue. This tree is a native of Britain, chiefly of England, in woods and hedges, and forms the inost common elm in some parts of Essex. It bears seeds in nearly as great abundance as the Ulmus c. montana; and, like that variety, may be propagated from seeds, by layers, and cuttings of the root, or by grafting and inoculation.

36. U. c. montana glabra vegeta. Vigorous-growing Smooth-leaved, Mountain Field Elm; Ulmus montana vegeta, of Lindley; Ulmus $m$. glabra vegeta, of Loudon; Huntingdon Elm, Chichester Elm, Scampston Elm, of the English. This is by far the most vigorous-growing kind of elın propagated in British nur* series, often making shoots from six to ten feet in length in one season; and the tree attaining a height of upwards of thirty feet in ten years from the graft. "Having written to Huntingdon, Chichester, York, Newcastle, and various other places," observes Mr. Loudon, "respecting this elm, we have received the following information from Mr. John Wood, nurseryman near Huntingdon, dated November, 1836:- 'The Huntingdon elm,' he says, 'was raised here about eighty or ninety years ago, by an uncle of mine, from seed collected in this neighbourhood. I have sent many plants of it all over the country; and it has been 
given out from Norwich, Bristol, and other places, under the name of the Chichester elm; but you may rely on my word that the Chichester elm and the Huntingdon elm are one and the same thing. 'The tree is the fastest grower, and produces the best timber of all the elms. I have lately cut down some trees, planted about forty years ago, and have used the planks in various ways in house-building." "*

37. U. c. Montana glabra Major. Larger Smooth-leaved Monntain Field Elm; Ulmus m. glabra major, of Loudon; a Canterbury seedling, of more vigorous growth than the Ulmus c. montana glabra, and, indeed, is a rival of the Huntingdon elm, in quickness of growth. It resembles the latter in its bark; but is more spreading in its branches; and preserves its foliage long after that of the Ulmus c. montana glabra.

3S. U. c. montana Glabra Glandulosa. Glandulous-leaved Smooth-lerted Mimntain Field Elm; Ulmus m. glabra glandulosa, of Loudon, with leaves very glandular beneath.

39. U. c. Montana glabra Latifolia. Broad-leaved Smooth-leaved Mounluin Field Elm; Ulmus m. glabra latifolia, of Loudon, with leaves oblong, acute, and very broad.

40. U. c. montana glabra microphylla. Small-leaved Smooth-leaved Mountuil Field Elm ; Ulmus m. glabra microphylla, of Loudon.

41. U. c. montana glabra Pendula. Pendulous-branched Smooth-leared Mountain Field Elm; Ulmus m. glabra pendula, of Loudon; Dounton E'lm, of the English; a tree raised in 1810, in Smith's nursery, at Worcester, from seeds obtained from a tree in Nottinghamshire. Mr. Knight, of Downton Castle, purchased some trees from this nursery; and one of them turned out to be that weeping variety, which has since obtamed the name of the "Downton Eim." "Un writing to Mr. Smith," observes Loudon, "to endeavour to get some information respecting the trees that produced the seed, he informs us in answer, that, after making every inquiry in Nottinghamshire, respecting these trees, he finds, 'they were a mixture of wych and English; probably they were all planted as Linglish; but being grafted trees, and being planted by the side of a public road, they might have been broken off at the graft, when young. At any rate, the plants produced from the seeds were a complete mixture of the English and wych elms, both by their leaves and their manner of growth. The original trees in Nottinghamslire have been long since cut down, and the ground built upon. The plants which I raised, not meeting with a ready sale, I grafted them with the common English elm, which is more in demand in this neighbourhood.' Mr. Knight observes that the 'Downton elm is more remarkable for the singularity of its form and growth, than for its value as a timber tree.'"

42. U. c. montana Glabra Variegata. Variegated-leaved Smooth-leaved Mountain Field Elm; Ulmus m. glabra variegata, of L.oudon, with variegated leaves.

Geography and History. The Ulmus campestris is a native of the middle and south of Europe, the west of Asia, and of Barbary. In France and Spain, it is found in great abundance; and many botanists consider it as a native of England; but as this tree seldom ripens its seeds in Britain, though it does so freely, in the neighbourhood of Paris, it can hardly be considered as truly indigenous to that island. According to Sir J. E. Smith, it is formd wild in woods and hedges in the southern parts of England, particularly in the New Forest, in Hampshire, and in Sussex and Norfolk.

This tree was known to the ancient Greeks, as it appears evident from Pliny mentioning that they had two distinct kinds of elm, one inlabiting the momntains, and the other the plains. The Romans, he adds, had four kinds; the "mom-

* Arboretum Brtannicum, iii., p. 110.1. 
tain," or "tall elm," (Ulmus atinia,) which corresponas to the Ulmus campestris; the "Gaulic elm;" the "elm of Italy," which had its leaves in tufts; and the "wild elm."

In Britain, the elm has been planted from time immemorial, or, at least, from the era of the possession of that island by the Romans; probably, having been bronght over, as was conjectured by Dr. Walker, during the Crusades. The oldest trees on record are, perhaps, a beautiful group at Mongewell, in Oxfordshire, which were celebrated in the time of Leland, in the reign of Queen Elizabeth. The largest of these trees, according to Mr. Loudon, is seventy-nine feet high, fourteen feet in circumference at three feet above the ground, with a head sixty-five feet in diameter. There are, doubtless, much older trees in England; for the elm, being of much less national importance than the oak, has never possessed the same attractions for antiquaries. Evelyn, to prove that the elm attains a "prodigious growth in less than a person's age," mentions a tree, which he had seen "planted by the hand of a countess, living not long since, which was near twelve feet compass, and of a height proportionable." ***** "Mine own hands," he adds, "measured a table more than once, of about five feet in breadth, nine and a half feet in length, and six inches thick, all entire and clear. This, cut out of a tree felled by my father's order, was made a pastry board. ***** The incomparable walks at the royal palaces, in the neighbourhood of Madrid, were planted with this majestic tree." These elms are said to have been the first that were planted in Spain; and Baron Dillon tells us that, when he saw them, about the end of the last century, they were six feet in diameter, and in a healthy state. Several of these trees were still in existence, as lately as 1833 . The plants were taken from Britain, by Philip II., who had married Mary Tudor, daughter of Henry VIII., and queen of England. In Scotland, the English elm was hardly known before the union of the two kingdoms. Dr. Walker mentions it, in 1780, as being nowhere found in that country of a large size; but, as promising to afford a much greater quantity of wood than the Scotch elm, in the same space of time. He particularizes a tree planted in 1771 , which, in 1799 , was thirty-five feet high. In Ireland, the English, or narrow-leaved elm, is said, in Mackay's "Flora Hibernica," to be abundant, but scarcely indigenous.

Among the recorded trees of this species, in Britain, perhaps there are none more remarkable than the "Crawley Elm," which has been figured by Strutt, in his "Sylva Britannica, as well as by Loudon, in his "Arboretum Britannicum," and stands on the high road from London to Brighton. According to the lastnamed gentleman, it is seventy feet high, with a trunk, which is hollow, sixtyone feet in circumference on the exterior, at the ground, and thirty-five feet round the inside, at two feet from the base. There is a regular door to the cavity of this tree, the key of which is kept by the lord of the manor; but it is opened on particular occasions, when the neighbours meet to regale themselves in its interior, where there is a room, with a floor paved with bricks, sufficiently capacious to contain a party of twelve or more persons. Madame de Genlis says, a poor woman gave birth to an infant in the hollow of this tree, where she afterwards resided for a long time.

At Coombe Abbey, in Warwickshire, there is an Ulmus campestris one hundred and fifty feet high, with a trunk nine and a half feet in diameter, and an ambitus or spread of branches of seventy-four feet. It is estimated to be over two hundred years of age.

The principal public avenues of elms, in England, are in St. James' Park, and at Cambridge and Oxford; and there are also some very fine ones on private gentlemen's seats, especially at White Knights, near Reading, at Littlecote Hall, and at Strathfieldsaye.

One of the largest trees of this species in Scotland, is at Wemyss Castle, in 
Fifeshire, which is ninety feet high, with a trunk nine feet and hree inclies in diameter, and an ambitus of fifty-one feet.

In Ireland, the dimensions of several elms are recorded by Hayes, though the species is not named, it is presumed that some of them belong to the Ulmus campestris. Near Arklow, at Shelton, an elm had a trunk five feet and four inches in diameter at the surface of the ground. In the county of Kildare, there stood an clm. which, till the year 1762 , was, perhaps, the finest tree of the species in the world. The diameter of the head, taken from the extremities of the lower branches, exceeded thirty-four yards; but in the end of that year the two principal arms fell from the trunk one night, apparently from their own weight, as the weather was perfectly calm. The timber contained in these branches sold for five guineas. In this situation the tree continued till the winter of 1776 , when a violent storm tore up the whole by the roots, with a great mass of soil and rock adhering to them. Some time previous to this, the trunk had been carefully measured, and was found to be thirty-eight and a half feet in circumference. It had been hollow for many years; and the value of its timber by no means answered what might have been expected, from the sale of the two branches in 1762. There is said to be no certain record as to the age of this tree; but popular tradition supposes it to have been planted by the monks of St. Wolstan, some time before the dissolution of that monastery, which happened in the year 1538. In Kilkenny, at Mount Juliet, there is an Ulmus campestris one hundred and two feet in height, with a trunk four feet and two inches in diameter, and an anıbitus of thirt $y$-two feet. An elm, at Carton, the seat of the Duke of Leinster, is fourteen feet and eight inches in circumference near the base, diminishing like the shaft of a Horic column, and being thirteen feet in girth, at sixteen feet from the ground.

The most remarkable Ulmus c. montana on record, as growing in England, is mentioned by Cook, in his treatise on "Forest and Fruit 'Trees." It stood in Sir Walter Bagot's Park, in Staffordshire, and attained the height of one hundred and twenty feet, with a trunk seventeen feet in diameter at the surface of the ground. It required two men five days to fell it, and it contained forty-eight loads of wood in the head; and yielded eight pairs of naves; eight thousand six hundred and sixty feet of boards and planks; and the whole tree was estimated to weigh ninety-seven tons.

One of the largest and most beautiful specimens of the Ulmus c. montana, in Scotland, is growing at Kinfauns Castle, in Perthshire, and is figured by Mr. Loudon, in his "Arboretum Britannicum." He represents it to be seventy feet high, with a trunk six feet and a half in diameter, and an ambitus of sixty fiet.

In Ireland, at Bawn, near Mansfieldtown, in the county of loutl, there is a remarkable Ulmus c. montana, which is considered to be upwards of one humdred and twenty years old. In 1839, it was seventy feet in height, with a trunk nime feet and eight inches in diameter at the base, five feet and four inches, at six feet above the ground, and with a head ninety feet in diameter.

In France, the elm was scarcely known, as an ornamental tree, till the time of Francis I.; and it appears to have been first planted there to adoru public wallis about the year 1540. It was afterwards planted largely, particularly in churchyards, by Sully, in the reign of Henry IV.; and, by the desire of that ling, who. according to Evelyn, expressed a wish to have it planted in all the highways in France, it became the tree most generally adopted for promenades and hedgerows. Many old trees existed at the period of the first Frencli revolution, which were called "Sully," or "Rosni," and " Henri Quatre;" names that had been given them apparently to commemorate their illustrious plauters. Bose states that he himself had seen some of these elms in Burgundy, with trunks from fonr in five feet in diameter, which, though hollow, yet supported heads capable of sheltering some thousands of men. It is said that Hemry IV. planted an elm in the gartem 
of the Luxembourg, at Paris, which stood until it was destroyed, in the revomtion, last referred to. There are many fine avenues of elms existing in France, at the present day, particularly those in the Champs Elysées, and at Versailles.

Among the largest existing trees of the Ulmus campestris in France, is one at Nantes, in the nursery of M. De Nerrières, which, in eighty years after planting, had attained the height of seventy feet, with a trunk six feet in diameter.

In Italy, at Monza, there is an Ulmus campestris, which, in twenty-nine years after planting, had attained the height of seventy-five feet, with a trunk one foot and nine inches in diameter, and an ambitus of forty-five feet. In the same place there is also an Ulmus c. suberosa, of about the same age and dimensions.

In Switzerland, near Morges, there stood an Ulmus camıestris, which was blown down some years since, that had a trunk seventeen feet and seven inches in diameter, and was estimated to be three hundred and thirty-five years old.

The precise date at which the Ulmus campestris was introduced into the United States is uncertain. There are many trees of this species, and of the Ulmus c. montana, growing within the environs of Boston, in Massachusetts, which, from their dimensions, must somewhat exceed one hundred years of age. The largest specimen of the species we have met with, is on the seat of Mr. Henry Codman, in Roxbury, which has attained the height of one hundred feet, with a trunk sixteen feet in circumference, at three feet above the ground. Among the eleven individuals which stand in Tremont street, in Boston, opposite the Granary Cemetery, there are several that measure nine feet in circumference, at about a yard above the pavement. On the authority of Mr. John Welles, these trees were planted by Major Adino Paddock, and John Ballard, in the year 1762.

In the Park, at New York, near the north-westerly corner of the City Hall, there is a beautiful specimen of the Ulmus campestris, which has attained a height of about fifty feet, with a trunk two feet in diameter.

Poetical, Mythological, and Legendary Allusions. The ancient poets frequently mention the elm, which, in common with many other trees bearing inesculent fruit, was devoted by them to the infernal gods. The Greeks and Romans considered all as funeral trees which produced no fruit fit for the use of man. Homer alludes to this, when he tells us, in the "Iliad," that Achilles raised a monument to the father of Andromache in the midst of a grove of elms, -

"Jove's sylvan daughters bade their elms bestow

A barren shade, and in his honour grow."

And in more modern times, Strutt informs us, in his "Sylva Britannica," that the venerable Bishop of Durham, erected an urn in the midst of the grove of elms, at Mongewell, in Oxfordshire, inscribing thereon, to the memory of t'vo highly valued friends, the following classical fragment,-

\footnotetext{
"In this once-favoured walk, beneath these elms,

Where thickened foliage, to the solar ray

Impervious, sheds a venerable gloom,

Oft in instructive converse we beguiled

The fervid time, which each returning year

To friendship's call devoted. Such things were;

But are, alas! no more."
}

Where, he observes, "it was delightful for him to contemplate wandering, in his ninetieth year, amidst shades with which he was almost coeval, and which, in freshness and tranquillity, afforded most suitable emblems of his own greel and venerable old age."

Ovid tells us that, when Orpheus returned to earth after his descent into the infernal regions, his lamentations for the loss of Eurydice were so pathetic, that the earth opened, and the elm and other trees sprang up to give him shade. 
Virgil, in his "Georgics," mentions that the Roman husbandmen bent the young elms, while growing, into the proper shape for tle burys, or plough-tail,_-

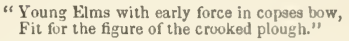

The elm was planted by the Romans for supporting the vine; and it is still so employed, along with the Lombardy poplar, in the south of Italy. Coluniella informs us that vineyards, with elm-trees as props were named "arbusta," the vines theinselves being called "arbustivæ vitis," to distinguish them from others raised in more confined situations. Once in tivo years, the elms were carefinlly pruned, to prevent their leaves from overshadowing the grapes; and this operation being deemed of great importance, Corydon is reproached by Virgil, for the double neglect of suffering both his elms and vines to remain unpruned,-

$$
\begin{aligned}
& \text { "Simiputata tibi frondosa vitis in ulmo est." } \\
& \text { Your vine half-pruned upon the leafy elm. }
\end{aligned}
$$

The use, however, which the Romans made of the elm, as a prop to the vine, has given rise to the most numerous allusions to this tree by the poets, not only ancient, but modern. Ovid makes Vertumnus allude to it, when he is recommending matrimony to Pomona,-

$$
\begin{aligned}
& \text { " 'If that fair elm,' he cried, 'alone should stand, } \\
& \text { No grapes would glow with gold, and tempt the hand; } \\
& \text { Or if that vine without her elm should grow, } \\
& \text { 'T would creep, a poor neglected shrub, below." " }
\end{aligned}
$$

Milton, in describing the occupations of Adam and Eve, in Paradise, says, -

$$
\begin{aligned}
& \text { "They led the vine } \\
& \text { To wed her elm; she, spoused, about him twines } \\
& \text { Her marriageable arms; and with her brings } \\
& \text { Her dower, the adopted clusters, to adorn } \\
& \text { His barren leaves." }
\end{aligned}
$$

Tasso alludes to the same custom, in the passage,-

"The married elm fell with his fruitful vine."

And Beaumont, when he says,-

$$
\text { "The amorous vine }
$$

Wordsworth, also, speaks of it, in that beautiful reflection, the "Pillar of Trajau," -

$$
\begin{aligned}
& \text { "So, pleased with purple clusters to entwine } \\
& \text { Some lofty Elm-tree, mounts the daring vine." }
\end{aligned}
$$

Cowper very accurately sketches the variety of form in the elm, and alludes in the different sites where it is to be found. In the "Task," he first introduces this tree rearing its lofty head by the river's brink, -

\footnotetext{
"There, fast rooted in his bank, Stand, never overlonked, our favourite elms, That screen the herdsman's solitary hut."
}

Then he gives an enchanting scene, where a lowly cot is surrounded by these trees, -

$$
\begin{aligned}
& \text { "T is perched upon the green hill-top, but close } \\
& \text { Fnvironed with a ring of branching elms, } \\
& \text { That overhang the thatch." }
\end{aligned}
$$

And he then introduces us to a grove of elms,- 
In many parts of Britain, the wych elm, (Ulmus c. montana,) or witch hazel, as it is still occasionally called, has long been considered a preservative against witches; probably from the coincidence between the words wych and witch. In some of the midland counties, even at the present day, it is said that a little cavity is made in the churn, to receive a small portion of witch hazel, withont which, the dairy-maids imagine that they would not be able "to get the butter to come." In the early ages of Christianity, the European hunters were accustomed to hang the skins of the wolves they had killed in the chase, on the elms in the churchyards, as a kind of trophy.*

Soil and Situation. The Ulmus campestris delights in a sound, sweet, and fertile soil, which is rather moist and loamy; and thrives best in an open situation, such as good pasture grounds in the vicinity of rivers, or smaller streams. "The propriety of planting the elm," says Marshall, in his work on "Planting and Rural Ornament," "depends entirely upon the soil. It is the height of folly to plant it upon light sandy soil. There is not, generally speaking, a good elm in the whole county of Norfolk. By the time they arrive at the size of a man's waist, they begin to decay at the heart; and, if not taken at the critical time, they presently become useless as timber. This is the case in all light soils. It is in stiff, strong land which the elm delights. It is observable, however, that here it grows comparatively slow. In light land, especially if it be rich, its growth is very rapid; but its wood is light, porous, and of little value, compared with that grown upon strong land, which is of a closer, stronger texture, and at the heart will have the colour, and alnıst the hardness and heaviness of iron. On such soils, the elm becomes profitable, and is one of the four cardinal trees, which ought, above all others, to engage the planter's attention; it will bear a very wet situation."

Propagation and Culture. The Ulmus campestris produces an abundance of suckers from the roots, both near and at a considerable distance from the stem; and thronghout Europe, these afford the most ready mode of propagation, and that which appears to have been most generally adopted till the establishment of regular commercial nurseries; the suckers having been procnred from the roots of grown-up trees, in hedge-rows, parks or plantations. In Britain, the present mode of propagation is by layers from stocks, $\dagger$ or by grafting on the Scotch elm (Ulmus c. montana.) The layers are made in autumn, or in the course of the winter, and become sufficiently rooted to be taken off in a year. Grafting is generally performed by the "whip" or "splice" mode, near the root, in spring; and the plants niake shoots of three or four feet in length the same year. Few plants succeed more readily by grafting than the elm; so much so, that when the graft is made close to the surface of the soil, and the scion tied on with matting, the mere earthing of the plants from the soil, in the intervals between the rows, will serve as a substitute for claying. It has been recommended that the graft be made six or eight inches above the collar, in order to lessen the risk of the scion, when it becomes a tree throwing out roots, which, as is the case with many of the varieties, would become troublesome by their suckers. Budding is sometimes performed, but less frequently. On the continent of Europe, plants

* See Loudon's Arboretum Britannicum, iii. p. 1382 ; also Woodland Gleanings, p. 30 et seq.

+ The process of producing layers consists in bending the young branches of trees and shrubs into the soil to a certain depth, and elevating their tops above the surface of the ground, in an upward direction, as denoted in the adjoining figure. In time, the buried parts of these branches take root, and finally become perfect plants. The ground should be kept quite clear of weeds, and the layers should be watered in dry weather; and, when sufficiently rooted, they should be carefully separated from the stool, or parent plant, with all the rootlets attached to them, and planted in nursery lines, or in the situations where they are permanently to remain. 
are very often procured from stools, simply by heaping $11 p$ earth about the shoots which proceed from them. 'These shoots throw out roots into the earth; and, after growing three or four years, during which time they acquire the height of ten or fifteen feet, they are clipped off, when they are either planted in the sites where they are finally to remain, or in nursery lines. When they are transplanted to their final situations, the side shoots are cut off, and the main stem is headed down to the height of eight or ten feet; so that newly-planted trees appear to be nothing more than naked truncheons. The first year, a great many shoots are produced from the upper extremity of each plant; and in the autunn of that year, or in the second spring, their shoots are all cut off but one, which soon forms an erect stem, and a tree with as regular a head as if no decapitation had taken place. This mode corresponds with the recommendation of Livelyn, to plant trees about the "scantling of your leg, and to trim otf their heads at five or six feet in height;" and also with Cato's mode of having the stems five or six fingers thick, who says that "you can hardly plant an elm too big, provided you trim the roots and cut off the head." All the avenues and rows of elm-trees, in Europe, it is said, were planted in this manner, previously to abont the middle of the last century; and, according to M. Poiteau, the same practice is still the most general in France. In Britain, young elms having been two or three times transplanted in the nurseries, are removed to their final sitnations, without heading down; and, in the moist climate of that country, they grow vigorously the first year without much pruning. But, in the south of Europe, where the climate of summer is hotter and more arid, and is attended with a consequent increased evaporation from the leaves of plants, the trees are liable to be killed when transplanted with all their branches on; and hence the mode of depriving them of their branches as described above. For similar reasons, the same practice is requisite in the United States to ensure success. In France and Belginm, the Ulmus campestris.is the most common tree planted by road sides, and along the bonlevards and streets of cities and towns; and, in such cases, a large pit is previonsly dug, four or five feet in diameter, and from two to three feet in depth; and a considerable portion of fine, rich mould is placed in immediate contact with the roots of the trees, and the pit filled with the best part of the soil, which had been previously dug out of it. During the first snmmer, water is regularly supplied, and the trees, or rather stumps, grow freely; very little attention being required afterwards, except to encourage the leading shoots, and to shorten in, the lateral branches, so as to encourage the plants to assume a tree-like form. In the neighbourhood of Paris, and in the south of France, the L'mus campestris occasionally bears seeds, which are sometimes sown by nurserymen, in order to procure new varieties, and by the managers of the national forests, in order to obtain a supply of plants, at a cheap rate; but in Britain, this tree very rarely ripens seeds, or produces them at all; nevertheless, it has done so, in a few places, as in Lea Park, near Littlebourne, about four miles from Canterbury. It is observed by Bosc, that some of the more remarkable varieties, such as the twisted elm, (Ulmus c. tortuosa,) \&c., come tolerably true from seeds, speaking of the mass of young plants; but that among these are constantly to be formd numerons subvarieties. The seeds, which fall from the trees as soon as they are ripe, are swept up and immediately sown in beds of light, rich soil; being placed abont an inch apart every way, they are covered to the depth of about an eighth of an inch. The plants come up the same season, and are fit for transplanting into nursery lines in the autumn following.

"Of all the European timber trees," observes l.oudon, "not belonging to the coniferous family, except the Lombardy poplars, the narrow-leaved clin. (L'hnus campestris,) requires the least care or pruning after it is plinted; and, at the same time, no tree will bear better than it does, the knife or the shears. All 
the branches may be cut from the stem, except a small tuft at the top; and stiil the tree will grow vigorously, affording, where that mode of feeding cattle is considered profitable, an ample crop of branches every three or four years. When headed down to the height of ten or twelve feet, it is very prolific of branches, as a pollard, and will live and be productive, in this state, for a great number of years. When grown exclusively for the timber of its trunk, however, it requires to be allowed a considerable amplitude of head; perhaps not less than one third of its whole height. The timber, in this case, is found to be far more compact and durable, though not so curiously veined and variously coloured as it is when the tree is allowed to produce branches from the gromnd upwards. The timber of the elm, not being remarkable for its durability, is, in old trees, very commonly found decayed at the heart; and this is generally the case, even when the exterior circumference of the trunk is in a healthy and vigorous state, and prolific of branches. The most profitable age for felling the elm is between seventy and eighty years; and if the trunk is disbarked a year before it is cut down, the wood will be more thoroughly seasoned."**

Accidents, Diseases, and Insects. The Ulmus campestris, from the straightness, toughness, and strength of its trunk, in proportion to its head, is not liable to be injured by high winds, except at an advanced age, in yielding at the roots, -an accident which much more frequently befalls this tree than the American species, as was fairly tested on Boston Common, in the memorable gale of September, 1S15, when several English elms, in the Mall, were uprooted, while the native species, by their side, withstood the blast with but slight injury. The European elm, however, is subject to many diseases, and is very liable to be attacked by insects. The principal disease with which it is assailed, is a species of ulceration, appearing on the body of the tree, according to Michaux, "at a height of three or four feet from the ground, and which discharges a great quantity of sap." "The disease penetrates gradually," he adds, "into the interior of the tree, and corrupts its substance. Many attempts have been made to cure it in the beginning, and to arrest its progress, but hitherto without success. The best treatment is to pierce the tree to the depth of two or three inches, with an auger, in the very heart of the malady, which is manifested by the flowing of the sap." The matter discharged by this ulcer has been analysed by M. Vauquelin, and found to contain carbonates of lime, potash, and of magnesia, and sulphate of potash. The nıode of treatment recommended in the "Nouvean Cours d'Agriculture," is to pierce the ulcer as above advised by Michaux, and then to dress the wound with powdered charcoal, or a mixture of cow-dung and clay. This species, when grown in an unsuitable soil, that is, in one which is either excessively wet or extremely dry, is very subject to a disease called carcinoma. It shows itself by the extravasated cambium forming long, black streaks down the bark, and by its sweetness, attracts numerous insects, of several tribes, to feed upon it. Mr. Spence thinks that this disease, very probably, is caused by the scolyti. "I have seen," he says, in a communication to Mr. Loudon, "many elms pierced by these insects, where the extravasated cambium partly oozed ont in white masses, like gum, or manna, and partly formed long, black streaks down the bark, and numerous insects were attracted to feed on it."

Among the insects attacking the Ulmus campestris, is what is vulgarly called the elm flea, (Haltica,) which devours the leaves, bnt is said to do no serious injury to the tree itself. It is a beautifnl little insect, covered with a brilliant cuirass of green and gold, and having the thighs of its hinder legs so large as to appear almost ronnd. They are so lively and so quick in their movenents, that, hough a branch may appear covered with them one moment, the next they will

* Arboretum Britannicum, iii., p. 1384. 
ail have vanished. The larvæ are small and slender, and devour the leaves with equal avidity as the perfect insect. Sometimes small bladders or galls are produced on the leaves of the elm, by the puncture of some kind of insect, (probably a cynips,) which are at first green, but afterwards turn black. Each of these galls contain a fluid, which, according to Du Hamel, is called elm balm, and was formerly employed for the cure of recent wounds.

In the "Nouveau Cours d'Agriculture," there are mentioned four other insects that prey upon the elm. The first is the larva of the Bombyy chrysorrhau, of Fabricius, which destroys the leaf-buds and leaves entirely, so as to give the tree, in spring, the appearance of winter. The second is the Galerucu ulmuriensis, of Fabricius, a coleopterous insect, the larvæ of which, in some seasons, entirely destroy the parenchyma of the leaves of the elms, in the public promenades both in Britain and in continental Europe. These larvie are of a blackish colour, and exhale, when crushed, a most disagreeable odour. The moment they are touched, they coil up, and suffer themselves to fall to the ground. 'The perfect insect is extremely sluggish in its movements, feigning death, in cases of danger, rather than unfolding its wings to fly away. It conceals itself in the crevices of the bark, also under stones, and between the bricks of walls; and sometimes will produce three generations in the course of one summer. 'The third is a species of goat-moth, (Cossus ligniperda, of Fabricius,) the larva of which is about three inches long, with its body sprinkled with slender hairs; being of a reddish-brown on the back, becoming yellow beneath, with eight breathing-holes on the sides, and a black head. It cxhales a most disagreable goat-like odour, which is produced by an oily and very acrid liquor, that it discharges at its mouth, and the nse of which is supposed to soften the wood before it devours it. The pupa is brown, the abdominal segments bearing two rows of spines, directed backwards. Before cntering into its chrysalis state, which sometimes takes place under ground, the larva spins a strong web, intermixed with particles of wood, that constitutes its cocoon. 'The perfect insect has darkgray wings, clouded with dark-brown, and streaked with black. It belongs to that class of insects which fly by night, and appears, in Enrope, in the month of June. The female lays but one set of eggs, but these generally amount to one thousand in number, and are always deposited at the base of the trees, whence the larvæ penetrate the bark, wherever they can find the easicst entrance. The eggs are small, in proportion to the size of the imago; and the caterpillar, which grows to a large size, is said to remain in the larva state three years. 'This insect, in Europe, not only feeds upon the elm, but also preys upon the alder, the oak, the ash, the walnut, the beech, the lime, and on some kinds of the willow, and of the poplar. The larvæ devour the liber or inner bark, making long galleries in the wood, somewhat after the manner of those of the wood leopard moth, (Zeuzera æesculi,) in the common pear-tree, and finally destroying the tree. Many remedies have been proposed, but that of Latreille appears to be most approved of in France. This consists in surrounding the base of the tree, where it has been observed that the females always deposit their eggs, with a thick coating of a mixture of clay and cow-dung, which the insect cannot penetrate. The green woodpecker preys upon these caterpillars, and its stomach, on dissection, emits an intolerable stench. The fourth enemy to the elm, and the one which is considered by far the most injurious, is the larva of the Scolylus destructor; but it is sometimes assisted in its ravages by that of the Siroly/ns armatus. In about the month of June or July, the fentale insert hores through the bark, until she has reached the point between the soft wood and the immer bark; she then forms in the latter a vertical chanuel, usually upwards, of about two inches in length, on cach side of which she deposits her eggs, as she. advances, to the number of from twenty to fifty in all. It appears probable that, 
after doing this, she dies, without making her way uut again, as she may often be found dead at the end of the channel. About September, the larvæ are hatched, which commence feeding upon the matter of the inner bark, at the edge of the channel; and, in a very slight degree, on that of the soft wood opposite, advancing, as they feed, in a course at about right angles from the primary channel, on each side of it. The true food of the insect is the inner bark; and the erosion of the soft wood is so slight, as to be, perhaps, nearly accidental. The course of each individual larva, on each side of the primary channel, is about parallel to that of the larva next to it; and each forms a channel by its feeding that is enlarged as the larva increases in size. When each larva has finished its course of feeding, it stops in its progress, turns to a pupa, and then to a beetle; and, in the latter state, gnaws a straight hole through the bark. These beetles begin to come out in about the end of May, or the beginning of June, of the year following that in which the eggs were deposited. The sexes afterwards pair, and the females, bearing eggs, pierce through the bark, as above detailed; and so on, from generation to generation, and year to year. The result of the erosions of the female parent, and of the larvæ, in the inner bark and soft wood, is that of cutting off the vital connection between these two parts; and, when the erosions effected in a tree have become numerous, of occasioning its death, by preventing the ascent and descent of the sap. It has been asserted that the female scolytus never attacks a tree in a perfectly healthy state, for the purpose of depositing her eggs; and, also, that trees suffering under carcinnma are particularly liable to her ravages. It has also been remarked that these insects seldom destroy the trees they attack the first year; and that they prefer a tree that they have already begun to devour, to one that is young and vigorous; but they never attack a tree that is entirely dead. Yet it is true that both the males and females pierce young and healthy trees for the purpose of eating the inner bark, which constitntes their principal food; and that the numerous holes which they thus canse, partly from the loss of sap which exudes from them, and partly from the effect of the rain that lodges in them, in a few years bring the trees, in which they occur, into an incipient state of decay. These trees are indiscriminately selected by the female insects for the deposition of their eggs, just as in trees beginning to decay naturally; and thus healthy trees are effectually destroyed by the combined operations, first and last, of the scolyti of both sexes, though not in consequence of the sole deposition of the eggs of the female. The most effectual mode recommended to prevent the future depredations of these insects, is, first, to pare away, with a spoke-shave, or other tool, the rough exterior bark of the trees bearing the marks of their ravages; and if there be no trace in the inner bark, either of small holes in old trees, or of those superficial furrows which the scolyti of both sexes make for food in young trees, they may be pronounced as being in a sound and healthy state. But if the inner bark exhibits small holes which communicate with channels as described above, the next thing to be done is to determine whether the female has already deposited her eggs within it, or whether it contains the young scolyti either in a larva or chrysalis state. In order to know this, it will be necessary to cut away, here and there, portions of the bark, quite into the wood; and if the existence of either the eggs or of the insects be proved, the trees should be cut down, and the bark be taken off and burnt. Those trees pierced with exterior superficial holes or furrows, which have no larvæ in them, are such as have been attacked for food only; and, if they be carefully brushed over with coal-tar, the fumes of which is highly offensive to the perfect scolyti, there is every probability that they will be secure from the future attacks of the females; and that the repetition of the same process in the spring, for one or two years, wonld enable them to resume their vigour, and become healthy trees.*

* See Loudon's Arboretum Britannicum, iii., p. 1387, et seq. 
Properties and Uses. 'The wood of the Ulmus campestris is of a brownist, colour, and is hard and fine-grained. When green, it weighs nearly seventy pounds to a cubic foot, and when dry, not more than forty-eight and a half pounds. It possesses greater lateral adhesion, but less longitudinal toughness than that of the Scotci elm, (Ulmus c. montana,) and, consequently, does 110 t crack so much as that variety in drying. In ship-building, it is valuable for forming the blocks and dead-eyes, and other wooden fixtures of rigging, being particularly suitable for these purposes, from its hard and adhesive nature, and indisposition to crack or split, when exposed to the vicissitudes of moisture and dryness. One of the principal uses of the English elm, however, in slip-bnilding, is for keels. In Norfolk, the timber of this tree is generally used for naves to wheels; and in many parts of England, and particularly about London, it is also employed for coffins. Elm timber is also remarkably durable in water, and is particularly adapted for piles, pumps, water-pipes, and for any other similas purpose. It has been used in Europe, from time immemorial, for water-pipes, or gutters, for conveying the water of salt springs to the large boxes or paus, where the watery particles are evaporated by the heat of the sun, or by fire; and it is well known that the Anglo-Saxons called all the places where there were salt springs, "wich" or "wych" (as Droitwich, Nantwich, \&c.); hence, probably, originated the name "wych elm," which was formerly applied to all British elms, including the Ulmus c. montana. The knobs, which grow upon old elms, are sawn into thin plates by cabinet-makers, particularly in France and Germany; and, when polished, they exhibit very curious and beautiful arrangements of fibre, which render their wood exceedingly ornamental, for articles of fancy. As fuel, the wood of the elm, according to Hartig, is to that of beech as twelve hundred and fifty-nine is to fifteen hmndred and forty; and, as charcoal, as fourteen nundred and seven is to sixteen hundred. The ashes of this tree are rich in alkaline salts; and among seventy-three kinds of trees, M. Werneck found tliat it occupied the tenth place in productiveness of potash. The inner bark, like that of the European lime-tree, is sometimes employed for making bast-mats and ropes. Young deer are very fond of this bark; and in Norway the inhabitants kiln-dry it, and grind it with corn to make flour for bread. The leaves and young shoots of the elm were used by the Romans to feed cattle, and they are still employed, in may parts of France, for the same purpose: and both in France and Norway, they are boiled to serve as food for pigs. In Russia, the leaves of the Ulmus c. parvifolia are used for tea. The bark is highly astringent, and both the leaves and bark, it is said, contain a considerable proportion of glue. From the bark there has been extracted a principle called ulmine, which is regarded by some as a constituent of every vegetable. A decoction of the bark imparts a yellow colour to wool. In Norway, the bark is employed in tanning skins. The fruit, in a green state, is sometimes eaten as a salad.

As a picturesque tree, "the elm," observes Gilpin, "has not so distinct a character as either the oak or the ash. It partakes so much of the oak, that, when it is rough and old, it may easily, at a little distance, be mistaken for one; though the oak, (I mean such an oak as is strongly marked with its peculiar character,) can never be mistaken for the elm. This is certainly a defect in the elm: for strong characters are a great source of picturesque beauty. 'This defect, however, appears chiefly in the skeleton of the elm; in full foliage, its character is more marked. No tree is better adapted to receive grand masses of light. In this respect, it is superior both to the oak and the asli. Nor is its foliage, shadowing as it is, of the heavy kind. Its leaves are small, and this gives it a natural lightness; it commonly hangs loosely, and is, in general, very picturesque. 'The elm naturally grows upright, and, when it merts with a soil it loves, rises higher than the generality of trees; and, after it lias assumed the diguity and hoary 
roughness of age, few of its forest brethren, (though, properly speaking, it is not a forester,) excel it in grandeur and beauty. The elm is the first tree that salutes the early spring, with its light and cheerful green; a tint which contrasts agreea-. bly with the oak, whose early leaf has generally more of the olive cast. We see them sometimes in fine harmony together, about the end of April and the beginning of May. We often, also, see the elm planted with the Scotch pine. In the spring, its light-green is very discordant with the gloomy hue of its companion; but, as the year advances, the elm leaf takes a darker tint, and unites in harmony with the pine. In autumn, also, the yellow leaf of the elm mixes as kindly with the orange of the beech, the ochre of the oak, and many of the other fading hues of the wood. * * * * * The elm throws out a beautiful bloom, in the form of a spicated ball, about the bigness of a nutmeg, of a darkcrimson colour. This bloom sometimes appears in such profusion as to thicken and enrich the spray exceedingly, even to the fulness almost of foliage. * * * * * The branch of the elm has neither the strength nor the various abrupt twistings of the oak; nor does it shoot so much in horizontal directions. Such, also, is the spray. It has a more regular appearance, not starting off at rightangles, but forming its shoots more acutely with the parent branch; neither does the spray of the elm shoot, like the ash, in regular pairs from the same knot, but in a kind of alternacy. It has, generally, at first, a flat appearance; but, as one year's shoot is added to another, it has not strength to support itself; and, as the tree grows old, it often becomes pendent also, like the ash; whereas the toughness and strength of the oak enable it to stretch out its branches horizontally to the very last twig." *

As an ornamental tree, the Ulmus campestris is employed both in Britain and on the continent, more especially in France and Holland, for lining avenues, and particular for public walks. For this purpose it is well adapted, from the comparative rapidity of its growth, the straightness of its trunk, the facility with which it bears lopping, the denseness of its foliage, its hardiness, and its great longevity.

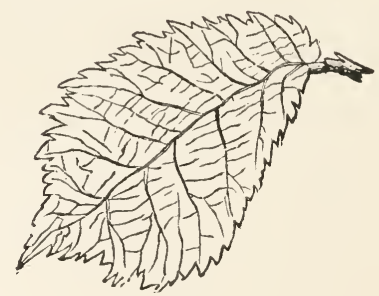




\section{Ulmus americana,}

\section{THE AMERICAN ELM.}

\author{
Ulmus americana, \\ Orme d'Amerique, Orme parasol, \\ Amerikanische Ulme, \\ Ulmo americano, \\ American White Elm, Canadian Elm, \\ White Elm, Rock Elm,
}

\section{Synonymes.}

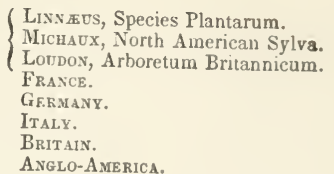

Engravings. Michaux, North American Sylva, pl. 126; Loudon, Arboretum Brilannicum, iii., fig. 1246, and vii. pl. 24;
et 244 ; and the figures below.

Specific Characters. Leaves with their disks unequal at the base, $4-5$ inches long, inclusive of a long, acuminate point, from $2-2 \frac{1}{2}$ inches broad, serrate, and mostly doubly so ; the axils of the veins underneath joined by a membrane; petioles from $1-1 \frac{1}{2}$ inches in length, and clothed with short hairs. Flowers effuse, with the peduncles short and glabrous. Stamens 5-8. Samarx fringed at he edger with hairs, ovate, acute. Young branches brown, and covered with fine, short hairs.-Adapted, from Willdenow's Enum. Plant.

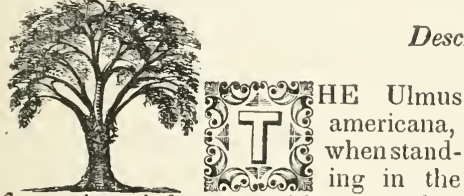
forest, is a lofty tree, with a remarkably clean, straight, round trunk, with a small, much contorted head; but, in a clearing, where it grows in an insulated manner, receiving a full supply of light and air, it appears in all its majesty, towering to an elevation of eighty or one hundred feet, with a stem from four to six feet in diameter, which, at

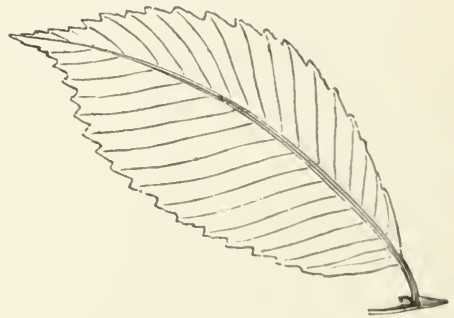
ten or twenty feet above its base, usually ramifies into three or more primary limbs, that continue gradually spreading outward and upwards to a great length, dividing and sub-dividing into many smaller ramifications, and ditlusing, on all sides, numerous long, flexible, and pendulous branchlets, bending into regular festoons, and giving to the tree a broad and somewhat flat-topped summit, of regular proportions and admirable beanty. When growing in the last-named situation, this tree is often marked by two or more small branches, four or five feet in length, proceeding from near the first ramification, and descending along the trunk; and the larger branches or limbs are sometimes covered with little raggel twigs, as if clothed with tufts of hair. The bark of the trunk is tender, deeplyfurrowed, and almost white. 'The leaves, which are four or five inches long, are? alternate, unequal at the base, oval-acuminate, generally doubly denticulated, with regular and prominent ribs, rough, and of an ahmost glossy deep-green abore, and pale and downy beneath. The flowers, which appear in March, $\Lambda$ pril, or Ma y, before the leaves, are very small, of a purplish colour, supported by short, slen- 
der foot-stalks, and are united in bunches at the extremity of the branches. The seeds, which are contained in flat oval, fringed capsules, notched at the base, arrive at maturity, in the northern parts of the United States, from the middle of May to the first of June.

Varieties. The Ulmus americana, like its European congener, has comparatively, the same aptitude to vary from seeds, and has already given rise to several varieties; but, as such a state of confusion exists in botanical works, not only as relates to the American elms, but to all others of the genus, and as the observations and experiments as regards their culture and growth, have been somewhat limited, it is difficult to determine whether they all belong to one race, or consist of several distinct species, - a problem which can never be satisfactorily solved before they are studied and cultivated under the most varied circumstances, during a period of several years. As with the European elms, we have classified them all under one head, giving, as usual, anıong our synonymes, the names under which they are described as species, by one or more authors.

1. U. A. SUBSESSILIfolia. Subsessile-leaved American Elm; Ulmus americana, of authors; a large tree, with divergent branches, indigenous chiefly to the Alleghany Mountains, sometimes attaining a height of seventy or eighty feet. The leaves, which are three or four inches long, are subsessile, ovate-acuminate, doubly serrate, oblique, and sub-cordate at the base, rough above, and slightly pubescent beneath.

2. U. A. ALBA, Loudon. Whitish-branched American Elm; a tree native of Louisiana and other states, growing to a height of fifty or sixty feet, having long, flexible, hanging branches, with whitish bark. The leaves are oblong, obliquelyacute at the base, doubly-denticulate, rough and lucid above, and villous beneath.

3. U. A. PEndula, Loudon. Pendulous-branched American Elm.

4. U. A. RUBra, London. Reddish-branched American Elm, with the branches red, and the leaves ovate, rugose, and rongh.

5. U. A. Folis variegatis, Loudon. Variegated-leaved American Elm.

6. U. A. Racemosa. Racemose-flowered American Elm; Ulmus racemosa, of Nuttall, Gray and Torrey, and others; Orme à grappe, of the French; TraubenUlme, of the Germans; Thomas' Elm, Norhern Cork-barked Elm, of the AngloAmericans. This variety was first described and figured by Mr. David Thomas, of Cayuga county, in the state of New York, in the nineteenth volume of Silliman's "American Journal of Science and Art." It abounds throughout western New York, and is also found in Canada and Vermont. The large primary branches produce corky excrescences, somewhat like those of the wahoo elm (Ulmus a. alata.) The leaves are broadly-ovate, acuminate, doublyserrated, glabrous, and somewhat shining above, with the under surface and ribs slightly pubescent. The flowers, which are yellow, and appear in April or May, are small, distinctly pedicellate, and, unlike those of any other elm, are disposed in racemes, composed of several clusters of two to four together, and extending from the length of from one inch to two inches and a half, often furnished with one or two small, but perfect leaves, before the opening of the termi-

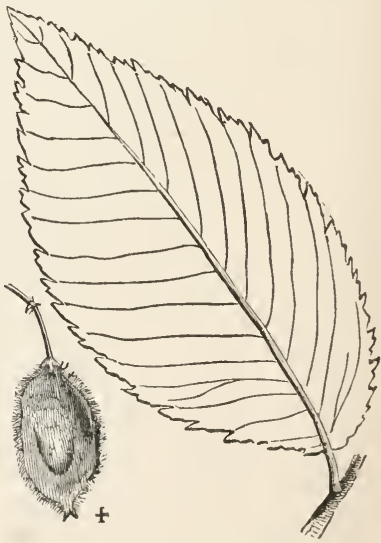
nal buds. The samaræ are large, of an elliptic form, very pubescent, thickly fringed on the margin, with their membranes more extended on one side, as indi- 
cative of a second, though abortive cell. The seeds ripen in May or June, at which time they may be collected and sown; and, if properly treated, they will immediately come up, and make strong shoots the first season.

7. U. A. Fulva. Tawny-budded American Elm; Ulmus rubra, of Michaux Ulmus fulva, of Pursh, Loudon, and others; Orme rouge, Orme gras, of the French; Gelbliche Ulme, of the Germans; Slippery Elm, Red Elm, Red-scoorden Elm, Moose Elm, of the British and Anglo-Americans. This tree bears a strong resemblance to the Dutch cork-barked elm, (Ulmus campestris major,) of Europe. It often attains a height of fifty or sixty feet, with a trunk fifteen or twenty inches in diameter. The bark of its trunk is brown, and deeply-furrowed; and that of the branches rough, and lighter coloured. The leaves are ovate-oblong, acuminate, nearly erual, and more or less cordate at the base, serrated, with unequal teeth, rugose, very rough, and hairy on both surfaces; being larger, thicker, and rougher than those of the Ulmus americana. The leaf-buds, which are also larger and rounder than those of that tree, are covered, a fortnight before their developement, with a tawny, or russetty down, by which this tree can readily be distinguished from any other variety. The flowers, which appear in April and May, are produced in tufts at the extremity of the young shoots; and

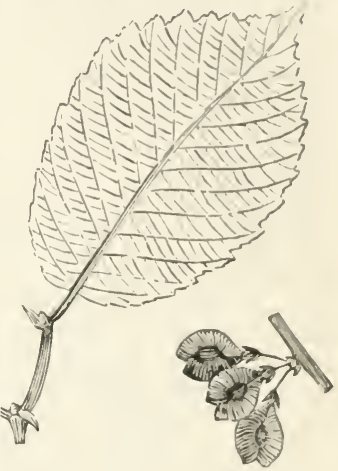
the scales which surround the branches, like the buds, are covered with down ; the calyx is downy and sessile; the stamens short, and of a pale-rose colour. The seeds, which usually ripen from the middle to the last of May, are large, destitute of fringe, orbicular or obovate in shape, and strongly resemble thase of the English elm. With the exception of the maritime districts of Carolina, Georgia, and Florida, this tree is found in almost every part of the United States, and of Canada; but, in Ohio, Kentucky, and Tennessee, it is more multiplied than east of the Alleghanies, where it grows on the richest lands of an uneven surface. It is less abundant, however, than the Ulmus americana, with which it rarely associates, as it requires a more substantial soil, somewhat free from mois. ture, and even delights in elevated and open situations, such as the steep banks of the Hudson and of the Susquehannah. 'The heart-wood is coarse-grained, and less compact than that of the Ulmus americana, and is of a dull-red tinge; whence the name "Red Elm." Even in the branches of one or two inches in diameter, the perfect wood forms the principal part. From its durability, the timber of this tree is employed with advantage in the regions where it abounds, in the construction of houses, and sometimes of ships. It is said to be the best of the $A$ merican woods for making blocks employed in the rigging of vessels, and its scarcity in the Atlantic states is the only cause of its limited consumption for that purpose. It also makes excellent rails, which are of long duration, and are formel with little labour, as the trunk may be easily and regularly split. 'The bark, which is very mucilaginous, contains certain proportions of sugar, galic acid, and supertartrate of potash. Medicinally, it is said to be alternative, tonic, and diuretic, and is employed for the cure of herpetic, and leprous eruptions. 'The leaves, which emit an agreeable smell, have been employed as food for the larva of the silk-moth. The bark and small branches, with the leaves, macerated in water, yield a thick and abundant mucilage, which is used in forming a refreshing and sootling drink, in coughs and rheums. This mucilage is also substituted for the coots of the marsh mallow, (Althwa officinalis,) in making cinollient suppurative cataplasms. 
8. U. A. INCISA, Loudon. Deeply-toothed-leaved American Elm. This variety differs from the others, in having the leaves somewhat more deeply serrated, and rather smaller, approaching nearer to those of the Ulmus campestris effusa, of Europe.

9. U. A. Longifolia. Long-leaved American Elm; Ulmus longifolia, of Rafinesque; a shrub, with smooth, slender, striated branchlets, eight or ten feet in length, native of Alabama and Tennessee. The leaves, which are three or four inches,long, about an inch wide, and smooth on both sides, are borne on short petioles, are thin, oblong-elongate, sub-cordate at the base, doubly serrated, an a uminate at the apex.

10. U. A. obovata. Obovate-leaved American Elm; Ulmus obovata, of Rafinesque; a tree thirty or forty feet in lieight, a native of Kentucky and Illinois. 'The branchlets are terete, smooth, and rugose. The leaves, which are from four to six inches long, and three or four inches wide, are borne on short petioles, are obovate, acuminate, obliquely-obtuse at the base, doubly serrated, nearly smooth on the upper side, and villous beneath.

11. U. A. Grandidentata. Large-toothed American Elm; Ulmus dentata, Yellow Elm, of Rafinesque; a tree, native of Alabama, with terete, smooth branchlets. Its leaves, which are six or seven inches long, and three or four inches broad, ale borne on petioles, at least an inch longer than in any other elm; they are acute and entire at the base, obovate, with large, sub-equal, sharp teeth in the upper lialf, sub-acuminate at the end, and smooth on both sides. 'The flowers occur in fascicles, with the pedicels filiform, the calyx campanulate, the stamens exserted, and the pistil cuneate-oblong, bifid by the two styles. The samaræ are fasciculate, peduncled, oblong, bifid, and fimbriate on the sides.

12. U. A. Alata. Cork-winged American Elm; Ulmus alata, of Michaux, Loudon, and others; Orme ailé, Orme fongeux, of the French; Geflügelte Ulme, of the Germans; Wahoo Elm, of the British and Anglo-Americans. 'This variety forms a tree of a middling stature, commonly not exceeding thirty feet, with a trunk nine or ten inches in diameter. 'The branches are garnished throughout their entire lengtl, on two opposite sides, with fungous appendages, about a quarter of an inch in width, which have given rise to the name of alata, or winged. The leaves, which are borne on short petioles, are of an oblong-oval form, narrowed to an acute point, denticulated, and almost equal at the base. The flowers put forth in April, just before the unfolding of the leaves, and do not differ materially from those of the other elms. The samaræ, which are much smaller than those of the Ulmus americana, are downy, and bear a dense fringe at the edge. This tree is indigenous to eastern Virginia, the maritime districts of Carolina and Georgia, to western 'Tennessee, and some parts of Kentucky. It is generally found on

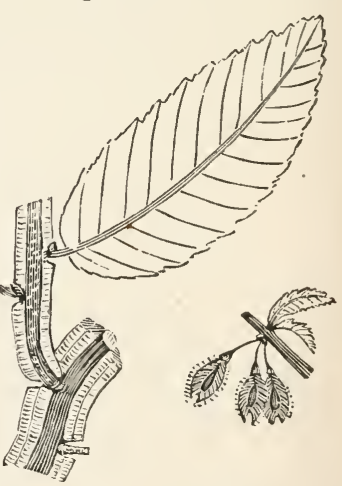
the banks of rivers, and in the great swamps enclosed by the pine-barrens. The wood of this variety is fine-grained, more compact, heavier, and stronger than that of the Ulmus americana. The heart-wood is of a dull chocolate-colour, and always bears a gruat proportion to the sap-ivood. In some parts of the southern states, it is used for the naves to coach-wheels, where it is preferred for this purpose to the tupelo, (Nyssa,) being both harder and tougher than that wood; but ir is not particularly appropriated to any other use. This variety was introduced $i$ ito Britain in 1820, where there are small specimens to be found in many of the cullections. It is perfectly hardy in New York, as has been fully tested on the 
Hudson, above the Highlands, where there is a fine tree whieh annually flowers in April or May.

13. U. A. Dimidiata. Dimidiate-leaved American Elm; Ulmus dimidiata, or Rafinesque; a shrub with smooth, angular branchlets, native of Cieorgia and Florida, and growing from eight to twelve feet in height. The leaves, which are borne on short petioles, are of two forms, from one to two inches in lengtli, all of a pale eolour, sub-coriaceous texture, equally serrate, with the base very oblique, often one side decurrent, and the other reduced in size or dimidiate; that is, in the narrow leaves the base of one side is removed upwards of the petiole, and is much reduced in its dimensions.

14. U. a. opaca. Densely-shaded American Elm; Ulmus opaca, of Nuttall; Orme opaque, of the French; Undurchsichtige Ulme, of the Germans. 'T'his curious elm was discovered in 1818 , by Mr. Nuttall, near the eonfluence of Kiamesha and Red Rivers, in the territory of Arkansas. He describes it as forming a majestic, spreading tree, with smooth and brownish branchlets, of the dimensions of the ordinary oak, and remarkable for the smallness and thickness of its oblique and unusually blunt leaves, which, with their short stalks, are only about an ineh in length, and half as broad as they are long; they are very numerous, close together, seabrous, with minute papillæ, are of a somewhat shining and deep-

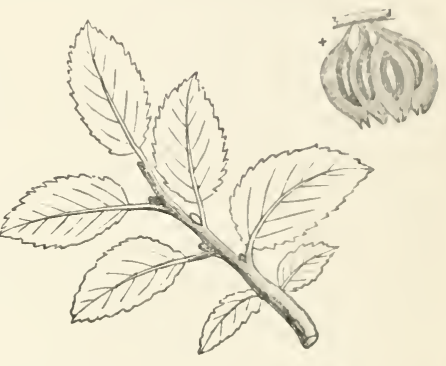
green above, and paler beneath; they are oblong-ovate; mostly obtuse, doubly dentieulated, oblique at the base, as well as the whole outline, with one half mueh narrower than the other; and the nerves on the under side, are pubescent, strong, pennate, simple or forked. The flowers are fasciculated in small numbers, and oceur on short peduncles. The samaræ are of an elliptie form, rather deeply bifid at the summit, and covered with a dense, somewhat ferruginous pubeseence, even when ripe. The density of shade produced by this tree, adds Mr. Nuttall, "so erowded with rigid leaves, and the peeuliarity of its appearance, entitle it to a place in the nurseries of the eurious, and it is probably quite hardy enough for all temperate elimates. To this speeies Virgil's epithet,

'Fœcundæ frondibus ulml.'

might more justly be applied than to any other." **

Geography and History. The Ulmus americana is indigenous to North America from Nova Scotia to Louisiana. It appears to be the most multiplied, and attains the greatest dimensions, within the territory situated between the fortyfirst and forty-sixth degrees of north latitude, whieh comprises the principal parts of the provinees of Upper and lower Canada, Nova Seotia, and New Brunswick, and of the states of New England and New York. In the middle states, and farther southward, it becomes less multiplied; but west of the Alleghanies, it is partieularly abundant in ali the fertile bottoms watered by the streams that swell the Mississippi and the Ohio, which are inundated by the floods of spring.

This speeies was introduced into Germany in the early part of the IVllth century, and one of the first-planted trees is still growing at schwöbbache, near P'yrmont, in Westphalia. It does not appear to have been propagated in Britain, however, before the year 1752, when it was planted at Mile Eind, London, by

*orth American Sylva, p. ?6. 
Mr. Jarnes Gordon; though, as Martyn observes, no notice was taken of it, or of any other American elm, in the edition of Miller's "Dictionary," which was published sixteen years afterwards. It has doubtless existed in the arboretum at Kew, and probably, in the grounds at Syon, but it is not to be found of much magnitude, at present, in either of these collections. There are trees, however, in the garden of the London Horticultural Society, and in the Edinburgh botanic garden, which exceed thirty feet in height. The American elm seldom flowers in England, and never ripens its seeds.

Seeds of the Ulmus americana were sent to France by M. Michaux, in 1807, from which several thousand plants were raised; and, of which, according to the "Nouveau Du Hamel," there are very fine specimens at Trianon, where they are distinguished from all other elms by the superior beanty of their leaves.

In America, the "favourite elm," and several other native trees, are inseparably connected with the history of the country. They forcibly appeal to the imaginations of the people, not only by being associated with the sports of childhood, the coming and singing of birds, and with the haunts of young men and maidens, fondly and joyously traced in by-gone days; but they teach lessons of wisdom to aged and hoary-headed men-bespeak their country's wrongs-their country's glory, and tell them much concerning the mutability of things below. Had these trees the gifts of reason and speech, or could their "leaves form words when shaken by the wind," how many tales of loves and woes-of human suffering and human joys would they unfold. But, as these ancient tenants of the soil are not endowed with voice and memory, let us be ourselves the oracles, and discourse to our own ears upon some of the events which have transpired withir. the dim vista of two hundred years.

\title{
PENN'S TREATY ELM.
}

\author{
"With kind, assuring words, \\ And answering deeds, he binds the deathless chain \\ Of friendship; and though o'er his silent grave, \\ Time long hath wander'd, still at the blest name \\ Of the beloved Miquon, starts the tear \\ Of Indian gratitude." \\ Traits of the Aborigines.
}

Towards the close of the year 1682, the commissioners, who accompanied the first detachment of colonists to Pennsylvania, had, in compliance with the proprietary's instructions, negotiated a treaty with the neighbouring tribes of Indians, for the purchase of the lands which they were to occupy, and for the assurance of perpetual peace and friendship between the two races of people. "The religious principles of Penn," says his biographer, "which led him to the practice of the most scrupulous morality, did not permit him to look upon the king's patent, or legal possession according to the laws of England, as sufficient to establish his right to the country, without purchasing it by fair and open bargain of the natives, to whom it properly belonged. He had instructed commissioners, who arrived in America before him, to buy it of the latter, and to make with them a treaty of eternal friendship. This, those commissioners had done, and now, by mutual agreement between him and the Indian chiefs, it was to be solemnly ratified. He proceeded, therefore, accompanied by his friends, consisting of men, women, and young persons of both sexes, to Coaquannoc, the Indian name for the place where Philadelphia now stands. On his arrival, he found the sachems and their tribes assembling. They were seen through the woods, as far as the eye could reach, and looked frightfully, both on account of their number and their arms. The Quakers are reported to have been but a handful in comparison, and without ally weapon; so that dismay and terror must have seized them, had they not confided in the righteousness of their cause. It is much to be regretted, 
when we have accounts of ininor treaties, between Willianı Penn and the Indians that no historian has any particular detail of this, though so many mention it, and all concur in considering it the most glorious of any in the amnals of the world. There are, however, relations in Indian speeches, and traditions in ( ilies, descended from those who were present on the occasion, from which we may learn something concerning it. It appears, that though the parties were to assemble at Coaquannoc, the treaty was made a little higher up, at shackamaxon. Upon this site, Kensington now stands, the houses of which may be considered as the suburbs of Philadelphia. There was at Slackamaxon, an elm tree of a prodigious size. To this the leaders on both sides repaired, approachIng each other under its widely-spreading branches. William Penn appeared in his usual dress. He had neither crown, sceptre, mace, sword, halberd, or any insigna of eminence. He was distinguished only by wearing a sky-blue sash round his waist, made of silk net-work, and of no larger dimensions than an officer's military sash, which, except in colour, it resembled. On his right hand was Colonel Markham, his secretary and relative; on his left, his friend Pearson, followed by the train of Qulakers. Before him were carried various articles of merchandize, which, when they came near the sachems, were spread upon the ground. He held a roll of parchment, containing the confirmation of the treaty of purchase and amity, in his hand. One of the sachems, who was the chief of them, then put upon his own head a kind of chaplet, in which appeared a small horn. This, according to scripture language, and among the primitive eastern nations, was an emblem of kingly power; and whenever the clief who had a right to wear it, put it on, it was understood that the place was made sacred, and the persons of all present inviolable. Upon putting on this horn, all the Indians threw down their bows and arrows, seating themselves round their chicfs, in the form of a half moon, upon the ground. The principal sachem then announced to William Penn, by the aid of an interpreter, that the nations were ready to hear him. He then said that the Great Spirit, who made him and them, who ruled the heavens and the earth, and was acquainted with the innermost thoughts of man, knew that he and his friends had a hearty desire to live in peace and friendship with them, and serve them to the utmost of their power. It was not their custom to use hostile weapons against their fellow creatures, therefore came they to this treaty unarmed. Their object was not to do injury, and thus provoke the Great Spirit, but to do good. 'They had met them on the broad pathway of good faith and good will, so that no advantage was to be taken on either side, but all was to be openness, brotherhood, and love. After these and other words, he unrolled the parchment, and by means of the sane interpreter, conveyed to them, article by article, the conditions of the purcliase, and the words of the contract then made for their eternal union. Among other things, they were not to be molested in their lawful pursuits, even in the territory they had alienated, for it was to be common to them as well as to the Einglish. 'They were to have the same liberty to do all things therein, relating to the improvement of their grounds, and providing sustenance for their families, which the Eilglish had. If any dispute should arise between the two, it should be settled by twelve persons, half of whom should be English, and half Indians. He then paid them for the land, and made them many presents beside, from the merchandize which was spread before them. Having done this, he laid the roll of parchment on the ground, observing again, that the ground shonld be common to both people. If then added, that he would not do like the inhabitants of Maryland, that is, call them only children or brothers; for parents were sometimes minind to therr children, and brothers would often differ; neither would he compare the friendship between them to a chain, which the rain might rust, or a tree fall upen and break; but he should consider them as the same flesh and blood with the C'hris- 
tians,-tne same as if a man's body was to be divided into two parts. Takıng up the parchment, he then presented it to the sachem who wore the horn in his chaplet, and desired him and the other sachems to preserve it carefully for three generations, that their children might know what had passed between then, when they were no longer living to repeat it. It is to be regretted that the speeches of the Indians on this memorable day, have not come down to us. It is only known that they solemnly pledged themselves, according to the manner of their country, to live in love with William Penn and his children as long as the sun and moon should endure. Thus ended this famous treaty of which more has been said in the way of praise, than of any other ever transmitted to posterity." To this may be added the concise eulogium of Voltaire, who pronounced it to be "the only treaty which was ratified without an oath, and the only one which was never broken."

The tree, under which the foregoing transaction took place, was long regarded by the Pennsylvanians with universal veneration. During the war of independence, General Simcoe, who commanded a British force at Kensington, when his soldiers were cutting down all the trees around them for fuel, placed a centinel under Penn's elm, to guard it from injury. In 1810, this tree was blown down in a gale of wind, when, on counting the annular rings, it proved to be two hundred and eighty-three years of age, having been one hundred and fifty-five years old at the time the treaty was signed. Shortly after this accident occurred, a large portion of the tree was conveyed to the seat of the representative of the Pem family, at Stoke, near Windsor, in England, where, it is said, it still remains in a state of complete preservation.

\section{LIBERTY TREES.}

"When people first thought of making Liberty a goddess," says Dr. Smith, "and consecrating trees to her, we cannot say; but, about the time when the tronbles between the American colonies and the mother country commenced, there appears to have been laid, in England, an unpopular excise upon cider, and the sufferers under the act assembled near Honiton, in Devonshire, and appropriated an apple-tree as an altar at which they might sacrifice the image of the minister with whom the act originated. It was in imitation of this exhibition, that, we suppose, our revolutionary Liberty. Trees took their rise. The most famous were the ones at Boston, Providence, Newport and New York. It fell to the native elm to be selected for this purpose in America. That which was set apart in Boston, was a wide-spreading and beautiful tree, which stood in front of the house that now makes the corner of Essex and Washington streets, * opposite Boylston market. * * * * * Several other large elms grew in the vicinity, and our aged inhabitants remember the place by the name of the neighbourhood of the elm-trees. It was on the 14th of August, 1765, that this tree was devoted to the 'Sons of Liberty,' to expose on it the effigies of the men who had rendered themselves odious by their agency in procuring or favouring the passage of the Stamp Act ; and, on the 11th of September following, they fixed a copper plate, two feet and a half, by three feet and a half in dimensions upon it, bearing the inscription, in gold letters, the tree of liberty, Aug. 14, 1765. Ever after, most of the popular meetings of the 'Sons of Liberty' were held in the square round this tree. ****** The British made it an object of ridicule. 'The soldiers made poor Ditson, whom they tarred and feathered, parade in front of this tree, before they would let him go, and one of the greatest exploits during the siege was the felling of this famous eye-sore. T'is was effect d about the last week

\footnotetext{
* It was remarked by La Fayette, at the time he visited Boston, in 1824, that "The world should never forget the spot where once stood the Liberty Tree, so famous in vour annals."
} 
in August, 1775. One Job Williams was the leader of the party that accomplished the feat, leaving nothing but the stump above ground-the iont they conld not touch. One of their comrades lost his life by accident on the occasion. This tree had been planted one hundred and twenty-mine years, (according to the Pemberton MSS.) 'in 1646, and bore the first fruits of Liberty in America.' II e are informed by an old and reputable inhabitant, who was present at the time, that the tree when cut, made fourteen cords of wood." *

The Liberty tree at Providence, in Rhode Island, was also an elı, and stood in Olney's Lane, in front of a house formerly occupied as a tavern. It is said to have been remarkable for its size, and served as a point of reference to strangers when they arrived in the place. This elın was dedicated to the "sous of Liberty" on Monday, July 25th, 1768, when a great concourse of people had assembled, and an animated discourse was delivered from the summer-lionse in the tree, by Mr. Silas Downer, a member of the bar. The people placing their hands on the tree, he pronounced aloud the following words :- "We do, in the name and behalf of all the true sons of liberty in America, Great Britain, Ireland, Corsica, or wheresoever they may be dispersed throughout the world, dedicate this tree of liberty. May all our counsels and deliberations, under its venerable branches be guided by wisdom and directed for the support and maintenance of that liberty which our forefathers sought out and found under the trees in the wilderness; may it long flourish, and may the sons of liberty often repair hither to confirm and strengthen each other. When they look toward this sacred elm, may they be penetrated with a sense of their dnty to themselves and their posterity, and may they, like the house of David, grow stronger, while their enemies, like the house of Saul, shall grow weaker and weaker-AMEN."

\section{TREES OF FRIENDSHIP.}

In the town of Natick, in Massachusetts, in front of the residence of the Rer. Mr. Peabody, successor to the Apostle Eliot, near the site of the old Indian meeting house, there formerly stood two stately elms, which were planted in about the year 1722. It is related by Mr. John Welles, that a deputation of Indians came to their newly-settled minister, bearing these trees upon their shoulders, requesting permission to plant them out before his door, as a mark of their regard, or as the "Tree of Friendship." These trees, it is said, flonrished for about ninety years, when the larger one was struck by lightning, and soon after died. The other shortly after began to decline, and subsequenty fell into a state of decay. The girth of these trees, at a foot above the gromind, was twenty-one feet, having acquired an annual increase of trunk of about ninetenths of an inch.

In the year 1752, Mr. Peabody died, and the year following, he was sueceedel by Rev. Stęphen Badger, who, on taking up his residence in that vicinty, was soon after visited by some Indians of the same tribe, with the request that they might also plant the "Tree of Friendship" before his door. "The request was granted, and two elm trees were planted, which are still standing, in full vigour having attained about the same dimensions as those planted in 17.2.2.

\section{THE GREAT ELM IN BOSTON.}

The noble elm, which stands so conspicuonsly near the centre of the Common. in Boston, and which adds so much to the picturesque beanty of those public grounds, is much revered by the citizeus, and ustrally attuacts the admiration and

* Boston News-Letter and City Record, Edited by Dr. Jerome V. C. Smith, i. p. 19. 
particular attention of strangers. According to a statement in the "Boston Traveller," of the 20th of April, 1844, it did not, as many suppose, spring from the soil on which it now stands, but was set out there by Captain Daniel Henchman-at what time, we are unable precisely to say, but believe it was somewhere about the year 1670 , and therefore it is about one hundred and seventyfive years old. It was stated by Madam Scott, the widow of John Hancock, that Captain Henchman brought this tree from the North End, and planted it in the place where it now stands, on the moist lands of the Common-a proper place for an elm. In Whitman's history of the Ancient and Honourable Artillery Company, we find it stated that Captain Henchman was a school-master in Boston, from 1666 to 1671. He joined the Ancient and Honourable Artillery Company in 1675. "He was a distinguished captain in King Philip's war, of a conıpany of foot, June 26, 1675, in company with Captain Prentice, with a troop of horse, and was the person who set out the great elm tree on Boston Common, for a shade to the military companies which might exercise there in after time." About forty-five years ago, this tree had a large hollow in it, and was apparently rapidly decaying; but by proper modes of treatment, which modern times have discovered, and particularly that recommended by Forsyth, its decay was arrested, its vigour restored, and it is now apparently as flourishing as ever, and without any appearance of the hollow, which was once large enongh for a boy to hide himself in.

The present height of this tree, (April, 1846,) is about sixty-five feet; the girth of its trunk, at a yard above the ground, eighteen feet, and the diameter of its head, ninety feet.

\section{THE GREAT ELM IN PITTSFIELD.}

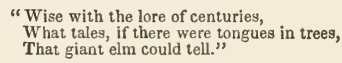

In the centre of the public square, in the beautiful town of Pittsfield, in Massachusetts, there stands alone, in all its majesty, encircled by a new generation of lesser trees, a venerable old elm, which measures one hundred and twentyeight feet in height, with a trunk thirteen feet and nine inches in circumference, at a yard from the ground, and ninety feet to the lowermost limbs. At the time the town was first settled, nearly one hundred years ago, it was a beautiful tall tree, at least a century and a half old, which, from the symmetry of its trunk, and its palm-like summit, was spared by the woodman's axe, while the rest of its forest brethren were felled to the ground. With this much revered and ancient tenant of the soil, there are associated numerous incidents, which, in themselves, would fill a volume; and it is to be regretted that the immediate object and limited length of this treatise, prevents us from entering into them in detail. It was beneath the shade of this tree that the American troops, of that part of Massachusetts, at present known as the county of Berkshire, and the valley of the Housatunnuk, were marshalled, previous to their march to Bunker Hill. And the first agricultural fair in America was held, in October, 1814, under its boughs.

At the request of a highly valued friend, we insert the following spirited and graphic lines, by Mr. N. S. Dodge, of Pittsfield, which appeared, a few years since, in the "Berkshire Whig." "Their intrinsic merit, more especially from the relation which they bear to this "primeval aboriginal of the soil," which has been rocked by the storms of centuries, and scathed by the thunder's bolt, 
and still maintains his proud and ereet preëminence, may commend itse taste and attention of the many admirers of this old and venerable frienc

\title{
Tbe Tuabe Old zalm.
}

\author{
Hail to the Elm! the brave old Elm! \\ Our last lone forest tree, \\ Whose limbs outstand the lightning's brand, \\ For a brave old Elm is he ! \\ For fifteen score of full told years \\ He has horne his leafy prime, \\ Yet he holds them well, and lives to tell \\ His tale of the olden time! \\ Then hail to the Elm! the green-topp'd Elm! \\ And long may his branches wave, \\ For a relic is he, the gnarl'd old tree, \\ Of the times of the good and brave. \\ The weary hunter from the chase \\ Rested beneath his shade; \\ In the twilight pale the lover's tale \\ Was told the dark-hair'd maid! \\ And gath'ring from the mountain sides \\ When roused the braves to war, \\ Like a banner he, the old Elm tree, \\ Waved on the sight afar. \\ When echo from the eastern heights \\ Told of old Bunker's hill, \\ And mustering thick, while hearts beat quick, \\ Were men of nerve and will. \\ The old tree reared his crested top, \\ Like a warrior bold and free, \\ An emblem true to each yeoman's view \\ Of death or victory.
}

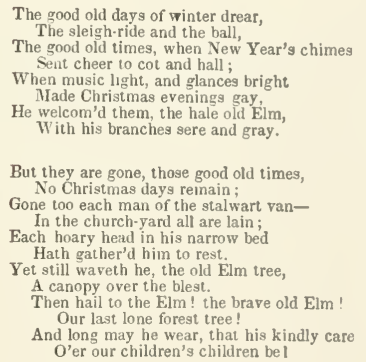

To the extreme regret of the citizens of Pittsfield, especially of those who were boin under its shade, this tree was struck by lightning on the 30th of Jume, 18 11 , by which a broad strip of bark was rent from the entire length of the trunk. Measures were immediately taken to repair the injury, by the application of a plastic compound, but some of the branches begin to exhibit marks of decay, and it is feared that this noble relic of antiquity is fast approaching its funal dissolution.

THE HATFIELD ELI.

The largest Ulmus americana we have on reeord, stood, until a few years sinee, in the town of Hatfield, in Massachnsetts, near the river Connecticut. The girth of its trunk, at a yard above the gromud, was thirty-four feet, and twenty-four and a half feet at five feet above. 'There was a ent in the truuk about four feet above the ground, which popular tradition says was made by the tomahawk of an Indian, for the greatest rise of the water ever known in the above-named river. 
THE GREAT ELM AT JOHNSTOWN.

At Johnstown, near Providence, in Rhode Island, there is an American elm, with a trunk twenty-four feet and three inches in circumference at two feet above the ground, twenty-one feet and eight inches at a yard above, and holds nearly the same size for tweive feet. The trunk divides into eight main branches, which extend themselves into a broad, spreading summit.

\section{THE WASHINGTON ELM.}

Is the city of Cambridge, in Massachusetts, there stands, in the vicinity of Harvard University, a beautiful elm, named after General Washington, which has a trunk thirteen feet and three inches in circumference, and is estimated to be one hundred and thirty years of age. It is said that the "celebrated Whitfield, when excluded from the pulpits of the town and college, preached under the shade of this tree in the summer of $1744 . *$

Soil, Propagation, \&॰c. The Ulmus americana delights in low and humid situations, such as the rich bottoms or interval lands along the banks of rivers and streams, or on the borders of swamps, where the soil is deep and fertile. It will grow, however, on any soil that is not too dry and barren, and in any sitution within its natural limits, how much soever exposed. The propagation and management of this species, and those of the European elm, are nearly the same, and consequently need not be repeated here.

Accidents, Insects, \&ैc. The American elm is subject to but few diseases, and is not very liable to accidents, except in being sometimes prostrated by violent winds. But, unfortunately, the foliage of this noble tree serves as food for several kinds of insects, or their larvæ, while its bark and wood are pierced by others for the purpose of making provision for their young. Among the latter class may be mentioned the pigeon tremex, (Tremex columba,) which pierces the tree half an inch or more in depth, wherein she deposits her eggs. The body of the female is described, by Dr. Harris, as "cylindrical, about as thick as a common lead-pencil, and an inch and a half, or more, in length, exclusive of the borer, which is an inch long, and projects three-eighths of an inch beyond the end of the body. The latter rounds upwards, like the stem of a boat, and is armed with a point, or short horn. The head and the thorax, are rust-coloured, varied with black. The abdomen, or hinder and longest part of the body, is black, with seven ochre-yellow bands across the back, all of them but the first two interrupted in the middle. The horned tail, and a round spot before it, impressed as if with a seal, are ochre-yellow. The antennæ are rather short and blunt, rust-coloured, with a broad, black ring in the middle. The wings expand two inches and a quarter, or more; they are smoky-brown, and semi-transparent. The legs are ochre-yellow, with blackish thighs. The borer, awl, or needle, is as thick as a bristle, spear-pointed at the end, and of a black colour; it is concealed, when not in use, between two narrow, rust-colored side-pieces, forming a kind of scabbard to it." The male, continues the same author, "is extremely unlike the female, in colour, form and size, and is not furnished with the remarkable borer of the other sex. He is rust-coloured variegated with black. His antenıæ are rust-yellow, or blackish. His wings are smoky, but clearer than those of the female. His hind-body is somewhat flattened, rather widest behind, and ends with a conical horn. His hind-legs are flattened, much wider than those of the female, and of a blackish colour; the other legs are rust-coloured,

* North American Review: 
and roore or less shaded with black. The length of his body varies from threequarters of an inch to one inch and a quarter; and his wings expand from one inch and a quarter to two inches, or more. ***** 'l'he fenale, when about to lay her eggs, draws her borer out of its sheath, till it stands perpendicularly under the middle of the body, when she plunges it, by repented wriggling motions, through the bark into the wood. When the hole is nade deep enough, she then drops an egg therein, conducting it to the place by means of the two furrowed pieces of the sheath. The borer often pierces the bark and wood to the depth of half an inch, or more, and is sometimes driven in so tightly, that the insect cannot draw it ont again, but remains fastened to the tree till she dies. 'T'he eggs are oblong-oval, pointed at each end, and rather less than one-twenticth of an inch in length. 'The larva or grub, is yellowish-white, of a cylindrical shape, rounded behind, with a conical, horny joint, on the upper part of the hinder extremity, and it grows to the length of about an inch and a half. It is often destroyed by the maggots of two kinds of ichneumon-flies (Pimplu atruta, and lunator, of Fabricins.) These flies may frequently be seen thrusting their slender borers, measuring from three to four inches in length, into the trunks of trees shabited by the grubs of the tremex, and by other wood-eating insects; and, like the female tremex, they sometimes become fastened to the trees, and die. without being able to draw their borers out again." $*$ Among the lepidopterous larvæ that attack the elm, are those of the four-horned ceratomia, (C'eratomia quadricornis, of Harris, ) and those of several species of Geometridæ, such as spanworms, loopers, measurers, etc., including those of the lime-tree winter-moth, (Hybernia tiliaria, of Harris,) and the common canker-worm (Phalana vernatu, of Peck.) The leaves of this tree are also preyed upon by a coleopterous beetle, and its larvæ, (Chrysomela scalaris, of Le Conte,) and likewise by the larve of a species of saw-fly (Cimbex ulmi, of Peck, or C. americana, of Leach.) 'These insects, according to Dr. Harris, appear from the latter part of May to the middle of June, during which period the female lays her eggs upon the trees. The larva, which come to their growth in August, measure from an inch to an inch and a half in length, are rather thick and cylindrical in their form, and have twentytwo legs, or a pair to every ring, except the fourth. They have a firm, rough skin, of a pale, greenish-yellow colour, covered with numerous transverse wrinkles, with a black stripe, consisting of two narrow black lines, along the top of the back, from the head to the tail; and their spiracles, or breathing-holes, are also black. When at rest, they lie on their sides, curled up in a spiral form, and, in this position, look not much unlike some kinds of cockle or snail shells. Like all the false caterpillars of the genus cimbex, this insect, when handled or disturbed, betrays its fears or its displeasure by spirting out a watery fluid from certain little pores, situated on the sides of its body, just above its spiracles. After its feeding state is over, it crawls down from the tree to the gromnd, and conceals itself under fallen leaves or other rubbish, and there makes an oblong-oval, brown cocoon, very closely woven, as tongh as parchment, and about an inch in length. In this, the false caterpillar remains unchanged throughout the winter, and is not transformed to a chrysalis till the following spring. $\Lambda t$ length the insect bursts its chrysalis skin, and, by pushing against the end of its cocoon, forces off a little circular piece, like a lid, and, through the opening thus made, it comes forth in a winged form. $†$

Properties and Uses. The wood of the Ulınus americana, like that of the European elm, is of a dark-brown colour, and is liable to deeay when exposed to the alternations of moisture and dryness; and, when cut transversely or obliquely to the longitudinal fibres, it exhibits the same numerons and func undulations:

- Report on the Insects of Massachusetts, pp. 389, 390, et 391.

† Ibidem, p. 375 
but it splits more easily, and has less compactness, harduess, and strength, weighing, when perfectly dry, only thirty-three pounds to a cubic foot. The principal uses to which this timber is applied, are for making naves or hubs to wheels, for piles and foundation pieces to mills, canal locks, and for many other purposes where strength is required, and the work is cor stantly buried in water or mud. In the state of Maine, it is occasionally employed for the keels to vessels, for which purpose it is well adapted on account of its size. It is also employed for the sivingle-trees of the carriages of great guns; and in some parts If the country, where more appropriate wood is not to be found, it is used for making ox-yokes, sleds, and other implements of husbandry. The bark, which is easily detached from the tree during eight months of the year, is sometimes used for making bast-mats, ropes, or withes, and for the bottoms of chairs. The wood, when dry, makes excellent fuel, and when burned, yields a large proportion of ashes, which abound in alkaline salts. In Canada, and in the northern parts of the states of Maine, New Hampshire, Vermont, and New York, a profitable business is followed, especially in connection with clearing the forests, in preparing the salts of ley, for the manufacture of potash. The method generally adopted for procuring these salts, is detailed by Gosse, in his "Canadian Naturalist," as follows:- "One man, or more commonly two, go into the woods with holders, and a kettle or large caldron, and make a kind of camp, very much like a sugar camp. As winter is the usual season of operation, they often make a rude hut, or some little protection from the cold. They commence their business by felling such trees in the neighbourhood as suit their purpose; unless they have another object in view, the clearing of the land for cultivation, in which case, they cut, and burn indiscriminately, all the timber, except such as is saved for some peculiar purpose, such as cedar for fencing, \&c. Having cut enough to begin, and divided it into $\log$ s, they pile them on one another by rolling them up an inclined plane, made by stakes from the lower logs to the ground. They then fill the interstices with dry brush, seasoned wood, \&c., and set fire to the whole, taking care to have sufficient wood that will burn to consume that which would not burn without assistance. The ashes are collected from time to time, and put into a holder, shaped like an inverted cone, with the bottom open; a little straw is placed over the hole at the bottom, a receiver placed beneath, and water poured on the ashes, the water filters through, and runs into the receiver, having extracted the alkali contained in the ashes, which stains it of a dark colour, like that of brandy. This is called lye, or ley, and is boiled down till the water is evaporated, and the alkali is left, which is the potash in a very impure state; it is of a black colour, and is called salts of ley. This is sold to those who keep a potashery where it is cleansed from its impurities, I believe, by burning in a furnace, and becomes the potash of commerce."

As a picturesque tree, the American elm, in woodland scenes, is rarely surpassed by its forest brethren, in point of beauty, or of size. When standing in a wood, in a soil it loves, it naturally grows upright, and rises higher than a generality of other trees; and, when standing insulated and alone, in a newly-cleared field, with its top decayed and dead, save here and there a small tuft of leaves, stretching forth its naked and withered arms, it forms a striking emblem of the aged patriarch, who has outlived all his fellows, and is a stranger in the land which gave him birth, in whom death is already struggling with life, and will soon gain the ascendency. But when cultivated or grown in a pasture or in the lawn standing in lonely majesty, towering to the height of a hundred feet, with its lowermost limbs diverging outward and upwards, at a few yards above the ground, and afterwards dividing, and sub-dividing into numerous smaller ramifications, and diffusing on all sides its pendulous branchlets, floating lightly in the air, it forms an object of dignity and grandeur. This tree, too, is among the first 
to salute the early spring with its light and cheerful green, which, though discordant at first with the gloomy hue of the pines and firs, partakes of a darker tint, as the season advances, and unites in harmony with their unchanged boughs. In autumn, also, before the nightly frosts and chilly winds have done their work, the bright golden foliage of the elm kindly mixes with the various hues of the poplar and the maples, which display all shades of red, from the deepest crimson to the brightest orange; a tint that contrasts agreeably, at this season, with the pale-yellow, sober foliage of the birch and the beech, with the different shades of brown in the bass-wood and the ash, or with the buff-yellow of the larch. The beech, the ash, and the larch, however, do not, in general, take much part in this gorgeous pageant. The ash is chiefly leafless at this time, and its glory has passed away before the other two have scarcely begun to fade. Indeed, "the glossy green of the beech is perhaps more effective than if it partook of the general change; and even the gloomy blackness of the resiniferous trees, by relieving and throwing forward the gayer tints, is not without effect."

In America, particularly in New England, the elm is very generally adopted as an ornamental tree for lining streets, high-ways, \&c., and as such, there are but few others more appropriate. 


\title{
Genus PLANERA, Gmel.
}

\author{
Thimscese. \\ Sysic $13 x$. \\ Polygamis Monuecis; or Tetr-Pent-andris Digrnis. \\ Syst. Lin
}

Synonymis.

Plonera, Timus, Ehamers,

OF Atrans.

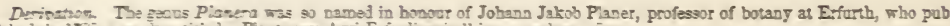
Estad, in 17ss, a wots entitied " Placiarum Agri Erionilensis," in ode rolume, Sra.

Generic Chorocters. Seres polrgamons, or each in a distinct fower; in each case upon the same flant. Calry of female and biserual flowers bell-shaped. distinct from the orary, membranous, green. of one piece but haring 5 ciliate lobes. Stamens, in the biserual flower, $1-5$. less dereloped than those in the male flower. Orer top-shaped, rillous. Stigmas 2. sessile, direrging. white, pimpled. Fruit rondish gibbous. pointed. dr. 2-celled. each cell containing 1 -seed. Calru of male tlower as in the female and bisexual flowers. Stamens $1-5$. inserted near the centre of the bottom of the calrx. and opposite to its lobes. Anthers reaching a little berond the lobes of the calrx. borne outwardly to the flsment of 2 lobes that seem ss 4 , and 2 cells that open sidewise and lengthwise. In $P$. gmelini, ( $P$. dinifolig.) the fruits are in heads; and in P. richandii. nearly solitary. Leares alternate, and more or less orate and rootked: feather-reined and annual; and the flowers, small, and not showt. P. richartin has stipuies, whech are siraight, pointed, rillous, and soon fall off.-Adapted, from Turpin, . Ti chave, ard Lrudon.

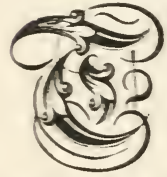

HE genus Planera embraces deciduous trees and shrubs, natires of western Asia. and of North America; quite hardy in Britain, and in the middle states of the American union. and are readily propagated br grafiing on the elm. br lavers, and cuttings of the roots. or from seeds, in ant common soil. There are at least two species in this genus, the zelkoua-tree, (Planera richardii,) and Gmelin's planera (Planera ulmifolia.) The former is a beautiful lofty tree, growing to a height of serenty or eighty feet. natire of the country between the Black and Caspian Seas, particularly of Imiretta and Mingrelia: also of the north of Persia. and of Georgia. It is distinguished by its shining-green, broadly crenulated leares, its smooth, greenish trunk, and somenhat resembles the beech. except that its branches are more numerous, and grow more erect. Both the sap-mood and the heart-mood of the zelhoua are emplored as timber for the same purposes as the oak. The heart-wood, when cut obliquely, resembles that of the robinia. and like that mood, presents numerous interlacements of fibre. It is rerr heart, and when dry, becomes so extremely hard, that it is difficult to penetrate it with nails. It has, also. the great advantage of never becoming morm-eaten. howerer old it may be. It is remarkably durable as posts, to stand either in water or in the earth. The largest recorded tree of this species, in Europe, is on the estate of M. le Compte de Dijon. at Podenas, near Nérac, in France, in the department of the Lot et Garonne. It $\pi^{2}$ as planted in 17 59 ; and on the 29th of Januarr, 1\$31, it measured nearly eighty feet in height, with a trunk three feet in diameter, at a yard abore the ground. The Planera richardii was first introduced into Britain in about the rear 1760 , and planted in the gardens at syon and at Kem, in which there are specimens exceeding fifty feet in height. The zel'roua or zelhona, was introduced into the United States in $1 ; s 4$, by the late William Hamilton, at the Woodlands, near Philadelphia, where there are fire beautiful fastigiate-growing trees, from forty-fire to fitty or more feet in beight, with trunks from eighteen inches to two feet in diameter. 


\section{Planera ulmefolia, THE ELM-LEATED PLANERA.}

Planera ulmifotic,

Planera gmelini,

Planera ż feuilles doorme,

Clmenblattrige Planera,

Planera a foglie di olmo,

Gmelin's Planera, Planer-tree,

Symonymes.

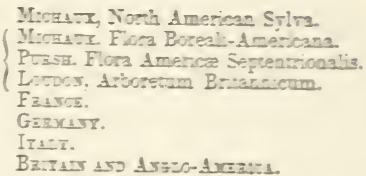

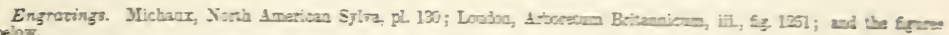

Sprocijic Charocters. Flowers in Leads, opening befure the leares, and bome on branches or tranchlers dereloped in some jear previous. Leares with obrious petioles, dis orate-asuminate, egas a: be base, and serrate.

\section{Description.}

Eacos 3. 4 twenty to forty ieet. with a trunk eter. The leares are abou an inch anteen inche acuminate, denticulated, of a lively green on the upper surface, and gray beneath, much resembling those of the Llmus campestris, except in being serrated with equal teeth. The flowers, which appear early. and before the leares, occur at the ends of the branches, in globose heads, and upon rerr short

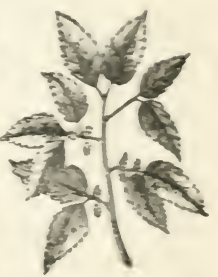
foot-stalks. They are small, of a greenish-brown colour. and are not all conspicuous. The fruit, which is small. oral, inflated, and rough, becomes brown beiore the fall of the leares, and contains minute seeds.

Geography: f.c. This species is a native of North America, where it is found in Kentucky, Tennessee, the country bordering on the Mississippi, and throughout most of the southern states. particularly in the large swamps on the borders of the rirer Savannah, in Georgia. It was introduced into Britain in 1816 , but is rare in collections; though it might readily be muluplied by grafung on the elm.

Properties and Uses. The wood of the Planera ulmifolia, according to Michaur. is hard. strong, and seemingly proper for rarious uses: but, as it is somewhat rare, and rather limited in its growth, it is not appropriated to any particular use in the arts.

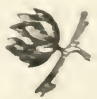




\title{
Genus CELTIS, Tourn.
}

\author{
Ulmaceæ. \\ Syst. Nat. \\ Polygamia Monœcia; or Pentandria Digynia.
}

Derivation. The word Celtis is one of the names anciently given to the lotus, and is said to refer to the European nettle tree, (Celtis australis,) having been known to the ancient Celts.

Cineric Characters. Flowers borne upon the shoots of the year, axillary ; either solitary, or 2-3 together, each, in any case, upon a peduncle; or from 2 to many, in a raceme or panicle; in the kinds hardy in Britain, the flowers are protruded just previously to the leaves to which they, or the fruits, are afterwards axillary; bisexual, or less commonly, by the imperfection of the pistil, only male in effect ; both kinds upon one plant, and when they occur in the same raceme, the latter are the lower. Calyx bell. shaped, distinct from the ovary, 5-6-parted, the segments imbricate in æstivation. Stamens 5-6, inserted into the base of the calyx, oppositely to its lobes, and they are shorter than the lobes. Filaments at first incurved. Anthers cordate-acuminate; the cells 2, opening at the sides. Ovary ovate, 1-celled. Stigmas 2, sessile, acuminate, long, spreading or recurved, downy or glanded, simple or 2 . parted. Fruit a drupe, sub-globose. Ovule and seed, each 1, and pendulous. Embryo sickle-shaped, its radicle uppermost ; traces of sub-gelatinous albumen are between the cotyledons. Leaves alternate, in 2 ranks, ovate and pointed, unequal at the base, serrate; rough on the upper surface, apparently from the callous bases and remains of bristles; annual in the hardy kinds, in Britain, and these have the primary veins forming but a small angle with the midrib, and extending through a considerable portion of the length of the disk. Stipules lanceolate, soon falling off. Leaves in the bud not folded, but plaited, with scales present between leaf and leaf. Fleshy part of the fruit eatable, but small in quantity.-Loudon, Arboretum, from Nees Von Esenbeck, Sprengel, and Others.

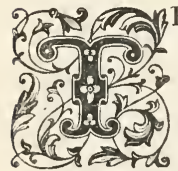

HE genus Celtis is composed of handsome trees and shrubs, natives of Europe, northern Africa, the Levant, China, India, North and South America, the West Indies, \&c. Most of them have spreading heads and slender branchlets, covered with tough fibrous bark of the nature of hemp, varying in size and foliage, bearing small edible fruit, which is remarkably sweet, and is said to be wholesome. The most noted species are the European nettle-tree, (Celtis australis,) and the North American nettle-tree (Celtis occidentalis.) The former is a deciduous tree, native of both shores of the Mediterranean, and is particularly abundant throughout the whole of the south of France, Spain, and Italy, and is distinguished by its long, slender, flexible branches, with a grayish bark, spotted with white, and slightly covered, at the extremities, with down. The leaves are of a dark-green, marked strongly by the nerves on the lower side, and, when young, are covered with a yellowish pubescence. They are ovallanceolate, terminating in a point at the summit, and at the base, with one side prolonged down to the petiole. The flowers, which are small, greenish, and inconspicuous, are produced at the same time as the leaves. The fruit, which is blackish, when ripe, and resembles a small, withered, wild cherry, is said not to hecome edible till the appearance of the first frost; and remains upon the tree until the following spring. It is remarkably sweet, and is supposed to have been the lotus of the ancients, the food of the Lotophagi, which Herodotus, Dioscorides, and Theophrastus describe as sweet, pleasant, and wholesome; and which, Homer says, was so delicious as to make those who ate of it, forget their country. This tree is much used in the north of Italy, and in the south of France, for planting squares and public walks, where it is frequently to be found from firty to fifty, and evell seventy feet in height. The wood is extremely compact, ranking between that of the live oak and the box, for hardness and density, and consequently is applicable to a great variety of purposes in the arts.

All the species will grow in a rather moist soil, and may be propagated by lay. ers, and in most cases from seeds. 


\section{Celtis occidentalis, \\ THE AMERICAN NETTLE-TREE.}

\section{Synonymes.}

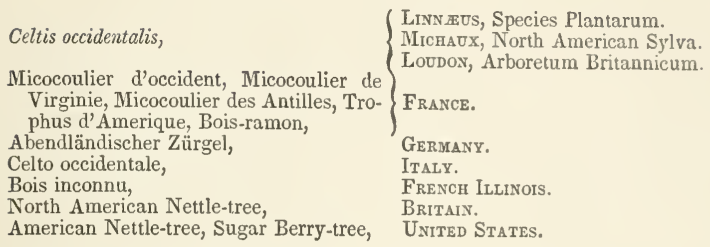

Derivations. The specific name occidentalis is derived from the Latin occido, to set, or go down; having reference to this tree as growing in a direction, from Europe, towards the setting sun. The appellation Netlle-tree relates to the similariby the leaves of this tree to those of some kinds of nettle (Urtica.) This species is called Sugar Berry, from the sweetness of the fruit.

Engravings. Michaux, North American Sylva, pl. 114; Loudon, Arboretum Britannicum, vii., pl. 243 et 219 ; and the figures below.

Specific Characters. Leaves alternate, ovate-acuminate; in the acuminate part, and at the base, entire; in the interval on each side, serrate; base acute, oblique, unequal; glabrous on the upper surface, pubescent beneath, and marked with conspicuous veins. Flowers solitary; in the lower part of the branch, 3 in an axil; in the upper part, 1 only in the axil. Fruit solitary, axillary, on pedicels sub equal or shorter than the petioles; globular, obscurely purple or red.
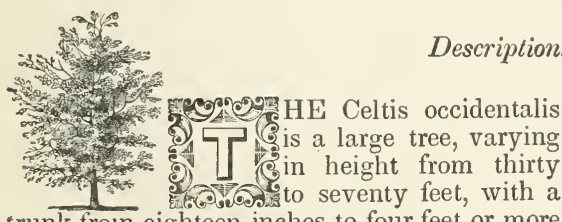
trunk froin eighteen inches to four feet or more in diameter. Its branches are numerous and slender, and the limbs originate at small distances from the ground, and seek a horizontal or an inclined direction. The bark of the trunk is rough, and that of the secondary branches smooth and even. The branchlets are angular, pubescent, but not dotted. The leaves, when young, are ovate-lanceolate, and somewhat downy. When adult, they are broadly ovate-acuminate, about three inches long, ovaloblique or acute at the base, very acuminate at the summit, and distinctly toothed in their central margins. Their colour is a beautiful dark

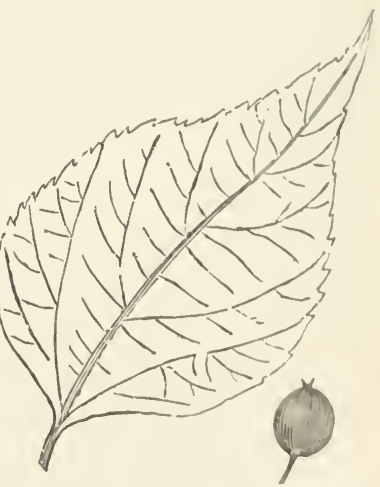
green, smooth or slightly rough on the upper surface, and hairy or pubescent beneath, with numerous prominent veins. 'I'hey may readily be distinguished from those of the European species, by being larger, of a lighter and more shining green, and by their dying off earlier, with a brighter yellow hue. 'The flowers, which put forth in March, April, or May, are very small, white, and are succeeded by purplish-red drupes. of a round form, and about the size of a will 
cherry. When ripe, it is rather fleshy, very sweet, and, like that of the Celtis australis, of Europe, becomes shrivelled, and of a brownish or blackish cast.

Varieties. The trees belonging to the genus celtis, like those of pyrus, fraxinus, ulmus, and others, from the sinilarity of their habits, and their apparent aptitude to sport by the influences of soil, climate, \&c., it seems to us, are subject to similar variations, and consequently should be reduced in the number of their species. We have accordingly, for the sake of brevity, and the convenience of classification, brought all the North American kinds, including those usually regarded as species by botanists, under one head, and have considered them only as varieties of the Celtis occidentalis. Those, however, who differ from us, in opinion, will find no difficulty in recognizing among our synonymes, the names, as given by Michaux, Nuttall, Loudon, and others, whereby they will be enabled to know under what head they are described in the works of these authors.

1. C. o. Lovgrfolia. Long-leaved American Nettle-tree; Celtis longifolia, of Nuttall; Micocoulier à longues feuilles, of the French; Langblättriger Zürgel, of the Germans; a fine shady tree, sometimes attaining the height of sixty or seventy feet, native of Missouri, Arkansas, Louisiana, and Texas. The branches, when young, are tomentose, but become dotted and smooth with age. The leaves are broadly ovate-lanceolate, entire, gradually acute, oblique and unequal at the base, from two inches to three inches and a half in length, and from one inch to an inch and a half wide, and smooth on both surfaces. The flowers, which come out in March or April, with the unfolding of the leaves, are small, of a greenish colour, and are succeeded by small brownish-yellow berries

2. C. o. TEnufolia, Lamarck. Thin-leaved American Nettle-tree; Celtis temuifolia, of Nuttall; Micocoulier à fenilles déliées, of the French; Dünnblättriger $Z \ddot{Z}$ rgel, of the Germans; a small shrub, with erect divaricate branches, growing to a height of from two to five feet, a native of Maryland and Virginia; flowering in May, and bearing small, solitary berries, which are glaucous and brown. The branchlets are angular and smooth. The leaves, which are from one to $\mathrm{t}$ wo inches long, in the adult state, are cordate-ovate, slightly acuminated, serrulate in the middle, but occasionally without teeth, smooth, and rather thin.

3. C. o. maritrusa. Sea-side-inhabiting American Nettle-tree; Celtis maritima, of Rafinesque; a small crooked shrub, three or four feet in height, growing on the sea-shore from Long Island, in New York, to Chesapeake Bay. Its branches are cinerous, and slightly dotted; the leaves small, ovate-acuminate, with large serratures, rough on both sides, with the petioles and nerves pubescent; and flowers in May.

4. C. o. Cordata, Loudon. Heart-leaved American Nettle-tree; a tree with reddish branchlets, attaining a height of twenty to forty feet, and native of Kentucky, Illinois, \&c., where it is sometimes called hack-berry, which more properly belongs to the Celtis o. crassifolia. The leaves, which are from three to five inches in length, and from an inch to two inches wide, are ovate-oblong, or acuminate, sub-cordate, or truncate, and slightly oblique at the base, rough above, and smooth beneath, with regular reticulate nerves.

5. C. o. Reticulata. Reticulate-nerved-leaved American Nettle-tree; Celtis reticulata, of Torrey and Nuttall; Micocoulier à feuilles reticulées, of the French; Netzblättriger Zü̈rgel, of the Germans; a tall shrub, with numerous smooth, slender branches, discovered by Dr. E. P. James, near the base of the Rocky Mountains, in 1519. It has since been met with by Thomas Nuttall, in the same mountain range, along the borders of the Oregon, towards the Blue Mountains, particularly on the banks of the Brulée, a small stream falling into that river. The leaves, according to Mr. Nuttall, become thick and rigid, and are about an inch and a half long, by less than an inch wide, acute, but scarcely acuminate, with a few irregular serratures toward the point, though a number 
if the leaves may be observed to possess no serratures at all; they are very oblique, and slightly sinuated at the base, are shining and scabrous on the upper surface, and pubescent beneath along their prominent reticulate nerves, though at length nearly or quite smooth. The drupes are globose, solitary, on short peduncles, and are of a brownish-yellow colour.

6. C. o. CRASSIFolia. Thick-leaved American Nettle-tree; Celtis crassifolia, of Michaux, Loudon and others; Micocoulier à feuilles épaisses, Micocoulier à feuilles en cour, of the French; Dickblättriger ZZ̈̈rgel, of the Germans; Hack Berry, Hag Berry, Hog Berry, Hoop Ash, of the Anglo-Americans. This tree, which has hitherto been treated as a species, sometimes grows to a height of more than eighty feet, but with a trunk of the very disproportionate diameter of only eighteen or twenty inches. It is distinguished by the form of its trunk, which is straight and undivided to a great height; and by its bark, which is of a grayish colour, unbroken, and covered with asperities, unequally distributed over its surface. Its leaves are larger than those of any other tree of the genus, being six inches long, and from three to four inches broad; they are oval-acuminate, broad, heart-shaped, auricled and unequal at the base, serrated with unequal teeth, of a thick and rather leathery texture, and rough on both surfaces. The petioles are from one fourth to one half of an inch in length, and are slightly hairy. The flowers, which put

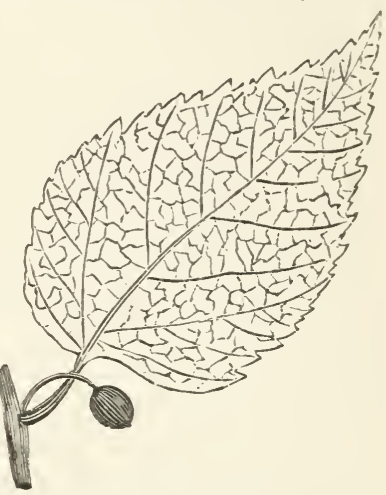
forth in May, are small, white, and are often united in pairs on a common peduncle. The fruit, which is of a roundish form, and slightly pointed at the apex, is of a darkbrown, or nearly black colour, when ripe, about the size of a bird-cherry, and is borne on slender peduncles, that are longer than the petioles of the leaves. The banks of the Dela ware, above Philadelphia, may be considered as its nothernmost limit, as an indigenous tree. East of the Alleghanies, it is restricted within narrow boundaries, being a stranger to the lower parts of Virginia, and of the more southern states; but west of these mountains it is profusely multiplied, in all the valleys that stretch along the rivers throughout Ohio, Kentucky, and Tennessee. It was introduced into Britain in 1812, where it is only considered as an ornamental tree. It is well adapted for plantations, where a screen or shade is required, from the rapidity and luxuriance of its growth, and the large size and thick texture of its leaves. The wood is of but little value, from its weakness and liability to decay, when exposed to the alternations of moisture and dryness. It is compact and fine-grained, however, though not heavy; and when freshly exposed it is quite white. Sawn in a direction parallel or oblique to its longitudinal fibres, it exhibits the fine undulations that are observed in the locust and in the elm. The sap-wood, if laid open in spring, will change in a few minutes, from pure white, to green. In the parts of the country where this tree abounds, its timber is sometimes employed, in building, for the covering which supports the shingles of the roofs. As it is elastic, and can easily be divided, it is also sometimes used by farmers for the bottoms of chairs, and by the Indians for making baskets. In Ohio it is employed for the rails to rural fences, as it is straight.grained, free from knots, and is wrought with the greatest ease.

Geography, $\rho \bullet c$. The Celtis occidentalis is sparingly scattered throughout the United States, from Massachusetts on the north, Carolina and Georgia on the south, and Missouri and Illinois on the west. In its natural habitat, it prefers ? 
cool, shady situation, and a deep, fertile soil, as along the borders of rivers, among other trees. It was introduced into Britain, by Mr. John Tradescant, in 1656, where it has proved to be a very hardy and ornamental tree, and has since been cultivated in many of the European gardens.

The largest recorded tree of this species, in Britain, is at Syon, which has attained the height of fifty-four feet, with a trunk nearly two feet and a half in diameter, and an ambitus or spread of branches of thirty feet.

The largest Celtis occidentalis, in France, is in the Jardin des Plantes, at Paris, which has been planted about one hundred and forty years, and has attained a height of nearly seventy feet, with a trunk about two feet in diameter, and an ambitus of forty feet.

At Brück, on the Leytha, in Austria, there is a tree of this species, which, in forty-five years after planting, had attained the height of sixty feet, with a trunk two feet and a half in diameter, and an ambitus of forty feet.

In Germany, in the botanic garden at Göttingen, there is an American nettletree, which, in thirty years after planting, had attained the height of thirty feet, with a trunk a foot in diameter.

In the United States, at Springfield, in Massachusetts, there is a Celtis occidentalis fourteen feet in circumference.

Propagation, f.c. The Celtis occidentalis is readily propagated by layers or from seeds, and will best succeed in a rich, fertile soil, which is rather cool and moist. The only insect of note that is found upon this tree, in the United States, is the larva of the hack-berry moth, (Sphinx drupiferarum, of Abbott,) which is nearly three inches long, half of an inch thick, of a green colour, beautifully marked and shaded with pink, and a brilliant white.

Properties and Uses. The wood of the Celtis occidentalis, when perfectly seasoned, is of a dark-brown colour, hard, compact, supple and tenacious, which renders it appropriate for many purposes; but, from its comparative scarcity, and growing among an abundance of more valuable trees, it never has been applied to many uses in the arts. It has sometimes been employed by the wheelwright for shafts, by coopers for hoops, and it has been wrought into whip-stocks, axehelves, and various other articles of use.

In Europe, it is cultivated solely as an ornamental tree; and as it possesses the property of keeping on its leaves very late, which die off of a bright yellow. it well deserves a place in every collection. 



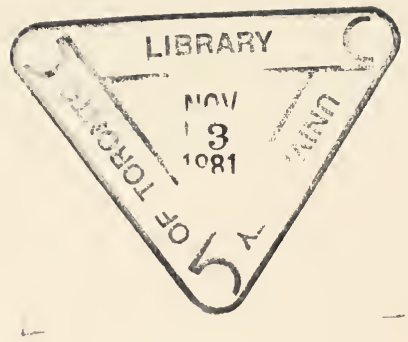




JINDING _......JVG 1981

\section{DEC -21997}

QK Browne, Daniel Jay

481

The trees of America

B78

cop. 2

Forectsy 


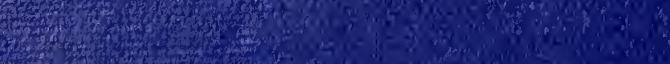

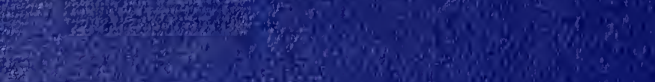

a

4.

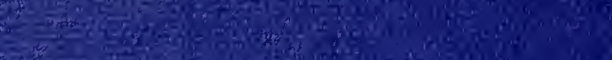

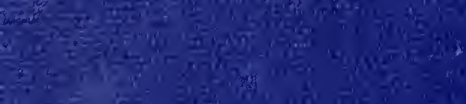

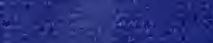

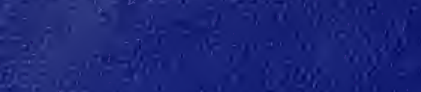

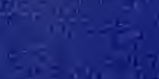

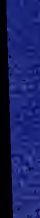

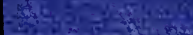

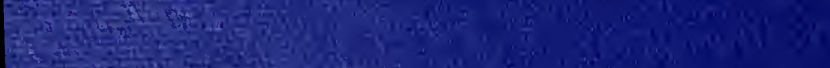

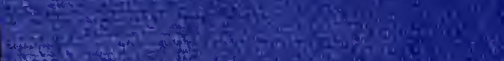

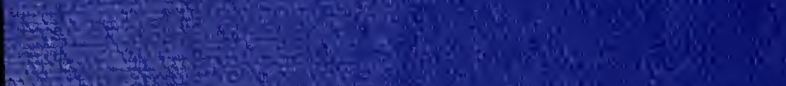

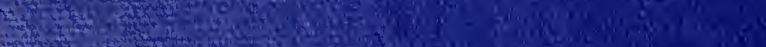

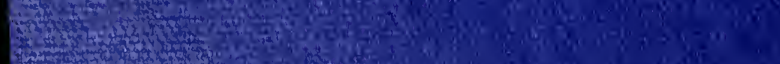

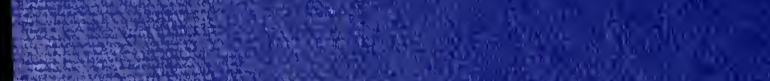

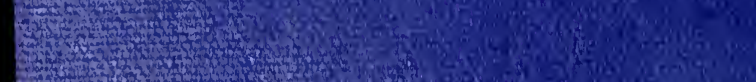

